SAND94-1293

Distribution

Unlimited Release

Printed October 1994

Category UC -630

\title{
1993 SITE ENVIRONMENTAL REPORT SANDIA NATIONAL LABORATORIES ALBUQUERQUE, NEW MEXICO
}

T. A. Culp, C. F. Cheng, W. Cox, N. Durand, M. Irwin, A. Jones,

F. Lauffer, M. Lincoln, Y. McClellan, K. Molley, and T. Wolff

7500 Environmental Operations Center

Sandia National Laboratories

Albuquerque, NM 87185

\begin{abstract}
This 1993 report contains monitoring data from routine radiological and nonradiological environmental surveillance activities. Summaries of significant environmental compliance programs in progress, such as National Environmental Policy Act documentation, environmental permits, environmental restoration, and various waste management programs for Sandia National Laboratories in Albuquerque, New Mexico, are included. The maximum offsite dose impact was calculated to be 0.0016 millirem. The total population within a 50-mile ( 80 kilometer) radius of Sandia National Laboratories/New Mexico received an estimated collective dose of 0.027 person-rem during 1993 from the laboratories' operations. As in the previous year, the 1993 operations at Sandia National Laboratories/New Mexico had no discernible impact on the general public or on the environment. This report is prepared for the U.S. Department of Energy in compliance with DOE Order 5400.1.
\end{abstract}




\title{
ACRNOWLEDGMENTS
}

This 1993 report was compiled by the staff of the Environmental Operations Center (7500) of Sandia National Laboratories/New Mexico (SNL/NM). R. Deola and L. Marlman provided input related to meteorological and ambient air monitoring, J. Bonaguidi and $\mathrm{C}$. Robertson supplied information for wastewater issues, C. Fink provided information for the Spill Prevention, Control, and Countermeasure Program, M. Lincolin supplied information on radiological and mixed waste issues, D. Statler provided input on the status of the Tiger Team audit, and $S$. Tyhurst supplied information for environmental incident reports. R. Sanchez, B. Bailey White, and B. Balassi of Creative Computer Services (CCS) provided word processing and editorial support. T. Wiggins of Environmental Resources Management (ERM) performed technical editing and coordinated document production.

\section{NOTES TO THE READER}

If you have comments or questions about this report, or need further information, contact:

\author{
Sandia National Laboratories \\ Media Relations Dept. \\ MS 0167 \\ P.0. Box 5800 \\ Albuquerque, NM 87185 \\ (505) $844-4207$ or \\ (505) $844-2282$
}

The organizational structure in use by the Environmental Operations Center (7500) at the time of this document's production is shown below:

7500 Environmental Operations Center

7511 Compliance and Quality Control Department

7512 Administrative and Information Support Department

7572 Generator Interface Department

7573 Waste Management and Regulatory Projects Department

7574 Water Quality Department

7575 Air Quality Department

7576 Pollution Prevention Department

7577 Waste Operations Department

7582 Environmental Restoration I Department

7583 Environmental Restoration II Department

7584 Environmental Restoration III Department

7585 Environmental Restoration IV Department 


\section{DISCLAIMER}

This report was prepared as an account of work sponsored by an agency of the United States Government. Neither the United States Government nor any agency thereof, nor any of their employees, make any warranty, express or implied, or assumes any legal liability or responsibility for the accuracy, completeness, or usefulness of any information, apparatus, product, or process disclosed, or represents that its use would not infringe privately owned rights. Reference herein to any specific commercial product, process, or service by trade name, trademark, manufacturer, or otherwise does not necessarily constitute or imply its endorsement, recommendation, or favoring by the United States Government or any agency thereof. The views and opinions of authors expressed herein do not necessarily state or reflect those of the United States Government or any agency thereof. 


\section{DISCLAIMER}

\section{Portions of this document may be illegible in electronic image products. Images are produced from the best available original document.}




\section{EXECUTIVE SUMMARY}

Sandia National Laboratories/New Mexico (SNL/NM) is located southeast of Albuquerque, NM, on Kirtland Air Force Base (KAFB). Because radionuclides are potentially released in small quantities from SNL/NM activities to offsite areas, SNL/NM maintains an Environmental Surveillance Program for routine radiological sampling and surveillance. The program includes biannual sampling and analysis of soil, arroyo sediment, vegetation, and surface water. Soil, arroyo sediment, and vegetation are analyzed for tritium (H-3) and by gamma spectroscopy; soil and arroyo sediment are also monitored for uranium (U). Also, gross alpha, gross beta, gamma spectroscopy, $\mathrm{U}$ and $\mathrm{H}-3$ analyses are performed for water samples. Environmental thermoluminescent dosimeters are used to measure gamma radiation. These samples and analyses are performed at SNL/NM onsite, perimeter, and community locations. The majority of the onsite radionuclide concentrations measured in 1993 were consistent with historical values and also consistent with community values measured in 1993 and in previous years. Perimeter radionuclide concentrations were also found to be consistent with historical values and consistent with community values. The Environmental Surveillance Program was enhanced in 1993 with the addition of the analysis of soil and arroyo sediment for metals. The data generated from this analysis is included in this report.

A total of eight facilities at SNL/NM reported releases of airborne quantities of radionuclides during 1993. A total of 3.2 curies (Ci) of argon-41, 0.62 Ci of nitrogen-13, $0.012 \mathrm{Ci}$ of oxygen-15, and 1.9 of $\mathrm{H}-3$ were released as result of SNL/NM activities in 1993. The National Emission Standards for Hazardous Air Pollutants (NESHAP) maximally exposed individual was determined to be located at the Kirtland Underground Munitions Storage Complex facility onsite. The maximum effective dose equivalent calculated to this location was 0.0016 millirems per year (mrem/yr), or 0.016 percent of the $10 \mathrm{mrem} / \mathrm{yr}$ dose limit specified in NESHAP and in DOE orders. The total population dose for the 50-mi radius surrounding SNL/NM was calculated to be 0.027 person-rem during 1993 from SNL/NM operations, whereas it received greater than 57,000 person-rem from natural background radiation (see Chapter 5.0).

Groundwater Monitoring: The SNL/NM Environmental Restoration (ER) Department conducts groundwater monitoring programs at the SNL/NM Chemical Waste Landfill (CWL), SNL/NM Mixed Waste Landfill (MWL), Technical Area II (TA-II), and the Liquid Waste Disposal System (LWDS) and for the Sitewide Hydrogeologic Characterization Project. Site-specific groundwater sampling activities are conducted at the CWL and MWL to satisfy the reporting requirements of Title 40, Code of Federal Regulations, Part 265.94; base-wide groundwater sampling is mandated by U.S. Department of Energy (DOE) Order 5400.1. Monthly water-leve1 measurements are also made as part of an ongoing effort to supplement monitoring activities of the SNL/NM ER program.

As of December 1993, the SNL/NM groundwater monitoring network consisted of 43 wells and 3 springs. Twenty-six of the wells are owned by SNL/NM, 14 by KAFB, 2 by the State of New Mexico, and 1 by the DOE. In 1993, water levels in 35 wells and 2 springs were measured, access permitting, on a monthly basis. Sixteen to 17 wells and all three springs were sampled quarterly in 1993 as part of the SNL/NM Groundwater Surveillance Project. These include South Fence 
Road Wells from the Sitewide Hydrogeologic Characterization Project. Five wells at the CWL were sampled on a quarterly basis, and four wells at the MWL were sampled on a quarterly basis, in accordance with site-specific sampling programs. In addition, groundwater samples were collected at new monitoring wells installed at TA-II and LWDS.

Quarterly basewide groundwater sampling (April, July, September, and December 1993) was conducted to provide baseline groundwater characteristics and groundwater contamination detection monitoring.

Groundwater sampling at the CWL was conducted in accordance with Appendix $G$ of the CWL closure plan which includes annual sampling for all Appendix IX parameters and quarterly sampling for Appendix IX volatile organic compounds and total metals. Annual sampling for assessment monitoring at the CWL occurred in February 1993; quarterly sampling took place in May, August, and November 1993. At the request of the New Mexico Environment Department, additional monitoring for total and dissolved chromium occurred at monitoring we11 CWL-BW3.

Groundwater monitoring was conducted at the MWL in accordance with Resource Conservation and Recovery Act (RCRA) regulations functioning as "applicable or relevant and appropriate requirements" (ARAR). Sampling was conducted at the MWL during January, April, and November 1993. No analytes were detected at levels above U.S. Environmental Protection Agency (EPA) maximum contaminant levels (MCL) or DOE derived concentration guides (DCGs).

Two new monitoring wells were completed and sampled at TA-II in 1993. The soils and groundwater were found to be nonhazardous and nonradioactive.

Groundwater monitoring activities were conducted at the LWDS in accordance with RCRA regulations as ARAR. Background sampling was conducted at the LWDS during June and November 1993. No analytes were detected at levels above EPA MCLs or DOE DCGs. As of the fall of 1993, four additional wells were installed along the South Fence Road as part of the Sitewide Hydrogeologic Characterization Project.

Other Compliance Activities

National Environmental Policy Act of 1969 (NEPA)

During 1993, SNL/NM NEPA compliance activities focused on:

- Fulfilling commitments made in the Final Action Plan to Tiger Team

- Continuing with the development of baseline information

- Developing the NEPA program

NEPA compliance activities increased, and policies and procedures were developed to ensure environmental values are considered as part of the review of SNL/NM's proposed actions. One finding of no significant impact (FONSI) was issued in 1993: Environmental Assessment for the Radioactive and Mixed Waste Management Facility. 
During 1993, there were 14 environmental assessments under development for DOE facilities at SNL/NM or for proposed actions involving SNL/NM research activities.

With the Secretary of Energy's National Environmental Policy Act Notice of February 5, 1990, SNL/NM has increased its emphasis on NEPA reviews. The DOE's commitment to (1) infusing environmental values into DOE decision making and (2) disclosing federal activities through the NEPA process has resulted in a large increase in the number of Environmental Assessments that are being written to cover SNL/NM proposed actions. 


\section{CONTENTS}

Page

EXECUTIVE SUMMARY . . . . . . . . . . . . . . . . . . . . v v

1.0 INTRODUCTION . . . . . . . . . . . . . . . . . . . . . 1-1

1.1 Site Operation . . . . . . . . . . . . . . . . . . 1-1

1.2 Location and Population .. . . . . . . . . . . . . $1-1$

1.3 Climate and Meteorology . . . . . . . . . . . . . . $1-3$

1.4 Geology .. . . . . . . . . . . . . . . . . . $1-4$

1.5 Hydrology . . . . . . . . . . . . . . . . . . . 1-4

1.5.1 Groundwater Hydrology . . . . . . . . . . . . . 1-4

1.5.2 Surface-Water Hydrology . . . . . . . . . . . 1-7

1.6 Biology . . . . . . . . . . . . . . . . . . $1-7$

1.7 Technical Areas ..................... . . . . . . $1-7$

1.8 Remote Test Areas . . . . . . . . . . . . . . . $1-14$

2.0 COMPLIANCE SUMMARY . . . . . . . . . . . . . . . . . . $2-1$

2.1 Compliance Regulations .. . . . . . . . . . . . . . 2-1

2.2 Current Issues and Actions................ $2-6$

2.3 Environmental Permits . . . . . . . . . . . . . . 2-8

2.3.1 Air ..................... 2 $2-8$

2.3.2 Water.................... 2- $2-9$

2.3.3 Solid Waste. . . . . . . . . . . . . . . . . . $2-9$

2.3.4 Summary of the Status of Current Permits and
Other Notifications............. . . 2-10

2.4 U.S. Department of Energy Tiger Team Assessment
Summary . . . . . . . . . . . . . . . . . 2-10

3.0 ENVIRONMENTAL PROGRAMS INFORMATION . . . . . . . . . . . . . 3-1

3.1 Environmental Restoration Project . . . . . . . . . . . 3-1

3.2 Underground Storage Tank Management . . . . . . . . . . . 3-2

3.3 Spill Prevention Control and Countermeasure Plan . . . . . 3-2

3.4 Waste Management Programs . . . . . . . . . . . . . . $3-2$

3.4.1 Hazardous Waste and the Resource Conservation and

Recovery Act . . . . . . . . . . . . . . . . . 3-2

3.4.2 Radioactive Waste ............... . 3-3

3.4.3 Mixed Waste . . . . . . . . . . . . . . . . 3-5

3.4.4 Special-Case Waste. . . . . . . . . . . . . . 3-5

3.4.5 Polychlorinated Biphenyl Waste. . . . . . . . . 3-6

3.4.6 Nonfacilities Asbestos Waste . . . . . . . . . . 3-6

3.4.7 Waste Minimization Program . . . . . . . . . . 3-6 


\section{CONTENTS \\ (Continued)}

Page

3.5 National Environmental Policy Act of 1969 Compliance

Activities and Documentation in 1993 . . . . . . . . . 3-7

3.5.1 Background . . . . . . . . . . . . . . . $3-7$

3.5.2 NEPA Documents . . . . . . . . . . . . . 3-8

3.5.3 1993 Activities . . . . . . . . . . . . . . . 3-10

3.5.4 NEPA Training and Outreach . . . . . . . . . 3-13

3.5.5 NEPA Baseline Information . . . . . . . . . . 3-14

3.5.6 Environmental Assessment Findings of No
Significant Impact . . . . . . . . . . . . . 3-14

3.5.7 Miscellaneous NEPA Activities. . . . . . . . 3-15

3.6 Summary of 1993 Release and Environmental
Incident Reports . . . . . . . . . . . . . . . 3-15

3.6.1 Summary of Release Reporting . . . . . . . . . . . 3-15

3.6.2 Summary of Environmental Incident Reporting . . . 3-17

4.0 TERRESTRIAL SURVEILLANCE . . . . . . . . . . . . . . . . . . 4-1

4.1 Surveillance Locations .. . . . . . . . . . . . . . . . 4-1

4.2 Sample Collection and Analysis . . . . . . . . . . . . . . 4-7

4.3 Terrestrial Radiological Surveillance Results . . . . . . 4-7

4.3.1 Vegetation . . . . . . . . . . . . . . . 4-8

4.3.2 Soil .................... . . 4-8

4.3.3 Surface Water............... . 4-11

4.3.4 Sediment . . . . . . . . . . . . . . . 4-14

4.3.5 Environmental Thermoluminescent Dosimeters . . . 4-14

4.4 Terrestrial Nonradiological Surveillance Results . . . . . 4-14

5.0 AIR QUALITY SURVEILLANCE AND EMISSIONS MONITORING . . . . . . . $\quad$ 5-1

5.1 Meteorological Monitoring Program . . . . . . . . . . . . $5-1$

5.2 Air Quality Environmental Sampling and Surveillance . . . 5-1

5.2.1 Monitoring Locations . . . . . . . . . . . . . 5-1

5.2.2 Sample Collection and Analysis . . . . . . . . 5-4

5.3 Air Emissions Radiological Monitoring . . . . . . . . . . 5-4

5.3.1 Radioactive Effluent Monitoring . . . . . . . . . 5-6

5.3.2 Technical Area $V$ Reactors... . . . . . . . . 5-6 


\section{CONTENTS}

(Continued)

Page

5.4 Air Quality Radiological Monitoring Results . . . . . . 5-6

5.5 Assessment of Potential Dose to the Public . . . . . . . 5-8

5.5.1 Air Emission Sources . . . . . . . . . . . 5-8

5.5.2 Public Receptors . . . . . . . . . . . . . . 5-11

5.5.3 Meteorological Data.............. . 5-11

5.5.4 Demographic Data . . . . . . . . . . . . . . . 5-11

5.5.5 Results of the Dose Assessment . . . . . . . . . . 5-11

5.5.6 Population Dose at Kirtland Air Force Base . . . 5-14

5.5.7 Population Dose for the 50-Mile Radius . . . . . 5-14

5.6 Summary of the 1993 offsite Dose Impacts . . . . . . . . 5-14

5.7 Air Quality Management .. . . . . . . . . . . 5-16

5.7.1 Air Quality Regulations ...... . . . . . . . 5-16

5.7.2 Airborne Emissions and Permits . . . . . . . . . 5-17

5.7.3 Criteria Pollutants Inventory. . . . . . . . 5-19

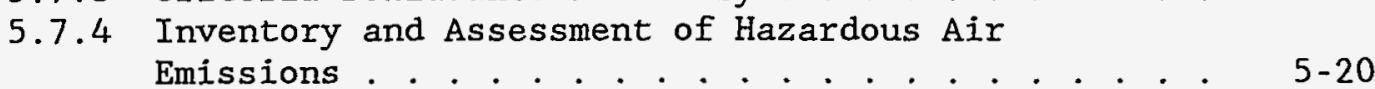

6.0 WATER MONITORING PROGRAMS .................. 6-1

6.1 Wastewater Programs . . . . . . . . . . . . . 6-1

6.1.1 Discharges to Publicly Owned Treatment Works . . . 6-1

6.1.2 Summary of Monitoring Results . . . . . . . . . 6-2

6.2 Storm Water Program . . . . . . . . . . . . . . . 6-8

6.3 Surface Discharge Programs . . . . . . . . . . . . 6-9

6.3.1 Discharge Plans . . . . . . . . . . . . . 6-9

6.3.2 Summary of Analytical Results . . . . . . . . . 6-9

7.0 GROUNDWATER MONITORING . . . . . . . . . . . . . . . . 7-1

7.1 Regulatory Overview . . . . . . . . . . . . . . . . 7-1

7.2 Sandia National Laboratories/New Mexico Groundwater

7.3 Water Level Measurements .. . . . . . . . . . . . . 7-4

7.3.1 Direction of Groundwater Flow . . . . . . . . . . 7-17

7.3.2 Production Well Pumping ............ 7-21 


\section{CONTENTS (Concluded)}

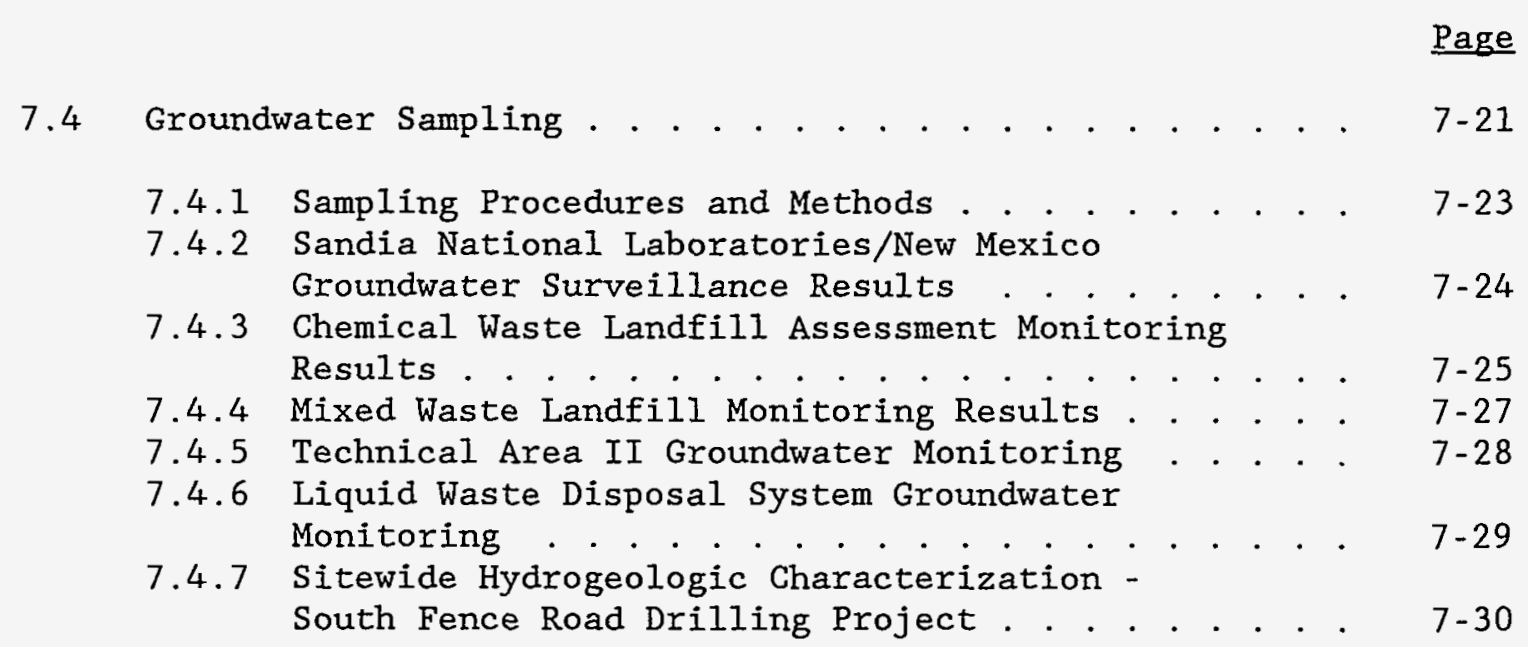

8.0 QUALITY ASSURANGE PROGRAMS . . . . . . . . . . . . . . . . . . . 8-1

8.1 Quality Assurance Policies and Responsibilities

8.2 Quality Assurance of Environmental Sampling

and Analysis..................... 8-1

8.2.1 Quality Assurance for Sampling Programs . . . . . . 8-1

8.2.2 Quality Assurance for Analytical Programs . . . . . 8-2

8.2.3 Data Review and Validation . . . . . . . . . . . 8-4

8.3 Contractor Quality Assurance Overview . . . . . . . . . . 8-4

9.0 REFERENCES .......................... . . . . . 9-1

APPENDIX A Meteorological Data . . . . . . . . . . . . . . . A-1

APPENDIX B Sandia National Laboratories/New Mexico Environmental
Restoration Program Sites . . . . . . . . . . . B-I

APPENDIX C Sample Collection and Analysis . . . . . . . . . . . . . C- C-1

APPENDIX D Minimum Detection Limits . . . . . . . . . . . . . . . D D-1

APPENDIX E Quality Assurance Data . . . . . . . . . . . . . . . . E-1

APPENDIX F Terrestrial Monitoring Data . . . . . . . . . . . . . . F-1

APPENDIX G Environmental Regulations and Standards . . . . . . . . G G-1

$\begin{array}{ll}\text { APPENDIX H } & \text { Septic Tank Registration For Sandia National } \\ & \text { Laboratories/New Mexico . . . . . . . . . . . . . . H-1 }\end{array}$

APPENDIX I National Environmental Policy Act Documentation . . . . I-1

APPENDIX J 1993 Environmental Compliance Activities at the
Kauai Test Facility . . . . . . . . . . . . . J J

APPENDIX K Groundwater Monitoring Data . . . . . . . . . . . . . K-1 


\section{FIGURES}

Page

1-1 Albuquerque Site Regional Setting ................ . 1-2

1-2 Albuquerque Basin of North Central New Mexico . . . . . . . . . . 1-5

1-3 Generalized Geology in the Vicinity of Sandia National Laboratories/New Mexico and Kirtland Air Force Base . . . . . . . 1-6

$1-4$ Mesa Vegetation . . . . . . . . . . . . . . . . . . . . . . . 1-8

1-5 Manzano Foothills Vegetation . . . . . . . . . . . . . . . . . 1-8

1-6 Sandia National Laboratories/New Mexico Technical Areas I through $\mathrm{V}$ and Remote Areas . . . . . . . . . . . . . . . . . . . 1-9

1-7 Technical Area I ...................... . 1-10

1-8 View of Technical Areas II and IV . . . . . . . . . . . . . . . . 1-12

1-9 Technical Area $\mathrm{V}$ and a Portion of Technical Area III . . . . . . 1-13

1-10 Main Burn Site at the Entrance of Coyote Canyon . . . . . . . . . 1-15

3-1 Process for Creating and Reviewing U.S. Department of Energy National Environmental Policy Act Documentation . . . . . . 3-9

3-2 Flow Chart of the Environmental Assessment Process . . . . . . . . 3-11

3-3 Flow Chart of the Environmental Impact Statement Process . . . . . 3-12

4-1 Onsite and Perimeter Terrestrial Monitoring Locations . . . . . . 4-2

4-2 Community Terrestrial Monitoring Locations . . . . . . . . . . . 4-3

5-1 Locations of Meteorological Towers and Air Monitoring Stations........................ . 5-2

5-2 PM-10 Monitoring Station . . . . . . . . . . . . . . . . 5-3

5-3 Sandia National Laboratories/New Mexico Air Sampling Truck. . . . 5-5

5-4 Summary of Atmospheric Releases of Argon-41, Tritium, Krypton-85, and Xenon-135 From Sandia National

Laboratories/New Mexico Facilities Since 1978 . . . . . . . . . . 5-7

5-5 Facilities Locations at Sandia National Laboratories/
New Mexico... . . . . . . . . . . . . . . . . . . . . . . .

5-6 Boundary Receptor Locations Around Sandia National Laboratories/New Mexico .. . . . . . . . . . . . 5-13

6-1 Sandia National Laboratories/New Mexico Wastewater Monitoring Station Locations . . . . . . . . . . . . . . . . . . 6-4

7-1 Location Map of Sandia National Laboratories and Kirtland Air Force Base Wells and Springs . . . . . . . . . . . . . . . . . 7-3

7-2 Chemical Waste Landfill Monitoring Well Locations . . . . . . . 7-5

7-3 Mixed Waste Landfill Monitoring Well Locations . . . . . . . . . . 7-6

7-4 Technical Area II Monitoring Well Locations . . . . . . . . . . . 7-7

7-5 Liquid Waste Disposal System Site Borehole and
Monitoring Well Locations

7-6 South Fence Road Well Locations, Sitewide Hydrogeologic Characterization Project . . . . . . . . . . . . . . . . . . . . . 7-9

7-7 Water Pumped by Kirtland Air Force Base Production Wells, 1993 . . 7-10 


\section{FIGURES}

(Concluded)

Page

7-8 Hydrographs for Chemical Waste Landfill Shallow

Monitoring Wells, 1993 . . . . . . . . . . . . . . . . . . . . 7-12

7-9 Hydrographs for Chemical Waste Landfill Deep

Monitoring Wells, 1993 . . . . . . . . . . . . . . . . . . . . . 7-13

7-I0 Hydrographs for Mixed Waste Landfill Monitoring

Wells, 1993 . . . . . . . . . . . . . . . . . . . . . . . 7-14

7-11 Hydrographs for Other Monitoring Wells in Technical

Area III, 1993 . . . . . . . . . . . . . . . . . . . . . . . 7-15

7-12 Hydrographs for Monitoring Wells East of the Faults, 1993 . . . . 7-16

7-13 Hydrographs for Monitoring Wells at Kirtland Air Force

Base Sanitary Lagoons, with Water Pumped by Kirtland

Air Force Base Production Wells, 1993 . . . . . . . . . . . . . . 7-18

7-14 Hydrographs for Monitoring Wells Near Tijeras Arroyo, 1993 . . . . 7-19

7-15 Hydrographs for Kirtland Air Force Base Golf Course Monitoring Wells, 1993 . . . . . . . . . . . . . . . . . . . . . . 7-20

7-16 Kirtland Air Force Base Potentiometric Surface Map, July 1993 Contours Derived from Monitoring Well

Water Levels Only . . . . . . . . . . . . . . . . . . . . 7-22 


\section{TABLES}

Page

1-1 Summary Meteorological Data for the Albuquerque Area in 1993.. . 1-3

2-1 Summary of the Environmental Permits Issued or in Process . . . . 2-11

3-1 EPA-Permitted Sandia National Laboratories/New Mexico Hazardous Waste Transporters Used in Calendar Year 1993 . . . . . 3-4

3-2 Waste Disposal Facilities Used by Sandia National Laboratories/New Mexico in Calendar Year 1993 . . . . . . . . . . 3-4

3-3 Annual Summary of 1993 Reportable Quantity Release Reporting . . . 3-16

4-1 Sandia National Laboratories/New Mexico Terrestrial Surveillance Locations and Sample Types . . . . . . . . . . . . . 4-4

4-2 Mean Concentrations of Tritium in Vegetation Sampled in May 1993 . . . . . . . . . . . . . . . . . . . . . . . . . . . 4-9

4-3 Mean Concentrations of Tritium in Vegetation Sampled in August 1993 . . . . . . . . . . . . . . . . . . . . . . . . . . . 4-9

4-4 Mean Concentrations of Uranium, Cesium-137, and Tritium in Soil Samples Collected in May and August 1993 . . . . . . . . . 4-10

4-5 Mean Concentrations of Gross Alpha, Gross Beta, Gamma Spectroscopy, Uranium, and Tritium in Surface Water for May 1993 . . . . . . . . . . . . . . . . . . . . . . . 4-12

4-6 Mean Concentrations of Gross Alpha, Gross Beta, Gamma Spectroscopy, Uranium, and Tritium in Surface Water for August 1993 . . . . . . . . . . . . . . . . . . . . . . 4-13

4-7 Concentrations of Uranium, Tritium, and Cesium-137 in Sediment for May and August 1993 . . . . . . . . . . . . . . . . 4-15

4-8 Summary of Thermoluminescent Dosimeter Measurements for 1993. . . 4-16

4-9 Summary of Soil Samples . . . . . . . . . . . . . . . . . . . . 4-17

4-10 Summary of Sediment Samples . . . . . . . . . . . . . . . 4-19

5-1 Summary of Radionuclide Releases for 1993 . . . . . . . . . . . . 5-9

5-2 Annual Effective Dose Equivalent to Boundary Receptors . . . . . . 5-12

5-3 Annual Effective Dose Equivalent to Kirtland Air Force Base Receptors . . . . . . . . . . . . . . . . . . . . . . . . . 5-15

5-4 Summary of Offsite Dose Impacts in Comparison to the National Emission Standards for Hazardous Air Pollutants and to Natural Background Radiation . . . . . . . . . . . . . . . 5-16

5-5 Summary of 1993 Air Permits . . . . . . . . . . . . . . . . 5-18

5-6 1993 Criteria Pollutant Inventory . . . . . . . . . . . . . . . . 5-19

5-7 Emergency Generator Emissions Estimates . . . . . . . . . . . . . 5-20

5-8 Summary of Significant Chemical Usage Laboratory-Wide . . . . . . 5-22

6-1 Sandia National Laboratories/New Mexico Wastewater Discharge Permits . . . . . . . . . . . . . . . . . . . 6-1

6-2 Sandia National Laboratories/New Mexico Wastewater Sample Locations . . . . . . . . . . . . . . . . . . . . . . . . . 6-3

6-3 Summary of Characteristics for Sandia National Laboratories/New Mexico Wastewater Sampling Stations . . . . . . 6-5 


\section{TABLES}

(Concluded)

Page

6-4 Summary of Concentration Violations for Permit 2069D-3, Station WW004, During 1993 . . . . . . . . . . . . . . . . 6-6

6-5 Summary of Concentration Violations for Permit 2069H-2, Station WW009, During 1993 . . . . . . . . . . . . . . . . 6-7

6-6 Summary of Concentration Violations for Permit 2069K, Station Ww011, During 1993 ... . . . . . . . . . . 6-8 


\section{ABBREVIATIONS}

\section{International System of Units Prefixes}

Exponent Prefix Symbol

$\begin{array}{lll}10^{6} & \text { mega } & \mathrm{M} \\ 10^{3} & \text { kilo } & \mathrm{K} \\ 10^{-3} & \text { milli } & \mathrm{m} \\ 10^{-6} & \text { micro } & \mu\end{array}$

Units
Exponent Prefix Symbol

$\begin{array}{lll}10^{-9} & \text { nano } & \mathrm{n} \\ 10^{-12} & \text { pico } & \mathrm{p} \\ 10^{-15} & \text { femto } & \mathrm{f} \\ 10^{-18} & \text { atto } & \mathrm{a}\end{array}$

\begin{tabular}{|c|c|c|c|}
\hline ac & acre & $\mathrm{L}$ & liter \\
\hline cf & cubic feet & $1 \mathrm{~b}$ & pound \\
\hline${ }^{\circ} \mathrm{C}$ & Celsius degree & $\mathrm{Ib} / \mathrm{yr}$ & pounds per year \\
\hline $\mathrm{cm}$ & centimeter & 1ps & liters per second \\
\hline $\mathrm{cm} / \mathrm{yr}$ & centimeters per year & $\mathrm{m}$ & meter \\
\hline${ }^{\circ} \mathrm{F}$ & Fahrenheit degree & $\mathrm{m}^{2}$ & square meter \\
\hline $\begin{array}{l}\text { fbgs } \\
\mathrm{ft}\end{array}$ & $\begin{array}{l}\text { feet below ground surface } \\
\text { foot }\end{array}$ & $\mathrm{MBtu} / \mathrm{hr}$ & $\begin{array}{l}\text { mega-British thermal } \\
\text { units per hour }\end{array}$ \\
\hline$f t^{2}$ & square foot & $\mathrm{m} / \mathrm{s}$ & meters per second \\
\hline$f t^{3}$ & cubic foot & $\mathrm{mg} / \mathrm{L}$ & milligrams per liter \\
\hline g & gram & $\mathrm{mi}$ & mile \\
\hline gal & gallon & $\mathrm{mi}^{2}$ & square mile \\
\hline gpd & gallons per day & $\mathrm{mi} / \mathrm{hr}$ & miles per hour \\
\hline gpm & gallons per minute & $\min$ & minute \\
\hline$h r$ & hour & $\mathrm{mL}$ & milliliter \\
\hline ha & hectare & $\mathrm{ppb}$ & parts per billion \\
\hline in. & inch & ppm & parts per million \\
\hline in./yr & inches per year & qt & quart \\
\hline $\mathrm{J}$ & Joule & s & second \\
\hline $\mathrm{kg}$ & kilogram & $\mathrm{yd}^{2}$ & square yard \\
\hline $\mathrm{km}$ & kilometer & yr & year \\
\hline $\mathrm{km}^{2}$ & square kilometer & $\%$ moisture & weight percent of water \\
\hline
\end{tabular}

\section{Symbols}
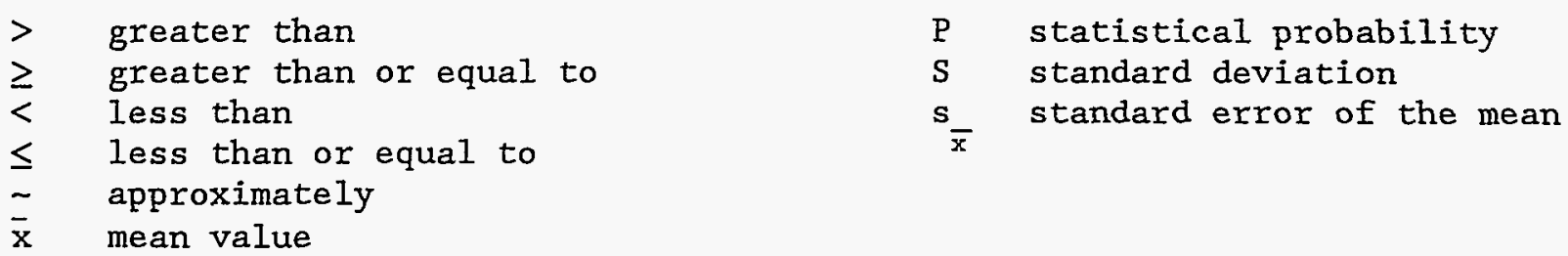


\section{ABBREVIATIONS (Continued)}

\section{Abbreviations for Referenced Nuclides and Components}

$\begin{array}{llll}\mathrm{Al} & \text { aluminum } & \mathrm{Ni} & \text { nickel } \\ \mathrm{Am}-241 & \text { americium-241 } & \mathrm{N}-13 & \text { nitrogen-13 } \\ \mathrm{Ar} & \text { argon } & \mathrm{N}-15 & \text { nitrogen-15 } \\ \mathrm{Ar}-41 & \text { argon-41 } & \mathrm{O}-15 & \text { oxygen-15 } \\ \mathrm{As} & \text { arsenic } & \mathrm{O}-18 & \text { oxygen-18 } \\ \mathrm{Ba} & \text { barium } & \mathrm{Pu} & \text { plutonium } \\ \mathrm{Be} & \text { beryl1ium } & \mathrm{Pu}-241 & \text { plutonium-241 } \\ \mathrm{C}-13 & \text { carbon-13 } & \mathrm{Po}-210 & \text { polonium-210 } \\ \mathrm{Ca} & \text { calcium } & \mathrm{K} & \text { potassium } \\ \mathrm{Cd} & \text { cadmium } & \mathrm{K}-40 & \text { potassium-40 } \\ \mathrm{Cs} & \text { cesium } & \mathrm{Ra}-226 & \text { radium-226 } \\ \mathrm{Cs}-137 & \text { cesium-137 } & \mathrm{Ra}-228 & \text { radium-228 } \\ \mathrm{Cr} & \text { chromium } & \mathrm{Rb}-88 & \text { rubidium-88 } \\ \mathrm{Co} & \text { cobalt } & \mathrm{Se} & \text { selenium } \\ \mathrm{Co}-60 & \text { cobalt-60 } & \mathrm{Ag} & \text { silver } \\ \mathrm{Cu} & \text { copper } & \mathrm{Na} & \text { sodium } \\ \mathrm{D} & \text { deuterium } & \mathrm{Sr}-90 & \text { strontium-90 } \\ \mathrm{DU} & \text { depleted uranium } & \mathrm{S} & \text { sulphur } \\ \mathrm{I}-129 & \text { iodine-129 } & \mathrm{Th} & \text { thorium } \\ \mathrm{Fe} & \text { iron } & \mathrm{U} & \text { uranium } \\ \mathrm{Fe}-55 & \text { iron-55 } & \mathrm{U}_{\text {tot }} & \text { total uranium } \\ \mathrm{Kr} & \text { krypton } & \mathrm{HTO} & \text { tritiated water vapor } \\ \mathrm{Kr}-85 & \text { krypton-85 } & \mathrm{HT} & \text { tritiated hydrogen } \\ \mathrm{Kr}-85 \mathrm{~m} & \text { krypton-85m } & \mathrm{H}-3 & \text { tritium } \\ \mathrm{Kr}-87 & \text { krypton-87 } & \mathrm{U} & \text { uranium } \\ \mathrm{Kr}-88 & \text { krypton-88 } & \mathrm{U}-238 & \text { uranium-238 } \\ \mathrm{Pb} & \text { lead } & \mathrm{V} & \text { vanadium } \\ \mathrm{Pb}-212 & \text { lead-212 } & \mathrm{Xe} & \text { xenon } \\ \mathrm{Mg} & \text { magnesium } & \mathrm{Xe}-133 & \text { xenon-133 } \\ \mathrm{Mn} & \text { manganese } & \mathrm{Xe}-135 & \text { xenon-135 } \\ \mathrm{Hg} & \text { mercury } & \mathrm{Xe}-135 \mathrm{~m} & \text { xenon-135m } \\ \mathrm{U} \text { nat } & \text { natural uranium } & \mathrm{Zn} & \text { zinc } \\ & & & \end{array}$

Radioactivity Measurements

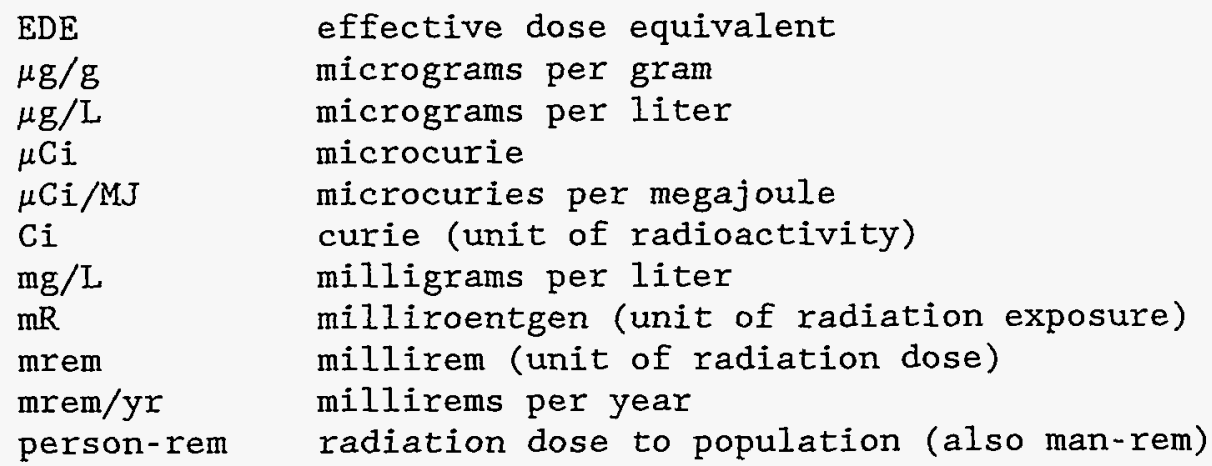




\title{
ABBREVIATIONS \\ (Continued)
}

\author{
$\mathrm{pCi} / \mathrm{L}$ picocuries per liter \\ $\mathrm{pCi} / \mathrm{mL}$ picocuries per milliliter \\ $\mathrm{R}$ \\ roentgen (unit of radiation exposure) \\ rem \\ roentgen equivalent man (amount of ionizing radiation \\ required to produce the same biological effect as $1 \mathrm{R}$ of \\ high-penetration $\mathrm{X}$-rays) \\ Sv sievert (unit of radiation dosage, $-8.38 \mathrm{R}$ )
}

Acronyms

$\begin{array}{ll}\text { ACM } & \text { asbestos-containing material } \\ \text { ACRR } & \text { Annular Core Research Reactor } \\ \text { ADM } & \text { Action Description Memorandum } \\ \text { ADS } & \text { Activity Data Sheet } \\ \text { AIP } & \text { Agreement-in-Principle } \\ \text { AIRFA } & \text { American Indian Religious Freedom Act } \\ \text { AL/KAO } & \text { Albuquerque/Kirtland Area Office } \\ \text { ALARA } & \text { as low as reasonably achievable } \\ \text { ANSI } & \text { American National Standards Institute } \\ \text { AQCR } & \text { Air Quality Control Regulation } \\ \text { AR } & \text { averaged replicate } \\ \text { ARAR } & \text { applicable or relevant and appropriate requirements } \\ \text { ARPA } & \text { Archaeological Resources Protection Act } \\ \text { AT\&T } & \text { American Telephone and Telegraph } \\ \text { CA } & \text { Corrective Action } \\ \text { CAA } & \text { Clean Air Act } \\ \text { CAAA } & \text { Clean Air Act Amendments } \\ \text { CAM } & \text { continuous air monitor } \\ \text { CDX } & \text { countermeasures demonstration experiment } \\ \text { CEQ } & \text { Council on Environmental Quality } \\ \text { CERCLA } & \text { Comprehensive Environmental Response, Compensation, and } \\ & \text { Liability Act } \\ \text { CERF } & \text { Civil Engineer Research Facility } \\ \text { CFC } & \text { chlorofluorocarbon } \\ \text { CFR } & \text { Code of Federal Regulations } \\ \text { CO } & \text { carbon monoxide } \\ \text { CO } 2 & \text { carbon dioxide } \\ \text { CV } & \text { coefficient of variation } \\ \text { CWA } & \text { Clean Water Act } \\ \text { CWL } & \text { Chemical Waste Landfill } \\ \text { CX } & \text { categorial exclusion } \\ \text { CY } & \text { calendar year } \\ \text { DCG } & \text { derived concentration guide } \\ \text { DNA } & \text { Defense Nuclear Agency } \\ \text { DOC } & \text { U.S. Department of Commerce } \\ \text { DOD } & \text { U.S. Department of Defense } \\ \text { DOE } & \text { U.S. Department of Energy } \\ \text { DOE/AL } & \text { U.S. Department of Energy Albuquerque Operations office } \\ & \end{array}$ 


\section{ABBREVIATIONS (Continued)}

\section{$\underline{\text { Acronyms }}$}

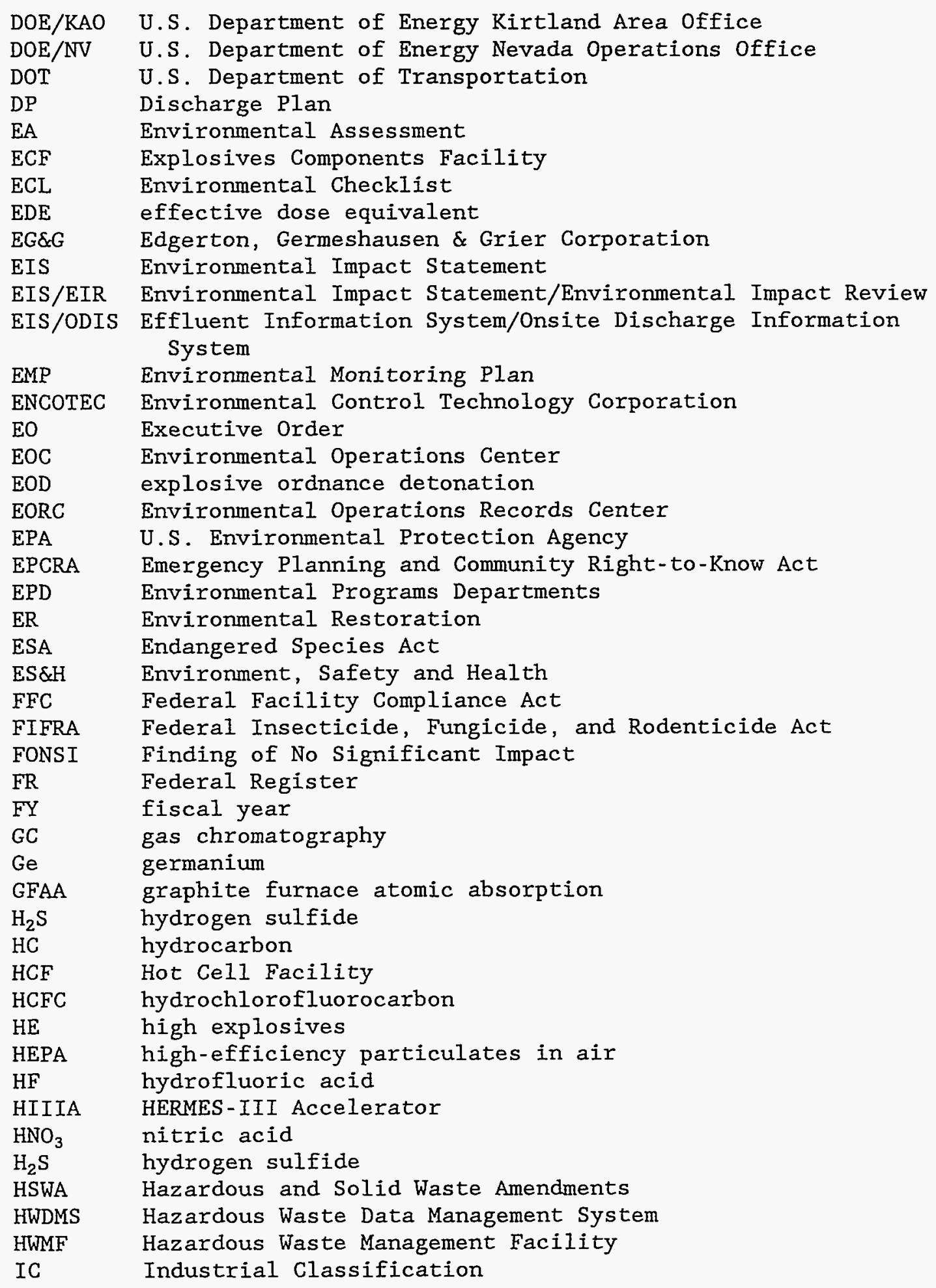




\section{ABBREVIATIONS (Continued)}

\section{$\underline{\text { Acronyms }}$}

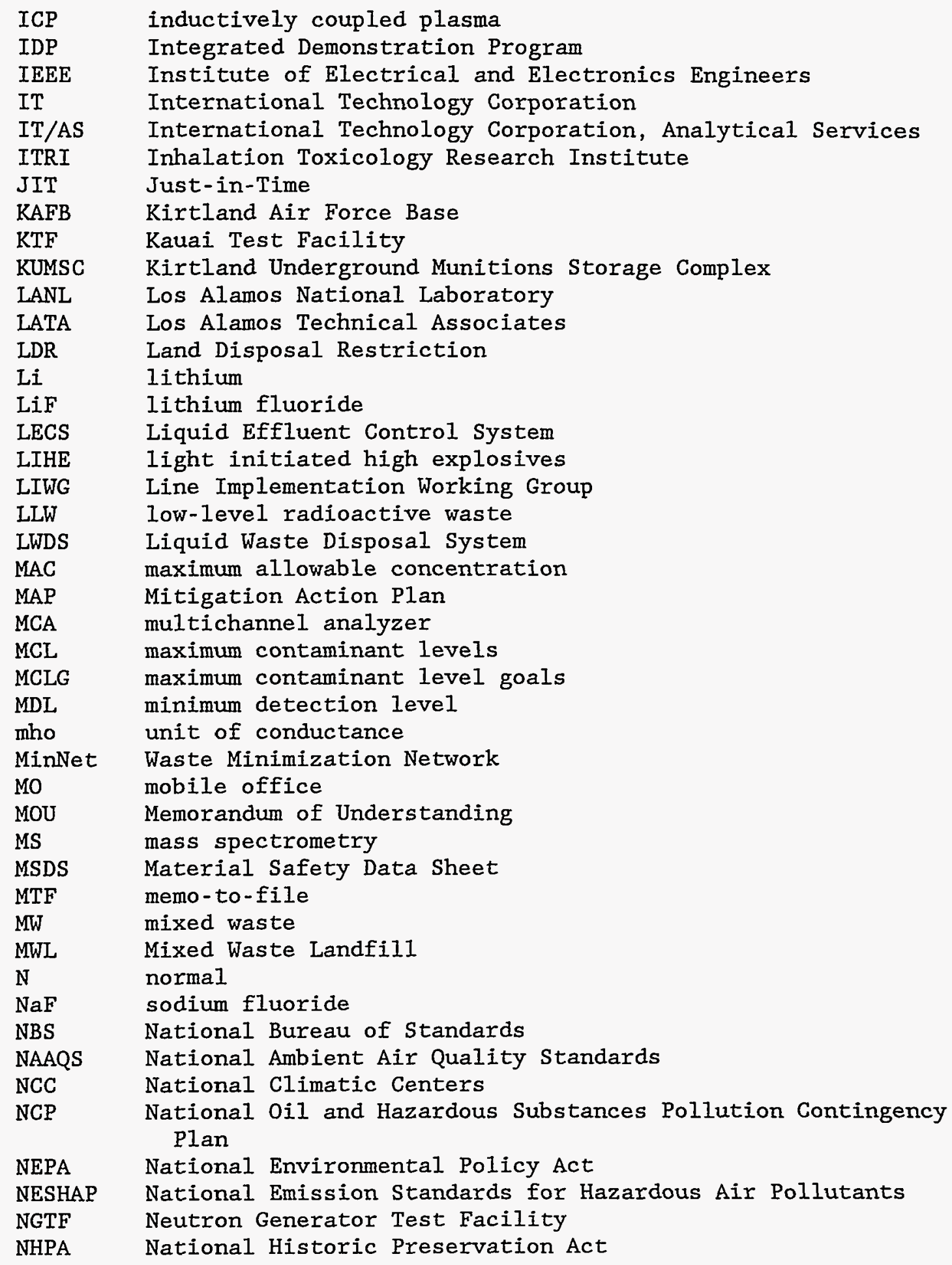




\title{
ABBREVIATIONS (Continued)
}

\author{
Acronyms \\ NIOSH National Institute for Occupational Safety and Health \\ NIST National Institute of Standards (formerly NBS) \\ NM New Mexico \\ NMED New Mexico Environment Department \\ NMHWMR New Mexico Hazardous Waste Management Regulations \\ NMWQA New Mexico Water Quality Authority \\ NMWQCC New Mexico Water Quality Control Commission \\ NMWQR New Mexico Water Quality Regulations \\ $\mathrm{NO}_{2} \quad$ nitrogen dioxide \\ $\mathrm{NO}_{\mathrm{x}} \quad$ oxides of nitrogen \\ NOAA National Oceanographic and Atmospheric Administration \\ NOD Notice of Deficiency \\ NOI Notice of Intent \\ NON Notification of Noncompliance \\ NOV Notice of Violation \\ NPDES National Pollutant Discharge Elimination System \\ NPL National Priorities List \\ NPN nitrate plus nitrite \\ NRC National Response Center \\ NSPS New Source Performance Standards \\ NTS Nevada Test Site \\ NTU nephelometric turbidity unit \\ $\mathrm{O}_{3} \quad$ ozone \\ ODS ozone-depleting substance \\ OEL Occupational Exposure Limit \\ OSHA Occupational Safety and Health Administration \\ OSI, onsite investigation \\ OU operable unit \\ PA Preliminary Assessment \\ PA/SI Preliminary Assessment/Site Inspection \\ PBFA-II Particle Beam Fusion Accelerator-II \\ PCB polychlorinated biphenyl \\ PDL Process Development Laboratory \\ PDWR Primary Drinking Water Regulations \\ PEIS Programmatic Environmental Impact Statement \\ $\mathrm{pH} \quad$ hydrogen ion concentration (a measure of acidity) \\ PM particulate matter \\ PM-10 respirable particulate matter \\ PMRF Pacific Missile Range Facility \\ POTW publicly-owned treatment works \\ $P P \quad$ pollution prevention \\ PSD Prevention of Significant Deterioration \\ PWA Process Waste Assessment \\ QA quality assurance \\ QAP Quality Assessment Program \\ QC quality control \\ R\&D research and development
}




\section{ABBREVIATIONS}

(Continued)

\section{Acronyms}

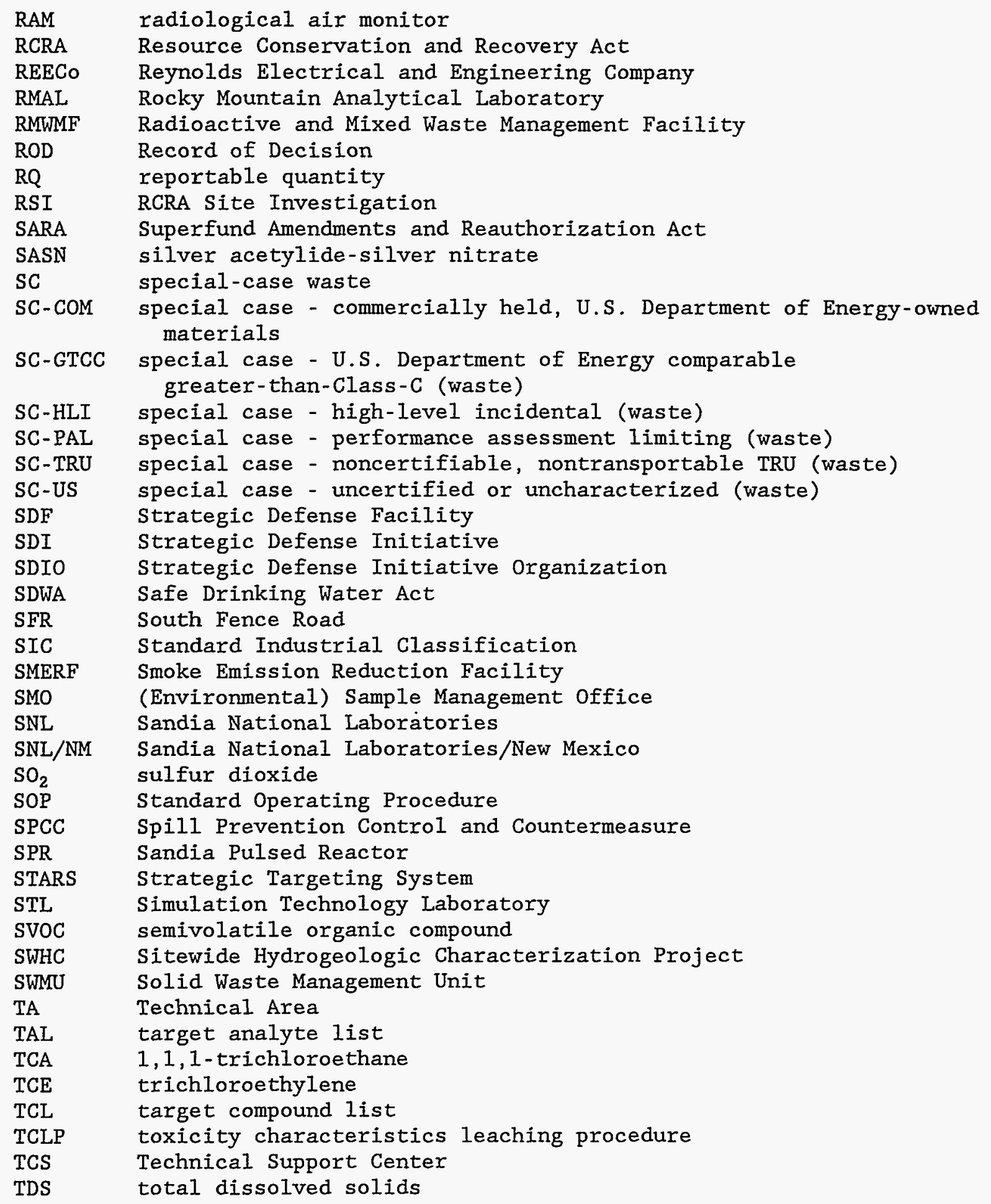




\section{ABBREVIATIONS \\ (Concluded)}

\section{Acronyms}

$\begin{array}{ll}\text { TLD } & \text { thermoluminescent dosimeter } \\ \text { TOC } & \text { total organic carbon } \\ \text { TOX } & \text { total organic halogen } \\ \text { TPH } & \text { total petroleum hydrocarbons } \\ \text { TRI } & \text { toxic chemical release } \\ \text { TRU } & \text { transuranic } \\ \text { TSCA } & \text { Toxic Substances Control Act } \\ \text { TSDF } & \text { treatment, storage, and disposal facility } \\ \text { TSP } & \text { total suspended particulates } \\ \text { TSS } & \text { total suspended solids } \\ \text { TTCE } & \text { tetrachloroethane } \\ \text { TTF } & \text { Thermal Treatment Facility } \\ \text { TTO } & \text { total toxic organics } \\ \text { TTR } & \text { Tonopah Test Range } \\ \text { USAF } & \text { U.S. Air Force } \\ \text { USC } & \text { United States Code } \\ \text { USEC } & \text { U.S. Enrichment Corporation } \\ \text { USGS } & \text { U.S. Geological Survey } \\ \text { USNRC } & \text { U.S. Nuclear Regulatory Commission } \\ \text { UST } & \text { underground storage tank } \\ \text { VOC } & \text { volatile organic compound } \\ \text { WAC } & \text { waste acceptance criteria } \\ \text { WIPP } & \text { Waste Isolation Pilot Plant } \\ \text { WIPPWAC } & \text { Waste Isolation Pilot Program Waste Acceptance Criteria } \\ \text { WMin } & \text { waste minimization } \\ \text { WMin/PP } & \text { Waste Minimization/Pollution Prevention } \\ \text { WMOA } & \text { Waste Minimization Opportunities Assessment } \\ & \end{array}$




\subsection{INTRODUCTION}

\subsection{SITE OPERATION}

Sandia National Laboratories/New Mexico (SNL/NM) is operated by Sandia Corporation, a prime contractor of the U.S. Department of Energy (DOE). Sandia Corporation is a subsidiary of Martin Marietta Corporation. The major responsibilities are national security and energy projects (ERDA 1977). SNL/NM's mission includes the weaponization of nuclear explosives and the designing of arming, fusing, and firing systems used in nuclear bombs and warheads. Safety, reliability, and survivability of weapon systems receive primary emphasis.

Other projects include nuclear reactor safety studies for the U.S. Nuclear Regulatory Commission (USNRC), development of safe transport and storage systems for special nuclear materials including plutonium (Pu) and uranium (U), radioactive waste disposal techniques and site studies, pulsed power research, thermonuclear fusion research, solar energy research, environmental technologies research, and fossil fuel and geothermal energy research.

\subsection{LOCATION AND POPULATION}

SNL/NM is located in Bernalillo County at the foot of the Manzano Mountains adjacent to Albuquerque, NM (Figure 1-1). At their nearest points, SNL/NM facilities are $2-1 / 2$ miles (mi) (4.0 kilometers [km]) south of Interstate 40 and approximately $6.5 \mathrm{mi}(10.5 \mathrm{~km})$ east of downtown Albuquerque. The facilities are surrounded by Kirtland Air Force Base (KAFB) East, with co-use agreements on some U.S. Air Force (USAF) property. An area of the Manzano Mountains east of KAFB has been withdrawn from the U.S. Forest Service for the exclusive use of the Air Force and the DOE.

The laboratory consists of five technical areas and several remote test areas situated in the eastern half of the 118-square-mile $\left(\mathrm{mi}^{2}\right)$ (190-square-kilometer $\left[\mathrm{km}^{2}\right]$ ) KAFB military reservation. KAFB is located on two broad mesas bisected by the Tijeras Arroyo, an east/west canyon. These mesas are bound by the Manzano Mountains (Cibola National Forest) to the east and the Rio Grande to the west. Elevations range from 4,921 feet ( $\mathrm{ft}$ ) (1,500 meters [m]) at the Rio Grande to $10,680 \mathrm{ft}(3,255 \mathrm{~m})$ at Sandia Crest, which is in the Sandia Mountains adjacent to Albuquerque. KAFB is at a mean elevation of $5384 \mathrm{ft}(1630 \mathrm{~m})$.

The largest population center in Bernalillo County, and also the closest population center to KAFB, is Albuquerque, located slightly north of the base. The 1990 census figures show an Albuquerque population of 384,736 (U.S. Department of Commerce [DOC], Bureau of the Census, 1991). The Isleta Indian Pueblo, which borders KAFB on the south, is the next nearest population center with a 1980 census of 1872. An estimated total population of 578,313 people live within a $50-\mathrm{mi}(80-\mathrm{km})$ radius of KAFB (DOC 1991). This includes permanent residents of $\mathrm{KAFB}$ living in the KAFB housing areas. 


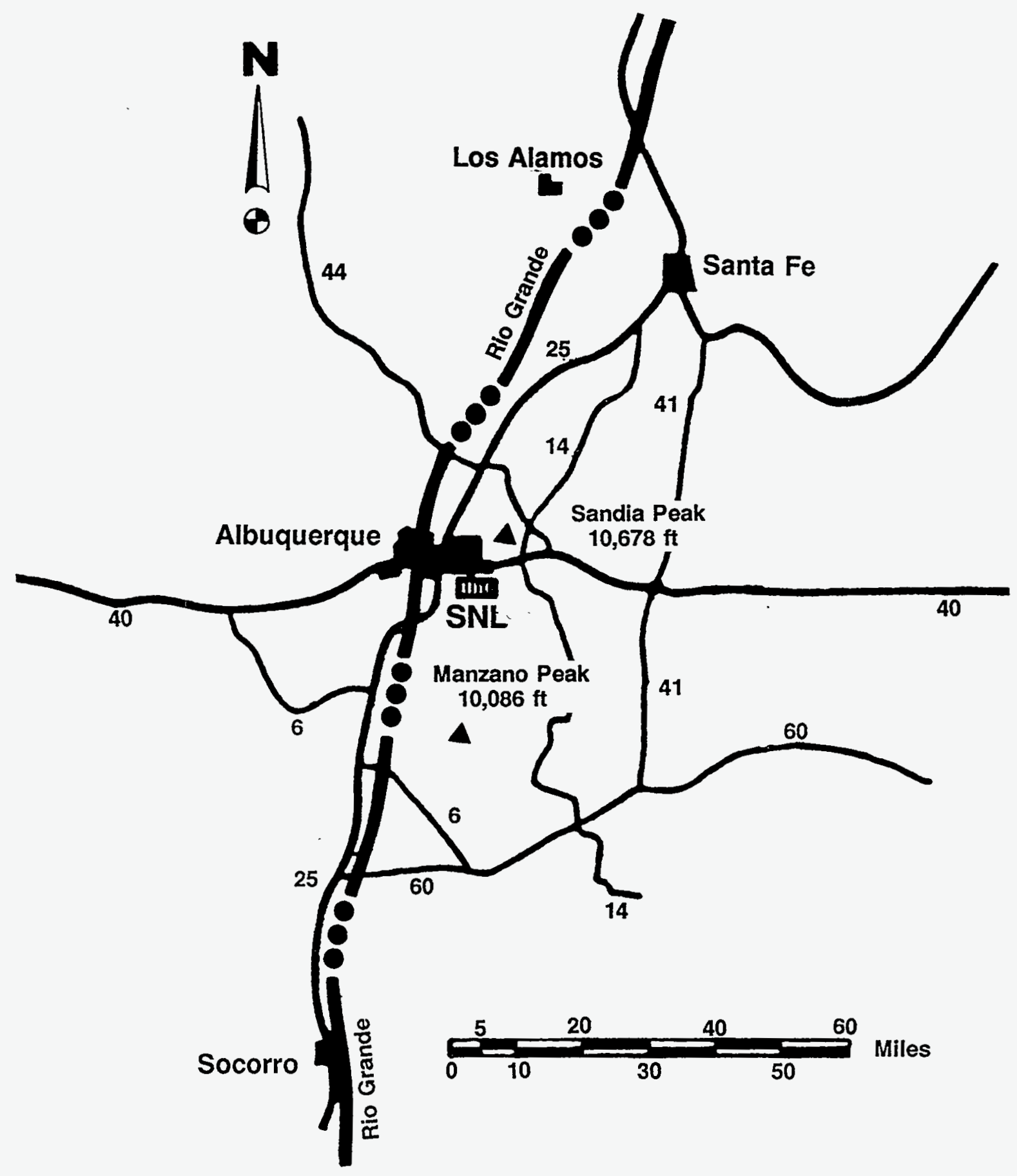

Figure 1-1. Albuquerque Site Regional Setting 


\subsection{CLIMATE AND METEOROLOGY}

The Albuquerque-Belen Basin is characterized by low precipitation; wide temperature extremes; frequent, drying winds; heavy rain showers, usually short in duration and often with erosive effects; and erratic, seasonal distribution of precipitation. Albuquerque air temperatures are characteristic of high-altitude, dry continental climates. Daytime temperatures during the winter average about 50 degrees Fahrenheit $\left({ }^{\circ} \mathrm{F}\right)$ (10 degrees Celsius $\left[{ }^{\circ} \mathrm{C}\right]$ ), and summer daytime temperatures average $<90^{\circ} \mathrm{F}\left(32^{\circ} \mathrm{C}\right)$, except in July, when the maximum reaches $93^{\circ} \mathrm{F}\left(34^{\circ} \mathrm{C}\right.$ ) (see Appendix A, Table A-1). The average annual precipitation is 8.2 inches (in.) (21 centimeters [cm]); half of this precipitation occurs from July through september in the form of brief thundershowers. Winter months are typically dry with $<2.0$ in. $(5 \mathrm{~cm})$ of precipitation normally recorded. The average annual relative humidity is $\sim 43$ percent (see Appendix A, Table A-2). Strong winds, often accompanied by blowing dust, occur mostly in late winter and early spring.

Table 1-1 summarizes meteorological data taken from the Albuquerque International Airport in 1993. The 30-year (yr) annual average precipitation is 8.0 in. $(20.6 \mathrm{~cm}$ ) (see Appendix A, Table A-1).

Table 1-1. Summary Meteorological Data for the Albuquerque Area in 1993

Temperature $\left({ }^{\circ} \mathrm{C}\right) \quad$ Precipitation $(\mathrm{cm})$

Wind $(\mathrm{m} / \mathrm{s})$

Month

Mean High Low

Mean Maximum Direction

$\begin{array}{lrllllll}\text { January } & 4.3 & 15.6 & -9.4 & 2.39 & 2.6 & 20.1 & \mathrm{E} \\ \text { February } & 5.8 & 18.9 & -6.7 & 4.62 & 3.1 & 22.8 & \mathrm{SW} \\ \text { March } & 9.3 & 24.4 & -8.9 & 0.56 & 3.4 & 19.2 & \mathrm{SW} \\ & & & & & & & \\ \text { April } & 13.9 & 30.0 & -2.2 & \mathrm{~T} & 3.2 & 23.3 & \mathrm{~W} \\ \text { May } & 18.7 & 33.9 & 1.7 & 0.51 & 3.7 & 21.5 & \mathrm{~S} \\ \text { June } & 23.9 & 37.8 & 8.3 & 1.12 & 3.7 & 30.0 & \mathrm{NW} \\ & & & & & & & \\ \text { July } & 26.6 & 37.8 & 15.0 & 0.58 & 3.4 & 21.9 & \mathrm{NE} \\ \text { August } & 24.2 & 36.1 & 13.9 & 7.75 & 3.1 & 24.1 & \mathrm{~N} \\ \text { September } & 20.6 & 32.2 & 6.7 & 1.24 & 3.6 & 25.0 & \mathrm{NW} \\ & & & & & & & \\ \text { October } & 13.4 & 30.6 & -3.9 & 1.63 & 3.8 & 19.7 & \mathrm{E} \\ \text { November } & 6.3 & 20.6 & -7.2 & 2.46 & 3.7 & 24.6 & \mathrm{~W} \\ \text { December } & 2.9 & 16.1 & -10.6 & 0.08 & 3.4 & 21.0 & \mathrm{~W}\end{array}$




\subsection{GEOLOGY}

The Albuquerque Basin is a north/south-trending basin located within the Rio Grande Rift Zone (Figure 1-2). The uplifted fault blocks of the Sandia and Manzano mountains comprise the eastern basin boundary. The west side of the basin is bounded by the Nacimiento Uplift, the Lucero Uplift, and the Ladron Mountains. During the Miocene and Pliocene, the basin filled with as much as $12,000 \mathrm{ft}(3,650 \mathrm{~m})$ of sediments eroded from the surrounding highlands. This sequence, the Santa Fe Group, thins toward the edge of the basin where it is truncated at the bounding uplifts. Santa Fe Group sediments are overlain in places by the Pliocene Ortiz gravel and Rio Grande fluvial deposits and are interbedded with Tertiary and Quaternary basalts and pyroclastics. Basin-fill alluvial fans of the Santa $\mathrm{Fe}$ Group consist of channel, debris flow, floodplain, and interlayered eolian deposits. Grain sizes range from clay to boulders with moderately well developed stratification and some graded bedding. Bed thickness varies from inches to feet and most of the bedding is thought to be lenticular with limited areal extent, although buried channels can extend downdip (westward) for long distances.

The geology underlying the eastern section of KAFB includes major faulting (Figure 1-3). The younger (Tertiary age) Hubbell springs and Sandia faults are north/south-trending, down-to-the-west, en echelon faults (Lozinsky et al. 1991; Woodward 1982; Kelley and Northrop 1975). The Hubbell springs fault extends northward from Socorro County, NM, to the southern portion of KAFB. The Sandia fault is thought to be the primary boundary between the Sandia Mountains uplift and the main Albuquerque basin, and may actually be an extension of the Hubbell Springs fault (Kelly 1977). The Tijeras fault is a scissors-type fault of Precambrian origin with left-lateral offset that appears to be downthrown to the southeast near the Four Hills area of KAFB as a result of Cenozoic movement (Kelley and Northrop 1975) and is assumed to be the boundary between the Sandia and Manzano uplifts. The Tijeras, Sandia, and Hubbell Springs faults probably converge near the Chemical Waste Landfill (CWL) at SNL/NM Technical Area III (TA-III).

\subsection{HYDROLOGY}

\subsubsection{Groundwater Hydrology}

The fault complex separates the regional aquifer system into a deeper zone west of the faults and a relatively shallower zone east of the faults. The depth to groundwater underlying SNL/NM facilities varies from $\sim 50$ to $100 \mathrm{ft}$ (15 to $30 \mathrm{~m}$ ) east of the faults and from $\sim 380$ to $\sim 500 \mathrm{ft}(116$ to $153 \mathrm{~m})$ west of the faults. The hydrogeology east of the faults is poorly understood because there are few wells and the geology between the faults and the canyons of the Manzanita Mountains is complex. Most of the water supply and the majority of the monitoring wells east of the faults are located in fractured bedrock with modest yields. Groundwater typically flows out of the canyons and westward toward the fault complex. Titus (1963), in describing flow across the ojuelos fault in Valencia County, goes so far as to say, "As water moves across the fault into the more permeable rocks of the Santa $\mathrm{Fe}$, it cascades abruptly to the lower level within a short distance." On KAFB, a change in the water surface elevation of over $700 \mathrm{ft}(213 \mathrm{~m})$ has been observed in a $2-\mathrm{mi}(3-\mathrm{km})$ distance (from Explosive Ordnance Detonation [EOD] Hill west to the CWL), 


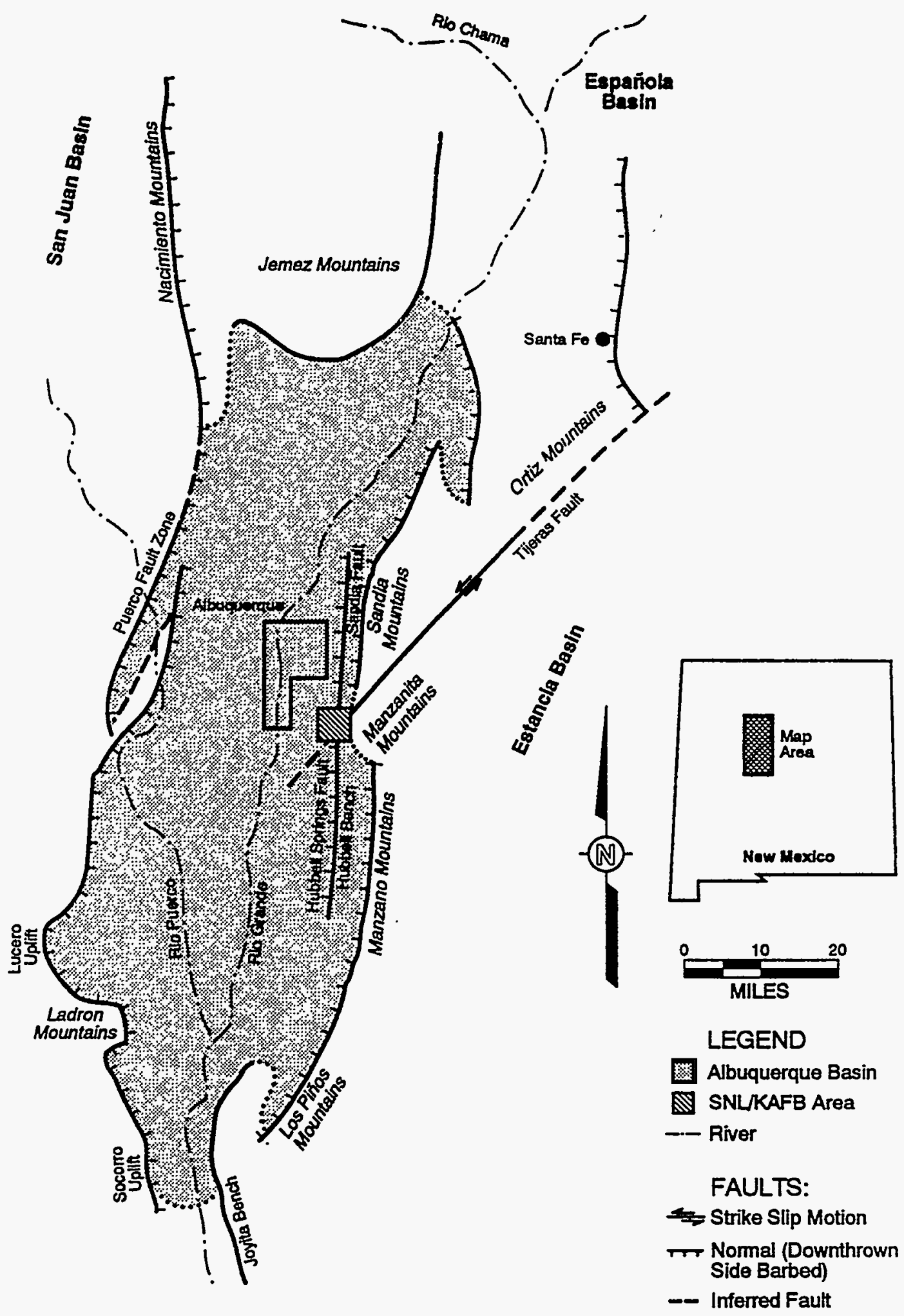

Figure 1-2. Albuquerque Basin of North Central New Mexico (Kelley and Northrup 1975) 


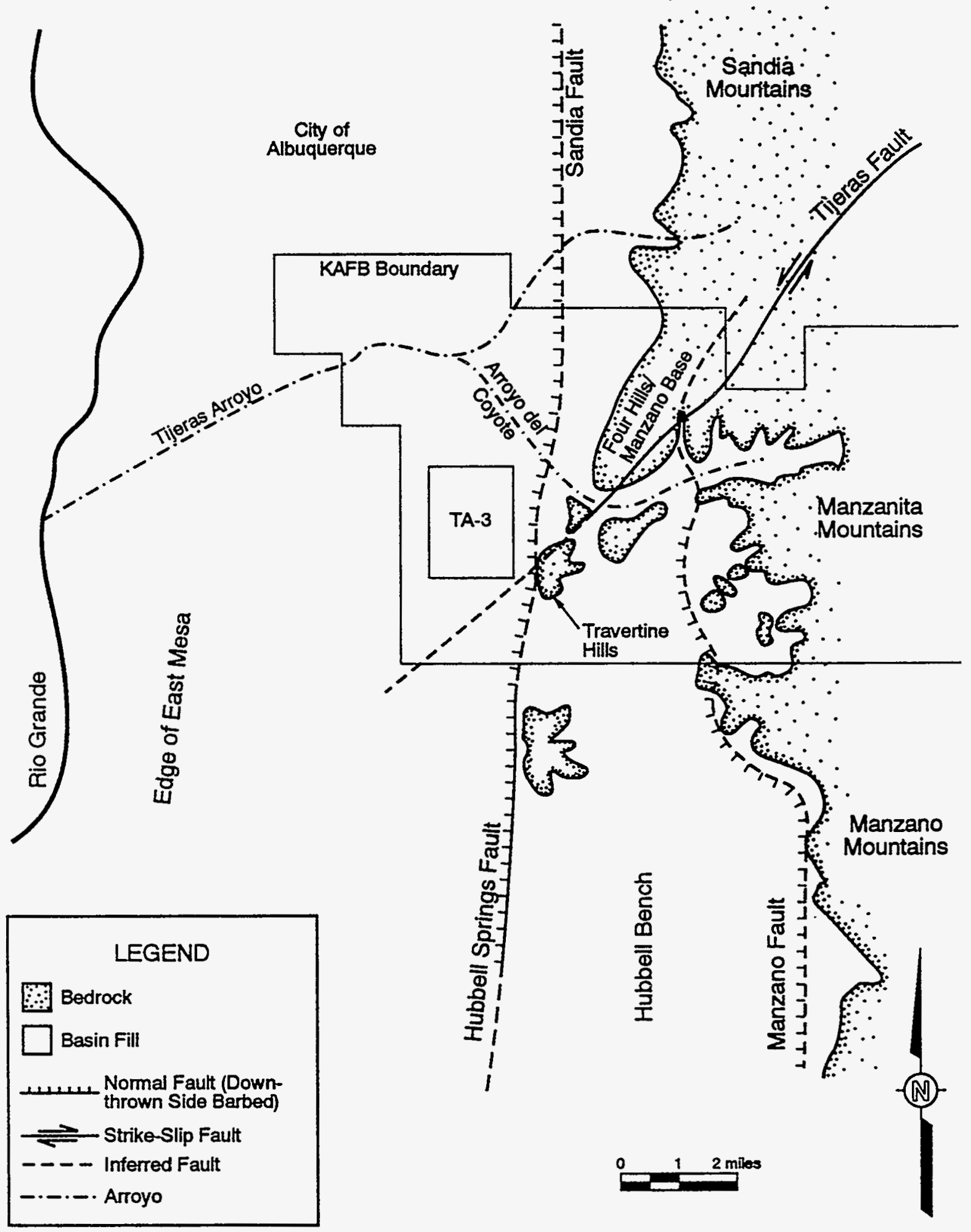

Figure 1-3. Generalized Geology in the Vicinity of Sandia National Laboratories/New Mexico and Kirtland Air Force Base. Areas of bedrock outcrop, major drainages, faults, and landforms are indicated (Grant 1982). 
resulting in a hydraulic gradient of $\sim 0.07$. West of the faults, the hydraulic gradient decreases to $\sim 0.005$ and the depth to bedrock increases rapidly. The apparent direction of groundwater flow is generally westward (toward the Rio Grande) but trends more northward as one approaches the KAFB pumping wells. Although the impact of the KAFB wells (and nearby City of Albuquerque wells) is shown by the fluctuations in monitoring well water levels at the KAFB Sanitary Lagoons, the radial extent of the cone of depression is not clear at this time.

\subsubsection{Surface-Water Hydrology}

The major surface hydrologic feature in central New Mexico is the Rio Grande, which flows north to south through Albuquerque and lies $\sim 6 \mathrm{mi}(10 \mathrm{~km})$ west of KAFB. Rio Grande water is primarily used for irrigation of agricultural crops . There are no continuously running streams on SNL/NM property, although there are two perennial springs (Coyote and Sol se Mete) on KAFB and one (Hubbell Springs) on Isleta Pueblo south of KAFB. The two primary surface channels at SNL/NM are Tijeras Arroyo and the smaller Arroyo del Coyote (Figure 1-3). Arroyo del Coyote joins Tijeras Arroyo $\sim 1 \mathrm{mi}(2 \mathrm{~km})$ west of the Tijeras Arroyo Golf Course; both flow intermittently during heavy summer thundershowers. Tijeras Arroyo (above the confluence with Arroyo del Coyote) drains $\sim 80 \mathrm{mi}^{2}$ $\left(208 \mathrm{~km}^{2}\right.$ ) ; Arroyo del Coyote (above the confluence with Tijeras Arroyo) drains $\sim 27 \mathrm{mi}^{2}\left(70 \mathrm{~km}^{2}\right.$ ) (U.S. Army Corps of Engineers 1979). Neither drainage is viewed as a significant flood hazard, and any impact on groundwater resources from flooding would likely be minimal. All active SNL/NM facilities are located well outside the 500-yr floodplain described by the U.S. Army Corps of Engineers (1979) for both arroyos. The extent of infiltration (and potential groundwater recharge) in the primary surface channels is currently unknown.

\subsection{BIOLOGY}

The semidesert Southwest climate produces low surface-water availability, resulting in many species of drought-resistant flora such as grasses and cacti (ERDA 1977). The mesa vegetation on KAFB, consisting of grasses and shrubs, is illustrated in Figure 1-4. Figure 1-5 shows juniper trees and cacti that are present at the higher elevations bordering the mountains east of KAFB. Russian thistle (tumbleweeds) proliferate in mechanically disturbed areas. The City of Albuquerque, adjacent to KAFB, has flora typically found in urban environments.

\subsection{TECHNICAI AREAS}

SNL/NM consists of five technical areas and several additional test areas (Figure 1-6). Each area has its own distinctive operations. The following paragraphs describe the activities in each area and summarize potential sources for radioactive and nonradioactive effluent releases.

TA-I (Figure 1-7) has the largest employee population ( 5000). This area is dedicated primarily to three activities: the design, research, and development of weapon systems; limited production of weapon system components; and energy programs. TA-I also includes the main library and offices, laboratories, and shops used by administrative and technical staff. Generally, the only potential radioactive releases in TA-I are tritium (H-3) from two laboratory 


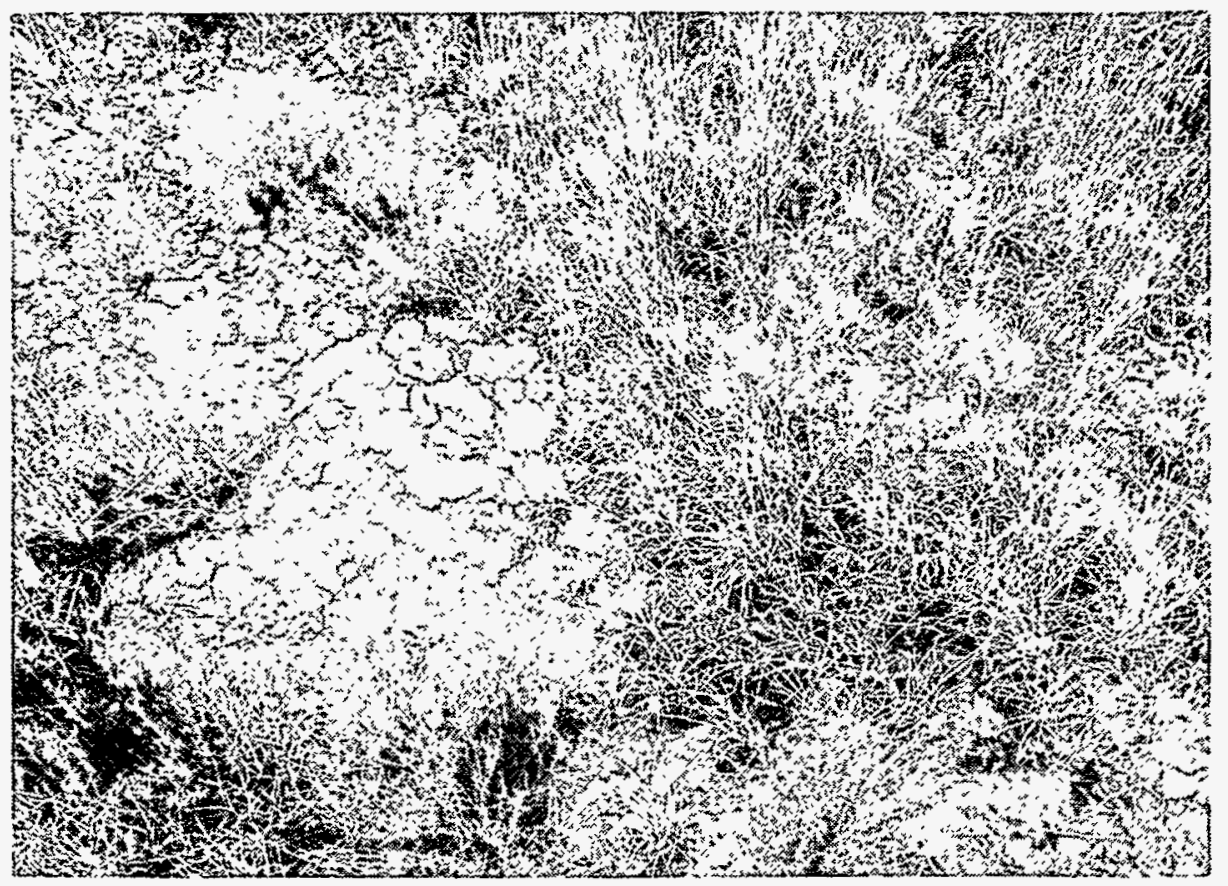

Figure 1-4. Mesa Vegetation

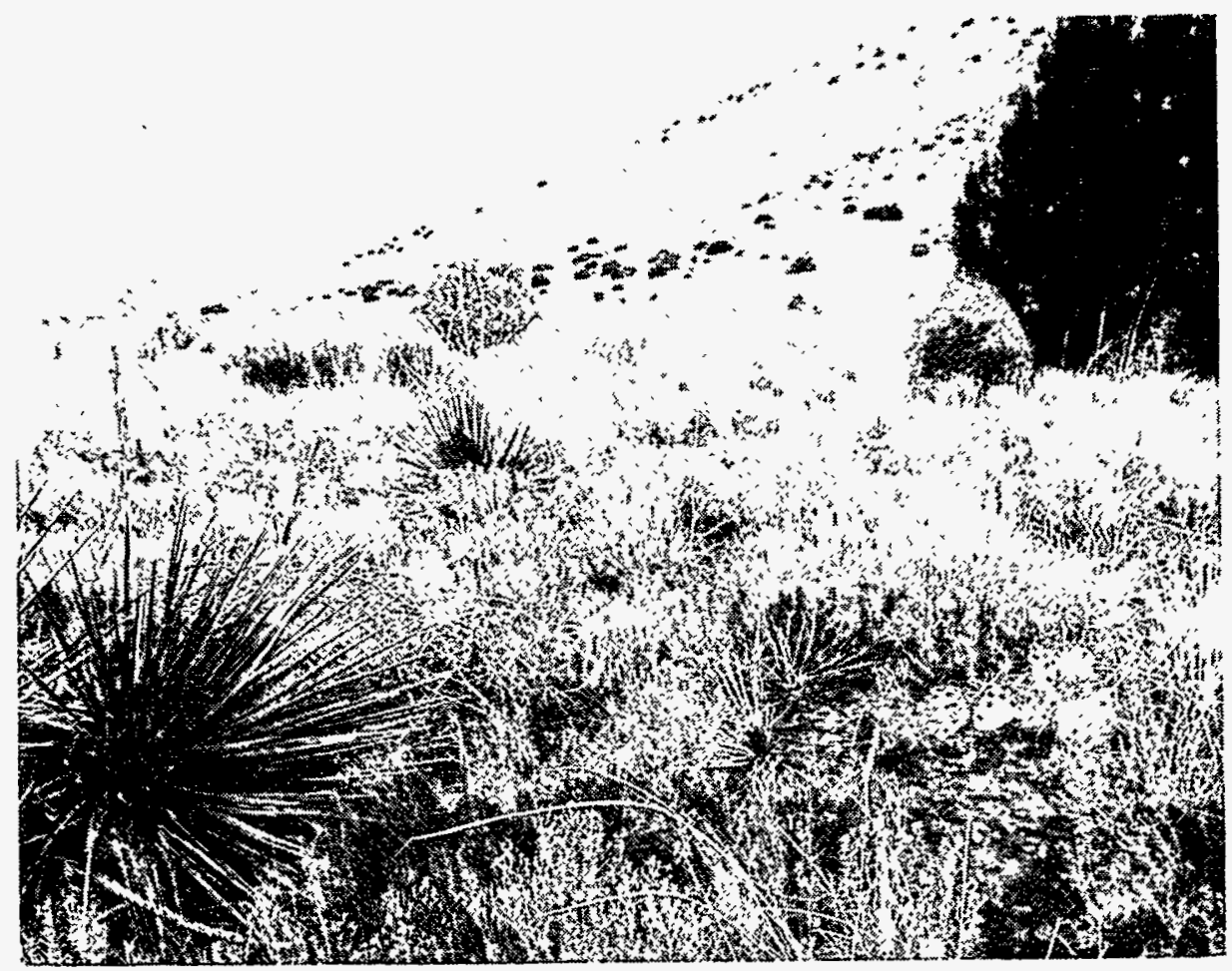

Figure 1-5. Manzano Foothills Vegetation 


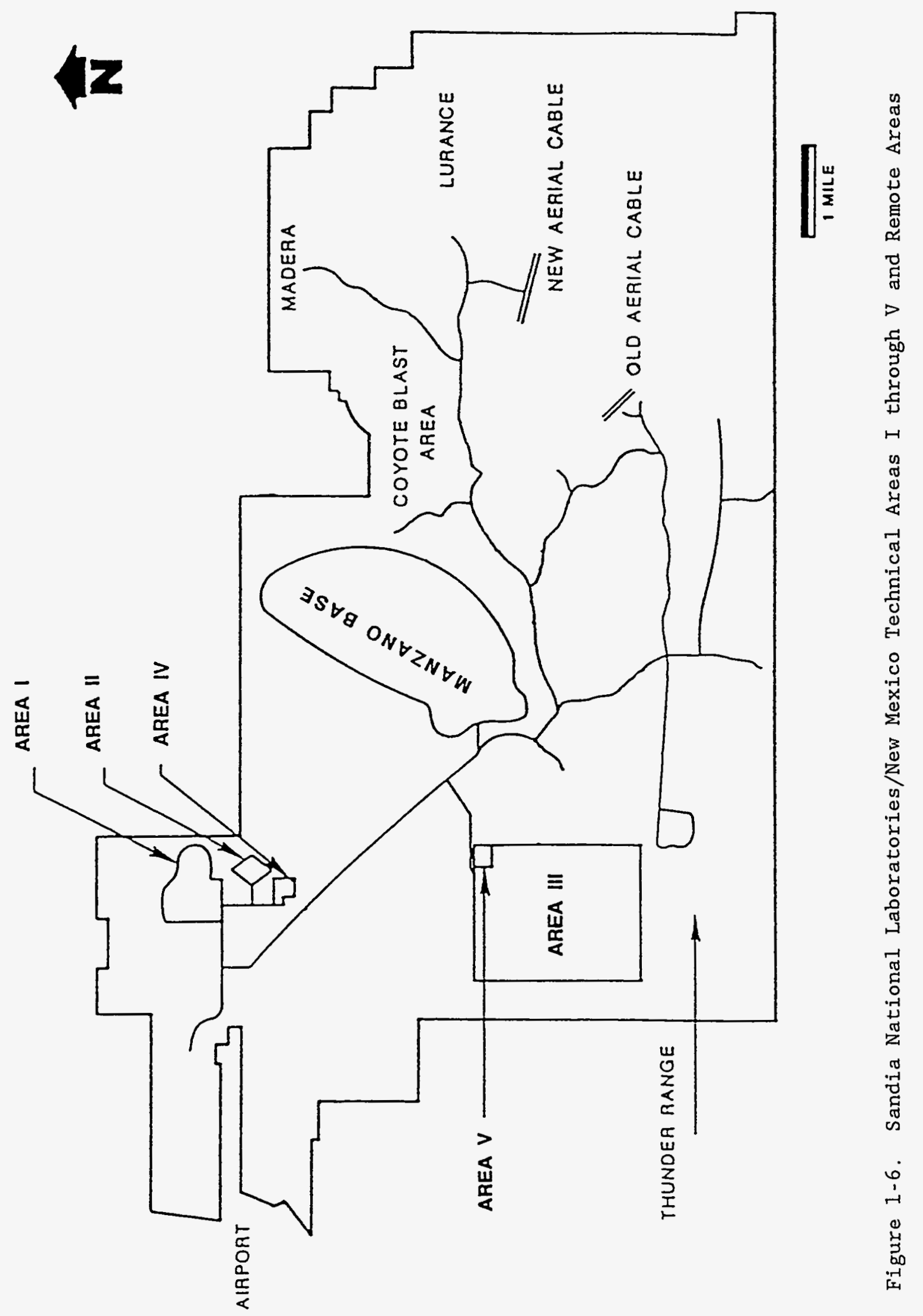




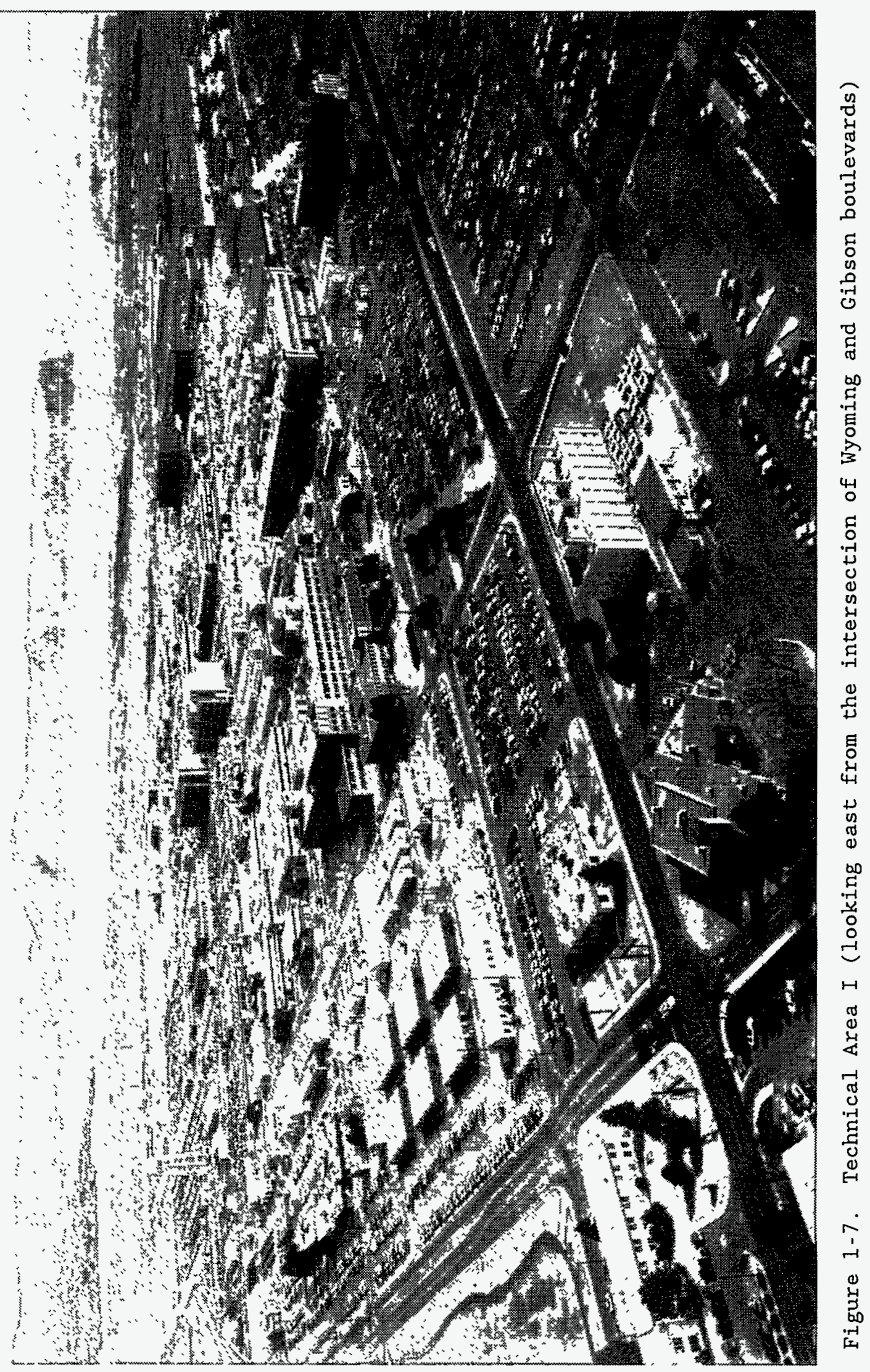


sources and activation products (such as argon-41 [Ar-41], nitrogen-13 [N-13], and oxygen-15 (0-15]) from two small accelerators. Only small quantities of activation products are released from these stacks annually. Potential sources for nonradioactive effluents include the paint shops, process development laboratory, emergency diesel generator plant, solvent spray booth, foundry, and steam plant.

TA-II (the diamond-shaped area in Figure 1-8) is a small area used for explosive testing. Microcurie ( $\mu \mathrm{Ci}$ ) amounts of $\mathrm{H}-3$ may be released each year from component testing. Techniques for measuring fractures in geologic strata are developed at this facility. Also located in TA-II are an inactive low-level radioactive waste (LLW) disposal site, a small radioactive material decontamination and storage facility (Building 906), and a storage facility designed to temporarily hold polychlorinated biphenyl (PCB)-contaminated materials to be transported to an EPA-Iicensed disposal facility. The inactive LLW disposal site has not been used for over $20 \mathrm{yr}$. A new facility, the Explosive Components Facility (ECF), is planned to replace TA-II. This facility will integrate many of the existing TA-II activities, as well as some remote testing activities currently performed in other test areas.

TA-III (Figure 1-9) is located adjacent to and south of TA-V, $5 \mathrm{mi}(8 \mathrm{~km}$ ) south of TA-I. It is comprised of 20 test facilities which include extensive environmental test facilities (such as sled tracks, centrifuges, and a radiant heat facility). No radioactive effluents are released through normal operations in the area with the exception of small quantities of depleted uranium associated with sled track testing. Other facilities in TA-III include a paper incinerator, an inactive $L L W$ and mixed waste (MW) disposal site, and a melting and solidification laboratory. The inactive radioactive waste disposal site in TA-III consists of two adjoining fenced areas that occupy $\sim 1.5$ acres (ac) ( 0.6 hectares [ha]) (SNL 1989). One area was used for LLW disposal in seven shallow trenches. The second area was used for disposal of classified LLW in 37 pits. LLW consisted primarily of H-3-contaminated materials. Three additional pits located in the classified waste disposal area were used exclusively for natural and depleted uranium (DU) waste disposal. The site is currently used as an interim storage facility for radioactive and MW.

An inactive hazardous-waste disposal and storage site is also located near the southern boundary of TA-III. This facility has not been used for disposal of hazardous wastes since November 7, 1985. It was used as an interim hazardous waste storage area from 1985 to 1988. A closure plan and post-closure permit application were prepared in May 1988. The newer hazardous waste repackaging and storage building, located south of TA-I, has been in use since 1988 .

TA-IV (Figure 1-8) consists of several inertial-confinement fusion research and pulsed-power research facilities. One large accelerator, the Particle Beam Fusion Accelerator-II (PBFA-II), was completed in 1985. A large accelerator facility, the Simulation Technology Laboratory (STL), houses seven pulsed-power accelerators: HERMES-III, RLA, TROLL, STF, SPEED, HYDRAMITE, and PROTO II. Several of these accelerators have been transferred from TA-V. HERMES-III became operational in 1988. Another accelerator facility, SATURN, was completed in 1987. During 1993, radioactive emissions from TA-IV were short-lived radionuclides, primarily $\mathrm{N}-13$ and $0-15$. 


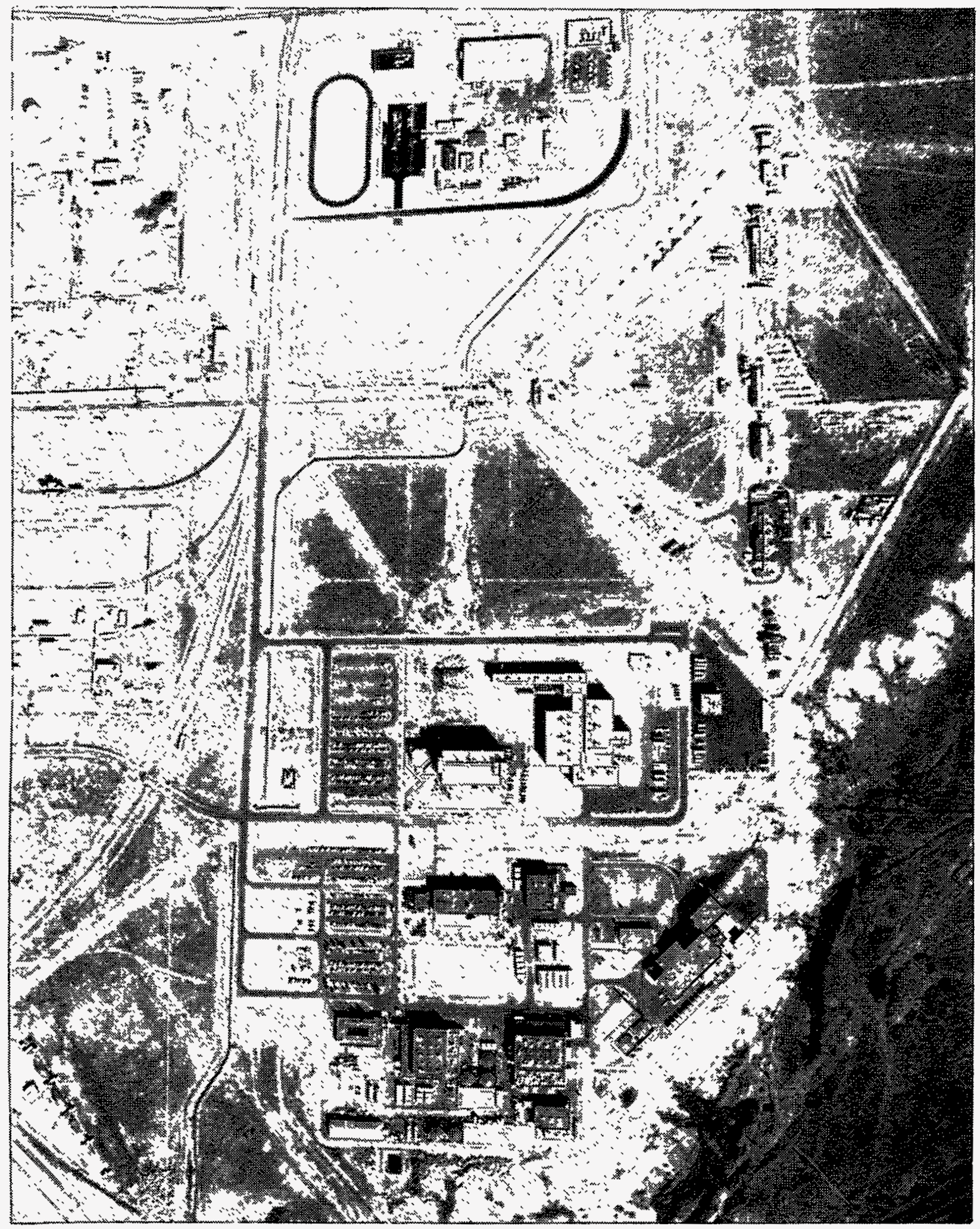

Figure 1-8. View of Technical Areas II and IV 


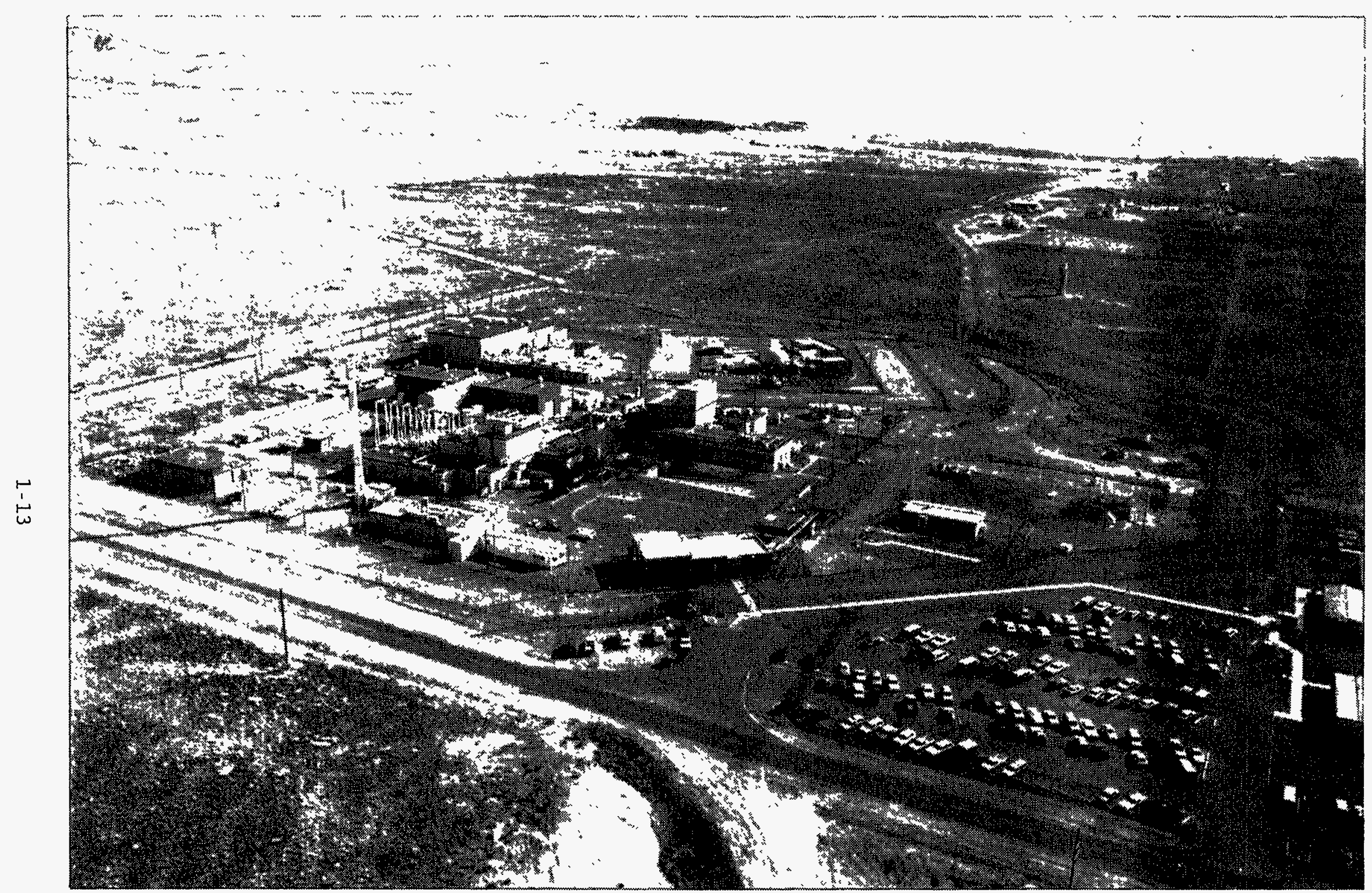

Figure 1-9. Technical Area $\mathrm{V}$ and a Portion of Technical Area III (looking toward the southeast with the solar tower in the distance) 
TA-V (Figure 1-9) houses two research reactors in two reactor facilities, an intense gamma irradiation facility (using cobalt-60 [Co-60] and cesium-137 [Cs137]), and a hot cell facility.

The two research reactor facilities in $\mathrm{TA}-\mathrm{V}$ are small and quite dissimilar: the Sandia Pulsed Reactor (SPR) is an unreflected, unmoderated assembly of enriched $U$; the Annular Core Research Reactor (ACRR) consists of an annular core of 226 fuel elements in an open water tank. Both the SPR and ACRR air exhaust systems are equipped with particulate effluent samplers. The ACRR also has a continuous gaseous effluent monitor. The only airborne releases are air activation products from reactor operations primarily composed of Ar-41 and xenon-133 (Xe-133). The reported amount of Ar-41, released from both reactor areas, was computed from reactor operating parameters.

\subsection{REMOTE TEST AREAS}

SNL/NM also has test areas outside the five technical areas. These areas are located south of TA-III and in canyons on the west side of the Manzano Mountains. Coyote Canyon and Thunder Range are two examples of such areas. In these remote areas, wild animals, including snakes, deer, coyotes, and owls, are often present. Figure 1-10 shows the Main Burn Site located in the Coyote Canyon remote area.

DU was used in the past for explosive testing in these remote areas. The test areas were surveyed following each test, and contaminated materials were collected and disposed of in accordance with DOE requirements. Environmental monitoring is done as necessary. Operations in these areas are administratively controlled to avoid $U$ contamination to public areas beyond the confines of KAFB. 


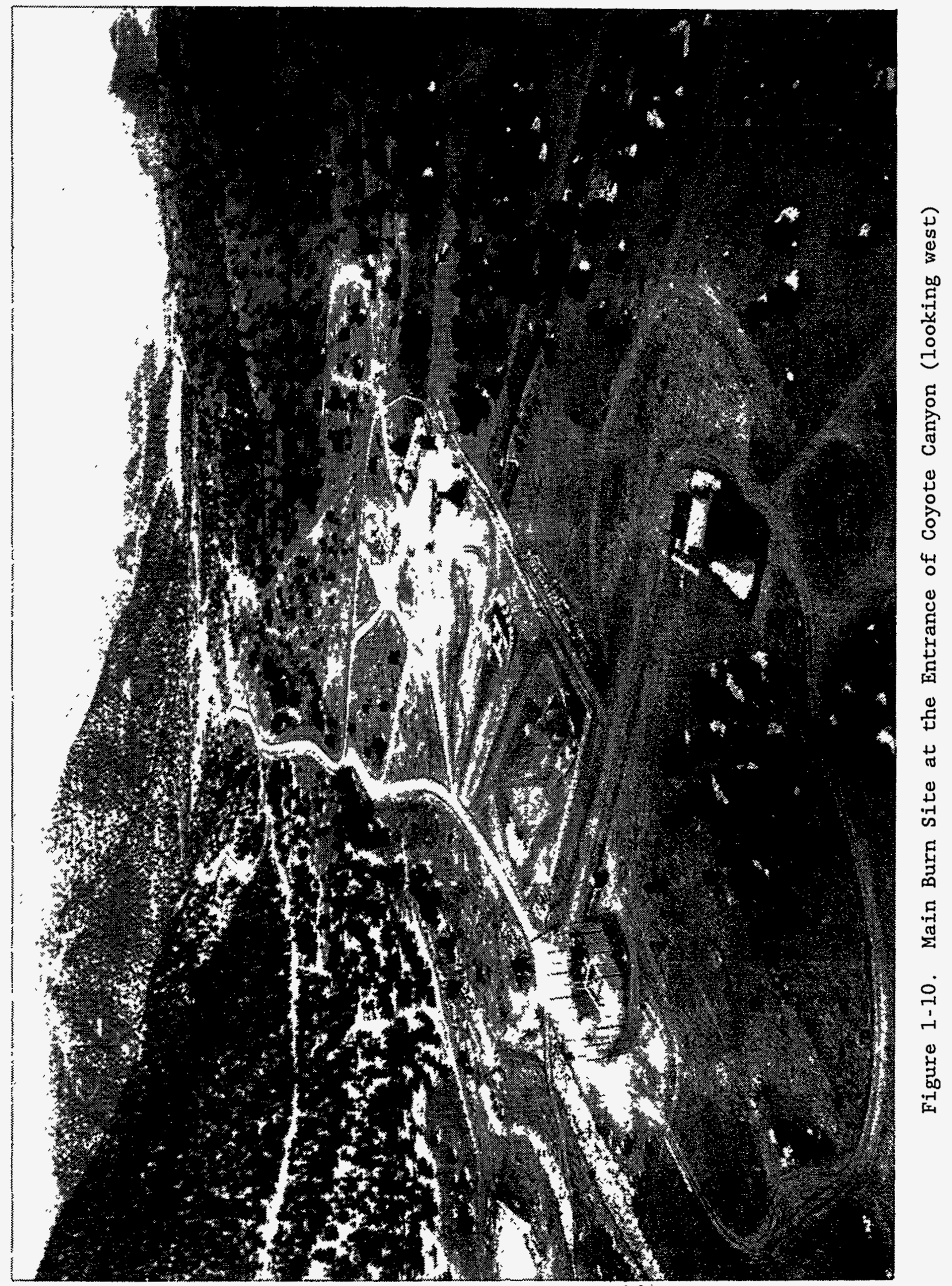




\subsection{COMPLIANCE SUMMARY}

\subsection{COMPLIANCE REGULATIONS}

Comprehensive Environmental Response Compensation and Liability Act (CERCLA): CERCLA and the Superfund Amendments and Reauthorization Act (SARA) define certain assessment activities and reporting requirements for all federal facilities. As required, CERCLA Section 103(c) (DOE 1989a) notifications were provided to the U.S. Environmental Protection Agency (EPA). Based on the Preliminary Assessment/Site Inspection (PA/SI) performed in 1988 and required by SARA $120(\mathrm{c})$, the EPA has determined that none of the Sandia National Laboratories/New Mexico (SNL/NM) inactive waste sites qualifies for the EPA list of high priority cleanups (i.e., none of the sites are on EPA's National Priorities List [NPL]). With respect to the SNL/NM inactive waste sites that are on Kirtland Air Force Base (KAFB), no other CERCLA or SARA activities are required. On October 1, 1992, SNL/NM submitted a National Pollutant Discharge Elimination System (NPDES) permit application for its storm water discharges.

In 1993, one reportable quantity release was reported. It was caused by a spill of waste material generated by a paint stripping operation on the roof of Building 807, Technical Area I (TA-I). The waste material (copper dust mixed with lead paint dust) was found on the roof and on the ground where the container bags were stored.

Resource Conservation and Recovery Act (RCRA). Environmental Restoration (ER) Project: The potential release sites identified by the ER Project for facilities at SNL/NM will be evaluated and corrected as required by RCRA 3004(u). Corrective actions (CAs) for releases from Solid Waste Management Units (SWMUS) are a part of the Hazardous and Solid Waste Amendments (HSWA) module R.CRA Part B permit, issued August 26, 1993.

SNL/NM has an inactive Chemical Waste Landfill (CWL) that was issued an interim status in 1985. A closure plan was developed for this site following the requirements described in RCRA 40 CFR Part 265. Due to the discovery of trichloroethylene (TCE) at levels slightly above the EPA's drinking water standard in groundwater 500 feet beneath the site, a corrective action plan for remediation of the volatile organic compounds (VOCs) was incorporated into the closure plan, entitled "The Chemical Waste Landfill Closure Plan and PostClosure Permit Application" (SNL 1991a). This plan was approved by the New Mexico Environment Department (NMED) in May 1993.

Regulatory interactions that have occurred at this site since granting of the interim status and initiation of the closure process can be summarized as follows:

1. In May 1988, NMED issued a groundwater monitoring compliance order which was followed by a compliance agreement in December 1989. In general, the compliance order required revisions to the supply plan and further groundwater characterization work.

2. In September 1992, NMED issued a Notice of Violation (NOV) to SNL/NM indicating that the CWL Closure Plan failed to meet the requirements 
of 40 CFR 265.111 (HWMR-6, Part VI, Section 265.111) with respect to not including more groundwater characterization activities. More specifically, the NMED wanted more wells installed and aquifer tests performed. SNL/NM and the U.S. Department of Energy (DOE) agreed to perform the work.

In January 1990, the State of New Mexico adopted the federal underground storage tank (UST) regulations ( $40 \mathrm{CFR} 280$ ), basing the State's regulations on the age of the USTs rather than depth to groundwater. At present, 40 tanks have been removed, and the 24 remaining USTs are registered with the NMED.

RCRA, Hazardous Waste Management: SNL/NM is a large-quantity generator and a permitted storage and treatment facility managed by the Chemical Waste Management Department. On January 25, 1993, NMED issued a Class 1 modification of the RCRA storage permit for the Hazardous Waste Management Facility (HWMF) primarily to correct typographical errors in the original permit.

Revision 6.0 of the RCRA treatment permit application for the Thermal Treatment Facility (TTF) was submitted to the NMED on March 31, 1993. In response to technical deficiencies of the application, Revision 6.1 was submitted to NMED on June 14, 1993. NMED issued a draft treatment permit for the TTF on November 15, 1993. A final permit will be issued in calendar year (CY) 1994 after public comments are heard and addressed.

NMED performs annual RCRA audits of the SNL HWMF and generator locations throughout SNL facilities. The NMED 1993 audit included NMED enforcement bureau personnel. NMED personnel spent five days auditing in all five technical areas. A Compliance Order was issued on September 8, 1993, 1isting eight violations. Four violations occurred at generator sites, three occurred at mixed waste (MW) storage areas, and one was found at the HWMF. The causes of the violations included open containers of hazardous waste, labeling errors, incomplete training, incomplete inspection data, and incomplete Land Disposal Restriction (LDR) forms. A civil penalty of $\$ 8,842.50$ was assessed. Corrective actions began immediately and SNL paid the penalty. NMED was satisfied by the response from SNL and closed out all violations.

RCRA. Mixed Waste Management: The State of New Mexico was granted regulatory authority for MW under RCRA on July 25, 1990. In August 1990, SNL/NM submitted a RCRA Part A permit application for MW to the NMED.

In October 1992, SNL/NM devised a permitting strategy for storage and treatment units that called for a phased submittal of the Part B permit application (i.e., a Part B permit application and two major amendments at specified intervals). The strategy was submitted to NMED in the form of a letter Agreement. The Part B permit application (the first submittal of the phased submittal) was submitted to NMED on schedule on November 8,1992 . The first amendment was submitted to NMED on schedule August 26, 1993. The second amendment is due to NMED on December 31, 1994. If further waste treatment units are required to meet RCRA LDRs, a third amendment will be considered for submittal by October 6, 1995, to permit these treatment units. 
In addition, the SNL/NM Part A permit application was revised to correct errors in the August 1990 Part A permit application, consolidate some storage units, add eight treatment processes, and assure comprehensive coverage of all MW expected to be managed at SNL/NM. Plans call for permitting $17 \mathrm{MW}$ storage units and 13 treatment processes. Twelve units included on the Part A permit application will be closed under interim status.

On December 30, 1992, the EPA, Region VI, issued a "Notification of Noncompliance and Necessity for Conference in Regard to the Land Disposal Restrictions for the United States Department of Energy, Sandia National Laboratories." The Notification of Noncompliance (NON) began the process toward full compliance with the LDRs at SNL/NM through a Federal Facilities Compliance Agreement. The DOE and SNL/NM took all the necessary steps to comply with the NON, beginning with a conference with EPA and NMED on April 26, 1993.

In October 1992, the Federal Facility Compliance (FFC) Act was enacted, amending RCRA. SNL began compiling the inventory that was required to be submitted within 180 days of enactment.

The process of negotiating a Federal Facilities Compliance agreement was cancelled by EPA on June 11, 1993, and replaced by a process developed by DOE for implementation of the October 1992 FFC Act. As part of the requirements of the FFC Act, SNL/NM submitted its MW inventory for the preliminary report required within 180 days of enactment and updated this inventory in November 1993 for the Final Mixed Waste Inventory Report (DOE 1993a). Also, as part of the FFC Act, the Conceptual Site Treatment Plan for SNL/NM MW (SNL 1993a) was submitted to NMED in October 1993.

National Environmental Policy Act of 1969 (NEPA): Since the issuance of the Secretary of Energy's NEPA Notice (SEN-15-90) of February 5, 1990, the promulgation of DOE's 1992 NEPA rule (10 CFR 1021), and the issuance of the revised DOE NEPA Order 5440.1E (DOE 1992a), the emphasis on NEPA reviews at SNL/NM has increased. DOE's commitment to infusing environmental values into DOE decision making and disclosing Federal activities through the NEPA process has resulted in an increase in the number of NEPA documents being written to cover SNL/NM's proposed actions. During 1993, SNL/NM NEPA compliance activities focused on several items:

- Fulfilling commitments made in the Final Action Plan to Tiger Team (SNL 1992a)

- Developing baseline information

- Developing the NEPA program

In 1993, NEPA compliance activities increased. Policies and procedures were further developed to ensure environmental values are considered as part of the review of SNL/NM proposed actions. A finding of no significant impact (FONSI) was issued after the satisfactory completion of the Environmental Assessment for the Radioactive and Mixed Waste Management Facility. The FONSI was published together with the Environmental Assessment (EA) in a single document (DOE 1991a). The NEPA Program also helped prepare the Environmental Assessment for the Purchase of Russian Low-Enriched Uranium Derived from the Dismantlement of Nuclear Weapons in the Countries of the Former Soviet Union (USEC 1994) for DOE Headquarters. 
The NEPA Program was responsible for the publication and distribution of two technical reports in early 1993:

1. "Sandia National Laboratories, New Mexico, Environmental Baseline Update" (SNL 1993b)

2. "Cultural Resources Regulatory Analysis, Area Overview, and Assessment of Previous Department of Energy and Kirtland Air Force Base Inventories for Sandia National Laboratories, New Mexico" (SNL 1993c)

More detailed information about the NEPA program may be found in section 3.5 .

Clean Air Act (CAA): For air quality compliance, SNL/NM is regulated by the new Clean Air Act Amendments (CAAA) standards and local regulations such as Air Quality Control Regulations (AQCR) for Albuquerque and Bernalillo County. SNL/NM periodically applies for open-burn permits (AQCR \#3), as well as topsoil disturbance permits (AQCR 非), for the control of airborne particulates. Other regulations such as AQCR 非 for visible air contaminants, AQCR 非l for volatile organic compounds, and AQCR 非15 through 非18 for emission standards of nitrogen dioxide $\left(\mathrm{NO}_{2}\right)$, sulfur dioxide $\left(\mathrm{SO}_{2}\right)$, and particulate matter (PM) from oil and gas burning equipment are also applied to SNL/NM on a source-specific basis.

SNL/NM also complies with the National Emission Standards for Hazardous Air Pollutants (NESHAP) for radionuclide air emissions (Subpart $\mathrm{H}$ ), beryllium (Be) air emissions (Subpart C), and asbestos emissions (Subpart M) (40 CFR 61). Other compliance mandates are found in Titles V and VI of CAAA. Title V of CAAA requires existing major sources/facilities to obtain "Operating Permits" as promulgated in $40 \mathrm{CFR} 70$ and AQCR 非1 (in draft). Title VI intends to protect the stratospheric ozone by limiting the usage of Class I and Class II ozone-depleting substances (ODSs) as promulgated in $40 \mathrm{CFR} 82$ and AQCR 非 37 .

Various inventories of air emissions were performed during the first quarter of 1994 for CY 1993: criteria pollutants, radionuclide emissions, ozone-depleting substances, and SARA Title III, Section 313, Toxic Chemical Releases. The criteria pollutant inventory will be based on AP-42 emission factors and calculations (EPA 1986a). The SARA Title III, Section 313, Toxic Chemical Releases, NESHAP radionuclides inventories, and associated annual reports will be submitted to the EPA. To date, the 1993 emissions are all in compliance with applicable standards.

During 1993, progress was made in the areas of compliance with NESHAP for radionuclides regarding the quality assurance (QA) plan and confirmatory measurement monitoring for significant sources. The stack monitoring system for the HERMES III accelerator facility was completed for design, installation, and testing in 1993. The evaluation of the existing systems in ACRR and HCF facilities was conducted and final sampling plans are being written for confirmatory monitoring of these two facilities.

Clean Water Act (CWA): SNL/NM has seven wastewater discharge permits from the City of Albuquerque for sanitary sewer discharges and has resolved past minor violations of the permits with the City. Instances in which the monitoring results exceeded regulatory limits are discussed in Section 6.1.2. Two surface 
impoundments are permitted, and there are 67 septic tanks at SNL/NM (Appendix $\mathrm{H}$ ), three of which remain active. Most of the septic tanks are registered with NMED. NMED has ruled that several categories of low-volume and/or clean wastewater surface discharges require no discharge plans. On October 1, 1992, SNL/NM submitted an NPDES individual permit application and a Notice of Intent to Discharge (NOI) for its storm water discharges. The individual permit application was for the regulated industrial activities onsite, and the NOI was for the construction of the Explosive Components Facility.

Safe Drinking Water Act of 1974 (SDWA): The SDWA is the legislative vehicle designed to protect human health by regulating the discharge of nontoxic and toxic pollutants into both groundwater and surface water sources by residential, municipal, and industrial sources. The goal of the Act is to preserve the quality of the nation's groundwater for agricultural and drinking water use.

Individual states are given responsibility by EPA for developing programs and procedures necessary to ensure that the quality of the groundwater meets the standards set by EPA. States set standards for the allowable concentrations of pollutants in surface discharges as well as requirements for pre-notifying, monitoring, and reporting discharges.

Individual states can elect to accept primacy of the regulations only if the state's regulations are stricter than the federal standards. Since New Mexico's regulations must be no less stringent than those set by the EPA, the SDWA standards still apply to SNL/NM.

Toxic Substances Control Act (TSCA): TSCA, administered by the EPA, requires testing and regulation of chemical substances that enter the environment. At SNL/NM, compliance with TSCA primarily involves regulation of polychlorinated biphenyls (PCBs). All electrical distribution equipment found to contain PCBs in concentrations $\geq 50$ parts per million ( $\mathrm{ppm}$ ) are being either removed from service for disposal or retrofitted to contain $<50 \mathrm{ppm}$ PCBs. As of December 31, 1993, 47 electrical distribution items containing $\geq 50 \mathrm{ppm}$ PCBs were in service; of these, five are $\geq 500 \mathrm{ppm}$ PCBs. All but a few of the nondistribution electrical items tested were found to be free of PCBs. As of December 31, 1993, 12 of these items contained $\geq 50 \mathrm{ppm} \mathrm{PCBs;} \mathrm{of} \mathrm{those} \mathrm{12,} 6$ are $\geq 500 \mathrm{ppm}$ PCBs. During 1993, approximately 21,000 kilograms (kg) of PCB waste were disposed of.

Federal Insecticide, Fungicide, and Rodenticide Act (FIFRA): EPA-registered pesticides are applied at SNL facilities. These pesticides are applied by an EPA-certified applicator. SNL/NM retains records of the quantities and types of pesticides that are used as well as Material Safety Data Sheets (MSDSs) for each pesticide.

Endangered Species Act (ESA): The ESA provides for protection of threatened and endangered species of flora and fauna. Where applicable, this act requires consultations with the U.S. Fish and Wildlife Service on listed or proposed species and critical habitats. Consultations are also required with the New Mexico Game and Fish Department and the New Mexico Department of Natural Resources to satisfy state procedures for fauna and flora protection. 
Several surveys for threatened, endangered, and sensitive species and habitats were also conducted in 1993 to help fulfill the policy objectives of NEPA and provide information in the environmental consequences that must be addressed in the NEPA process. There are no Federal-listed threatened or endangered species known to occur within KAFB. There are, however, New Mexico-listed endangered plants that occur within KAFB.

Cultural Resources Acts: Cultural resources management at SNL/NM is required under acts such as the National Historic Preservation Act (NHPA), the Archaeological Resources Protection Act (ARPA), and the American Indian Religious Freedom Act (AIRFA). SNL integrates cultural resources management into the NEPA Program. It is DOE's policy that NEPA review is required for all DOE actions potentially affecting the environment; thus, even actions that are categorically excludable are reviewed for impacts on cultural resources, among other things. (See Section 3.5 for further information on NEPA activities.)

Executive Orders: Executive Orders 11988, Floodplain Management, and 11990, Protection of Wetlands, apply to NEPA-related activities and require evaluation of the potential effects of actions taken in floodplains and wetlands. These executive orders are coordinated with other NEPA review requirements at SNL/NM and are both addressed in NEPA documents where relevant to proposed actions.

\subsection{CURRENT ISSUES AND ACTIONS}

\section{Air Quality Compliance:}

AQCR \#41 - Operating Permit Program

Proposed regulation AQCR 非1, "Operating Permit Program," is the implementation of the CAAA, Title V, "State Operating Permit Program" in Albuquerque/Bernalillo County. Most of SNL/NM operations were "grandfathered," and a permit to operate was not required in the past. The new AQCR 非1, which will be promulgated by EPA by November 15, 1994, requires all existing major sources to apply for an operating permit. A major source is defined as a facility which emits or has the potential to emit 100 or more tons per year of any criteria pollutant or 10 tons or more per year of any hazardous air pollutant, or 25 tons or more per year of any combination of such pollutants.

Based on the results of stack testing on the steam plant (Building 605) and the inventory of all stand-by generators and boilers outside the steam plant, SNL/NM will probably be a major source under Title $V$ of CAAA for nitrogen oxides $\left(\mathrm{NO}_{\mathrm{x}}\right)$. An action plan is being written for compliance with the upcoming "Operating Permit Program" regulation in AQCR 非1. Under the proposed AQCR 非1, SNL will be given one year from the date of promulgation to submit an application for the required operating permit.

AQCR 非37 (40 CFR 82) - Stratospheric Ozone Protection

The regulation requires recovery and recycling of ozone-depleting substances. It also requires certain certification for the equipment used and personnel who performed the tasks. It was identified during 1993 that some equipment used for recycling of refrigerant and technicians performing the tasks had not been certified. Action plans are being written by the line organization to address 
these noncompliance areas. In addition to the certification program, all associated recordkeeping will be improved.

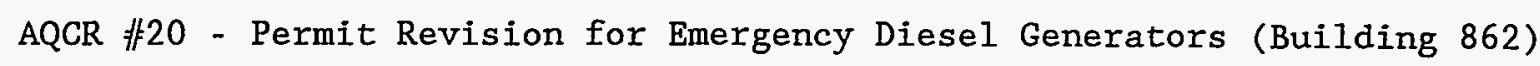

The current permit (非150) for the emergency generators residing in Building 862 does not adequately address the operational needs of the generator plant. The monthly allowable operating hours ( 4 hours [hr]) does not allow for routine maintenance of the generators. A request to the City of Albuquerque Air Pollution Control Division for the revision of Permit 非 150 will be made through the DOE office. A proposal of $120 \mathrm{hr}$ per year (instead of the current $4 \mathrm{hr}$ per month) for each generator will be proposed to the City. In addition, other stand-by generators outside Building 862 that require permits will be included in the revision.

AQCR 非4 - Variance for SMERF Testing in Compliance with AQCR \#5

The Smoke Emission Reduction Facility (SMERF) had problems in complying with the opacity standard (AQCR 非) for visibility. The facility was designed to be used for burn tests of small objects to reduce the impact to air quality in the area (the smaller objects had been tested in the open-burn fire pools in the past). The City has agreed to allow SNL/NM to submit a request for a 1 year (yr) variance in order to resolve the visibility issue.

Chemical Waste Landfill (GWL): The State of New Mexico issued an NOV for groundwater monitoring in 1989, and because the CAs could not be completed within the statutory 30 -day limit, the state subsequently issued a compliance order on the same matter. A compliance agreement between DOE, SNL/NM, and NMED was signed on January 11, 1990, to close the compliance order. The compliance agreement included (1) revising the CWL Sampling and Analys is Plan (SNL 1990a), (2) installing a fourth downgradient monitor well, and (3) characterizing the uppermost aquifer at the CWL. SNL/NM submitted the final report on May 29, 1991, fulfilling the compliance agreement requirements (SNL 1991b). Resubmission of the closure and postclosure plan for the CWL, which had undergone several revisions, was completed in December 1992 (SNL 1992a, 1993d). The closure plan and postclosure permit application were approved in February 1993. The annual groundwater monitoring report for the CWL was submitted on March 1 , 1994 (SNL 1994).

Landfill Disposal Restrictions (LDRs) and Toxicity Characteristic Leaching Procedures (TCLPs): In 1984, Congress amended RCRA by imposing a schedule for restrictions on the land disposal of hazardous waste. These restrictions are referred to collectively as LDRs. On May 8, 1990, the final LDRs were implemented, forbidding the land disposal of hazardous waste that does not meet prescribed treatment standards. However, due to a nationwide absence of MW treatment and disposal facilities, the EPA granted a National Capacity Variance that delays the implementation of most LDRs for MW until May 1992. The EPA also implemented the TCLPs in 1990. Those analytical procedures and the associated regulatory changes have increased the volume and complexity of RCRAregulated waste generated by SNL/NM. 
Hazardous Waste Fees: During the first quarter of CY 1992, the NMED held public meetings concerning setting fees to oversee hazardous waste programs. The fees were to be payable to NMED, and were to be based on the volume of generated hazardous waste and the number of hazardous waste management units at a facility. The fees were adopted in 1993 and will be imposed for CY 1994 .

Mixed Waste Authority: The State of New Mexico was granted regulatory authority for MW under RCRA on July 25, 1990. In August 1990, SNL/NM submitted a RCRA Part A permit application to NMED for the storage and limited treatment of MW ( $\mathrm{pH}$ neutralization, compaction, solidification, and shredding/baling). In October 1992, a permitting strategy in the form of a Letter Agreement was sent to NMED for submitting the SNL/NM MW Part B permit application. The Part $B$ permit application was submitted to NMED on November 8,1992 , and the first amendment was submitted August 26, 1993. An updated SNL/NM MW Part A permit application was also submitted in August 1993.

Mixed Waste Sampling and Analysis: The Radioactive and Mixed Waste Management Department (7573) has developed a method for sampling and analyzing waste that contains or is suspected of containing radioactive and hazardous components. The method includes participation from the Radiation Protection Operations and Measurements Departments (7714 and 7715) and the Department 7576 Environmental Sample Management office (SMO). Sampling is requested by the waste generator using a Department 7576 Request for Sampling and Analysis form. Samples are obtained by the Department 7576 sampling team and given to the Radiation Protection Measurements Department for analysis and/or screening prior to shipment to one of two contract analytical laboratories. The analytical results are forwarded to the SMO for verification of completeness and validation.

\subsection{ENVIRONMENTAL PERMITS}

As part of its commitment to full compliance with all applicable environmental laws and regulations, SNL/NM holds environmental permits which are governed as described below.

\subsubsection{Air}

The CAA is enforced by NMED and the joint Albuquerque/Bernalillo County Air Quality Control Board. These organizations provide administrative support for the following:

1. National Ambient Air Quality Standards (NAAQS) (40 CFR 50)

2. NESHAP (except for the radionuclide NESHAP, which is managed by the EPA, Region VI) (40 CFR 61)

3. New Source Performance Standards (NSPS), which regulate atmospheric emissions from certain types of facilities

4. Open-burn permits 
5. $\mathrm{NO}_{2}$ emissions from gas-burning equipment

6. Topsoil disturbance permits

\subsubsection{Water}

1. The CWA is administered through EPA, Region VI. The act encompasses the following regulations:

- NPDES, including pretreatment effluent guidelines and standards.

- The NPDES permit system for storm water runoff will require a permit for storm water discharges from certain industrial sources. SNL/NM has several targeted activities.

- Spill Prevention Control and Countermeasure (SPCC) Plan (Fink and Park 1992).

2. Sanitary sewer regulations, which are based on federal pretreatment standards and are promulgated by the City of Albuquerque

3. Surface and near-surface discharge regulations, which are administered by NMED

4. Groundwater monitoring regulations of RCRA, also administered by NMED

\subsubsection{Solid Waste}

1. CERCLA regulates inactive waste sites and contains requirements for reporting hazardous material spills to the National Response Center (NRG).

2. RCRA regulates generation, storage, treatment, recycling, transport, and disposal of hazardous, mixed, and nonhazardous solid waste in the following ways:

- Chemical hazardous waste, which is regulated by RCRA

- USTs for hazardous substances, which are regulated by RCRA

- Documented waste minimization programs, which are required by RCRA

- LDRs and treatment standards for chemical waste, which are applied by RCRA and were fully implemented in 1990

- Radioactive MW, which is dually regulated by the Atomic Energy Act and RCRA 
3. The New Mexico Hazardous Waste Act allows NMED to promulgate regulations no more stringent than federal regulations to manage RCRA hazardous waste. NMED received authority to regulate MW from EPA in July 1990. NMED also received authority to regulate Subpart X Miscellaneous Units from EPA in July 1990.

4. The New Mexico Solid Waste Act allows NMED to promulgate regulations to manage solid waste, such as non-hazardous, asbestos, and sanitary waste.

5. The Toxic Substances Control Act (TSCA) regulates the manufacture, distribution, use, handling, and disposal of certain toxic chemicals and materials, including polychlorinated biphenyls (PCBs) and asbestos.

\subsubsection{Summary of the Status of Current Permits and Other Notifications}

Table 2-1 lists the current environmental permits issued to SNL/NM and those that are under review by various agencies. Besides these environmental permits, notifications were given to the City of Albuquerque regarding asbestos removal (NESHAP, Subpart M) and Be emission/relocation (NESHAP, Subpart C). Also, several projects were evaluated for exemption and applicability of NESHAP, Subpart $H$, to facilities in TA-IV and $V$.

\subsection{U.S. DEPARTMENT OF ENERGY TIGER TEAM ASSESSMENT SUMMARY}

DOE has established teams of Environment, Safety, and Health (ES\&H) experts ("Tiger Teams") to inspect the various DOE laboratories for compliance with federal, state, and local environmental and safety regulations, permit agreements, DOE Orders, best management practices, and internal laboratory requirements. A DOE Tiger Team assessment of the ES\&H operations at SNL/NM was conducted from April 15 through May 24, 1991. This assessment was comprehensive, encompassing ES\&H disciplines, management, self-assessments, and quality assurance; transportation; and waste management operations.

The Tiger Team audit resulted in a variety of environmentally related findings concerning waste characterization and management, training, and compliance issues for offsite treatment, storage, and disposal facilities (TSDFs); radioactive \& mixed waste storage, characterization, and tracking; and other potential noncompliances with DOE Orders. Additionally, there were findings concerning groundwater monitoring, sampling, well/borehole closure, UST management, and ER activities. Some of these findings concerned only best management practices. Other deficiencies noted were in air quality monitoring, surface-water protection, groundwater protection, waste minimization, records management, radiological release control, and NEPA activities. The findings concerning NEPA activities were generally shared with the DOE.

In response to the Tiger Team findings, DOE and SNL/NM prepared an Action Plan. The draft Action Plan provided a formal written response to each of the findings and concerns cited in the Tiger Team report and presented plans, schedules, and costs for correcting the identified deficiencies. The Final Action Plan to Tiger Team was approved on February 28, 1992 (SNL 1992b). 
Table 2-1. Summary of the Environmental Permits Issued or in Process

\begin{tabular}{|c|c|c|c|c|}
\hline Permit No. & Type ${ }^{a}$ & Location & Agency & Expiration Date \\
\hline 2069 A-2 & Wastewater & WW001 & City of Albuquerque & $02 / 01 / 97$ \\
\hline $2069 \mathrm{D}-3$ & Wastewater & WW004 & City of Albuquerque & $02 / 01 / 97$ \\
\hline 2069 F-2 & Wastewater & WW006 & City of Albuquerque & $02 / 01 / 97$ \\
\hline 2069 G-2 & Wastewater & WW007b & City of Albuquerque & $07 / 31 / 94$ \\
\hline $2069 \mathrm{H}-2$ & Wastewater & WW009c & City of Albuquerque & $02 / 01 / 97$ \\
\hline $2069 I$ & Wastewater & WW008 & City of Albuquerque & $02 / 01 / 97$ \\
\hline $2069 \mathrm{~K}$ & Wastewater & WW011d & City of Albuquerque & $03 / 31 / 94$ \\
\hline$D P-530$ & $\begin{array}{c}\text { Surface Water } \\
\text { Discharge }\end{array}$ & TA-IV Lagoons & State of New Mexico & $12 / 26 / 94$ \\
\hline NM5890110518-1 & $\mathrm{HW}$ & 958,959 (HWMF) & NMED & $08 / 06 / 02$ \\
\hline NM5890110518 & $\mathrm{HW}$ & $6715(\mathrm{TTF})$ & NMED & Interim status \\
\hline $\begin{array}{l}\text { NM5890110518 } \\
\text { In process }\end{array}$ & MW (Part A) & $\begin{array}{l}\text { TA-I, III, V, } \\
\text { two } 6000 \text { Area } \\
\text { Igloos, and seven } \\
\text { Manzano bunkers }\end{array}$ & NMED & $\begin{array}{l}\text { (first submitted } \\
8 / 90 ; \text { revised and } \\
\text { resubmitted } 11 / 92 \text { ) }\end{array}$ \\
\hline NM5890110518 & $\mathrm{MW}(\operatorname{Part} \mathrm{B})$ & $\begin{array}{l}\text { TA-I, III, V, two } \\
6000 \text { Area Igloos, } \\
\text { and seven Manzano } \\
\text { bunkers }\end{array}$ & NMED & $\begin{array}{l}\text { In process (first } \\
\text { phase submitted } \\
11 / 92 \text { ) }\end{array}$ \\
\hline NM5890110518 & $\begin{array}{l}\text { Corrective Action } \\
\text { (HSWA) }\end{array}$ & SNL/NM & EPA Region VI & $08 / 26 / 02$ \\
\hline \multicolumn{5}{|c|}{ 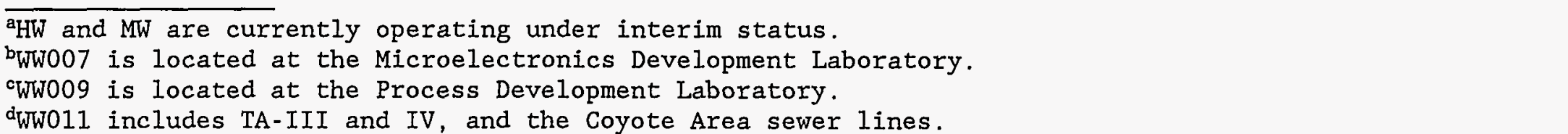 } \\
\hline
\end{tabular}


Many of the original deficiencies have been either completed or resolved through time or other actions. However, some actions have been postponed due to circumstances beyond the control of the finding owner, or the Action Plan has been redesigned to address current needs and situations. AII of the findings have been addressed to some degree during CY 1992 and CY 1993. In genera1, the SNL/NM Environmental Center has maintained steady progress toward the timely completion of the Action Plans. 


\subsection{ENVIRONMENTAL PROGRAMS INFORMATION}

\subsection{ENVIRONMENTAL RESTORATION PROJECT}

The Environmental Restoration (ER) Project is a phased U.S. Department of Energy (DOE) project to identify, assess, and remediate past spill, release, or disposal sites at all DOE facilities including Sandia National Laboratories/New Mexico (SNL/NM).

The initial identification of sites at the Albuquerque location was completed in 1987. The installation assessment report identified 117 sites that would require further evaluation (DOE 1987). Since completion of the installation assessment report, additional sites have been identified and the number of potential release sites at Albuquerque now totals 219. It is anticipated that a few additional sites may be identified in the future. The 1992 annual environmental monitoring report (Culp et al. 1993) listed 172 potential release sites. Since publication of that report, sites have been added that were identified through review of historical documents, interviews, or field reconnaissance.

The potential release sites identified in the installation assessment report and subsequent evaluations are grouped together within geographic and eventrelated boundaries. These groups of release sites are called Operable Units (OUs) for budget development and project tracking purposes. Table B-1 in Appendix B lists the ER Program sites and identifies the specific potential release sites that are assigned within an individual ou. Since publication of the 1992 report, the sites have been regrouped to reduce the total number of OUs from 23 to 17.

The grouping of potential release sites will allow the assessment investigator to collect samples efficiently and economically. The geographically derived site groups will also provide an opportunity to collect installation-generic data on a regional basis during a single sampling campaign.

The assessment and remediation of potential release sites identified by the ER Project at SNL/NM are being monitored by the U.S. Environmental Protection Agency (EPA) under the Hazardous and Solid Waste Amendments of 1984 (HSWA) module of the Resource Conservation and Recovery Act (RCRA) Part B Operating Permit. The authority to investigate all Solid Waste Management Units (SWMUs) is granted by Section 3004(u) of RCRA, which requires investigation of all past and present SWMUs with a potential for release of hazardous waste or hazardous constituent(s). Facilities seeking a RCRA permit are required to conduct these assessments and subsequent investigations if a release is found or suspected. During 1993, assessment efforts continued at the following OUs: the Chemical Waste Landfill (CWL), the Mixed Waste Landfill (MWL), Technical Area II (TA-II), TA-III and TA-V, septic tanks and drainfields, the liquid waste disposal system (LWDS), former storage tank sites, Tijeras Arroyo, TA-I, Central Coyote Field, Kauai Test Facility, Tonopah Test Range, Southwest Test Areas, Foothills Test Area, Canyons Test Area, Salton Sea, and remote facilities. 


\subsection{UNDERGROUND STORAGE TANK MANAGEMENT}

Underground storage tanks (USTs) at SNL/NM are managed in accordance with State of New Mexico UST regulations. The New Mexico UST regulatory program has been approved by the EPA, Region VI, in accordance with 40 Code of Federal Regulations (CFR) 281.

SNL/NM's inventory of active USTs was reduced in calendar year (CY) 1993 from six to five. UST 6587-2, a 10,000-gallon (gal) steel unleaded gasoline tank, was permanently closed by removal.

The New Mexico Environment Department (NMED) was notified at least 30 days in advance of the removal of UST 6587-2. An NMED representative was present to inspect the tank, piping, and excavation-zone soils during removal. Soil samples were taken from the excavation-zone in locations identified by the NMED representative and sent to an approved laboratory for analysis as required by NMED UST regulations. Official analytical results indicated no contamination of soil beneath the tank. Visual inspection of the soil surrounding the tank also showed no contamination; however, there was a release detected at the dispenser connected to this tank. A contract for an onsite investigation (OSI) has been placed to determine the extent of contamination. Analytical results were not available for this report.

All of SNL/NM's regulated USTs were upgraded to comply with UST leak-detection regulations that became effective on December 22, 1993.

\subsection{SPILL PREVENTION CONTROL AND COUNTERMEASURE PLAN}

Spill control activities at SNL/NM are managed using several orchestrated plans and programs. Spill Prevention Control and Countermeasure (SPCC) plans for SNL/NM (Fink and Park 1992), the Tonopah Test Range, and Livermore are augmented at SNL/NM by the Oil Spill Contingency Plan (Fink and Park 1993a) and the Hazardous and Radioactive Materials SPCC Plan (Fink and Park 1993b).

Oil-spill control activities at SNL/NM are coordinated using the SPCC PIan (Fink and Park 1992). This plan was prepared in accordance with 40 CFR 112. The 3-year (yr) rewrite, required by 40 CFR 112, was completed in 1990 and approved by the DOE. The next 3 -yr revision is in progress at this time.

Activities for 1993 included the following:

- Annual revision of the SPCC Plan (Fink and Park 1992)

- Annual revision of the Oil Spill Contingency Plan (required by 40 CFR 112) (Fink and Park 1993a)

- Annual inspection of the regulated facilities for SNL/NM

\subsection{WASTE MANAGEMENT PROGRAMS}

\subsubsection{Hazardous Waste and the Resource Conservation and Recovery Act}

All RCRA-regulated wastes generated by SNL/NM (except mixed wastes) are transported off site for disposal at EPA-permitted treatment, storage, and disposal facilities (TSDFs). 
Chemical wastes generated by SNL/NM research and development (R\&D) activities are collected from generator locations, segregated according to U.S. Department of Transportation (DOT) hazard class, and transported to the RCRA-permitted Hazardous Waste Management Facility (HWMF) for storage. At HWMF, the wastes are consolidated and packaged according to DOT and EPA requirements. Packaged wastes are transported by EPA-permitted carriers to EPA-permitted TSDFs or recyclers for final disposition.

The EPA-permitted commercial transporters used to transport SNL/NM hazardous waste during 1993 are listed in Table 3-1. The permitted TSDFs, recyclers, and the waste treatment methods employed at each facility are listed in Table 3-2.

During CY 1993, 483,606 kilograms $(\mathrm{kg})$ of chemical wastes were managed by SNL/NM's chemical waste management program, including $140,613 \mathrm{~kg}$ of RCRAregulated hazardous waste and $342,993 \mathrm{~kg}$ of nonregulated industrial wastes. In CY 1993, a total of 25, 263 packages were collected from SNL/NM generators, put into 5,089 containers, and sent to TSDFs and recyclers. The volume of waste processed in CY 1993 decreased 9,172 kg from that reported in CY 1992.

SNL/NM's Thermal Treatment Facility (TTF) is operated under EPA interim status. TTF was constructed to thermally treat residual explosives generated at SNL/NM. In CY 1993, TTF treated $0.2 \mathrm{~kg}$ of residual explosive waste.

\subsubsection{Radioactive Waste}

Onsite disposal of low-level radioactive waste (LLW) at SNL/NM was terminated in December 1988 as a result of a DOE Order. Presently, all newly generated LLW and mixed waste (MW) are stored temporarily aboveground at generator sites or in transportation containers at the inactive TA-III disposal site. During 1993, 1533 cubic feet $\left(\mathrm{ft}^{3}\right)$ of $\mathrm{LLW}$ waste and $128 \mathrm{ft}^{3}$ of mixed waste were accepted at the TA-III storage site. This waste consisted primarily of fission product and uranium-contaminated waste on a volumetric basis, and tritium (H-3) contaminated waste on an activity basis.

The Radioactive and Mixed Waste Management Facility (RMWMF) was completed in 1990. Due to changes in regulations during construction, some facility upgrades are required before operations can begin. This 6000-square-foot ( $\mathrm{ft}^{2}$ ) facility will serve as a centralized packaging and storage facility for LLW and LLW-MW that meet the facility waste acceptance criteria (WAC). An Environmental Assessment (EA) was prepared for the RMWMF and submitted to the DOE in 1990, with an approval of a finding of no significant impact (FONSI) received in April 1993. In addition, a Safety Assessment for the RMWMF was submitted to the DOE for review on March 25, 1994 (Seylar 1994). It is projected that the RMWMF will be operational in 1996.

SNL/NM generates $\sim 5 \mathrm{ft}^{3}$ of transuranic (TRU) waste per year. Ultimately, the TRU waste generated at SNL/NM will be disposed of at the Waste Isolation Pilot Plant (WIPP). Currently, all TRU waste is packaged and stored at generatorcontrolled locations. 
Table 3-1. EPA-Permitted, Sandia National Laboratories/New Mexico Hazardous Waste Transporters Used in Calendar Year 1993

1. Rinchem Company, Inc.

5. Division Transport

2. Safety-Kleen Corp.

3. Sandia

6. Custom Environmental Transport

4. USPCI

Identification of these companies is not necessarily an endorsement of their services by SNL/NM.

Table 3-2. Waste Disposal Facilities Used by Sandia National Laboratories/New Mexico in Calendar Year 1993

1. Hydrocarbon Recycles, Inc.

2. USPCI (Grassy Mountain, UT)

3. ENSCO, Inc.

4. Rollins Env. Svcs., Inc. (LA)

5. Rollins Env. Svcs., Inc. (TX)

6. Inmetco

7. MERECO

8. Chemical Waste Management-OSCO

9. BDT, Inc.

10. Envirosafe

11. Breslube

12. Kirtland Landfill

13. USPCI (Lone Mountain, OK)

14. Kirtland EOD Range

15. Safety-Kleen

16. Kinsbursky Bros.
Kiln Fuel/Recycling

Stabilization, Encapsulation, and Landfill

Incineration

Incineration

Incineration

Metals Recycling

Metals Recycling

Kiln Fuel/Recycling

Hydrolysis of Reactive Metals

Stabilization, Encapsulation, and Landfill

Oil Recycling

Non-RCRA/Nonenvironmentally Hazardous Trash

Stabilization, Encapsulation, and Landfill

Open Detonation/Open Burn

Solvent Recycling

Metal Recycling

adentification of these companies is not necessarily an endorsement of their services by SNL/NM. 


\subsubsection{Mixed Waste}

In August 1993, SNL/NM submitted an updated MW Part A and first amendment to the Part B permit application to the NMED. During 1993, the following activities were in place to meet regulatory and statutory requirements as listed for RCRA MWs generated at SNL/NM:

- Sampling and analysis of MW (40 CFR 261)

- Acquisition of additional mixed storage capacity (40 CFR 265)

- Inventory of MW generation and MW in storage (Federal Facility Compliance Act)

- Mixed waste generator training (40 CFR 262 and 265)

In July 1993, NMED inspected the hazardous waste (including MW) at SNL/NM. Five violations involving MW were delineated and are listed below with their associated fines:

- Failure to inspect availability and $\$ 600.00$ condition of spill-recovery equipment

- Failure to equip storage area with telephone or other communications device

$\$ 1,155.00$

- Failure to provide required training for one employee by scheduled renewal date

- Failure to mark containers with accumulation start dates

$\$ 1,417.50$

- Failure to mark container with complete accumulation start date

$\$ 720.00$

DOE Albuquerque Operations Office (DOE/AL) made two appraisals during 1992. One examined the SNL/NM waste operations program and documented ten findings; action plans were prepared by SNL/NM and submitted to the DOE Kirtland Area Office (DOE/KAO) on May 6, 1993. The second reviewed the SNL/NM waste moratorium program that controls the release of hazardous wastes from radiological areas. The appraisal identified seven observations for which action plans were prepared by SNL/NM and submitted to DOE/KAO on May 27, 1993.

\subsubsection{Special-Case Waste}

In 1993, SNL/NM completed a site-wide inventory of waste including six categories of special-case (SC) waste:

- DOE comparable greater-than-Class-C (SC-GTCC)

- Performance assessment limiting (SC-PAL)

- Uncertified or uncharacterized (SC-US)

- Noncertifiable, nontransportable TRU (SC-TRU)

- High-level, incidental (SC-HLI)

- Commercially held, DOE-owned materials (SC-COM) 
No special-case waste was identified.

\subsubsection{Polychlorinated Biphenyl Waste}

SNL/NM is in the process of phasing out polychlorinated biphenyl (PCB) waste oils and equipment to the greatest extent possible. All electrical distribution equipment (transformers and switches) found to contain PCBs in concentrations 250 parts per million ( $\mathrm{ppm}$ ) are being either removed from service for disposal or retrofitted to contain $<50$ ppm PCBs. As of December 31, 1993, there were 47 electrical distribution items containing $\geq 50 \mathrm{ppm}$ PCBs in service at SNL/NM. Of these 47,5 are $2500 \mathrm{ppm} \mathrm{PCBs.}$

Nondistribution electrical devices, such as capacitors, high-voltage power supplies, and a wide variety of oil-containing equipment, such as vacuum and hydraulic systems, have been checked for PCBs at SNL/NM. All but a few of these items were found to be free of PCBs. The items that do contain PCBs in concentrations $\geq 2 \mathrm{ppm}$ are on an inventory list and will be properly disposed of when the users no longer need the items for service. As of December 31 , 1993, there were 12 non-electrical distribution items containing $250 \mathrm{ppm}$ PCBs in service at SNL/NM. Of those 12 items, 6 are $\geq 500 \mathrm{ppm}$ PCBs. Approximately $21,000 \mathrm{~kg}$ of $\mathrm{PCB}$ waste were disposed of in 1993.

\subsubsection{Nonfacilities Asbestos Waste (Equipment with Asbestos-Containing Material)}

SNL/NM Chemical Waste Management Department oversees the storage and disposal of nonfacilities waste and equipment that contains friable asbestos. Approximately $16,300 \mathrm{~kg}$ of nonfacilities asbestos waste were disposed of in 1993.

In instances where equipment has asbestos-containing material (ACM) in nonfriable form and the equipment is still useful to SNL/NM, the items will remain in service at their current location, or they will be delivered to property reapplication, at the request of the current owner, for use elsewhere within SNL/NM.

If the asbestos in $\mathrm{ACM}$ is in friable form (i.e., if the asbestos fibers can easily be liberated to the environment), creating a health hazard, either the equipment will be properly disposed of or the asbestos will be abated from the equipment. Proper disposal consists of transporting the material to a landfill permitted to accept friable asbestos waste. The abatement option is exercised when the ACM is easily removed from an item and/or when the item is of such size that the landfill option is not a practical alternative. Two ovens and one belt furnace were abated in 1993.

\subsubsection{Waste Minimization Program}

A formal waste-minimization and pollution-prevention (WMin/PP) awareness program was initiated in 1989 to further comply with EPA regulations and DOE Orders 5400.1, 5400.3, and 5820.2A (DOE 1988a, 1988b, and 1989b) and to meet recent Executive Order (EO) 12856. The latter is an important signal of the fundamental change in Federal-agency environmental accountability and mandates a strong Federal pollution-prevention (PP) program. The SNL/NM pollution- 
prevention program addresses waste reduction activities for all media (air, water, and solid) for nonhazardous, hazardous, mixed, and radioactive wastes and aims to foster a cradle-to-grave philosophy to conserve resources and make $\mathrm{PP}$ part of everyday activities.

Accomplishments in 1993 include the following:

- In a joint effort by Centers 7500 and 6600 , and the line organization, over 400 Process Waste Assessments (PWAs) on waste-generating processes were completed. PWAs are descriptions of processes with a focus on multimedia environmental protection. These assessments provide the basis for identifying opportunities to reduce or eliminate wastes, air emissions, and water discharges. Reducing waste streams also reduces input requirements, thereby conserving resources and providing a safer workplace. Other benefits of PWAs include the ability to anticipate Environment, safety, and health (ES\&H) requirements during project development, reduced requirements for ad hoc data requests, and enhanced reporting capabilities.

- Using the PWAs, Waste Minimization Opportunities Assessments (WMOAs) were performed on selected processes. The WMOAs, conducted for a half or full day, included a diverse team of individuals drawn from the process, SNL/NM ES\&H professionals, and outside consultants. Each WMOA began with a 1- or 2-hour (hr) tour of the process operations, followed by a brainstorming session to generate a variety of waste-minimization ideas. Initially, these ideas were not screened in order to facilitate a creative atmosphere. Toward the end of the WMOA, however, ideas were placed into one of three categories: those implementable immediately with little or no testing, those requiring additional study, testing, or funding, or those not economically or technically feasible. In most cases, process personnel were responsible for implementing ideas or conducting further studies, with assistance from the Waste Minimization (WMin) organization as appropriate. In some cases, however, funding was available from the WMin group to assist with implementation or further study.

- The WMin Program was relocated within the PP Department to establish formal coordination with other environmental groups. The new PP Department provides laboratory-wide support for multimedia WMin/PP. This new department also establishes a focal point for the continued development of a comprehensive tracking and information system that interfaces with safety, health, and risk management systems.

\subsection{NATIONAL ENVIRONMENTAL POLICY ACT OF 1969 COMPLIANCE ACTIVITIES AND DOCUMENTATION IN 1993}

\subsubsection{Background}

The National Environmental Policy Act (NEPA), the nation's most comprehensive legislative and public policy statement for environmental protection, applies to all agencies of the Federal government. Executive Orders, DOE Orders, and DOE guidance apply NEPA and NEPA-related activities to SNL/NM. 
The Secretary of Energy's February 5, 1990, NEPA Notice (SEN-15-90), with directives intended to bring DOE into full compliance with NEPA, set in motion events that have led toward a major increase in commitment to the principles and practices underlying NEPA. New compliance and guidance procedures are being developed by both DOE and SNL/NM. These new requirements have greatly increased NEPA compliance activities.

On April 24, 1992, DOE published its NEPA regulations in the form of a final rule entitled "National Environmental Policy Act Implementing Procedures" (10 CFR 1021). The final rule includes an expanded list of typical classes of actions that require NEPA review. The new rule revoked DOE's former NEPA guidelines of December 15, 1987.

The final rule, incorporating policy initiatives instituted by the Secretary of Energy, is more specific and detailed than DOE's former NEPA guidelines. In the new rule, DOE adopts NEPA-implementing regulations published by the Council on Environmental Quality (CEQ) as 40 CFR 1500-1508. The CEQ, created by the Executive Office of the President under the authority of NEPA, establishes NEPA regulations used by all Federal agencies.

DOE/AL 5440.1D Supplemental Directive was issued on March 19, 1992 (DOE 1992b). This Order is currently being revised to conform to DOE Order 5440.1E (DOE 1992a) and $10 \mathrm{CFR} 1021$ regulations. DOE Order 5440.1E was issued on November 10, 1992. This order establishes responsibilities and procedures to implement NEPA in conformance with the new DOE NEPA regulations.

At SNL/NM, the Risk Management/NEPA Department (7258) administers the NEPA Program. The program's responsibilities include the following activities:

- Consulting and training line organization personnel in NEPA compliance

- Coordinating NEPA document preparation

- Maintaining a corporate NEPA document file

- Reviewing and assuring the quality of NEPA documents before their submittal to the DOE

These responsibilities are documented in SNL/NM's NEPA Program Document (PG470110) that was approved in 1991 (SNL 1991c).

\subsubsection{NEPA Documents}

Although only DOE has authority to decide the appropriate level of NEPA documentation, SNL/NM assists DOE by drafting the appropriate documentation for DOE approval (Figure 3-1). NEPA documents serve as vehicles for assessing potential environmental impacts of proposed Federal actions and disclosing Federal activities. These documents include those described below.

Environmental Checklists (ECLs): ECLs are used to document the use of a categorical exclusion, that is, a category of actions for which neither an Environmental Assessment (EA) nor Environmental Impact Statement (EIS) is normally required. 


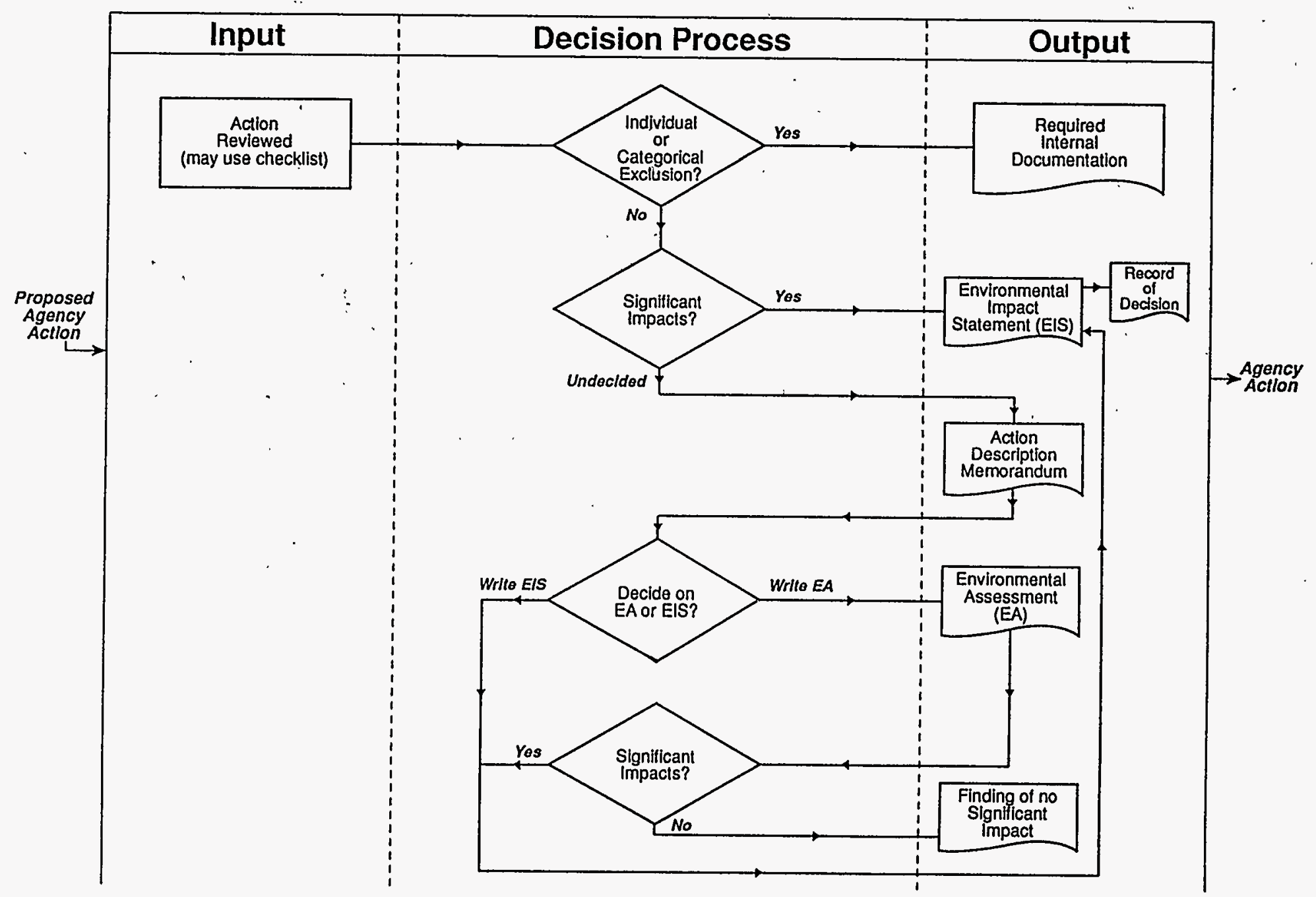

Figure 3-1. Process For Creating and Reviewing U.S. Department of Energy National Environmental Policy Act Documentation 
Action Description Memoranda (ADMs): ADMs are documents containing concise descriptions of proposed actions and brief discussions of relevant potential environmental issues. DOE uses ADMs to determine the appropriate level of NEPA documentation for proposed actions. Actions which are not categorically excluded or covered in approved NEPA documents require preparation of EAs or EISs.

At DOE/AL, a combined ECL and ADM, or ECL/ADM, is used for the following purposes:

- Provide a means of reviewing a proposed action to determine if it qualifies for categorical exclusion (CX)

- Help determine the appropriate level of NEPA documentation (EA or EIS) for actions not categorically excluded

Environmental Assessments: EAs are concise public documents intended to provide brief but sufficient evidence and analysis for determining whether to prepare an EIS or a FONSI. EAs are used primarily to evaluate proposals for the possibility of significant impacts; they also aid compliance with NEPA when no EIS is required and facilitate preparation of an EIS when one is necessary. Figure 3-2 is a flowchart of the EA process.

Finding of No Significant Impact (FONSI): An EA can lead to only one of two conclusions: (1) an EIS must be prepared, or (2) the impacts of a proposed action are insignificant. The latter is called a "finding of no significant impact," or FONSI. Many proposals would not qualify for a FONSI without commitments to mitigation measures that render the impacts insignificant.

Environmental Impact Statement: An EIS is a detailed written statement for major Federal actions significantly affecting the quality of the human environment. The EIS process is shown in Figure 3-3.

Mitigation Action Plan (MAP): According to DOE Order 5440.1E (DOE 1992a), an MAP is required where a FONSI would be based in part on a DOE commitment to take certain mitigation actions. The MAP is not intended to address mitigation activities that are normally or routinely undertaken as part of the proposed action. The MAP focuses on actions that are over and above what would routinely occur as part of the proposed action.

Site-Wide NEPA Documents: According to DOE's NEPA rule (10 CFR 1021): "A sitewide NEPA document means a broad scope EIS or EA that is programmatic in nature and identifies and assesses the individual and cumulative impacts of ongoing and reasonable future actions at a DOE site. . "

\subsubsection{Activities}

SNL/NM provided information for two documents that are still being prepared:

1. The DOE "Nuclear Weapons Complex Reconfiguration Programmatic Environmental Impact Statement (PEIS)" (DOE 1993b). This PEIS is one of DOE's most important undertakings to be handled in a NEPA document. 


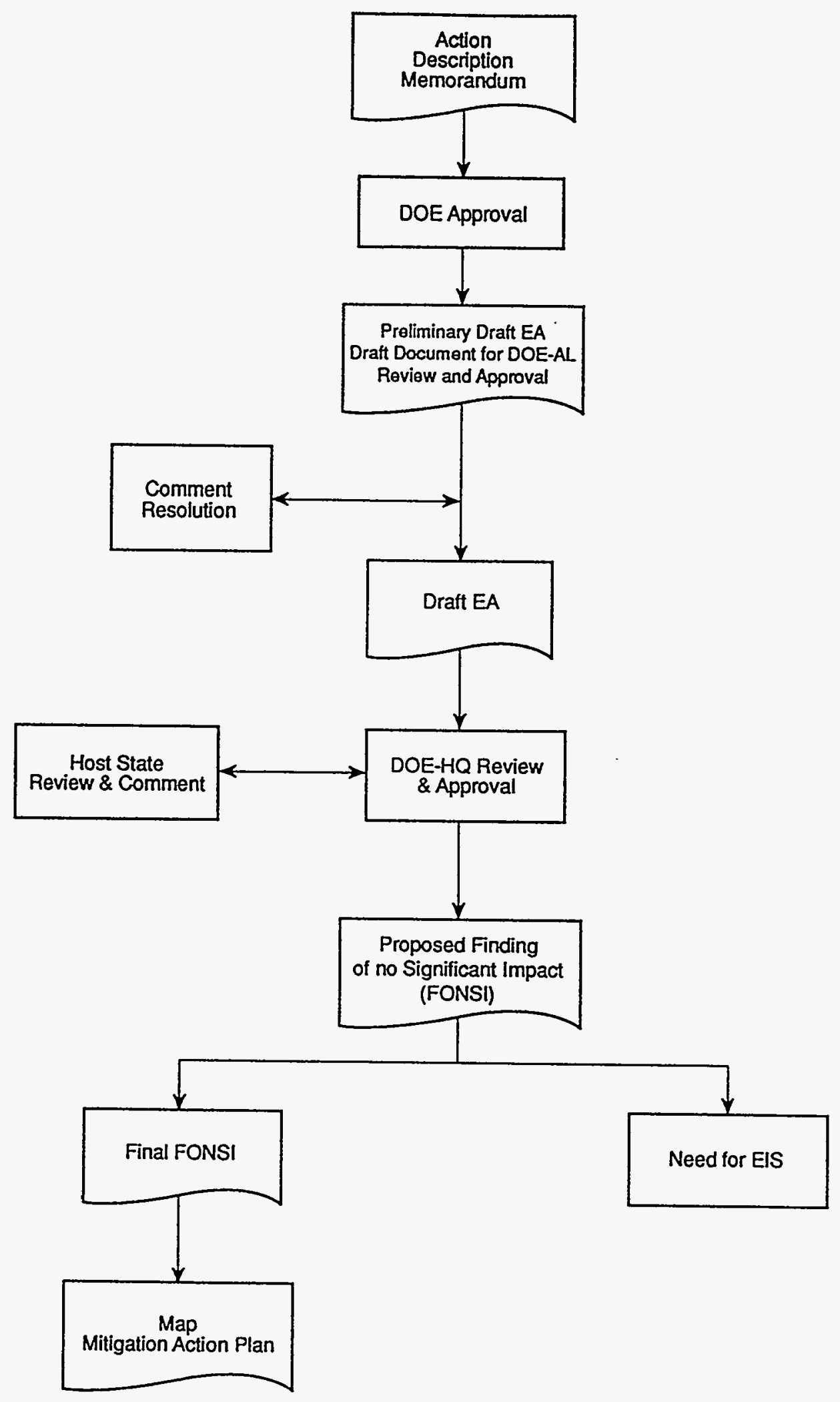

Figure 3-2. Flowchart of the Environmental Assessment Process 


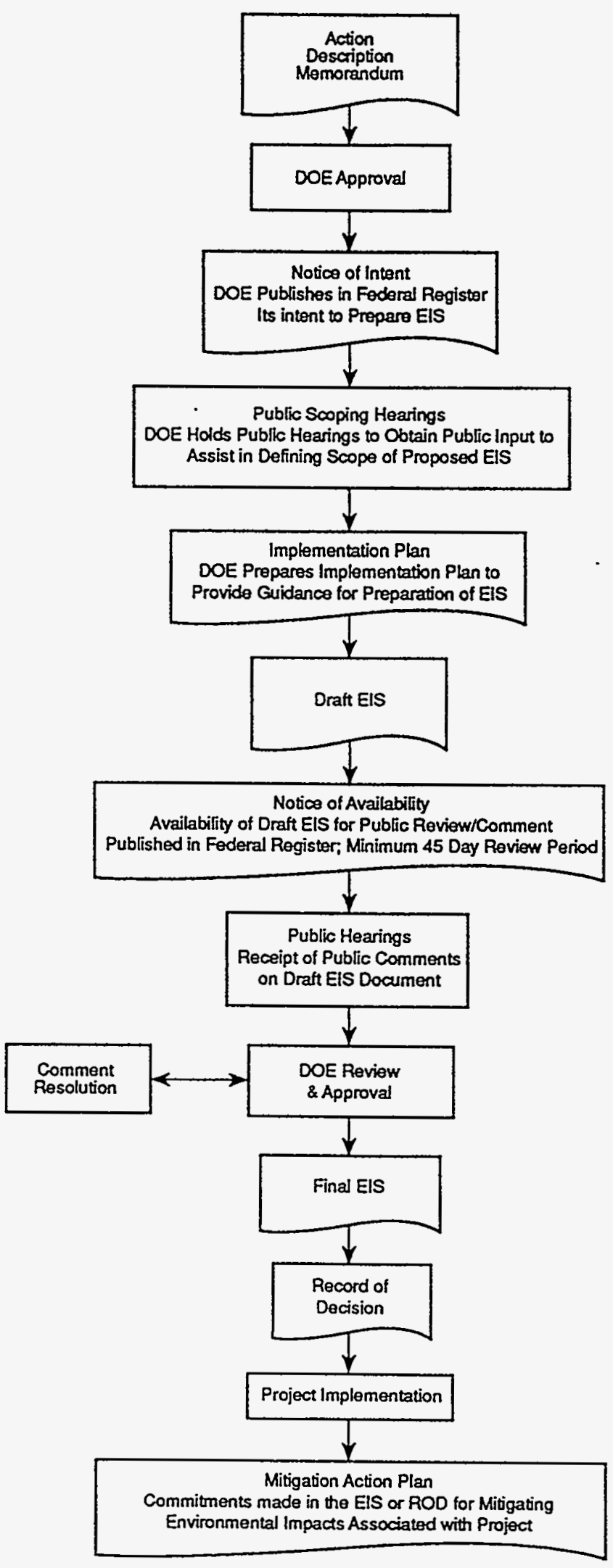

Figure 3-3. Flowchart of the Environmental Impact Statement Process 
2. The "Implementation Plan for Environmental Restoration and Waste Management Programmatic Environmental Impact Statement" (DOE 1994a).

The NEPA process deals comprehensively with environmental problems and integrates NEPA requirements with other environmental reviews and required consultations. This helps fulfill the policy objectives of NEPA and provides information on the environmental consequences that must be addressed in NEPA documents.

Several EOs are coordinated with NEPA review requirements and apply to NEPArelated activities. For example, EO 11988, Flood Plain Management, and EO 11990, Protection of Wetlands, contain specific requirements for Federal agencies, and both are addressed in NEPA documents where relevant to proposed actions.

Compliance with environmental laws concerning cultural resources, such as the National Historic Preservation Act (NHPA), helps fulfill the policy objectives of NEPA and provides information on the environmental consequences that must be addressed in the NEPA process. Section 106 of NHPA directs Federal agencies to take into account the effects of their actions on properties included in or eligible for the National Register. In support of NEPA documentation, several archaeological surveys were completed for SNL/NM. No significant cultural resources were located on DOE-owned properties.

The Endangered Species Act provides for protection of threatened and endangered species of flora and fauna. Where applicable, this act requires consultations with the U.S. Fish and Wildlife Service on listed or proposed species and critical habitats. Consultations are also required with the New Mexico Game and Fish Department and the New Mexico Department of Natural Resources to satisfy State procedures for fauna and flora protection.

Several surveys for threatened, endangered, and sensitive species and habitats were also conducted in 1993 to help fulfill the policy objectives of NEPA and provide information on the environmental consequences that must be addressed in the NEPA process. There are no Federal-listed threatened or endangered species known to occur within Kirtland Air Force Base (KAFB). There are, however, New Mexico-listed endangered plants that occur within KAFB.

\subsubsection{NEPA Training and Outreach}

Professional non-Sandia trainers and Sandia NEPA professionals provide training to Sandians on NEPA processes. The objectives of the training are to enhance efficiency and effectiveness in complying with NEPA.

SNL/NM's ES\&H Division, which publishes the "ES\&H Training Catalog" (SNL 1993e), offers four NEPA courses, three of which (ENV120, 122, and 124) were offered during 1993:

1. "NEPA Awareness" (ENV120). This is an introduction to NEPA, developed by the NEPA program and Sandia's Training Department and directed toward Sandians not familiar with the law, its implement- 
ing regulation, and Sandia's responsibilities as a contractor for DOE.

2. "NEPA Executive Overview" (ENV121). This overview provides basic information on NEPA law and regulations.

3. "NEPA Implementation" (ENV122). This 3-day course details the NEPA process for those developing NEPA documents.

4. "NEPA Writing" (ENV124). This hands-on course provides instruction on correctly writing NEPA documents.

A 1-day in-house NEPA Executive Overview course is being developed jointly by the NEPA Program and the Training Department. It is anticipated that SNL/NM will offer this pilot program in April or May 1994. This course will focus on making NEPA an integral part of the regular recurring planning and management process and will replace the current NEPA Overview course (ENV121).

Two NEPA Compliance Workshops were held in 1993:

1. A NEPA Compliance Guide Workshop for Sandia ES\&H coordinators on July 27, 1993

2. A NEPA workshop for the ER Program on October 14, 1993

\subsubsection{NEPA Baseline Information}

Information gathering to characterize the existing environment on lands used by SNL/NM continued in 1993. The information will be compiled into reports designed to promote uniformity in the quality of baseline information incorporated into SNL/NM NEPA documents. The following two SNL reports were published by the NEPA group in early 1993:

1. "Sandia National Laboratories, New Mexico, Environmental Baseline Update" (SNL 1993b)

2. "Cultural Resources Regulatory Analysis, Area Overview, and Assessment of Previous Department of Energy and Kirtland Air Force Base Inventories for Sandia National Laboratories, New Mexico" (SNL 1993c)

\subsubsection{Environmental Assessment Findings of No Significant Impact}

One FONSI was issued in 1993 for the EA for the Radioactive and Mixed Waste Management Facility (DOE 1991a). Two other EAs were essentially completed in 1993. The FONSI for the EA for the neutron generator/switch tube prototyping relocation was issued on April 8, 1994 (DOE 1994b). The FONSI for the EA for the Robotic Manufacturing Science and Engineering Laboratory was issued on April 13, 1994 (DOE 1994C). 


\subsubsection{Miscellaneous NEPA Activities}

Consistent with DOE's Supplemental Directive, AL 5440.1D, the NEPA program used NEPA identification numbers in 1993 (DOE 1992b). The new numbers are unique and are assigned by SNL/NM at the earliest appropriate state of a proposed action. The assigned number is to be included on all budget and project/planning, authorization, and control documents.

The NEPA Program supported two NEPA proposed actions involving SNL line organizations in 1993:

1. Katmai Scientific Drilling Projects for which an EIS is being prepared by the Park Service.

2. EA for the U.S. purchase of low-enriched uranium converted from Russian highly-enriched uranium. This EA was prepared at SNL/NM for DOE's Office of Nuclear Energy (USEC 1994). A FONSI was issued in late 1993.

During 1993 there were 14 EAs under development for DOE facilities at SNL/NM or for proposed actions involving SNL/NM research activities. These EAs are listed in Appendix I, Table I-1.

\subsection{SUMMARY OF 1993 RELEASE AND ENVIRONMENTAL INCIDENT REPORTS}

\subsubsection{Summary of Release Reporting}

There are four release reporting documents required by organizations external to - SNL.

1. Reportable Quantity (RQ) Release Reporting

2. The Radioactive Effluent Information System/Onsite Discharge Information System (EIS/ODIS) Annual Report

3. The National Emission Standards for Hazardous Air Pollutants (NESHAP) for Radionuclides (Subpart H) Annual Report

4. The Superfund Amendment and Reauthorization Act (SARA), Section 313, Toxic Chemical Release Report

Reportable Quantity Reporting: RQ reporting is required by the Comprehensive Environmental Response Gompensation and Liability Act (CERCLA) and SARA, Title III. CERCLA requires that any release to the environment in any 24-hr period of any pollutant or hazardous substance in a quantity greater than or equal to the $R Q$ be reported immediately to the National Response Center (NRC). However, if the release is Federally permitted under CERCLA Section 101(10)(H), it is exempted from CERCLA reporting. This reporting exemption also applies to any Federally permitted release under SARA, Title III.

Table 3-3 contains the annual summary of RQ Release Reporting for SNL/NM. In 1993, one release was reported. It was caused by a spill of waste material generated by a paint stripping operation on the roof of Building 807, TA-I. 
Table 3-3. Annual Summary of 1993 Reportable Quantity Release Reporting

\begin{tabular}{llllllll}
\hline Date & $\begin{array}{c}\text { SNL/NM } \\
\text { Location }\end{array}$ & Material & $\begin{array}{c}\text { Quantity } \\
(\mathrm{Ib})\end{array}$ & $\begin{array}{c}\text { RQ } \\
(\mathrm{Ib})\end{array}$ & $\begin{array}{c}\text { Release } \\
\text { To }\end{array}$ & $\begin{array}{c}\text { NRC } \\
\text { Number }\end{array}$ & $\begin{array}{c}\text { Report } \\
\text { Date }\end{array}$ \\
\hline $09 / 07 / 93$ & TA-I & Lead & 1.0 & 1.0 & Ground & 196711 & $09 / 08 / 93$ \\
\hline
\end{tabular}

The waste material (copper dust mixed with lead paint dust) was found on the roof and on the ground where the container bags were stored. Non-RQ accidental releases are discussed in Section 3.6.2.

EIS/ODIS Reporting: DOE Order 5400.1 requires that data about radioactive effluent and onsite discharge from the previous year for all planned and unplanned releases must be reported to the Waste Information System Branch of Edgerton, Germeshausen \& Grier Corp. (EG\&G), Idaho, Inc., by April 1 each year.

The EIS/ODIS report for 1993, submitted on March 14, 1994, covered all routine and nonroutine releases from SNL/NM operations. The TA-V reactors (the Annular Core Research Reactor [ACRR] and the Sandia Pulsed Reactor [SPR]) produced the majority of radioactive air releases. During 1993, SNL/NM released a total of 3.2 curies (Ci) of argon-41 (Ar-41), $1.0 \mathrm{Ci}$ of nitrogen-13 $(\mathrm{N}-13), 0.51 \mathrm{Ci}$ of oxygen-15 (0-15), $0.41 \mathrm{Ci}$ of rubidium-88 (Rb-88), $0.4 \mathrm{Ci}$ of xenon-135 (Xe-135), 0.36 Ci of krypton-88 ( $\mathrm{Kr}-88), 0.2 \mathrm{Ci}$ of carbon-13 (C-13), $0.18 \mathrm{Ci}$ of xenon-135m (Xe-135m), $0.17 \mathrm{Ci}$ of krypton-87 ( $\mathrm{Kr}-87), 0.14 \mathrm{Ci}$ of krypton-85m (Kr-85m), $0.1 \mathrm{Ci}$ of nitrogen-15 (N-15), and other microcurie $(\mu \mathrm{Ci})$ levels of fission and activation products. All of these releases were within regulatory limits.

Routine sewage discharges from all processes within the technical areas to the City of Albuquerque publicly owned treatment works (POTW) totaled $2.9 \times 10^{8}$ gal. These discharges averaged approximately $3.1 \mathrm{pCi} / \mathrm{L}$ gross alpha activity and $11 \mathrm{pCi} / \mathrm{L}$ gross beta activity.

NESHAP Reporting: The NESHAP standards of 40 CFR 61, Subpart $H$, for radionuclides require that an annual report from each DOE site must be submitted to the EPA by June 30 each year. The report includes the calculated maximum offsite dose impacts (effective dose equivalent) to the nearby public receptors and the associated input data for this calculation (40 CFR 61.94[c]). The NESHAP annual report will be submitted to EPA, Region VI, on or before the June 1 due date.

Section 5.5 presents detailed results of the dose assessment for the public due to SNL/NM operations in 1993.

Toxic Chemical Release Reporting: The Toxic Chemical Release (TRI) Report is required by SARA, Title III, Section 313 (40 CFR 372). SARA requires that facilities (within Standard Industrial Classification [SIC] of 20 to 39) report 
releases of listed toxic chemicals if the usage quantity is greater than 10,000 pounds per year (lb/yr) for any of the listed chemicals. Although SNL/NM operation is not categorized within the specified SIC code, EO 12856, "Federal Compliance with Right-to-Know Laws and Pollution Prevention Requirements," requires Federal facilities meeting established thresholds to submit TRI Reports under the Emergency Planning and Community Right to Know Act (EPCRA). SNL/NM has been filing the TRI Reports with DOE and the EPA since 1991 (for reporting year CY 1990). SNL/NM will report the CY 1993 toxic chemical releases in June 1994.

\subsubsection{Summary of Environmental Incident Reporting}

There were a total of 26 non-RQ incidents in 1993: nine DOE-reportable occurrences and 17 nonreportable occurrences.

The reportable occurrences varied in size and quantity from $<1$ gal to many thousands of gallons. Of the nine total occurrences, one was a release of an oil or nonhazardous petroleum product mixed with antifreeze and water. One reportable occurrence involved the release of natural gas. There was one release of $<1$ gal of mixed acid, two releases of 500-2000 gal of wastewater to the ground surface, three releases of water mixed with low levels of potentially hazardous materials, and one release of cooling water, which contained an additive for corrosion inhibition and descaling.

The nonreportable occurrences varied in size and quantity from a few gallons to several hundred gallons. Of the 17 total nonreportable occurrences, three were releases of oils or nonhazardous petroleum products. Three nonreportable occurrences involved natural gas or propane gas. Four were releases of cooling water containing various additives for corrosion inhibition and descaling. There were also three releases of 100-400 gal of wastewater to the ground surface, and four releases of 100-500 gal of process water to the ground surface.

Of the total 26 reportable and nonreportable occurrences, 22 were liquid releases. Of the 22 liquid releases, 1 was $<1$ gal of liquid; 1 was $>1$ gal, but $<5$ gal; 11 were between 5 gal and 100 gal; and 9 were $>100$ gal. 


\subsection{TERRESTRIAL SURVEILLANCE}

Sandia National Laboratories/New Mexico (SNL/NM) has maintained environmental radiological surveillance activities since February 1959 (Burnett et al. 1961; Brewer 1973, 1974; Holley 1975; Holley and Simmons 1976; Simmons 1977, 1978, 1979, 1980; Millard 1981; Millard et al. 1982, 1983, 1984, 1985, 1986, 1987, 1988, 1989; Hwang et al. 1990, 1991; Culp et al. 1992, 1993). Calendar year (CY) 1993 marked the first year that stable metal surveillance activities were conducted. The objectives of the radiological and stable metal surveillance activities are to detect any potential releases and/or migration of contaminated material related to onsite operations to offsite locations and also to determine potential impacts (if any) of site-related activities to the offsite population and the surrounding environment. These surveillance activities also provide a check on the effectiveness of safety systems in effect at the various technical areas (TAs).

During March and April 1993, Edgerton, Germeshausen \& Grier Corporation (EG\&G) Energy Measurements Group performed an aerial radiological survey of SNL/NM and the surrounding area. The survey team measured the terrestrial gamma radiation to determine the levels of natural and man-made radiation. The helicopter used in this survey was outfitted with two detector pods and flown at approximately 150-feet ( $\mathrm{ft}$ ) (46 meters $[\mathrm{m}]$ ) above the survey area. It is anticipated that the results of the aerial gamma survey will be available in 1994. Any pertinent information from this survey will be included in the 1994 Site Environmental Report for SNL/NM.

\section{I SURVEILLANCE LOCATIONS}

The Environmental Surveillance Program staff collected soil, arroyo sediments, surface water, and vegetation twice a year: in May and August. The sampling stations are located in three distinct areas: on the SNL/NM site, at the site perimeter, and in the surrounding community. Onsite locations are near areas of known contamination, potential sources of contamination, or in areas where contamination, if present, would be expected to accumulate. The perimeter locations are used to monitor the SNL/NM site boundary for potential siterelated contamination migrating to offsite receptors. The community locations represent offsite locations unrelated to SNL/NM activities. Data collected at community locations serve as a reference point to compare to samples collected from SNL/NM site perimeter and onsite locations. Thermoluminescent dosimeters (TLDs) are used to measure ambient levels of gamma radiation. TLDs are also located on site, off site, and in the surrounding community. In the past, no site-related contamination has been found at perimeter or community locations.

Most terrestrial surveillance locations remain essentially the same from year to year (Figures 4-1 and 4-2). Table 4-1 lists the SNL/NM terrestrial surveillance locations and specifies the type of sample collected (vegetation, soil, sediment, or surface water) and the presence of a TLD for each location. There are a total of 64 fixed sampling locations: 32 onsite at SNL/NM; 16 distributed around the site perimeter; and 16 community locations distributed in and around Albuquerque within a 50-mile (mi) (80-kilometer [km]) radius of SNL/NM. New monitoring locations are added as necessary to monitor new facilities and operations, or to supplement existing data. Environmental 


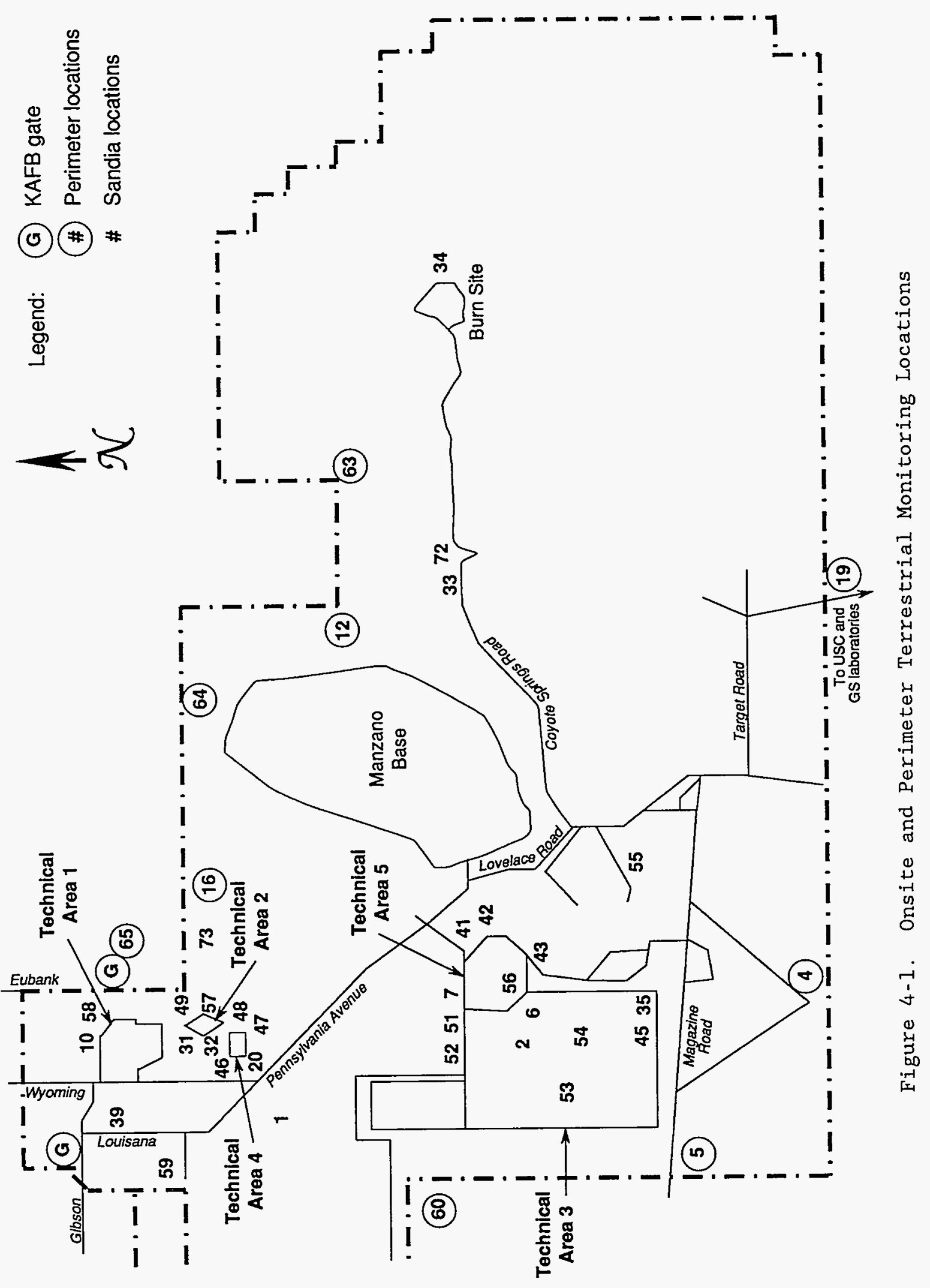




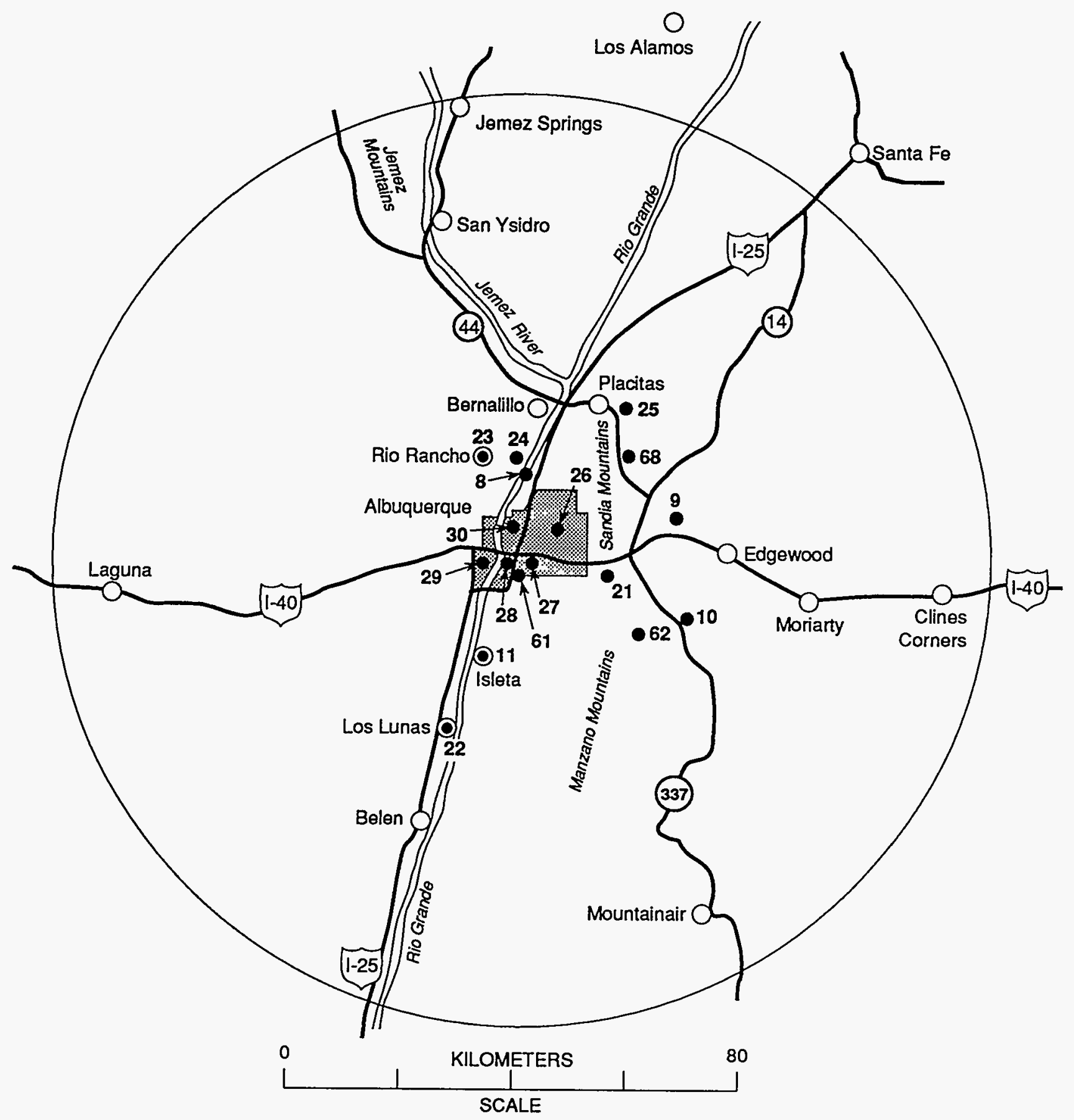

Location of a community

- Sampling location with individual identification number

C Community where a sampling station exists

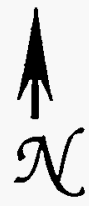

Figure 4-2. Community Terrestrial Monitoring Locations 
Table 4-1. Sandia National Laboratories/New Mexico Terrestrial Surveillance Locations and Sample Types

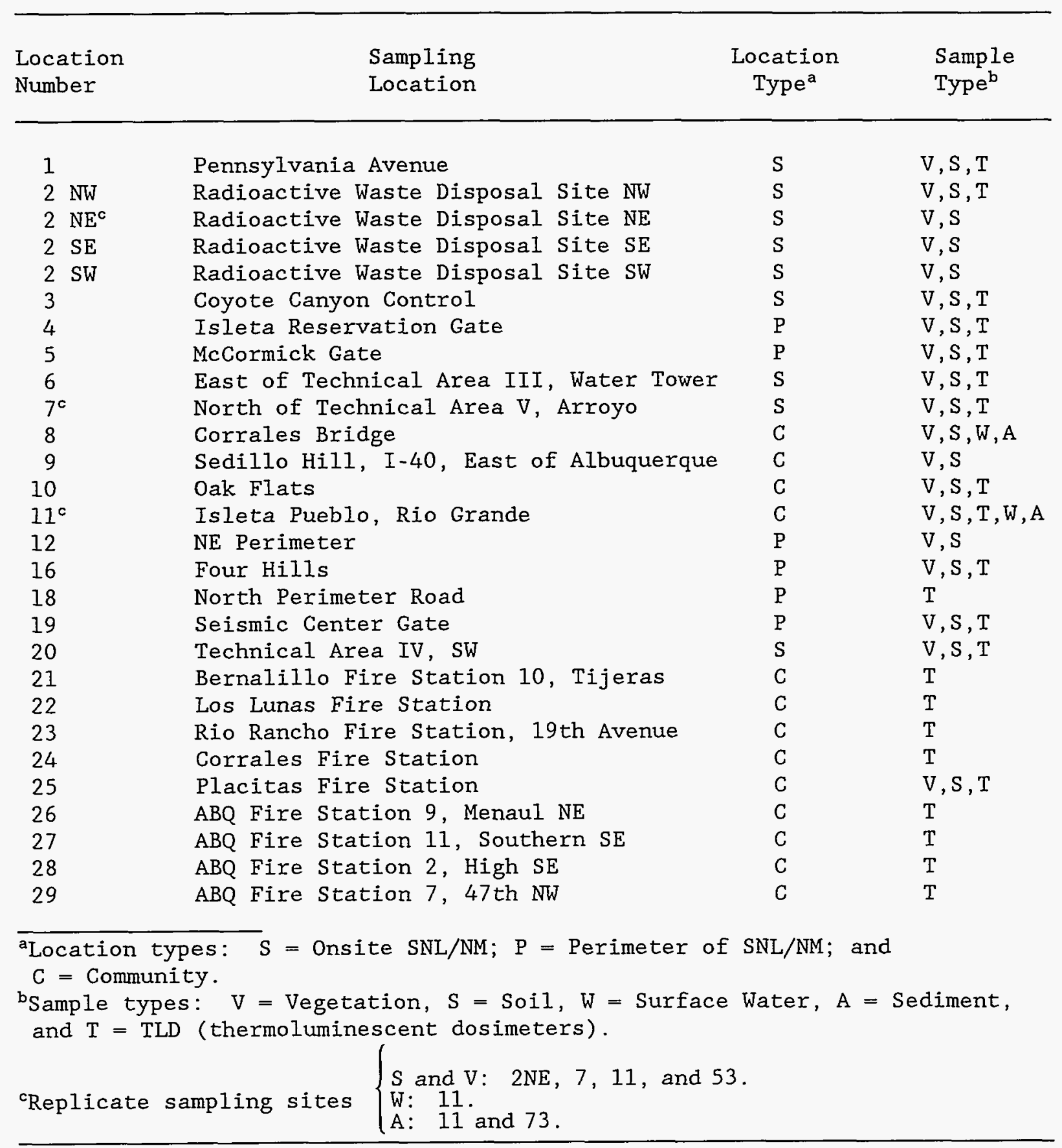


Table 4-1. Sandia National Laboratories/New Mexico Terrestrial Surveillance Locations and Sample Types (Continued)

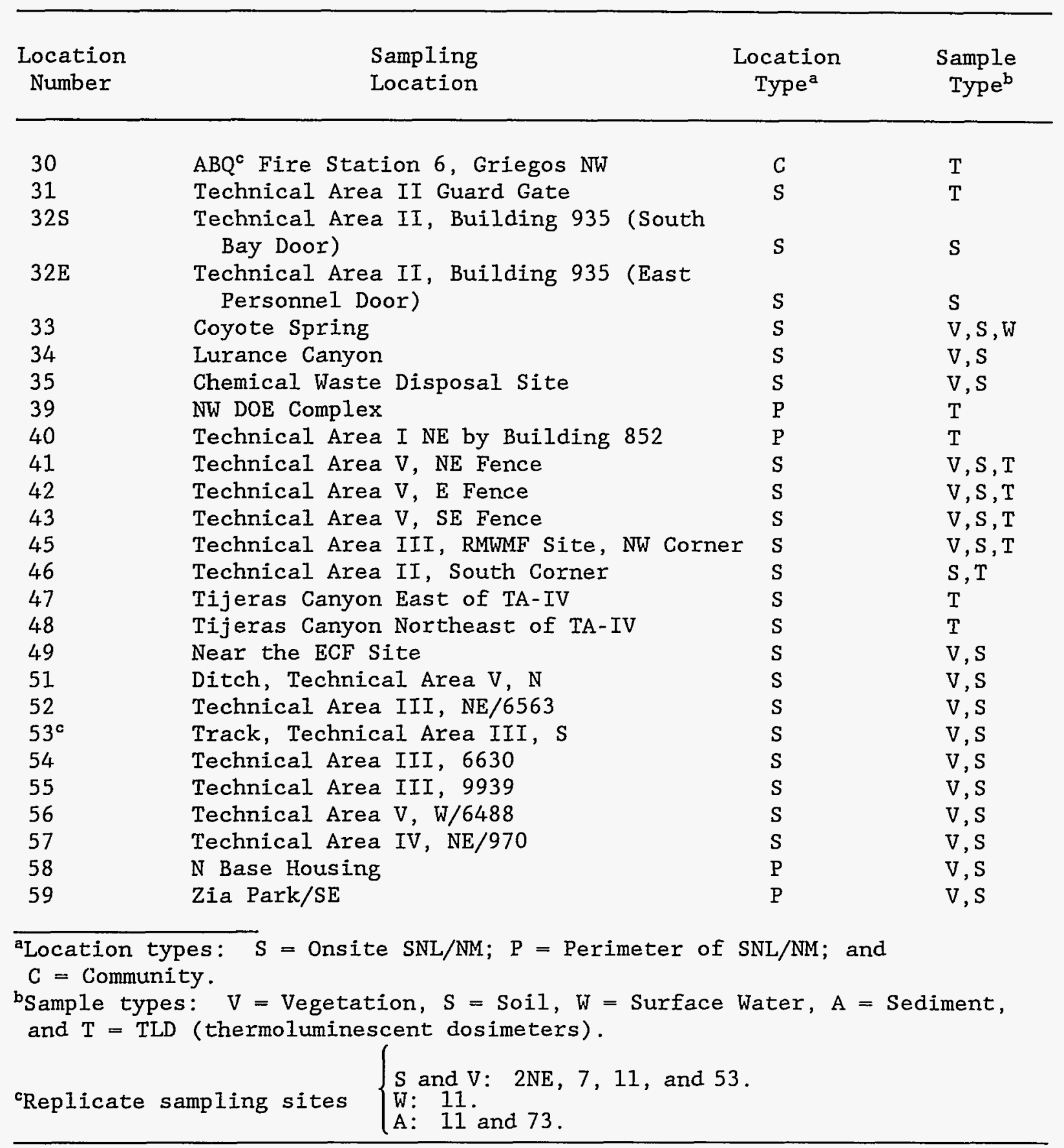


Table 4-1. Sandia National Laboratories/New Mexico Terrestrial Surveillance Locations and Sample Types (Concluded)

\begin{tabular}{|c|c|c|c|}
\hline $\begin{array}{c}\text { Location } \\
\text { Number }\end{array}$ & $\begin{array}{l}\text { Sampling } \\
\text { Location }\end{array}$ & $\begin{array}{c}\text { Location } \\
\text { Type }\end{array}$ & $\begin{array}{l}\text { Sample } \\
\text { Type }^{\mathrm{b}}\end{array}$ \\
\hline $\begin{array}{l}60 \\
61 \\
62 \\
63 \\
64 \\
65 \\
66 \\
68 \\
72 \\
73^{c}\end{array}$ & $\begin{array}{l}\text { Tijeras Arroyo, Old City Prison Farm } \\
\text { Airport (west end) } \\
\text { East Resident } \\
\text { No Sweat Boulevard } \\
\text { North Manzano } \\
\text { Sandia Research Park } \\
\text { KUSMC } \\
\text { Las Huertas } \\
\text { Coyote Arroyo } \\
\text { Tijeras Arroyo }\end{array}$ & $\begin{array}{l}P \\
P \\
C \\
P \\
P \\
P \\
S \\
C \\
S \\
P\end{array}$ & $\begin{array}{l}\text { V,S }, A \\
\text { V,S } \\
\text { V,S } \\
\text { V,S } \\
\text { V,S } \\
\text { V,S } \\
\text { V,S } \\
\text { W,A } \\
\text { A } \\
\text { A }\end{array}$ \\
\hline \multicolumn{4}{|c|}{ 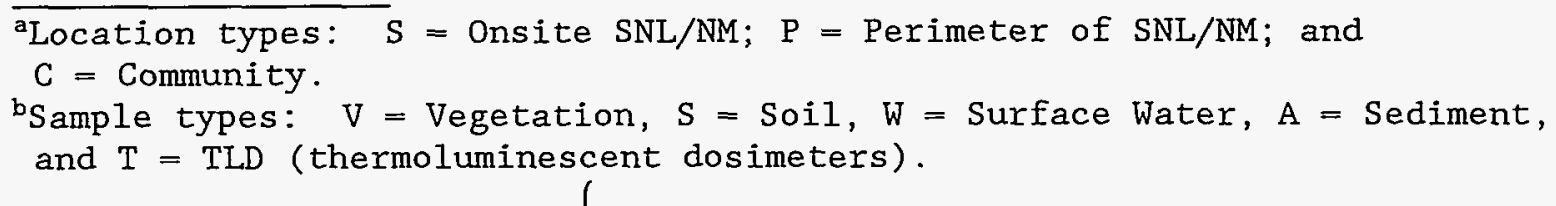 } \\
\hline
\end{tabular}

surveillance locations 72 and 73 were established in 1992 as part of a shortterm (2 year [yr]) arroyo sediment sampling network. Location 72 is in Coyote Arroyo near its confluence with Tijeras Arroyo. Location 73 is in Tijeras Arroyo where the arroyo enters the SNL/NM site. In addition, arroyo sediment was sampled at location 60 . Location 60 is in the Tijeras Arroyo where it exits the SNL/NM site (see Figure 4-1 and Table 4-1). Although no contamination has been identified at these sites, it has been decided to include locations 72 and 73 as permanent, fixed, sampling locations with arroyo sediment included as a permanently sampled media at these locations and at location 60 .

In the past, limited groundwater sampling and analysis has been performed by the Environmental Surveillance Program. Groundwater surveillance locations included ten Kirtland Air Force Base (KAFB) production wells. Groundwater sampling consisted of the sampling of those base production wells which were in operation on the days set aside for the collection of groundwater samples. Within the last year the Environmental Surveillance Program has transferred this function to the Non-Environmental Restoration Groundwater Program where it was consolidated with the site-wide groundwater monitoring efforts (Chapter. $7.0)$. 


\subsection{SAMPLE COLLECTION AND ANALYSIS}

Environmental samples were gathered in accordance with the activity-specific Environment, Safety, and Health (ES\&H) Standard Operating Procedure (SOP) entitled "Environmental Sampling Procedure" (SNL 1992c). Native vegetation (grasses unless otherwise noted), soil, sediment, and surface water samples were collected biannually: once early in the growing season (May) and once toward the end of the growing season (August). TLDs were exchanged every calendar quarter. The sampling protocol for soil, sediment, and vegetation was a composite program. Surface water samples were collected by grab sampling. Total surface water (unfiltered), filtered water, and suspended solids $(>0.45 \mu \mathrm{m})$ were analyzed. Appendix $C$ describes sample collection and analytical procedures. Appendix D lists minimum detection limits for each type of radionuclide analysis.

The radionuclide analysis included laboratory tests on soil, sediment, vegetation, and surface water. Soil, sediment, and vegetation samples were analyzed for tritium (H-3) and by gamma spectroscopy analysis; soil and sediment were also analyzed for total uranium $\left(U_{t o t}\right)$. Gross alpha, beta, and gamma spectroscopy analyses and $U$ and $\mathrm{H}-3$ analyses are performed on surface water samplings.

The monitoring program was enhanced in 1993 to include the analysis of metals in soil and sediment. Soil and sediment samples were analyzed for 18 elements. The inductively coupled plasma (ICP) method was used to determine metals in samples.

A total of 247 samples were analyzed for H-3, 264 by gamma spectroscopy, and 160 for total $U_{\text {tot }}$ in 1993. In addition, 38 water samples or fractions of samples were screened for gross alpha and gross beta. Table C-1 of Appendix $C$ summarizes sampling frequencies and types of analysis for the radioactive environmental monitoring program.

\subsection{TERRESTRIAL RADIOLOGICAL SURVEILIANCE RESULTS}

Appendix $F$ presents the terrestrial monitoring data for all individual sample stations and sampled media. Calculated summary data tables are discussed in the following paragraphs of this section. Less-than-detection values were set equal to the detection value for statistical calculations. In cases of replicate sampling, only the first sample collected (sample A) was used in summary calculations to avoid skewing summary data toward replicate sample data. In the case of sediment samples, data from individual locations were not pooled to determine descriptive statistics for a given sample location type (i.e., onsite, perimeter, and community); instead, individual samples were compared to one another. Where sediment replicate samples were collected, descriptive statistics were considered the best estimate of the true radionuclide concentration at the sampled station and were used for comparison with other locations. 


\subsubsection{Vegetation}

Tables F-1 and F-2 of Appendix F list concentrations of H-3, potassium-40 (K40), and percent water in vegetation (grass species unless otherwise noted) for 24 SNL/NM onsite, 12 perimeter, and 6 community sampling locations and any corresponding replicate samples. These locations were sampled twice in 1993. Tables 4-2 and 4-3 summarize the mean $(\bar{x})$, standard deviation (S), and range of values for the three types of sampling locations and two sampling periods. The H-3 concentrations are reported as picocuries per milliliter ( $\mathrm{pCi} / \mathrm{mL})$ of extracted water.

Tritium concentrations in vegetation collected in May and August from perimeter and community locations appear to be consistent with each other and with previous years' results. The majority of the individually reported $\mathrm{H}-3$ concentrations in vegetation collected from onsite locations are within the range of values for the perimeter and community locations. Where vegetation H-3 concentrations are elevated, soil sampled at the same location is also elevated. These sample locations are near sites known to be contaminated with H-3. These sites are currently undergoing characterization for eventual environmental restoration and are located in areas of restricted access. Monitoring will continue at these locations to identify and measure contaminant migration.

\subsubsection{Soil}

Tables F-3 and F-4 of Appendix F list concentrations of $U_{\text {tot }}, \mathrm{H}-3$, cesium-137 (Cs-137), K-40, and percent water in soil samples for the 28 SNL/NM onsite, 12 perimeter, and 6 community locations and any corresponding replicate samples. These locations were sampled twice in 1993 unless otherwise noted. Table 4-4 summarizes the mean $(\vec{x})$, standard deviation (S), and range of values for the three types of sampling locations and two sampling periods.

Tritium concentrations in soil collected in May and August from perimeter and community locations appear to be consistent with each other and with previous years' results. The majority of the individually reported $\mathrm{H}-3$ concentrations in soil collected from onsite locations fall within the range of values for the perimeter and community locations. Where onsite soil concentrations are elevated with $\mathrm{H}-3$, the sample location is near sites known to be contaminated with $\mathrm{H}-3$. These sites are currently undergoing characterization for eventual environmental restoration and are located in areas of restricted access. Monitoring will continue at these locations to identify and measure contaminant migration.

The Cs-137 concentrations for all location types and sampling periods were consistent with previous years' results and consistent with each other. Concentrations appear to reflect fallout levels of Cs-137 and normal sample variation.

Total uranium concentrations in soil collected in May and August from perimeter and community locations appear to be consistent with each other and with previous years' results. The majority of the individually reported $U$ concentrations in soil collected from onsite locations fall within the range of values for the perimeter and community locations. Where onsite soil 
Table 4-2. Mean Concentrations of Tritium in Vegetation Sampled in May 1993

\begin{tabular}{|c|c|c|c|c|c|}
\hline \multirow[b]{2}{*}{ Nuclide } & \multirow[b]{2}{*}{ Location } & \multirow[b]{2}{*}{$\begin{array}{l}\text { Sample } \\
\text { Size }\end{array}$} & \multicolumn{3}{|c|}{$\begin{array}{c}\text { Concentration } \\
(\mathrm{pCi} / \mathrm{mL})\end{array}$} \\
\hline & & & $\begin{array}{l}\text { Mean } \\
(\bar{x})\end{array}$ & $\begin{array}{c}\text { Standard } \\
\text { Deviation } \\
\text { (S) }\end{array}$ & Range \\
\hline \multirow[t]{4}{*}{$\mathrm{H}-3$} & SNL & 24 & 0.37 & 1.8 & -0.15 to 8.7 \\
\hline & Perimeter & 12 & 0.00 & 0.07 & -0.12 to 0.10 \\
\hline & Community & 6 & -0.04 & 0.05 & -0.08 to 0.05 \\
\hline & Total & 42 & & & \\
\hline
\end{tabular}

Table 4-3. Mean Concentrations of Tritium in Vegetation Sampled in August 1993

\begin{tabular}{|c|c|c|c|c|c|}
\hline \multirow[b]{2}{*}{ Nuclide } & \multirow[b]{2}{*}{ Location } & \multirow[b]{2}{*}{$\begin{array}{l}\text { Sample } \\
\text { Size }\end{array}$} & \multicolumn{3}{|c|}{$\begin{array}{c}\text { Concentration } \\
(\mathrm{pCi} / \mathrm{mL})\end{array}$} \\
\hline & & & $\begin{array}{l}\text { Mean } \\
(\bar{x})\end{array}$ & $\begin{array}{c}\text { Standard } \\
\text { Deviation } \\
\text { (s) }\end{array}$ & Range \\
\hline \multirow[t]{2}{*}{$\mathrm{H}-3$} & $\begin{array}{l}\text { SNL } \\
\text { Perimeter } \\
\text { Community }\end{array}$ & $\begin{array}{r}24 \\
12 \\
6 \\
\end{array}$ & $\begin{array}{l}1.4 \\
-0.05 \\
-0.08\end{array}$ & $\begin{array}{l}3.6 \\
0.10 \\
0.05\end{array}$ & $\begin{array}{l}-0.18 \text { to } 14 \\
-0.19 \text { to } 0.13 \\
-0.15 \text { to }-0.02\end{array}$ \\
\hline & Total & 42 & & & \\
\hline
\end{tabular}


Table 4-4. Mean Concentrations of Uranium, Cesium-137, and Tritium in Soil Samples Collected in May and August 1993

\begin{tabular}{|c|c|c|c|c|c|}
\hline \multirow[b]{2}{*}{ Nuclide } & \multirow[b]{2}{*}{ Type } & \multirow[b]{2}{*}{$\begin{array}{c}\text { Sample } \\
\text { Size }\end{array}$} & \multicolumn{3}{|c|}{ Concentration } \\
\hline & & & $\begin{array}{l}\text { Mean } \\
(\bar{x})\end{array}$ & $\begin{array}{c}\text { Standard } \\
\text { Deviation } \\
\text { (s) }\end{array}$ & Range \\
\hline May & & & & & \\
\hline $\begin{array}{l}\mathrm{U} \\
(\mu \mathrm{g} / \mathrm{g})\end{array}$ & $\begin{array}{l}\text { SNL } \\
\text { Perimeter } \\
\text { Community }\end{array}$ & $\begin{array}{r}28 \\
12 \\
6\end{array}$ & $\begin{array}{l}1.1 \\
0.9 \\
1.3\end{array}$ & $\begin{array}{l}0.7 \\
0.2 \\
0.6\end{array}$ & $\begin{array}{l}0.3 \text { to } 4.2 \\
0.5 \text { to } 1.3 \\
0.5 \text { to } 2.0\end{array}$ \\
\hline $\begin{array}{l}\text { Cs }-137 \\
(\mathrm{pC} i / g)\end{array}$ & $\begin{array}{l}\text { SNL } \\
\text { Perimeter } \\
\text { Community }\end{array}$ & $\begin{array}{r}28 \\
12 \\
6\end{array}$ & $\begin{array}{l}0.30 \\
0.47 \\
0.47\end{array}$ & $\begin{array}{l}0.35 \\
0.49 \\
0.42\end{array}$ & $\begin{array}{l}0.00 \text { to } 1.7 \\
0.00 \text { to } 1.6 \\
0.06 \text { to } 1.1\end{array}$ \\
\hline $\begin{array}{l}\mathrm{H}-3 \\
(\mathrm{pC} \mathrm{i} / \mathrm{mL})\end{array}$ & $\begin{array}{l}\text { SNL } \\
\text { Perimeter } \\
\text { Community }\end{array}$ & $\begin{array}{r}28 \\
12 \\
6\end{array}$ & $\begin{array}{r}22 \\
0.11 \\
0.10\end{array}$ & $\begin{array}{l}81 \\
0.12 \\
0.15\end{array}$ & $\begin{array}{l}-0.14 \text { to } 400 \\
-0.07 \text { to } 0.36 \\
-0.09 \text { to } 0.31\end{array}$ \\
\hline August & & & & & \\
\hline $\begin{array}{l}\mathrm{U} \\
(\mu \mathrm{g} / \mathrm{g})\end{array}$ & $\begin{array}{l}\text { SNL } \\
\text { Perimeter } \\
\text { Community }\end{array}$ & $\begin{array}{r}28 \\
12 \\
6\end{array}$ & $\begin{array}{l}1.3 \\
1.4 \\
2.0\end{array}$ & $\begin{array}{l}0.5 \\
0.5 \\
0.7\end{array}$ & $\begin{array}{l}0.5 \text { to } 2.4 \\
0.5 \text { to } 2.0 \\
1.4 \text { to } 3.0\end{array}$ \\
\hline $\begin{array}{l}\text { Cs }-137 \\
(\mathrm{pC} i / g)\end{array}$ & $\begin{array}{l}\text { SNL } \\
\text { Perimeter } \\
\text { Community }\end{array}$ & $\begin{array}{r}28 \\
12 \\
6\end{array}$ & $\begin{array}{l}0.19 \\
0.27 \\
0.16\end{array}$ & $\begin{array}{l}0.16 \\
0.27 \\
0.16\end{array}$ & $\begin{array}{l}0.00 \text { to } 0.51 \\
0.00 \text { to } 0.77 \\
0.00 \text { to } 0.44\end{array}$ \\
\hline $\begin{array}{l}\mathrm{H}-3 \\
(\mathrm{pCi} / \mathrm{mL})\end{array}$ & $\begin{array}{l}\text { SNL } \\
\text { Perimeter } \\
\text { Community }\end{array}$ & $\begin{array}{r}28 \\
12 \\
6\end{array}$ & $\begin{array}{rl} & 2.8 \\
-0.01 & 0.00\end{array}$ & $\begin{array}{l}7.0 \\
0.07 \\
0.06\end{array}$ & $\begin{array}{l}-0.17 \text { to } 30 \\
-0.11 \text { to } 0.15 \\
-0.08 \text { to } 0.08\end{array}$ \\
\hline
\end{tabular}


concentrations of $U$ are believed to be elevated, the sample location is near a site of known or potential contamination. These sites are currently undergoing characterization of eventual environmental restoration and are located in areas of restricted access. Monitoring will continue at these locations to identify and measure contaminant migration.

\subsubsection{Surface Water}

Tables F-5 and F-6 of Appendix F list concentrations of gross alpha, gross beta, gross gamma, $\mathrm{U}_{\text {tot }}$, and $\mathrm{H}-3$ in surface water for the one SNL/NM onsite and three community locations and any corresponding replicate samples. These locations were sampled twice in 1993. Tables 4-5 and 4-6 summarize mean concentrations of gross alpha, gross beta, gross gamma, $\mathrm{U}_{\text {tot }}$, and $\mathrm{H}-3$ for total (unfiltered) water, filtered water, and associated suspended solids in surface water samples.

Station 8 is located on the Rio Grande where the Corrales Bridge goes over the river and is upgradient of both SNL/NM and Albuquerque. Station 11 is located on the Rio Grande at the Isleta Pueblo and is downgradient of both SNL/NM and Albuquerque. Data from samples collected in May 1993 show the upgradient and downgradient locations to be indistinguishable from each other. Suspended solids appear to be elevated in gross alpha and gross beta concentrations compared to data gathered in previous years, but within previously observed range of values.

Data from samples collected in August 1993 show some variation between sample fractions and sampling locations. While some variation does exist, the majority of the data appear to be consistent with previous years results and consistent between the upgradient and downgradient locations. Where variation between sampling locations appears to exist, the upgradient location appears to be elevated in total water gross alpha activity and in total water and filtered water uranium. Some of the variation in sample data may represent normal sample variation or be related to the activities in and around the Rio Grande.

Results from the onsite surface water sample taken from Station 33 (Coyote Spring) are consistent with results from previous years. Results from offsite surface water reference location Station 68 (Las Huertas stream) are also consistent with results from previous years. In general, onsite surface water appears to be higher than the offsite surface water in gross alpha, gross beta, and $U$ total. Other results appear to be comparable to one another.

Differences in activity concentrations in surface water may be due, in part, to random variation in sampling, normal sample variation, and/or environmental factors. Environmental factors may include sediment loading, flow rate, and volume. 
Table 4-5. Mean Concentrations of Gross Alpha, Gross Beta, Gamma Spectroscopy ${ }^{a}$, Uranium, and Tritium in Surface Water for May 1993

\begin{tabular}{|c|c|c|c|c|c|}
\hline $\begin{array}{l}\text { Analysis } \\
\text { (units) }\end{array}$ & Station & Location $^{b}$ & $\begin{array}{c}\text { Total } \\
\text { Waterc } \\
(\bar{x} \pm s)\end{array}$ & $\begin{array}{c}\text { Filtered } \\
\text { Waterc } \\
(\bar{x} \pm s)\end{array}$ & $\begin{array}{l}\text { Suspended } \\
\text { Solids } \\
(\bar{x} \pm s)\end{array}$ \\
\hline $\begin{array}{l}\text { Gross Alpha } \\
(\mathrm{pCi} / \mathrm{L})\end{array}$ & $\begin{array}{r}8 \\
11 \\
33 \\
68\end{array}$ & $\begin{array}{l}\mathrm{C} \\
\mathrm{C} \\
\mathrm{S} \\
\mathrm{C}\end{array}$ & $\begin{array}{l}6 \pm 2 \\
3 \pm 2 \\
2 \pm 13 \\
1 \pm 2\end{array}$ & $\begin{array}{l}2 \pm 1 \\
1 \pm 1 \\
8 \pm 7 \\
1 \pm 1\end{array}$ & $\begin{array}{c}16 \pm 10 \\
15 \pm 8 \\
-1 \pm 7 \\
9 \pm 7\end{array}$ \\
\hline $\begin{array}{l}\text { Gross Beta } \\
(\mathrm{pCi} / \mathrm{L})\end{array}$ & $\begin{array}{r}8 \\
11 \\
33 \\
68\end{array}$ & $\begin{array}{l}\mathrm{C} \\
\mathrm{C} \\
\mathrm{S} \\
\mathrm{C}\end{array}$ & $\begin{aligned} 7 & \pm 2 \\
6 & \pm 2 \\
45 & \pm 15 \\
2 & \pm 2\end{aligned}$ & $\begin{array}{c}5 \pm 1 \\
4 \pm 1 \\
35 \pm 8 \\
3 \pm 1\end{array}$ & $\begin{aligned} 21 & \pm 10 \\
37 & \pm 10 \\
19 & \pm 10 \\
6 & \pm 7\end{aligned}$ \\
\hline $\begin{array}{l}\mathrm{U}_{\text {tot }} \\
(\mathrm{mg} / \mathrm{L})\end{array}$ & $\begin{array}{r}8 \\
11 \\
33 \\
68\end{array}$ & $\begin{array}{l}\mathrm{C} \\
\mathrm{C} \\
\mathrm{S} \\
\mathrm{C}\end{array}$ & $\begin{array}{l}<0.005 \\
<0.005 \\
<0.005 \\
<0.005\end{array}$ & $\begin{array}{r}<0.005 \\
<0.005 \\
0.006 \\
<0.005\end{array}$ & $\begin{array}{l}-- \\
-- \\
-- \\
--\end{array}$ \\
\hline $\begin{array}{l}\mathrm{H}-3 \\
(\mathrm{pCi} / \mathrm{mL})\end{array}$ & $\begin{array}{r}8 \\
11 \\
33 \\
68\end{array}$ & $\begin{array}{l}\mathrm{C} \\
\mathrm{C} \\
\mathrm{S} \\
\mathrm{C}\end{array}$ & $\begin{array}{l}-- \\
-- \\
-- \\
--\end{array}$ & $\begin{array}{l}-0.15 \pm 0.41 \\
-0.12 \pm 0.17 \\
-0.06 \pm 0.17 \\
-0.14 \pm 0.17\end{array}$ & $\begin{array}{l}-- \\
-- \\
-- \\
--\end{array}$ \\
\hline \multicolumn{6}{|c|}{$\begin{array}{l}\text { a No values detected above instrument background. } \\
{ }^{b} \mathrm{C}=\text { Community; } \mathrm{S}=\mathrm{SNL} / \mathrm{NM} \text {. } \\
{ }^{\mathrm{c}} \text { Variability of the radioactive disintegration process (counting error) at } \\
\text { the } 95 \text {-percent confidence level, } 1.96 \text { sigma. }\end{array}$} \\
\hline
\end{tabular}


Table 4-6. Mean Concentrations of Gross Alpha, Gross Beta, Gamma Spectroscopya, Uranium, and Tritium in Surface Water for August 1993

\begin{tabular}{|c|c|c|c|c|c|}
\hline $\begin{array}{l}\text { Analysis } \\
\text { (units) }\end{array}$ & Station & Location $^{\mathrm{b}}$ & $\begin{array}{c}\text { Total } \\
\text { Water: } \\
(\bar{x} \pm s)\end{array}$ & $\begin{array}{l}\text { Filtered } \\
\text { Waterc } \\
(\bar{x} \pm s)\end{array}$ & $\begin{array}{l}\text { Suspended } \\
\text { Solids } \\
(\bar{x} \pm s)\end{array}$ \\
\hline $\begin{array}{l}\text { Gross Alpha } \\
(\mathrm{pCi} / \mathrm{L})\end{array}$ & $\begin{array}{r}8 \\
11 \\
33 \\
68\end{array}$ & $\begin{array}{l}\mathrm{C} \\
\mathrm{C} \\
\mathrm{S} \\
\mathrm{C}\end{array}$ & $\begin{array}{r}14 \pm 5 \\
9 \pm 3 \\
8 \pm 8 \\
2 \pm 2\end{array}$ & $\begin{aligned} 3 & \pm 2 \\
3 & \pm 1 \\
20 & \pm 15 \\
2 & \pm 2\end{aligned}$ & $\begin{array}{c}3 . \pm 1 \\
0.3 \pm 0.3 \\
0.3 \pm 0.3 \\
0.3 \pm 0.3\end{array}$ \\
\hline $\begin{array}{l}\text { Gross Beta } \\
(\mathrm{pC} i / L)\end{array}$ & $\begin{array}{r}8 \\
11 \\
33 \\
68\end{array}$ & $\begin{array}{l}C \\
C \\
S \\
C\end{array}$ & $\begin{aligned} 15 & \pm 5 \\
20 & \pm 3 \\
23 & \pm 10 \\
2 & \pm 3\end{aligned}$ & $\begin{aligned} 4 & \pm 2 \\
6 & \pm 2 \\
43 & \pm 19 \\
2 & \pm 2\end{aligned}$ & $\begin{aligned} 4 & \pm 1 \\
-0.3 & \pm 0.7 \\
0.0 & \pm 0.7 \\
-0.3 & \pm 0.7\end{aligned}$ \\
\hline $\begin{array}{l}\mathrm{U}_{\mathrm{tot}} \\
(\mathrm{mg} / \mathrm{L})\end{array}$ & $\begin{array}{r}8 \\
11 \\
33 \\
68\end{array}$ & $\begin{array}{l}\mathrm{C} \\
\mathrm{C} \\
\mathrm{S} \\
\mathrm{C}\end{array}$ & $\begin{aligned} & 4.0 \\
&< 0.005 \\
& 0.006 \\
&<0.005\end{aligned}$ & $\begin{aligned} & 2.4 \\
&< 0.005 \\
& 0.006 \\
&<0.005\end{aligned}$ & $\begin{array}{l}<0.005 \\
<0.005 \\
<0.005 \\
<0.005\end{array}$ \\
\hline $\begin{array}{l}\mathrm{H}-3 \\
(\mathrm{pCi} / \mathrm{mL})\end{array}$ & $\begin{array}{r}8 \\
11 \\
33 \\
68\end{array}$ & $\begin{array}{l}\mathrm{C} \\
\mathrm{C} \\
\mathrm{S} \\
\mathrm{C}\end{array}$ & $\begin{aligned} 0.00 & \pm 0.15 \\
-0.07 & \pm 0.15 \\
0.16 & \pm 0.16 \\
-0.02 & \pm 0.14\end{aligned}$ & $\begin{array}{r}-0.01 \pm 0.15 \\
-0.03 \pm 0.15 \\
-0.09 \pm 0.15 \\
0.04 \pm 0.14\end{array}$ & $\begin{array}{l}-- \\
-- \\
-- \\
--\end{array}$ \\
\hline
\end{tabular}

aNo values detected above instrument background.

${ }^{\mathrm{b}} \mathrm{C}=$ Community; $\mathrm{S}=\mathrm{SNL} / \mathrm{NM}$.

'Variability of the radioactive disintegration process (counting error) at the 95-percent confidence level, 1.96 sigma. 


\subsubsection{Sediment}

Concentrations of $\mathrm{U}_{\text {tot }}, \mathrm{H}-3$, and $\mathrm{Cs}-137$ in sediments are reported in Tables F-7 and F-8 of Appendix $F$ and summarized in Table 4-7 for the two Rio Grande sediment stations, one mountain stream sediment station, and three arroyo sediment stations. All stations were sampled twice in 1993.

The $U_{\text {tot }}, \mathrm{H}-3$, and $\mathrm{Gs}-137$ concentrations for upgradient SNL/NM perimeter (Station 73), onsite (Station 72), and downgradient SNL/NM perimeter (Station 60) arroyo sediment-monitoring stations are believed to be consistent with each other. Differences in radionuclide concentrations are believed to represent normal sample variation and do not indicate any contaminant loading of the arroyo system due to activities at SNL/NM.

The $\mathrm{U}_{\text {tot }}, \mathrm{H}-3$, and $\mathrm{Cs}-137$ concentrations in upgradient (Station 8) and downgradient (Station 11) (relative to SNL/NM and Albuquerque) Rio Grande sediment-monitoring stations are believed to be consistent with each other and also consistent with sediment collected from an upgradient mountain stream (Station 68). Differences in radionuclide concentrations are believed to represent normal sample variation.

\subsubsection{Environmental Thermoluminescent Dosimeters}

Table 4-8 summarizes the annual TLD dose equivalent estimates for the onsite, perimeter, and community locations (listed in Table 4-1). (Table F-9 of Appendix $F$ provides data for individual stations.) These estimates include natural background and facility contributions (if any). The annual external dose equivalent mean for 12 community and 7 perimeter locations was 95.4 millirems per year (mrem/yr) and $94.8 \mathrm{mrem} / \mathrm{yr}$, respectively. The mean of the 15 locations adjacent to onsite facilities was $97.9 \mathrm{mrem} / \mathrm{yr}$. No significant difference in annual dose equivalent estimates (alpha $=0.05$ ) existed between the three location types. Results were also consistent with previous years' results.

\subsection{TERRESTRIAL NONRADIOLOGICAL SURVEILLANCE RESULTS}

The environmental monitoring program was enhanced to include sampling for total metals. The samples are categorized by site: samples taken on SNL (onsite), samples taken near the SNL perimeter and samples taken in the surrounding community (offsite). Community samples were collected in areas unrelated to SNL activities. Both soil and arroyo sediment samples were analyzed for the following metals: aluminum, barium, beryllium, cadmium, calcium, chromium, cobalt, copper, iron, lead, magnesium, manganese, nickel, potassium, strontium, titanium, vanadium and zinc. Comparable sets of samples were analyzed from May and August, 1993. The analytical data is presented in Appendix F. Comparison of onsite, perimeter, and offsite samples will help to determine if SNL activities have contributed to the deposition of metals in the past. If SNL activities do contribute to metal deposition, then comparison of samples from the same sites over time will provide information to help monitor SNLs contribution to the increase in metals. 
Table 4-7. Concentrations of Uranium, Tritium, and Cesium-137 in Sediment for May and August 1993

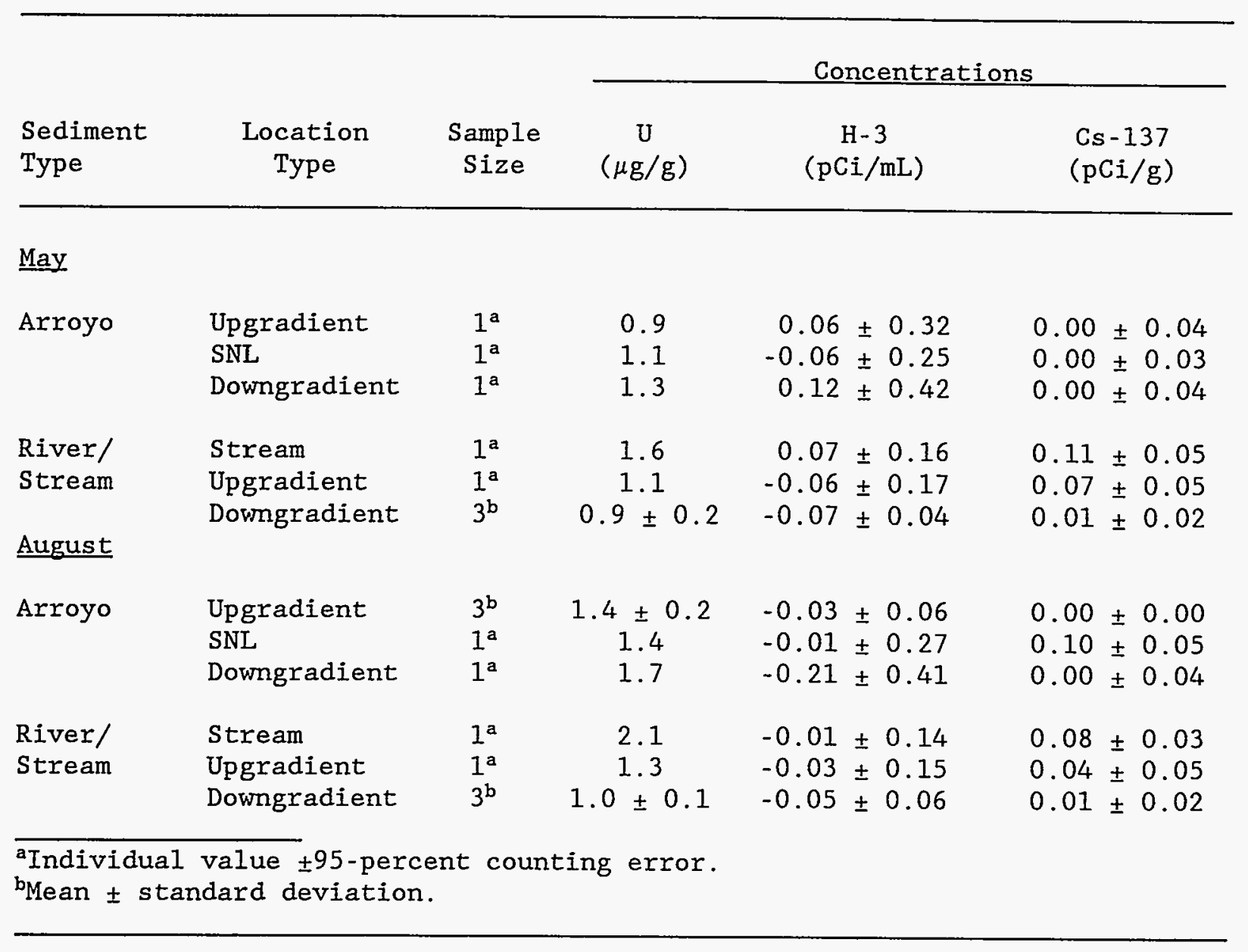


Table 4-8. Summary of Thermoluminescent Dosimeter Measurements for $1993^{a}$

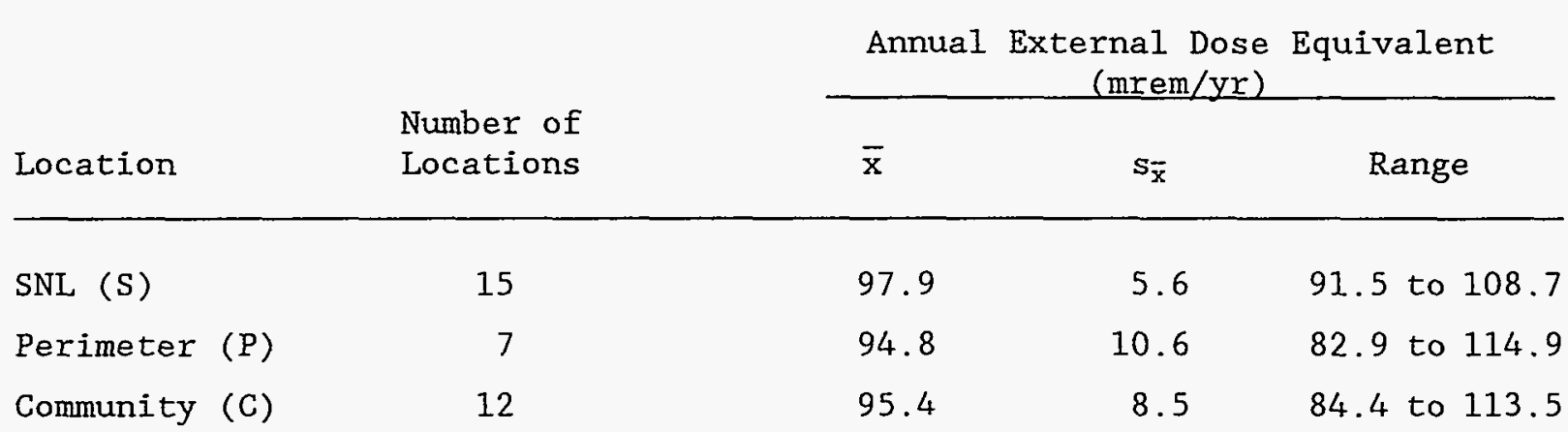

aTable F-11 of Appendix F lists detailed results.

Soil Samples: Tables F-10, F-11, F-12, and F-13 in Appendix F list the concentrations of metals in soil samples from SNL TAS I, II, and IV, SNL TAs III and V, perimeter, and community sites, respectively, taken in May 1993. Tables F-14, F-15, F-16, and F-17 list the data for the corresponding samples taken in August 1993. The results are summarized in Table 4-9. The onsite data for contiguous TAS I, II, and IV (Group 1) are analyzed separately from the data for contiguous TAs III and V (Group 2).

Statistically, the only concentration means which could be shown to be significantly higher for onsite samples than for offsite samples at the $95 \%$ confidence level were for titanium in Group 1 in both May and August. The samples most responsible for the higher mean titanium concentrations were from sampling sites $32 \mathrm{E}, 32 \mathrm{~S}$, and 49 which are in close relative proximity. A salient feature of the data summary in Table 4-9 is the 1,930 ppm mean concentration of lead in the May Group 1 samples. The corresponding mean lead concentration in the August Group 1 samples is also high, at $117 \mathrm{ppm}$. These high mean concentrations of lead do not show up as statistically significant because the standard deviations for both the onsite and offsite sample populations are relatively large. The high mean lead concentration in the May Group 1 samples is primarily the result of $11,000 \mathrm{ppm}$ in the sample from site 20 , and $560 \mathrm{ppm}$ in the sample from site 32E. The lead concentrations in samples taken from these two sites in August were also high, at 260 and $400 \mathrm{ppm}$ respectively. The Site 20 sampling location is in the vicinity of the KAFB skeet shooting range, in the direction of shotgun firing. Of the offsite soil samples, the Site 8 samples had a lead concentration of $100 \mathrm{ppm}$ in May and 80 $\mathrm{ppm}$ in August. These were well above the corresponding mean concentrations 25.8 and $18.7 \mathrm{ppm}$. Site 8 is at the Corrales Bridge about ten kilometers north of the center of Albuquerque at I-25. The concentration means for a number of metals were lower in the onsite samples than in the offsite samples. None of the concentration means were significantly higher for perimeter samples than for offsite samples. 
Table 4-9. Summary of Soil Samples

\begin{tabular}{|c|c|c|c|c|c|}
\hline & & \multicolumn{4}{|c|}{ Metal Concentration Mean (ppm) } \\
\hline & & $\begin{array}{l}\text { Onsite } \\
\text { Group } 1^{\mathrm{a}}\end{array}$ & $\begin{array}{l}\text { Onsite } \\
\text { Group } 2^{\mathrm{b}}\end{array}$ & Perimeter & Offsite \\
\hline Aluminum & $\begin{array}{l}\text { May } \\
\text { Aug }\end{array}$ & $\begin{array}{l}7,883 \\
8,200\end{array}$ & $\begin{array}{l}8,680 \\
9,510\end{array}$ & $\begin{array}{r}19,502 \\
9,982\end{array}$ & $\begin{array}{l}11,700 \\
11,100\end{array}$ \\
\hline Barium & $\begin{array}{l}\text { May } \\
\text { Aug }\end{array}$ & $\begin{array}{l}108 \\
108\end{array}$ & $\begin{array}{l}77.6 \\
92.0\end{array}$ & $\begin{array}{l}116 \\
134\end{array}$ & $\begin{array}{l}165 \\
160\end{array}$ \\
\hline Beryllium & $\begin{array}{l}\text { May } \\
\text { Aug }\end{array}$ & $\begin{array}{l}0.5 \\
0.5\end{array}$ & $\begin{array}{l}0.5 \\
0.5\end{array}$ & $\begin{array}{r}0.5 \\
1.00\end{array}$ & $\begin{array}{l}0.600 \\
0.589\end{array}$ \\
\hline Cadmium & $\begin{array}{l}\text { May } \\
\text { Aug }\end{array}$ & $\begin{array}{l}0.733 \\
0.750\end{array}$ & $\begin{array}{r}0.72 \\
0.5\end{array}$ & $\begin{array}{r}0.5 \\
1.00\end{array}$ & $\begin{array}{r}0.5 \\
0.522\end{array}$ \\
\hline Calcium & $\begin{array}{l}\text { May } \\
\text { Aug }\end{array}$ & $\begin{array}{l}31,500 \\
38,800\end{array}$ & $\begin{array}{l}13,580 \\
17,400\end{array}$ & $\begin{array}{l}23,400 \\
30,300\end{array}$ & $\begin{array}{l}29,800 \\
29,900\end{array}$ \\
\hline Chromium & $\begin{array}{l}\text { May } \\
\text { Aug }\end{array}$ & $\begin{array}{l}18.0 \\
16.8\end{array}$ & $\begin{array}{l}17.7 \\
19.4\end{array}$ & $\begin{array}{l}19.2 \\
19.9\end{array}$ & $\begin{array}{l}21.3 \\
27.2\end{array}$ \\
\hline Cobalt & $\begin{array}{l}\text { May } \\
\text { Aug }\end{array}$ & $\begin{array}{l}4.40 \\
4.48\end{array}$ & $\begin{array}{l}3.04 \\
3.33\end{array}$ & $\begin{array}{l}4.80 \\
5.40\end{array}$ & $\begin{array}{l}5.10 \\
4.60\end{array}$ \\
\hline Copper & $\begin{array}{l}\text { May } \\
\text { Aug }\end{array}$ & $\begin{array}{l}16.0 \\
11.5\end{array}$ & $\begin{array}{l}6.72 \\
7.21\end{array}$ & $\begin{array}{l}9.60 \\
9.50\end{array}$ & ${ }^{11} .70$ \\
\hline Iron & $\begin{array}{l}\text { May } \\
\text { Aug }\end{array}$ & $\begin{array}{l}11,200 \\
10,400\end{array}$ & $\begin{array}{l}8,780 \\
9,330\end{array}$ & $\begin{array}{l}12,200 \\
12,200\end{array}$ & $\begin{array}{l}13,400 \\
12,200\end{array}$ \\
\hline Lead & $\begin{array}{l}\text { May } \\
\text { Aug }\end{array}$ & $\begin{array}{r}1,930 \\
117\end{array}$ & $\begin{array}{l}8.75 \\
8.50\end{array}$ & $\begin{array}{l}11.2 \\
10.2\end{array}$ & $\begin{array}{l}25.8 \\
18.7\end{array}$ \\
\hline Magnesium & $\begin{array}{l}\text { May } \\
\text { Aug }\end{array}$ & $\begin{array}{l}3,350 \\
3,870\end{array}$ & $\begin{array}{l}2,445 \\
2,640\end{array}$ & $\begin{array}{l}3,950 \\
4,040\end{array}$ & $\begin{array}{l}3,800 \\
3,440\end{array}$ \\
\hline Manganese & $\begin{array}{l}\text { May } \\
\text { Aug }\end{array}$ & $\begin{array}{l}217 \\
215\end{array}$ & $\begin{array}{l}150 \\
152\end{array}$ & $\begin{array}{l}261 \\
270\end{array}$ & $\begin{array}{l}347 \\
311\end{array}$ \\
\hline Nicke1 & $\begin{array}{l}\text { May } \\
\text { Aug }\end{array}$ & $\begin{array}{l}7.20 \\
7.67\end{array}$ & $\begin{array}{l}7.05 \\
6.70\end{array}$ & $\begin{array}{l}8.00 \\
7.90\end{array}$ & $\begin{array}{l}10.0 \\
9.78\end{array}$ \\
\hline Potassium & $\begin{array}{l}\text { May } \\
\text { Aug }\end{array}$ & $\begin{array}{l}2,110 \\
2,030\end{array}$ & $\begin{array}{l}2,140 \\
2,160\end{array}$ & $\begin{array}{l}2,630 \\
2,350\end{array}$ & $\begin{array}{l}2,880 \\
2,330\end{array}$ \\
\hline
\end{tabular}


Table 4-9. Summary of Soil Samples (Concluded)

\begin{tabular}{|c|c|c|c|c|c|}
\hline & & \multicolumn{4}{|c|}{ Metal Concentration Mean (ppm) } \\
\hline & & $\begin{array}{l}\text { Onsite } \\
\text { Group } 1^{a}\end{array}$ & $\begin{array}{l}\text { Onsite } \\
\text { Group } 2^{b}\end{array}$ & Perimeter & Offsite \\
\hline \multirow[t]{2}{*}{ Strontium } & May & 54.0 & 29.1 & 43.1 & 62.3 \\
\hline & Aug & 63.8 & 40.4 & 57.1 & 65.1 \\
\hline \multirow[t]{2}{*}{ Titanium } & May & $553 *$ & 201 & 352 & 288 \\
\hline & Aug & $508 x$ & 262 & 412 & 286 \\
\hline \multirow[t]{2}{*}{ Vanadium } & May & 24.0 & 15.7 & 23.1 & 26.9 \\
\hline & Aug & 22.2 & 19.3 & 24.3 & 24.8 \\
\hline \multirow[t]{2}{*}{ Zinc } & May & 41.0 & 35.2 & 40.9 & 51.9 \\
\hline & Aug & 33.8 & 33.1 & 45.9 & 39.8 \\
\hline
\end{tabular}

Sediment Samples: Tables F-18 and F-19 of Appendix F list the concentrations of metals in sediment from perimeter samples and offsite samples, respectively, taken in May 1993. Tables F-20 and F-21 list the data for the corresponding samples taken in August 1993. The results are summarized in Table 4-10. The concentration means for cobalt, iron, and vanadium in the onsite August samples are higher than those for the offsite samples. The differences in the means are small but statistically significant because the standard deviations for these samples are relatively small. The highest cobalt concentration, 5 ppm, was measured in the sample from Site 60 , but this was only slightly above the mean concentration $3.02 \mathrm{ppm}$ for the offsite samples. Since the corresponding differences in concentration means for the May samples are not statistically significant, the August results might be the result of normal sample variability and low concentrations of cobalt in the samples. The same considerations apply to vanadium. The highest concentration of vanadium, $26 \mathrm{ppm}$ was also found in the sample from Site 60 , but this was only slightly above the mean of 16.6 for the offsite samples. Future monitoring will help to determine whether the concentrations of cobalt and vanadium are actually higher onsite than offsite and whether they are increasing. It is of interest that the highest concentration of iron was also found in the sample from Site 60 . It is possible that the sediment from Site 60 is naturally high in metals. The concentration of iron, of little significance in itself, might act as an indicator of metal deposition by SNL/NM activities. 
Table 4-10. Summary of Sediment Samples

\begin{tabular}{|c|c|c|c|}
\hline & & Metal & (ppm) \\
\hline & & Onsite & Offsite \\
\hline Aluminum & May & 5,630 & 5,480 \\
\hline & Aug & 6,360 & 5,340 \\
\hline Barium & May & 67.7 & 160 \\
\hline & Aug & 133 & 130 \\
\hline Beryllium & May & 0.5 & 0.5 \\
\hline & Aug & 0.5 & 0.5 \\
\hline Cadmium & May & 0.5 & 0.5 \\
\hline & Aug & 0.5 & 0.5 \\
\hline Calcium & May & 40,600 & 42,400 \\
\hline & Aug & 42,000 & 28,000 \\
\hline Chromium & May & 19.3 & 22.2 \\
\hline & Aug & 28.0 & 35.2 \\
\hline Cobalt & May & 3.80 & 2.90 \\
\hline & Aug & $4.28^{\prime \prime}$ & 3.02 \\
\hline Copper & May & 6.37 & 6.34 \\
\hline & Aug & 7.52 & 5.08 \\
\hline Iron & May & 10,100 & 8,820 \\
\hline & Aug & $10,200^{*}$ & 7,620 \\
\hline Lead & May & 3.83 & 5.20 \\
\hline & Aug & 7.80 & 6.10 \\
\hline Magnesium & May & 2,860 & 2,450 \\
\hline & Aug & 3,000 & 2,020 \\
\hline Manganese & May & 200 & 190 \\
\hline & Aug & 218 & 170 \\
\hline Nickel & May & 6.70 & 5.40 \\
\hline & Aug & 6.40 & 6.80 \\
\hline Potassium & May & 1,370 & 1,290 \\
\hline & Aug & 1,440 & 1,250 \\
\hline
\end{tabular}


Table 4-10. Summary of Sediment Samples (Concluded)

\begin{tabular}{|c|c|c|c|}
\hline & & Metal & $(\mathrm{ppm})$ \\
\hline & & Onsite & Offsite \\
\hline Strontium & May & 87.7 & 73.6 \\
\hline & Aug & 73.8 & 54.4 \\
\hline Titanium & May & 546 & 252 \\
\hline & Aug & 716 & 734 \\
\hline Vanadium & May & 21.0 & 18.4 \\
\hline & Aug & $21.2^{* t}$ & 16.6 \\
\hline Zinc & May & 25.0 & 62.8 \\
\hline & Aug & 25.0 & 19.6 \\
\hline
\end{tabular}




\subsection{AIR QUALITY SURVEILLANCE AND EMISSIONS MONITORING}

\subsection{METEOROLOGICAL MONITORING PROGRAM}

A meteorological monitoring program has been implemented at Sandia National Laboratories/New Mexico (SNL/NM). The monitoring program commenced operations on January 3, 1994. This program is integral to compliance with 40 Code of Federal Regulations (CFR) 61, Department of Energy (DOE) Orders 5400.1, 5400.5, and 5500.3, and DOE guidelines outlined in DOE/EH-0173T (DOE 1988a, 1990, $1991 b, 1991 \mathrm{c})$. In addition to compliance with the above, the program will also generate data consistent with program guidelines for regulatory modeling applications.

The main objective of the program is to provide data representative of the meteorology at SNL/NM. The program includes a nine-tower meteorological monitoring network which consists of six 10-meter (m) (33-foot [ft]) towers, two $60-\mathrm{m}(197-\mathrm{ft})$ towers, and one $50 \mathrm{-m}(164-\mathrm{ft})$ tower. All towers are instrumented at the $3-$ and $10-\mathrm{m}(10-$ and $33-\mathrm{ft})$ levels. Instrumentation has also been installed at the top of the taller towers. Tower location and names are portrayed in Figure $5-1$.

The meteorological variables measured at all tower levels include wind speed and direction, the standard deviation of the horizontal wind speed (sigma theta), and temperature. Relative humidity is measured at all towers at the 3-m level. There are also two atmospheric pressure sensors and three rain gauges in the meteorological network. Barometric pressure is measured at towers ST6 and A15, while rain gauges are located at $\mathrm{SC1}, \mathrm{A} 36$, and A15 (Figure 5-1).

Meteorological data collected within the network will be used to: characterize transport and diffusion of actual or potential pollutants, provide emergency response support, support environmental surveillance, perform regulatory air dispersion modeling for permitting applications, perform atmospheric flow modeling over complex terrain, and support laboratory research and engineering design.

The 1994 Site Environmental Report for SNL/NM will include summarized meteorological data, wind roses, and atmospheric stability information for each of the tower sites. In the future, a climatological data base will be developed for comparison to annual data. For 1993, the only available meteorological information is the summarized Albuquerque International Airport data recorded by National Weather Service personnel (Table 1-1).

\subsection{AIR QUALITY ENVIRONMENTAL SAMPLING AND SURVEILLANCE}

\subsubsection{Monitoring Locations}

Air quality monitoring equipment has been installed at seven sites (Figures 5-1 and 5-2):

1. Criteria Pollutant Monitoring Station, in Technical Area I (TA-I) east of Building 833 and next to Tower A15 


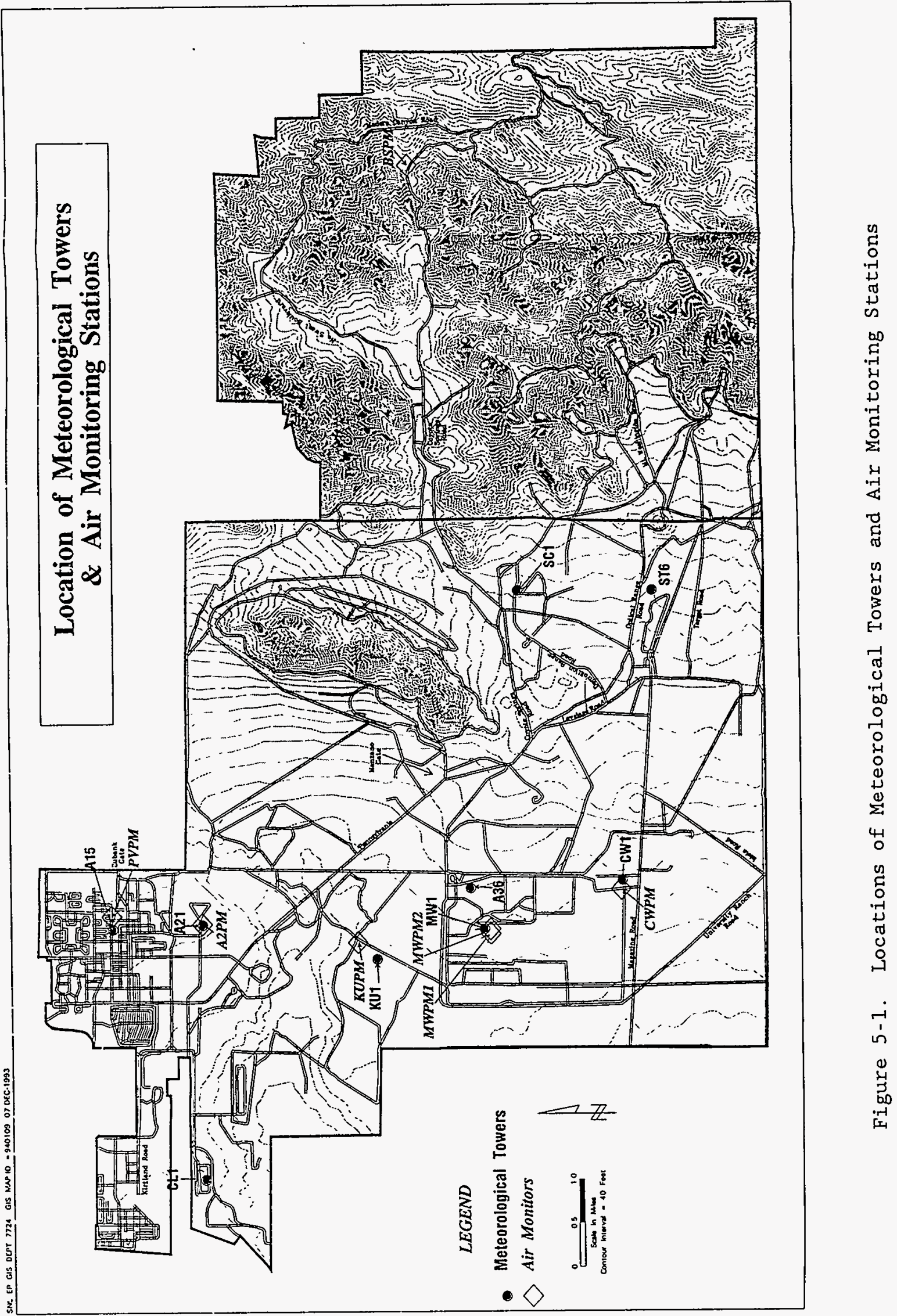




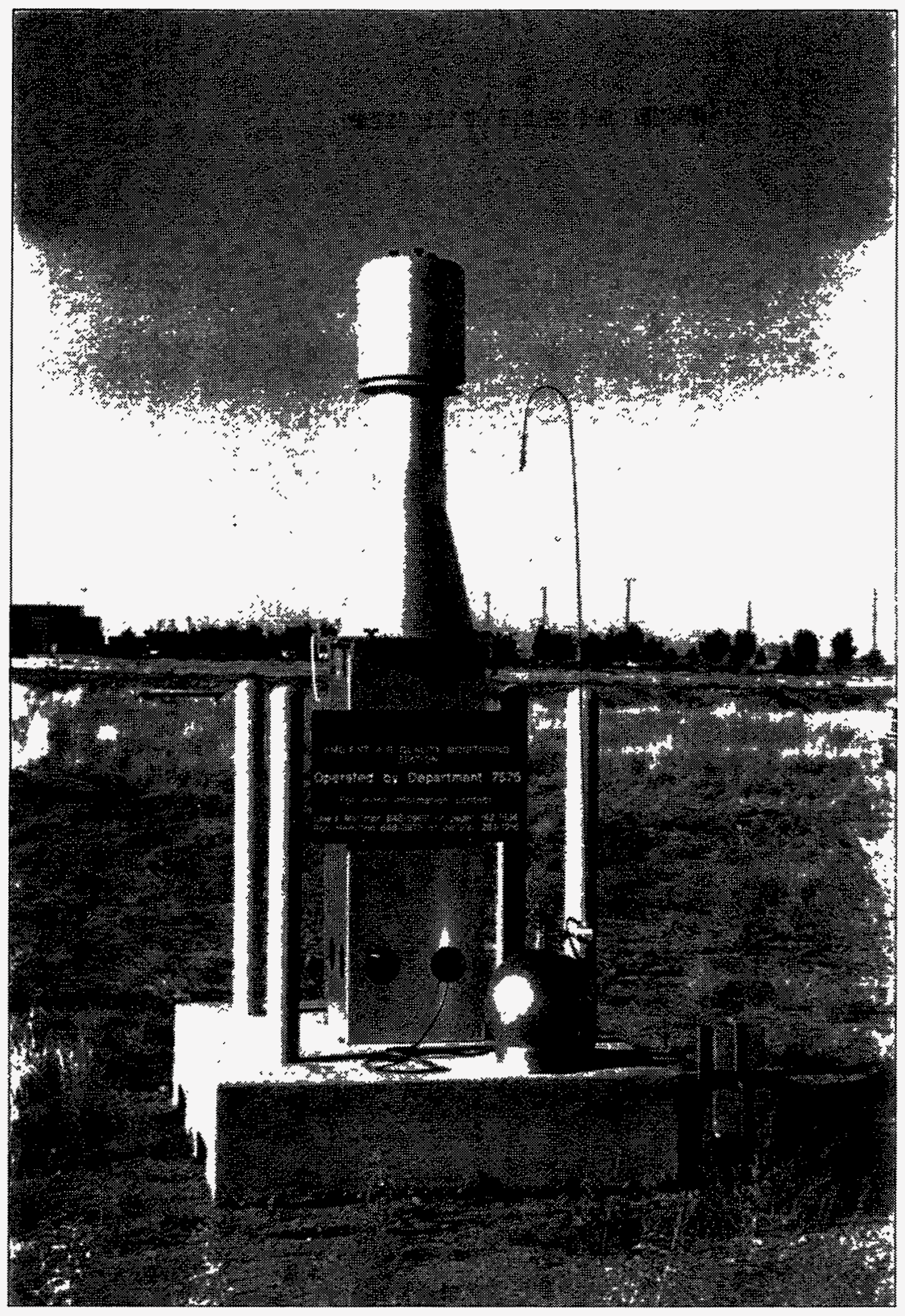

Figure 5-2. PM-10 Monitoring Station 
2. PVPM, a respirable particulate matter (PM-10) and volatile organic compound (VOC) monitoring station, south of Building T-33 in TA-I

3. A2PM, a PM-10 and VOC monitoring station, southwest of Building 900 , at the entrance to TA-II

4. KUPM, a PM-10 monitoring station, east of Kirtland Underground Munitions Storage Complex (KUMSC) administration building in TA-III

5. MWPM1 and MWPM2, PM-10 (two) and VOC monitoring stations, at the Mixed Waste Landfill (MWL) in TA-III

6. CWPM, a PM-10 and VOC monitoring station at the Chemical Waste Landfill (CWL) in TA-III

7. BSPM, a PM-10 and VOC monitoring station, east of Burn Site in TA-III

Air quality monitoring locations were selected based on factors such as predominant wind direction, traffic patterns, potential for community exposure, potential for windblown dust, or combinations of these and other factors. In addition to these permanent locations, mobile sampling capabilities are also available. A truck equipped with monitoring equipment can respond to accidental releases on an as-needed basis, or for short-term projects (Figure 5-3). A trailer with air sampling equipment is available for more long-term needs.

\subsubsection{Sample Collection and Analysis}

Since the air quality monitoring program has been operational only since January 3, 1994, no data for calendar year 1993 (CY 93) can be presented in this report. For CY 1994, it is anticipated that the following data will be presented:

- Criteria Pollutant Data: Sulfur dioxide $\left(\mathrm{SO}_{2}\right)$, oxides of nitrogen $\left(\mathrm{NO}_{\mathrm{x}}\right)$, ozone $\left(\mathrm{O}_{3}\right)$, carbon monoxide $(\mathrm{CO})$, and airborne lead ( $\left.\mathrm{Pb}\right)$

- PM-10: Respirable airborne particulate matter 10 microns or smaller in diameter

- VOCs: Volatile organic compounds, primarily solvents and fuels

\subsection{AIR EMISSIONS RADIOLOGICAL MONITORING}

Few facilities within SNL/NM routinely generate radioactive effluents or emissions. These facilities include the accelerators in TA-IV (e.g., the HERMES-III Accelerator and the Particle Beam Fusion Accelerator-II [PBFA-II]), the reactor facilities in TA-V (e.g., the Annular Core Research Reactor [ACRR], Hot Cell Facility [HCF], and Sandia Pulsed Reactor [SPR]), the Neutron Generator Test Facility (NGTF) in TA-II, and small accelerators and tritium (H-3) laboratories in TA-I. 


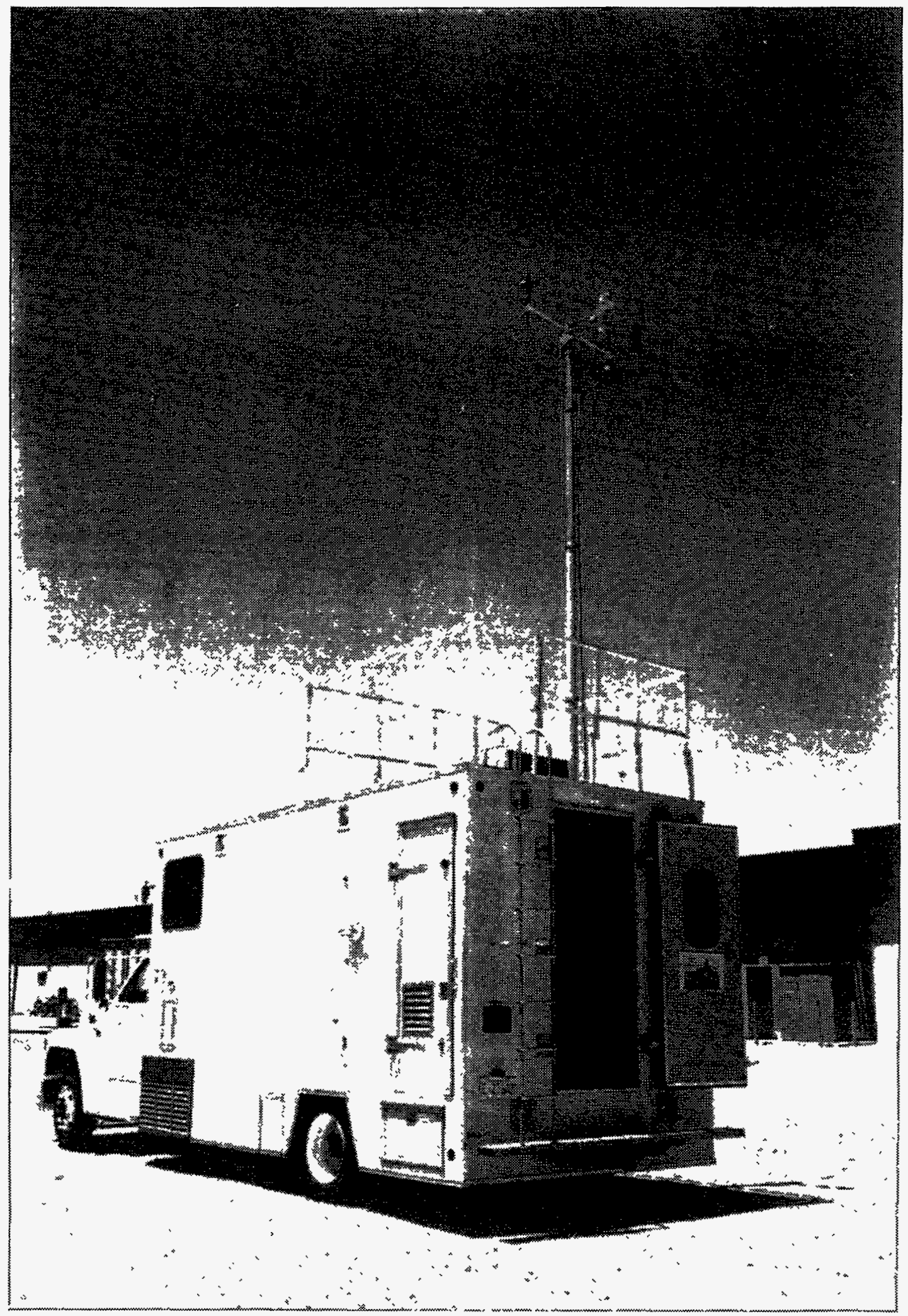

Figure 5-3. Sandia National Laboratories/New Mexico Air Sampling Truck 


\subsubsection{Radioactive Effluent Monitoring}

Calculations indicate that small quantities of $\mathrm{H}-3$, nitrogen-13 (N-13), oxygen-15 (0-15), argon-41 (Ar-41), krypton-85 ( $\mathrm{Kr}-85)$, and xenon-135 (Xe-135) emissions were released to the atmosphere as a result of SNL/NM 1993 operations. SNL/NM's radionuclide air emissions were so small, they were not measurable with existing monitors at those facilities. Therefore, the radionuclide release data are calculated based on theoretical parameters such as reactor operating power (in megajoules [MJ]) and the conversion factor for the activation products (in microcuries per megajoule [ $\mu \mathrm{Ci} / \mathrm{MJ}]$ ) for the generation of noble gases (e.g., Ar-41) from the reactors in TA-V. Figure 5-4 summarizes these annual air emissions from 1978 to 1993.

\subsubsection{Technical Area V Reactors}

Noble gases and small quantities of $\mathrm{H}-3$ are released from TA-V reactor stacks. High-efficiency particulates in air (HEPA) filters are used to separate particulates from the SPR, ACRR, and HCF exhaust air. Charcoal filters are used to collect noble gases and halogen from the SPR and ACRR stack exhaust air. Gamma scans are performed on the filters to check for specific activities. Particulate or gaseous grab samples are collected periodically or as necessary for specific radionuclide analyses. These sample results have been used as a confirmatory measure to verify the calculated values.

The SPR reactor filter banks consist of a prefilter, a HEPA filter, and a charcoal filter. A radiological air monitor (RAM) is located on the stack exhaust downstream of the filter banks. Grab samples axe collected periodically using a low-volume particulate air filter which is analyzed using gamma spectroscopy techniques.

The ACRR reactor filter banks also consist of a prefilter, a HEPA filter, and a charcoal filter. The ACRR has two exhaust stacks. The main-room stack in the high bay is equipped with two continuous air monitors (CAMs), a particulate and a gaseous air monitor, as well as a RAM which is located on the HEPA filter housing. Gamma and beta scans are performed on the filters to determine the gross activity. Particulate or gaseous grab samples are also collected, if necessary, for more detailed analysis (e.g., Ar-41) with a multichannel analyzer (MCA). The second ACRR exhaust stack, the central cavity purge stack, has a particulate CAM as well as a RAM which is located directly on the HEPA filter housing. Grab samples for the MCA analysis can also be collected.

The TA-V HCF filter banks are equipped with a prefilter and HEPA filters. RAMs are located on the filter banks on both the cold exhaust and hot exhaust. Grab samples for particulates can also be collected, if needed for further analyses. These sample results have been used for evaluation of the exhaust filtration system.

\subsection{AIR QUALITY RADIOLOGICAL MONITORING RESULTS}

Isokinetic sampling equipment has been installed within the main stack of the HCF and the ACRR stack to collect air samples. Both monitoring systems were tested in 1992 for continuous effluent sampling and analyses of gross alpha and beta, noble gases, and iodine. Collection and evaluation of the monitoring 


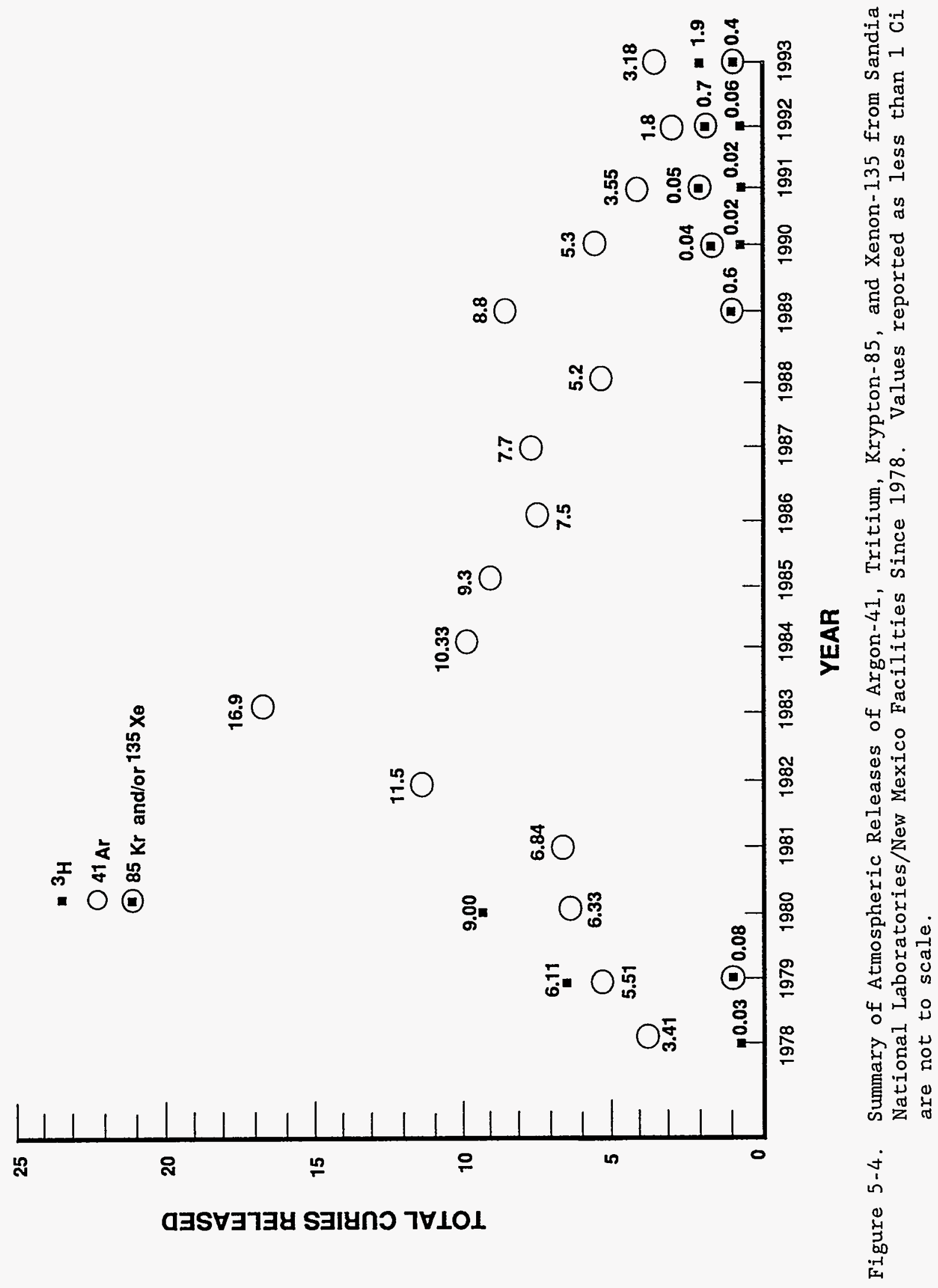


system data was continued in 1993. Some modifications to the data analysis software were made to remedy the false-release indications. A process has been initiated to verify the source term and confirm the monitoring system data. It is expected, based on the present information and data, that these facilities will not require continuous stack effluent monitoring. SNL/NM, therefore, plans to use the existing stack monitors for periodic measurements. When the monitoring systems become operational, the results of the continuous air sampling and analyses will be reported.

\subsection{ASSESSMENT OF POTENTIAL DOSE TO THE PUBLIC}

The U.S. Environmental Protection Agency (EPA) promulgated National Emission Standards for Hazardous Air Pollutants (NESHAP) for radionuclides in December 1989. NESHAP ( 40 CFR 61, Subpart $H$ ) requires radiation dose to be calculated for the maximally exposed individual at a public access location including office, school, or residence. A comprehensive survey of all public access locations on Kirtland Air Force Base (KAFB) was conducted during 1990 to address this new requirement. In addition, a determination has been made that all non-SNL/NM personnel who work or live on KAFB are considered "members of the public" in accordance with the definition in DOE Order 5400.5 (DOE 1990). The 1993 dose assessment was performed for all KAFB receptors including residences, schools, and other locations where non-SNL/NM personnel abide or reside.

All dose calculations presented in this section were performed using the EPA CAP-88 computer code (EPA 1991). The cumulative dose at each receptor location was calculated to be well below the effective dose equivalent (EDE) limit of 10 millirem per year (mrem/yr) for the maximally exposed individual. As indicated in Section 5.3, few facilities within SNL/NM routinely generate radioactive emissions; most of these are located in TA-IV and TA-V. Most of the radioactive releases are air emissions. Therefore, air doses represent the main potential radiological dose impact to offsite locations from routine operations at SNL/NM.

\subsubsection{Air Emission Sources}

A total of eight facilities at SNL/NM reported releases of airborne quantities of radionuclides during 1993. Seven of the eight sources were point source releases which occurred as stack emissions. The eighth release source was a diffuse area source with a measurable annual release. Table 5-1 summarizes the radionuclides, quantity of release, and release type (point or diffuse) by facility for 1993. Figure 5-5 shows the locations of facilities reporting radionuclide air emissions in 1993. A total of 3.2 Curies (Ci) of Ar-41, 0.62 $\mathrm{Ci}$ of $\mathrm{N}-13,0.012 \mathrm{Ci}$ of $0-15$, and $1.9 \mathrm{Ci}$ of $\mathrm{H}-3$ were released into the atmosphere in 1993 as a result of SNL/NM operations. Smaller amounts of additional radionuclides were also released. Many of the radionuclides released are of such short half-lives (e.g., 10 min for $\mathrm{N}-13,15$ min for rubidium-88 [Rb-88]) that radioactive decay during transport reduces doses at most of the receptor locations considered.

During 1993, there were no new sources or modified sources at SNL/NM. 
Table 5-1. Summary of Radionuclide Releases for 1993

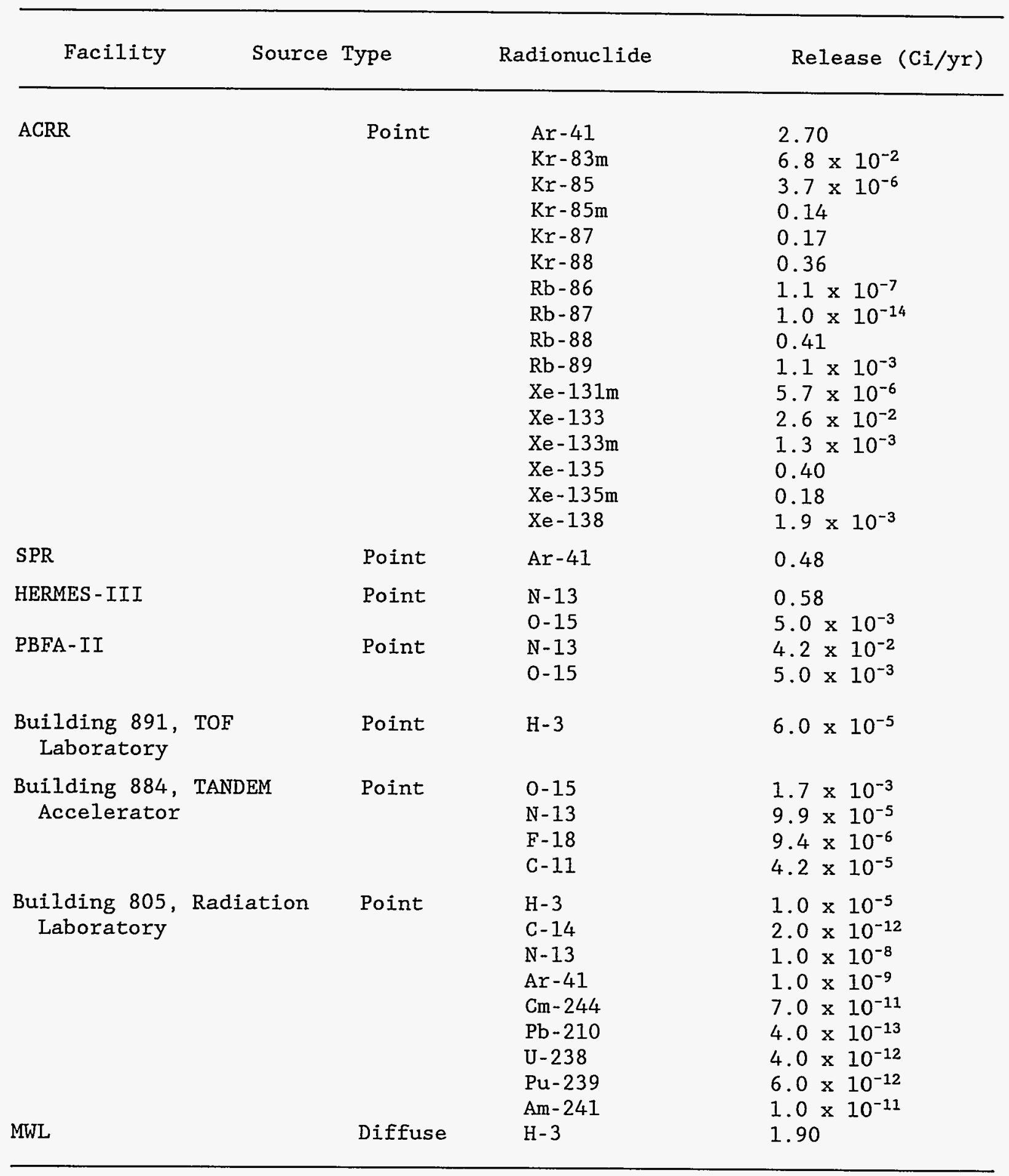




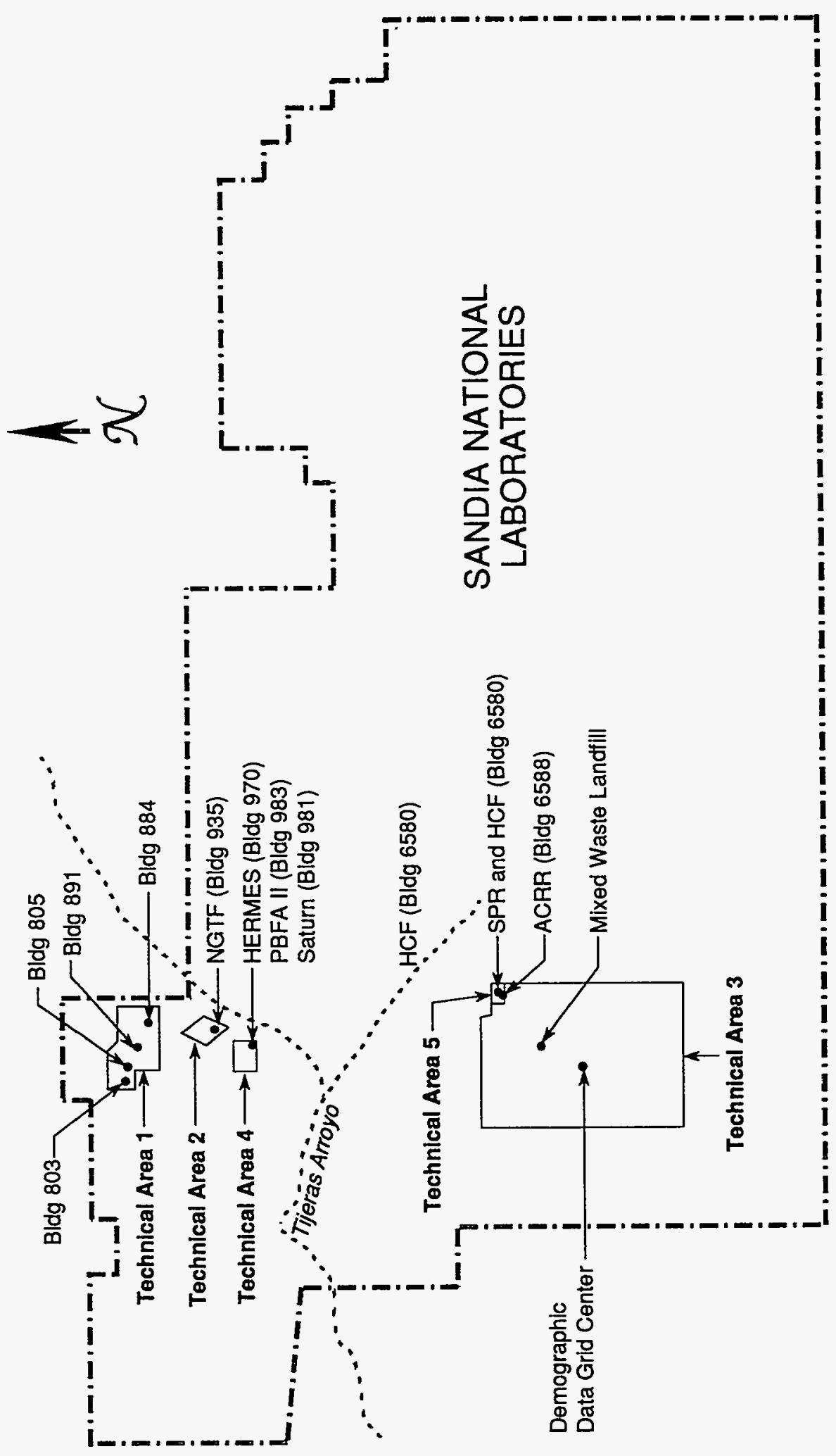

年 


\subsubsection{Public Receptors}

The population of the five KAFB housing areas is approximately 6600 . The nonresidential areas include security offices, guard gates, credit unions, banks, restaurants, the KAFB landfill, golf course, U.S. Army Field offices at KUMSC, Manzano-area offices, Inhalation Toxicology Research Institute (ITRI), Rinchem, Raytheon/Defense Nuclear Agency (DNA), and other U.S. Air Force and Army research facilities and engineering offices (LATA 1991). The effective dose equivalent (EDE) was calculated for all these public receptors on KAFB in addition to locations outside KAFB boundaries. Using 1990 population census data, population doses were calculated for KAFB residents $(6,636)$ and all other people living within a $50-\mathrm{mile}$ (mi) (81-kilometer $[\mathrm{km}]$ ) radius of SNL/NM $(571,677)$.

\subsubsection{Meteorological Data}

The meteorological data used in the dose calculations for SNL/NM were provided by CAP88-PC (EPA 1991). The information was gathered from 1960 through 1964 at the Albuquerque International Airport, an average distance of approximately $3.5 \mathrm{mi}(6 \mathrm{~km})$ from the SNL/NM release locations.

\subsubsection{Demographic Data}

The categories of demographic data include population, beef cattle, dairy cattle, and food crops used for human consumption. These four parameters were calculated for each of the CAP-88 gridded zones (total of 80). In general, demographic data are available by county. The densities for population, beef cattle, dairy cattle, and food crops were calculated as the quotient of the most recent county data and the county land area. For 1993 calculations, 1990 census (U.S. Department of Commerce [DOC], Bureau of the Census, 1991) and 1988 agricultural data were used. These calculations were based on a total of 571,677 people, 32,335 beef cattle, 7,290 dairy cattle, and $2.4 \times 10^{8}$ square meters $\left(\mathrm{m}^{2}\right)\left(2.6 \times 10^{9}\right.$ square feet $\left.\left[\mathrm{ft}^{2}\right]\right)$ of food crops from the surrounding nine counties (LATA 1991).

\subsubsection{Results of the Dose Assessment}

The EDEs for two receptor groups, boundary and KAFB, were calculated for the 1993 releases using the CAP-88 computer code to determine maximum exposure to individuals and to the population within a 50 -mi radius.

The nine boundary receptor locations are the Tijeras Arroyo, the City Landfill, the Airport (west end), the Northwest Base Housing (southeast corner), the Eubank Gate, the Northeast Resident, the East Resident, the Isleta Mine, and the West Resident. Table 5-2 presents the 1993 results. The dose at Tijeras Arroyo is consistent with previous years and is the highest $\left(3.5 \times 10^{-4} \mathrm{mrem} / \mathrm{yr}\right)$ of the nine boundary locations. Figure 5-6 shows the nine boundary locations.

Dose calculations were also performed for 14 KAFB receptor locations; the KUMSC, the KAFB Landfill, Raytheon/DNA, Rinchem, the golf course lobby, the golf course maintenance building, the riding club, the Civil Engineer Research Facility (CERF), Lovelace Hospital, Manzano area offices, the Credit Union, North Base housing, Building 887, and Trailer Village. Because of the shorter 
Table 5-2. Annual Effective Dose Equivalent (mrem/yr) to Boundary Receptors

\begin{tabular}{|c|c|c|c|c|c|c|c|c|c|}
\hline Receptor & $\begin{array}{l}\text { Radiation } \\
\text { Laboratory }\end{array}$ & TANDEM & $\begin{array}{c}\text { TOF } \\
\text { Laboratory }\end{array}$ & ACRR & SPR/CX & HERMES & PBFA-II & $\begin{array}{l}\text { Mixed } \\
\text { Waste } \\
\text { Landfill }\end{array}$ & Total \\
\hline Tijeras Arroyo & $1.8 \mathrm{E}-09$ & $4.1 \mathrm{E}-10$ & $4.7 \mathrm{E}-09$ & $1.8 \mathrm{E}-04$ & $1.5 E-05$ & $6.5 E-07$ & $4.7 E-08$ & $1.5 \mathrm{E}-04$ & $3.5 \mathrm{E}-04$ \\
\hline City Landfill & $1.0 E-09$ & $8.3 E-11$ & $3.7 \mathrm{E}-09$ & $3.4 E-05$ & $3.2 E-06$ & $1.2 \mathrm{E}-07$ & $8.4 \mathrm{E}-09$ & $4.6 \mathrm{E}-05$ & $8.3 E-05$ \\
\hline Airport (west end) & $2.7 E-09$ & $1.6 E-09$ & $5.5 E-09$ & $1.4 \mathrm{E}-04$ & $1.2 \mathrm{E}-05$ & $5.0 \mathrm{E}-06$ & $3.6 \mathrm{E}-07$ & $5.7 E-05$ & $2.1 \mathrm{E}-04$ \\
\hline $\begin{array}{l}\text { SE Corner of NW } \\
\text { Base Housing }\end{array}$ & $1.2 E-08$ & $1.2 E-08$ & $1.2 \mathrm{E}-08$ & $1.0 E-04$ & $9.0 \mathrm{E}-06$ & $4.7 \mathrm{E}-05$ & $3.6 \mathrm{E}-06$ & $7.5 E-05$ & $2.4 \mathrm{E}-04$ \\
\hline Eubank Gate & $6.5 E-09$ & $2.0 E-07$ & $1.5 E-08$ & $1.3 E-04$ & $2.1 E-05$ & $1.4 E-05$ & $1.0 \mathrm{E}-06$ & $7.3 E-05$ & $2.3 E-04$ \\
\hline NE Resident & $1.0 E-09$ & $2.1 E-10$ & $3.7 E-09$ & $3.2 E-05$ & $3.0 \mathrm{E}-06$ & $2.8 \mathrm{E}-07$ & $2.1 E-08$ & $3.8 \mathrm{E}-05$ & $7.2 \mathrm{E}-05$ \\
\hline E Resident & $6.8 \mathrm{E}-10$ & $1.7 E-11$ & $3.2 E-09$ & $6.3 E-06$ & $6.4 E-07$ & $1.5 E-08$ & $1.1 E-09$ & $2.6 E-05$ & $3.3 E-05$ \\
\hline Isleta Gate & $7.3 E-10$ & $1.9 E-11$ & $3.3 E-09$ & $1.0 \mathrm{E}-05$ & $1.0 \mathrm{E}-06$ & $1.1 E-08$ & $7.8 \mathrm{E}-10$ & $3.3 E-05$ & $4.4 E-05$ \\
\hline W Resident & $8.7 E-10$ & $3.5 E-11$ & $3.5 E-09$ & $2.7 E-05$ & $2.6 \mathrm{E}-06$ & $4.0 E-08$ & $2.8 \mathrm{E}-09$ & $3.7 E-05$ & $5.6 E-05$ \\
\hline
\end{tabular}



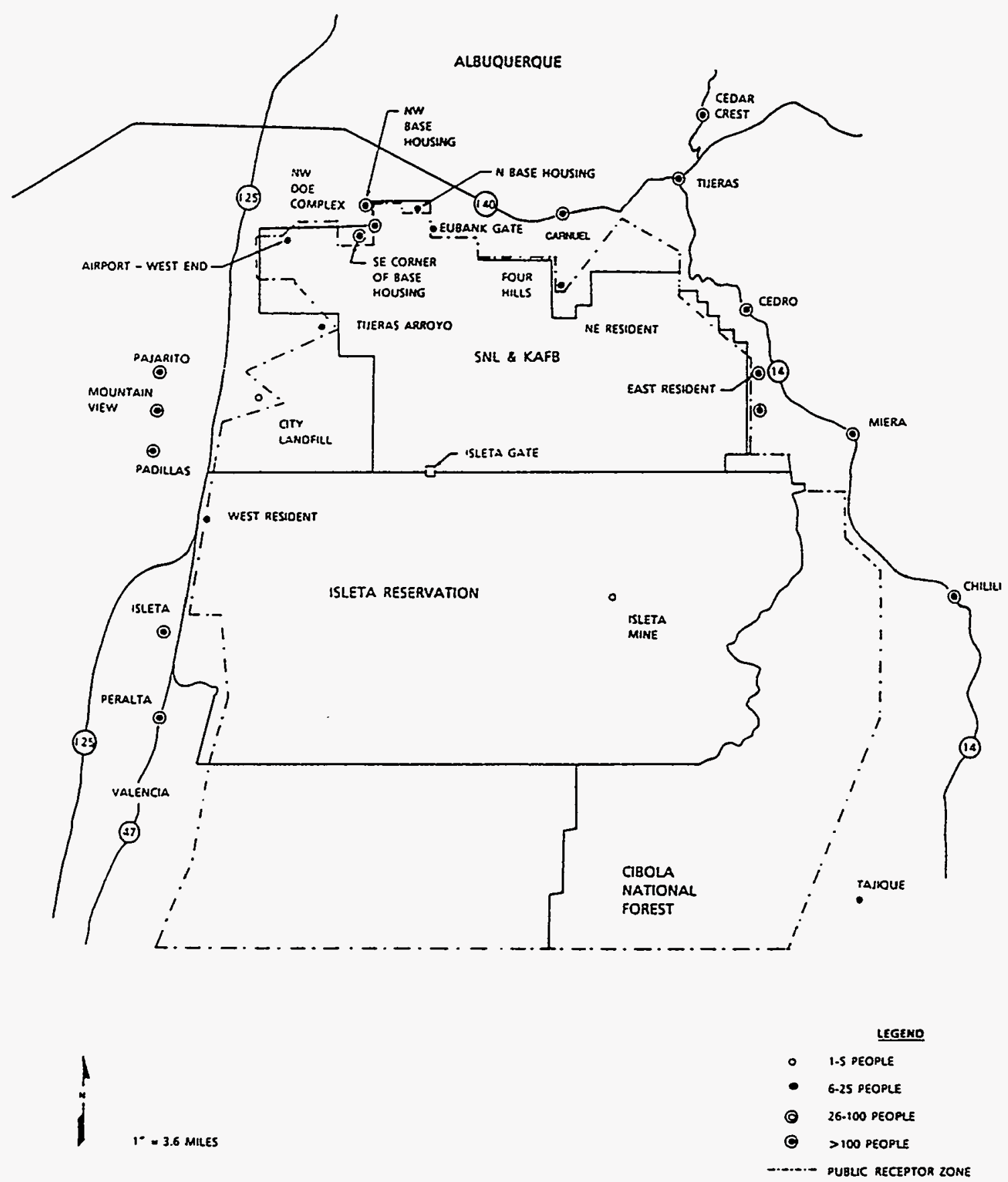

Figure 5-6. Boundary Receptor Locations Around Sandia National Laboratories/New Mexico 
distance from the release sources to these KAFB receptors, the doses (Table 5-3) at these receptors are generally higher than those presented in Table 5-2.

The composite dose analysis revealed maximum EDE (based on NESHAP compliance standards) at the KUMSC receptor site, $\sim 5282 \mathrm{ft}(\sim 1610 \mathrm{~m})$ northwest of TA-V. The EDE to a maximally exposed individual at the KUMSC was calculated to be 1.6 $\times 10^{-3}$ millirem (mrem), due principally to an external air submersion exposure to Ar-41. The Ar-41 dose represents 95 percent of the total EDE. Most of the Ar-41 dose comes from the ACRR and SPR/CX facilities. Several receptor locations are within a factor of 10 of the EDE assessed for the KUMSC receptor location (see Table 5-3).

\subsubsection{Population Dose at Kirtland Air Force Base}

A population dose was calculated for the KAFB public receptors. There are five major base housing areas on KAFB. A 100-percent occupancy of all the units was assumed, yielding a total KAFB population of 6636. A population dose of 1.2 $\mathrm{x} 10^{-3}$ person-rem was estimated for all KAFB housing areas resulting from all SNL/NM 1993 releases. The population dose results from an external exposure via air immersion to Ar-41 and to internal exposure via ingestion of $\mathrm{H}-3$.

\subsubsection{Population Dose for the 50-Mile Radius}

A population dose was calculated for the 50 -mi radius surrounding SNL/NM using a single, common grid analysis for all SNL/NM sources. Because the analysis area is large, the relatively small distances between sources will have minimal impact on the resulting population dose. As stated earlier, the CAP-88 computer code calculated exposure estimates using demographic data based on the 1990 population census and 1988 agricultural census: 571,677 people, 32, 335 beef cattle, 7290 dairy cattle, and $2.4 \times 10^{8} \mathrm{~m}^{2}$ of food crops from the nine counties included in the study area (EPA 1991, DOC 1991, LATA 1991). The population dose from 1993 SNL/NM operations was calculated to be 0.026 person-rem EDE for the surrounding population (residing outside KAFB). The population dose is the result of an external exposure via air immersion to Ar41 and to internal exposure via ingestion of $\mathrm{H}-3$.

\subsection{SUMMARY OF THE 1993 OFFSITE DOSE IMPACTS}

During 1993, the NESHAP maximally exposed individual was determined to be at the KUMSC facility site, approximately $1610 \mathrm{~m}$ northwest of SNL/NM TA-V. The maximum EDE at this location was calculated to be $1.6 \times 10^{-3} \mathrm{mrem}$. In addition, a population dose to the public was calculated to be $2.6 \times 10^{-2}$ person-rem to the 571,677 people living within a 50 -mi radius of SNL/NM. The population dose to the 6636 residents of KAFB was calculated to be $1.2 \times 10^{-3}$ person-rem. The cumulative dose to the total population, including the KAFB population and the 50-mi-radius population, was $2.7 \times 10^{-2}$ person-rem from all 1993 releases. Table 5-4 summarizes dose impacts. 
Table 5-3. Annual Effective Dose Equivalent (mrem/yr) to Kirtland Air Force Base Receptors

\begin{tabular}{|c|c|c|c|c|c|c|c|c|c|}
\hline Receptor & $\begin{array}{l}\text { Radiation } \\
\text { Laboratory }\end{array}$ & TANDEM & $\begin{array}{c}\text { TOF } \\
\text { Laboratory }\end{array}$ & ACRR & $\mathrm{SPR} / \mathrm{CX}$ & HERMES & PBFA-II & $\begin{array}{c}\text { Mixed } \\
\text { Waste } \\
\text { Landfill }\end{array}$ & Total \\
\hline KUMSC & $2.8 \mathrm{E}-09$ & $2.7 \mathrm{E}-09$ & $1.0 E-09$ & $1.6 \mathrm{E}-03$ & $5.9 E-05$ & $1.7 \mathrm{E}-05$ & $1.2 E-06$ & $5.5 E-05$ & $1.6 \mathrm{E}-03$ \\
\hline KAFB Landfill & $4.5 E-09$ & $1.9 \mathrm{E}-08$ & $1.5 E-09$ & $2.2 \mathrm{E}-04$ & $1.8 \mathrm{E}-05$ & $7.1 E-05$ & $5.4 E-06$ & $1.8 \mathrm{E}-05$ & $3.4 \mathrm{E}-04$ \\
\hline Raytheon/DNA & $2.0 E-08$ & $3.1 \mathrm{E}-08$ & $6.5 E-09$ & $1.6 \mathrm{E}-04$ & $1.3 \mathrm{E}-05$ & $1.5 E-04$ & 1. $3 \mathrm{E}-05$ & $1.7 E-05$ & $3.6 \mathrm{E}-04$ \\
\hline Rinchem & 1.7E-08 & $2.8 E-07$ & $5.4 E-09$ & $2.6 \mathrm{E}-04$ & $1.4 E-05$ & $1.1 E-04$ & $9.9 \mathrm{E}-06$ & $1.5 E-05$ & $3.1 \mathrm{E}-04$ \\
\hline Golf Course Lobby & $1.6 \mathrm{E}-09$ & $2.2 E-09$ & $5.6 \mathrm{E}-10$ & $3.0 \mathrm{E}-04$ & $2.0 \mathrm{E}-05$ & $1.0 \mathrm{E}-05$ & $7.3 \mathrm{E}-07$ & $1.3 \mathrm{E}-05$ & $3.5 \mathrm{E}-04$ \\
\hline $\begin{array}{l}\text { Golf Course Maintenance } \\
\text { Bldg. }\end{array}$ & $1.8 \mathrm{E}-09$ & $6.9 E-09$ & $6.5 \mathrm{E}-10$ & $5.1 \mathrm{E}-04$ & $3.2 E-05$ & $3.2 E-05$ & $2.2 \mathrm{E}-06$ & 1.1E-05 & $6.0 \mathrm{E}-04$ \\
\hline Riding Club & $1.0 \mathrm{E}-09$ & $9.3 E-10$ & $3.8 \mathrm{E}-10$ & $6.3 E-04$ & $3.5 E-05$ & $3.9 E-06$ & $2.3 E-06$ & $2.0 E-05$ & $7.0 E-04$ \\
\hline CERF & $3.5 E-10$ & 1. $2 \mathrm{E}-10$ & $1.5 \mathrm{E}-10$ & $8.2 \mathrm{E}-05$ & $7.3 E-06$ & $2.9 \mathrm{E}-07$ & $2.8 E-07$ & $1.0 \mathrm{E}-05$ & $3.1 \mathrm{E}-04$ \\
\hline Lovelace & $6.8 \mathrm{E}-10$ & $2.1 \mathrm{E}-10$ & $2.9 \mathrm{E}-10$ & 8. 3E-05 & $7.8 E-06$ & $2.1 E-07$ & $2.1 E-08$ & $1.0 \mathrm{E}-05$ & $1.1 \mathrm{E}-04$ \\
\hline Manzano & $6.5 E-10$ & $5.4 \mathrm{E}-10$ & $2.5 E-10$ & $2.1 E-04$ & $1.4 \mathrm{E}-05$ & $2.2 E-06$ & $1.5 \mathrm{E}-08$ & $1.5 E-05$ & $2.5 E-04$ \\
\hline Credit Union & $4.5 \mathrm{E}-06$ & $2.2 \mathrm{E}-07$ & $1.3 E-06$ & $9.8 \mathrm{E}-05$ & $8.6 E-06$ & $2.1 \mathrm{E}-05$ & $1.6 \mathrm{E}-07$ & $1.2 \mathrm{E}-05$ & $1.6 \mathrm{E}-04$ \\
\hline North Base Housing & $3.1 \mathrm{E}-08$ & $1.8 \mathrm{E}-07$ & $9.6 \mathrm{E}-09$ & $2.0 \mathrm{E}-04$ & $9.1 E-06$ & $1.9 E-05$ & $1.4 E-06$ & $1.1 E-05$ & $2.4 \mathrm{E}-04$ \\
\hline Building 887 & $2.3 \mathrm{E}-08$ & $6.7 E-06$ & $7.1 E-09$ & $1.2 \mathrm{E}-04$ & $1.0 E-05$ & $3.1 E-05$ & $2.2 E-06$ & $1.2 E-05$ & $1.8 \mathrm{E}-04$ \\
\hline Trailer Village & $1.6 \mathrm{E}-08$ & $9.1 E-05$ & $5.1 E-09$ & $1.4 E-04$ & $1.2 E-05$ & $2.9 E-05$ & $2.0 \mathrm{E}-06$ & $1.3 \mathrm{E}-05$ & $2.1 \mathrm{E}-04$ \\
\hline
\end{tabular}


Table 5-4. Summary of Offsite Dose Impacts in Comparison to the National Emission Standards for Hazardous Air Pollutants and to Natural Background Radiation

\begin{tabular}{|c|c|c|c|}
\hline Parameters & $\begin{array}{c}1993 \\
\text { SNL/NM } \\
\text { Calculated Dose }\end{array}$ & $\begin{array}{l}\text { NESHAP } \\
\text { Standard }\end{array}$ & $\begin{array}{c}\text { Natural Background } \\
\text { Radiation in } \\
\text { Albuquerque Area }\end{array}$ \\
\hline $\begin{array}{l}\text { Maximum Effective Dose } \\
\text { Equivalent (mrem/yr) }\end{array}$ & 0.0016 & 10 & $95^{a}$ \\
\hline $\begin{array}{l}\text { Annual Population } \\
\text { Dose }^{c} \text { (person-rem) }\end{array}$ & 0.027 & $\ldots b$ & $>57,000$ \\
\hline \multicolumn{4}{|c|}{$\begin{array}{l}\text { a Based on the average of community thermoluminescent dosimeter (TLD) values } \\
\text { (dose from external penetrating radiation) } \\
b_{--}=\text {Not measured } \\
\text { 'Dose for the population in } 50 \text {-mi radius surrounding SNL/NM, including the } \\
\text { population on KAFB }\end{array}$} \\
\hline
\end{tabular}

\subsection{AIR QUALITY MANAGEMENT}

\subsubsection{Air Quality Regulations}

Ambient air quality for SNL/NM is regulated by the Albuquerque/Bernalillo County Air Quality Control Regulations (AQCRs). These include the following:

- Ambient Air Quality Standard (regulates arsenic [As], copper [Cu], zinc $[\mathrm{Zn}]$, beryllium $[\mathrm{Be}], \mathrm{CO}$, hydrogen sulfide $\left[\mathrm{H}_{2} \mathrm{~S}\right], \mathrm{Pb}, \mathrm{NO}_{\mathrm{X}}, \mathrm{SO}_{2}$, total suspended particulates [TSP], hydrocarbons [HC], soiling index, and total reduced sulfur)

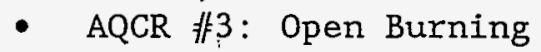

- AQCR 非5: Visible Air Contaminants

- AQCR 非: Airborne Particulate Matter (PM)

- AQCR 非1: Volatile Organic Compounds (VOCs)

- AQCRs 非5-18: Process Equipment Emissions ( $\mathrm{NO}_{\mathrm{x}}, \mathrm{SO}_{2}$, and particulates) for $0 i 1$ - and Gas-Burning Equipment

- AQCR 非19: Breakdown, Abnormal Operating Conditions, or Scheduled Maintenance

- AQCR \#20: Authority-to-Construct Permit

- AQCR 非1: Permit Fees

- AQCR 非2: Registration of Air Contaminant Sources

- AQCR 非3: Source Surveillance

- AQCR \#24: Variance Procedure

- AQCR 非28: Motor Vehicle Inspection 
- AQCR 非29: Prevention of Significant Deterioration

- AQCR \#30: New Source Performance Standards

- AQCR 非31: National Emission Standards for Hazardous Air Pollutants (NESHAP) (radionuclides excluded)

- AQCR 非37: Stratospheric Ozone Protection

The Air Pollution Control Division of the Albuquerque City Environmental Health Department has established several ambient-air sampling stations throughout the city, including the area near SNL/NM, to monitor TSP, ozone, PM-10, CO, and $\mathrm{NO}_{\mathrm{x}}$. The results were published periodically in the local newspaper. No exceedances of the measured pollutants were observed at the station near SNL/NM in 1993.

\subsubsection{Airborne Emissions and Permits}

Several sources at SNL/NM emit air pollutants that are regulated by the AQCRs. The emissions from these sources are described below:

- Topsoil Disturbance (AQCR \#18): Before disturbing the soil of any area larger than $3 / 4$ acre, SNL/NM or its contractor applies for a Topsoil Disturbance Permit and implements a plan for controlling dust emissions generated by construction activities in accordance with the requirements of AQCR 非, Airborne Particulate Matter. These mitigation measures include watering, phasing of construction, rescheduling of construction during windy periods, limiting vehicle access and vehicle speed, and using dust palliatives where watering is ineffective.

- Open Burning (AQCR \#3): The open-burn regulation was revised on June 16,1992 , to include new activities such as the disposal of explosives by burning to avoid the hazards of transport or handling, aboveground detonation of more than 20 pounds (1b) of explosives, and ignition of rocket motors containing more than $20 \mathrm{lb}$ of explosives or more than 4000 Ib of fuel. In addition to the scope changes, the City also revised the previous permit basis into two categories: multiple-event permit and single-event permit. The single-event permit was designed to regulate significant impact activities.

Open-burn permits were obtained from the City of Albuquerque prior to each scheduled regulated test according to the requirement of AQCR 非 Open Burning. A total of 20 multiple- and single-event open burn permits were issued or extended to SNL/NM during 1993 (see Table 5-5).

- Volatile Organic Compounds (AOCR \#11): This regulation requires all underground storage (fuel) tanks with annual throughput of 100,000 gal or more of gasoline to implement Stage-I recovery control for Vocs. Only one tank in TA-I requires Stage-I recovery and it has been in compliance with the requirements. During 1992, the Transportation Service Division Procedures Manual was revised to incorporate the requirement of Stage-I recovery in the procedure for receiving fuel (Hindl et al. 1992). The compliance has been demonstrated by the certification stamp and signature of the receiving personnel on the delivery receipt for each shipment and unloading of fuel. 
Table 5-5. Summary of 1993 Air Permits

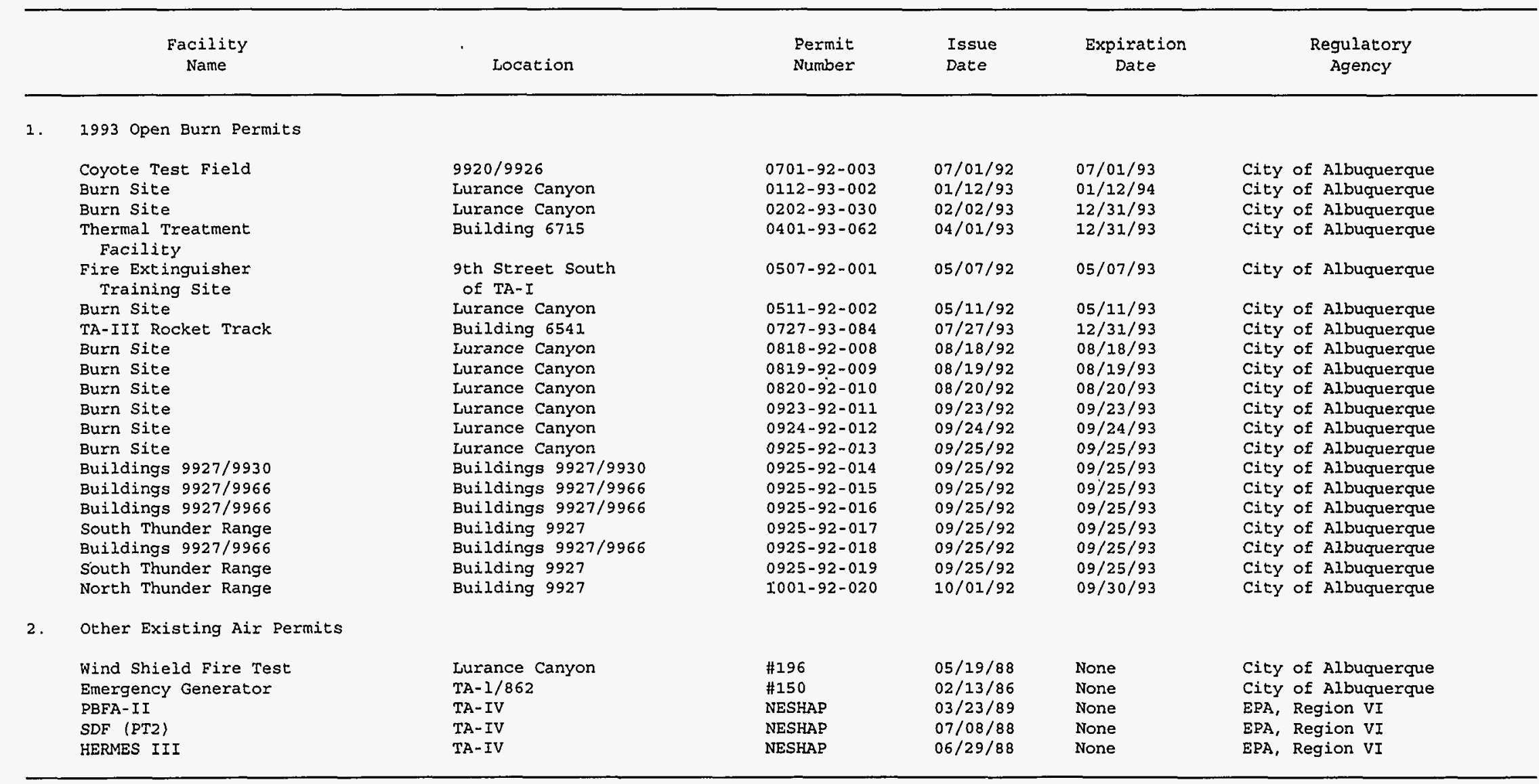


- Steam Boilers and Emergency Diesel Generators (AQCRs 非15-非18): SNL/NM currently has five steam boilers with capacities that range from 71.5 to 190.8 mega-British thermal units per hour $(\mathrm{MBtu} / \mathrm{hr})$. Because these generators were grandfathered sources, no permits were required or obtained. The four emergency diesel generators in Building 862 are permitted by the City of Albuquerque. There are other emergency generators on-site that may require permits.

\subsubsection{Criteria Pollutants Inventory}

Five steam boilers were operated by SNL/NM during 1993. The steam plant consumed a total of almost 862 million cubic feet (cf) of natural gas and 2000 gallons (gal) of fuel oil, and produced 621 million lb of steam. Based on the operation data provided by Plant Engineering, emissions of $\mathrm{NO}_{\mathrm{x}}, \mathrm{CO}, \mathrm{SO}_{2}, \mathrm{HC}$, and TSP were calculated for each boiler. Table 5-6 summarizes the calculated results. Published emission factors in EPA AP-42 for the criteria pollutants were used in the annual emission calculations (EPA 1986a).

SNL/NM also operates an emergency generator plant (Building 862) with four $600-\mathrm{kW}$ standby generators. Based on AP-42 published emission factors and 1993 operation data, the emissions from the emergency generators are summarized in Table 5-7.

Table 5-6. 1993 Criteria Pollutant Inventory (tons per year)

\begin{tabular}{lcccccc}
\hline & \multicolumn{6}{c}{ Steam Generators } \\
\cline { 2 - 5 } $\begin{array}{c}\text { Pollutants/ } \\
\text { Source }\end{array}$ & No. 1 & No. 2 & No. 3 & No. 5 & No. 6 & $\begin{array}{c}\text { Total } \\
\text { Emissions }\end{array}$ \\
\hline NO $_{\mathrm{x}}$ & 9.30 & 10.22 & 8.45 & 70.10 & 57.01 & 155.09 \\
$\mathrm{CO}$ & 2.33 & 2.56 & 2.11 & 5.10 & 4.15 & 16.24 \\
$\mathrm{TSP}$ & 0.91 & 1.00 & 0.83 & 0.64 & 0.52 & 3.90 \\
$\mathrm{SO}_{2}$ & 0.04 & 0.04 & 0.04 & 0.15 & 0.06 & 0.33 \\
$\mathrm{TOC}$ & 0.39 & 0.42 & 0.35 & 0.22 & 0.18 & 1.55
\end{tabular}

${ }^{a}$ Number 4 boiler was retired and no emissions were generated. Amounts are in tons per year. 
Table 5-7. Emergency Generator Emissions Estimates

\begin{tabular}{|c|c|c|c|c|c|}
\hline \multirow{2}{*}{$\begin{array}{l}\text { Pollutants/ } \\
\text { Source }\end{array}$} & \multicolumn{4}{|c|}{ Steam Generators ${ }^{\mathrm{a}}(600 \mathrm{~kW})$} & \multirow{2}{*}{$\begin{array}{c}\text { Total } \\
\text { Emissions }\end{array}$} \\
\hline & No. 1 & No. 2 & No. 3 & No. 4 & \\
\hline $\begin{array}{l}1993 \text { Hours } \\
\text { of Operation }\end{array}$ & 65.5 & 65.5 & 69.5 & 69.7 & -- \\
\hline $\mathrm{NO}_{x}{ }^{\mathrm{a}}$ & $3.50 \mathrm{E}-01$ & $3.50 \mathrm{E}-01$ & $3.71 \mathrm{E}-01$ & $3.72 \mathrm{E}-01$ & $1.44 \mathrm{E}+00$ \\
\hline $\mathrm{CO}^{\mathrm{a}}$ & $1.77 \mathrm{E}-02$ & $1.77 \mathrm{E}-02$ & $1.88 \mathrm{E}-02$ & $1.88 \mathrm{E}-02$ & $7.30 \mathrm{E}-02$ \\
\hline $\mathrm{TSP}^{\mathrm{b}}$ & $5.80 \mathrm{E}-02$ & $5.80 \mathrm{E}-02$ & $6.15 E-02$ & $6.17 \mathrm{E}-02$ & $2.39 \mathrm{E}-01$ \\
\hline $\mathrm{SO}_{\mathrm{x}}{ }^{b}$ & $5.41 \mathrm{E}-02$ & $5.41 E-02$ & $5.74 \mathrm{E}-02$ & $5.76 \mathrm{E}-02$ & $2.23 E-01$ \\
\hline $\mathrm{HC}^{\mathrm{b}}$ & $6.62 \mathrm{E}-02$ & $6.62 \mathrm{E}-02$ & $7.03 \mathrm{E}-02$ & $7.05 E-02$ & $2.73 \mathrm{E}-01$ \\
\hline \multicolumn{6}{|c|}{$\begin{array}{l}\text { abased on Kramer \& Associates performance tests (Kramer \& Associates } \\
\text { 1988a, 1988b) } \\
\text { bBased on AP-42 Emission Factors for Diesel Industrial Engines (EPA 1986a) }\end{array}$} \\
\hline
\end{tabular}

\subsubsection{Inventory and Assessment of Hazardous Air Emissions}

A Hazardous Chemical Usage Inventory team was formed in October 1993 to develop a streamlined process to collect Lab-wide chemical usage information. The team is composed of members from line organization, the Line Implementation Working Group (LIWG), and Environment, Safety, and Health (ES\&H) personnel. Jointly, the team reviewed the regulatory reporting requirements, defined the scope of the inventory, investigated existing databases, and developed an efficient process to carry out the Hazardous Chemical Usage Inventory.

Scope: A two-phase approach was taken in assessing the hazardous air emissions for CY 1993. In the first phase, a laboratory-wide chemical-usage survey was conducted. The chemicals listed for the inventory (along with the reason for their inclusion) encompassed (1) toxic chemicals listed under $40 \mathrm{CFR} 372.65$ for the purpose of complying with the Superfund Amendments and Reauthorization Act (SARA), Title III (also known as the Emergency Planning and Community Right-toKnow Act [EPCRA]), Section 313; (2) hazardous chemicals listed in NM AQCR 非52, Registration of Existing Toxic Air Pollution Sources, for the purpose of identifying and registering existing toxic air-emission points with the New Mexico Environment Department (NMED) to comply with the Agreement in Principle (AIP) between NMED and DOE's Albuquerque Operations Office (DOE/AL); (3) hazardous air pollutants listed in the Clean Air Act Amendments (CAAA), Title III, Section 112, for the purpose of assessing the impact of the CAAA, Title V, State Operating Permit Program; and (4) ozone-depleting substances listed under $40 \mathrm{CFR} 82$, for the purpose of assessing the impact due to the phase-out of Class I ozone-depleting substances. 
In Phase I, CY 92 and CY 93 purchase information from Fisher Scientific Co., SNL/NM chemical Just-in-Time (JIT) supplier, was evaluated to identify materials which contained regulated chemicals. Purchasing information was printed on inventory forms and distributed to all chemical users through vicepresident ES\&H Coordinators. The chemical users were requested to provide usage data on the chemicals purchased through JIT. They were also asked to provide chemical constituents and usage information on materials that contained regulated chemicals but that were not purchased JIT through Fisher Scientific Co.

Approximately 600 chemical-usage inventory forms were received and the data were keyed into a computer data base. Chemical usages were summarized and two chemicals were selected for assessment based on the amount of laboratory-wide usage and associated activities.

In Phase II, users of the two selected chemicals were requested to calculate air emissions using established EPA guidelines and other methods.

Results: According to the inventory data base, SNL/NM uses a wide variety of materials and chemicals in various processes. A summary of significant chemical usage is shown in Table 5-8. 
Table 5-8. Summary of Significant Chemical Usage Laboratory-Wide

\begin{tabular}{|c|c|c|}
\hline CAS & Usage (1b) & Chemical \\
\hline 108883 & $48,663.18$ & Toluene \\
\hline 1330207 & $48,486.58$ & Xylene \\
\hline 1310732 & $24,955.89$ & Sodium hydroxide \\
\hline 7664939 & $20,431.75$ & Sulfuric acid \\
\hline 110827 & $19,444.22$ & Cyclohexane \\
\hline 7647010 & $14,868.52$ & Hydrogen chloride \\
\hline 107211 & $10,732.40$ & Ethylene glycol \\
\hline 67641 & $8,505.08$ & Acetone \\
\hline 7439896 & $6,064.60$ & Iron salts, soluble, as $\mathrm{Fe}$ \\
\hline 74986 & $5,127.63$ & Propane \\
\hline 76131 & $4,635.47$ & Freon 113 (CFC-113) \\
\hline 67561 & $3,775.91$ & Methanol (Methyl alcohol) \\
\hline 71432 & $3,684.20$ & Benzene \\
\hline 67630 & $3,643.47$ & Isopropyl alcohol \\
\hline 100414 & $3,358.97$ & Ethylbenzene \\
\hline 7697372 & $3,031.27$ & Nitric acid \\
\hline 8052424 & $2,389.01$ & Asphalt (petroleum) fumes \\
\hline 75694 & $2,000.00$ & Trichlorofluoromethane (CFC-11) \\
\hline 12125018 & $1,936.65$ & Ammonium fluoride \\
\hline 110543 & $1,743.68$ & n-Hexane \\
\hline 95636 & $1,710.18$ & 1,2,4-Trimethylbenzene \\
\hline 7664393 & $1,445.48$ & Hydrogen fluoride \\
\hline 100425 & $1,368.31$ & Styrene \\
\hline 75456 & $1,135.40$ & Hydrochlorofluorocarbon- 22 \\
\hline 7782414 & $1,133.29$ & Fluorine \\
\hline
\end{tabular}




\subsection{WATER MONITORING PROGRAMS}

\subsection{WASTEWATER PROGRAMS}

\subsubsection{Discharges to Publicly Owned Treatment Works}

Sandia National Laboratories/New Mexico (SNL/NM) contains over 15 miles (mi) (24 kilometers $[\mathrm{km}]$ ) of sewer lines interconnected with those of Kirtland Air Force Base (KAFB). During 1993, SNL/NM had three categorical pretreatment operations and four general wastewater streams discharging to the City of Albuquerque publicly owned treatment works (POTW). For the U.S. Environmental Protection Agency (EPA) categorical discharge limitations, see the list of permits that have 40 Code of Federal Regulations (CFR) designation in Table $6-1$.

Table 6-1. Sandia National Laboratories/New Mexico Wastewater Discharge Permits

\begin{tabular}{|c|c|c|c|c|}
\hline $\begin{array}{l}\text { Permit } \\
\text { Number }\end{array}$ & $\begin{array}{l}\text { Station } \\
\text { Manhole }\end{array}$ & $\begin{array}{l}\text { Waste Stream } \\
\text { Process }\end{array}$ & $\begin{array}{l}\text { Issuing } \\
\text { Agency }\end{array}$ & $\begin{array}{l}\text { Permit } \\
\text { Expiration }\end{array}$ \\
\hline $2069 A-3$ & WW001 & General & $\begin{array}{l}\text { City of Albuquerque/ } \\
\text { I.C. }-7391^{\mathrm{a}}\end{array}$ & $02 / 01 / 97$ \\
\hline $2069 D-4$ & WW004 & $\begin{array}{l}\text { Metal } \\
\text { Finishing }\end{array}$ & $\begin{array}{l}\text { City of Albuquerque/ } \\
40 \text { CFR } 433 \text {.A15 }\end{array}$ & $02 / 01 / 97$ \\
\hline $2069 \mathrm{~F}-3$ & WW006 & General & $\begin{array}{l}\text { City of Albuquerque/ } \\
\text { I.C. }-3674,3694, \\
\text { and } 9711\end{array}$ & $02 / 01 / 97$ \\
\hline $2069 G-2$ & WW007 & $\begin{array}{l}\text { Microelectronics } \\
\text { Development } \\
\text { Laboratory }\end{array}$ & $\begin{array}{l}\text { City of Albuquerque/ } \\
40 \text { CFR } 469 . \mathrm{A}\end{array}$ & $07 / 31 / 94$ \\
\hline $2069 \mathrm{H}-3$ & WW009 & $\begin{array}{l}\text { Process } \\
\text { Development } \\
\text { Laboratory }\end{array}$ & $\begin{array}{l}\text { City of Albuquerque/ } \\
40 \mathrm{CFR} 433\end{array}$ & $02 / 01 / 97$ \\
\hline $2069 I-2$ & WW008 & General & $\begin{array}{l}\text { City of Albuquerque/ } \\
\text { I.C. }-3674,3679, \\
\text { and } 9711\end{array}$ & $02 / 01 / 97$ \\
\hline $2069 \mathrm{~K}$ & Ww011 & General & $\begin{array}{l}\text { City of Albuquerque/ } \\
\text { I.C. }-3674,3679 \text {, } \\
\text { and } 9711\end{array}$ & $03 / 31 / 94$ \\
\hline
\end{tabular}


In November 1993, SNL/NM began construction of the Liquid Effluent Control System (LECS) to retain process wastewater for radiological screening prior to disposal into the sanitary sewer. Until the system is completed, SNL/NM will continue to use the two 5,000-gallon (gal) holding tanks in Technical Area $\mathrm{V}$ (TA-V). Samples are collected several times weekly as grab samples, then delivered to radiological laboratories for screening analysis. Before sampling, influent flow is switched to the other tank to isolate the active tank's sample volume. Samples are analyzed for gross alpha particle activities, gross beta particle activities, tritium ( $\mathrm{H}-3)$, and gamma emitters. Comparison samples are collected from tap-water sources in TA-V for background analyses. Every fifth sampling, duplicate samples are collected and shipped to an SNL-contracted laboratory for independent analysis. The sampling results indicate the wastewater discharge from TA-V wastewater holding tanks are below regulatory limits set by the U.S. Nuclear Regulatory Commission (USNRC), the U.S. Department of Energy (DOE), and the State of New Mexico.

SNL/NM's policy prohibits the disposal of radiological material above regulatory levels into the sanitary sewer system. Although radiological analyses for the permitted outfall locations are not permit requirements, results are included to satisfy reporting requirements established by the City of Albuquerque's Sewer Use and Wastewater Control Ordinance, Section 8-9-44.H, which states that all analyses performed in accordance with prescribed procedures established by EPA under provisions contained in 40 GFR 136 shall be reported. Results of radiological sampling are contained in the Wastewater Monitoring Program Quarterly Reports (IT 1993a, 1993b, 1993c, 1994).

Discharges by SNL/NM to the POTW are regulated by the City of Albuquerque Public Works Department, Liquid Waste Division, under the authority of the City's Sewer Use and Wastewater Control Ordinance. The City's ordinance is approved by EPA in accordance with the Clean Water Act (CWA) as amended.

To comply with EPA regulations, the City of Albuquerque has implemented an industrial wastewater pretreatment program. This program requires SNL/NM to obtain permits for wastewater discharges to the City's POTW. These permits specify the required quality of discharges and the frequency of reporting the monitoring results.

Table 6-2 and Figure 6-1 describe the wastewater sampling locations. Table 6-3 summarizes location characteristics. The sampling procedures, permit limits for individual sampling stations, dates of sample collection and sample frequency, analytical methods, and quality control/quality assurance criteria are defined in the SNL/NM Wastewater Sampling Plan (Booher 1992). Complete documentation concerning the wastewater sampling program can be found in the Wastewater Monitoring Program Quarterly Reports.

\subsubsection{Summary of Monitoring Results}

This section describes each permit and addresses those instances in which the monitoring results did not comply with the permit limits described in the Wastewater Monitoring Program Quarterly Reports for 1993. 
Table 6-2. Sandia National Laboratories/New Mexico Wastewater Sample Locations

\begin{tabular}{|c|c|c|}
\hline $\begin{array}{l}\text { Permit } \\
\text { Number }\end{array}$ & $\begin{array}{l}\text { Station } \\
\text { Manhole }\end{array}$ & $\begin{array}{l}\text { Average Flow } \\
\text { Location }(g p d)^{a}\end{array}$ \\
\hline $2069 A-2$ & $\begin{array}{l}\text { WW001 } \\
\text { Tijeras Arroyo }\end{array}$ & South Technical Area IV 28,849 \\
\hline $2069 D-3$ & $\begin{array}{l}\text { WW004 } \\
\text { Building } 841 \mathrm{SE}\end{array}$ & Technical Area I 39,154 \\
\hline $2069 F-2$ & Ww006 & East of KAFB Lagoons 514,123 \\
\hline $2069 G-2$ & $\begin{array}{l}\text { WW007 } \\
\text { Building } 858 \text { Basement }\end{array}$ & Technical Area I110,939 \\
\hline $2069 \mathrm{H}-2$ & $\begin{array}{l}\text { Ww009 } \\
\text { Building } 878 \text { Basement }\end{array}$ & Technical Area I 3,659 \\
\hline $2069 I$ & $\begin{array}{l}\text { Ww008 } \\
\text { Tijeras Arroyo }\end{array}$ & South Technical Area I 25,576 \\
\hline $2069 \mathrm{~K}$ & Ww011 & Technical Area III 10,000 \\
\hline
\end{tabular}

Permit 2069A-2: This permit is a general wastewater discharge permit for wastewater discharges from a portion of SNL/NM TA-I.

- Analytical Results: Analytical results from laboratory analyses show all analyte concentrations to be less than permitted requirements.

- Hydrogen ion concentration (pH): No $\mathrm{pH}$ excursion of wastewater discharges above the permitted $\mathrm{pH}$ limits occurred for greater than 1 hour (hr) during 1993. Dates of $\mathrm{pH}$ excursions for $1 \mathrm{hr}$ or less, total time the wastewater $\mathrm{pH}$ was out of permit limits, dates of sample collection, and sampling frequencies for each month for Permit 2069A-2 are contained in the Wastewater Monitoring Program Quarterly Reports for 1993 (IT 1993a, 1993b, 1993c, 1994). 


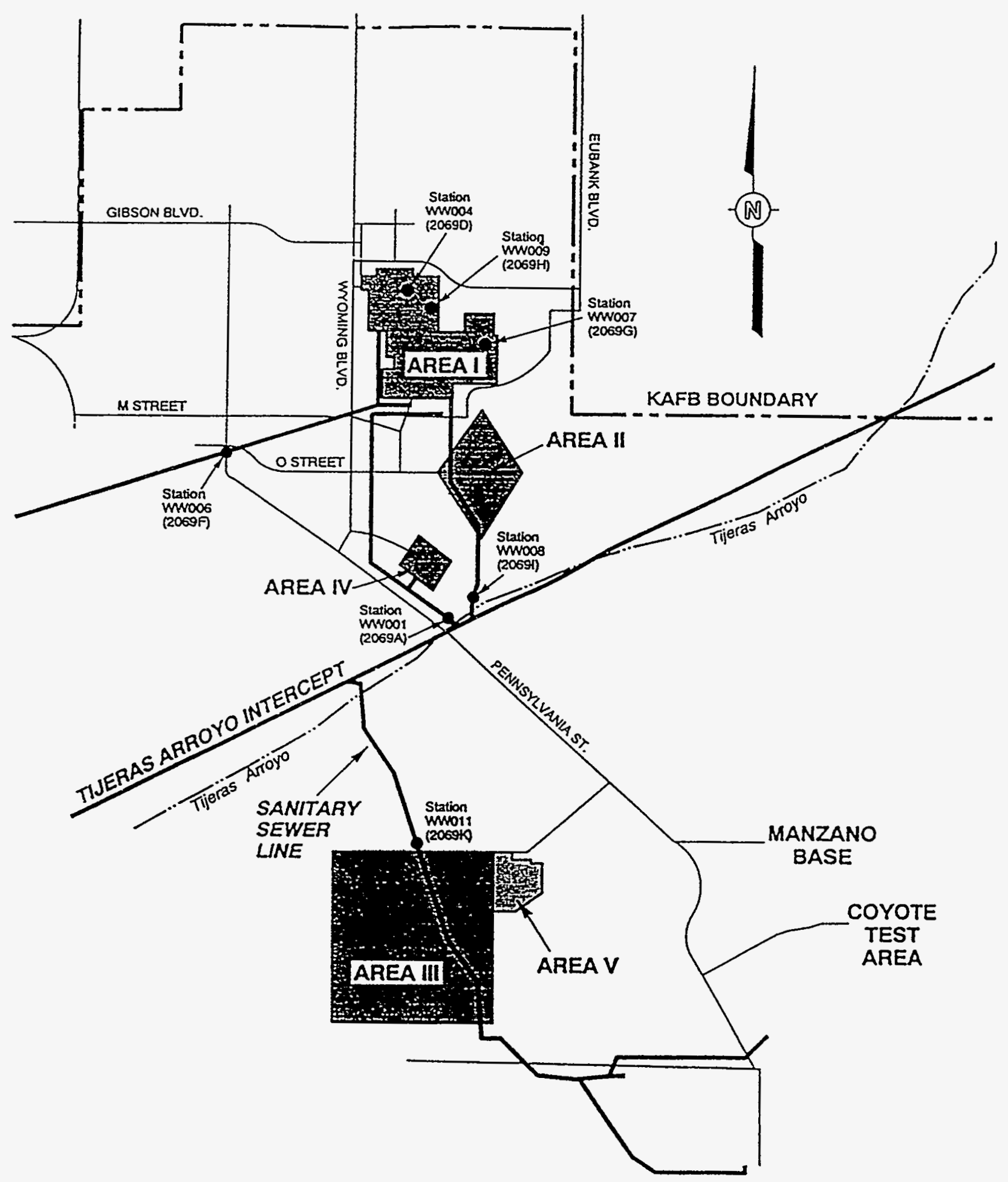

Figure 6-1. Sandia National Laboratories/New Mexico Wastewater Monitoring Station Locations 
Table 6-3. Summary of Characteristics for Sandia National Laboratories/New Mexico Wastewater Sampling Stations

Station

Number
Flumes

3-in. Parshall

2-in. Parshall

WW004

WW006

WW007

WW008

WW009

WW011 6-in. Parshal1

$45^{\circ}$ V-Notch Weir

6-in. Parshall

2-in. Parshall

6-in. Parshall
Flow Meter and

Sampling Equipment

Isco 3210 Flow Meter Isco 2700R Sampler Leeds and Northrop $\mathrm{pH}$ Analyzer System

Isco 3210 Flow Meter Isco 2700R Sampler Leeds and Northrop $\mathrm{pH}$ Analyzer System

Isco 3210 Flow Meter Isco 2700R Sampler Leeds and Northrop $\mathrm{pH}$ Analyzer System

Isco 3210 Flow Meter Isco 2700R Sampler Leeds and Northrop $\mathrm{pH}$ Analyzer System

Isco 3210 Flow Meter Isco 2700R Sampler Leeds and Northrop $\mathrm{pH}$ Analyzer System

Isco 3210 Flow Meter Isco 2700R Sampler Leeds and Northrop $\mathrm{pH}$ Analyzer System

Isco 3210 Flow Meter Isco 2700R Sampler Leeds and Northrop $\mathrm{pH}$ Analyzer System 
Permit 2069D-3: This permit covers discharges from the categorical, regulated metal-plating activity in Building 841 of SNL/NM TA-I.

- Analytical Results: Analytical results from laboratory analyses show all analyte concentrations to be less than permitted requirements with the exception of a total toxic organics (TTO) concentration from a sample collected on September 15, 1993. This deviation exceeded permit limit, but caused no impact on the operation of the POTW. The sample concentration and permit limits are summarized in Table 6-4. Corrective actions are documented in the Quarterly Reports for 1993.

- $\mathrm{pH}$ : No $\mathrm{pH}$ excursion of wastewater discharges above the permitted $\mathrm{pH}$ limits occurred for greater than $1 \mathrm{hr}$ during 1993. Dates of $\mathrm{pH}$ excursions for $1 \mathrm{hr}$ or less, total time the wastewater $\mathrm{pH}$ was out of permit limits, dates of sample collection, and sampling frequencies for each month for Permit 2069D-3 are contained in the Wastewater Monitoring Program Quarterly Reports for 1993.

Table 6-4. Summary of Concentration Violations for Permit 2069D-3, Station WW004, During 1993

Sample Date/Sample Type Concentration (mg/L) Permit Limit (mg/L)

$\begin{array}{lll}\text { September } 15, \begin{array}{l}1993 / 24-\mathrm{hr} \\ \text { Composite }\end{array} & 1.3 & 0.71\end{array}$

Permit 2069F-2: This permit is a general wastewater discharge permit for wastewater discharges from a portion of SNL/NM TA-I and some KAFB facilities.

- Analytical Results: Analytical results from laboratory analyses show all analyte concentrations to be less than permitted requirements.

- $\mathrm{pH}$ : No $\mathrm{pH}$ excursions of wastewater discharges above the permitted $\mathrm{pH}$ limits occurred for greater than $1 \mathrm{hr}$ during 1993. Dates of $\mathrm{pH}$ excursions for $1 \mathrm{hr}$ or less, total time the wastewater $\mathrm{pH}$ was out of permit limits, dates of sample collection, and sampling frequencies for each month for Permit 2069F-2 are contained in the Wastewater Monitoring Program Quarterly Reports for 1993 (IT 1993a, 1993b, 1993c, 1994).

Permit 2069G-2: This permit covers discharges from categorical, regulated semiconductor production activity in Building 858 of SNL/NM TA-I.

- Analytical Results: Analytical results from laboratory analyses show all analyte concentrations to be less than permitted requirements. 
- $\mathrm{pH}:$ No $\mathrm{pH}$ excursions of wastewater discharges above the permitted $\mathrm{pH}$ limits occurred for greater than $1 \mathrm{hr}$ during 1993. Dates of $\mathrm{pH}$ excursions for $1 \mathrm{hr}$ or less, total time the wastewater $\mathrm{pH}$ was out of permit limits, dates of sample collection, and sampling frequencies for each month for Permit 2069G-2 are contained in the Wastewater Monitoring Program Quarterly Reports for 1993.

Permit 2069H-2: This permit covers discharges from the categorical, regulated, printed circuit activity at the Process Development Laboratory (PDL) in Building 878 of SNL/NM TA-I.

- Analytical Results: Analytical laboratory analyses show all analyte concentrations to be less than permitted requirements with the exception of a copper $(\mathrm{Cu})$ concentration from a sample collected on November 5, 1993. This violation exceeded the permit limit, but caused no impact on the operation of the POTW. The sample concentration and permit limits are summarized in Table 6-5. Corrective actions are documented in the Quarterly Reports for 1993.

- $\mathrm{pH}$ : No $\mathrm{pH}$ excursions of wastewater discharges above the permitted $\mathrm{pH}$ limits occurred for greater than $1 \mathrm{hr}$ during 1993. Dates of $\mathrm{pH}$ excursions for $1 \mathrm{hr}$ or less, total time the wastewater $\mathrm{pH}$ was out of permit limits, dates of sample collection, and sampling frequencies for each month for Permit 2069H-2 are contained in the Wastewater Monitoring Program Quarterly Reports for 1993.

Table 6-5. Summary of Concentration Violations for Permit 2069H-2, Station WW009, During 1993

Sample Date/Sample Type Concentration (mg/L) Permit Limit (mg/L)

November 5, 1993/24-hr $\quad 3.7 \quad 2.960$

Composite

(Copper)

Permit 2069I: This permit is a general wastewater discharge permit for wastewater discharges from SNL/NM TA-I, TA-II, and TA-IV.

- Analytical Results: Analytical results from laboratory analyses show all analyte concentrations to be less than permitted requirements.

- $\mathrm{pH}$ : No $\mathrm{pH}$ excursion of wastewater discharges above the permitted $\mathrm{pH}$ limits occurred for greater than $1 \mathrm{hr}$ during 1993. Dates of $\mathrm{pH}$ excursions for $1 \mathrm{hr}$ or less, total time the wastewater $\mathrm{pH}$ was out of permit limits, dates of sample collection, and sampling frequencies for each month for Permit 2069I are contained in the Wastewater Monitoring Program Quarterly Reports for 1993 (IT 1993a, 1993b, 1993c, 1994). 
Permit 2069K: This permit is a general wastewater discharge permit for wastewater discharges from SNL/NM TA-III and TA-V.

- Analytical Results: Analytical results from laboratory analyses show all analyte concentrations to be less than permitted requirements with the exception of a cyanide concentration from a sample collected on June 17, 1993. The violation exceeded the permit limit, but caused no impact on the operation of the POTW. The sample concentration and permit limits are summarized in Table 6-6. Corrective actions are documented in the Quarterly Reports for 1993.

- $\mathrm{pH}$ : No $\mathrm{pH}$ excursions of wastewater discharges above the permitted $\mathrm{pH}$ limits occurred for greater than $1 \mathrm{hr}$ during 1993. Dates of $\mathrm{pH}$ excursions for $1 \mathrm{hr}$ or less, total time the wastewater $\mathrm{pH}$ was out of permit limits, dates of sample collection, and sampling frequencies for each month for Permit 2069K are contained in the Wastewater Monitoring Program Quarterly Reports for 1993.

Table 6-6. Summary of Concentration Violations for Permit 2069K, Station WW011, During 1993

Sample Date/Sample Type Concentration (mg/L) Permit Limit (mg/L)

$\begin{array}{ccc}\text { June } 17, \begin{array}{l}\text { 1993/24-hr } \\ \text { Composite } \\ \text { (Cyanide) }\end{array} & 6.10 & 3.8\end{array}$

\subsection{STORM WATER PROGRAM}

An amendment to the regulations implementing the CWA was promulgated on November 16, 1990, in the Federal Register. This amendment implements Section 402[p] of CWA, which was added by Section 405 of the Water Quality Act of 1987. The implementing regulations are published in $40 \mathrm{CFR} \mathrm{122-124.} \mathrm{These} \mathrm{enactments}$ require EPA to regulate storm water discharges associated with industrial activities. Industrial activities covered by these new regulations include Standard Industrial Classification (SIC) Codes 21 through 39 . SNL/NM has several activities that fall under these SIC codes, including those at the Microelectronics Development Laboratory, the Process Development Laboratory, the Albuquerque Microelectronics Operation, and the plating shops in Building 840 .

There are also requirements for permitting specific facility operations: salvage yards, vehicle maintenance yards, construction activities that disturb five or more acres, and hazardous waste treatment, storage, and disposal facilities. SNL/NM has ongoing activities that fall under all these descriptions and others that require SNL/NM to submit a National Pollutant Discharge Elimination System (NPDES) permit application for its storm water discharges. 
The permit application was prepared and submitted to EPA, Region VI, on October 1 , 1992. The construction activities are being covered by a Notice of Intent to Discharge (NOI) that was also submitted to EPA, Region VI, on October 1 , 1992. The permit applications and NOIs will be reviewed and approved by the EPA with State of New Mexico review and concurrence. No formal response has been received.

No storm water sampling was conducted in 1993. A permit application was submitted in 1992 to EPA Region VI. No formal response has been received regarding the permit application. Until the permit application is acted upon, no further sampling is required.

\subsection{SURFACE DISCHARGE PROGRAMS}

\subsubsection{Discharge Plans}

All discharges to surface impoundments for SNL/NM are under the authority of the New Mexico Water Quality Control Commission (NMWQCC) Regulations as implemented by the New Mexico Environment Department (NMED) Ground Water Bureau. During 1993, SNL/NM had two active permitted discharge plans from the State of New Mexico: Discharge Plan-530 (DP-530) and DP-771.

DP-530 covers discharges to lagoons I and II from pulsed-power operations in TA-IV. Water that accumulates in the secondary containment area for the Pulsed-Power Development Facilities oil storage tanks is discharged to two surface impoundments (lagoons I and II) outside TA-IV. DP-530 was approved for these discharges in March 1988 and amended in December 1989, November 1992, and June 1993. The approved discharge plan, as amended, requires quarterly measurement of water levels and semiannual sampling and analysis. During 1993, water-level measurements were taken in March, June, August, and December, and sampling was done in March and August. Reports containing water level measurements and monitoring results were submitted in January and July to the NMED Ground Water Bureau. The results are documented in the semiannual reports for DP-530 (SNL 1993f, 1993g).

A second discharge plan, DP-771, was closed on October 1, 1993. DP-771 covered discharges from experiments at the Solar Test Facility. The requirement for surface discharges ended in 1992, and no discharges were made during 1993. NMED approval of DP-771 was received in March 1991 and amended in March 1992. This groundwater discharge plan was submitted by the Solar Detoxification Facility for the discharge of up to 2700 gallons per day (gpd) of process water from solar detoxification experiments. The permit required notification of any experiment modifications to the NMED prior to any water discharge from the modified test. The permit also required quarterly monitoring of listed contaminants for each test at the Solar Detoxification Facility. The results of monitoring are documented in the quarterly reports for DP-771 (Pacheco and Bonaguidi 1993; Pacheco and Copus 1993a, 1993b).

\subsubsection{Summary of Analytical Results}

This section contains a summary of the DP-530 analytical report of Lagoons I and II. 
Total dissolved solids (TDS), chloride, and sulfate were detected in calendar year (CY) 1993 samples from Lagoons I and II at concentrations less than the applicable NMWQCC standards. TDSs were detected in amounts of 519 milligrams per liter (mg/L) for Lagoon I and $480 \mathrm{mg} / \mathrm{L}$ for Lagoon II. The NMWQCC standard for TDS is $1000 \mathrm{mg} / \mathrm{L}$. Chloride concentrations in Lagoons I and II were reported at $97.2 \mathrm{mg} / \mathrm{L}$ and $125 \mathrm{mg} / \mathrm{L}$, respectively. The NMWQCC standard is 250 $\mathrm{mg} / \mathrm{L}$. Sulfates were reported in Lagoons $I$ and $I I$ at $10 \mathrm{mg} / \mathrm{L}$ and $65 \mathrm{mg} / \mathrm{L}$, respectively. The NMWQCC standard for sulfate is $600 \mathrm{mg} / \mathrm{L}$. 


\subsection{GROUNDWATER MONITORING}

This chapter describes groundwater monitoring activities conducted by the Environmental Operations Center, Organization 7500 , at Sandia National Laboratories/New Mexico (SNL/NM) during calendar year 1993 (CY 93). These groundwater monitoring activities are associated with the SNL/NM Environmental Restoration (ER) Project and the Groundwater Surveillance Task. In addition, water level elevations in monitoring wells in the SNL/NM area are measured monthly to establish groundwater flow patterns in the region.

Details of groundwater monitoring activities for CY 93 are discussed in the following sections of this chapter:

Groundwater Surveillance Task (hereinafter referred to as "basewide" groundwater monitoring): Samples were collected from monitoring wells and springs on and adjacent to Kirtland Air Force Base (KAFB) for baseline hydrogeochemical characterization and groundwater contamination detection monitoring. In 1993, basewide sampling occurred in April, July, September, and December. The results of the sampling events are discussed in Section 7.4.2. Water levels were measured each month at 36 wells on KAFB. Water level data are discussed in Section 7.3.

Chemical Waste Landfill (CWL): Annual assessment monitoring took place in February; quarterly assessment sampling was performed in May, August, and November. The results of CWL groundwater monitoring are reported in accordance with the regulatory requirements specified in 40 Code of Federal Regulations (CFR) 265, Subpart F, and the CWL final closure plan (SNL 1992a, 1993d). The results are discussed in Section 7.4.3.

Mixed Waste Landfill (MWL): Semiannual detection groundwater sampling occurred in January, April, and November. The results are discussed in Section 7.4.4.

Technical Area II (TA-II): Two additional monitoring wells were installed and sampled during 1993. Section 7.4 .5 provides details.

Liquid Waste Disposal System (LWDS): Two monitoring wells were installed and sampled in CY 93. The results are discussed in Section 7.4.6.

Sitewide Hydrogeologic Characterization Project (SWHC): Four new monitoring wells were installed during 1993; two of the wells were sampled as part of the sitewide activity. The results are discussed in Section 7.4.7. The two other wells were sampled quarterly as part of the basewide sampling program (Section 7.4.2).

\subsection{REGULATORY OVERVIEW}

The Groundwater Surveillance Task is the implementation of Department of Energy (DOE) Order 5400.1 (DOE 1988a) at SNL/NM. This Order requires SNL/NM to do several things:

1. Obtain data for the purpose of determining baseline conditions of groundwater quality and quantity 
2. Demonstrate compliance with and implementation of all applicable regulations and DOE Orders

3. Provide data to permit the early detection of groundwater pollution or contamination

4. Identify existing and potential groundwater contamination sources and maintain surveillance of these sources

5. Provide data upon which decisions can be made concerning land disposal practices and the management and protection of groundwater resources

The purpose of the Groundwater Surveillance Task is to detect any contaminants entering SNL/NM from outside sources and any contaminants leaving SNL/NM with the specific objective of establishing the impact of DOE facilities operations on groundwater quantity and quality.

The CWL currently must meet the interim status Resource Conservation and Recovery Act (RCRA) Groundwater Monitoring Regulations (40 CFR 265, Subpart F). In February 1993, the CWL final closure plan and postclosure permit application (SNL 1992a, 1993d) was approved by all concerned parties. The current groundwater monitoring requirements for this site are discussed in detail in Sections 2.0 and 7.0 of the closure plan. The sampling and analysis plan is provided in Appendix $G$ of the closure plan. During 1993, annual monitoring for Appendix IX parameters occurred in February, and quarterly monitoring for Appendix IX volatile organic compounds (VOCs) and metals occurred in May, August, and November. As required by 40 CFR 265.94.b.2, the results of this sampling effort are provided in Section 7.4 .3 of this report.

The MWL is regulated by the U.S. Environmental Protection Agency (EPA) as a solid waste management unit (SWMU) under RCRA. Groundwater monitoring activities at the MWL are in accordance with the requirements of $40 \mathrm{CFR} \mathrm{264,}$ "Standards for Owners and Operators of Hazardous Waste Treatment, Storage, and Disposal Facilities, " Subpart F, Section 264.101, " Corrective Action for Solid Waste Management Units."

Groundwater sampling activities at TA-II, LWDS, and SWHC are conducted as part of the site-specific investigations under the Hazardous and Solid Waste Amendments (HSWA) permit for SNL/NM.

\subsection{SANDIA NATIONAL LABORATORIES/NEW MEXICO GROUNDWATER MONITORING WELL NETWORK}

In $C Y$ 93, the following SNL/NM groundwater monitoring activities were performed:

Static water levels were measured in 34 SNL/NM and KAFB wells and 2 springs (including Hubbell Spring on Isleta Indian Pueblo) (Figure 7-1).

The basewide project sampled groundwater from 16 to 17 SNL/NM, KAFB, New Mexico Environment Department (NMED), and DOE wells and 3 springs (including the Isleta Indian Pueblo Hubbel1 Spring) (Figure 7-1). 


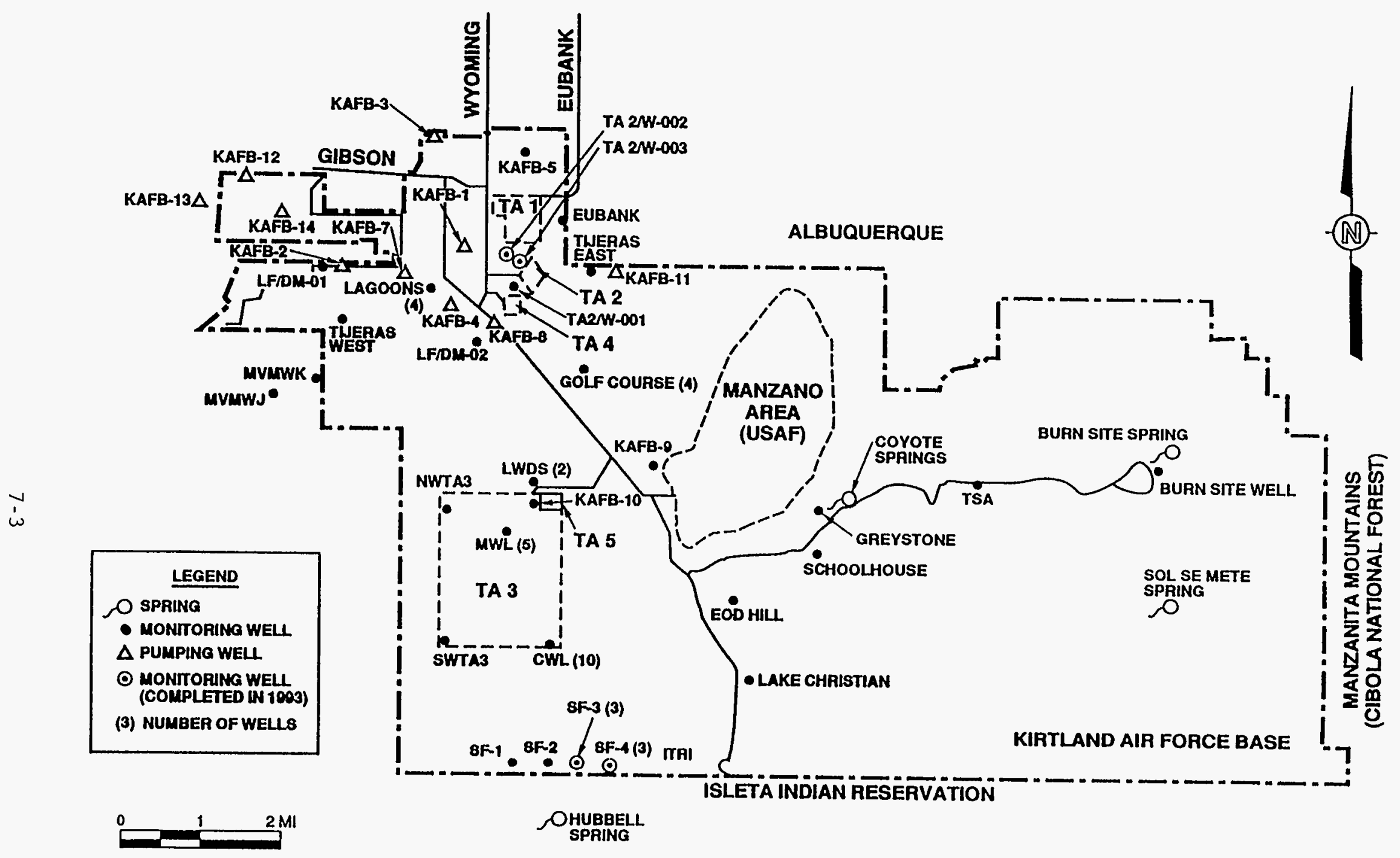

Figure 7-1. Location Map of Sandia National Laboratories and Kirtland Air Force Base Wells and Springs 
CWL groundwater monitoring consisted of sampling seven wells (designated "MW") surrounding the landfill and three background wells (designated "BW") (Figure 7-2).

MWL groundwater monitoring consisted of sampling at four wells surrounding the landfill, including one background monitoring well and one monitoring well located inside the landfill (Figure 7-3).

TA-II groundwater samples were collected from one well near the Building 901 septic leachfield and two background monitoring wells in the vicinity of TA-II (Figure 7-4).

LWDS groundwater samples were obtained from two newly installed wells, one adjacent to the LWDS lagoons and the other near the location of the buried LWDS waste line immediately outside TA-V (Figure 7-5).

The SWHC task has installed a series of monitoring wells at four locations along the south fenceline of KAFB. These include a nested pair of wells at SFR-1 (SFR-1D and SFR-1S), SFR-2S, three monitoring wells at SFR-3 (SFR-3, SFR-3T, and SFR-3P), and two monitoring wells at SFR-4 (SFR-4T and SFR-4P) (Figure 7-6).

\subsection{WATER LEVEL MEASUREMENTS}

Monthly water level measurements were made during 1993 at 34 wells and 2 springs in accordance with SNL/NM procedure PRO 90-02 (Goodrich 1990). Water level elevations were also measured in all CWL and MWL wells prior to each sampling event to ensure that the monitoring well network consisted of at least one upgradient well and three downgradient wells. Seven of the wells and springs included in the program are located east of the faults, with depth to groundwater varying from 0 to 100 feet ( $\mathrm{ft}$ ) ( 0 to 30 meters [m]); all others are west of the faults, with depths to groundwater up to $500 \mathrm{ft}(150 \mathrm{~m})$. Monthly summaries of all depth-to-water measurements and corresponding water surface elevations made at SNL/NM from January through December 1993 are included in "Calendar Year 1993 Annual Groundwater Monitoring Report" (SNL 1994). The water level data collected during 1993 and the subsequent groundwater elevation analyses are discussed in the following sections.

The locations of monitoring wells used for SNL/NM water level measurements are shown in Figure 7-1. Hydrographs constructed from the water-level data are presented as Figures 7-8 through 7-15. Each of these hydrographs has been presented with the same relative vertical scale to facilitate interpretation and comparisons. Wells have been grouped on the hydrographs by their locations. Where data are missing, dashed lines have been used to maintain continuity between adjacent points in the plots. Each of the hydrographs is discussed below.

For comparison with the monitoring well water-level data, the KAFB production well pumping volumes are plotted by month for 1993 in Figure 7-7. There is a seasonal pattern of increased pumpage during the spring and summer months, followed by a significant drop in pumping during the fall and winter. 


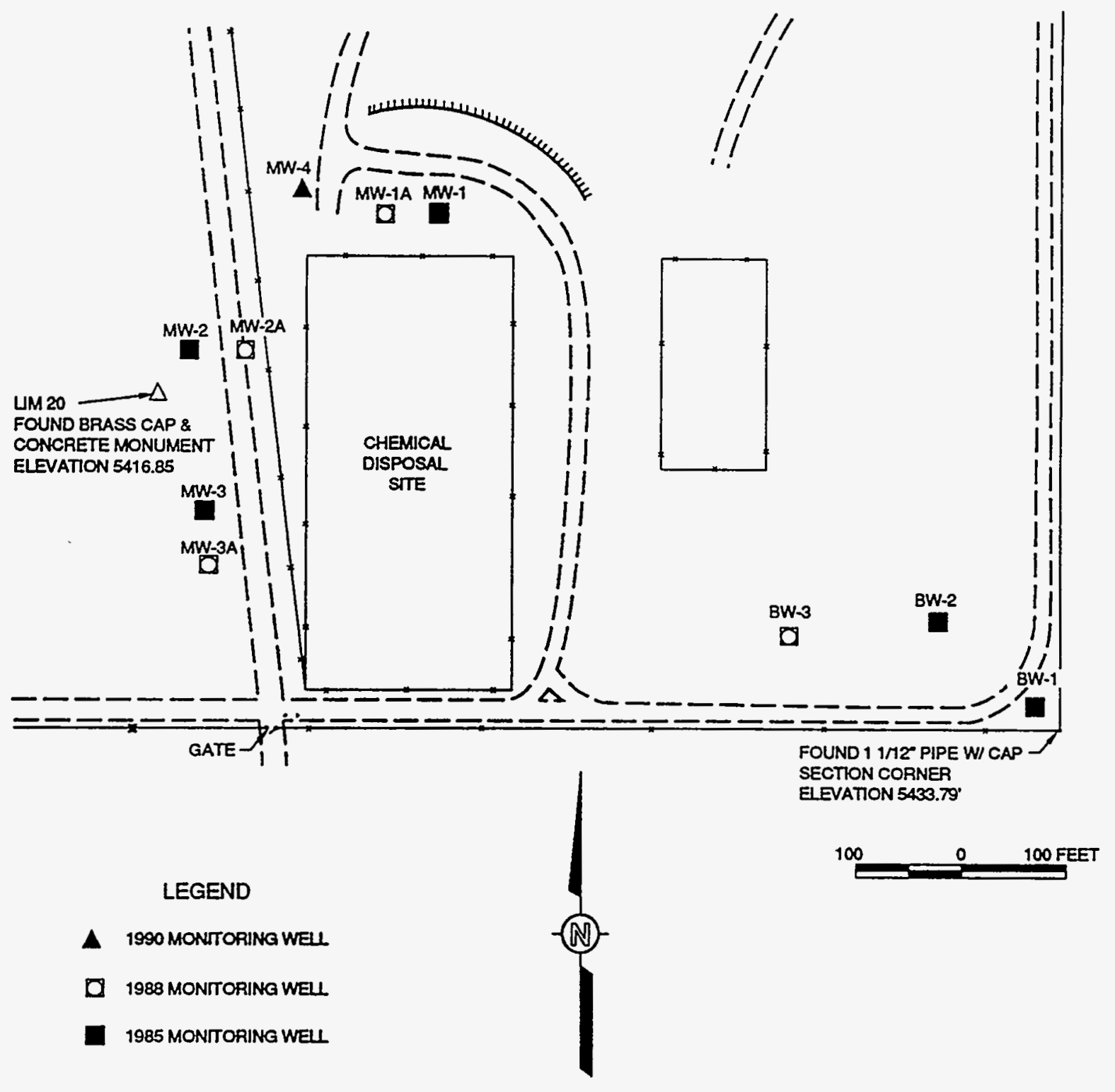

Figure 7-2. Chemical Waste Landfill Monitoring Well Locations 


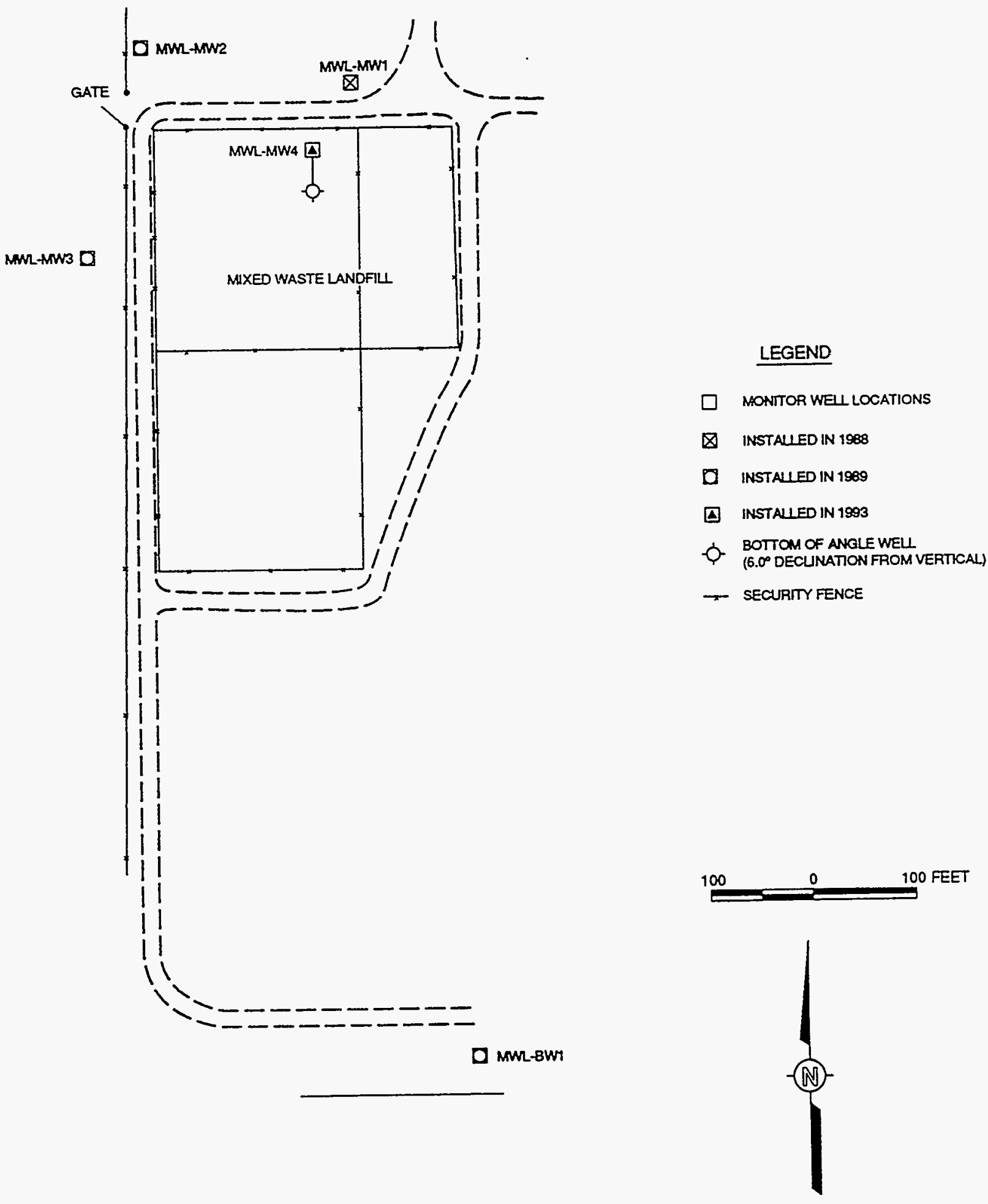

Figure 7-3. Mixed Waste Landfill Monitoring Well Locations 


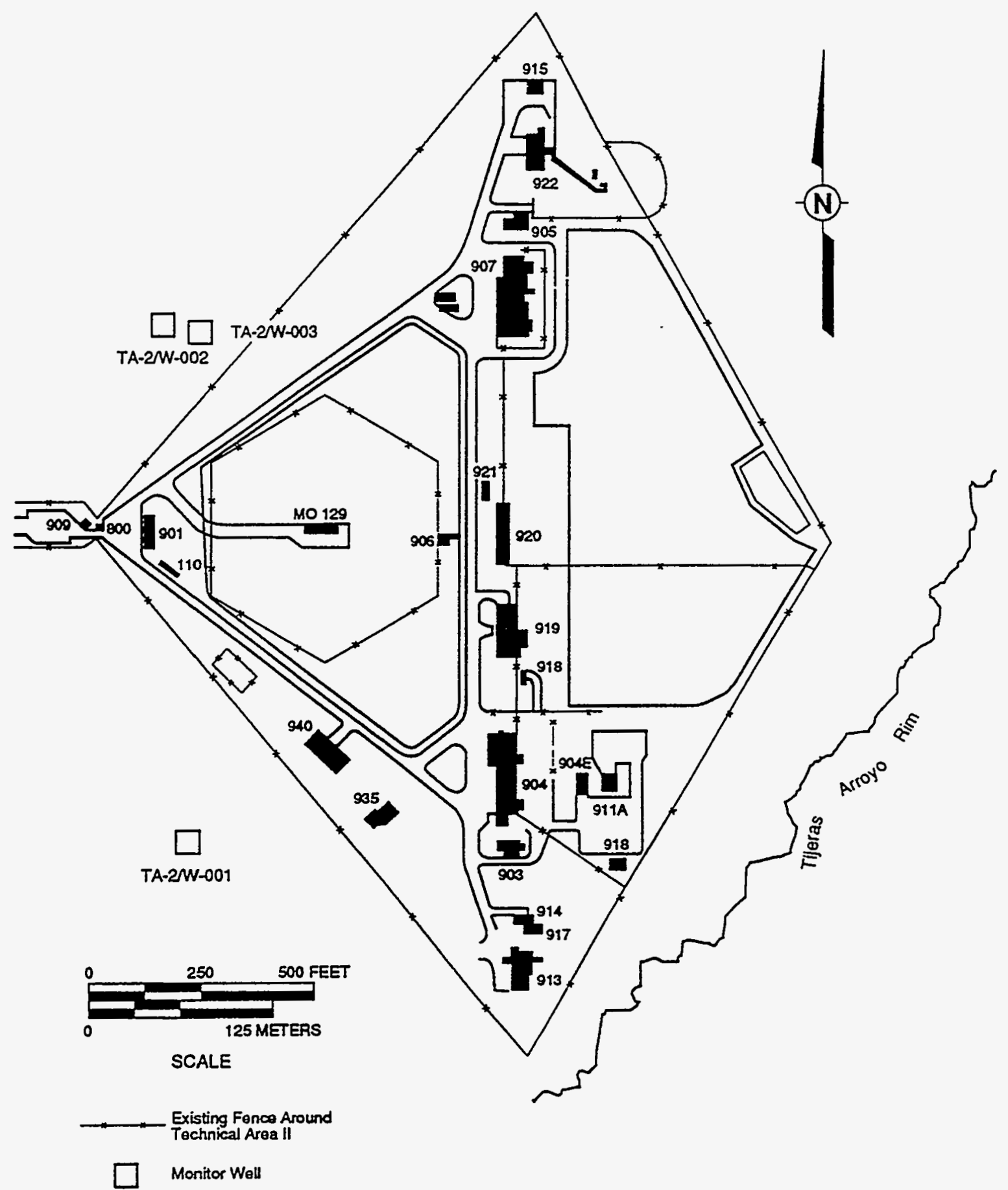

Figure 7-4. Technical Area II Monitoring Well Locations 


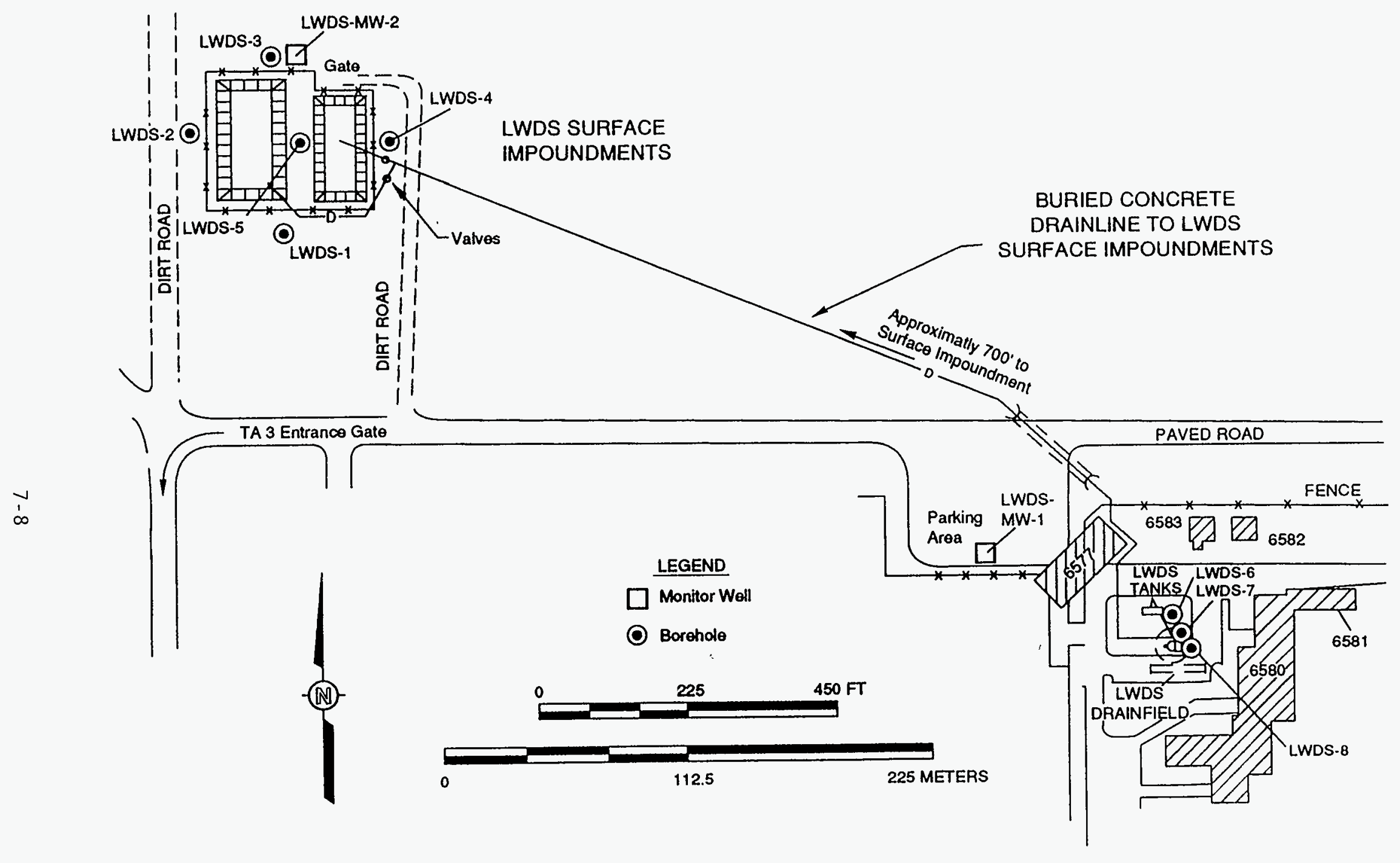

Figure 7-5. Liquid Waste Disposal System Site Borehole and Monitoring Well Locations 

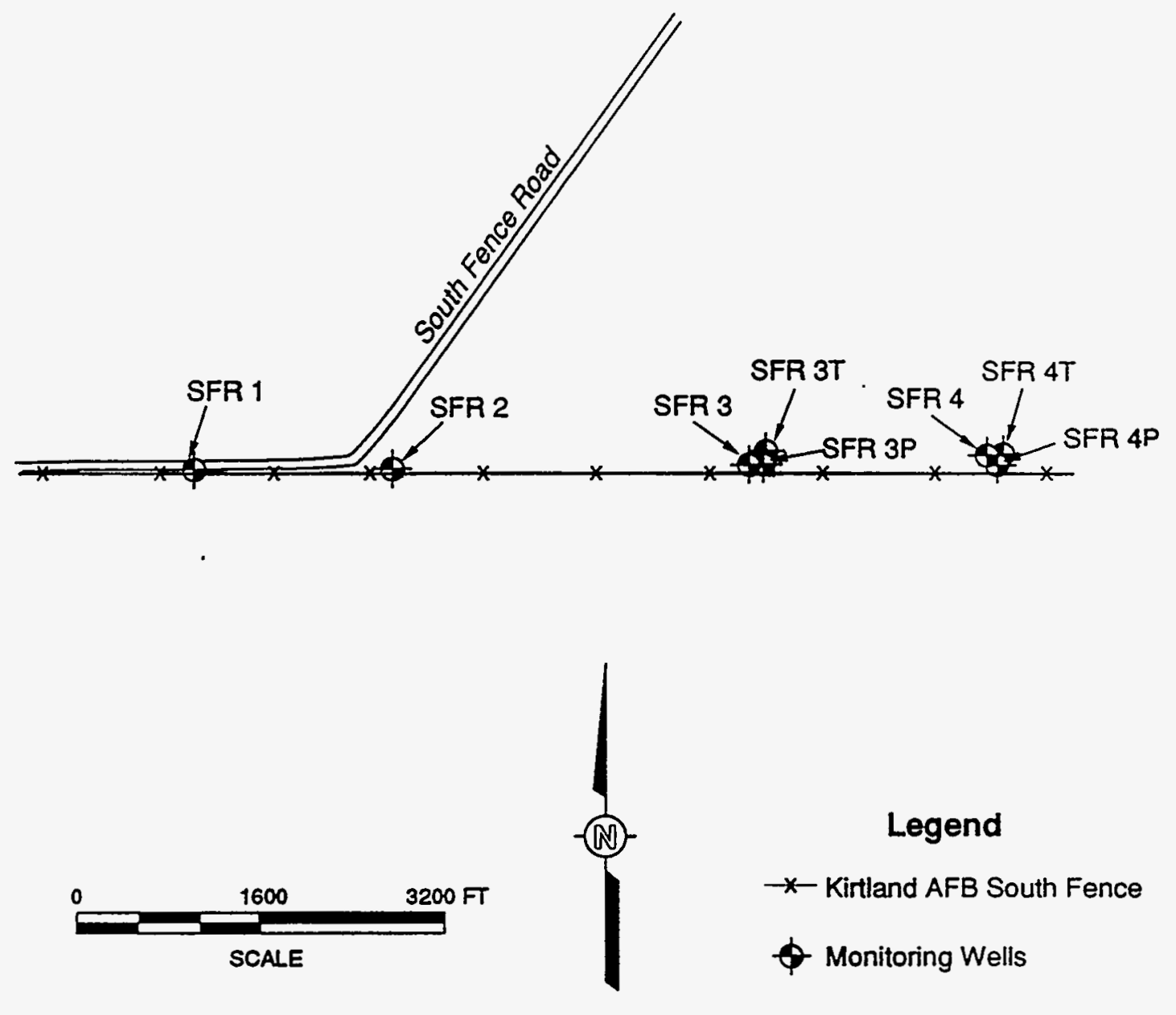

Figure 7-6. South Fence Road Well Locations, Sitewide Hydrogeologic Characterization Project 


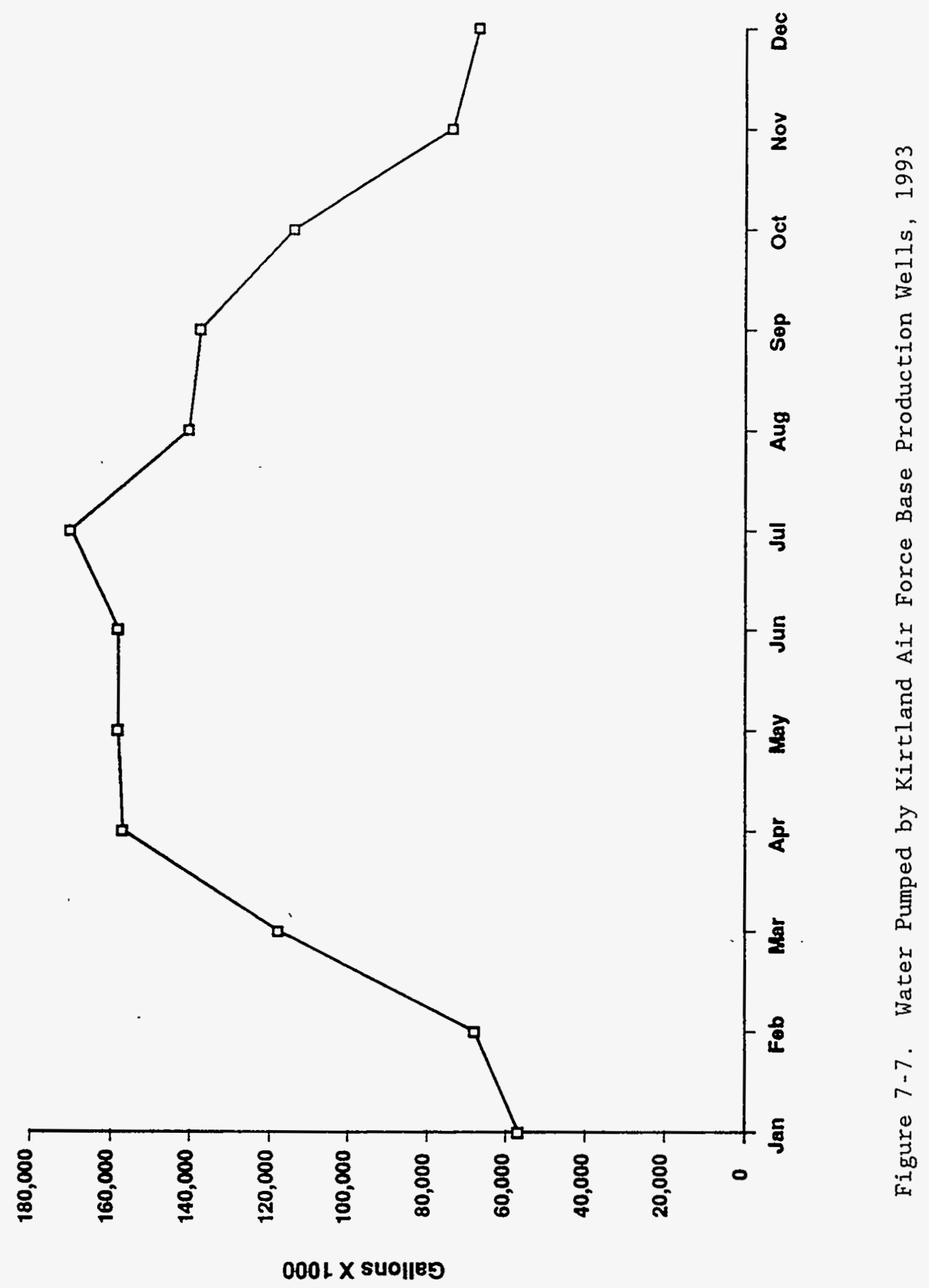


The CWL wells have been divided into two groups: the shallow monitoring well network (Figure 7-8) and the deep monitoring well network (Figure 7-9). The hydrographs of these wells show that the potentiometric surface elevation at the CWL is fairly constant over time, with minor fluctuations. In general, the wells show a slight decline in water levels from March through August or September, followed by a slight rise in the water levels. In four cases (CWLBW3, CWL-MW1A, CWL-BW2, and CWL-MW2) the water levels exhibit a small isolated rise in February 1993. In addition to the general pattern discussed above, the shallow wells show a pattern of significant water level drop in November 1993, followed by a slight rise in December. The deep wells, on the other hand, show one of the following: (1) a steady rise from August to December (CWL-BWl and CWL-BW2), (2) a rise from August through November followed by a drop in December (CWL-MW3), (3) a rise from August through October followed by a drop in November and a slight rise in December (CWL-MW4), or (4) a rise from August through September followed by a slow, steady decline through December (CWL-MW2). The shallow well network at the CWL satisfies the requirements of 40 CFR 265.91 in that the wells are located such that CWL-BW3 is hydraulically upgradient, while CWL-MW1A, CWL-MW2A, and CWL-MW3A are hydraulically downgradient from the site (Figure 7-8). Similarly, the network of deep wells are located such that CWL-BWI and CWL-BW2 are hydraulically upgradient from CWL-MW2, CWL-MW3, and CWL-MW4 (Figure 7-9). The downgradient we1ls are located at the limit of the waste management facility, where they are capable of immediately detecting any release that may migrate to the aquifer.

The potentiometric surface elevation of the wells at the MWL were measured in January, March, and April 1993. During these three months, the water levels were relatively constant, except for a rise in the water measured in MWL-MWI from January to April 1993 (Figure 7-10).

The hydrographs for other wells in TA-III are shown in Figure 7-11. The hydrograph for the KAFB-10 well shows a slight dip in water levels during the summer moths, June through August 1993. The hydrograph for the NW-TA3 well exhibits relatively constant water levels throughout the year, with only slight variations. In contrast, the hydrograph for SW-TA3 exhibits a large drop in water level associated with the well being purged dry in early october. Note that there is also a drop in the water level in May 1993, a few weeks after the April 1993 basewide quarterly purging and sampling event. This drop is followed by a rise in June as the well continues to recover. In July, this well was purged and sampled again, resulting in another drop in water level in the August 1993 measurement. This well is characterized by very slow recovery, on the order of three weeks, after being purged. Hence, the hydrograph is depicting variations in water level as a function of proximity to a purging event rather than actual variations in the potentiometric surface in the area.

The hydrographs for the wells located east of the fault complex are shown in Figure 7-12. (Note that the vertical axis of the hydrograph has been split into three sections to fit all four wells on the same figure; however, the vertical axis segments are the same relative scale as the vertical axes of the other hydrographs.)

Each of these wells exhibit relatively flat hydrographs, but with slight declines during the spring and summer months, followed by a rise in water 


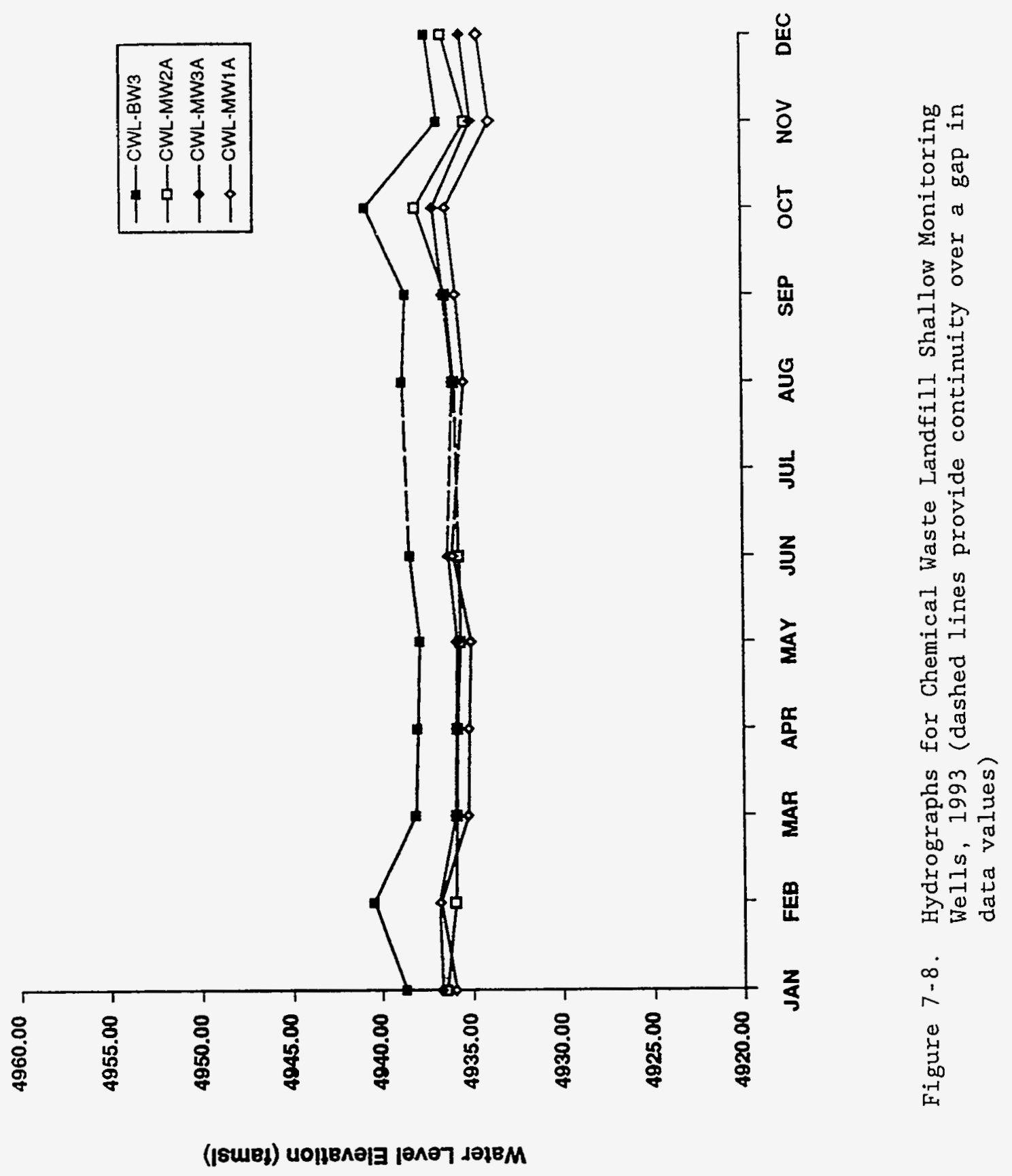




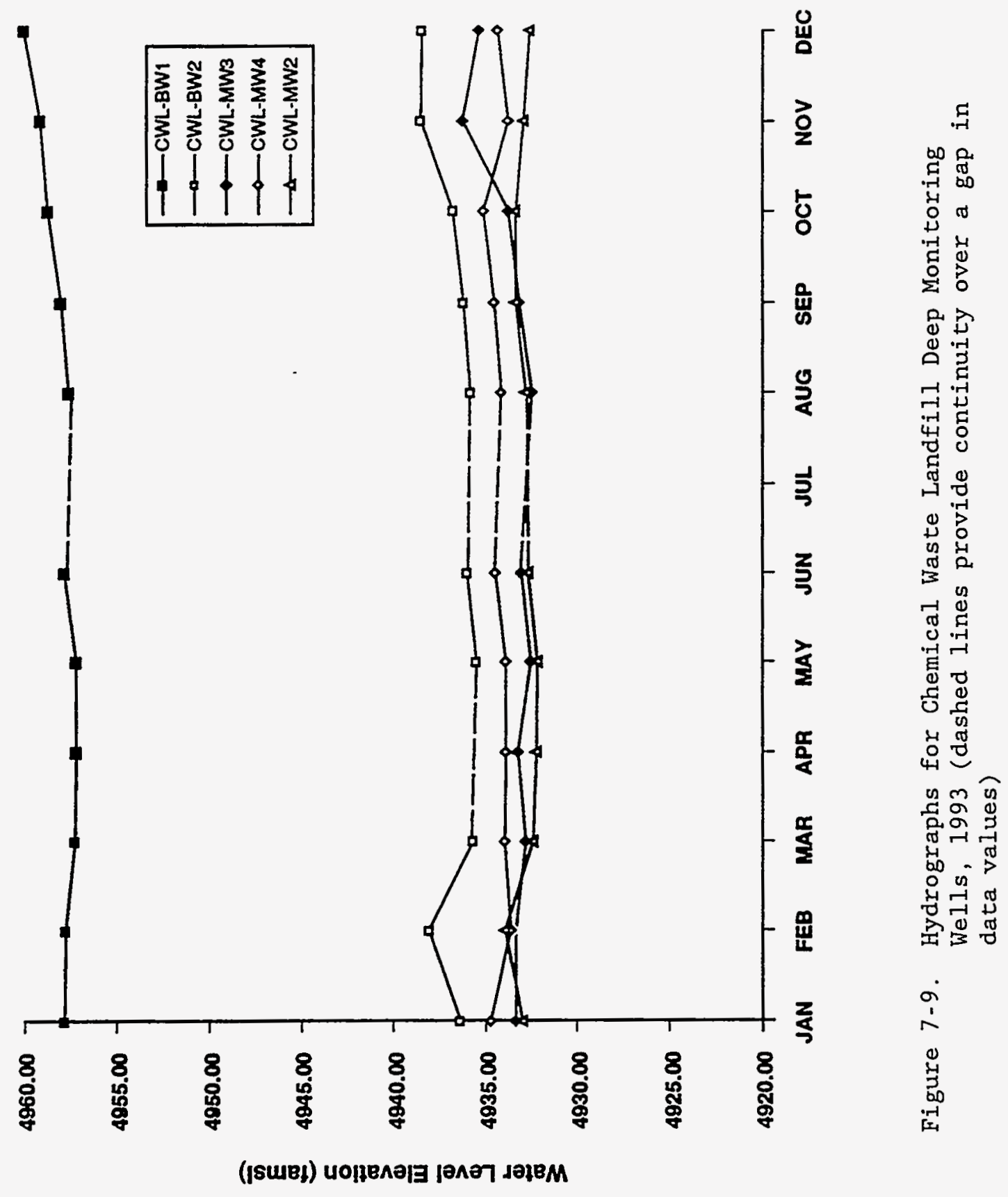




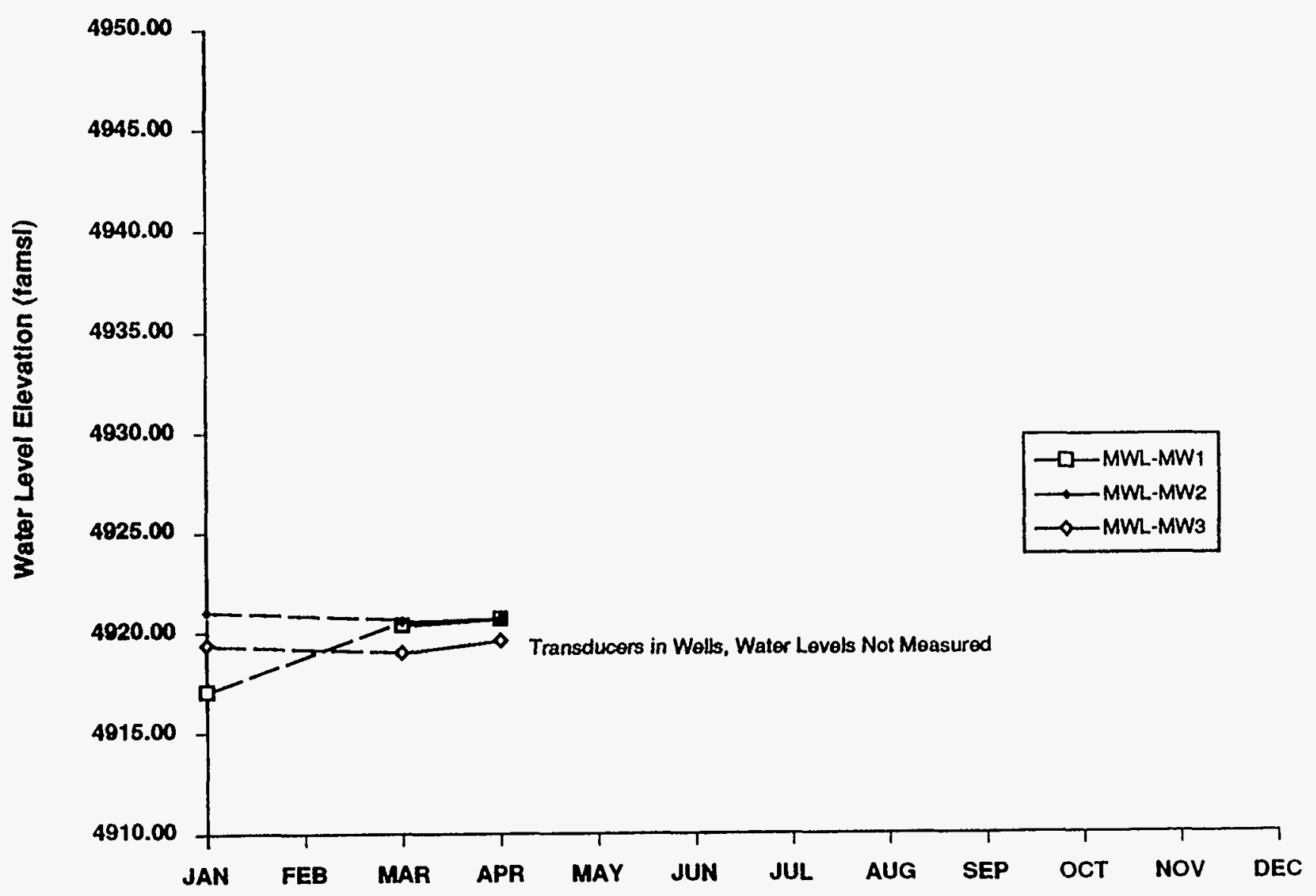

Figure 7-10. Hydrographs for Mixed Waste Landfill Monitoring Wells, 1993 (dashed lines provide continuity over a gap in data values) 


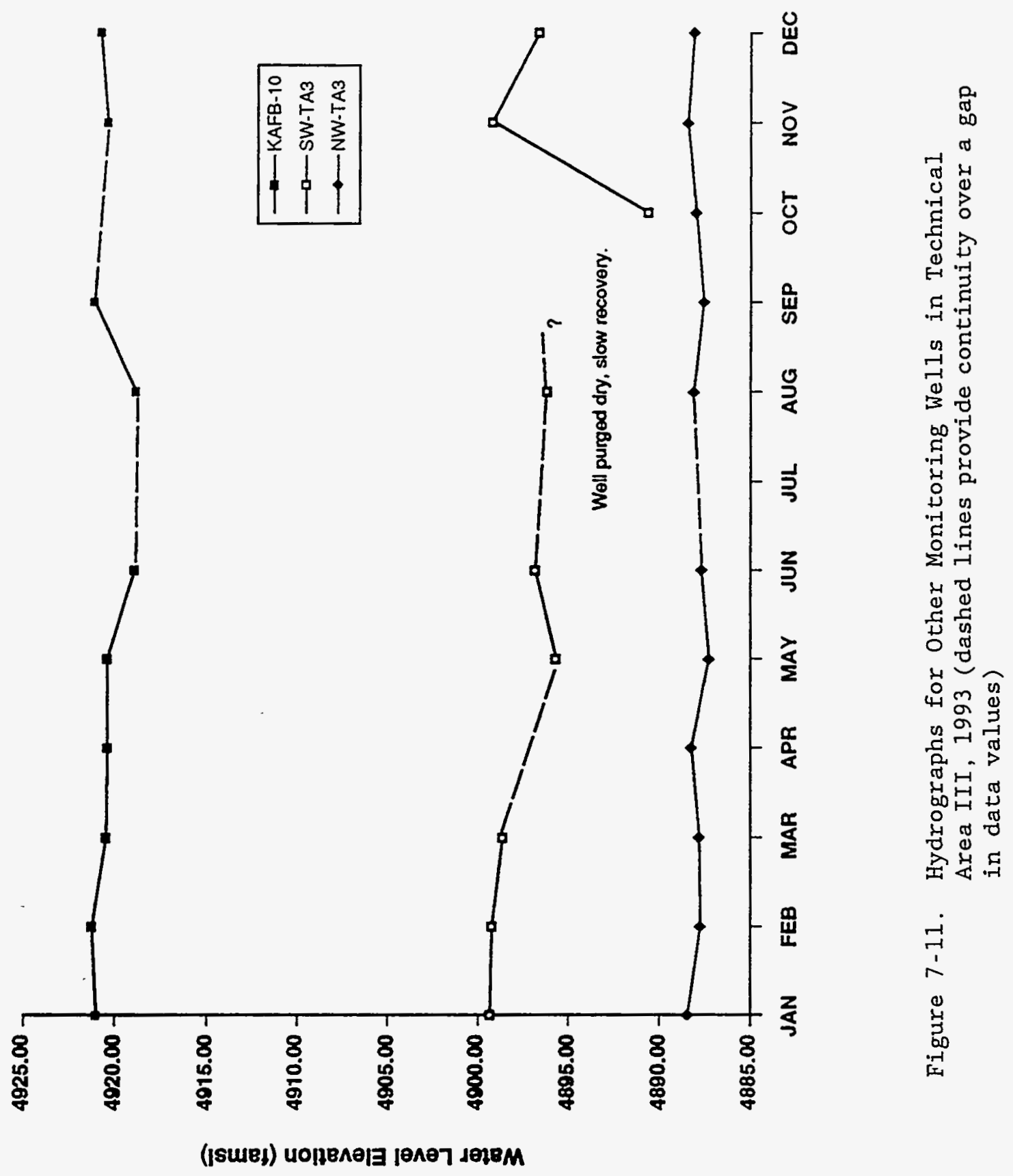




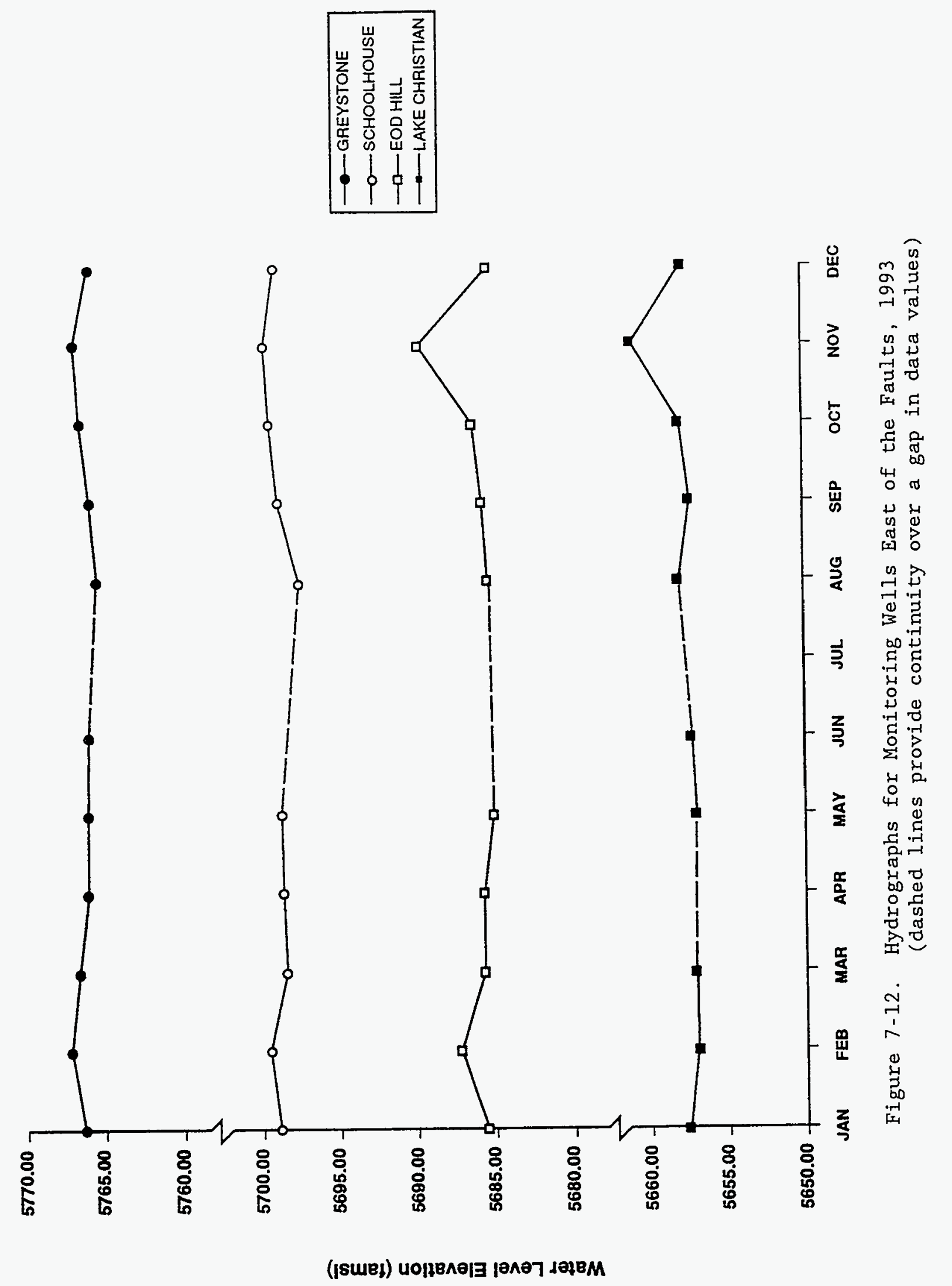


levels that peaks in November. The autumn rise in the water table may reflect recharge associated with the summer precipitation season.

The hydrographs for the KAFB Sanitary Lagoon monitoring wells have been superimposed with the graph of the volumes of water pumped per month from KAFB production wells during 1993 (Figure 7-13).

The KAFB Sanitary Lagoon wells are located close to a number of active KAFB production wells, and there appears to be an inverse correlation between water levels in the Lagoon monitoring wells and the KAFB pumping rates (i.e., the monitoring well water levels decline during periods of increased pumping volume and rise during periods of decreased pumping volume). The pattern of the hydrographs indicates a direct response of the aquifer to pumping in that area.

In Figure 7-14, the hydrographs for all but one well (LF/DM-01) located near Tijeras Arroyo (that is, wells LF/DM-02, MVMW-J, MVMW-K, Tijeras East, and Tijeras West) exhibit subtle declines in water levels from February through May, followed by a slight rise in June, followed by a sharp rise beginning in October, to a peak water-level elevation in November 1993.

The slight decline in March through May may reflect a response to the seasonal increase in KAFB production well pumping, while the sharp rise in October and November may reflect the seasonal drop in KAFB production well pumping volumes at that time. In addition, the October and November rise may be attributable to recharge from summer rains.

However, the LF/DM-01 hydrograph (Figure 7-14) shows a dramatic drop in waterlevel elevation between February 1993 and August 1993, and an even steeper drop from August to September, returning to a level similar to that of August in October, November, and December. These radical variations are an artifact of a change in the wellhead elevation associated with construction activities along the airfield margin during 1993. They do not represent radical variations in the groundwater level elevations. The water level measurements will be corrected in the future once the new wellhead elevation has been resurveyed.

The Golf Course Well hydrographs show a fairly steady, slow rise in water levels over the spring, summer, and early fall, followed by a drop in November 1993 (Figure 7-15). This pattern of seasonal rise and fall may reflect seasonal irrigation patterns at the golf course. A local groundwater mounding may be occurring during the months of maximum irrigation followed by dissipation of the mound during lower irrigation months.

\subsubsection{Direction of Groundwater Flow}

To determine the general horizontal hydraulic gradient throughout the SNL/NM-KAFB area, groundwater surface elevations have been measured in all accessible SNL/NM monitoring wells and adjacent KAFB and state of New Mexico monitoring wells on a monthly basis since May 1989. Static water level data from all these monitoring wells (SNL 1994) were used as indicators of the potentiometric surface at various locations. While many of the water levels appear to represent an unconfined water table, the water levels measured in some of the wells indicate confined aquifers. The data points were contoured 


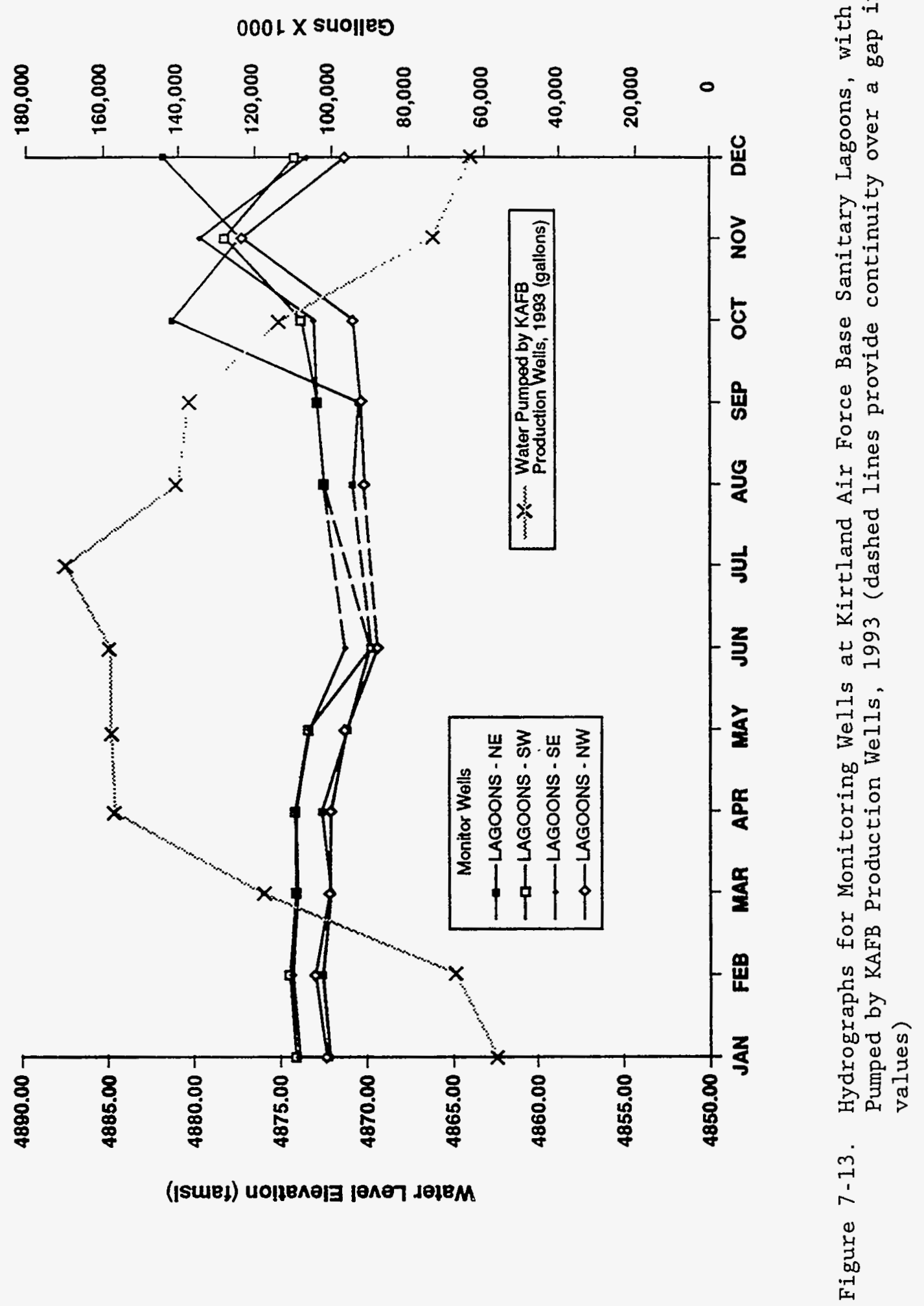




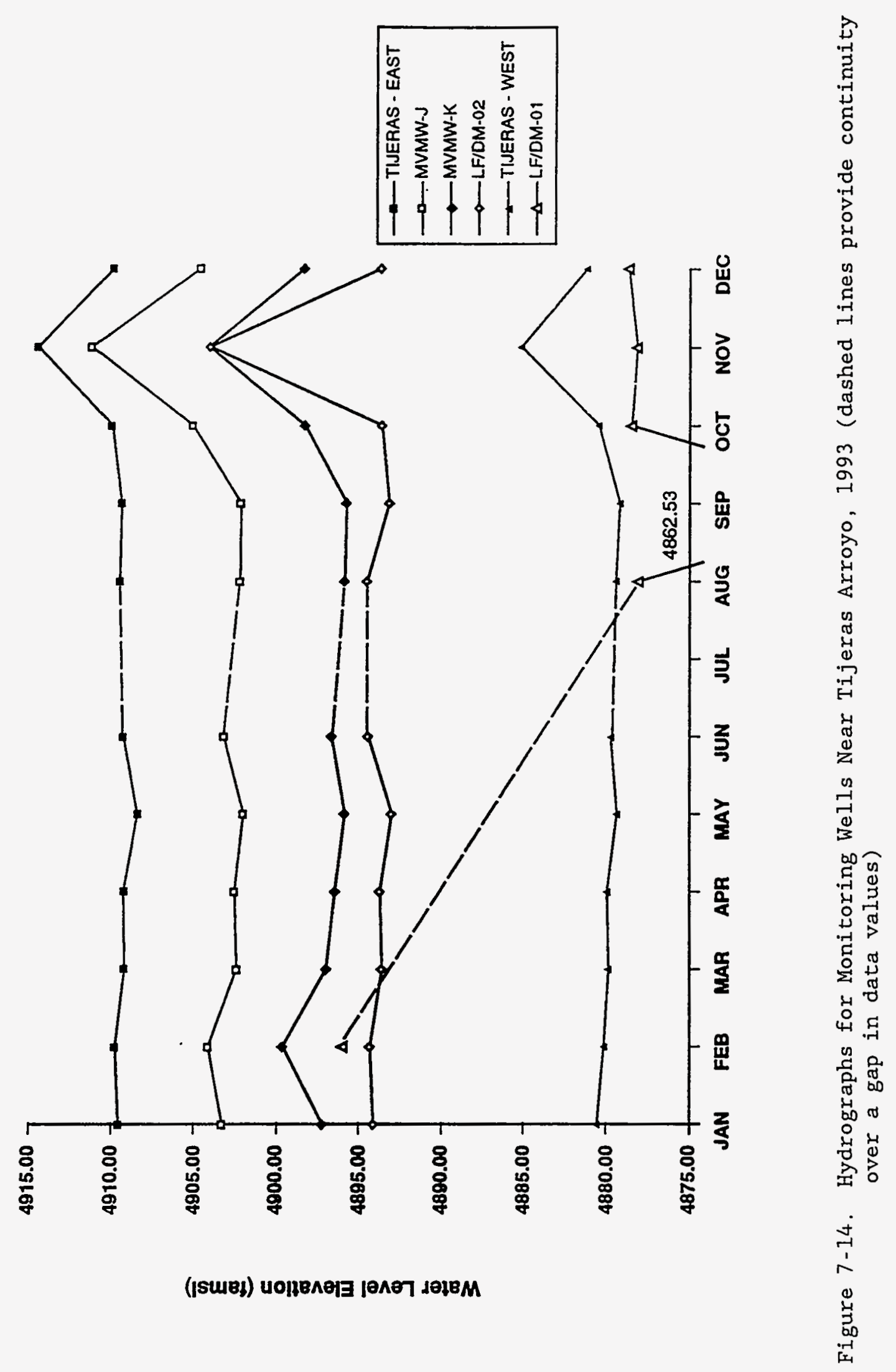




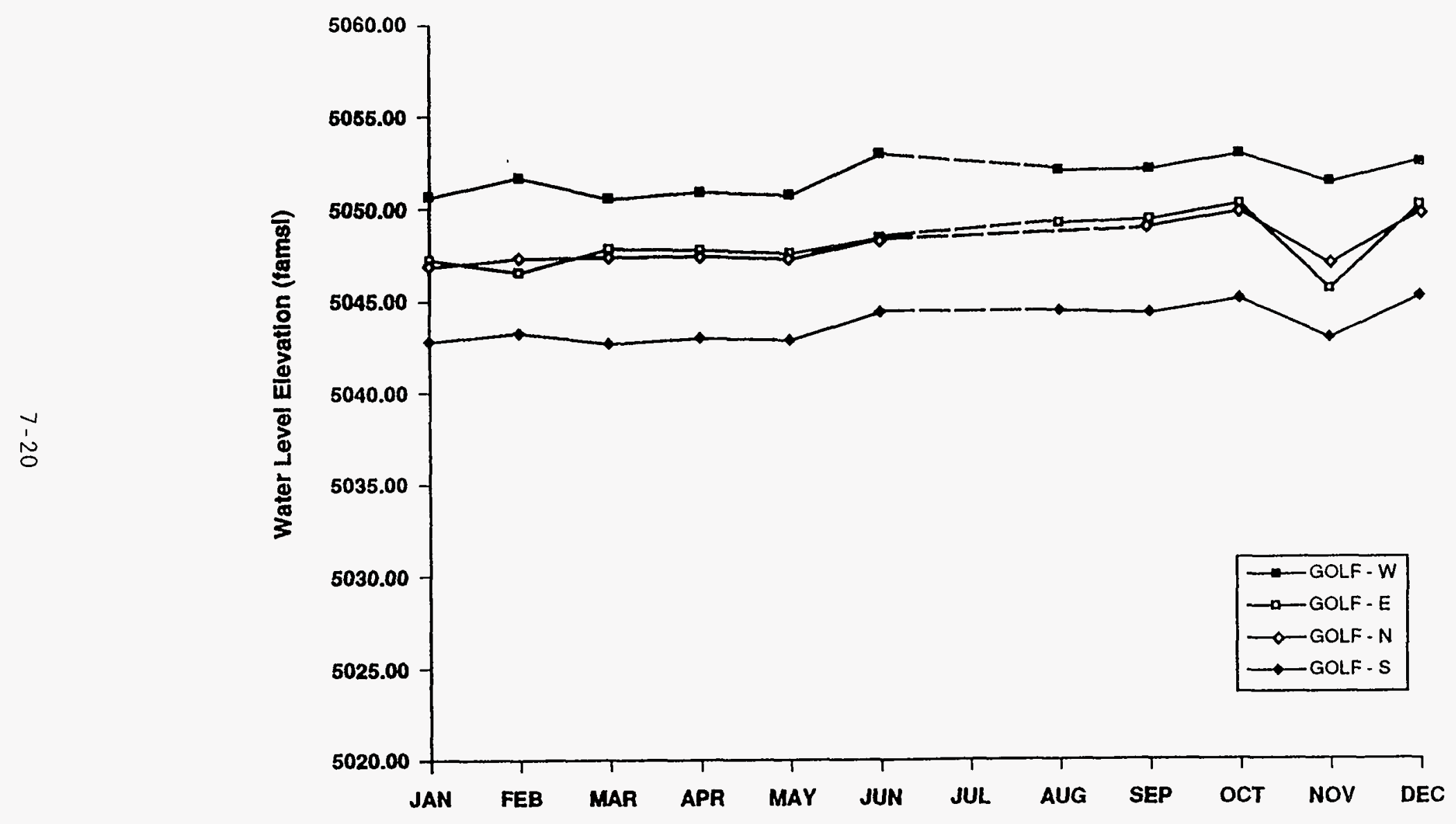

Figure 7-15. Hydrographs for Kirtland Air Force Base Golf Course Monitoring Wells, 1993 (dashed lines provide continuity over a gap in data values) 
using SURFER ${ }^{\circ}$ (Golden Software 1991) to generate the potentiometric surface map of the SNL/NM area (Figure 7-16). The direction of groundwater flow is perpendicular to the equipotential lines. The apparent direction of groundwater flow is generally to the west and northwest.

It is clear that the data set of water level elevations contains several ambiguities, which complicate the interpretation of a potentiometric surface. First, it is possible that some of the water levels in the wells reflect completions in different groundwater zones; therefore, the data set does not represent the elevation of a single groundwater unit. Second, the screens of the wells are of varying lengths. The KAFB production wells are screened over large intervals, usually starting at the water table and extending several hundred feet into the saturated zone. The monitoring wells typically have 20 -ft screens placed across the water table. If the groundwater flow is not uniformly horizontal (i.e., vertical gradients exist), then the longer screen lengths do not provide true groundwater table elevation data. They provide the average groundwater potential across the length of the screen, which may differ from a piezometer measurement at the water table surface if vertical gradients are present. The potentiometric surface contour map (Figure 7-16) is the best currently available interpretation of the data, pending further investigation. The Sitewide Hydrogeologic Characterization activities are, in part, investigating these complications of the potentiometric surface data interpretation.

\subsubsection{Production We11 Pumping}

The apparent direction of groundwater flow in the KAFB area currently is west and northwest, in contrast to the southwesterly direction reported by Bjorklund and Maxwell (1961). This difference is probably due to the fact that groundwater pumping by KAFB and nearby City of Albuquerque production wells has had an effect on the hydraulic gradient in the area, creating an apparent cone of depression in the potentiometric surface in the northern portion of KAFB (Figure 7-16). Over 1.4 billion gallons of water were pumped from the KAFB production wells in 1993 (Figure 7-7) (Klimm 1993). About twice as much water is pumped during the summer months, when there is a high water demand, compared to the winter months. Due to a lack of spatial data, the shape and extent of the cone of depression formed by the production wells is not precisely known at this time and is under investigation by SNL/NM and other KAFB tenants.

\subsection{GROUNDWATER SAMPLING}

The results of groundwater surveillance sampling for the basewide project are presented in "Calendar Year 1993 Annual Groundwater Monitoring Report" (SNL 1994). Sixteen to seventeen wells and three springs across KAFB and SNL/NM were sampled each quarter. This includes two sitewide project wells sampled in April, July, and September and four in December 1993. Details of the quarterly sampling events may be found in the reports on quarterly basewide groundwater monitoring for April, July, September, and December 1993 (IT 1993c, 1993d, 1993e, and 1993f). The results of both annual groundwater quality monitoring and quarterly assessment monitoring conducted at CWL in 1993 are also found in "Calendar Year 1993 Annual Groundwater Monitoring Report" (SNL 1994). Details of the sampling events may be found in the CWL annual 


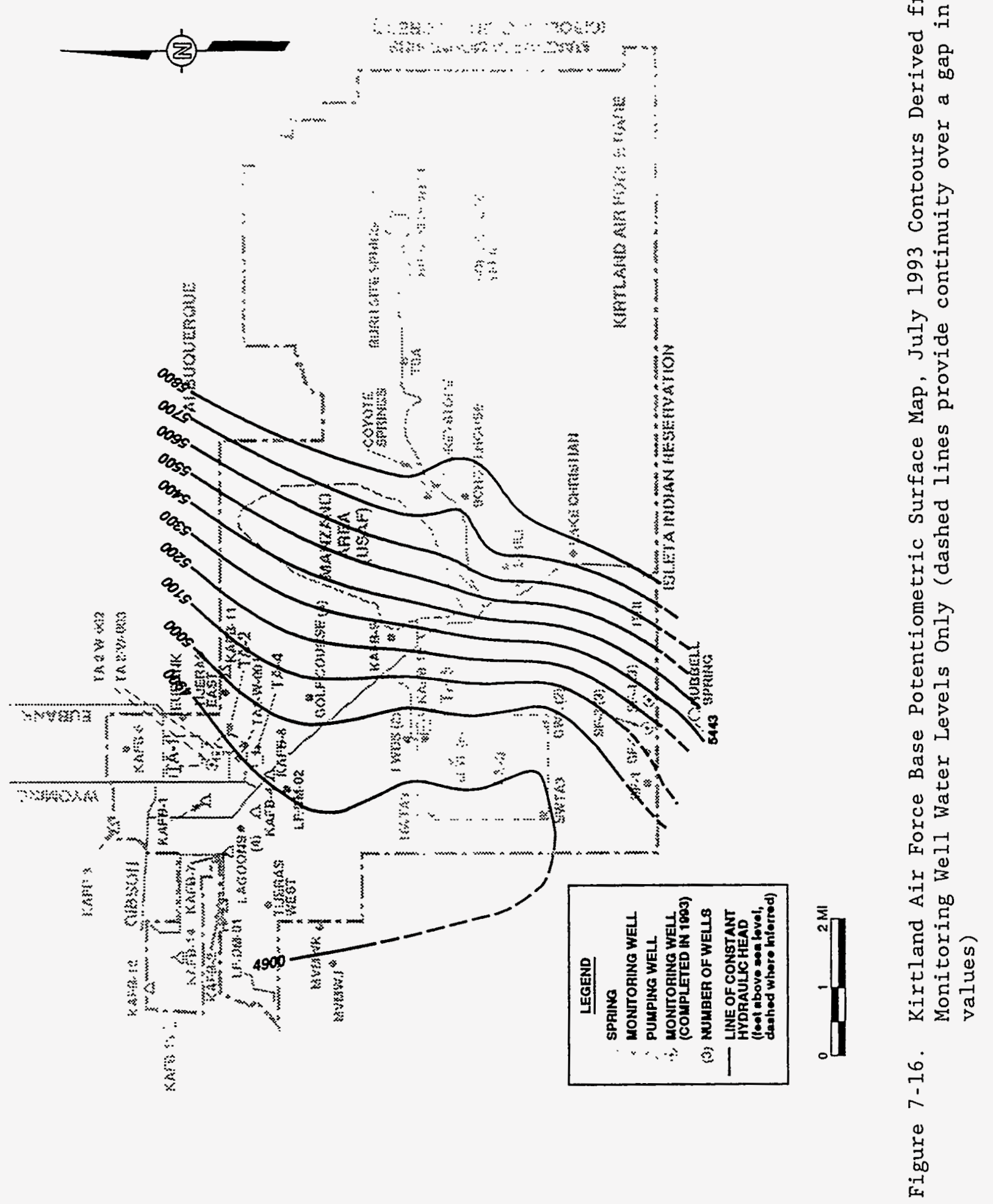


groundwater assessment monitoring report (IT 1993g) and in the quarterly groundwater assessment monitoring reports (IT 1993h, 1993i, 1993j).

Groundwater from MWL monitoring wells MWL-BW1, MWL-MW1, MWL-MW2, and MWL-MW3 was sampled in January, April, and November 1993 (SNL 1994). Details of these sampling events may be found in the MWL draft reports on semiannual groundwater sampling (IT 1993k, 19931).

Groundwater samples were collected from TA-II monitoring wells in November 1992, March 1993, and June 1993, from LWDS-MW1 in November 1993, and from LWDS-MW2 in June 1993 (SNL 1994).

\subsubsection{Sampling Procedures and Methods}

Samples were collected for the Basewide Groundwater Surveillance Program in 1993 in accordance with the "Sitewide Groundwater Monitoring Program Sampling and Analysis Plan" (SNL 1993h, draft); this plan was also used as guidance for groundwater sampling at TA-II, LWDS, and the sitewide South Fence Road wells. The protocols for collection and analysis of representative groundwater samples at CWL in 1993 are specified in the "Chemical Waste Landfill Final Closure Plan and Post Closure Permit Application," Appendix G, "Sampling and Analysis Plan for Groundwater Assessment Monitoring at the Chemical Waste Landfill, Revision 4" (SNL 1992a). MWL sampling and analysis activities were conducted in accordance with the "Mixed Waste Landfill Sampling and Analysis Plan" (SNL 1990b, draft).

The general procedure for collecting groundwater samples at all areas in 1993 included the following activities:

1. Measuring the groundwater elevation in each well

2. Purging each well of three casing volumes of groundwater (up to a maximum of 100 gallons, with exceptions for low-yield wells, as noted in individual event reports)

3. Collecting the desired groundwater sample and appropriate quality control (QC) samples in specified containers provided by the analytical laboratories with appropriate preservatives as needed

4. Sending the samples to the analytical laboratories for analyses under strict chain-of-custody documentation.

Measurements of field water quality parameters were made during purging to determine stabilization of water quality parameters prior to sample collection so that representative samples could be collected. Specific details pertaining to each groundwater sampling event are described in the individual sampling reports referenced herein. These reports contain summary tables, complete field and laboratory data, QC data, and descriptions of the analytical methods employed by the analytical laboratories. 


\subsubsection{Sandia National Laboratories/New Mexico Groundwater Surveillance Results}

The SNL/NM Groundwater Surveillance Project sampled 16 to 17 wells and 3 springs on a quarterly basis during April, July, September, and December 1993. Analytes detected above acceptable levels may determine the method of disposal of wastewater, which consists of purge water and dilute decontamination solutions. These analytes include any organic compounds detected at or above the minimum detection limits (MDL) (Appendix $\mathrm{K}$, Tables $\mathrm{K}-\mathrm{la}, \mathrm{b}, \mathrm{c}$, and $\mathrm{d}$ ) and any other analytes detected at or above maximum contaminant levels (MCL) established by the EPA Primary Drinking Water Regulations (PDWR) in 40 CFR 141.11(b) and maximum contaminant level goals (MCLG) established by EPA PDWR in $40 \mathrm{CFR} 141.51$ (b) (Tables $\mathrm{K}-2 \mathrm{a}, \mathrm{b}, \mathrm{c}$, and $\mathrm{d}$ ).

Prior to and immediately after the sampling of each well or spring, a set of field water quality parameters was measured when adequate water volumes were available. These parameters include $\mathrm{pH}$, temperature, specific conductivity, and turbidity (Tables K-3a, b, c, and d). Detailed discussion of these measurements can be found in the appropriate quarterly reports.

Basewide sampling during 1993 represents a major expansion in the analyte list from previous years. The new analyte list was devised to provide a set of data for groundwater contamination detection monitoring comparable to the analytes investigated for other projects, such as the CWL, MWL, LWDS, and TA-II. Previous to 1993, basewide sampling analytes had been chosen simply to characterize the water quality. For meeting regulatory guidance and for consistency with other projects, the new analyte list follows 40 CFR 265, Subpart F. This new list is representative of parameters for potential contaminants, indicators of potential contamination, and safe drinking water. Because total organic halogens (TOX) analysis may not accurately indicate potential contamination, volatile organic compounds (VOCs) (EPA method 8260) (EPA 1986b) and a library search for other VOCs have been added to the analyte list. In addition, groundwater samples are screened for radionuclides using gamma spectroscopy.

Analytical results from each of the sampling events are presented in "Calendar Year 1993 Annual Groundwater Monitoring Report" (SNL 1994), which contains the results of all analyses except for herbicides and pesticides, which have not been detected in any basewide groundwater sampling events.

Volati.le Organic Compounds: Analyses for VOCs and library searches for the four reported quarters detected VOCs which are all common laboratory solvents (e.g., acetone, 2-butanone, carbon tetrachloride, and methylene chloride) (SNL 1994) (Tables K-4a, b, c, and d). The fact that these contaminants are present in QC samples (e.g., trip blanks, equipment blanks, and method blanks) suggests that they were introduced at the laboratory and do not indicate groundwater contamination. The minor concentrations of unknown compounds tentatively identified by the library search also probably represent laboratory contamination (Tables $\mathrm{K}-5 \mathrm{a}, \mathrm{b}, \mathrm{c}$, and $\mathrm{d}$ ).

Inorganic Compounds and Phenolics: The population of basewide sampling sites may be divided into two sample sets (one east of the Hubbell Springs and Sandia faults, the other west of these faults) on the basis of geographic location and water-level elevation at a given site. Burn Site Well, Sol se Mete Springs, 
Coyote Spring, Greystone Manor Well, Schoolhouse Well, Explosive Ordnance Detonation (EOD) Hill Well, South Fence Well 非, South Fence Well 非, and Hubbell Spring are either east of or along the fault complex. All of the other wells are west of the faults. East-side wells are typically characterized by relatively low $\mathrm{pH}$, high alkalinity, high concentrations of bromide, chloride, fluoride, and sulfate, and lower nitrate plus nitrite (NPN) concentrations, relative to the west side wells (SNL 1994). Phenolics were not detected in the groundwater regardless of the well or spring location (Tables $\mathrm{K}-6 \mathrm{a}, \mathrm{b}, \mathrm{c}$, and d).

Metals: The wells and springs sampled east of the faults typically have higher concentrations of calcium, magnesium, potassium and sodium than the wells west of the faults. This corresponds to the higher alkalinity and ion concentrations for east-side waters discussed above. Some samples contained metals above established MCLs. These include barium concentrations slightly above the MCL of 1.0 milligrams per liter (mg/L) at MVMW-K, Greystone Manor, and Schoolhouse wells; chromium concentrations above the MCL of $0.05 \mathrm{mg} / \mathrm{L}$ at CWL-BW2, MWL-BWI, SF-2, and SW-TA3 wells; cadmium concentrations above the MCL of $0.010 \mathrm{mg} / \mathrm{L}$ at KAFB-10; and lead concentrations above the MCL of $0.05 \mathrm{mg} / \mathrm{L}$ at KAFB-10 (Tables $\mathrm{K}-7 \mathrm{a}, \mathrm{b}, \mathrm{c}$, and $\mathrm{d}$ ).

Coliform Bacteria: Coliform analyses were performed on the samples collected for the April and September 1993 quarters (SNL 1994). The presence of coliform bacteria has been detected in a variety of wells, but fecal coliform has been detected only in Hubbell Spring. This spring is surrounded by a cattle pasture where the presence of fecal coliform is to be expected (Tables $\mathrm{K}-8 \mathrm{a}$ and $\mathrm{K}-8 \mathrm{~b}$ ).

Radionuclide Screening: Gamma spectroscopy radionuclide screening detected naturally occurring isotopes. These isotopes are not indicators of anthropogenic radioactive contamination (Tables $\mathrm{K}-9 \mathrm{a}, \mathrm{b}, \mathrm{c}$, and $\mathrm{d}$ ).

Groundwater samples collected in September 1993 were analyzed for the following radionuclides: isotopic uranium (U), isotopic thorium (Th), isotopic plutonium (Pu), strontium-90 (Sr-90), radium-226 (Ra-226), radium-228 (Ra-228), gross alpha and gross beta activities (Table K-10). Groundwater samples collected in December 1993 were analyzed for tritium (H-3) (Table K-11).

\subsubsection{Chemical Waste Landfill Assessment Monitoring Results}

Annual sampling for assessment monitoring at CWL occurred in February 1993; quarterly sampling took place in May, August, and November 1993 (SNL 1994). These sampling events were conducted in accordance with the "Sampling and Analysis Plan for Groundwater Monitoring at the Chemical Waste Landfill, Revision 4" (Appendix G of the CWL closure plan [SNL 1992a]), which includes annual sampling for all Appendix IX parameters and quarterly sampling for Appendix IX VOCs and total metals. At the request of the NMED, additional monitoring for total and dissolved chromium occurred at monitoring well CWLBW3 and is summarized in the following Metals section. A summary of detected compounds for the February sampling event is presented in Appendix $\mathrm{K}$, Table $\mathrm{K}$ 12; for May the detected VOCs are presented in Table K-13; the August results are in Table K-14a for detected VOCs and Table K-14b for metals; and detected compounds for the November sampling are reported in Table K-15. 
Volatile Organic Compounds: Appendix IX VOC laboratory analysis of 1993 CWL groundwater samples detected trichloroethylene (TCE) in monitoring wells CWLMW1A, CWL-MW2A, and CWL-MW3A. TCE was detected in CWL-MW2A duplicate samples in all four quarters of 1993: February $(0.005$ and $0.006 \mathrm{mg} / \mathrm{L})$, May $(0.002$ and $0.002 \mathrm{mg} / \mathrm{L})$, August $(0.003$ and $0.004 \mathrm{mg} / \mathrm{L})$, and November $(0.003$ and 0.004 $\mathrm{mg} / \mathrm{L})$. Duplicate samples were collected from this well because it has the greatest known potential for detectable VOCs, and sampling system precision measurements cannot be made unless detectable quantities of analytes are present in the duplicate sample. TCE was also detected in CWL-MW3A in all four quarters of 1993: February $(0.002 \mathrm{mg} / \mathrm{L})$, May $(0.002 \mathrm{mg} / \mathrm{L})$, August $(0.003$ $\mathrm{mg} / \mathrm{L})$, and November $(0.001 \mathrm{mg} / \mathrm{L})$. TCE was only detected in CWL-MWlA in May $(0.001 \mathrm{mg} / \mathrm{L})$ and August $(0.007 \mathrm{mg} / \mathrm{L})$. TCE was not detected in any other CWL groundwater sample in 1993.

The reported occurrence of TCE in a greater number of samples in 1993 as compared to previous sampling events is an artifact of the lower analytical MDLs achieved in 1993. Samples prior to 1993 were analyzed with an MDL of $0.005 \mathrm{mg} / \mathrm{L}$, and the 1993 samples were analyzed at the more sensitive detection limit of $0.001 \mathrm{mg} / \mathrm{L}$.

All other VOCs detected in CWL groundwater samples are common laboratory solvents (e.g., acetone, 2-butanone, carbon disulfide, methylene chloride, and toluene). As these compounds were also detected in associated trip blanks, equipment blanks and/or laboratory method blanks, their presence is considered to be a result of laboratory contamination and not an indication of groundwater contamination.

Since concentrations of VOCs in the CWL monitoring wells have not varied significantly during this sampling year, there is no indication that these constituents are migrating away from the site. This conclusion is supported by the conceptual model of limited contaminant transport developed for this site in Section 3.0 of the CWL closure plan (SNL 1992a).

Metals: All groundwater samples collected from CWL monitoring wells during 1993 were analyzed for Appendix IX metals plus iron. Nickel and chromium are the only metals on the list found to exceed the maximum allowable concentration (MAC) limits set by the New Mexico Water Quality Control Commission. Nickel was detected in CWL-BW3 above the MAC of 200 micrograms per liter $(\mu \mathrm{g} / \mathrm{L})$ in May $(270 \mu \mathrm{g} / \mathrm{L})$ and November $(240 \mu \mathrm{g} / \mathrm{L})$. Total chromium analytical results from monitoring well CWL-BW3 exceed the MAC for chromium ( $50 \mu \mathrm{g} / \mathrm{L}$ ) at least once in every quarter. These chromium results are discussed further below.

Total chromium was detected in groundwater samples collected from CWL-BW3 in February 1993 at $53 \mu \mathrm{g} / \mathrm{L}$. At the request of the NMED, additional samples for total and dissolved chromium were collected from monitoring well CWL-BW3. CWLBW3 was sampled at differing purge rates using different filtering procedures: filtered and unfiltered samples were collected at both slow and normal purge rates to evaluate the effect of purge rates and turbidity on the metal content of the groundwater. Filtered samples contain only dissolved chromium, whereas unfiltered samples reflect total chromium, including that attributable to particulates as well as the aqueous fraction. Slow purge rates were used in an attempt to minimize the quantity of suspended particulates incorporated into the sample. In May 1993, chromium was detected in the unfiltered, slow-purge 
sample at $64 \mu \mathrm{g} / \mathrm{L}$ (total chromium); in the filtered, slow-purge sample at $0.62 \mu \mathrm{g} / \mathrm{L}$ (dissolved chromium); and in the unfiltered normal-purge sample at $260 \mu \mathrm{g} / \mathrm{L}$ (total chromium). In August 1993, one sample was taken before purging the well, and consecutive samples were taken the next day after purging the well dry three times in an attempt to minimize the effect of stagnant well water and casing-groundwater interactions on groundwater metal contents. This sampling protocol was requested by NMED, and split samples were collected by NMED each time. Total chromium was detected in an unfiltered slow-purge sample at $46 \mu \mathrm{g} / \mathrm{L}$; in a low-turbidity, unfiltered sample at $98 \mu \mathrm{g} / \mathrm{L}$; in an unfiltered sample collected at a low-purge volume of 26 gallons at $49 \mu \mathrm{g} / \mathrm{L}$; and in a normal-purge (three well volumes), unfiltered sample at $48 \mu \mathrm{g} / \mathrm{L}$. In November 1993, monitoring well CWL-BW3 was found to contain total chromium at $60 \mu \mathrm{g} / \mathrm{L}$.

The significant difference in total chromium and dissolved chromium concentrations indicates that the great majority of chromium is associated with particulate matter. A study performed by Stein et al. (1991) suggests that a likely source of particulate chromium is corrosion of stainless steel in well casings, screens, and/or downhole pump components, or naturally occurring sediment. Stainless steel also contains nickel and iron, which were also detected in CWL samples.

\subsubsection{Mixed Waste Landfill Monitoring Results}

Groundwater monitoring sampling at the MWL took place in January, April, and November 1993 (SNL 1994). Sampling was conducted in accordance with the "Mixed Waste Landfill Sampling and Analysis Plan" (SNL 1990b, draft) or as otherwise requested by the SNL/NM Task Leader. In January, sample fractions were collected for chloride, phenolics, sulfate, total Target Analyte List (TAL) metals, total organic carbon (TOC), TOX, gross alpha activity, gross beta activity, gamma spectrometry, and individual radionuclides. April samples were analyzed for the same parameters, with the addition of nitrate, alkalinity, and dissolved TAL metals. November samples were analyzed for the same parameters as January samples, with the addition of fluoride, NPN, ammonia, alkalinity, total dissolved solids (TDS), pH, specific conductivity, and VOCs (for MWL-MW4 only). Non-radiological analytical results for January, April, and November are reported in Appendix $\mathrm{K}$, Tables $\mathrm{K}-16 \mathrm{a}, \mathrm{b}$, and $\mathrm{c}$, respectively. Radiological analytical data for the same sampling periods are presented in Tables $\mathrm{K}-17 \mathrm{a}$, $b$, and $c$.

Metals: January 1993 metals analyses detected total barium, cadmium, chromium, iron, magnesium, nickel, and zinc. April analyses detected total and dissolved aluminum, barium, chromium, iron, magnesium, manganese, nickel, and $z$ inc. November analyses detected total barium, chromium, iron, lead, magnesium, manganese, nickel, and zinc. All metals were detected at concentrations lower than the EPA MCL. The metals analyses also detected calcium and sodium; however, these compounds are discussed in the following Inorganic Compounds section.

Radionuclides: Groundwater samples collected from MWL wells in 1993 were analyzed for gross alpha and gross beta activities, gamma spectroscopy, and individual radionuclides. Individual radionuclides for January and April 1993 analyses were H-3, Ra-226, Ra-228, americium-241 (Am-241), cesium-137 (Cs-137), iodine-129 (I-129), iron-55 (Fe-55), polonium-210 (Po-210), and Sr-90. 
Individual radionuclides for November 1993 analyses were isotopic $U$, Th, and $\mathrm{Pu}$ for all wells, and Sr-90 for MWL-MW4 only.

Gross alpha and gross beta activities were analyzed from January and April 1993 sampling in quadruplicate to enable measurement of statistical variance. Average gross alpha and average gross beta activities did not exceed DOE derived concentration guides (DCGs). Individual radionuclides detected above quantifiable instrument detection limits include Ra-226, Ra-228, Cs-137, I-129, Fe-55, lead-212 (Pb-212), Th-228, uranium-238 (U-238), Am-241, and Sr-90. DOE DCGs were exceeded by individual radionuclides in the following cases: Th-228 (January, MWL-MW1), Pb-212 (January, MWL-MW2), I-129 (April, MWL-BWI), and U238 (January, MWL-MW2 and BW1).

Organic Compounds: TOX were not measured above detection limits in any sample during any of the sampling events at the MWL in 1993. During the January 1993 sampling, TOC was measured at low levels $(0.93$ to $1.5 \mathrm{mg} / \mathrm{L})$ in all wells. During the April sampling, TOC was measured at high levels in we1ls MWL-MW1, MWL-MW2, and MWL-MW3 (13.8 to $23.2 \mathrm{mg} / \mathrm{L}$ ) and at low levels in the other wells ( 1.5 to $4.9 \mathrm{mg} / \mathrm{L})$. During the November sampling, no TOC was detected. The likely cause of the high measurements in April samples was a documented laboratory problem with TOC calibration of a new analytical instrument. TOC and TOX were sampled in quadruplicate in January and April 1993 to aid statistical evaluation. No regulatory limits have been established for TOX or TOC. No phenolic compounds or VOCs were detected in any MWL wells during 1993 sampling.

Inorganic Compounds: Major ion and water-chemistry analyses were performed on samples collected during April and November. Total and dissolved calcium and sodium were detected in all samples. Chloride and sulfate were also detected in all samples.

\subsubsection{Technical Area II Groundwater Monitoring}

By the end of June 1993, three boreholes had been drilled and completed as monitoring wells at TA-II for the SNL/NM ER Project (SNL 1994) (Figure 7-4). The first area investigated is southwest of the TA-II fenceline, at the Building 901 septic-system leachfield, with the installation of monitoring well TA-II/W-001 (also referred to as TA-II/SW-1/320). The second and third monitoring wells were installed northwest of the TA-II fenceline in an area where no contamination was suspected. The monitoring wells installed at this location are TA-II/W-002 and TA-II/W-003 (also referred to as TA-II/NW-1/325 and $\mathrm{TA}-\mathrm{II} / \mathrm{NW}-1 / 598$, respectively).

Drilling for TA-II/W-001 began on November 2, 1992. The well was completed in a water-bearing zone at 330 feet below ground surface (fbgs) on November 20, 1992. Groundwater was collected from the open borehole on November 22, 1992, prior to developing and installing the well.

Drilling for TA-II/W-002 began on March 7, 1993, and was completed on March 23, 1993, at a total depth of $330 \mathrm{fbgs}$. Groundwater samples were collected immediately after well development on March 26, 1993, and were analyzed for VOCs, semivolatile organic compounds (SVOCs), phenolics, inorganics, ion charge balance, TDS, and metals (unfiltered). Groundwater samples were also analyzed 
for pesticides, high explosives ( $\mathrm{HE}$ ), and cyanide; none of these analytes were detected.

Drilling for TA-II/W-003 began on May 14, 1993, and was completed on June 26, 1993, at a total depth of $650 \mathrm{fbgs}$. The regional aquifer was apparently encountered in two separate zones (525 to $550 \mathrm{fbgs}$ and 570 to $590 \mathrm{fbgs}$ ). The monitoring well was installed on July 7, 1993, with two screened intervals (535 to 555 and 585 to 595 fbgs). Groundwater samples were collected on June 11 and 13, 1993, and analyzed for inorganics, ion charge balance, TDS, and metals (unfiltered). The well was also sampled by NMED in October 1993 for VOCs, SVOCs, metals, radionuclides, and major ions. Preliminary analytical results show no indication of contamination (Betsill 1993).

Groundwater analytical results for these sampling events are summarized for organic compounds in Appendix $\mathrm{K}$, Table $\mathrm{K}-18$, for inorganic compounds in Table $\mathrm{K}-19$, and for total metals in Table $\mathrm{K}-20$.

Additional groundwater samples were collected from these wells in 1993, but analytical results are not available at this time.

\subsubsection{Liquid Waste Disposal System Groundwater Monitoring}

Groundwater monitoring activities at the LWDS took place in June and November 1993 (SNL 1994). Sampling was conducted in accordance with the "Mixed Waste Landfill Sampling and Analysis Plan" (SNL 1990b, draft) or as otherwise requested by the Task Leader. Details of the sampling events may be found in the groundwater monitoring reports (IT 1993m, 1993n). In June, sample fractions were collected from LWDS MW-2 for VOCs, SVOCs, major cations (calcium, magnesium, sodium, and potassium), major anions (chloride, sulfate, and carbonate), total phosphate, NPN, TDS, total TAL metals, TOC, gross alpha and gross beta activity, gamma spectroscopy, and H-3 (Appendix K, Table K-21a). November samples from LWDS MW- 1 include fractions for all June analytes (Table K-21b). In general, analytical results for 1993 LWDS sampling events are comparable to other groundwater sampling results from non-ER site monitoring wells at SNL/NM.

Metals: LWDS MW-2 metals analyses detected total barium ( $\mathrm{Ba}$ ), Fe, magnesium $(\mathrm{Mg})$, potassium $(\mathrm{K})$, selenium $(\mathrm{Se})$, and sodium $(\mathrm{Na})$. LWDS MW-1 analyses detected total arsenic (As), $\mathrm{Ba}$, calcium ( $\mathrm{Ca}$ ), $\mathrm{Fe}, \mathrm{Mg}$, manganese ( $\mathrm{Mn}$ ), $\mathrm{K}$, Se, and $\mathrm{Na}$. All metals were detected at concentrations lower than the EPA MCLs.

Radionuclides: In 1993, groundwater samples collected from LWDS wells were analyzed for gross alpha/beta activity, gamma spectroscopy, and H-3. Detected gross alpha and gross beta activity did not exceed DOE DCGs ( 15 and $30 \mathrm{pCi} / \mathrm{L}$, respectively). H-3 was not measured above the detection limits $(360 \mathrm{pCi} / \mathrm{L})$ in either LWDS well.

Organic Compounds: TOC was measured at low levels in LWDS MW-1 (0.94 and $0.93 \mathrm{mg} / \mathrm{L}$ ) and was not detected in LWDS MW-2 (at an MDL of $0.5 \mathrm{mg} / \mathrm{L}$ ). Trace amounts of benzene $(0.006 \mathrm{mg} / \mathrm{L})$ and TCE $(0.006 \mathrm{mg} / \mathrm{L})$ were detected in samples from LWDS MW-1, and common laboratory contaminants were measured below laboratory reporting limits in samples from both wells. No sVOCs were measured above detection limits in samples from either well. 
Inorganic Compounds: Chloride, sulfate, and nitrate were detected in samples from both wells. Major ion and water-chemistry analyses were performed on groundwater samples.

\subsubsection{Sitewide Hydrogeologic Characterization - South Fence Road Drilling Project}

Phase II of the South Fence Road (SFR) drilling project was completed in CY 93 (SNL 1994). This phase included the drilling and completion of three characterization/monitoring wells and one observation well. Two wells are located at the existing SFR-3 location, while the other characterization/ monitoring well and observation well are located at the SFR- 4 site.

In addition to the Phase II work, two wells drilled in SFR-Phase I (SFR-2S and SFR-1D) were sampled on May 6, 1993 (Appendix K, Table K-22). MCLs used were primary drinking-water standards unless otherwise noted (NMED 1991). These wells will not be used as public water supply or stock wells. As such, they were not disinfected as is normal for drinking-water supplies. TOC, pesticides, herbicides, total phenolics, and VOCs (except acetone) were not detected above the MDL. Acetone was found in both of the well samples, but was also present in the laboratory method blank, indicating laboratory contamination. As such, the acetone results are not considered valid indicators of groundwater contamination.

The ToX content is measured in parts per billion. The results are indicative only of halogenated organics and cannot be used to quantify concentrations of specific compounds (Nielsen 1991). The levels are low and in the range of other TOX values obtained at SNL/NM.

Parameters such as total alkalinity, $\mathrm{Ca}$, and $\mathrm{Mg}$ are indicators of water hardness and do not have associated regulatory standards. The water from both wells has high levels of total alkalinity and $\mathrm{Ca}$, which are consistent with the hardness of the water in the Albuquerque area. Both wells exhibit a neutral $\mathrm{pH}(-7)$ which is also indicative of water with a high mineral content.

The levels of chloride, fluoride, NPN, sulfate, Ba, and $\mathrm{Mn}$ are all below the primary or secondary MCLs. The Na level for both wells (approximately $77 \mathrm{mg} / \mathrm{L}$ ) exceeds the secondary (recommended) limit of $20 \mathrm{mg} / \mathrm{L}$ for people on sodiumrestricted diets, but is insignificant in these wells since they are not to be used as drinking water wells.

Future sampling of these wells will be conducted as part of the SNL/NM Groundwater Surveillance Project.

Results of quarterly sampling of SFR-1 and SFR-2 are provided in the Basewide Groundwater Surveillance Program sections of this report and in the corresponding basewide quarterly reports (IT 1993d, 1993e, 1993f). 


\subsection{QUALITY ASSURANCE PROGRAMS}

\subsection{QUALITY ASSURANCE POLICIES AND RESPONSIBILITIES FOR ENVIRONMENTAL PROGRAMS}

The Environmental Operations Center (EOC) (Center 7500) has developed and implemented a quality plan that defines a specific approach to ensure that items and services meet the standards set by Sandia National Laboratories, New Mexico (SNL/NM), the Department of Energy (DOE), and applicable regulatory agencies: U.S. Environmental Protection Agency (EPA), Occupational Safety and Health Administration (OSHA), and State and local governments. The EOC Quality $P$ lan is being written in accordance with guidelines set forth in DOE Order 5700.6C, "Quality Assurance" (DOE 1991b); the SNL Integrated Quality Program" (SNL 1993i); and the ES\&H Center 7700 Quality Plan (SNL, in preparation).

The EOC Quality Plan describes quality guidelines and standards for all activities and functions conducted by or for the EOC. This plan stresses prevention of problems by ensuring that (1) requirements are defined in documents such as plans and procedures, (2) requirements are understood through familiarization and training, and (3) all activities necessary for fulfilling the requirements are performed by qualified personnel. There is an ongoing effort to include applicable quality elements from the EOC Quality Plan in implementation plans and operating procedures within the departments responsible for hazardous, radioactive, and mixed waste operations, and environmental protection, remediation, and compliance activities. In addition, each EOC employee is responsible for ensuring that all environmentally related activities are performed in accordance with the policies and guidelines set in the EOC Quality Plan, which is distributed to all EOC personnel and contractors. A copy is also kept on file in the SNL/NM Environmental Operations Records Center (EORC).

\subsection{QUALITY ASSURANCE OF ENVIRONMENTAL SAMPLING AND ANALYSIS}

This section summarizes quality assurance (QA) activities related to environmental monitoring, remediation, and waste management programs. Sampling is conducted in accordance with program-specific sampling and analysis plans or work plans, each of which contains relevant QA elements. These documents are prepared and implemented in accordance with the EOC Quality Plan and meet appropriate regulatory guidelines for conducting sampling and analysis activities. QA elements for sampling and analysis follow EPA QA guidelines for activities related to environmental management. QA for sampling and analytical activities performed in conjunction with these programs is discussed in the following subsections.

\subsubsection{Quality Assurance for Sampling Programs}

Quality assurance for sampling activities includes the following items:

- Collection of samples using defined sampling procedures

- Sample collection equipment

- Sample container decontamination

- Sample handling, preservation, and documentation 
- Quality control (QC) samples at defined frequencies to estimate sample representativeness and potential contamination acquired during the sampling and handling process

In addition, prior to sample collection, specific procedures are prepared to address the mechanics of the process, the location and frequency of samples to be collected, and proper sample preservation and documentation techniques. Sample collection for all programs is performed by trained personnel only, who must complete an analytical request/chain of custody form for each sample. Each sample is assigned a unique control number and documented with a samplecollection log.

Depending on the type of investigation, project-specific QC samples may include the following: trip, equipment, or field blanks, and environmental replicate samples. QC samples are submitted to contractor laboratories in accordance with project-specific data quality objectives and sampling and analysis plans. Replicate environmental samples are collected and submitted to the laboratory to assess the overall variability (precision) of data associated with a particular sampling location. To assess the quality of the sampling process, blank samples are submitted to document the level of contamination contributed by sampling and handling.

\subsubsection{Quality Assurance for Analytical Programs}

Most of the chemical analyses of waste and environmental samples collected at SNL/NM during 1993 were performed by independent analytical laboratories. During 1993, these laboratories analyzed over 8000 samples, operating under stringent QA plans that comply with the EOC Quality Plan and applicable EPA requirements and guidelines. Before analytical laboratories are selected, contractor laboratories are appraised (preaward audits) in accordance with the EOC Quality Plan. These laboratories are then reappraised annually using inspections and audits, which are kept on file in EORC. Table E-1 of Appendix E lists laboratories that provided analytical support to SNL/NM's environmentally related sampling activities during 1993. Information about the quantities and types of samples processed through the EOC Sample Management Office (SMO) are available in the SMO Sample Tracking Data Base () .

Analyses employed EPA test procedures wherever possible; otherwise, a suitable validated test procedure was used. Instruments were calibrated in accordance with established procedures and were, verified before analysis using certified standard reference materials to ensure the accuracy of data generated.

With each analytical batch of SNL/NM samples, QC samples were concurrently prepared at defined frequencies and analyzed for each analyte of interest to measure analytical accuracy, precision, contamination, and the matrix effect associated with each analytical measurement. For each QC measurement, QC sample results were compared to statistically established control criteria. Analytical data generated, with concurrent QC sample results that were inside established control limits, were considered acceptable. Analytical data generated, with QC sample results that were outside control limits, were considered out of control and corrective action was initiated; reanalysis was performed for all samples in the analytical batch. This process guaranteed the 
quality of data generated by each analytical laboratory. Results of concurrently analyzed QC sample data were included with each analytical report prepared for SNL/NM. These reports included sample identification numbers; dates of sample collection, preparation, and analysis; analytical-method reference number; analytes, concentration measured, and detection limit; and associated QC control data.

During 1993, over 1,000 QC samples were submitted to monitor overall laboratory performance. Analyses were performed to comply with SNL/NM QA requirements, to meet project-specific data quality objectives, and to monitor and document analytical precision and accuracy. Contractor laboratories operate under strict QA/QC programs. Periodically, they participate in the EPA's programs for blind-audit check sampling to monitor the overall precision and accuracy of analyses routinely performed on SNL/NM samples.

To assess the quality of stable chemistry analyses, double-blind samples were submitted along with routine environmental samples to the contractor laboratories at defined frequencies. These check samples were submitted quarterly based on the frequency and type of samples submitted to assess and document laboratory precision and accuracy. Check samples were prepared by the EPA or Environmental Resource Associates, Arvada, $\mathrm{CO}$, and submitted to the contractor laboratories at frequencies indicated above. All check samples were prepared in batch quantities and subjected to round-robin analyses to verify analyte concentrations. The samples were prepared by spiking concentrated solutions containing various analytes of interest into reagent-grade water, free of analytical interferents or soil, to create check samples at concentration ranges of one to five times the method detection limit. The check samples were prepared in duplicate so analytical precision, as well as accuracy, could be assessed. Check samples submitted to the laboratories consisted of solutions containing trace metals, cyanides, phenolic compounds, and other selected anions, cations, and organic compounds. In addition to aqueous and soil samples, oil samples containing known concentrations of polychlorinated biphenyls (PCBs) were prepared by the EPA and submitted to the laboratories for analysis.

For programs using the EOC SMO (the Wastewater Monitoring, Groundwater Monitoring, Waste Management, and Environmental Restoration programs), results of each set of check sample analyses are available in Quarterly Performance Evaluation Reports. The reports include average percent recoveries for each suite of samples analyzed and the relative range of actual recoveries and relative percent differences for each analyte tested. A corrective-action request was issued for any exceedance of accepted limits. AII reports and corrective action responses are maintained in the EORC. The resulting data were used to assess each laboratory's performance using relative percent difference and percent recovery for respective indicators of precision and accuracy. Review of laboratory performance data generated during 1993 indicates that the majority of analytes tested by the SNL/NM analytical laboratories are within EPA (or interlaboratory, round-robin) prescribed control limits.

Tables E-2 through E-4 of Appendix E present results of replicate sampling as part of the Environmental Monitoring Program. Radionuclide analysis results include the mean concentration, standard deviation, and coefficient of variation (CV). The $C V$ is used as a measure of the reproducibility of the data and 
includes the variation associated with the sampling location and analytical techniques. Replicate samples of water, vegetation, soil, and sediment were collected as a regular part of the Environmental Monitoring Program.

The Environmental Monitoring Program evaluated its contractor laboratory (AccuLabs Research, Inc.) performance by means of the laboratory's participation in the interlaboratory comparison programs of the EPA Environmental Monitoring Systems Laboratory and the DOE Quality Assessment Program (QAP) (Tables E-5 and E-6 of Appendix E). Results of the EPA Cross-Check program and the DOE QAP are on file in the SNL/NM EORC.

\subsubsection{Data Review and Validation}

Sample collection, control documentation, and measurement data were reviewed for each sample collected. Analytical data reported by test laboratories were reviewed for laboratory and field precision and accuracy, completeness, representativeness, and comparability with respect to the data-quality objectives of the particular program. Data were reviewed and validated at a minimum of three levels:

1. By the analytical laboratory where the data were validated in accordance with the laboratory's QA plan and standard operating procedures

2. By a knowledgeable member of the SNL/NM SMO staff or contractor who reviewed the analytical reports and corresponding sample collection and control documentation for the following:

- Compliance with contract requirements

- SNL/NM QA requirements

- Documentation completeness

- Project-specific data quality requirements

3. By the SNL/NM project leader responsible for program objectives and regulatory compliance Records are maintained by EORC in accordance with the requirements of the EOC Quality Plan. EORC also maintains all data files related to this report.

\subsection{CONTRACTOR QUALITY ASSURANCE OVERVIEW}

The SMO has several contractors who provide consulting, waste management and disposal, water sampling and analysis, and other analytical services. These contractors are overseen by contract monitors (with support from the EOC Quality Coordinator) through one of the following mechanisms:

1. Monitored by task (for consulting services) using a project evaluation sheet to evaluate individual projects. Contractors provide monthly reports on the status of progress and budget. 
2. Performance checks and annual onsite appraisals as discussed above (for analytical laboratories). Quarterly blind samples, replicates, and blanks are submitted to the laboratories for performance checks. Corrective actions are documented and implemented.

3. Cost-plus-award-fee contract for hazardous waste management and the Environmental Restoration Program. The contract has a 30 -percent fixed and 70-percent variable award fee based on quarterly performance evaluations. 


\subsection{REFERENCES}

Betsill 1993: Betsill, J. D., "Summary Report of Drilling and Sampling Three Bore Holes and Monitor Well Installation at Tech Area 2 During FY93," internal report, Sandia National Laboratories, Albuquerque, NM (1993).

Bjorklund and Maxwell 1961: Bjorklund, L. J., and B. W. Maxwell, "Availability of Ground Water in the Albuquerque Area, Bernalillo and Sandoval Counties, New Mexico," Technical Report 21, New Mexico State Engineer Report (1961).

Booher 1992: Booher, W., "Sandia National Laboratories/New Mexico Wastewater Sampling Plan," Plan 92-06, Revision 1, Sandia National Laboratories, Albuquerque, NM (October 1992).

Brewer 1973: Brewer, L. W., "Environmental Monitoring Report for Sandia National Laboratories From 1964 Through 1972," SLA73-0339, Sandia National Laboratories, Albuquerque, NM (1973).

Brewer 1974: Brewer, L. W., "Environmental Monitoring Report for Sandia National Laboratories for 1973," SLA-74-0167, Sandia National Laboratories, Albuquerque, NM (1974).

Burnett et al. 1961: Burnett, W. D., D. J. Coleman, R. G. Elsbrock, and R. J. Everett, "Radioactive Environmental Survey at Sandia Corporation," SC-4628(M), Sandia National Laboratories, Albuquerque, NM (1961).

Culp et al. 1992: Culp, T., W. Cox, S. Hwang, A. Jones, S. Longley, A. Parsons, T. Wolff, J. Fish, and S. Ward, "1991 Environmental Monitoring Report," SAND92-0939, Sandia National Laboratories, Albuquerque, NM (1992).

Culp et al. 1993: Culp, T., W. Cox, H. Hwang, M. Irwin, A. Jones, B. Matz, K. Molley, W. Rhodes, D. Stermer, and T. Wolff, "1992 Environmental Monitoring Report, " SAND93-1448, Sandia National Laboratories, Albuquerque, NM (1993).

DOC 1991: U.S. Department of Commerce, Bureau of the Census, "1990 United States Census--Preliminary Report," DOC, U.S. Government Printing Office, Washington, DC (1991).

DOE 1987: U.S. Department of Energy Albuquerque Operations Office (DOE/AL), "Comprehensive Environmental Assessment and Response Program Phase 1: Installation Assessment," draft, DOE/AL, Environment, Safety and Health Division, Albuquerque, NM (September 1987).

DOE 1991a: U.S. Department of Energy Albuquerque Field Office (DOE/AFO), "Environmental Assessment for the Radioactive and Mixed Waste Management Facility at Sandia National Laboratories, Albuquerque, New Mexico," DOE/EA-0466, DOE/AFO, Albuquerque, NM (1991). 
DOE 1991b, see Orders section.

DOE 1991c, see Orders section.

DOE 1991d: U.S. Department of Energy, "Environmental Regulatory Guide for Radiological Effluent Monitoring and Environmental Surveillance," DOE/EH-0173T, DOE, Assistant Secretary for Environment, Safety and Health, Washington, DC (1991).

DOE 1993a: U.S. Department of Energy, "U.S. DOE Interim Mixed Waste Inventory Report Waste Streams Treatment Capacities and Technologies," DOE/NBM1100, Volumes 1 through 6, DOE, Washington, DC (April 1993).

DOE 1993b: U.S. Department of Energy, "Nuclear Weapons Complex Reconfiguration Programmatic Environmental Impact Statement (PEIS)," DOE/EIS-0161, DOE, Washington, DC (1993).

DOE 1994a: U.S. Department of Energy, "Implementation Plan for Environmental Restoration and Waste Management Programmatic Environmental Impact Statement," DOE/EIS-0200, DOE, Office of Environmental Restoration and Waste Management, Washington, DC (January 1994).

DOE 1994b: U.S. Department of Energy Albuquerque Field Office (DOE/AFO), "Neutron Generator/Switch Tube (NG/ST) Prototyping Relocation Environmental Assessment," DOE/EA-0879, DOE/AFO, Albuquerque, NM (Apri1 8, 1994).

DOE 1994c: U.S. Department of Energy Albuquerque Field Office (DOE/AFO), "Environmental Assessment for the Robotic Manufacturing Science and Engineering Laboratory (RMSEL)," DOE/EA-0885, DOE/AFO, Albuquerque, NM (April 13, 1994).

EO, see Orders section.

EPA 1976: U.S. Environmental Protection Agency, "USEPA National Interim Primary Drinking Water Regulations, "EPA-570/9-76-003, EPA, Washington, DC (1976).

EPA 1986a: U.S. Environmental Protection Agency, "Supplement A to Compilation of Air Pollutant Emission Factors, Volume I: Stationary Point and Area Sources," EPA AP-42, EPA, Office of Air and Radiation, Office of Air Quality Planning and Standards, Research Triangle Park, NC (1986).

EPA 1986b: U.S. Environmental Protection Agency, 'Volatile Organic Compounds by Gas Chromatography/Mass Spectrometry (GC/MS): Capillary Column Technique,' Method 8260 (Revised July 1992) in "Test Methods for Evaluating Solid Waste: Physical/Chemical Methods," Third Edition, EPA 530/SW-846, Superintendent of Documents, U.S. Government Printing Office, Washington, DC (1986). 
EPA 1990: U.S. Environmental Protection Agency, Field Measurements:

Dependable Data When You Need It, prepared by Midwest Research Institute for the EPA, Office of Underground Storage Tanks, under Contract No. 6801-7383, and 68-WO-0015 (1990).

EPA 1991: U.S. Environmental Protection Agency, "CAP-88, Clean Air Act Assessment Package, " Radiation Shielding Information Center, CCG-542, Oak Ridge, TN (1991).

ERDA 1977: U.S. Energy Research and Development Administration, "Environmental Impact Assessment, Sandia National Laboratories, Albuquerque, New Mexico," EIA/MA 77-1, ERDA (1977).

Fink and Park 1992: Fink, C., and E. Park, "Spill Prevention Control and Countermeasure Plan," Plan 90-11, Revision 1, Sandia National Laboratories, Albuquerque, NM (December 14, 1992).

Fink and Park 1993a: Fink, C., and E. Park, "Oil Spill Contingency Plan," Plan 90-11, Revision 1, Sandia National Laboratories, Albuquerque, NM (February 1993).

Fink and Park 1993b: Fink, C., and E. Park, "Hazardous and Radioactive Materials Spill Prevention Control and Countermeasure Plan," draft, Sandia National Laboratories, Albuquerque, NM (1993).

Golden Software 1991: Golden Software, Inc., "SURFER Software," Version 3, Golden Software, Inc., 809 14th Street, P.0. Box 281, Golden, CO 80402 (1991).

Goodrich 1990: Goodrich, M. T., "A Technical Procedure for the Measurement of Static Water Levels in Ground-Water Monitor Wells," PRO 90-02, Sandia National Laboratories, Albuquerque, NM (1990).

Grant 1982: Grant, P. R., Ir., "Geothermal Potential in the Albuquerque Area, New Mexico," in Guidebook - New Mexico Geological Society, Vol. 33, pp. 325 through 331 (1982).

Hindl et a1. 1992: Hindl, S., J. L. Davis, R. E. Barton, and W. A. Rose, "1992 Transportation Service Division Procedures Manual," Sandia National Laboratories, Albuquerque, NM (March 27, 1992).

Holley 1975: Holley, W. L., "Environmental Monitoring Report, Sandia Laboratories 1974," SAND75-0257, Sandia National Laboratories, Albuquerque, NM (1975).

Holley and Simmons 1976: Holley, W. L., and T. N. Simmons, "Environmental Monitoring Report, Sandia Laboratories 1975," SAND76-0209, Sandia National Laboratories, Albuquerque, NM (1976).

Hwang et a1. 1990: Hwang, H. S., G. Chavez, J. Phelan, A. Parsons, G. Yeager, D. Dionne, B. Schwartz, T. Wolff, J. Fish, C. Gray, and D. Thompson, "1989 Environmental Monitoring Report," SAND90-0301, Sandia National Laboratories, Albuquerque, NM (1990). 
Hwang et al. 1991: Hwang, H. S., G. Yeager, T. Wolff, A. Parsons, M. Goodrich, D. Diónne, C. Massey, B. Schwartz, J. Fish, and D. Thompson, "1990 Environmental Monitoring Report," SAND91-0592, Sandia National Laboratories, Albuquerque, NM (1991).

IT 1993a: IT Corporation, "Quarterly Wastewater Monitoring Report, March 1993 - May 1993, " prepared for Sandia National Laboratories, Albuquerque, NM (July 1993).

IT 1993b: IT Corporation, "Sandia National Laboratories Wastewater Monitoring Program Quarterly Report, June 1993 - August 1993, " prepared for Sandia National Laboratories, Albuquerque, NM (October 1993).

IT 1993c: IT Corporation, "Quarterly Wastewater Monitoring Report, September 1993 through November 1993," prepared for Sandia National Laboratories, Albuquerque, NM (1993).

IT 1993d: IT Corporation, "Report on Quarterly Basewide Groundwater Monitoring, April 1993," prepared for Sandia National Laboratories, Albuquerque, NM (1993).

IT 1993e: IT Corporation, "Report on Quarterly Basewide Groundwater Monitoring, July 1993," prepared for Sandia National Laboratories, Albuquerque, NM (1993).

IT 1993f: IT Corporation, "Report on Quarterly Basewide Groundwater Monitoring, September 1993," prepared for Sandia National Laboratories, Albuquerque, NM (1993).

IT 1993g: IT Corporation, "Report on Annual Groundwater Assessment Monitoring at the Chemical Waste Landfill, Sandia National Laboratories/New Mexico, February 1993," prepared for Sandia National Laboratories, Albuquerque, NM (1993).

IT 1993h: IT Corporation, "Report on Quarterly Groundwater Assessment Monitoring at the Chemical Waste Landfill, Sandia National Laboratories/New Mexico, May 1993," prepared for Sandia National Laboratories, Albuquerque, NM (1993).

IT 1993i: IT Corporation, "Report on Quarterly Groundwater Assessment Monitoring at the Chemical Waste Landfill, Sandia National Laboratories/New Mexico, August 1993, " prepared for Sandia National Laboratories, Albuquerque, NM (1993).

IT 1993j: IT Corporation, "Report on Quarterly Groundwater Assessment Monitoring at the Chemical Waste Landfill, Sandia National Laboratories/New Mexico, November 1993," prepared for Sandia National Laboratories, Albuquerque, NM (1993).

IT 1993k: IT Corporation, "Report on Semiannual Groundwater Sampling at the Mixed Waste Landfill, Sandia National Laboratories/New Mexico, January 1993, " prepared for Sandia National Laboratories, Albuquerque, NM (1993). 
IT 19931: IT Corporation, "Report on Semiannual Groundwater Sampling at the Mixed Waste Landfill, Sandia National Laboratories/New Mexico, April 1993," prepared for Sandia National Laboratories, Albuquerque, NM (1993).

IT 1993m: IT Corporation, "Analytical Results for Groundwater Samples

Collected June 24, 1993, from the Groundwater Monitoring Well MW-2 at the Liquid Waste Disposal Site," prepared for Sandia National Laboratories, Albuquerque, NM (1993).

IT 1993n: IT Corporation, "Field and Laboratory Documentation for Groundwater Samples, Monitoring Well LWDS MW-1," prepared for Sandia National Laboratories, Albuquerque, NM (1993).

IT 1994: IT Corporation, "Sandia National Laboratories Wastewater Monitoring Program Quarterly Report, November 1993 - January 1994," prepared for Sandia National Laboratories, Albuquerque, NM (1994).

Kelley 1977: Kelley, V. C., "Geology of Albuquerque Basin, New Mexico," Memoir 33, New Mexico Bureau of Mines and Mineral Resources, Socorro, NM (1977).

Kelley and Northrup 1975: Kelley, V. C., and S. A. Northrup, "Geology of Sandia Mountains and Vicinity, New Mexico," Memoir 29, New Mexico Bureau of Mines and Mineral Resources, Socorro, NM (1975).

Klimm 1993: Klimm S., Personal communication, KAFB 377th Airborne Wing, Base Engineering Group (1993).

Kramer \& Associates 1988a: "Nitrogen Oxides Performance Tests for Emergency Generators at Sandia Laboratories, Albuquerque, New Mexico, " prepared for Sandia National Laboratories, Albuquerque, NM (March 1988).

Kramer \& Associates 1988b: "Sulfur Dioxide Performance Tests for Emergency Generators at Sandia Laboratories, Albuquerque, New Mexico, " prepared for Sandia National Laboratories, Albuquerque, NM (April 1988).

LATA 1991: Los Alamos Technical Associates, "AIRDOS-EPA Data Upgrade and Dose Calculations for SNL, Albuquerque," LATA, Los Alamos, NM (1991).

Lozinsky et al. 1991: Lozinsky, R. P., J. W. Hawley, and D. W. Lowe, "Geologic Overview and Pliocene-Quaternary History of the Albuquerque Basin, Central New Mexico," Field Guide to Geologic Excursions in New Mexico and Adjacent Areas of Texas and Colorado, Bulletin 37, B. Julian and J. Zidek, editors, New Mexico Bureau of Mines and Mineral Resources, Socorro, NM (1991).

Millard 1981: Millard, G. C., "Environmental Monitoring Report, Sandia National Laboratories 1980," SAND81-0566, Sandia National Laboratories, Albuquerque, NM (1981).

Millard et al. 1982: Millard, G. C., C. E. Gray, T. N. Simmons, and B. L. O'Neal, "1981 Environmental Monitoring Report, Sandia National Laboratories, Albuquerque, New Mexico," SAND82-0833, Sandia National Laboratories, Albuquerque, NM (1982). 
Millard et al. 1983: Millard, G. C., C. E. Gray, T. N. Simmons, and B. L. O'Neal, "1982 Environmental Monitoring Report, Sandia National Laboratories, Albuquerque, New Mexico," SAND83-0789, Sandia National Laboratories, Albuquerque, NM (1983).

Millard et al. 1984: Millard, G. C., C. E. Gray, and B. L. O'Neal, "1983 Environmental Monitoring Report, Sandia National Laboratories, Albuquerque, New Mexico," SAND84-0429, Sandia National Laboratories, Albuquerque, NM (1984).

Millard et al. 1985: Millard, G. C., C. E. Gray, and D. J. Thompson, "1984 Environmental Monitoring Report, Sandia National Laboratories, Albuquerque, New Mexico," SAND85-0550, Sandia National Laboratories, Albuquerque, NM (1985).

Millard et al. 1986: Millard, G. C., C. E. Gray, and D. J. Thompson, "1985 Environmental Monitoring Report, Sandia National Laboratories, Albuquerque, New Mexico," SAND86-0752, Sandia National Laboratories, Albuquerque, NM $(1986)$.

Millard et al. 1987: Millard, G. C., P. Pei, S. Felicetti, C. Gray, D. Thompson, and J. Phelan, "1986 Environmental Monitoring Report, Sandia National Laboratories, Albuquerque, New Mexico," SAND87-0606, Sandia National Laboratories, Albuquerque, NM (1987).

Millaxd et al. 1988: Millard, G., C. P. Pei, S. Felicetti, C. Gray, D. Thompson, and J. Phelan, "1987 Environmental Monitoring Report, Sandia National Laboratories, Albuquerque, New Mexico," SAND88-0697, Sandia National Laboratories, Albuquerque, NM (1988).

Millard et al. 1989: Millard, G. C., G. Yeager, J. Phelan, T. Wolff, P. Pei, D. Dionne, C. Gray, D. Thompson, and R. Hamilton, "1988 Environmental Monitoring Report, Sandia National Laboratories, Albuquerque, New Mexico," SAND89-1368, Sandia National Laboratories, Albuquerque, NM (1989).

Nielsen 1991: Nielsen, D. M., Practical Handbook of Ground-Water Monitoring, Chelsea, Michigan: Lewis Publishers, pp. 717 (1991).

NMED 1991: New Mexico Environmental Department, Water Supply Regulations, as Appended Through April 16, 1991, New Mexico Environment Department, Santa $\mathrm{Fe}$, NM (1991).

NMWQR 1991: New Mexico Water Quality Regulations, New Mexico Water Quality Control Commission Regulations (1967, as amended through August 17, 1991).

Pacheco and Bonaguidi 1993: Pacheco, J. E., and J. Bonaguidi, "State of New Mexico Environment Department Discharge Plan DP-771 Solar Detoxification Experiment Facility, Quarterly Report for Period Beginning July 1, 1993 and Ending September 30, 1993," Sandia National Laboratories, Albuquerque, NM (October 12, 1993). 
Pacheco and Copus 1993a: Pacheco, J. E., and E. R. Copus, "State of New Mexico Environment Department Discharge Plan DP-771 Solar Detoxification Experiment Facility, Quarterly Report for Period Beginning January 1 , 1993 and Ending March 31, 1993," Sandia National Laboratories, Albuquerque, NM (April 19, 1993).

Pacheco and Copus 1993b: Pacheco, J. E., and E. R. Copus, "State of New Mexico Environment Department Discharge Plan DP-771 Solar Detoxification Experiment Facility, Quarterly Report for Period Beginning April 1, 1993 and Ending June 30, 1993," Sandia National Laboratories, Albuquerque, NM (July 16, 1993).

Secretary of Energy, 1990. "National Environmental Policy Act Notice," SEN-15 90 (February 5, 1990).

SEN-15-90, see Secretary of Energy.

Seylar 1994: Seylar, R. F., "Draft Safety Assessment, Radioactive and Mixed Waste Management Facility, Sandia National Laboratories, New Mexico," Sandia National Laboratories, Albuquerque, NM (March 15, 1994).

Simmons 1977: Simmons, T. N., "Environmental Monitoring Report, Sandia Laboratories 1976," SAND77-0616, Sandia National Laboratories, Albuquerque, NM (1977).

Simmons 1978: Simmons, T. N., "Environmental Monitoring Report, Sandia Laboratories 1977," SAND78-0620, Sandia National Laboratories, Albuquerque, NM (1978).

Simmons 1979: Simmons, T. N., "Environmental Monitoring Report, Sandia Laboratories 1978, "SAND79-1033, Sandia National Laboratories, Albuquerque, NM (1979).

Simmons 1980: Simmons, T. N., "Environmental Monitoring Report, Sandia Laboratories 1979," SAND80-0342, Sandia National Laboratories, Albuquerque, NM (1980).

SNL 1989: Sandia National Laboratories, "Site Development Plan," Sandia National Laboratories, Albuquerque, NM (1989).

SNL 1990a: Sandia National Laboratories, "Chemical Waste Landfill Sampling and Analysis Plan," Rev. 2.0, Sandia National Laboratories, Albuquerque, NM (1990).

SNL 1990b: Sandia National Laboratories, "Mixed Waste Landfill Sampling and Analysis Plan," draft, Sandia National Laboratories, Albuquerque, NM (1990).

SNL 1991a: Sandia National Laboratories, "Chemical Waste Landfill Final Closure Plan and Postclosure Permit Application," Sandia National Laboratories, Albuquerque, NM (1991). 
SNL 1991b: Sandia National Laboratories, "Compliance Agreement Final Report: Hydrogeologic Characterization," Sandia National Laboratories, Albuquerque, NM (1991).

SNL 1991c: Sandia National Laboratories, "National Environmental Policy Act (NEPA) Program," PG470110, Sandia National Laboratories, Albuquerque, NM (1991).

SNL 1992a: Sandia National Laboratories, "Chemical Waste Landfill Final Closure Plan and Postclosure Permit Application," Sandia National Laboratories, Albuquerque, NM (December 21, 1992).

SNL 1992b: Sandia National Laboratories, "Final Action Plan to Tiger Team," SAND92-01.20, Sandia National Laboratories, Albuquerque, NM (1992).

SNL 1992c: Sandia National Laboratories, "Environmental Sampling Procedure," SP471991, Environmental Protection Department (7725), Sandia National Laboratories, Albuquerque, NM (1992).

SNL 1993a: Sandia National Laboratories, "Conceptual Site Treatment Plan for Mixed Waste," Revision 1 (October 15, 1993), Sandia National Laboratories, Albuquerque, NM (March 1993).

SNL 1993b: Sandia National Laboratories, "Sandia National Laboratories, New Mexico Environmental Baseline Update," SAND92-7339, Sandia National Laboratories, Albuquerque, NM (1993).

SNL 1993c: Sandia National Laboratories, "Cultural Resources Regulatory Analysis, Area Overview, and Assessment of Previous Department of Energy and Kirtland Air Force Base Inventories for Sandia National Laboratories, New Mexico," SAND92-7345, Sandia National Laboratories, Albuquerque, NM (1993).

SNL 1993d: Sandia National Laboratories, "Chemical Waste Landfill Final Closure Plan Approval," Sandia National Laboratories, Albuquerque, NM (February 22, 1993).

SNL 1993e: Sandia National Laboratories, "Environment, Safety and Health Training Catalog," MN471010 ES\&H Training Department, Sandia National Laboratories, Albuquerque, NM (March 1993).

SNL 1993f: Sandia National Laboratories, "New Mexico Environment Department Discharge Plan DP-530 Lagoon Discharge Report, Sandia National Laboratories, Albuquerque, Pulsed Power Development Facilities, Technical Area IV, January 1993 through June 1993," submitted by Sandia National Laboratories, Albuquerque, NM, to the New Mexico Environment Department (1993).

SNL 1993g: Sandia National Laboratories, "State of New Mexico Environment Department Discharge Plan DP-530 Lagoon Discharge Report, Sandia National Laboratories, New Mexico, Pulsed Power Development Facilities, Technical Area IV," prepared for Second Semiannual, CY 1993, Sandia National Laboratories, Albuquerque, NM (December 1993). 
SNL 1993h: Sandia National Laboratories, "Sitewide Groundwater Monitoring Program Sampling and Analysis Plan," draft, Sandia National Laboratories, Albuquerque, NM (1993).

SNL 1993i: Sandia National Laboratories, "Sandia National Laboratories' Integrated Quality Program," SAND93-0891, Sandia National Laboratories, Albuquerque, NM (1993).

SNL 1994: Sandia National Laboratories, "Calendar Year 1993 Annual Groundwater Monitoring Report," Groundwater Protection Program, Sandia National Laboratories, Albuquerque, NM (1994).

Stein et al. 1991: Stein, C. L., K. M. Kimball, H. R. Westrich, and J. L. Krumhans1, "Chromium in Ground-Water Monitoring Wells at the Chemical Waste Landfill, SNL Technical Area III," SAND91-0131, Sandia National Laboratories, Albuquerque, NM (1991).

Titus 1963: Titus, F. B., "Geology and Ground-Water Conditions in Eastern Valencia County, New Mexico," Ground-Water Report No. 7, State Bureau of Mines and Mineral Resources, New Mexico Institute of Mining and Technology, Socorro, NM (1963).

U.S. Army Corps of Engineers, 1979. "Special Flood Hazard Information, Tijeras Arroyo and Arroyo del Coyote, Kirtland AFB, New Mexico," U.S. Army Corps of Engineers, Albuquerque District, Albuquerque, NM (1979).

USEC 1994: U.S. Enrichment Corporation, "Environmental Assessment for the Purchase of Russian Low Enriched Uranium Derived From the Dismantlement of Nuclear Weapons in the Countries of the Former Soviet Union, "USEC/EA94001, Bethesda, MD (1994).

Woodward 1982: Woodward, L. A., 'Tectonic Framework of Albuquerque Country,' in "Albuquerque Country II," Guidebook - 33rd New Mexico Geological Society, Field Conference (1982). 


\section{ACTS}

American Indian Religious Freedom Act (AIRFA) of 1978, as amended.

Archaeological Resources Protection Act (ARPA) of 1979, as amended.

Atomic Energy Act of 1954, as amended.

Clean Air Act (CAA) of 1955, as amended. Title 42 U.S.C. 7401.

Clean Water Act (CWA) of 1948, (Federal Water Pollution Control Act), as amended. Title 33 U.S.C. 1251.

Comprehensive Environmental Response, Compensation, and Liability Act (CERCLA) of 1980, as amended. Title 40 U.S.C. 9601.

Emergency Planning and Community Right to Know Act (EPCRA) of 1986 (Enacted by Public Law 99-499, October 17, 1986; 42 U.S.C. 11001 et seq.).

Federal Facility Compliance Act of 1992. Public Law 102-386.

Federal Insecticide, Fungicide, and Rodenticide Act (FIFRA), as amended. Title 7 U.S.C. 136.

National Environmental Policy Act (NEPA) of 1969, as amended. Title 42 U.S.C. 4321.

National Historic Preservation Act of 1966, as amended, Section 106, Advisory Council on Historic Preservation Comment on Federal Undertakings (16 U.S.C. 470f).

New Mexico Hazardous Waste Act, 1978. New Mexico Statute Amendment \$74-4-1 through 74-4-12, 1978, amended as laws 1983, Chapter 302.

New Mexico Solid Waste Act, Article 9; Enacted by Laws of 1990, Chapter 99; Amended by Laws of 1991, Chapters 185, 194.

Resource Conservation and Recovery Act (RCRA) of 1976. Public Law 94-580, 1976 , 90 Statute 2795.

Superfund Amendments and Reauthorization Act (SARA) of 1986. Title III, Section 313, "Toxic Chemical Release Reporting."

Toxic Substances Control Act (TSCA) of 1976. U.S.C. $\$ 2601$ et seq.

Water Quality Act of 1987. Public Law 100-4, 1987, 100 Statute 7. 


\section{CODE OF FEDERAL REGULATIONS}

10 CFR 1021, 1992. "National Environmental Policy Act Implementing Procedures," as revised April 24, 1992.

40 CFR 50, 1971. "National Primary and Secondary Ambient Air Quality Standards."

40 CFR 61, 1973. "National Emission Standards for Hazardous Air Pollutants (NESHAP)," including 1985, Subpart H. "National Emission Standards for Emissions of Radionuclide Other Than Radon From Department of Energy Facilities," as amended.

40 CFR 70, 1993. "State Operating Permit Programs."

40 CFR 82, 1988. "Protection of Stratospheric Ozone."

40 CFR 112, 1973. "Oil Pollution Prevention," as amended March 26, 1976.

40 CFR 122, 1980. "EPA Administered Permit Programs: The National Pollutant Discharge Elimination System," as amended November 5, 1991.

40 GFR 123, 1980. "State Program Requirements," as amended November 16, 1990.

40 CFR 124, 1980. "Procedures for Decisionmaking," as amended November 16, 1990.

40 CFR 136, 1973. "Guidelines Establishing Test Procedures for the Analysis of Pollutants," as amended. August 15, 1990.

40 CFR 141, 1975. "National Primary Drinking Water Regulations," as amended January 15, 1992 .

40 CFR 261, 1980. "Identification and Listing of Hazardous Waste," as amended January 2, 1992.

40 CFR 262, 1980. "Standards Applicable to Generators of Hazardous Waste," as amended.

40 CFR 264, 1980. "Standards for Owners and Operators of Hazardous Waste Treatment, Storage, and Disposal Facilities, "including Subpart F, Section 264.101, "Releases for Solid Waste Management Units," as amended June 10, 1994.

40 CFR 265, 1980. "Interim Status Standards for Owners and Operators of Hazardous Waste Treatment, Storage, and Disposal Facilities," as amended December 23, 1991.

40 CFR 268, 1986. "Land Disposal Restrictions," as amended August 19, 1991.

40 CFR 280, 1985. "Underground Storage Tanks," as amended December 23, 1991. 
40 CFR 281, 1988. "Approval of State Underground Storage Tank Programs," as amended.

40 CFR 372, 1988. "Toxic Chemical Release Reporting: Community Right-to Know," as amended.

40 CFR 413, 1981. "Electroplating Point Source Category," as amended.

40 CFR 433, 1983. "Metal Finishing Point Source Category," as amended.

40 CFR 469, 1983. "Electrical and Electronic Components Point Source Category."

40 CFR 1500 through 1508, 1978. Chapter V, "Council on Environmental Quality." 


\section{ORDERS}

DOE 1988a: U.S. Department of Energy, "General Environmental Protection Program," DOE Order 5400.1, DOE, Washington, DC (1988, change 1, June 21, 1990).

DOE 1988b: U.S. Department of Energy, "Radioactive Waste Management," DOE Order 5820.2A, DOE, Washington, DC (1988).

DOE 1989a: U.S. Department of Energy, "Comprehensive Environmental Response Compensation and Liability Act Requirements," DOE Order 5400.4, DOE, Washington, DC (1989).

DOE 1989b: U.S. Department of Energy, "Hazardous and Radioactive Mixed Waste Program," DOE Order 5400.3, DOE, Washington, DC (1989).

DOE 1990: U.S. Department of Energy, Chapter I, "General Radiological Protection of the Public and the Environment;" Chapter II, "Requirements for Radiation Protection of the Public and the Environment;" and Chapter III, "Derived Concentration Guides for Air and Water," DOE Order 5400.5, DOE, Washington, DC (February 8, 1990, change 2, January 7, 1993).

DOE 1991a, see main reference section.

DOE 1991b: U.S. Department of Energy, "Quality Assurance," DOE Order 5700.6C, DOE, Washington, DC (August 21, 1991).

DOE 1991c: U.S. Department of Energy, "Planning and Preparedness for Operational Emergencies," DOE Order 5500.3A, DOE, Washington, DC (1991, change 1, February 27, 1992).

DOE 1991d, see main reference section.

DOE 1992a: U.S. Department of Energy, "NEPA Compliance Program," DOE Order 5440.1E, DOE, Washington, DC (1992).

DOE 1992b: U.S. Department of Energy Albuquerque Operations Office (DOE/AL), "Department of Energy Albuquerque Field Office National Environmental Policy Act Compliance Program," Supplemental Directive AL 5440.1D, DOE/AL, Albuquerque, NM (1992).

Executive Order 11988, Floodplain Management (Signed May 24, 1977; 42 FR 26951, 3 CFR, 1977 Comp., p. 117; Amended by Executive Order 12148, July 20, 1979; 44 FR 43239, 3 CFR, 1979 Comp., p. 412).

Executive Order 11990, Protection of Wetlands (Signed May 24, 1977; 42 FR 26961, 3 CFR, 1977 Comp., p. 121).

Executive Order 12856, "Federal Compliance With Right-to-Know Laws and Pollution Prevention Requirements (Signed August 3, 1993; 58 FR 41981, August 6, 1993). 


\section{APPENDIX A}

METEOROLOGICAL DATA 
A- 2 


\section{CONTENTS}

TABLES

Page

A-1 Long-Term Historical Data for Albuquerque, New Mexico, 1961 to 1990 . . . . . . . . . . . . . . . . . . . . . . A-5

A-2 Normals, Means, and Extremes for Albuquerque, New Mexico, 1961 to 1990 . . . . . . . . . . . . . . . . . . . . . . . . . A-6

REFERENCES . . . . . . . . . . . . . . . . . . . . . . . . . . A-7 
A -4 
Table A-1. Long-Term Historical Data for Albuquerque, New Mexico, 1961 to 1990 (NOAA 1990)

\begin{tabular}{|c|c|c|c|c|c|}
\hline \multirow[b]{2}{*}{ Month } & \multicolumn{2}{|c|}{ Temperature } & \multirow{2}{*}{$\begin{array}{c}\text { Precipitation } \\
\text { Water } \\
\text { Equivalent }(\mathrm{cm})\end{array}$} & \multicolumn{2}{|r|}{ Wind } \\
\hline & $\begin{array}{r}\text { Daily } \\
\text { Minimum }\end{array}$ & $\begin{array}{r}\text { Range }\left({ }^{\circ} \mathrm{C}\right) \\
\text { Maximum }\end{array}$ & & $\begin{array}{l}\text { Speed } \\
(\mathrm{m} / \mathrm{s})\end{array}$ & Direction \\
\hline January & -5.4 & 8.4 & 1.04 & 3.6 & 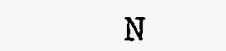 \\
\hline February & -3.4 & 11.6 & 1.02 & 4.0 & $\mathrm{~N}$ \\
\hline March & -0.2 & 15.9 & 1.32 & 4.5 & $\mathrm{SE}$ \\
\hline April & 4.2 & 21.4 & 1.02 & 4.9 & $\mathrm{~S}$ \\
\hline May & 9.2 & 26.6 & 1.17 & 4.7 & s \\
\hline June & 14.7 & 32.6 & 1.30 & 4.5 & $\mathrm{~S}$ \\
\hline July & 18.2 & 33.8 & 3.30 & 4.1 & $\mathrm{SE}$ \\
\hline August & 17.1 & 31.9 & 3.84 & 3.7 & $\mathrm{SE}$ \\
\hline September & 12.7 & 28.3 & 2.16 & 3.8 & $\mathrm{SE}$ \\
\hline October & 6.2 & 22.1 & 2.18 & 3.7 & $\mathrm{SE}$ \\
\hline November & -0.7 & 14.0 & 0.97 & 3.5 & $\mathrm{~N}$ \\
\hline December & -4.9 & 8.9 & 1.32 & 3.4 & $\mathrm{~N}$ \\
\hline \multicolumn{6}{|c|}{$\begin{array}{l}\text { Notes: } \\
\text { Temperature and precipitation values are normals recorded for the } 1961 \text { to } \\
1990 \text { period. Wind direction is the prevailing direction through } 1963 \text {. } \\
\text { Average wind speeds are reported. The data were collected at the } \\
\text { Albuquerque International Airport, elevation } 1.62 \mathrm{~km} \text {. The original } \\
\text { measurements have been converted to metric units. }\end{array}$} \\
\hline
\end{tabular}


Table A-2. Normals, Means, and Extremes for Albuquerque, New Mexico, 1961 to 1990 (NOAA 1990)

\begin{tabular}{|c|c|c|c|c|c|c|c|c|c|c|c|c|c|c|}
\hline \multirow{3}{*}{ 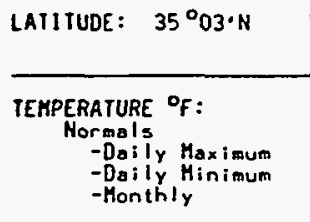 } & \multicolumn{3}{|c|}{ LONGIIUDE: $106^{\circ} 37 \cdot \mathrm{H}$} & \multicolumn{5}{|c|}{ ELEVATION: FI. GPNO 5311 BARO } & \multirow{2}{*}{\multicolumn{2}{|c|}{\begin{tabular}{c|c|}
5313 & IIME \\
AUG & SEP \\
\end{tabular}}} & \multicolumn{2}{|c|}{ ZONE: MOUNTAIM } & \multicolumn{2}{|c|}{ HBAN: 23050} \\
\hline & $|(8)|$ & JAN & FEB & MAR & APR & & JUNE & & & & OCT & NOV & DEC & \\
\hline & & $\begin{array}{l}47.2 \\
22.3 \\
34.8\end{array}$ & $\begin{array}{l}52.9 \\
25.9 \\
39.4\end{array}$ & $\begin{array}{l}60.7 \\
31.7 \\
46.2\end{array}$ & $\begin{array}{l}70.6 \\
39.5 \\
55.1\end{array}$ & $\begin{array}{l}79.9 \\
48.6 \\
64.3\end{array}$ & $\begin{array}{l}90.6 \\
58.4 \\
74.5\end{array}$ & $\begin{array}{l}92.8 \\
64.7 \\
78.8\end{array}$ & $\begin{array}{l}89.4 \\
62.8 \\
76.1\end{array}$ & $\begin{array}{l}83.0 \\
54.9 \\
69.0\end{array}$ & $\begin{array}{l}71.7 \\
43.1 \\
57.4\end{array}$ & $\begin{array}{l}57.2 \\
30.7 \\
44.0\end{array}$ & $\begin{array}{l}48.0 \\
23.2 \\
35.6\end{array}$ & $\begin{array}{l}70.3 \\
42.1 \\
56.2\end{array}$ \\
\hline $\begin{array}{l}\text { Extremes } \\
\text { - Record Highest } \\
\text { - Year } \\
\text { - Record Lowes: } \\
\text { - Year }\end{array}$ & $\begin{array}{l}51 \\
51\end{array}$ & $\begin{array}{r}69 \\
1971 \\
-17 \\
1971 \\
\end{array}$ & $\begin{array}{r}76 \\
1986 \\
-55 \\
1951 \\
\end{array}$ & $\begin{array}{r}85 \\
1971 \\
8 \\
1948 \\
\end{array}$ & $\begin{array}{r}89 \\
1989 \\
19 \\
1980\end{array}$ & $\begin{array}{r}98 \\
1951 \\
28 \\
1975 \\
\end{array}$ & $\begin{array}{r}105 \\
1980 \\
40 \\
1980\end{array}$ & $\begin{array}{r}105 \\
1980 \\
52 \\
1985 \\
\end{array}$ & $\begin{array}{r}101 \\
1979 \\
52 \\
1968 \\
\end{array}$ & $\begin{array}{r}100 \\
1979 \\
37 \\
1971 \\
\end{array}$ & $\begin{array}{r}91 \\
1979 \\
25 \\
1980 \\
\end{array}$ & $\begin{array}{r}77 \\
1975 \\
-7 \\
1976 \\
\end{array}$ & $\begin{array}{r}72 \\
1958 \\
-7 \\
1990 \\
\end{array}$ & $\begin{array}{r}105 \\
\text { JUN } 1980 \\
-177 \\
\text { JAN } 1971 \\
\end{array}$ \\
\hline $\begin{array}{l}\text { NORMAL DEGREE DAYS: } \\
\text { Heat ing Ibase } 65^{\circ} \mathrm{FI}\end{array}$ & & 936 & 717 & 583 & 302 & 81 & $\mathbf{0}$ & 0 & 0 & 12 & 242 & 630 & 911 & 4414 \\
\hline Cooling lbase $65^{\circ} \mathrm{Fl}$ & & 0 & 0 & 0 & 0 & 59 & 285 & 428 & 344 & 132 & 6 & 0 & 0 & 1254 \\
\hline$X$ OF POSSIBLE SUNSHINE & 51 & 73 & 73 & 73 & 77 & 79 & 83 & 76 & 75 & 79 & 79 & 77 & 72 & 76 \\
\hline $\begin{array}{l}\text { MEAN SKY COVER (tenths) } \\
\text { SUnr ise - Sunset } \\
\text { MEAN NUKBER OF DAYS: }\end{array}$ & 51 & 4.8 & 5.0 & 5.0 & 4.6 & 4.2 & 3.4 & 4.5 & 4.4 & 3.6 & 3.5 & 4.0 & 4.6 & 4.3 \\
\hline $\begin{array}{l}\text { Sunrise to Sunset } \\
\text { - Clear } \\
\text {-Partly Cloudy } \\
\text { - Cloudy }\end{array}$ & $\begin{array}{l}51 \\
51 \\
51\end{array}$ & $\begin{array}{r}13.0 \\
7.7 \\
10.3\end{array}$ & $\begin{array}{r}11.2 \\
7.6 \\
9.5\end{array}$ & $\begin{array}{r}11.4 \\
9.8 \\
9.7\end{array}$ & $\begin{array}{r}12.6 \\
9.5 \\
8.0\end{array}$ & $\begin{array}{r}14.9 \\
10.3 \\
6.3\end{array}$ & $\begin{array}{r}17.6 \\
8.6 \\
3.8\end{array}$ & $\begin{array}{r}12.0 \\
14.3 \\
4.7\end{array}$ & $\begin{array}{r}13.5 \\
12.4 \\
5.1\end{array}$ & $\begin{array}{r}16.7 \\
7.8 \\
5.5\end{array}$ & $\begin{array}{r}17.3 \\
7.7 \\
6.0\end{array}$ & $\begin{array}{r}15.2 \\
7.6 \\
7.2\end{array}$ & $\begin{array}{r}14.0 \\
7.5 \\
9.5\end{array}$ & $\begin{array}{r}168.8 \\
110.9 \\
85.5\end{array}$ \\
\hline $\begin{array}{l}\text { Precipitation } \\
\text {.01 inches or more }\end{array}$ & 51 & 4.0 & 4.0 & 4.6 & 3.4 & 4.4 & 3.9 & 8.8 & 9.5 & 5.7 & 4.8 & 3.4 & 4.2 & 60.6 \\
\hline $\begin{array}{l}\text { Snow. Ice pellets } \\
1.0 \text { inches or more }\end{array}$ & 51 & 1.0 & 1.0 & 0.7 & 0.2 & 0.3 & 0.0 & 0.0 & 0.0 & 0.0 & $0 . *$ & 0.4 & 0.9 & 4.2 \\
\hline $\begin{array}{l}\text { Thunderstorms } \\
\text { Heavy fog Yisibility }\end{array}$ & 51 & 0.1 & 0.3 & 0.9 & 1.6 & 3.9 & 5.0 & 10.9 & 10.9 & 4.6 & 2.3 & 0.5 & 0.2 & 41.4 \\
\hline $\begin{array}{l}\text { Me mile or } 185 s \\
\text { Temperature } \\
\text { - Haximum }\end{array}$ & 51 & 1.1 & 1.0 & 0.6 & 0.2 & $0 . *$ & 0.2 & 0.1 & $0 . *$ & 0.1 & 0.4 & 0.6 & 1.5 & 5.6 \\
\hline $\begin{array}{l}- \text { Maximum } \\
90^{\circ} \text { and above } \\
32^{\circ} \text { and below }\end{array}$ & $\begin{array}{l}30 \\
30\end{array}$ & $\begin{array}{l}0.0 \\
2.3\end{array}$ & $\begin{array}{l}0.0 \\
0.7\end{array}$ & $\begin{array}{l}0.0 \\
0.1\end{array}$ & $\begin{array}{l}0.0 \\
0.0\end{array}$ & $\begin{array}{l}2.6 \\
0.0\end{array}$ & $\begin{array}{r}17.2 \\
0.0\end{array}$ & $\begin{array}{r}23.2 \\
0.0\end{array}$ & $\begin{array}{r}15.9 \\
0.0\end{array}$ & $\begin{array}{l}3.9 \\
0.0\end{array}$ & $\begin{array}{l}0.1 \\
0.0\end{array}$ & $\begin{array}{l}0.0 \\
0.2\end{array}$ & $\begin{array}{l}0.0 \\
1.8\end{array}$ & $\begin{array}{r}62.9 \\
5.2\end{array}$ \\
\hline $\begin{array}{r}-M i n i j u m \\
32^{\circ} \text { and be low } \\
0^{\circ} \text { and belom }\end{array}$ & $\begin{array}{r}30 \\
30 \\
\end{array}$ & $\begin{array}{r}29.0 \\
0.4 \\
\end{array}$ & $\begin{array}{r}22.8 \\
0.0 \\
\end{array}$ & $\begin{array}{r}15.8 \\
0.0 \\
\end{array}$ & $\begin{array}{l}4.5 \\
0.0\end{array}$ & $\begin{array}{l}0.2 \\
0.0 \\
\end{array}$ & $\begin{array}{l}0.0 \\
0.0 \\
\end{array}$ & $\begin{array}{l}0.0 \\
0.0 \\
\end{array}$ & $\begin{array}{l}0.0 \\
0.0 \\
\end{array}$ & $\begin{array}{l}0.0 \\
0.0 \\
\end{array}$ & $\begin{array}{l}2.0 \\
0.0\end{array}$ & $\begin{array}{r}16.1 \\
0.1\end{array}$ & $\begin{array}{r}28.5 \\
0.1\end{array}$ & $\begin{array}{r}118.9 \\
0.6 \\
\end{array}$ \\
\hline AVG. SIATION PRESS. (mb) & 18 & 838.9 & 837.8 & 835.1 & 835.8 & 836.0 & 838.1 & 840.4 & 840.7 & 840.1 & 840.0 & 838.8 & 839.1 & 838.4 \\
\hline $\begin{array}{l}\text { RELATIVE HUNIDITY (z) } \\
\text { Hour } 05 \\
\text { Hour } 11 \\
\text { Hour } 17 \text { (Local Timel } \\
\text { Hour } 23 \\
\end{array}$ & $\begin{array}{r}30 \\
30 \\
30 \\
30 \\
\end{array}$ & $\begin{array}{l}70 \\
51 \\
40 \\
61 \\
\end{array}$ & $\begin{array}{l}65 \\
44 \\
33 \\
53\end{array}$ & $\begin{array}{l}56 \\
34 \\
24 \\
43\end{array}$ & $\begin{array}{l}49 \\
26 \\
19 \\
36 \\
\end{array}$ & $\begin{array}{l}48 \\
25 \\
18 \\
34\end{array}$ & $\begin{array}{l}46 \\
24 \\
18 \\
33\end{array}$ & $\begin{array}{l}60 \\
34 \\
27 \\
47\end{array}$ & $\begin{array}{l}66 \\
40 \\
30 \\
53\end{array}$ & $\begin{array}{l}62 \\
40 \\
31 \\
52\end{array}$ & $\begin{array}{l}62 \\
38 \\
30 \\
50\end{array}$ & $\begin{array}{l}65 \\
42 \\
36 \\
54\end{array}$ & $\begin{array}{l}70 \\
50 \\
43 \\
61\end{array}$ & $\begin{array}{l}60 \\
37 \\
29 \\
48\end{array}$ \\
\hline $\begin{array}{l}\text { PRECIPIJATION Tinches): } \\
\text { Hater Equivalent } \\
\text { - Normal } \\
\text { - Maximum Monthly } \\
\text {-Year } \\
\text { - Hinimum Monthly } \\
\text { - Year } \\
\text { - Haximum in } 24 \text { hrs } \\
\text { - Year }\end{array}$ & $\begin{array}{l}51 \\
51 \\
51\end{array}$ & $\begin{array}{l}0.41 \\
1.32 \\
1978 \\
T \\
1970 \\
0.87 \\
1962\end{array}$ & $\begin{array}{c}0.40 \\
1.42 \\
1948 \\
T \\
1984 \\
0.51 \\
1981\end{array}$ & $\begin{array}{l}0.52 \\
2.18 \\
1973 \\
T \\
1966 \\
1.11 \\
1973\end{array}$ & $\begin{array}{l}0.49 \\
1.97 \\
1942 \\
T \\
1989 \\
1.66 \\
1969\end{array}$ & $\begin{array}{r}0.46 \\
3.07 \\
1941 \\
1 \\
1945 \\
1.94 \\
1969\end{array}$ & $\begin{array}{l}0.51 \\
2.57 \\
1986 \\
1 \\
1975 \\
1.64 \\
1952\end{array}$ & $\begin{array}{l}1.30 \\
3.33 \\
1968 \\
0.08 \\
1980 \\
1.77 \\
9961\end{array}$ & $\begin{array}{l}1.51 \\
3.30 \\
1967 \\
1 \\
1962 \\
1.75 \\
1980\end{array}$ & $\begin{array}{l}0.85 \\
2.63 \\
1988 \\
1 \\
1957 \\
1,92 \\
1955\end{array}$ & $\begin{array}{l}0.86 \\
3.08 \\
1972 \\
0.00 \\
1952 \\
1.80 \\
1969\end{array}$ & $\begin{array}{l}0.38 \\
1.45 \\
1940 \\
0.00 \\
1949 \\
0.76 \\
1940\end{array}$ & $\begin{array}{l}0.52 \\
1.85 \\
1959 \\
0.00 \\
1981 \\
1.35 \\
1958\end{array}$ & $\begin{array}{l}8.12 \\
3.33 \\
\text { JUL } 1968 \\
0.00 \\
\text { DEC } 1981 \\
\text { SEP } 19.92 \\
1955\end{array}$ \\
\hline $\begin{array}{l}\text { Snow, lce pellets } \\
\text { - Maximum Honthiy } \\
\text { - Year } \\
\text { - Haximum in } 24 \mathrm{hrs} \\
\text {-Year }\end{array}$ & $\begin{array}{l}51 \\
51\end{array}$ & $\begin{array}{r}5.5 \\
1973 \\
5.1 \\
1973 \\
\end{array}$ & $\begin{aligned} 10.3 \\
1986 \\
6.0 \\
1986\end{aligned}$ & $\begin{array}{l}13.9 \\
1973 \\
107 \\
1973\end{array}$ & $\begin{array}{r}8.1 \\
1973 \\
10.9 \\
1988\end{array}$ & $\begin{array}{r}1.0 \\
1979 \\
190 \\
1979\end{array}$ & $\begin{array}{c}T \\
1990 \\
1 \\
1990\end{array}$ & $\begin{array}{c}\mathbf{J} \\
1990 \\
\mathbf{I} \\
1990\end{array}$ & $\begin{array}{l}0.0 \\
0.0\end{array}$ & $\begin{array}{c}1 \\
1971 \\
I \\
1971\end{array}$ & $\begin{array}{r}3.2 \\
1986 \\
3.2 \\
1986\end{array}$ & $\begin{array}{r}9.3 \\
1940 \\
5.5 \\
1946 \\
\end{array}$ & $\begin{array}{l}14.7 \\
1959 \\
14.2 \\
1958\end{array}$ & 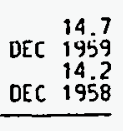 \\
\hline IND: & 51 & 8.1 & 8.9 & 10.1 & $1: .0$ & 10.6 & 10.0 & 9.1 & 8.3 & 8.6 & 8.3 & 7.9 & 7.7 & 9.0 \\
\hline $\begin{array}{l}\text { ing virection } \\
\text { th } 963 \text {, Ms. Min. }\end{array}$ & & N & N & SE & s & $s$ & 5 & SE & SE & SE & SE & N & N & SE \\
\hline $\begin{array}{l}\text { Tastest was. } \\
\text { - Direction !!! } \\
\text {-Speed IMPHI } \\
\text {-Year }\end{array}$ & $\begin{array}{l}6 \\
6\end{array}$ & $\begin{array}{r}09 \\
52 \\
1990\end{array}$ & $\begin{array}{r}09 \\
40 \\
1989\end{array}$ & $\begin{array}{r}28 \\
41 \\
1986\end{array}$ & $\begin{array}{r}17 \\
46 \\
1985\end{array}$ & $\begin{array}{r}28 \\
486 \\
1986\end{array}$ & $\begin{array}{r}08 \\
40 \\
1990\end{array}$ & $\begin{array}{r}36 \\
52 \\
1990\end{array}$ & $\begin{array}{r}27 \\
41 \\
1990\end{array}$ & $\begin{array}{r}25 \\
40 \\
1985\end{array}$ & $\begin{array}{r}09 \\
32 \\
1986\end{array}$ & $\begin{array}{r}27 \\
48 \\
1988\end{array}$ & $\begin{array}{r}09 \\
47 \\
1987\end{array}$ & $\begin{array}{r}09 \\
52 \\
\text { JAN } 1990\end{array}$ \\
\hline $\begin{array}{l}\text { Peak Gust } \\
\text { - Direction } 1 ! ! ! \\
\text { - Speed Imph! } \\
\text {-Date }\end{array}$ & 7 & $\begin{array}{r}7 \\
70 \\
1990\end{array}$ & $\begin{array}{r}4 \\
63 \\
1984\end{array}$ & $\begin{array}{r}N W \\
66 \\
1986\end{array}$ & $\begin{array}{r}E \\
64 \\
1990\end{array}$ & $\begin{array}{r}5 \\
61 \\
1987\end{array}$ & $\begin{array}{r}65 \\
67 \\
1986\end{array}$ & $\begin{array}{r}\text { N } \\
72 \\
1990\end{array}$ & $\begin{array}{r}E \\
63 \\
1989\end{array}$ & $\begin{array}{r}6 \\
61 \\
1985\end{array}$ & $\begin{array}{r}N H \\
51 \\
1986\end{array}$ & $\begin{array}{r}4 \\
63 \\
1988\end{array}$ & $\begin{array}{r}E \\
71 \\
1987\end{array}$ & $\begin{array}{r}\text { N } \\
72 \\
\text { JUL } 1990\end{array}$ \\
\hline
\end{tabular}

Notes: $T=$ trace amount. Blank entries denote missing/unreported data. "\#" indicates a station or instrument relocation. (a) $=$ length of record in years, al though individual months may be missing. "0.*" or "**" indicates the value is between 0.0 and 0.05 . Normals are based on the 1961-1990 record period. Extremes dates are the most recent occurrence. Wind direction numerals show tens of degrees clockwise from true north. "OO" indicates calm. Resultant directions are given to whole degrees. 


\section{REFERENCE}

NOAA 1990: National Oceanographic and Atmospheric Administration, "Local Climatological Data, Annual Summary with Comparative Data, Albuquerque, NM, NOAA" (1990). 


\section{APPENDIX B}

SANDIA NATIONAL LABORATORIES/NEW MEXICO ENVIRONMENTAL RESTORATION PROGRAM SITES 
B-2 


\section{CONTENTS}

TABLE

$\underline{\text { Page }}$

B-1 Environmental Restoration Program Site List by Activity

Data Sheet (ADS) . . . . . . . . . . . . . . . . B-5 


$$
\text { B- } 4
$$


Table B-1. Environmental Restoration Program Site List by Activity Data Sheet (ADS)

\begin{tabular}{|c|c|c|c|c|}
\hline $\begin{array}{l}\text { ADS No.- } \\
\text { Operable Unit }\end{array}$ & $\begin{array}{l}\text { Site } \\
\text { No. }\end{array}$ & Site Name & $\begin{array}{l}\text { RCRA/RFA } \\
\text { No. }\end{array}$ & Regulatory Driver \\
\hline $\begin{array}{l}\text { 1267-Chemical } \\
\text { Waste Landfill }\end{array}$ & 74 & Chemical Waste Landfill & $\begin{array}{l}1,2,3,4,5,6 \\
7,8,9,20,110\end{array}$ & $\begin{array}{l}40 \text { CFR } 265 \\
\text { Interim Status }\end{array}$ \\
\hline \multirow{3}{*}{$\begin{array}{l}\text { 1281-Kauai Test } \\
\text { Facility }\end{array}$} & 132 & Photo Laboratory Discharge & None & CERCLA \\
\hline & 133 & Drum Rack Area (Active) & None & CERCLA \\
\hline & 163 & Rocket Launcher Pads (Active) & None & CERCLA \\
\hline $\begin{array}{l}\text { 1289-Mixed Waste } \\
\text { Landfill }\end{array}$ & 76 & Mixed Waste Landfil1 (TA-III) & $\begin{array}{c}24,25,26,27,28,29 \\
30,115,116\end{array}$ & RCRA $3004(u)$ \\
\hline \multirow{13}{*}{$\begin{array}{l}\text { 1295-Septic Tanks } \\
\text { and Drainfields }\end{array}$} & 49 & BIdg. 9820 Drains & 126 & RCRA $3004(u)$ \\
\hline & 101 & $\begin{array}{l}\text { Explosive Contaminated Sumps, } \\
\text { Drains (Bldg. 9926) }\end{array}$ & None & RCRA $3004(u)$ \\
\hline & 116 & Bldg. 9990 Septic System & 79 & RCRA $3004(u)$ \\
\hline & 137 & Bldg. $6540 / 6542$ Septic & None & RCRA $3004(u)$ \\
\hline & 138 & Bldg. 6630 Septic System & 79 & RCRA $3004(u)$ \\
\hline & 139 & Bldg. 9964 Septic System & 79 & RCRA $3004(u)$ \\
\hline & 140 & Bldg. 9965 Septic System & 79 & RCRA $3004(u)$ \\
\hline & 141 & Bldg. 9967 Septic System & 79 & RCRA $3004(u)$ \\
\hline & 142 & B1dg. 9970 Septic System & 79 & RCRA $3004(u)$ \\
\hline & 143 & B1dg. 9972 Septic System & 79 & RCRA $3004(u)$ \\
\hline & 144 & Bldg. 9980 Septic System & 79 & RCRA 3004(u) \\
\hline & 145 & Bldg. 9981/9982 Septic Systems & None & RCRA $3004(u)$ \\
\hline & 146 & Bldg. 9920 Drain System & 79 & RCRA $3004(u)$ \\
\hline
\end{tabular}


Table B-1. Environmental Restoration Program Site List by Activity Data Sheet (ADS) (Continued)

\begin{tabular}{|c|c|c|c|c|}
\hline $\begin{array}{c}\text { ADS No.- } \\
\text { Operable Unit }\end{array}$ & $\begin{array}{l}\text { Site } \\
\text { No. }\end{array}$ & Site Name & $\begin{array}{l}\text { RCRA/RFA } \\
\text { No. }\end{array}$ & Regulatory Driver \\
\hline \multirow{10}{*}{$\begin{array}{l}\text { 1295-Septic Tanks } \\
\text { and Drainfields } \\
\text { (Continued) }\end{array}$} & 147 & Bldg. 9925 Septic Systems & 79 & RCRA $3004(u)$ \\
\hline & 148 & B1dg. 9927 Septic System & 79 & RCRA $3004(u)$ \\
\hline & 149 & B1dg. 9930 Septic System & 79 & RCRA $3004(u)$ \\
\hline & 150 & B1dg. 9939/9939A Septic Systems & None & RCRA $3004(u)$ \\
\hline & 151 & Bldg. 9940 Septic System & 79 & RCRA $3004(u)$ \\
\hline & 152 & Bldg. 9950 Septic System & 79 & RCRA $3004(u)$ \\
\hline & 1.53 & B1dg. 9956 Septic Systems & 79 & RCRA $3004(u)$ \\
\hline & 154 & Bldg. 9960 Septic Systems & 79 & NM UST LAW \\
\hline & 160 & Bldg. 9832 Septic System & 79 & RCRA $3004(u)$ \\
\hline & 161 & Bldg. 6636 Septic System & 79 & RCRA $3004(u)$ \\
\hline \multirow{8}{*}{$\begin{array}{l}\text { 1300-Former } \\
\text { Underground } \\
\text { Storage Tanks }\end{array}$} & 155 & Bldg. 659725,000 Gallon (TA-V) & None & RCRA $\underset{\text { IAW }}{3004(\mathrm{u}) / \mathrm{NM}}$ UST \\
\hline & 172 & Bldg. 888 UST (TA-I) & None & $\begin{array}{c}\text { RCRA } 3004(\mathrm{u}) / \mathrm{NM} \text { UST } \\
\text { IAW }\end{array}$ \\
\hline & 173 & Bldg. 6525 UST (TA-III) & None & $\begin{array}{c}\text { RCRA } 3004(u) / N M \text { UST } \\
\text { LAW }\end{array}$ \\
\hline & 174 & Bldg. 6581 UST (TA-V) & None & $\begin{array}{c}\text { RCRA } 3004(u) / N M ~ U S T \\
\text { LAW }\end{array}$ \\
\hline & 175 & Bldg. 6588 UST $(\mathrm{TA}-\mathrm{V})$ & None & $\begin{array}{c}\text { RCRA } 3004(u) / N M \text { UST } \\
\text { LAW }\end{array}$ \\
\hline & 176 & B1dg. 605 UST (TA-I) & None & $\begin{array}{c}\text { RCRA } 3004(u) / N M \text { UST } \\
\text { LAW }\end{array}$ \\
\hline & 178 & B1dg. 6587 UST (TA-III) & None & RCRA $\underset{\text { LAW }}{3004(u) / N M ~ U S T ~}$ \\
\hline & 179 & Bldg. 7570 UST & None & $\begin{array}{c}\text { RCRA } 3004(u) / N M \text { UST } \\
\text { IAW }\end{array}$ \\
\hline
\end{tabular}




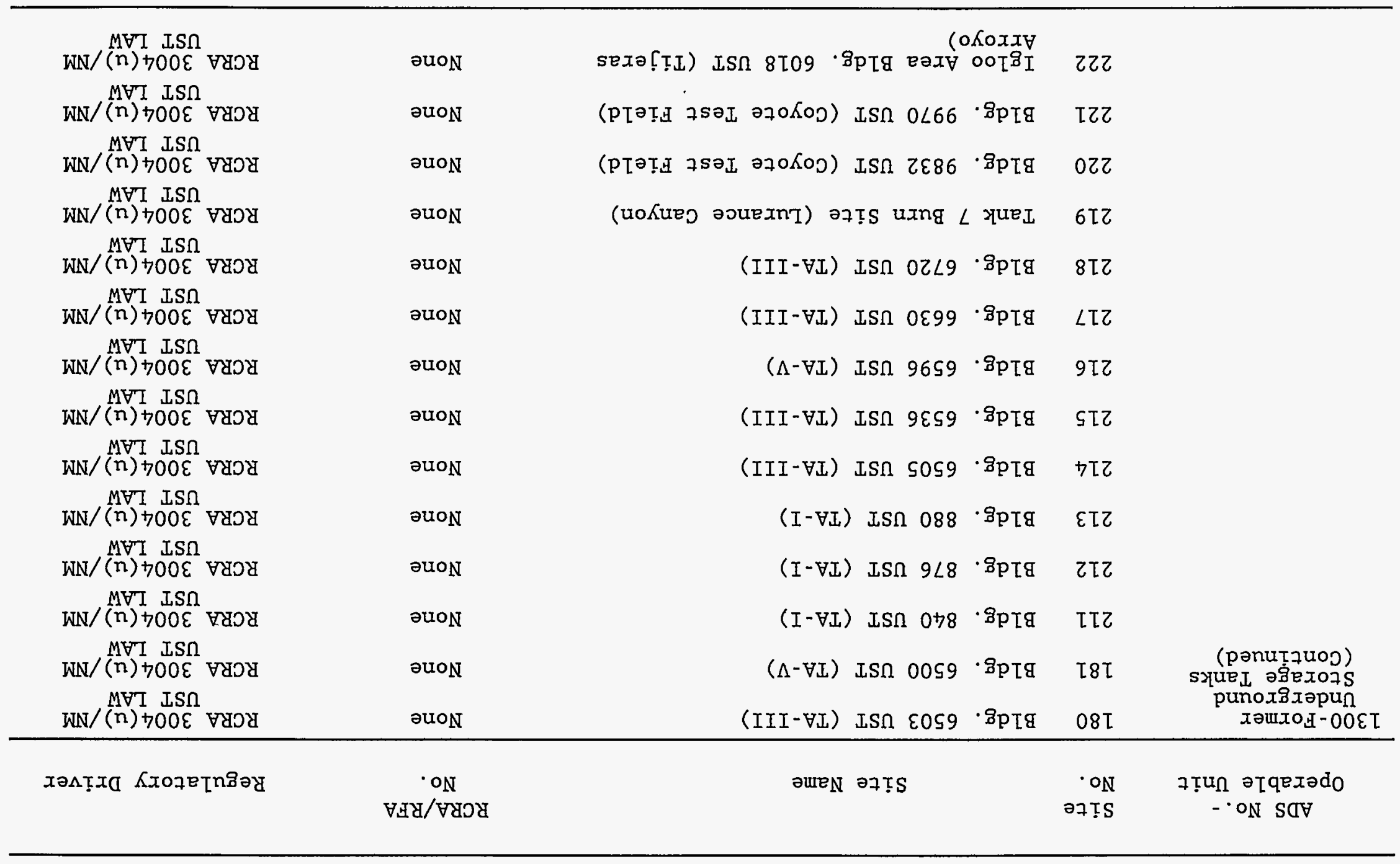


Table B-1. Environmental Restoration Program Site List by Activity Data Sheet (ADS) (Continued)

\begin{tabular}{|c|c|c|c|c|}
\hline $\begin{array}{l}\text { ADS No.- } \\
\text { Operable Unit }\end{array}$ & $\begin{array}{l}\text { Site } \\
\text { No. }\end{array}$ & Site Name & $\begin{array}{l}\text { RCRA/RFA } \\
\text { No. }\end{array}$ & Regulatory Driver \\
\hline $\begin{array}{l}1300-\text { Former } \\
\text { Underground } \\
\text { Storage Tanks } \\
\text { (Continued) }\end{array}$ & 223 & $\begin{array}{l}\text { Igloo Area Bldg. } 6028 \text { UST } \\
\text { (Tijeras Arroyo) }\end{array}$ & None & RCRA $3004(u) / N M$ \\
\hline \multirow[t]{15}{*}{ 1302-Technical Area I } & 25 & Burial Site (South of TA-I) & None & RCRA $3004(u)$ \\
\hline & 30 & PCB Spill (Reclamation Yard) & $52,53,54, \mathrm{~N}$ & RCRA $3004(u)$ \\
\hline & 32 & Steam Plant Oil Spill (TA-I) & $\mathrm{P}$ & RCRA $3004(u)$ \\
\hline & 33 & Motor Pool Oil Spill (TA-I) & Q & RCRA $3004(u)$ \\
\hline & 41 & Bldg. 838 Mercury Spill (TA-I) & 0 & RCRA $3004(u)$ \\
\hline & 42 & $\begin{array}{l}\text { Acid Spill Water Treatment } \\
\text { Facility (TA-I) }\end{array}$ & None & RCRA $3004(u)$ \\
\hline & 73 & $\begin{array}{l}\text { Hazardous Waste Repackaging/ } \\
\text { Storage (Bldg. 895) }\end{array}$ & 105 & RCRA $3004(u)$ \\
\hline & 96 & Storm Drain System (Active) & 113 & RCRA $3004(u)$ \\
\hline & 98 & $\begin{array}{l}\text { Bldg } 863, \text { TCA Photochemical } \\
\text { Reieases: Silver Catch Boxes }\end{array}$ & None & RCRA $3004(u)$ \\
\hline & 104 & PCB Spill, Computex Facility & None & RCRA. $3004(u)$ \\
\hline & 186 & TCE Dumping South of Bldg. 859 & None & RCRA $3004(u)$ \\
\hline & 187 & $\begin{array}{l}\text { Septic Tank Piping for POTW } \\
\text { (Active) }\end{array}$ & 80 & RCRA $3004(u)$ \\
\hline & 190 & $\begin{array}{l}\text { Tank Farm for Steam Plant } \\
\text { (Active) }\end{array}$ & None & RCRA $3004(u)$ \\
\hline & 192 & TA-1 Waste Oil Tank & None & RCRA $3004(u)$ \\
\hline & 226 & Acid Waste Iine (TA-I) & None & RCRA $3004(u)$ \\
\hline \multirow[t]{4}{*}{ 1303-Technical Area II } & 1 & Radioactive Waste Landfill (TA-II) & $32,33,34,35,36,37$ & RCRA $3004(u)$ \\
\hline & 2 & Classified Waste Landfill (TA-II) & 38,39 & RCRA $3004(u)$ \\
\hline & 3 & Chemical Disposal Pit (TA-II) & 40 & RCRA $3004(u)$ \\
\hline & 43 & $\begin{array}{l}\text { Radioactive Material Storage } \\
\text { Yard (TA-II) (Active) }\end{array}$ & 57 & RCRA $3004(u)$ \\
\hline
\end{tabular}


Table B-1. Environmental Restoration Program Site List by Activity Data Sheet (ADS) (Continued)

\begin{tabular}{|c|c|c|c|c|}
\hline $\begin{array}{l}\text { ADS No.- } \\
\text { Operable Unit }\end{array}$ & $\begin{array}{l}\text { Site } \\
\text { No. }\end{array}$ & Site Name & $\begin{array}{l}\text { RCRA/RFA } \\
\text { No. }\end{array}$ & Regulatory Driver \\
\hline \multirow{14}{*}{$\begin{array}{l}\text { 1303-Technical } \\
\text { Area II } \\
\text { (Continued) }\end{array}$} & 44 & $\begin{array}{l}\text { Decontamination Site and Uranium } \\
\text { Calibration Pits (TA-II) }\end{array}$ & 130 & RGRA $3004(u)$ \\
\hline & 48 & B1dg. 904 Septic System (TA-II) & 79 & RCRA $3004(u)$ \\
\hline & 113 & Area II Firing Sites (Active) & None & RCRA $3004(u)$ \\
\hline & 114 & Explosive Burn Pit (TA-II) & None & RCRA $3004(u)$ \\
\hline & 135 & Bldg. 906 Septic System & 79 & RCRA $3004(u)$ \\
\hline & 136 & Bldg. 907 Septic System & 79 & RCRA $3004(u)$ \\
\hline & 159 & Bldg. 935 Septic System & 79 & RCRA $3004(u)$ \\
\hline & 165 & B1dg. 901 Septic System & 79 & RCRA $3004(u)$ \\
\hline & 166 & Bldg. 919 Septic System & 79 & RCRA $3004(u)$ \\
\hline & 167 & B1dg. 940 Septic System & 79 & RCRA $3004(u)$ \\
\hline & 168 & Bldg. 901 UST (TA-II) & None & $\begin{array}{l}\text { RCRA } 3004(u) / N M \\
\text { UST LAW }\end{array}$ \\
\hline & 169 & Bldg. 910 UST (TA-II) & None & $\begin{array}{c}\text { RCRA } 3004(u) / N M \\
\text { UST LAW }\end{array}$ \\
\hline & 170 & Bldg. 911 UST (TA-II) & None & $\begin{array}{c}\text { RCRA } 3004(u) / N M \\
\text { UST LAW }\end{array}$ \\
\hline & 171 & Bldg. 912 UST (TA-II) & None & $\begin{array}{c}\text { RCRA } 3004(u) / N M \\
\text { UST LAW }\end{array}$ \\
\hline \multirow{4}{*}{$\begin{array}{l}\text { 1306-Technical } \\
\text { Areas III and IV }\end{array}$} & 18 & Concrete Pad (Active) & 54 & RCRA $3004(u)$ \\
\hline & 26 & Burial Site (West of TA-III) & None & RCRA $3004(u)$ \\
\hline & 31 & $\begin{array}{l}\text { Electrical Transformer } 0 i 1 \text { Spill } \\
\quad(\text { TA-III) }\end{array}$ & None & RCRA $3004(u)$ \\
\hline & 34 & $\begin{array}{c}\text { Centrifuge Oil Spill } \\
\text { (TA-III) (Active) }\end{array}$ & $\mathrm{R}$ & RCRA $3004(u)$ \\
\hline
\end{tabular}


Table B-1. Environmental Restoration Program Site List by Activity Data Sheet (ADS) (Continued)

\begin{tabular}{|c|c|c|c|c|}
\hline $\begin{array}{l}\text { ADS No.- } \\
\text { Operable Unit }\end{array}$ & $\begin{array}{l}\text { Site } \\
\text { No. }\end{array}$ & Site Name & $\begin{array}{l}\text { RCRA/RFA } \\
\text { No. }\end{array}$ & Regulatory Driver \\
\hline \multirow{16}{*}{$\begin{array}{l}\text { 1306-Technical } \\
\text { Areas III and IV } \\
\text { (Continued) }\end{array}$} & 35 & $\begin{array}{l}\text { Vibration Facility oil Spill } \\
\quad(\text { TA-III) }\end{array}$ & $\mathrm{R}$ & RCRA $3004(u)$ \\
\hline & 36 & Oil Spill - HERMES (TA-V) & S & RCRA $3004(u)$ \\
\hline & 37 & PROTO Oil spill (TA-V) (Active) & $\mathrm{T}$ & RCRA $3004(u)$ \\
\hline & 51 & B1dg. 6924 Pad, Tank, Pit & 10,11 & RCRA $3004(u)$ \\
\hline & 78 & Gas Cylinder Disposal Pit (TA-III) & 31 & RCRA $3004(u)$ \\
\hline & 83 & Long Sled Track (TA-III) (Active) & I & RCRA $3004(u)$ \\
\hline & 84 & Gun Facilities (TA-III) (Active) & None & RCRA $3004(u)$ \\
\hline & 100 & Bldg. $6620 \mathrm{HE}$ Sump/Drain (TA-III) & 84,85 & RCRA $3004(u)$ \\
\hline & 102 & Radioactive Disposal (East of TA-III) & None & RCRA $3004(u)$ \\
\hline & 105 & Mercury (BIdg. 6536) (TA-III) & None & RCRA $3004(u)$ \\
\hline & 107 & Explosive Test Area (SE TA-III) & None & RCRA $3004(u)$ \\
\hline & 111 & Bldg. 6715 Sump/Drains (TA-III) & 79 & RCRA $3004(u)$ \\
\hline & 188 & $\begin{array}{l}\text { Bldg. } 6597^{\circ} \text { Aboveground Containment } \\
\text { Spil1 Tank (TA-V) }\end{array}$ & 99 & RCRA $3004(u)$ \\
\hline & 196 & Bldg. 6597 Cistern $(\mathrm{TA}-\mathrm{V})$ & None & RCRA $3004(u)$ \\
\hline & 240 & Short Sled Track & None & RCRA $3004(u)$ \\
\hline & 241 & Storage Yard & None & RCRA $3004(u)$ \\
\hline \multirow{3}{*}{$\begin{array}{l}\text { 1307-Liquid Waste } \\
\text { Disposal System }\end{array}$} & 4 & LWDS Surface Impoundments & 18,19 & RCRA $3004(u)$ \\
\hline & 5 & LWDS Drainfield (TA-V) & 16,17 & RCRA $3004(u)$ \\
\hline & 52 & LWDS Holding Tanks $(\mathrm{TA}-\mathrm{V})$ & 135 & RCRA $3004(u)$ \\
\hline
\end{tabular}


Table B-1. Environmental Restoration Program Site List by Activity Data Sheet (ADS) (Continued)

\begin{tabular}{|c|c|c|c|c|}
\hline $\begin{array}{l}\text { ADS No.- } \\
\text { Operable Unit }\end{array}$ & $\begin{array}{l}\text { Site } \\
\text { No. }\end{array}$ & Site Name & $\begin{array}{l}\text { RCRA/RFA } \\
\text { No. }\end{array}$ & Regulatory Driver \\
\hline \multirow[t]{17}{*}{$\begin{array}{l}1309-T i j e r a s \\
\text { Arroyo }\end{array}$} & 7 & $\begin{array}{l}\text { Gas Cylinder Disposal (Arroyo del } \\
\text { Coyote) }\end{array}$ & 44 & RCRA $3004(u)$ \\
\hline & 16 & Open Dumps (Arroyo del Coyote) & 21,55 & RCRA $3004(u)$ \\
\hline & 23 & $\begin{array}{l}\text { Disposal Trenches (Near Tijeras } \\
\text { Arroyo) }\end{array}$ & $47,48,49$ & RCRA $3004(u)$ \\
\hline & 40 & Oil Spill (6000 Igloo Area) & W & RCRA $3004(u)$ \\
\hline & 45 & Liquid Discharge (Behind TA-IV) & None & RCRA $3004(u)$ \\
\hline & 46 & $\begin{array}{l}\text { O1d Acid Waste Iine Outfall } \\
\text { (Tijeras Arroyo) }\end{array}$ & 112 & RCRA $3004(u)$ \\
\hline & 50 & old Centrifuge Site (TA-II) & None & RCRA $3004(u)$ \\
\hline & 77 & $\begin{array}{l}\text { Oil Surface Impoundment (TA-IV) } \\
\text { (Active) }\end{array}$ & $12,81,82$ & RCRA $3004(u)$ \\
\hline & 227 & Bunker 904 Outfall (from TA-II) & None & RCRA $3004(u)$ \\
\hline & 228 & Centrifuge Dump Site & None & RCRA $3004(u)$ \\
\hline & 229 & Storm Drain System Outfall & None & RCRA $3004(u)$ \\
\hline & 230 & Storm Drain System Outfall & None & RCRA $3004(u)$ \\
\hline & 231 & Storm Drain System Outfall & None & RCRA $3004(u)$ \\
\hline & 232 & Storm Drain System Outfall & None & RCRA $3004(u)$ \\
\hline & 233 & Storm Drain System Outfall & None & RCRA $3004(u)$ \\
\hline & 234 & Storm Drain System Outfall & None & RCRA $3004(u)$ \\
\hline & 235 & Storm Drain System Outfall & None & RCRA $3004(u)$ \\
\hline
\end{tabular}


Table B-1. Environmental Restoration Program Site List by Activity Data Sheet (ADS) (Continued)

\begin{tabular}{|c|c|c|c|c|}
\hline $\begin{array}{l}\text { ADS No.- } \\
\text { Operable Unit }\end{array}$ & $\begin{array}{l}\text { Site } \\
\text { No. }\end{array}$ & Site Name & $\begin{array}{l}\text { RCRA/RFA } \\
\text { No. }\end{array}$ & Regulatory Driver \\
\hline \multirow[t]{10}{*}{$\begin{array}{l}\text { 1332-Foothills } \\
\text { Test Area }\end{array}$} & 8 & $\begin{array}{l}\text { Open Dump (Coyote Canyon Blast } \\
\text { Area) }\end{array}$ & 23 & RCRA $3004(u)$ \\
\hline & 15 & Trash Pits (Frustration Site) & 46 & RCRA $3004(u)$ \\
\hline & 19 & $\begin{array}{l}\text { TRUPAK Boneyard Storage Area (NW of } \\
\text { Old Aerial Cable) }\end{array}$ & 65 & RCRA $3004(u)$ \\
\hline & 27 & $\begin{array}{l}\text { Bldg } 9820 \text { - Animal Disposal Pit } \\
\text { (Coyote Springs) }\end{array}$ & 42 & RCRA $3004(u)$ \\
\hline & 28 & Mine shafts & None & RCRA $3004(u)$ \\
\hline & 58 & Coyote Canyon Blast Area & $136-139$ & RCRA $3004(u)$ \\
\hline & 66 & Boxcar Site & $\mathrm{H}$ & RCRA $3004(u)$ \\
\hline & 67 & Frustration Site & None & RCRA $3004(u)$ \\
\hline & 82 & Old Aerial Cable Site Scrap & 66,67 & RCRA $3004(u)$ \\
\hline & 87 & Building 9990 (Firing Site) & $108, D$ & RCRA $30.04(u)$ \\
\hline \multirow[t]{10}{*}{$\begin{array}{l}\text { 1333-Canyons Test } \\
\text { Area }\end{array}$} & 10 & $\begin{array}{l}\text { Burial Mounds (Bunker Area North of } \\
\text { Pendulum Site) }\end{array}$ & $60,61,62,63$ & RCRA $3004(u)$ \\
\hline & 12 & $\begin{array}{l}\text { Burial site/Open Dump (Lurance } \\
\text { Canyon) (Active) }\end{array}$ & 41 & RCRA $3004(u)$ \\
\hline & 13 & $\begin{array}{l}\text { 0il Surface Impoundment (Lurance } \\
\text { Canyon Burn Site) (Active) }\end{array}$ & 13 & RCRA $3004(u)$ \\
\hline & 59 & Pendulum Site & None & RCRA $3004(u)$ \\
\hline & 60 & $\begin{array}{l}\text { Bunker Area (North of Pendulum } \\
\text { Site) }\end{array}$ & 124 & RCRA $3004(u)$ \\
\hline & 63 & Balloon Test Area & E1 & RCRA $3004(u)$ \\
\hline & 64 & Gun Site (Madera Canyon) & E2 & RCRA $3004(u)$ \\
\hline & 65 & $\begin{array}{l}\text { Lurance Canyon Explosive Test Site } \\
\text { (Active) }\end{array}$ & None & RCRA $3004(u)$ \\
\hline & 72 & Operation Beaver Site & None & RCRA $3004(u)$ \\
\hline & 81 & $\begin{array}{l}\text { New Aerial Cable Site/Burial } \\
\text { Site/Dump/Test Area (Active) }\end{array}$ & $22,50,51,59$ & RCRA $3004(u)$ \\
\hline
\end{tabular}


Table B-1. Environmental Restoration Program Site List by Activity Data Sheet (ADS) (Continued)

\begin{tabular}{|c|c|c|c|c|}
\hline $\begin{array}{l}\text { ADS No:- } \\
\text { Operable Unit }\end{array}$ & $\begin{array}{l}\text { Site } \\
\text { No. }\end{array}$ & Site Name & $\begin{array}{l}\text { RCRA/RFA } \\
\text { No. }\end{array}$ & Regulatory Driver \\
\hline \multirow[t]{4}{*}{$\begin{array}{l}\text { 1333-Canyons Test } \\
\text { Area (Continued) }\end{array}$} & 92 & $\begin{array}{l}\text { Pressure Vessel Test Site (Coyote } \\
\text { Canyon Blast Area) (Active) }\end{array}$ & 64 & RCRA $3004(u)$ \\
\hline & 93 & Madera Canyon Rocket Launcher Pads & E3 & RCRA $3004(u)$ \\
\hline & 94 & Lurance Canyon Burn Site (Active) & 119 & RCRA $3004(u)$ \\
\hline & 225 & AEC Storage Facility/Kirtland AFB & None & RCRA $3004(u)$ \\
\hline \multirow[t]{14}{*}{$\begin{array}{l}\text { 1334-Central } \\
\text { Coyote Test Area }\end{array}$} & 9 & $\begin{array}{l}\text { Burial Site/Open Dump (Schoolhouse } \\
\text { Mesa) }\end{array}$ & 43 & RCRA $3004(u)$ \\
\hline & 11 & Radioactive/Explosive Burial Mounds & $68,69,70$ & RCRA $3004(u)$ \\
\hline & 20 & $\begin{array}{l}\text { Uranium Burn Site (Schoolhouse } \\
\text { Mesa) }\end{array}$ & None & RCRA $3004(u)$ \\
\hline & 21 & Metal Scrap (Coyote Springs) & 73 & RCRA $3004(u)$ \\
\hline & 22 & Storage/Burn (West of DEER) & 106 & RCRA $3004(u)$ \\
\hline & 47 & $\begin{array}{l}\text { Doomed Bunker Outfall (South KAFB } \\
\text { Boundary) }\end{array}$ & 133,134 & RCRA $3004(u)$ \\
\hline & 57 & Workman Site & G & RCRA $3004(u)$ \\
\hline & 61 & Schoolhouse Mesa Test Site & None & RCRA $3004(u)$ \\
\hline & 62 & $\begin{array}{l}\text { Graystone Manor Site (Coyote } \\
\text { Springs) }\end{array}$ & None & RCRA $3004(u)$ \\
\hline & 68 & Old Burn Site & 111 & RCRA $\cdot 3004(u)$ \\
\hline & 69 & Firing Pits (Near USGS) & None & RCRA $3004(u)$ \\
\hline & 70 & Explosives Test Pit (Water Towers) & 127 & RGRA $3004(u)$ \\
\hline & 71 & Moonlight Shot Area & $\mathrm{F}$ & RCRA $3004(u)$ \\
\hline & 88 & $\begin{array}{l}\text { Firing Site (Southwest of Coyote } \\
\text { Springs) }\end{array}$ & $\mathrm{J}$ & RCRA $3004(u)$ \\
\hline \multirow[t]{2}{*}{$\begin{array}{l}\text { 1335-Southwest } \\
\text { Test Area }\end{array}$} & 6 & $\begin{array}{l}\text { Gas Cylinder Disposal Pit (Building } \\
9966 \text { ) }\end{array}$ & $72, \mathrm{~L}$ & RCRA $3004(u)$ \\
\hline & 14 & Burial Site (Bldg. 9920)(Active) & 45 & RCRA $3004(u)$ \\
\hline
\end{tabular}


Table B-1. Environmental Restoration Program Site List by Activity Data Sheet (ADS) (Continued)

\begin{tabular}{|c|c|c|c|c|}
\hline $\begin{array}{l}\text { ADS No.- } \\
\text { Operable Unit }\end{array}$ & $\begin{array}{l}\text { Site } \\
\text { No. }\end{array}$ & Site Name & $\begin{array}{l}\text { RCRA/RFA } \\
\text { No. }\end{array}$ & Regulatory Driver \\
\hline \multirow{21}{*}{$\begin{array}{l}\text { 1335-Southwest } \\
\text { Test Area } \\
\text { (Continued) }\end{array}$} & 17 & $\begin{array}{l}\text { Scrap Yards/Open Dump (Thunder } \\
\text { Range) }\end{array}$ & $74,75,76$ & RCRA $3004(u)$ \\
\hline & 38 & Oil Spills (Bldg. 9920) & $\mathrm{U}$ & RCRA $3004(u)$ \\
\hline & 39 & Oil Spill - Solar Facility (Active) & $\mathrm{V}$ & RCRA $3004(u)$ \\
\hline & 53 & Building 9923 & None & RCRA $3004(u)$ \\
\hline & 54 & Pickax Site (Thunder Range) & 14,15 & RCRA $3004(u)$ \\
\hline & 55 & Red Towers Site (Thunder Range) & $\mathrm{K}$ & RCRA $3004(u)$ \\
\hline & 56 & old Thunderwells (Thunder Range) & A & RCRA $3004(u)$ \\
\hline & 85 & $\begin{array}{l}\text { Firing Site (Building 9920) } \\
\text { (Active) }\end{array}$ & 125 & RCRA $3004(u)$ \\
\hline & 86 & Firing Site (Bldg. 9927) (Active) & $\mathrm{C}$ & RCRA $3004(u)$ \\
\hline & 89 & $\begin{array}{l}\text { Shock Tube Site (Thunder Range) } \\
\text { (Active) }\end{array}$ & 56 & $\operatorname{RCRA} 3004(u)$ \\
\hline & 90 & $\begin{array}{l}\text { Beryllium Firing Site (Thunder } \\
\text { Range) (Active) }\end{array}$ & B & RCRA $3004(u)$ \\
\hline & 91 & $\begin{array}{l}\text { Lead Firing Site (Thunder Range) } \\
\text { (Active) }\end{array}$ & 132 & RCRA $3004(u)$ \\
\hline & 103 & Scrap Yard (B1dg. 9939) & None & RCRA $3004(u)$ \\
\hline & 108 & Firing Site (Bldg. 9940) (Active) & None & RCRA $3004(u)$ \\
\hline & 109 & Firing Site (Bldg. 9956) (Active) & None & RCRA $3004(u)$ \\
\hline & 112 & $\begin{array}{l}\text { Explosive Contaminated Sump } \\
\text { (Building 9956) (Active) }\end{array}$ & None & RCRA $3004(u)$ \\
\hline & 115 & Firing Site (Bldg. 9930) (Active) & None & RCRA $3004(u)$ \\
\hline & 117 & Trenches (Bldg. 9939) & None & RCRA $3004(u)$ \\
\hline & 191 & Equus Red & None & RCRA $3004(u)$ \\
\hline & 193 & Sabotage Test Area (Active) & None & RCRA $3004(u)$ \\
\hline & 194 & $\begin{array}{l}\text { General Purpose Heat Source Test } \\
\text { Area (Active) }\end{array}$ & None & RCRA $3004(u)$ \\
\hline
\end{tabular}


Table B-1. Environmental Restoration Program Site List by Activity Data Sheet (ADS) (Continued)

\begin{tabular}{|c|c|c|c|c|}
\hline $\begin{array}{l}\text { ADS No.- } \\
\text { Operable Unit }\end{array}$ & $\begin{array}{l}\text { Site } \\
\text { No. }\end{array}$ & Site Name & $\begin{array}{l}\text { RCRA/RFA } \\
\text { No. }\end{array}$ & Regulatory Driver \\
\hline $\begin{array}{l}\text { 1336-Salton Sea } \\
\text { Test Base }\end{array}$ & 157 & Salton Sea Test Base & None & CERCLA \\
\hline \multirow{15}{*}{$\begin{array}{l}\text { 1337-Off-Site } \\
\text { Areas }\end{array}$} & 156 & Pagano Salvage Yard & None & CERCLA - NPL \\
\hline & 164 & Edgewood Test Site & None & CERCLA \\
\hline & 177 & Holloman AFB Bldg. 882 UST & None & NM UST LAW-Closed \\
\hline & 182 & $\begin{array}{l}\text { White Sands Missile Range (WSMR) } \\
\text { Test Areas }\end{array}$ & None & CERCLA \\
\hline & 183 & LUST Cape Canaveral old Tank & None & CERCLA \\
\hline & 184 & $\begin{array}{l}\text { Holloman AFB Bldg. 882-1 Septic } \\
\text { System }\end{array}$ & None & CERCLA \\
\hline & 199 & AEC Storage Facility/Fort Hood & None & CERCLA \\
\hline & 200 & AEC Storage Facility/Fort Campbell & None & CERCLA \\
\hline & 201 & AEC Storage Facility/Barksdale AFB & None & CERCLA \\
\hline & 202 & AEC Storage Facility/Loring AFB & None & CERCLA \\
\hline & 203 & AEC Storage Facility/Ellsworth AFB & None & CERCLA \\
\hline & 204 & AEC Storage Facility/Fairchild AFB & None & CERCLA \\
\hline & 205 & AEC Storage Facility/Travis AFB & None & CERCLA \\
\hline & 206 & AEC Storage Facility/Westover AFB & None & CERCLA \\
\hline & 207 & $\begin{array}{l}\text { AEC Storage Facility/Yorktown Naval } \\
\text { Weapons Station }\end{array}$ & None & CERCLA \\
\hline \multirow[t]{6}{*}{. } & 208 & AEC Storage Facility/Medina & None & CERCLA \\
\hline & 209 & AEC Storage Facility/Nellis AFB & None & CERCLA \\
\hline & 210 & $\begin{array}{l}\text { AEC Storage Facility/Seneca Army } \\
\text { Depot }\end{array}$ & None & CERCLA \\
\hline & 243 & Los Lunas Bombing Range, NM & None & CERCLA \\
\hline & 244 & Bernardo Test Site, NM & None & CERCLA \\
\hline & 245 & New Site & None & CERCLA \\
\hline
\end{tabular}


Table B-1. Environmental Restoration Program Site List by Activity Data Sheet (ADS) (Continued)

\begin{tabular}{|c|c|c|c|c|}
\hline $\begin{array}{l}\text { ADS No.- } \\
\text { Operable Unit }\end{array}$ & $\begin{array}{l}\text { Site } \\
\text { No. }\end{array}$ & Site Name & $\begin{array}{l}\text { RCRA/RFA } \\
\text { No. }\end{array}$ & Regulatory Driver \\
\hline \multirow{7}{*}{$\begin{array}{l}\text { 1337-Off-Site } \\
\text { Areas (Continued) }\end{array}$} & 246 & New Site & None & CERCLA \\
\hline & 247 & New Site & None & CERCLA \\
\hline & 248 & New Site & None & CERCLA \\
\hline & 249 & New Site & None & CERCLA \\
\hline & 250 & New Site & None & CERCLA \\
\hline & 251 & New Site & None & CERCLA \\
\hline & 252 & New Site & None & CERCLA \\
\hline \multirow[t]{13}{*}{$\begin{array}{l}\text { 1338-Tonopah Test } \\
\text { Range }\end{array}$} & 118 & $\begin{array}{l}\text { Underground Diesel Tank } \\
\text { (TTR) }\end{array}$ & None & CERCLA \\
\hline & 119 & Area 3 Landfills (TTR) & None & CERCLA \\
\hline & 120 & Fire Training Area (TTR) & None & CERCLA \\
\hline & 121 & $\begin{array}{l}\text { Waste Oil Sumps, Bldg } 360 \\
\text { (TTR) }\end{array}$ & None & CERCLA \\
\hline & 122 & Area 3 Septic Systems (TTR) & None & CERCLA \\
\hline & 123 & $\begin{array}{l}\text { Photo Shop French Drains } \\
\text { (TTR) }\end{array}$ & None & CERCLA \\
\hline & 124 & $\begin{array}{l}\text { High Explosive Disposal Area } \\
\text { (TTR) }\end{array}$ & None & CERCLA \\
\hline & 125 & Area 9 Landfill (TTR) & None & CERCLA \\
\hline & 126 & $\begin{array}{l}\text { Mobile Photographic Lab } \\
\text { (TTR) }\end{array}$ & None & CERCLA \\
\hline & 127 & $\begin{array}{l}\text { Non-Violent Explosive } \\
\text { Destruct System (NEDS) } \\
\text { (TTR) }\end{array}$ & None & CERCLA \\
\hline & 128 & Antelope Lake (TTR) & None & CERCLA \\
\hline & 134 & Heavy Duty Shop Drains & None & CERCLA \\
\hline & 197 & Bomblet Pit (TTR) & None & CERCLA \\
\hline
\end{tabular}


Table B-1. Environmental Restoration Program Site List by Activity Data Sheet (ADS) (Continued)

\begin{tabular}{|c|c|c|c|c|}
\hline $\begin{array}{c}\text { ADS No.- } \\
\text { Operable Unit }\end{array}$ & $\begin{array}{l}\text { Site } \\
\text { No. }\end{array}$ & Site Name & $\begin{array}{l}\text { RCRA/RFA } \\
\text { No. }\end{array}$ & Regulatory Driver \\
\hline \multirow{21}{*}{$\begin{array}{l}\text { 1338-Tonopah Test } \\
\text { Range (Continued) }\end{array}$} & 198 & Dump at Tonopah (TTR) & None & CERCLA \\
\hline & 253 & First Gas Station USTs & None & CERCLA \\
\hline & 254 & Second Gas Station USTs & None & CERCLA \\
\hline & 255 & Septic Tank 33-2 & None & CERCLA \\
\hline & 256 & Septic Tank 33-3 & None & CERCLA \\
\hline & 257 & Septic Tank 33-4 & None & CERCLA \\
\hline & 258 & Septic Tank 33-5 & None & CERCLA \\
\hline & 259 & Septic Tank 33-6 & None & CERCLA \\
\hline & 260 & Septic Tank 33-7 & None & CERCLA \\
\hline & 261 & Septic Tank 33-8 & None & CERCLA \\
\hline & 262 & Septic Tank 33-9 & None & CERCLA \\
\hline & 263 & Septic Tank 33-10 & None & CERCLA \\
\hline & 264 & Septic Tank 33-11 & None & CERCLA \\
\hline & 265 & Septic Tank 33-12 & None & CERCLA \\
\hline & 266 & Septic Tank 33-13 & None & CERCLA \\
\hline & 267 & Leach Field near Bldg. $03-83 \mathrm{~T}$ & None & CERCLA \\
\hline & 268 & Snow Removal Soil Disposal Area & None & CERCLA \\
\hline & 269 & UPS Building Drains & None & CERCLA \\
\hline & 270 & Depleted Uranium Impact Site & None & CERCLA \\
\hline & 271 & Septic Sludge Disposal Pit $\not \equiv 1$ & None & CERCLA \\
\hline & 272 & Septic Sludge Disposal Pit 非 & None & CERCLA \\
\hline
\end{tabular}


Table B-1. Environmental Restoration Program Site List by Activity Data Sheet (ADS) (Continued)

\begin{tabular}{|c|c|c|c|c|}
\hline $\begin{array}{l}\text { ADS No.- } \\
\text { Operable Unit }\end{array}$ & $\begin{array}{l}\text { Site } \\
\text { No. }\end{array}$ & Site Name & $\begin{array}{l}\text { RCRA/RFA } \\
\text { No. }\end{array}$ & Regulatory Driver \\
\hline $\begin{array}{l}\text { 1338-Tonopah Test } \\
\text { Range (Continued) }\end{array}$ & $\begin{array}{l}273 \\
274\end{array}$ & $\begin{array}{l}\text { Buried DU Artillery Round 非 } \\
\text { Buried DU Artillery Round } \# 2\end{array}$ & $\begin{array}{l}\text { None } \\
\text { None }\end{array}$ & $\begin{array}{l}\text { CERCLA } \\
\text { CERCLA }\end{array}$ \\
\hline $\begin{array}{l}\text { DOE/AL Resp.- } \\
\text { Responsibility } \\
\text { of Others }\end{array}$ & 95 & $\begin{array}{l}\text { Live Fire Range (Central } \\
\text { Traịing Academy) }\end{array}$ & None & RCRA $3004(u)$ \\
\hline \multirow{3}{*}{$\begin{array}{l}\text { DOE/NVO Resp. - } \\
\text { Responsibility } \\
\text { of Others }\end{array}$} & 129 & Cactus Springs (TTR) & None & CERCLA \\
\hline & 130 & $\begin{array}{l}\text { Roller Coaster Radioactive } \\
\text { Decontamination Area (TTR) }\end{array}$ & None & CERCLA \\
\hline & 131 & $\begin{array}{l}\text { Roller Coaster Sanitary Sewage } \\
\text { System and Lagoons (TTR) }\end{array}$ & None & CERCLA \\
\hline
\end{tabular}


Table B-1. Environmental Restoration Program Site List by Activity Data Sheet (ADS) (Concluded)

\begin{tabular}{|c|c|c|c|c|}
\hline $\begin{array}{l}\text { ADS No.- } \\
\text { Operable Unit }\end{array}$ & $\begin{array}{l}\text { Site } \\
\text { No. }\end{array}$ & Site Name & $\begin{array}{l}\text { RCRA/RFA } \\
\text { No. }\end{array}$ & Regulatory Driver \\
\hline \multirow{4}{*}{$\begin{array}{l}\text { KAFB Resp. - } \\
\text { Responsibility of } \\
\text { Others }\end{array}$} & 24 & $\begin{array}{l}\text { Landfill and Open Dump (Tijeras } \\
\text { Arroyo) }\end{array}$ & None & RCRA $3004(u)$ \\
\hline & 80 & Current KAFB Landfill & None & RCRA $3004(u)$ \\
\hline & 158 & KAFB Lagoons & None & RCRA $3004(u)$ \\
\hline & 189 & $\begin{array}{l}\text { Dry Radioactive Waste Burial, NE } \\
\text { Corner of Manzano Base }\end{array}$ & None & RCRA $3004(u)$ \\
\hline \multirow[t]{3}{*}{ N/A-Not a SWMU } & 75 & Thermal Treatment Facility & None & RCRA TSD \\
\hline & 97 & Still Photo Lab (Bldg. 802) & None & None \\
\hline & 99 & Catch Boxes (TA-I) & 114 & None \\
\hline \multirow[t]{7}{*}{$\begin{array}{l}\text { Site Dropped from } \\
\text { List-Archival }\end{array}$} & 79 & $\begin{array}{l}\text { Gas Cylinder Disposal Pit (Thunder } \\
\text { Range) (See Archives) }\end{array}$ & None & None \\
\hline & 106 & $\begin{array}{l}\text { Explosives-Contaminated Drains } \\
\text { (Bldgs.9939,9960,9965,9967) } \\
\text { (See Archives) }\end{array}$ & None & None \\
\hline & 110 & $\begin{array}{l}\text { Thunder Range (Miscellaneous) } \\
\text { (See Archives) }\end{array}$ & None & None \\
\hline & 162 & Bldg. 9962 Seepage & None & None \\
\hline & 185 & Bldg. 863, TA-I (See Archives) & None & None \\
\hline & 195 & $\begin{array}{l}\text { Experimental Test Pit } \\
\text { (See Archives) }\end{array}$ & None & None \\
\hline & 224 & Bldg. $666 \mathrm{~A}$ and 666B UST (Kauai) & None & None \\
\hline
\end{tabular}


APPENDIX C

SAMPLE COLLECTION AND ANALYSIS 
C-2 


\section{CONTENTS}

Page

C.1 Sample Collection for Radioactive Effluents . . . . . . . . . C-5

C.2 Radiochemical Analysis .................. . C-5

C.3 External Penetrating Radiation ............... . C-7

C.4 Sample Collection and Analysis for Groundwater Samples . . . . C C-8

C.4.1 Sample collection . . . . . . . . . . . . . . . C 6 -8

C.4.2 Sources of Error . . . . . . . . . . . . . . . . . . C-8

C.5 Sample Collection and Analysis for Wastewater Sampling . . . C-14

\section{TABLES}

C-1 Sampling Frequencies and Types of Analysis for Radioactive

Environmental Monitoring Program . . . . . . . . . . . C C 6

C-2 Recommended Analytical Methods, Sample Containers, Preservation

Techniques, and Holding Times . . . . . . . . . . . . . C-9

REFERENCES . . . . . . . . . . . . . . . . . . C-15 
C -4 


\section{C.1 SAMPLE COLLECTION FOR RADIOACTIVE EFFLUENTS}

Environmental samples are gathered at Sandia National Laboratories/New Mexico (SNL/NM) in accordance with the activity-specific Environment, Safety and Health (ES\&H) Standard Operating Procedure (SOP) entitled "Environmental Sampling Procedure" (SNL 1992). Native vegetation (grasses unless otherwise noted), soil, arroyo sediment, and surface water are collected twice annually: once early in the growing season (May) and once later in the growing season (August). Thermoluminescent dosimeters (TLDs) are exchanged quarterly. Sampling frequencies and types of analyses are shown in Table C-1.

Vegetation: Three adjacent sections, each 3 square yards $\left(\mathrm{yd}^{2}\right)$, are marked, and native vegetation and soil samples are composited from within these sections. Because the native desert vegetation is sparse, samples include a mixture of representative grass species unless otherwise noted. The sample mass required for analysis is 0.5 kilogram $(\mathrm{kg})$. If insufficient mass exists within the marked sections, an additional sample is collected from the immediate vicinity. Radionuclide concentrations for vegetation may vary according to species uptake, retention, deposition, and location. Each vegetation sample is cut and blended before radiochemical analysis for tritium ( $\mathrm{H}-3$ ) and gamma spectrum analysis.

Surface Water: Surface water samples are collected in acid-cleaned plastic or glass containers that have been rinsed in distilled water. A 1-liter (L) water sample is acidified immediately after collection for total water radiochemical analysis. A 2-L water sample is filtered through 0.45 -micron filter paper to characterize the material in solution. An additional 3-L of water are filtered through 0.45 -micron filter paper. The sample retained on the filter paper is used to characterize the suspended particulate matter in the water column.

Soil/Sediment: Soil samples are collected from the same three 3-yd $\mathrm{d}^{2}$ sections as the vegetation samples. Sediment samples are collected from a series of three sections in arroyo bottoms. In both cases, samples are composites of the top 5 centimeters $(\mathrm{cm})$ of material. The $0.5 \mathrm{~kg}$ of soil required for analysis is ballmilled and sieved prior to radiochemical analysis.

\section{C.2 RADIOCHEMICAL ANALYSIS}

Vegetation: Aliquots of the vegetation samples are taken for each radiochemical analysis. One aliquot of vegetation is air-dried to reach a constant dry mass, then finely ground up and placed in a 500-milliliter (mL) Marinelli beaker for gamma-spectrum analysis. A 70-gram (g) sample (250-mL calibration geometry) is used for each gamma-spectrum analysis. A second $(100-\mathrm{g})$ aliquot of vegetation is heated with cyclohexane in a $1000-\mathrm{mL}$ distillation flask. The resulting water is collected in a Barrett trap and analyzed for $\mathrm{H}-3$ with a liquid scintillation detector using a 1 -mL sample volume.

Soil: Soil and sediment samples are analyzed for uranium (U) by leaching a $2-g$ aliquot with mixed acids (nitric acid $\left[\mathrm{HNO}_{3}\right]$ /hydrofluoric acid [HF]) and diluting with water to a $10-\mathrm{mL}$ volume to extract $U$ and other acid-soluble metals. A $0.1-\mathrm{mL}$ aliquot of acid solution is diluted to $10 \mathrm{~mL}$ with 2 -normal (2N) $\mathrm{HNO}_{3}$. Fifteen $\mathrm{mL}$ of aluminum nitrate and $10 \mathrm{~mL}$ of ethyl acetate are added 
Table C-1. Sampling Frequencies and Types of Analysis for Radioactive Environmental Monitoring Program

Sample Media ${ }^{a}$

\begin{tabular}{|c|c|c|c|c|c|c|c|}
\hline \multirow[b]{2}{*}{ Parameter } & \multirow[b]{2}{*}{$\begin{array}{l}\text { Vegetation } \\
\text { May/August }\end{array}$} & \multirow[b]{2}{*}{$\begin{array}{c}\text { Sediment } \\
\text { May/August }\end{array}$} & \multirow[b]{2}{*}{$\begin{array}{c}\text { Soil } \\
\text { May/August }\end{array}$} & \multicolumn{3}{|c|}{ Surface Water } & \multirow[b]{2}{*}{ TLD } \\
\hline & & & & $\begin{array}{c}\text { Total } \\
\text { May/August }\end{array}$ & $\begin{array}{l}\text { Solution } \\
\text { May/August }\end{array}$ & $\begin{array}{c}\text { Filters }{ }^{b} \\
\text { May/August }\end{array}$ & \\
\hline Number of Stations & $42 / 42$ & $6 / 6$ & $46 / 46$ & $4 / 4$ & $4 / 4$ & $4 / 4$ & 34 \\
\hline \multicolumn{7}{|l|}{ Analysis Performed } & 136 \\
\hline Gross Alpha & -- & -- & - & 12 & 15 & 11 & $\cdots$ \\
\hline Gross Beta & -- & $\cdots$ & -- & 12 & 15 & 11 & -- \\
\hline $\mathrm{U}_{\text {total }}$ & -- & 18 & 108 & 12 & 15 & 7 & -- \\
\hline Gamma Spectroscopy & 100 & 18 & 108 & 12 & 15 & 11 & $\cdots$ \\
\hline Tritium & 100 & 18 & 108 & 6 & 15 & $\cdots$ & -- \\
\hline$\% \mathrm{H}_{2} \mathrm{O}$ & 100 & 18 & 108 & -- & -- & -- & $\cdots$ \\
\hline ICP 20 Metal Scan & - & 18 & 108 & - & -- & -- & -- \\
\hline $\begin{array}{l}\text { Total Number of } \\
\text { Analyses }\end{array}$ & 300 & 90 & 540 & 54 & 75 & 40 & \\
\hline $\begin{array}{l}\text { a Includes sample bla } \\
\text { bFilter samples for } \\
\text { "TLD = thermolumines } \\
\text { Note that "--" indic }\end{array}$ & $\begin{array}{l}\text { ks and repli } \\
\text { nalysis of } s \\
\text { ent dosimete } \\
\text { ates no analy }\end{array}$ & $\begin{array}{l}\text { cate samples } \\
\text { aspended sol } \\
\text { r. Samples } \\
\text { sis was perf }\end{array}$ & $\begin{array}{l}\text { ds } \\
\text { ollected qua } \\
\text { rmed. }\end{array}$ & terly. & & & \\
\hline
\end{tabular}


and mixed for 10 minutes (min) to selectively extract $U$ into the organic phase. Three $0.1-\mathrm{mL}$ aliquots are then fused with a sodium fluoride (NaF)/lithium fluoride (LiF) flux and tested by fluorescence.

Percent Moisture: Percent moisture for soil and sediment samples is determined by one of two methods. Either moisture balance is used to provide a direct readout of percent moisture in $10 \mathrm{~g}$ of soil, or $10 \mathrm{~g}$ of soil is dried at 110 degrees celsius $\left({ }^{\circ} \mathrm{C}\right)$ until a constant dry weight is reached. This weight is then used in calculating percent moisture.

Gamma-Spectrum Analysis: Water, soil, and vegetation samples are analyzed according to American National Standards Institute/Institute of Electrical and Electronics Engineers (ANSI/IEEE) Standard 680-1978 (R1985), "Germanium Semiconductor Detector Gamma-Ray Efficiency Determination Using a Standard Marinelli (Reentrant) Beaker Geometry" (ANSI/IEEE 1978). The samples are analyzed for gamma-emitting radionuclides by placing $\sim 450 \mathrm{~g}$ of water or $862 \mathrm{~g}$ of soil in 500-mL Marinelli beakers and counting for $1000 \mathrm{~min}$ (100 min for soil) using high-efficiency, high-resolution intrinsic germanium (Ge) or $\mathrm{Ge}$ (Li) detectors and multichannel analyzers. The 70-g vegetation samples are analyzed in a $250 \mathrm{-mL}$ geometry. The detectors are calibrated and checked routinely using either a mixed radionuclide standard obtained from the National Institute of Standards (NIST) or by using a standard for specific radionuclides traceable to the National Bureau of Standards (NBS). The data are analyzed by computer software developed by Canberra Industries.

Surface Water: Surface water samples are further analyzed for gross alpha and gross beta activity by evaporating an aliquot of water ( $100 \mathrm{~mL}$ for alpha analysis, $400 \mathrm{~mL}$ for beta analysis) on a 5 -cm-diameter stainless-steel planchet and counting for $100 \mathrm{~min}$ using a low-background, gas-proportional detector. The detector is calibrated and checked routinely using radionuclide standards traceable to the NBS.

\section{C.3 EXTERNAL PENETRATING RADIATION}

TLDs are placed at current locations. The type of TLD phosphor used is LiF in chip form. All dosimeters are placed in open areas over soil substrates 1 meter (m) above ground level. A minimum of five TLDs are placed at each location to get an estimate of the variability in TLD response at that location. TLDs are exchanged on a quarterly basis. A dedicated set of environmental TLDs is maintained for this program.

All TLDs are annealed at $400^{\circ} \mathrm{C}$ for 1 hour ( $h r$ ) before field placement. Transit controls are used to document additional exposure received during transit from SNL/NM to field locations. The TLD readout equipment is calibrated by exposing TLDs to $0,10,20,30$, and 50 milliroentgen (mR) of cesium-137 (Cs-137) midway through each quarterly field cycle. Ten TLDs are exposed at each level.

Procedures used in the SNL/NM environmental dosimetry program are documented in the dosimetry procedures manual (Thompson 1987, SNL 1994). 


\section{C.4 SAMPLE COLLECTION AND ANALYSIS FOR GROUNDWATER SAMPLES}

\section{C.4.1 Sample Collection}

Sampling protocol is as follows: Water-level measurements are taken using an electric well-sounding instrument. After four to ten well volumes are evacuated from each well, pumping continues until $\mathrm{pH}$, temperature, and conductivity stabilize. The $\mathrm{pH}$ is considered stable when three consecutive measurements agree within $0.2 \mathrm{pH}$ units. Temperature is considered stable when three consecutive measurements agree within $0.2^{\circ} \mathrm{C}$. Conductivity is considered stable when two consecutive measurements agree within 10 micromhos. All groundwater samples are collected and preserved as described in Table C- 2 . Organic sample bottles are filled with a restricted water flow to minimize splashing which would volatilize low molecular weight compounds. Volatile aromatic organics are sampled by filling the bottle until a meniscus forms above the lip of the bottle to ensure no headspace. The concern is that the volatile materials will escape into the headspace and result in an erroneous reading. Because of the depth of the groundwater wells, dissolved carbon dioxide volatilizes when the samples are brought to the surface. The evolving carbon dioxide inevitably results in a headspace in the samples. This phenomenon is documented in the field logs. The U.S. Environmental Protection Agency (EPA) is reviewing the significance of headspace in samples containing organics. Specific details on sampling procedures are described in the sampling and analysis plan (SNL 1993).

For analysis, analytical methods described in EPA documents (EPA 1983) are used. If a method is not available in either of the above, an appropriate method from one of the standard references is used.

Inorganic analyses are performed primarily using inductively coupled plasma emission spectrometry (ICP), ion chromatography, and graphite furnace atomic absorption (GFAA). Organic analyses are performed primarily using gas chromatography (GC) and GC/mass spectrometry (GC/MS).

\section{C.4.2 Sources of Error}

The purpose of statistical testing for changes in groundwater parameter values over time is to utilize a methodology that can quantitatively show a significant change at a specified level. Identifying a significant change, however, does not in itself confirm that a release from the Chemical Waste Landfill (CWL) has reached the groundwater. One must review the data, the sampling and analytical methods, and the assumptions for the statistical tests to confirm that the statistical change represents a true change.

$\mathrm{pH}$ : Because relatively small changes in parameter values may indicate a significant change, the data must reflect similar methods for collection and analysis, including calibration methods and corrections for changes in conditions affecting the measurement.

A review of field data-collection logs reveals that all $\mathrm{pH}$ measurements have been made with a field pH instrument. Potential sources of error include temperature, gas exchange, and suspension effects. The meter is calibrated in the field using standard buffer solutions. A potential source of error for the $\mathrm{pH}$ 
Table C-2. Recommended Analytical Methods, Sample Containers, Preservation Techriques, and Holding Times

\begin{tabular}{|c|c|c|c|c|c|c|}
\hline Parameter & $\begin{array}{l}\text { Method No. } \\
(\mathrm{SW}-846)^{\mathrm{a}}\end{array}$ & $\begin{array}{l}\text { Estimated Method } \\
\text { Detection Limit }\end{array}$ & $\begin{array}{l}\text { Containex } \\
\text { Type }^{c}\end{array}$ & $\begin{array}{l}\text { Minimum } \\
\text { Volume }\end{array}$ & Preservation ${ }^{d}$ & $\begin{array}{l}\text { Maximum } \\
\text { Holding Time }\end{array}$ \\
\hline \multicolumn{7}{|l|}{ Indicator Parameters } \\
\hline $\mathrm{pH}$ & 9040 & NA & $\mathrm{P}, \mathrm{G}$ & $50 \mathrm{~mL}$ & NA & Field measurement \\
\hline Specific Conductance & Modified 9050 & NA & P, G & $100 \mathrm{~mL}$ & NA & Field measurement \\
\hline $\begin{array}{l}\text { Total Organic Carbon } \\
\text { (TOC) }\end{array}$ & 9060 & $1 \mathrm{mg} / \mathrm{I}$ & P, G & $4 \times 250 \mathrm{~mL}$ & $\begin{array}{l}\text { Cool to } 4^{\circ} \mathrm{C}, \mathrm{HCL} \\
\text { or HSO to } \mathrm{pH}<2\end{array}$ & 28 days \\
\hline $\begin{array}{l}\text { Total Organic Halogens } \\
\text { (TOX) }\end{array}$ & 9020 & $30 \mu \mathrm{g} / \mathrm{L}$ & $\begin{array}{l}\text { G, AG, Teflon- } \\
\text { lined cap }\end{array}$ & $4 \times 250 \mathrm{~mL}$ & $\begin{array}{l}\text { Cool to } 4^{\circ} \mathrm{C} \text {, } \\
\text { HSO to } \mathrm{pH}<2\end{array}$ & 28 days \\
\hline \multicolumn{7}{|c|}{ Groundwatex Quality Parameters } \\
\hline Chloride & $\begin{array}{l}9250 / 9251 \text { color } \\
\text { EPA } 300.0^{\circ} \text { IC }\end{array}$ & $\begin{array}{l}1 \mathrm{mg} / \mathrm{I} \\
3 \mathrm{mg} / \mathrm{I}\end{array}$ & P, G & $50 \mathrm{~mL}$ & None required & 28 days \\
\hline Phenols & 9065 4AAP & $10 \mu \mathrm{g} / \mathrm{L}$ & $\begin{array}{l}\text { G, Teflon- } \\
\text { lined cap }\end{array}$ & $500 \mathrm{~mL}$ & $\begin{array}{l}\text { Cool to } 4^{\circ} \mathrm{C} \text {, HSO } \\
\text { to } \mathrm{pH}<4\end{array}$ & 28 days \\
\hline Sulfate & $\begin{array}{l}9035 \text { color } \\
9036 \text { color } \\
9038 \text { color } \\
\text { EPA } 300.0^{c} \text { IC }\end{array}$ & $\begin{array}{l}10 \mathrm{mg} / \mathrm{L} \\
0.5 \mathrm{mg} / \mathrm{L} \\
1 \mathrm{mg} / \mathrm{L} \\
5 \mathrm{mg} / \mathrm{L}\end{array}$ & D, G & $50 \mathrm{~mL}$ & Cool to $4^{\circ} \mathrm{C}$ & 28 days \\
\hline Iron & 6010 ICP & $0.10 \mathrm{mg} / \mathrm{L}$ & $\mathrm{P}$ & $1000 \mathrm{mI}^{\mathrm{f}}$ & HNO to $\mathrm{pH}<2$ & 6 months \\
\hline Manganese & $6010 \mathrm{ICP}$ & $0.01 \mathrm{mg} / \mathrm{L}$ & p & $1000 \mathrm{~mL}^{\mathrm{f}}$ & HNO tO $\mathrm{pH}<2$ & 6 months \\
\hline \multicolumn{7}{|c|}{ 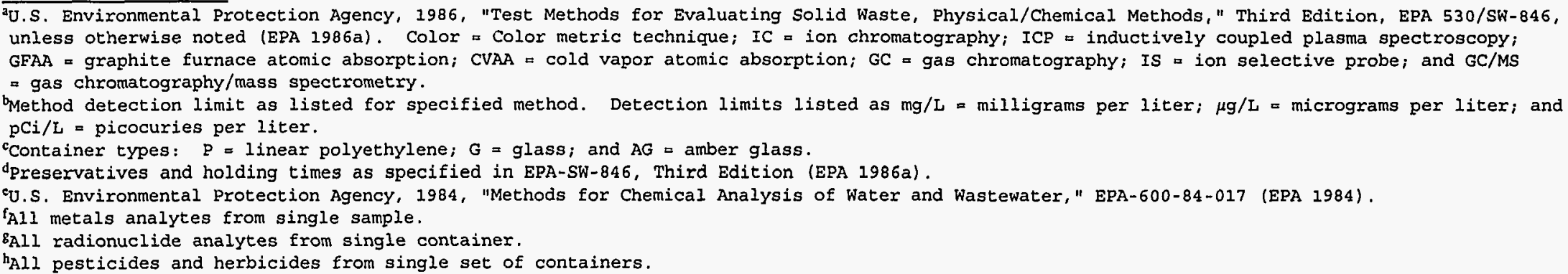 } \\
\hline
\end{tabular}


Table C-2. Recommended Analytical Methods, Sample Containers, Preservation Techniques, and Holding Times (Continued)

\begin{tabular}{|c|c|c|c|c|c|c|}
\hline Parameter & $\begin{array}{l}\text { Method No. } \\
(S W-846)^{\mathrm{a}}\end{array}$ & $\begin{array}{l}\text { Estimated Method } \\
\text { Detection Limit }\end{array}$ & $\begin{array}{l}\text { Container } \\
\text { Type }^{\mathrm{c}}\end{array}$ & $\begin{array}{l}\text { Minimum } \\
\text { Volume }\end{array}$ & Preservationd & $\begin{array}{l}\text { Maximum } \\
\text { Holding Time }\end{array}$ \\
\hline Sodium & 6010 ICP & $5.0 \mathrm{mg} / \mathrm{L}$ & $\mathrm{P}$ & $1000 \mathrm{~mL}^{\mathrm{f}}$ & HNO to $\mathrm{pH}<2$ & 6 months \\
\hline \multicolumn{7}{|c|}{ EPA Interim Drinking Water parameters } \\
\hline Arsenic & 7060 GFAA & $0.005 \mathrm{mg} / \mathrm{L}$ & $\mathrm{P}$ & $1000 \mathrm{~mL}^{\mathrm{f}}$ & HNO to $\mathrm{pH}<2$ & 6 months \\
\hline Barium & 6010 ICP & $0.01 \mathrm{mg} / \mathrm{L}$ & $\mathrm{P}$ & $1000 \mathrm{~mL}^{\mathrm{f}}$ & HNO to $\mathrm{pH}<2$ & 6 months \\
\hline Cadmium & $\begin{array}{l}7131 \mathrm{GFAA} \\
6010 \mathrm{ICP}\end{array}$ & $\begin{array}{l}0.0005 \mathrm{mg} / \mathrm{L} \\
0.005 \mathrm{mg} / \mathrm{L}\end{array}$ & $\mathrm{P}$ & $1000 \mathrm{~mL}^{f}$ & HNO to $\mathrm{pH}<2$ & 6 months \\
\hline Total Chromium & $\begin{array}{l}7191 \text { GFAA } \\
6010 \text { ICP }\end{array}$ & $\begin{array}{l}0.001 \mathrm{mg} / \mathrm{L} \\
0.01 \mathrm{mg} / \mathrm{L}\end{array}$ & $\mathrm{P}$ & $1000 \mathrm{~mL}^{\mathrm{f}}$ & HNO to $\mathrm{pH}<2$ & 6 months \\
\hline Lead & 7421 GFAA & $0.005 \mathrm{mg} / \mathrm{L}$ & $\mathrm{p}$ & $1000 \mathrm{~mL}^{\mathrm{f}}$ & HNO to $\mathrm{pH}<2$ & 6 months \\
\hline Mercury & 7470 CVAA & $0.0002 \mathrm{mg} / \mathrm{L}$ & P, G & $1000 \mathrm{~mL}^{\mathrm{f}}$ & HNO to $\mathrm{pH}<2$ & $\begin{array}{l}13 \text { days in plastic } \\
38 \text { days in glass }\end{array}$ \\
\hline Selenium & 7740 GFAA & $0.002 \mathrm{mg} / \mathrm{L}$ & $\mathrm{P}$ & $1000 \mathrm{~mL}^{\mathrm{f}}$ & HNO to $\mathrm{pH}<2$ & 6 months \\
\hline Silver & $\begin{array}{l}\text { EPA } 272.2^{e} \text { GFAA } \\
6010 \text { ICP }\end{array}$ & $\begin{array}{l}0.0005 \mathrm{mg} / \mathrm{L} \\
0.01 \mathrm{mg} / \mathrm{L}\end{array}$ & P Dark, AG & $1000 \mathrm{~mL}^{\mathrm{f}}$ & HNO to $\mathrm{pH}<2$ & 6 months \\
\hline Gross Alpha & 9310 & $3 \mathrm{pCi} / \mathrm{L}$ & $\mathrm{P}$ & 1 gal & HNO to $\mathrm{pH}<2$ & 6 months \\
\hline Gross Beta & 9310 & $4 \mathrm{pCi} / \mathrm{L}$ & $\mathrm{P}$ & $1 \mathrm{gal}$ & HNO to $\mathrm{pH}<2$ & 6 months \\
\hline
\end{tabular}

dU.S. Environmental Protection Agency, 1986, "Test Methods for Evaluating Solid waste, Physical/Chemical Methods, "Third Edition, EPA-Sw-846, unless otherwise noted (EPA 1985a). Color = Color metric technique; IC = ion chromatography; ICP = inductively coupled plasma spectroscopy; GFAA = graphite furnace atomic absorption; CVAA = cold vapor atomic absorption; GC = gas chromatography; IS = ion selective probe; and GC/MS = gas chromatography/mass spectrometry.

bMethod detection limit as listed for specified method. Detection limits listed as $\mathrm{mg} / \mathrm{L}=$ milligrams per liter; $\mu \mathrm{g} / \mathrm{L}=\mathrm{micrograms}$ per $\mathrm{liter}$; and $\mathrm{pCi} / \mathrm{L}=$ picocuries per liter.

Container Types: $P=$ linear polyethylene; $G=$ glass; and $A G=$ amber glass .

dpreservatives and holding times as specified in EPA-SW-846, Third Edition (EPA 1986a).

U.S. Environmental Protection Agency, 1984, "Methods for Chemical Analysis of water and wastewater," EPA-600-84-017 (EPA 1984).

$f_{A l l}$ metals analytes from single sample.

$\mathrm{g}_{\mathrm{All}}$ radionuclide analytes from single container.

$h_{A l l}$ pesticides and herbicides from single set of containers. 
Table C-2. Recommended Analytical Methods, Sample Containers, Preservation Techniques, and Holding Times (Continued)

\begin{tabular}{|c|c|c|c|c|c|c|}
\hline Parameter & $\begin{array}{l}\text { Method No. } \\
(\text { SW-846) }\end{array}$ & $\begin{array}{l}\text { Estimated Method } \\
\text { Detection Limit }\end{array}$ & $\begin{array}{l}\text { Container } \\
\text { Type }^{c}\end{array}$ & $\begin{array}{l}\text { Minimum } \\
\text { Volume }\end{array}$ & Preservation $^{d}$ & $\begin{array}{l}\text { Maximum } \\
\text { Holding Time }\end{array}$ \\
\hline Total Radium & 9315 & $3 \mathrm{pCi} / \mathrm{L}$ & P, G & 1 gals & HNO to $\mathrm{pH}<2$ & 6 months \\
\hline Endrin & $8080 \mathrm{GC}$ & $0.10 \mu \mathrm{g} / \mathrm{L}$ & AG, Teflon-lined cap & $2 \times 1000 \mathrm{~mL}^{\mathrm{h}}$ & $\begin{array}{l}\text { Cool to } 4^{\circ} \mathrm{C} \text {, } \\
\text { pH } 5-9\end{array}$ & $\begin{array}{l}7 \text { days to extraction, } \\
40 \text { days after extrac- } \\
\text { tion }\end{array}$ \\
\hline Lindane (q-BHC) & $8080 \mathrm{GC}$ & $0.05 \mu \mathrm{g} / \mathrm{L}$ & AG, Teflon-lined cap & $2 \times 1000 \mathrm{~mL}^{\mathrm{h}}$ & $\begin{array}{l}\text { Cool to } 4^{\circ} \mathrm{C} \text {, } \\
\text { pH } 5-9\end{array}$ & $\begin{array}{l}7 \text { days to extraction, } \\
40 \text { days after extrac- } \\
\text { tion }\end{array}$ \\
\hline Methoxychlor & $8080 \mathrm{GC}$ & $0.5 \mu \mathrm{g} / \mathrm{L}$ & AG, Teflon-lined cap & $2 \times 1000 \mathrm{~mL}^{\mathrm{h}}$ & $\begin{array}{l}\text { Cool to } 4^{\circ} \mathrm{C} \text {, } \\
\text { pH } 5-9\end{array}$ & $\begin{array}{l}7 \text { days to extraction, } \\
40 \text { days after extrac- } \\
\text { tion }\end{array}$ \\
\hline Toxaphene & $8080 \mathrm{GC}$ & $1.0 \mu \mathrm{g} / \mathrm{L}$ & AG, Teflon-lined cap & $2 \times 1000 \mathrm{~mL}^{\mathrm{h}}$ & $\begin{array}{l}\text { Cool to } 4^{\circ} \mathrm{C} \text {, } \\
\text { pH } 5-9\end{array}$ & $\begin{array}{l}7 \text { days to extraction, } \\
40 \text { days after extrac- } \\
\text { tion }\end{array}$ \\
\hline $2,4-D$ & $8150 \mathrm{GC}$ & $20 \mu \mathrm{g} / \mathrm{L}$ & AG, Teflon-lined cap & $2 \times 1000 \mathrm{~mL}^{\mathrm{h}}$ & $\begin{array}{l}\text { Cool to } 4^{\circ} \mathrm{C} \text {, } \\
\text { pH } 5-9\end{array}$ & $\begin{array}{l}7 \text { days to extraction, } \\
40 \text { days after extrac- } \\
\text { tion }\end{array}$ \\
\hline $2,4,5$-TP Silvex & $8150 \mathrm{GC}$ & $10 \mu \mathrm{g} / \mathrm{L}$ & AG, Teflon-lined cap & $2 \times 1000 \mathrm{~mL}^{\mathrm{h}}$ & $\begin{array}{l}\text { Cool to } 4^{\circ} \mathrm{C} \\
\text { pH } 5-9\end{array}$ & $\begin{array}{l}7 \text { days to extraction, } \\
40 \text { days after extrac- } \\
\text { tion }\end{array}$ \\
\hline \multicolumn{7}{|c|}{ 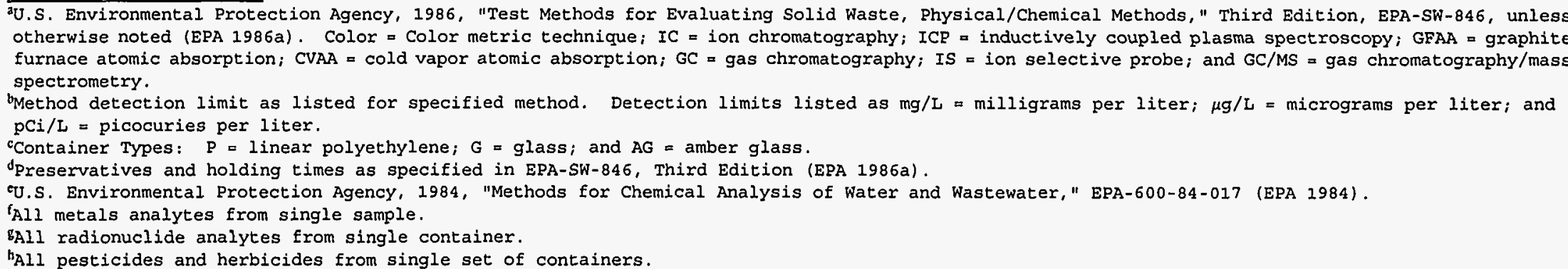 } \\
\hline
\end{tabular}


Table C-2. Recommended Analytical Methods, Sample Containers, Preservation Techniques, and Holding Times (Concluded)

\begin{tabular}{|c|c|c|c|c|c|c|}
\hline Parameter & $\begin{array}{l}\text { Method No. } \\
(S W-846)^{2}\end{array}$ & $\begin{array}{l}\text { Estimated Method } \\
\text { Detection Limit }\end{array}$ & $\begin{array}{l}\text { Container } \\
\text { Type }^{c}\end{array}$ & $\begin{array}{l}\text { Minimum } \\
\text { Volume }\end{array}$ & Preservation ${ }^{\mathrm{d}}$ & $\begin{array}{l}\text { Maximum } \\
\text { Holding Timed }\end{array}$ \\
\hline Turbidity & EPA $180.1^{\circ}$ & $<1$ NTU & $P, G$ & $200 \mathrm{~mL}$ & Cool to $4^{\circ} \mathrm{C}$ & $48 \mathrm{hr}$ \\
\hline Nitrate (as Nitrogen) & $\begin{array}{l}\text { EPA } 300.0^{\mathrm{e}} \text { IC } \\
\text { EPA } 353.2^{\mathrm{e}} \text { color }\end{array}$ & $\begin{array}{l}0.1 \mathrm{mg} / \mathrm{L} \\
0.1 \mathrm{mg} / \mathrm{L}\end{array}$ & $\begin{array}{l}P, G \\
P, G\end{array}$ & $\begin{array}{l}100 \mathrm{~mL} \\
100 \mathrm{~mL}\end{array}$ & $\begin{array}{l}\text { Cool to } 4^{\circ} \mathrm{C} \\
\text { Cool to } 4^{\circ} \mathrm{C} \text {, HSO } \\
\text { to } \mathrm{pH}<2\end{array}$ & $\begin{array}{l}48 \mathrm{hr} \\
28 \text { days }\end{array}$ \\
\hline $\begin{array}{l}\text { Total Coliform Bacteria } \\
\text { Supplemental Parameters }\end{array}$ & 9132 & $<2$ colony $/ 100 \mathrm{~mL}$ & P/G (sterilized) & $200 \mathrm{~mL}$ & $\mathrm{CoOl}$ to $4^{\circ} \mathrm{C}$ & $6 \mathrm{hr}$ \\
\hline volatile organics & 8240 GCMS & $5-100 \mu \mathrm{g} / \mathrm{L}$ & G, Teflon-lined Septa & $3 \times 40 \mathrm{~mL}$ & $\begin{array}{l}\text { Cool to } 4^{\circ} \mathrm{C}, 4 \\
\text { drops HCL optional }\end{array}$ & 14 days \\
\hline Semivolatile organics & 8270 GCMS & $10-50 \mu \mathrm{g} / \mathrm{L}$ & AG & $\begin{array}{l}2 \times 1 / 2 \mathrm{gal} \\
\text { or } 1 \times 1 \mathrm{gal}\end{array}$ & Cool to $4^{\circ} \mathrm{C}$ & $\begin{array}{l}7 \text { days to extraction, } \\
40 \text { days after ex- } \\
\text { traction }\end{array}$ \\
\hline
\end{tabular}

aU.S. Environmental Protection Agency, 1986, "Test Methods for Evaluating Solid Waste, Physical/Chemical Methods," Third Edition, EPA-SW-846, unless otherwise noted (EPA 1986a). Color = Color metric technique; IC = ion chromatography; ICP = inductively coupled plasma spectroscopy; GFAA = graphite furnace atomic absorption; $\mathrm{CVAA}=$ cold vapor atomic absorption; $\mathrm{GC}=$ gas chromatography; IS = ion selective probe; and $\mathrm{GC} / \mathrm{MS}=$ gas chromatography/mass spectrometry.

bethod detection limit as listed for specified method. Detection limits listed as $\mathrm{mg} / \mathrm{L}=$ milligrams per liter; $\mu \mathrm{g} / \mathrm{L}=\mathrm{micrograms}$ per liter; and $\mathrm{pCi} / \mathrm{L}=$ picocuries per liter.

$\mathrm{pCi} / \mathrm{L}=$ picocuries per liter.
${ }^{c}$ Container Types: $P=$ linear polyethylene; $G=$ glass; and $A G=$ amber glass.

Container Types: $P=$ linear polyethylene; $G=$ glass; and $A G=$ amber glass.
dPreservatives and holding times as specified in EPA-SW-846, Third Edition (EPA 1986a).

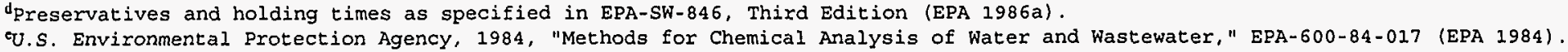

$f_{A 11}$ metals analytes from single sample.

$B_{\text {All }}$ radionuclide analytes from single container.

All pesticides and herbicides from single set of containers. 
measurements is thought to result from the calibration procedure when the buffer solutions are at a different temperature than the groundwater being measured. A review of the sensitivity of $\mathrm{pH}$ to temperature changes, however, shows that the measurement is somewhat insensitive to temperature changes. Standard buffer solutions in the $\mathrm{pH}$ range near 7 will have a variation in $\mathrm{pH}$ of 0.02 to 0.03 units over a temperature range of $10^{\circ}$ to $50^{\circ} \mathrm{C}$. The field measurements of temperature of the solutions measured for $\mathrm{pH}$ range from $15^{\circ}$ to $30^{\circ} \mathrm{C}$.

Because it is impractical to make in situ measurements of groundwater $\mathrm{pH}$, samples must be brought to the surface. Two methods are used to evacuate and sample the wells: (1) pumping with a small-diameter piston pump, and (2) bailing. The potential for gas exchange exists when the groundwater flows into the wellbore and continues until the groundwater sample is measured at the surface. The use of the piston pump to purge and sample wells reduces groundwater contact with the atmosphere. Generally, water is pumped into a sample container, and the $\mathrm{pH}$ is measured as soon as practical. Water collected by bailing in the wellbore is generally surged and mixed with the atmosphere existing in the wellbore above the water. The water within the bailer is then removed and placed into a bucket.

Wells MW-1 and BW-1, both 2-inch-diameter wells that do not allow a pump to pass restricted zones within the casing, must be bailed for purging and sampling. The water in wells $\mathrm{MW}-1$ and $\mathrm{BW}-1$ is extremely turbid; therefore, the suspension is allowed to settle for $-15 \mathrm{~min}$ before bailing. The loss or gain of certain volatile constituents that participate in controlling the solution $\mathrm{pH}$, such as carbon dioxide $\left(\mathrm{CO}_{2}\right)$ and hydrogen sulfide $\left(\mathrm{H}_{2} \mathrm{~S}\right)$, will alter the $\mathrm{pH}$ as a time-dependent phenomenon. The absorption of $\mathrm{CO}_{2}$ into the solution will generate carbonic acid, release hydrogen ions from carbonate-bicarbonate reactions, and cause a decrease in the $\mathrm{pH}$. The equilibrium $\mathrm{pH}$ from partial pressure of atmospheric $\mathrm{CO}_{2}$ is about 5 (Garrels and Christ 1965). Currently, the magnitude of this potential source of error for groundwater is not understood; however, a standard geochemistry textbook reveals a change of 1.5 $\mathrm{pH}$ units for a de-aerated alkaline solution allowed to absorb atmospheric constituents (Garrels and Christ 1965).

The effects of mineral suspensions on the results of $\mathrm{pH}$ determination are also an important source of error. Carbonate minerals such as calcite (limestone) and aragonite (caliche) hydrolyze in solution, releasing carbonate. The carbonate removes hydrogen ions from the solution, using the same carbonatebicarbonate reaction noted above, and acts to increase the $\mathrm{pH}$. The equilibrium $\mathrm{pH}$ due to calcite is $\sim 9.5$ (Garrels and Christ 1965).

The negative charges on the surfaces of clays are also capable of removing hydrogen ions from solutions and increasing the pH. A small laboratory experiment was performed to determine the effect of a clay (found near the water table during the drilling of well MW-IA, 50 feet [ft] to the west of MW-1) on the $\mathrm{pH}$ of distilled water. The results showed that the addition of small amounts of the clay would Iinearly increase the $\mathrm{pH}$ from 7.2 to 8.9 . Due to the large screen size and the necessity to bail MW-1 for purging and sampling, well MW-1 showed very high turbidity levels. 
Specific Conductivity: All data for the specific conductance parameter are found in the field data-collection logs. Temperature differences of $1^{\circ} \mathrm{C}$ can lead to about a 2-percent difference in the value of specific conductance. These data were not corrected for temperature in the field but were corrected to $25^{\circ} \mathrm{C}$ prior to reporting.

Statistical Assumptions: The statistical procedure used to test for significant change is specified in the groundwater monitoring regulations. A critical review of the assumptions that support this statistical test must be performed to determine whether the assumptions are upheld. If not, the validity of the conclusion of the statistical test must be questioned.

The Cochran's Approximation to the Behren-Fisher (CABF) t-test method was developed to analyze independent samples with unequal population variances. Because of the inherently high false-positive rate, there was sufficient criticism of this method that the EPA issued a final rule October 11, 1988, amending the statistical tests required for groundwater monitoring (EPA 1988). The rule specifies five other tests, more appropriate to groundwater monitoring than the CABF method, for permitted facilities under 40 Code of Federal Regulations (CFR) 264. EPA concluded that most land disposal facilities would have permits by November 1988 and thus there was no need to modify the interim status regulations of $40 \mathrm{CFR} 265$.

Two sources have identified potential problems using CABF as a method to detect releases from a hazardous waste management unit. EPA "RCRA Technical Enforcement Guidance Document" discusses t-tests available for facilities under interim status (EPA 1986b). In that document, the authors detail an alternative t-test, the Averaged Replicate (AR) t-test, that is recommended as more appropriate than the CABF $t$-test method for groundwater monitoring.

The October 1988 final rule on statistical methods for groundwater monitoring points out several reasons for rejecting the CABF t-test method: (1) it is not appropriate for the replicate sampling method required by the regulations, (2) it does not adequately consider the number of comparisons that must be made under the regulations, and (3) it has no control for seasonal variations in parameter values (EPA 1988). Concern arose regarding potential false-positive errors and false-negative errors exceeding reasonable rates for a regulated concern. As a result, four specific statistical tests, not including the CABF or the AR t-tests, and an option for the owner/operator to propose any other test, were issued as a final rule on October 11, 1988. Until SNL/NM certifies closure of the CWL and becomes a permitted facility requiring postclosure monitoring, the statistical tests must remain t-tests as specified in 40 CFR 265 for interim status facilities or by the New Mexico Environment Department (NMED).

\section{C.5 SAMPLE COLLECTION AND ANALYSIS FOR WASTEWATER SAMPLING}

Complete documentation for the wastewater sampling program can be found in the Wastewater Monitoring Program Quarterly Reports (IT 1993). These documents describe the methods and procedures used for the samples collected from the sampling locations (see Table 6-2 of Chapter 6). 


\section{REFERENCES}

ANSI/IEEE 1978: American National Standards Institute/Institute of Electrical and Electronics Engineers, "Germanium Semiconductor Detector Gamma Ray Efficiency Determination Using a Standard Marinelli (Reentrant) Beaker Geometry," ANSI/IEEE Standard 680-1978 (R1985), ANSI, New York, NY.

40 CFR 264, 1980. "Standards for Owners and Operators of Hazardous Waste Treatment, Storage, and Disposal Facilities, "including Subpart F, Section 264.101, "Releases for Solid Waste Management Units," as amended June 10, 1994.

40 CFR 265, 1980. "Interim Status Standards for Owners and Operators of Hazardous Waste Treatment, Storage, and Disposal Facilities," as amended December 23, 1991.

EPA 1983: U.S. Environmental Protection Agency, "Methods for Chemical Analysis of Water and Wastes," EPA-600/4-79-020, EPA, Washington, DC (1983).

EPA 1984: U.S. Environmental Protection Agency, "Methods for Chemical Analysis of Water and Waste Water," EPA-600-84-017, EPA, Washington, DC (1984).

EPA 1986a: U.S. Environmental Protection Agency, "Test Methods for Evaluating Solid Waste, Physical/Chemical Methods, Third Edition," EPA-SW-846, EPA, Washington, DC (1986).

EPA 1986b: U.S. Environmental Protection Agency, "RCRA Technical Enforcement Guidance Document (TEGD)," OSWER-9950.1, EPA, Washington, DC (1986).

EPA 1988: U.S. Environmental Protection Agency, "Statistical Methods for Evaluating Ground-Water Monitoring Data From Hazardous Waste Facilities," 53 FR 39720, EPA, Office for Water, Office of Solid Waste (Final Rule October 11,1988 ).

Garrels and Christ 1965: Garrels, R. M., and C. L. Christ, Solutions, Minerals and Equilibria, New York, NY: Harper and Row (1965).

IT 1993: International Technology Corporation, "Wastewater Monitoring Program Quarterly Reports for 1993" prepared for Sandia National Laboratories, Albuquerque, NM (1993).

SNL 1992: Sandia National Laboratories, "Environmental Sampling Procedure," SP471991, Environmental Protection Department (7725), Sandia National Laboratories, Albuquerque, NM (1992).

SNL 1993: Sandia National Laboratories, "Groundwater Surveillance Program, Sampling and Analysis Plan, March 1993 (Draft)," Sandia National Laboratories, Albuquerque, NM (1993). 
SNL 1994: Sandia National Laboratories, "Environmental Dosimetry Processing," Personnel Radiation Dosimetry Program (PRDP)-30-04, Sandia National Laboratories, Albuquerque, NM (April 21, 1994).

Thompson 1987: Thompson, D. J., "Description and Procedures of the

Environmental Radiation Dosimetry Program," SAND87-1916, Sandia National Laboratories, Albuquerque, NM (August 1987). 


\section{APPENDIX D}

\section{MINIMUM DETECTION LIMITS}


D- 2 


\section{CONTENTS}

TABLE

Page

D-1 Detection Limits for Selected Radiochemical Analysis . . . . . D-5 REFERENCE . . . . . . . . . . . . . . . . . . . . . . . . . D-6 


$$
\text { D }-4
$$


Table D-1. Detection Limits for Selected Radiochemical Analysis ${ }^{a}$

\begin{tabular}{|c|c|c|c|c|}
\hline \multirow[b]{2}{*}{ Analysis } & \multicolumn{2}{|c|}{ Sample } & \multirow[b]{2}{*}{$\begin{array}{l}\text { Detection } \\
\text { Limit }\end{array}$} & \multirow[b]{2}{*}{ Count Time } \\
\hline & Media & Minimum Size & & \\
\hline \multirow[t]{3}{*}{$\mathrm{H}-3$} & Water & $10 \mathrm{~mL}$ & $0.3 \mathrm{pCi} / \mathrm{mL}$ & $125 \mathrm{~min}$ \\
\hline & Vegetation & $10 \mathrm{~mL}^{\mathrm{b}}$ & $0.3 \mathrm{pCi} / \mathrm{mL}^{\mathrm{b}}$ & 125 min \\
\hline & Soil & $10 \mathrm{~mL}^{\mathrm{b}}$ & $0.3 \mathrm{pCi} / \mathrm{mL}^{\mathrm{b}}$ & $125 \min$ \\
\hline \multirow[t]{2}{*}{$\mathrm{U}_{\text {tot }}$} & Water & $100 \mathrm{~mL}$ & $0.002 \mathrm{mg} / \mathrm{L}$ & $\mathrm{N} / \mathrm{A}^{\mathrm{c}}$ \\
\hline & Soil & $100 \mathrm{~g}$ & $0.1 \mu \mathrm{g} / \mathrm{g}$ & $\mathrm{N} / \mathrm{A}$ \\
\hline Gross Alpha & Water & $100 \mathrm{~mL}$ & $3 \mathrm{pCi} / \mathrm{L}$ & $100 \mathrm{~min}$ \\
\hline Gross Beta & Water & $100 \mathrm{~mL}$ & $4 \mathrm{pCi} / \mathrm{L}$ & $100 \mathrm{~min}$ \\
\hline $\begin{array}{l}\text { Gamma } \\
\text { Spectral }\end{array}$ & - & -- & -- & $4 \mathrm{hr}$ \\
\hline \multicolumn{5}{|c|}{$\begin{array}{l}{ }^{\mathrm{a}} \text { ANSI (1989). } \\
\text { bExtracted water. } \\
{ }^{\mathrm{c}} \text { Not applicable. } \\
\text { dDetection limit and required sample size vary depending on radionuclide } \\
\text { and media of interest. }\end{array}$} \\
\hline
\end{tabular}




\section{REFERENCE}

ANSI 1989: American National Standards Institute, "Performance Criteria for Radiobioassay," ANSI-N13.30-DRAFT-89, ANSI, New York, NY (1989). 
APPENDIX E

QUALITY ASSURANCE DATA 
E-2 


\section{CONTENTS}

TABLES

Page

E-1 Analytical Laboratories Used During 1993 . . . . . . . . . E-5

E-2 Determination of Sample Variability in Replicate Samples

for Selected Radionuclide Analysis in Soil, Sediment, and

Vegetation for May 1993 . . . . . . . . . . . . . . . . . E-6

E-3 Determination of Sample Variability in Replicate Samples for

Selected Radionuclide Analysis in Soil, Sediment, and Vegetation

for August 1993 . . . . . . . . . . . . . . . . . . . . . . . . E-7

E-4 Determination of Sample Variability in Replicate Samples

for Selected Radionuclides Analysis in Surface Water for

May and August 1993 ... . . . . . . . . . . . . . E-8

E-5 1993 Quality Assurance Results for Selected Radiochemical

Analysis Environmental Protection Agency/Accu-Labs Research,

Inc., Intercomparison Study, Cross-Check Results . . . . . . . E-9

E-6 U.S. Department of Energy Operational Safety, Health and

Environment Division, Quality Assessment Program (QAP),

Accu-Labs Research, Inc., Results . . . . . . . . . . . . E-10

REFERENCE . . . . . . . . . . . . . . . . . . . . E-12 
E-4 
Table E-1. Analytical Laboratories Used During 1993

Accu-Labs Research, Inc.

Allied Signal Aerospace Company

Archive Laboratory

Assaigai Analytical Laboratories, Inc.

Environmental Control Technology Corporation (ENCOTEC)

Enseco-Rocky Mountain Analytical Laboratory (RMAL)

Iowa State University

IT Analytical Services, Cincinnati

IT Radiological Sciences Laboratory

Inhalation Toxicology Research Institute (ITRI)

New Jersey Institute of Technology

New Mexico State University

Southern Methodist University

Sandia National Laboratories/New Mexico (SNL/NM)

Daniel B. Stephens \& Associates

Texas Bureau of Economic Geology

TMA/Eberline

University of Texas 
Table E-2. Determination of Sample Variability in Replicate Samples for Selected Radionuclide Analysis in Soil, Sediment, and Vegetation for May $1993^{a, b}$

\begin{tabular}{|c|c|c|c|c|c|c|}
\hline $\begin{array}{l}\text { Sample } \\
\text { Matrix }\end{array}$ & Location & $\begin{array}{l}\text { Number } \\
\text { of } \\
\text { Samples }\end{array}$ & $\begin{array}{l}\mathrm{U}(\mu \mathrm{g} / \mathrm{g}) \\
\overline{\mathrm{x}} \pm \mathrm{s}_{\overline{\mathrm{x}}} \\
\quad(\mathrm{CV})^{\mathrm{c}}\end{array}$ & $\begin{array}{l}\mathrm{H}-3(\mathrm{pCi} / \mathrm{mL}) \\
\overline{\mathrm{x}} \pm \mathrm{s}_{\overline{\mathrm{x}}} \\
(\mathrm{CV})^{\mathrm{c}}\end{array}$ & $\begin{array}{l}\mathrm{Cs}-137(\mathrm{pCi} / \mathrm{g}) \\
\overline{\mathrm{x}} \pm \mathrm{s}_{\overline{\mathrm{x}}} \\
(\mathrm{CV})^{\mathrm{c}}\end{array}$ & $\begin{array}{l}\mathrm{K}-40(\mathrm{pCi} / \mathrm{g}) \\
\overline{\mathrm{x}} \pm \mathrm{s}_{\overline{\mathrm{x}}} \\
(\mathrm{CV})^{\mathrm{c}}\end{array}$ \\
\hline Soil & $2 \mathrm{NE}$ & 3 & $0.7 \pm 0.2(31)$ & $47 \pm 12(25)$ & $0.12 \pm 0.03(0.25)$ & $18 \pm 0(-)^{d}$ \\
\hline Soil & 7 & 3 & $0.8 \pm 0.2(20)$ & $0.18 \pm 0.11(61)$ & $0.92 \pm 0.16(17)$ & $18 \pm 1(3)$ \\
\hline Soil & 11 & 3 & $1.0 \pm 0.4(51)$ & $0.00 \pm 0.06(1700)$ & $0.05 \pm 0.05(92)$ & $19 \pm 1(6)$ \\
\hline Soil & 53 & 3 & $1.0 \pm 0.2(20)$ & $0.06 \pm 0.02(27)$ & $0.11 \pm 0.03(27)$ & $17 \pm 1(7)$ \\
\hline Sediment & 11 & 3 & $0.9 \pm 0.2(22)$ & $-0.07 \pm 0.04(57)$ & $0.01 \pm 0.02(200)$ & $19 \pm 2(11)$ \\
\hline Vegetation & $2 \mathrm{NE}$ & 3 & - & $10 \pm 2(16)$ & - & $6 \pm 2(27)$ \\
\hline Vegetation & 7 & 3 & $\cdots$ & $-0.07 \pm 0.03(44)$ & -- & $1 \pm 0(-)^{d}$ \\
\hline Vegetation & 11 & 3 & - & $0.03 \pm 0.10(340)$ & - & $20 \pm 4(20)$ \\
\hline Vegetation & 53 & 3 & -- & $-0.03 \pm 0.06(210)$ & -- & $1 \pm 0(87)$ \\
\hline \multicolumn{7}{|c|}{$\begin{array}{l}\text { aAll individual results are listed in Tables } F-1, F-3 \text {, and } F-7 \text { of Appendix } F \text {. } \\
\text { bWhere values are reported as less than detection limit, the detection limit is used in averaging. } \\
\text { cCoefficient of Variation (CV) }=\text { (Standard deviation } \div \text { mean) } \times 100 \text {. } \\
\text { dAll individual values are identical. }\end{array}$} \\
\hline
\end{tabular}


Table E-3. Determination of Sample Variability in Replicate Samples for Selected Radionuclide Analysis in Soil, Sediment, and Vegetation for August 1993a,b

\begin{tabular}{|c|c|c|c|c|c|c|}
\hline $\begin{array}{l}\text { Sample } \\
\text { Matrix }\end{array}$ & Location & $\begin{array}{l}\text { Number } \\
\text { of } \\
\text { Samples }\end{array}$ & $\begin{array}{l}\mathrm{U}(\mu \mathrm{g} / \mathrm{g}) \\
\overline{\mathrm{x}} \pm \mathrm{s}_{\overline{\mathrm{x}}} \\
(\mathrm{CV})^{\mathrm{c}}\end{array}$ & $\begin{array}{c}\mathrm{H}-3(\mathrm{pCi} / \mathrm{mL}) \\
\overline{\mathrm{x}} \pm \mathrm{s}_{\overline{\mathrm{x}}} \\
(\mathrm{CV})^{\mathrm{c}}\end{array}$ & $\begin{array}{c}C s-137\left(p^{C i} i / g\right) \\
\bar{x} \pm s_{\bar{x}} \\
(C V)^{c}\end{array}$ & $\begin{array}{c}\mathrm{K}-40(\mathrm{pCi} / \mathrm{g}) \\
\overline{\mathrm{x}} \pm \mathrm{s}_{\overline{\mathrm{x}}} \\
(\mathrm{CV})^{\circ}\end{array}$ \\
\hline Soil & $2 \mathrm{NE}$ & 3 & $0.8 \pm 0.1$ (12) & $12 \pm 0.6(4.7)$ & $0.04 \pm 0.04(87)$ & $18 \pm 1(3)$ \\
\hline Soil & 7 & 3 & $0.9 \pm 0.1$ (11) & $-0.05 \pm 0.04(87)$ & $0.52 \pm 0.06(11)$ & $19 \pm 0(-)^{d}$ \\
\hline Soil & 11 & 3 & $1.2 \pm 0.2(17)$ & $0.2 \pm 0.05(26)$ & $0.05 \pm 0.04(87)$ & $18 \pm 1(3)$ \\
\hline Soil & 53 & 3 & $1.1 \pm 0.2(20)$ & $-0.01 \pm 0.14(1400)$ & $0.13 \pm 0.03$ & $16 \pm I(6)$ \\
\hline Vegetation & $2 \mathrm{NE}$ & 3 & - & $16 \pm 2(13)$ & $\ldots$ & $0.1 \pm 0(-)^{d}$ \\
\hline Vegetation & 7 & 3 & -- & $0.11 \pm 0.02$ & - & $13 \pm 2(19)$ \\
\hline Vegetation & 11 & 3 & - & $-0.07 \pm 0.05(63)$ & - & $13 \pm 2(12)$ \\
\hline Vegetation & 53 & 3 & $\ldots$ & $0.03 \pm 0.08(300)$ & $\ldots$ & $6.5 \pm 1.4(21)$ \\
\hline Sediment & 11 & 3 & $1.0 \pm 0.1(100)$ & $-0.05 \pm 0.06(120)$ & $0.01 \pm 0.02(200)$ & $19 \pm 1(8)$ \\
\hline Sediment & 73 & 3 & $1.4 \pm 0.2(14)$ & $-0.03 \pm 0.06(200)$ & $0.00 \pm 0.0(-)^{d}$ & $25 \pm 1(5)$ \\
\hline
\end{tabular}


Table E-4. Determination of Sample Variability in Replicate Samples for Selected Radionuclides Analysis in Surface Water for May and August $1993^{\text {a }}$

\begin{tabular}{|c|c|c|c|c|c|c|}
\hline $\begin{array}{l}\text { Water } \\
\text { Matrix }\end{array}$ & Location & $\begin{array}{l}\text { Number } \\
\text { of } \\
\text { Samples }\end{array}$ & $\begin{array}{l}\text { Gross alpha } \\
\qquad(\mathrm{pC} i / L) \\
\bar{x} \pm \mathrm{s}_{\bar{x}}(\mathrm{CV})^{b}\end{array}$ & $\begin{array}{l}\text { Gross beta } \\
(\mathrm{pCi} / L) \\
\bar{x} \pm \mathrm{s}_{\overline{\mathrm{x}}}(\mathrm{CV})^{b}\end{array}$ & $\begin{array}{l}U_{\text {tot }}(m g / L) \\
\bar{x} \pm s_{\bar{x}}(C V)^{b}\end{array}$ & $\begin{array}{l}H-3(p C i / m L) \\
\bar{x} \pm s_{\bar{x}}(C V)^{b}\end{array}$ \\
\hline May 93 & 11 & & & & & \\
\hline Solution & & 3 & $2 \pm 1(30)$ & $6 \pm 2(40)$ & $0.005 \pm 0.000(-)^{C}$ & $-0.10 \pm 0.07(70)$ \\
\hline Total & & 3 & $3 \pm 0(-)^{c}$ & $7 \pm 1(9)$ & $0.005 \pm 0.001(11)$ & -- \\
\hline August 93 & 11 & & & & & \\
\hline Solution & & 3 & $3 \pm 1(300)$ & $5 \pm 1(20)$ & $0.005 \pm 0.0(-)$ & $0.00 \pm 0.03(-)^{d}$ \\
\hline Total & $D I^{e}$ & 3 & $10 \pm 4(40)$ & $21 \pm 4(20)$ & $0.006 \pm 0.001(20)$ & $-0.02 \pm 0.05(250)$ \\
\hline Suspended Solids & & 3 & $0 \pm 0(-)$ & $0.0 \pm 0.0(-)^{C}$ & $0.005 \pm 0.0(-)^{c}$ & -- \\
\hline Total & & 3 & $1 \pm 0(-)$ & $1 \pm 1(40)$ & $0.005 \pm 0.0(-)^{c}$ & $0.05 \pm 0.10(210)$ \\
\hline \multicolumn{7}{|c|}{$\begin{array}{l}\text { a All individual results are listed in Tables } F-5 \text { and } F-6 \text { of Appendix } F \text {. } \\
\text { bC Coefficient of Variation (CV) }=\text { (Standard deviation } \div \text { mean) } \times 100 \text {. } \\
\text { CAll individual values are identical. } \\
\text { d Uncalculatable (division by zero). } \\
\text { Eneionized water blanks. }\end{array}$} \\
\hline
\end{tabular}


Table E-5. 1993 Quality Assurance Results for Selected Radiochemical Analysis Environmental Protection Agency/Accu-Labs Research, Inc., Intercomparison Study, Cross-Check Results

\begin{tabular}{|c|c|c|c|c|c|}
\hline Month & $\begin{array}{c}\text { EPA Result } \\
\text { (pci/L } \pm 3 \text { sigma) }\end{array}$ & $\begin{array}{l}\text { Accu-Labs Results } \\
\text { (pCi/L } \pm 2 \text { sigma) }\end{array}$ & $\begin{array}{l}\text { Deviation From } \\
\text { Known (sigma) }\end{array}$ & $\begin{array}{l}\text { Grand } \\
\text { Average }\end{array}$ & $\begin{array}{l}\text { Deviation from } \\
\text { Grand Average }\end{array}$ \\
\hline & & Gross Alpha in Water & & & \\
\hline \multirow[t]{2}{*}{$\begin{array}{l}10 / 93 \\
07 / 93 \\
04 / 93 \\
01 / 93\end{array}$} & $\begin{array}{l}20.0 \pm 5.0^{\star} \\
15.0 \pm 5.0^{*} \\
95.0 \pm 24.0^{\star} \\
34.0 \pm 9.0^{\star}\end{array}$ & $\begin{array}{c}18 \pm 3 ; 15 \pm 2 ; 16 \pm 3 \\
15 \pm 2 ; 16 \pm 3 ; 17 \pm 2 \\
91 \pm 4 ; 89 \pm 4 ; 94 \pm 4 \\
\star \star\end{array}$ & $\begin{array}{r}-1.27 \\
0.35 \\
-0.26 \\
--\end{array}$ & $\begin{array}{l}14.08 \\
12.06 \\
96.63 \\
--\end{array}$ & $\begin{array}{r}0.78 \\
1.36 \\
-0.38 \\
--\end{array}$ \\
\hline & & Gross Beta in Water & & & \\
\hline \multirow[t]{2}{*}{$\begin{array}{l}10 / 93 \\
07 / 93 \\
04 / 93 \\
01 / 93\end{array}$} & $\begin{aligned} & 15.0 \pm 5.0^{*} \\
& 43.0 \pm 6.93^{*} \\
& 177.0 \pm 27.0^{*} \\
& 44.0 \pm 5.0^{*}\end{aligned}$ & $\begin{array}{r}14 \pm 2 ; 16 \pm 2 ; 14 \pm 2 \\
33 \pm 2 ; 36 \pm 2 ; 36 \pm 2 \\
157 \pm 4 ; 154 \pm 4 ; 155 \pm 4 \\
\star * *\end{array}$ & $\begin{array}{l}-0.12 \\
-2.00 \\
-1.39 \\
-.\end{array}$ & $\begin{array}{r}17.01 \\
37.65 \\
155.52 \\
\cdots\end{array}$ & $\begin{array}{l}-0.81 \\
-0.66 \\
-0.01 \\
--\end{array}$ \\
\hline & & Uranium in Water & & & \\
\hline \multirow[t]{2}{*}{$\begin{array}{l}07 / 93 \\
04 / 93 \\
02 / 93\end{array}$} & $\begin{array}{l}25.3 \pm 3.0^{*} \\
28.9 \pm 3.0^{*} \\
7.6 \pm 3.0^{*}\end{array}$ & $\begin{array}{l}27.8 ; 26.3 ; 27.4 \\
30.1 ; 29.9 ; 29.9 \\
60.8 ; 61.2 ; 61.2\end{array}$ & $\begin{array}{r}1.08 \\
0.44 \\
30.87\end{array}$ & $\begin{array}{r}24.91 \\
27.64 \\
7.16\end{array}$ & $\begin{array}{r}1.30 \\
1.17 \\
31.12\end{array}$ \\
\hline & & Iritium in water & & & \\
\hline $\begin{array}{l}11 / 93 \\
06 / 93 \\
06 / 93 \\
10 / 93 \\
11 / 93\end{array}$ & $\begin{aligned} & 7398 \pm 740^{*} \\
& 9844 \pm 984^{*} \\
& 5.0 \pm 5.0 \\
& 10.0 \pm 5.0 \\
& 40.0 \pm 5.0\end{aligned}$ & $\begin{array}{c}7640 \pm 280 ; 7600 \pm 280 ; 7370 \pm 280 \\
10100 \pm 300 ; 10200 \pm 300 ; 10500 \pm 300 \\
6 \pm 1 ; 6 \pm 1 ; 5 \pm 1 \\
13 \pm 1 ; 13 \pm 1 ; 14 \pm 1 \\
43 \pm 4 ; 41 \pm 4 ; 43 \pm 4\end{array}$ & $\begin{array}{r}0.32 \\
-0.78 \\
0.23 \\
1.15 \\
0.81\end{array}$ & $\begin{array}{c}7215.65 \\
9591.82 \\
\ldots \\
\ldots \\
\ldots\end{array}$ & $\begin{array}{r}0.75 \\
-1.23 \\
-- \\
\cdots \\
--\end{array}$ \\
\hline \multicolumn{6}{|c|}{$\begin{array}{l}\text { aCalculations performed by EPA according to "Environmental Radioactivity Laboratory Intercomparison } \\
\text { Studies Program, February } 1981, " \text { EPA } 600 / 4-81-004 \text { (Jarvis and Siu 1981) } \\
\text { bomplete results on file in Center } 7500 \text { Environmental Records Center. } \\
*=\text { not requested } \\
\star \star=\text { no result }\end{array}$} \\
\hline
\end{tabular}


Table E-6. U.S. Department of Energy Operational Safety, Health and Environment Division, Quality Assessment Program (QAP), Accu-Labs Research, Inc., Results

\begin{tabular}{|c|c|c|c|c|c|c|}
\hline \multirow[b]{2}{*}{ Radionuclide } & \multicolumn{3}{|c|}{ QAP XXXVIII - 9303} & \multicolumn{3}{|c|}{ QAP XXXIX - 9309 } \\
\hline & $\begin{array}{l}\text { ALR } \\
\text { Result }\end{array}$ & $\begin{array}{c}\text { EML } \\
\text { Result }\end{array}$ & $\begin{array}{l}\text { Ratio } \\
\text { ALR/EML }\end{array}$ & $\begin{array}{c}\text { ALR } \\
\text { Result }\end{array}$ & $\begin{array}{c}\text { EML } \\
\text { Result }\end{array}$ & $\begin{array}{l}\text { Ratio } \\
\text { ALR/EML }\end{array}$ \\
\hline \multicolumn{7}{|l|}{$\begin{array}{l}\text { Vegetation } \\
\text { (Bg/kg dry) } \\
\end{array}$} \\
\hline Pu-239 & $0.380 \pm 0.122$ & 0.323 & 1.18 & $0.79 \pm 0.27$ & 0.965 & 0.82 \\
\hline Pu-239 & $0.243 \pm 0.104$ & 0.323 & 0.75 & $* *$ & ** & ** \\
\hline Pu-238 & $1.36 \pm 0.10$ & 1.14 & 1.19 & $0.42 \pm 0.33$ & 0.463 & 0.91 \\
\hline$A m-241$ & $0.216 \pm 0.088$ & 0.231 & 0.94 & $0.49 \pm 0.12$ & 0.465 & 1.05 \\
\hline $\mathrm{sr}-90$ & $205 \pm 25$ & 237 & 0.86 & $206 \pm 17$ & 221 & 0.93 \\
\hline Cs-137 & $26.0 \pm 1.3$ & 24.6 & 1.06 & $105 \pm 3$ & 89.2 & 1.18 \\
\hline$k-40$ & $343 \pm 14$ & 383 & 0.90 & $886 \pm 26$ & 842 & 1.05 \\
\hline Co- 60 & * & * & * & $7.87 \pm 1.44$ & 6.45 & 1.22 \\
\hline \multicolumn{7}{|l|}{ Water $(\mathrm{Bq} / \mathrm{L})^{\mathrm{b}}$} \\
\hline Pu-239 & $0.904 \pm 0.118$ & 0.828 & 1.09 & $0.35 \pm 0.05$ & 0.338 & 1.04 \\
\hline Pu-238 & $0.463 \pm 0.074$ & 0.494 & 0.94 & $1.22 \pm 0.08$ & 1.14 & 1.07 \\
\hline$U-234$ & $0.137 \pm 0.052$ & 0.151 & 0.91 & $1.00 \pm 0.09$ & 1.06 & 0.94 \\
\hline$u-238$ & $0.139 \pm 0.051$ & 0.147 & 0.95 & $* *$ & $\star \star$ & $\star \star$ \\
\hline Am-241 & $0.330 \pm 0.053$ & 0.440 & 0.75 & $1.68 \pm 0.10$ & 1.39 & 1.21 \\
\hline $\mathrm{Sr}-90$ & $1.45 \pm 0.14$ & 1.03 & 1.41 & $2.54 \pm 0.31$ & 2.52 & 1.01 \\
\hline Cs- 137 & $55.8 \pm 2.8$ & 50.8 & 1.10 & $85.8 \pm 3.9$ & 75.5 & 1.14 \\
\hline $\mathrm{H}-3$ & $107 \pm 6$ & 97.0 & 1.10 & $282 \pm 11$ & 270 & 1.04 \\
\hline $\mathrm{Mn}-54$ & $110 \pm 3$ & 105 & 1.05 & $119 \pm 5$ & 109 & 1.09 \\
\hline $\operatorname{co-} 60$ & $48.6 \pm 1.9$ & 45.3 & 1.07 & $112 \pm 3$ & 99.6 & 1.12 \\
\hline Cs- 134 & $46.0 \pm 2.3$ & 42.4 & 1.08 & $57.7 \pm 3.2$ & 56.1 & 1.03 \\
\hline $\mathrm{Ce}-144$ & $90.8 \pm 6.4$ & 83.6 & 1.09 & $198 \pm 10$ & 173 & 1.14 \\
\hline $\begin{array}{l}\text { Units and results are a } \\
b_{U n i t s} \text { and results are } \\
*=\text { not requested } \\
* *=\text { no result } \\
\text { ALR }=\text { Accu-Labs Research } \\
\text { EML Environmental Meas }\end{array}$ & $\begin{array}{l}\text { as reported by DOE QAP. } \\
\text { as reported by DOE QAP. } \\
\text { surements Laboratory }\end{array}$ & \multicolumn{5}{|c|}{$\begin{array}{l}\text { To convert to } \mathrm{pci} / \mathrm{g}, \text { multiply } \mathrm{Bg} / \mathrm{kg} \text { by } 0.37 . \\
\text { To convert to } \mathrm{pC} i / L, \text { multiply by } 3.7 \times 10^{2}\end{array}$} \\
\hline
\end{tabular}


Table E-6. U.S. Department of Energy Operational Safety, Health and Environment Division, Quality Assessment Program (QAP), Accu-Labs Research, Inc., Results (Concluded)

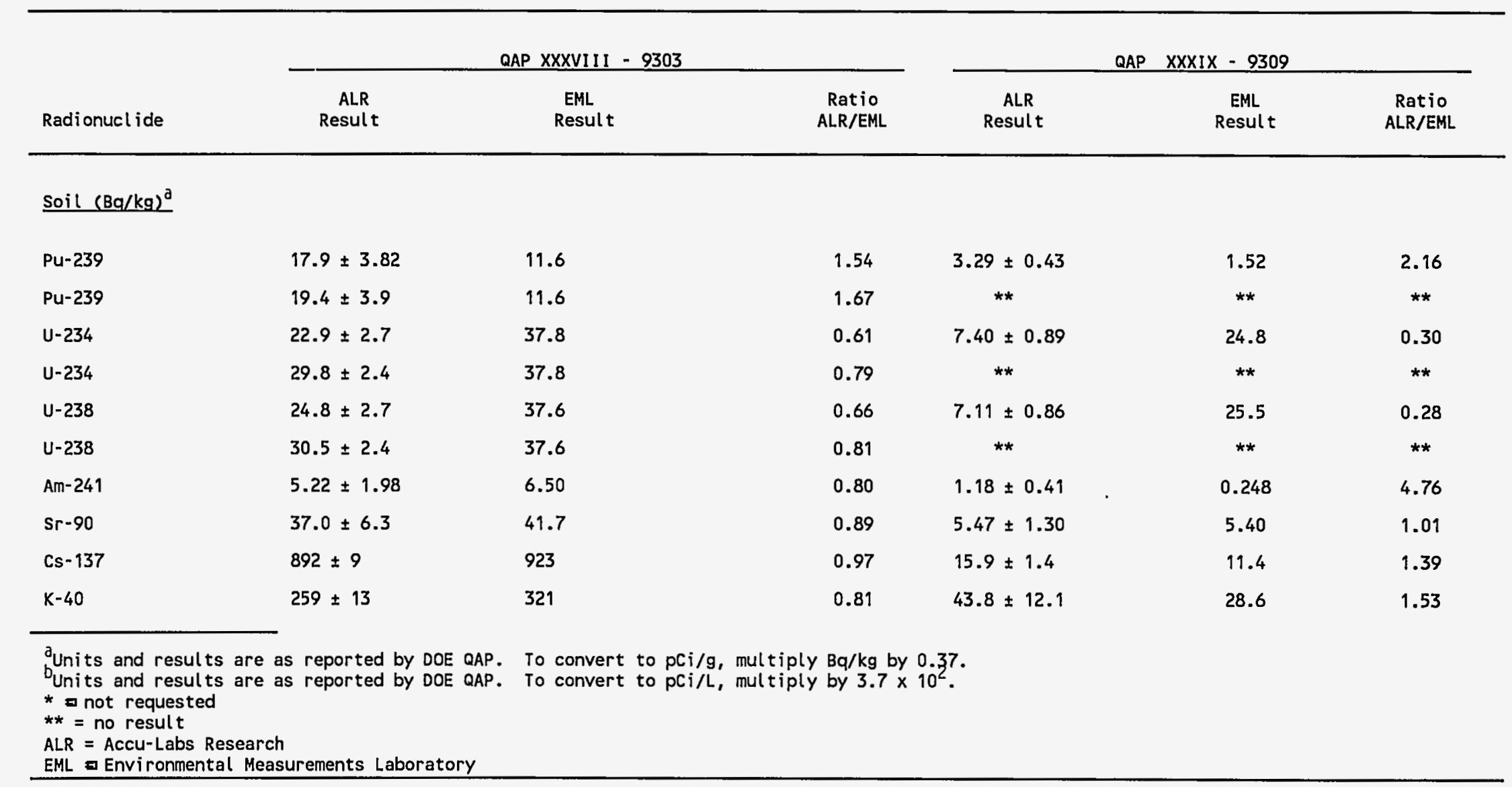




\section{REFERENCE}

Jarvis and Siu 1981: Jarvis, A. B., and L. Siu, "Environmental Radioactivity Laboratory Intercomparison Studies Program: Fiscal Year 1980-1981," EPA-600/4-81-004, prepared for the EPA by Environmental Monitoring Systems Laboratory, Las Vegas, NV (1981). 


\section{APPENDIX $F$}

TERRESTRIAL MONITORING DATA 
F-2 


\section{CONTENTS}

F-1 Vegetation Sample Analysis, May 1993 . . . . . . . . . . F-5

F-2 Vegetation Sample Analysis, August 1993 ........... . F-7

F-3 Soil Sample Analysis, May 1993 ............... F-9

F-4 Soil Sample Analysis, August 1993 . . . . . . . . . . . . . . . F-11

F-5 Surface Water Sample Analysis, May 1993 . . . . . . . . . . F-13

F..6 Surface Water Sample Analysis, August 1993 . . . . . . . . . . F-14

F-7 Arroyo Sediment Sample Analysis, May 1993 . . . . . . . . . F-15

F-8 Arroyo Sediment Sample Analysis, August 1993 . . . . . . . . . F-16

F-9 Thermoluminiscent Dosimeter Summary Radiation Exposure Data, 1993 . . . . . . . . . . . . . . . . . F F-17

F-10 Concentrations of Metals in Onsite Soil Samples (Group 1: Technical Areas I, II, and IV), May 1993 . . . . . F-19

F-11 Concentrations of Metals in Onsite Soil Samples (Group 2: Technical Areas III and V), May 1993 . . . . . . . F-20

F-12 Concentrations of Metals in Perimeter Soil Samples, May 1993 . . . . . . . . . . . . . . . . . . . . F-22

F-13 Concentrations of Metals in Offsite Soil Samples, May 1993 . . . . . . . . . . . . . . . . . . F-23

F-14 Concentrations of Metals in Onsite Soil Samples (Group 1: Technical Areas I, II, and IV), August 1993 . . . F-24

F-15 Concentrations of Metals in Onsite Soil Samples (Group 2: Technical Areas III and V), August 1993 . . . . . . F-25

F-16 Concentrations of Metals in Perimeter Soil Samples, August 1993 . . . . . . . . . . . . . . . . . . . . . . . . . F-27

F-17 Concentrations of Metals in Offsite Soil Samples, August 1993 . . . . . . . . . . . . . . . . . F $\mathrm{F} 28$

F-18 Concentrations of Metals in Perimeter Sediment Samples, May 1993 . . . . . . . . . . . . . . . . . . . F-29 


\section{CONTENTS (Concluded)}

TABLES

$\underline{\text { Page }}$

F-19 Concentrations of Metals in Offsite Sediment Samples, May 1993 . . . . . . . . . . . . . . . . . . . F-29

F-20 Concentrations of Metals in Perimeter Sediment Samples, August 1993 . . . . . . . . . . . . . . . . . . . . . . F-30

F-21 Concentrations of Metals in Offsite Sediment Samples, August, 1993 . . . . . . . . . . . . . . . . . . . F-30 
Table F-1. Vegetation Sample Analysis, May 1993

\begin{tabular}{|c|c|c|c|c|c|c|}
\hline Location & $\begin{array}{c}\text { Location } \\
\text { Type }^{\text {a }}\end{array}$ & $\begin{array}{c}\mathrm{H}-3 \\
(\mathrm{pC} i / \mathrm{mL})\end{array}$ & $\begin{array}{c}\mathrm{H}-3 \\
\mathrm{SDEV}\end{array}$ & $\begin{array}{l}\mathrm{H}_{2} \mathrm{O} \\
(\%)\end{array}$ & $\begin{array}{c}\mathrm{K}-40 \\
(\mathrm{pCi} / \mathrm{g})\end{array}$ & $\begin{array}{l}\mathrm{K}-40 \\
\mathrm{SDEV}\end{array}$ \\
\hline 1 & $S$ & -0.03 & 0.16 & 49.5 & 9 & 3.10 \\
\hline $2 \mathrm{NW}^{\mathrm{c}}$ & S & 1.10 & 0.20 & 32.6 & 19 & 4.00 \\
\hline $2 \mathrm{NE} \mathrm{A}$ & s & 8.70 & 0.30 & 24.6 & 6 & 2.80 \\
\hline $2 \mathrm{NE} B$ & S & 10.00 & 1.00 & 26.5 & 4 & 3.10 \\
\hline $2 \mathrm{NE} C$ & $\mathrm{~s}$ & 12.00 & 1.00 & 27.4 & 7 & 2.90 \\
\hline $2 \mathrm{SE}$ & $S$ & 0.13 & 0.16 & 22.0 & 5 & 2.80 \\
\hline $2 \mathrm{SW}$ & $S$ & -0.01 & 0.16 & 38.9 & 6 & 3.60 \\
\hline 3 & $S$ & 0.00 & 0.17 & 30.5 & 2 & 0.50 \\
\hline $4^{d}$ & $\mathrm{P}$ & 0.10 & 0.17 & 20.9 & 13 & 1.00 \\
\hline 5 & $P$ & -0.05 & 0.17 & 26.6 & 0 & 0.38 \\
\hline 6 & 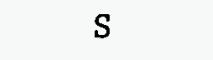 & -0.14 & 0.15 & 28.0 & 0 & 2.10 \\
\hline $7 \mathrm{~A}$ & $s$ & -0.11 & 0.17 & 27.9 & 1 & 0.63 \\
\hline 7 B & $S$ & -0.06 & 0.17 & 27.5 & 1 & 0.53 \\
\hline $7 \mathrm{C}$ & 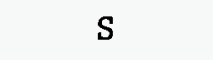 & -0.05 & 0.17 & 31.6 & 1 & 0.51 \\
\hline 8 & $\mathrm{C}$ & -0.04 & 0.17 & 34.7 & 10 & 3.00 \\
\hline 9 & $\mathrm{C}$ & -0.08 & 0.16 & 28.4 & 25 & 4.00 \\
\hline $10^{\mathrm{e}}$ & C & -0.06 & 0.16 & 21.7 & 30 & 4.00 \\
\hline $11 \mathrm{~A}$ & $C$ & 0.05 & 0.18 & 34.9 & 15 & 4.00 \\
\hline $11 \mathrm{~B}$ & $C$ & -0.08 & 0.17 & 31.3 & 22 & 4.00 \\
\hline $11 \mathrm{C}$ & C & 0.12 & 0.18 & 28.6 & 22 & 4.00 \\
\hline 12 & $\mathrm{P}$ & -0.12 & 0.17 & 32.2 & 11 & 4.00 \\
\hline 16 & $\mathbf{P}$ & 0.07 & 0.20 & 27.1 & 7 & 3.00 \\
\hline \multicolumn{7}{|c|}{ 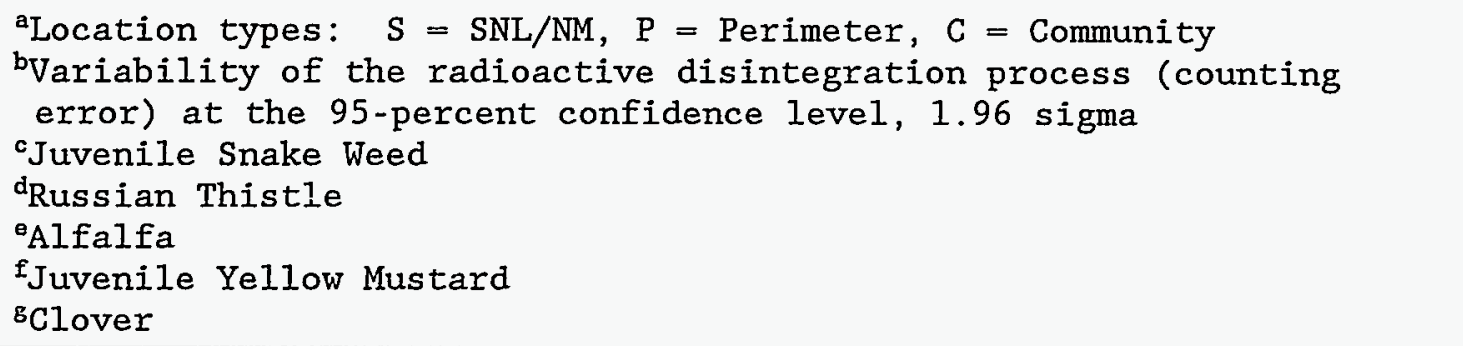 } \\
\hline
\end{tabular}


Table F-1. Vegetation Sample Analysis, May 1993 (Concluded)

\begin{tabular}{|c|c|c|c|c|c|c|}
\hline Location & $\begin{array}{c}\text { Location } \\
\text { Type }\end{array}$ & $\begin{array}{c}\mathrm{H}-3 \\
(\mathrm{pCi} / \mathrm{mL})\end{array}$ & $\begin{array}{c}\mathrm{H}-3 \\
\text { SDEV }^{\mathrm{b}}\end{array}$ & $\begin{array}{l}\mathrm{H}_{2} \mathrm{O} \\
(\%)\end{array}$ & $\begin{array}{c}\mathrm{K}-40 \\
(\mathrm{pCi} / \mathrm{g})\end{array}$ & $\begin{array}{l}\mathrm{K}-40 \\
\text { SDEV }\end{array}$ \\
\hline 19 & $\mathrm{P}$ & 0.06 & 0.17 & 38.4 & 1 & 0.51 \\
\hline 20 & $S$ & -0.09 & 0.16 & 30.3 & 6 & 2.90 \\
\hline 25 & $\mathrm{C}$ & -0.05 & 0.17 & 20.9 & 20 & 4.00 \\
\hline 33 & $S$ & -0.01 & 0.17 & 27.6 & 15 & 4.00 \\
\hline 34 & $S$ & -0.01 & 0.17 & 35.2 & 1 & 0.52 \\
\hline 35 & $S$ & -0.15 & 0.19 & 24.4 & 1 & 0.48 \\
\hline 41 & $S$ & 0.09 & 0.15 & 41.2 & 14 & 3.00 \\
\hline 42 & $S$ & 0.08 & 0.16 & 40.8 & 0 & 2.70 \\
\hline 43 & $S$ & -0.14 & 0.15 & 38.1 & 12 & 4.00 \\
\hline 45 & $S$ & -0.12 & 0.15 & 27.2 & 11 & 3.00 \\
\hline 46 & $S$ & -0.07 & 0.16 & 25.3 & 8 & 2.90 \\
\hline 49 & $\mathrm{~S}$ & 0.00 & 0.17 & 32.0 & 8 & 3.10 \\
\hline 51 & $\mathrm{~S}$ & 0.04 & 0.17 & 40.7 & 1 & 0.49 \\
\hline 52 & $S$ & -0.07 & 0.15 & 49.0 & 12 & 4.00 \\
\hline $53 \mathrm{~A}$ & $S$ & -0.08 & 0.34 & 21.1 & 1 & 0.51 \\
\hline $53 \mathrm{~B}$ & $S$ & -0.03 & 0.27 & 26.9 & 1 & 0.46 \\
\hline $53 \mathrm{C}$ & $S$ & 0.03 & 0.23 & 27.6 & 0 & 0.42 \\
\hline 54 & $\mathrm{~S}$ & -0.11 & 0.15 & 37.2 & 12 & 4.00 \\
\hline 55 & $\mathrm{~s}$ & 0.00 & 0.34 & 27.9 & 1 & 0.45 \\
\hline 58 & $P$ & -0.06 & 0.17 & 41.5 & 2 & 0.60 \\
\hline 59 & $P$ & 0.02 & 0.17 & 41.9 & 1 & 0.47 \\
\hline $60^{f}$ & $\mathrm{P}$ & -0.05 & 0.16 & 24.9 & 18 & 4.00 \\
\hline 61 & $\mathrm{P}$ & 0.01 & 0.18 & 32.8 & 20 & 4.00 \\
\hline $62^{8}$ & $\mathrm{C}$ & -0.04 & 0.16 & 22.4 & 20 & 4.00 \\
\hline 63 & $\mathrm{P}$ & 0.09 & 0.23 & 22.4 & 1 & 0.50 \\
\hline 64 & $P$ & -0.03 & 0.17 & 38.6 & 3 & 2.80 \\
\hline 65 & $\mathrm{P}$ & -0.05 & 0.19 & 28.1 & 2 & 0.40 \\
\hline 66 & $\mathrm{~S}$ & -0.01 & 0.17 & 51.2 & 1 & 0.59 \\
\hline \multicolumn{7}{|c|}{$\begin{array}{l}\text { aLocation types: } \mathrm{S}=\mathrm{SNL} / \mathrm{NM}, \mathrm{P}=\text { Perimeter, } \mathrm{C}=\text { Community } \\
\text { bVariability of the radioactive disintegration process (counting } \\
\text { error) at the } 95 \text {-percent confidence level, } 1.96 \text { sigma } \\
\text { c Juvenile Snake Weed } \\
\text { dRussian Thistle } \\
\text { eAlfalfa } \\
\text { fJuvenile Yellow Mustard } \\
{ }^{\mathrm{B}} \mathrm{Cl} \text { lover }\end{array}$} \\
\hline
\end{tabular}


Table F-2. Vegetation Sample Analysis, August 1993

\begin{tabular}{|c|c|c|c|c|c|c|}
\hline Location & $\begin{array}{l}\text { Location } \\
\text { Type }^{\mathrm{a}}\end{array}$ & $\begin{array}{c}\mathrm{H}-3 \\
(\mathrm{pC} i / \mathrm{mL})\end{array}$ & $\begin{array}{c}\mathrm{H}-3 \\
\mathrm{SDEV}\end{array}$ & $\begin{array}{l}\mathrm{H}_{2} \mathrm{O} \\
(\%)\end{array}$ & $\begin{array}{c}\mathrm{K}-40 \\
(\mathrm{pCi} / \mathrm{g})\end{array}$ & $\begin{array}{l}\mathrm{K}-40 \\
\mathrm{SDEV}^{\mathrm{b}}\end{array}$ \\
\hline 1 & 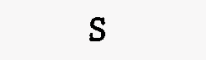 & 0.05 & 0.17 & 32.5 & $<0.1$ & -- \\
\hline $2 \mathrm{NE} \mathrm{A}$ & $S$ & 14.00 & 1.00 & 21.0 & $<0.1$ & -- \\
\hline $2 \mathrm{NE} \mathrm{B}$ & $S$ & 18.00 & 1.00 & 23.6 & $<0.1$ & - - \\
\hline $2 \mathrm{NE} \mathrm{C}$ & $\mathrm{S}$ & 17.00 & 1.00 & 33.5 & $<0.1$ & - - \\
\hline $2 \mathrm{NW}$ & $\mathrm{S}$ & 5.20 & 0.30 & 28.1 & $<0.1$ & -- \\
\hline $2 \mathrm{SE}$ & $S$ & 9.20 & 0.40 & 22.1 & $<0.1$ & - \\
\hline $2 \mathrm{SW}$ & $S$ & 6.20 & 0.30 & 21.6 & $<0.1$ & -- \\
\hline 3 & S & -0.06 & 0.27 & 28.3 & 7.1 & 2.5 \\
\hline $4^{c}$ & $P$ & -0.16 & 0.16 & 23.6 & 50.0 & 5.0 \\
\hline 5 & $\mathrm{P}$ & -0.19 & 0.33 & 20.6 & 2.6 & 2.1 \\
\hline 6 & $\mathbf{S}$ & 0.07 & 0.17 & 41.6 & $<0.1$ & $\ldots$ \\
\hline $7 \mathrm{~A}^{\mathrm{d}}$ & S & 0.09 & 0.17 & 29.9 & 9.9 & 2.8 \\
\hline $7 \mathrm{~B}^{\mathrm{d}}$ & S & 0.14 & 0.19 & 25.3 & 14.0 & 3.0 \\
\hline $7 \mathrm{C}^{\mathrm{d}}$ & $\mathrm{S}$ & 0.11 & 0.17 & 32.2 & 14.0 & 3.0 \\
\hline 8 & $C$ & -0.15 & 0.19 & 24.7 & 9.7 & 2.6 \\
\hline 9 & $\mathrm{C}$ & -0.05 & 0.22 & 34.2 & 5.3 & 2.7 \\
\hline 10 & $C$ & -0.13 & 0.16 & 22.6 & 8.6 & 2.8 \\
\hline $11 \mathrm{~A}$ & C & -0.02 & 0.16 & 38.7 & 11.0 & 3.0 \\
\hline $11 \mathrm{~B}$ & $C$ & -0.10 & 0.16 & 51.8 & 14.0 & 3.0 \\
\hline $11 \mathrm{C}$ & $\mathrm{C}$ & -0.10 & 0.16 & 40.5 & 13.0 & 3.0 \\
\hline 12 & $P$ & 0.07 & 0.45 & 18.3 & 5.5 & 2.2 \\
\hline 16 & $\mathrm{P}$ & -0.02 & 0.17 & 27.6 & 4.0 & 2.4 \\
\hline 19 & $\mathrm{P}$ & -0.15 & 0.16 & 34.8 & 5.2 & 2.6 \\
\hline 20 & $\mathrm{~S}$ & 0.00 & 0.27 & 12.4 & 5.4 & 2.3 \\
\hline \multicolumn{7}{|c|}{ 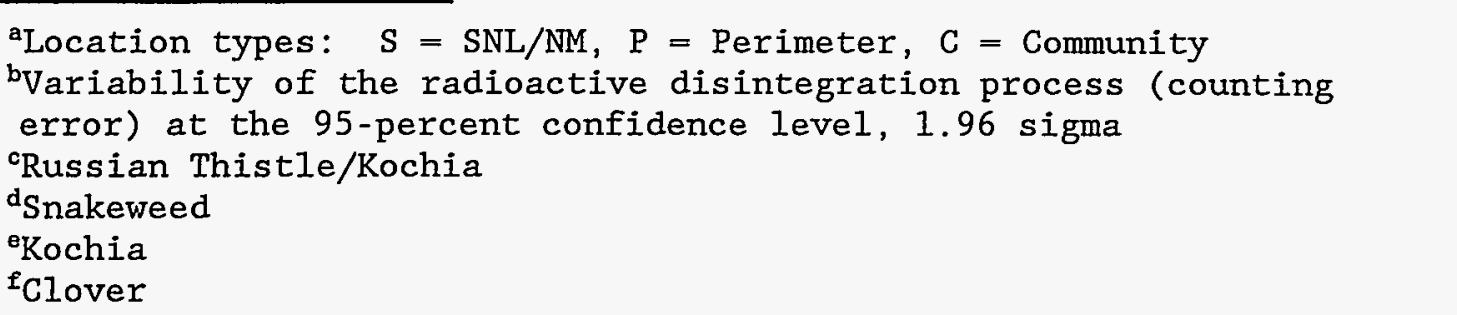 } \\
\hline
\end{tabular}


Table F-2. Vegetation Sample Analysis, August 1993 (Concluded)

\begin{tabular}{|c|c|c|c|c|c|c|}
\hline Location & $\begin{array}{c}\text { Location } \\
\text { Type }\end{array}$ & $\begin{array}{c}\mathrm{H}-3 \\
(\mathrm{pCi} / \mathrm{mL})\end{array}$ & $\begin{array}{c}\mathrm{H}-3 \\
S D E V^{\mathrm{b}}\end{array}$ & $\begin{array}{l}\mathrm{H}_{2} \mathrm{O} \\
(\%)\end{array}$ & $\begin{array}{c}\mathrm{K}-40 \\
(\mathrm{pCi} / \mathrm{g})\end{array}$ & $\begin{array}{l}\mathrm{K}-40 \\
\text { SDEV }\end{array}$ \\
\hline 25 & C & -0.11 & 0.16 & 39.9 & 8.5 & 3.0 \\
\hline 33 & $S$ & 0.02 & 0.17 & 56.5 & 13.0 & 3.0 \\
\hline 34 & $S$ & -0.03 & 0.19 & 28.6 & 4.2 & 2.4 \\
\hline 35 & $S$ & 0.08 & 0.17 & 43.0 & $<0.1$ & - \\
\hline $41^{e}$ & $\mathrm{~S}$ & 0.02 & 0.17 & 47.1 & 38.0 & 4.0 \\
\hline $42^{e}$ & $\mathrm{~S}$ & -0.09 & 0.17 & 29.2 & 47.0 & 5.0 \\
\hline $43^{e}$ & $\mathrm{~S}$ & 0.01 & 0.17 & 24.3 & 25.0 & 4.0 \\
\hline 45 & $S$ & -0.04 & 0.17 & 35.2 & $<0.1$ & - \\
\hline $46^{\circ}$ & S & -0.06 & 0.16 & 41.0 & 42.0 & 4.0 \\
\hline 49 & S & -0.02 & 0.21 & 25.6 & 0.0 & 1.4 \\
\hline 51 & $S$ & -0.06 & 0.17 & 30.8 & 4.3 & 2.4 \\
\hline 52 & $\mathrm{~S}$ & 0.05 & 0.17 & 29.1 & $<0.1$ & -- \\
\hline $53 \mathrm{~A}$ & $\mathrm{~S}$ & -0.06 & 0.17 & 46.8 & 7.7 & 2.4 \\
\hline $53 \mathrm{~B}$ & $\mathrm{~s}$ & 0.04 & 0.17 & 41.8 & 6.8 & 2.4 \\
\hline $53 \mathrm{C}$ & $S$ & 0.10 & 0.18 & 53.0 & 5.0 & 2.6 \\
\hline 54 & $S$ & -0.04 & 0.19 & 31.0 & $<0.1$ & - \\
\hline 55 & $S$ & -0.18 & 0.19 & 32.0 & 12.0 & 3.0 \\
\hline 58 & $\mathrm{P}$ & 0.02 & 0.17 & 35.4 & 32.0 & 5.0 \\
\hline 59 & $\mathrm{P}$ & -0.02 & 0.17 & 35.7 & 4.4 & 2.2 \\
\hline $60^{\circ}$ & $\mathrm{P}$ & -0.07 & 0.18 & 18.6 & 52.0 & 5.0 \\
\hline 61 & $\mathrm{P}$ & -0.13 & 0.15 & 38.1 & 5.9 & 2.8 \\
\hline $62^{\mathrm{f}}$ & $\mathrm{C}$ & -0.04 & 0.17 & 26.6 & 14.0 & 3.0 \\
\hline 63 & $\mathrm{P}$ & -0.04 & 0.17 & 19.8 & 10.0 & 3.0 \\
\hline $64^{d}$ & $\mathrm{P}$ & 0.13 & 0.17 & 47.9 & 20.0 & 4.0 \\
\hline $65^{d}$ & $\mathrm{P}$ & -0.03 & 0.17 & 37.2 & 15.0 & 3.0 \\
\hline $66^{d}$ & $\mathrm{~s}$ & 0.03 & 0.17 & 38.7 & 14.0 & 3.0 \\
\hline \multicolumn{7}{|c|}{ 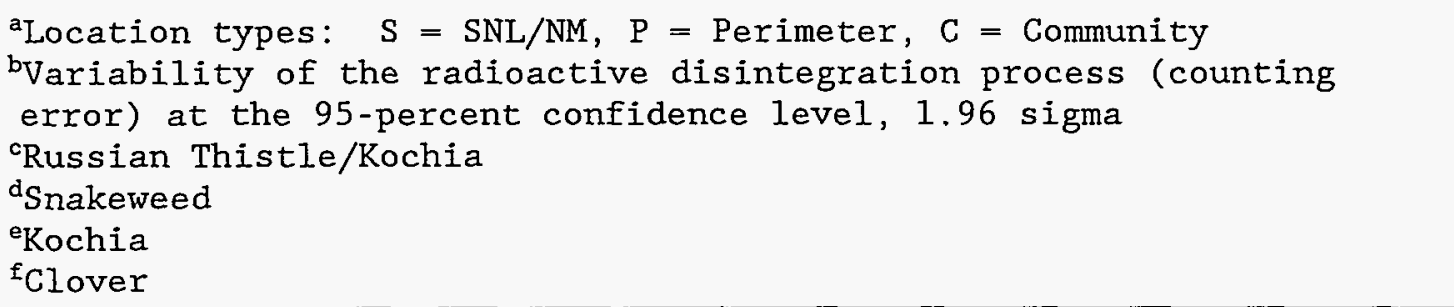 } \\
\hline
\end{tabular}


Table F-3. Soil Sample Analysis, May 1993

\begin{tabular}{|c|c|c|c|c|c|c|c|c|c|}
\hline Location & $\begin{array}{l}\text { Location } \\
\text { Type }^{a}\end{array}$ & $\begin{array}{r}U_{\text {tot }} \\
(\mu \mathrm{g} / \mathrm{g})\end{array}$ & $\begin{array}{c}\mathrm{H}-3 \\
(\mathrm{pC} i / m L)\end{array}$ & $\begin{array}{c}\mathrm{H}-3 \\
\mathrm{SDEV}\end{array}$ & $\begin{array}{l}\mathrm{B}_{2} \mathrm{O} \\
(\mathrm{z})\end{array}$ & $\begin{array}{l}\mathrm{Cs}-137 \\
(\mathrm{pCi} / \mathrm{g})\end{array}$ & $\begin{array}{c}\text { Cs-137 } \\
\text { SDEV }\end{array}$ & $\begin{array}{c}\mathrm{K}-40 \\
(\mathrm{pCi} / \mathrm{g})\end{array}$ & $\begin{array}{l}K-40 \\
\text { SDEV }\end{array}$ \\
\hline 1 & $\mathbf{s}$ & 1.0 & 0.13 & 0.17 & 1.4 & 0.36 & 0.06 & 23 & 1 \\
\hline $2 \mathrm{NE} \mathrm{A}$ & $\mathbf{s}$ & 0.9 & 34.00 & 1.00 & 2.2 & 0.12 & 0.06 & 18 & 1 \\
\hline $2 \mathrm{NE} B$ & $\mathbf{s}$ & 0.5 & 52.00 & 1.00 & 1.9 & 0.15 & 0.06 & 18 & 1 \\
\hline $2 \mathrm{NE} \mathrm{C}$ & $s$ & 0.6 & 56.00 & 1.00 & 2.2 & 0.09 & 0.04 & 18 & 1 \\
\hline $2 \mathrm{NW}$ & $\mathbf{s}$ & 0.3 & 4.40 & 0.20 & 1.6 & 0.16 & 0.05 & 17 & 1 \\
\hline $2 \mathrm{SE}$ & $\mathbf{S}$ & 1.2 & 3.10 & 0.20 & 2.1 & 0.08 & 0.04 & 17 & 1 \\
\hline $2 \mathrm{SW}$ & $\mathbf{s}$ & 1.5 & 0.59 & 0.18 & 2.0 & 0.18 & 0.06 & 17 & 1 \\
\hline 3 & $\mathrm{~S}$ & 0.4 & 0.02 & 0.16 & 3.4 & 0.55 & 0.07 & 19 & 1 \\
\hline 4 & $\mathbf{P}$ & 0.9 & 0.09 & 0.16 & 3.4 & 0.12 & 0.05 & 19 & 1 \\
\hline 5 & $\mathrm{P}$ & 0.5 & 0.11 & 0.16 & 2.8 & 0.57 & 0.07 & 18 & 1 \\
\hline 6 & $\mathbf{s}$ & 4.2 & 0.06 & 0.17 & 2.6 & 0.70 & 0.07 & 18 & 1 \\
\hline $7 \mathrm{~A}$ & $\mathbf{s}$ & 0.8 & 0.07 & 0.41 & 0.8 & 0.81 & 0.08 & 19 & 1 \\
\hline $7 \mathrm{~B}$ & $\mathbf{s}$ & 0.6 & 0.18 & 0.21 & 1.2 & 0.85 & 0.08 & 18 & 1 \\
\hline $7 \mathrm{c}$ & $\mathbf{s}$ & 0.9 & 0.29 & 0.21 & 1.0 & 1.10 & 0.10 & 18 & 1 \\
\hline 8 & $\mathrm{C}$ & 2.0 & 0.31 & 0.18 & 1.4 & 0.20 & 0.05 & 16 & 1 \\
\hline 9 & $\mathrm{C}$ & 1.2 & -0.06 & 0.16 & 7.2 & 0.84 & 0.07 & 12 & 1 \\
\hline 10 & $c$ & 1.6 & 0.00 & 0.16 & 2.6 & 0.46 & 0.06 & 14 & 1 \\
\hline $11 \mathrm{~A}$ & $c$ & 0.5 & -0.07 & 0.21 & 0.9 & 0.06 & 0.05 & 20 & 1 \\
\hline $11 \mathrm{~B}$ & $\mathrm{C}$ & 1.4 & 0.02 & 0.16 & 1.4 & 0.00 & 0.04 & 18 & 1 \\
\hline $11 \mathrm{C}$ & $\mathrm{C}$ & 1.0 & 0.04 & 0.16 & 1.3 & 0.09 & 0.04 & 18 & 1 \\
\hline 12 & $\mathbf{P}$ & 0.9 & 0.36 & 0.20 & 1.1 & 1.60 & 0.10 & 16 & 1 \\
\hline 16 & $\mathrm{P}$ & 1.3 & -0.07 & 0.17 & 1.3 & 0.13 & 0.04 & 29 & 1 \\
\hline 19 & $\mathrm{P}$ & 0.8 & 0.20 & 0.16 & 4.6 & 1.00 & 0.10 & 20 & 1 \\
\hline 20 & $\mathbf{S}$ & 1.7 & -0.14 & 0.15 & 1.2 & 0.60 & 0.08 & 18 & 1 \\
\hline 25 & C & 0.6 & -0.01 & 0.16 & 2.3 & 0.17 & 0.04 & 17 & 1 \\
\hline $32 \mathrm{E}$ & $\mathbf{s}$ & 1.6 & 400.00 & 10.00 & 1.2 & 0.12 & 0.05 & 20 & 1 \\
\hline \multicolumn{10}{|c|}{$\begin{array}{l}\text { aLocation types: } S=S N L / N M, P=\text { Perimeter, } C=\text { Community } \\
\text { bVariability of the radioactive disintegration process (counting error) at the 95-percent confidence } \\
\text { level, } 1.96 \text { sigma }\end{array}$} \\
\hline
\end{tabular}


Table F-3. Soil Sample Analysis, May 1993 (Concluded)

\begin{tabular}{|c|c|c|c|c|c|c|c|c|c|}
\hline Location & $\begin{array}{l}\text { Location } \\
\text { Type }\end{array}$ & $\begin{array}{c}U_{\text {tot }} \\
(\mu g / 8)\end{array}$ & $\begin{array}{c}\mathrm{H}-3 \\
(\mathrm{pC} \dot{i} / \mathrm{mL})\end{array}$ & $\begin{array}{c}\mathrm{H}-3 \\
\text { SDEV }\end{array}$ & $\begin{array}{l}\mathrm{H}_{2} \mathrm{O} \\
(x)\end{array}$ & $\begin{array}{c}\mathrm{Cs}-137 \\
(\mathrm{pCi} / \mathrm{g})\end{array}$ & $\begin{array}{c}\text { Cs-137 } \\
\text { SDEV }\end{array}$ & $\begin{array}{c}\mathrm{k}-40 \\
(\mathrm{pC} \mathrm{i} / \mathrm{g})\end{array}$ & $\begin{array}{l}K-40 \\
\text { SDEV }\end{array}$ \\
\hline $32 \mathrm{~s}$ & $\mathbf{s}$ & 1.1 & 170.00 & 10.00 & 1.0 & 0.21 & 0.05 & 23 & 1 \\
\hline 33 & $\mathrm{~s}$ & 0.9 & 0.18 & 0.17 & 2.6 & 0.28 & 0.06 & 17 & 1 \\
\hline 34 & $\mathrm{~s}$ & 0.7 & -0.06 & 0.15 & 6.7 & 1.70 & 0.10 & 17 & 1 \\
\hline 35 & $s$ & 0.8 & 0.07 & 0.16 & 1.2 & 0.22 & 0.06 & 20 & 1 \\
\hline 41 & $S$ & 0.7 & -0.01 & 0.19 & 2.4 & 0.15 & 0.06 & 16 & 1 \\
\hline 42 & $s$ & 1.2 & 0.00 & 0.17 & 4.2 & 0.08 & 0.05 & 18 & 1 \\
\hline 43 & $s$ & 0.4 & 0.07 & 0.17 & 2.9 & 0.10 & 0.04 & 17 & 1 \\
\hline 45 & $s$ & 0.8 & -0.02 & 0.17 & 2.8 & 0.36 & 0.06 & 17 & 1 \\
\hline 46 & $\mathrm{~s}$ & 0.7 & 0.31 & 0.42 & 0.7 & 0.51 & 0.07 & 17 & 1 \\
\hline 49 & $s$ & 1.7 & 0.06 & 0.23 & 1.0 & 0.00 & 0.38 & 20 & $I$ \\
\hline 51 & $s$ & 1.1 & 0.14 & 0.16 & 2.4 & 0.00 & 0.04 & 18 & 1 \\
\hline 52 & $\mathrm{~S}$ & 1.2 & 0.08 & 0.17 & 3.3 & 0.11 & 0.04 & 18 & 1 \\
\hline $53 \mathrm{~A}$ & $\mathbf{S}$ & 0.8 & 0.07 & 0.16 & 3.4 & 0.12 & 0.03 & 16 & 1 \\
\hline $53 \mathrm{~B}$ & $s$ & 1.1 & 0.04 & 0.15 & 2.9 & 0.08 & 0.05 & 18 & 1 \\
\hline $53 \mathrm{C}$ & $s$ & 1.2 & 0.06 & 0.16 & 3.1 & 0.14 & 0.05 & 18 & 1 \\
\hline 54 & $s$ & 0.8 & 0.01 & 0.17 & 7.8 & 0.14 & 0.05 & 20 & 1 \\
\hline 55 & $\mathrm{~S}$ & 0.5 & 0.03 & 0.15 & 3.2 & 0.17 & 0.06 & 20 & 1 \\
\hline 56 & $\mathrm{~s}$ & 0.6 & 0.26 & 0.24 & 1.1 & 0.00 & 0.04 & 20 & 1 \\
\hline 57 & $\mathrm{~s}$ & 1.3 & -0.04 & 0.28 & 0.09 & 0.06 & 0.05 & 21 & 1 \\
\hline 58 & $P$ & 0.8 & 0.09 & 0.16 & 1.9 & 0.22 & 0.06 & 23 & 1 \\
\hline 59 & $\mathbf{P}$ & 1.0 & -0.04 & 0.15 & 1.3 & 0.00 & 0.04 & 20 & 1 \\
\hline 60 & $\mathbf{P}$ & 1.3 & 0.10 & 0.16 & 1.0 & 0.00 & 0.04 & 20 & 1 \\
\hline 61 & $\mathrm{P}$ & 0.9 & 0.22 & 0.17 & 1.5 & 0.00 & 0.04 & 17 & 1 \\
\hline 62 & c & 1.9 & -0.09 & 0.15 & 4.8 & 1.10 & 0.10 & 15 & 1 \\
\hline 63 & $P$ & 1.2 & 0.12 & 0.16 & 6.3 & 0.70 & 0.08 & 12 & 1 \\
\hline 64 & $P$ & 0.9 & 0.08 & 0.17 & 2.1 & 0.63 & 0.07 & 28 & 1 \\
\hline 65 & $\mathrm{P}$ & 0.8 & 0.03 & 0.18 & 1.1 & 0.66 & 0.07 & 20 & 1 \\
\hline 66 & $s$ & 0.8 & 0.13 & 0.16 & 2.4 & 0.60 & 0.10 & 17 & 1 \\
\hline \multicolumn{10}{|c|}{$\begin{array}{l}\text { aLocation types: } S=S N L / N M, P=\text { Perimeter, } C=\text { Community } \\
\text { bVariability of the radioactive disintegration process (counting error) at the } 95 \text {-percent confidence } \\
\text { level, } 1.96 \text { sigma }\end{array}$} \\
\hline
\end{tabular}


Table F-4. Soil Sample Analysis, August 1993

\begin{tabular}{|c|c|c|c|c|c|c|c|c|c|}
\hline Location & $\begin{array}{l}\text { Location } \\
\text { Type }^{2}\end{array}$ & $\begin{array}{c}U_{t o \alpha} \\
(\mu g / g)\end{array}$ & $\begin{array}{c}\mathrm{H}-3 \\
(\mathrm{pCi} / \mathrm{mL})\end{array}$ & $\begin{array}{c}\mathrm{H}-3 \\
\text { SDEV }\end{array}$ & $\begin{array}{l}\mathrm{H}_{2} \mathrm{O} \\
\left(\frac{\mathrm{g}}{6}\right)\end{array}$ & $\begin{array}{l}\mathrm{Cs}-137 \\
(\mathrm{pCi} / \mathrm{g})\end{array}$ & $\begin{array}{l}C s-137 \\
\text { SDEV }\end{array}$ & $\begin{array}{c}\mathrm{K}-40 \\
(\mathrm{pCi} / \mathrm{g})\end{array}$ & $\begin{array}{l}K-40 \\
S D E V^{b}\end{array}$ \\
\hline 1 & $s$ & 1.5 & -0.01 & 0.17 & 2.1 & 0.18 & 0.07 & 23 & 1 \\
\hline $2 \mathrm{NE} A$ & $s$ & 0.9 & 12.00 & 1.00 & 2.8 & 0.00 & 0.04 & 18 & 1 \\
\hline $2 \mathrm{NE} B$ & $s$ & 0.8 & 12.00 & 1.00 & 2.3 & 0.07 & 0.04 & 18 & 1 \\
\hline $2 \mathrm{NE} C$ & $s$ & 0.7 & 13.00 & 1.00 & 1.7 & 0.06 & 0.05 & 17 & 1 \\
\hline $2 \mathrm{NW}$ & $S$ & 1.3 & 8.3 & 0.40 & 1.1 & 0.32 & 0.06 & 17 & 1 \\
\hline $2 \mathrm{SE}$ & $s$ & 1.5 & 2.6 & 0.20 & 3.4 & 0.20 & 0.06 & 16 & 1 \\
\hline $2 \mathrm{SW}$ & $\mathbf{s}$ & 1.0 & 5.00 & 0.30 & 3.8 & 0.29 & 0.06 & 17 & 1 \\
\hline 3 & $s$ & 1.1 & 0.02 & 0.17 & 3.3 & 0.41 & 0.07 & 21 & 1 \\
\hline 4 & P & 0.9 & 0.00 & 0.17 & 2.1 & 0.09 & 0.04 & 17 & 1 \\
\hline 5 & $\mathrm{P}$ & 0.5 & 0.03 & 0.17 & 2.5 & 0.45 & 0.06 & 18 & 1 \\
\hline 6 & $s$ & 1.1 & -0.03 & 0.17 & 4.3 & 0.50 & 0.03 & 16 & 1 \\
\hline $7 \mathrm{~A}$ & $S$ & 0.8 & 0.00 & 0.17 & 2.1 & 0.50 & 0.08 & 19 & 1 \\
\hline $7 \mathrm{~B}$ & $S$ & 1.0 & -0.07 & 0.17 & 1.7 & 0.58 & 0.07 & 19 & 1 \\
\hline $7 \mathrm{C}$ & $s$ & 0.9 & -0.07 & 0.17 & 1.5 & 0.47 & 0.06 & 19 & 1 \\
\hline 8 & $\mathrm{C}$ & 1.5 & 0.08 & 0.41 & 0.6 & 0.18 & 0.06 & 18 & 1 \\
\hline 9 & $C$ & 1.9 & -0.01 & 0.15 & 4.9 & 0.13 & 0.05 & 13 & 1 \\
\hline 10 & $C$ & 2.7 & 0.02 & 0.15 & 2.4 & 0.44 & 0.07 & 13 & 1 \\
\hline $11 \mathrm{~A}$ & C & 1.4 & -0.08 & 0.23 & 0.7 & 0.00 & 0.03 & 18 & 1 \\
\hline $11 \mathrm{~B}$ & $\mathrm{C}$ & 1.0 & -0.07 & 0.14 & 1.4 & 0.07 & 0.04 & 18 & 1 \\
\hline $11 \mathrm{C}$ & C & 1.2 & -0.06 & 0.23 & 0.6 & 0.08 & 0.05 & 19 & 1 \\
\hline 12 & $P$ & 0.8 & 0.05 & 0.17 & 1.8 & 0.65 & 0.07 & 15 & 1 \\
\hline 16 & $P$ & 1.7 & -0.08 & 0.17 & 1.4 & 0.12 & 0.06 & 28 & 1 \\
\hline 19 & $\mathbf{P}$ & 1.4 & -0.11 & 0.27 & 0.8 & 0.07 & 0.05 & 20 & 1 \\
\hline 20 & $\mathbf{s}$ & 1.8 & 0.58 & 0.69 & 0.2 & 0.20 & 0.05 & 17 & 1 \\
\hline 25 & C & 1.6 & -0.04 & 0.14 & 2.5 & 0.00 & 0.04 & 18 & 1 \\
\hline $32 \mathrm{E}$ & $s$ & 2.1 & 30.00 & 1.00 & 0.9 & 0.16 & 0.04 & 20 & 1 \\
\hline $32 \mathrm{~s}$ & $s$ & 2.0 & 20.00 & 1.00 & 1.9 & 0.31 & 0.06 & 20 & 1 \\
\hline
\end{tabular}


Table F-4. Soil Sample Analysis, August 1993 (Concluded)

\begin{tabular}{|c|c|c|c|c|c|c|c|c|c|}
\hline Location & $\begin{array}{l}\text { Location } \\
\text { Type }\end{array}$ & $\underset{(\mu \mathrm{g} / \mathrm{g})}{U_{\mathrm{tax}}}$ & $\begin{array}{c}H-3 \\
(p C i / m L)\end{array}$ & $\begin{array}{c}H-3 \\
\text { SDEVb }\end{array}$ & $\begin{array}{l}\mathrm{H}_{2} \mathrm{O} \\
(8)\end{array}$ & $\begin{array}{l}\mathrm{Cs}-137 \\
(\mathrm{pcj} / \mathrm{g})\end{array}$ & $\begin{array}{c}C s-137 \\
\text { SDEV }\end{array}$ & $\begin{array}{c}\mathrm{K}-40 \\
(\mathrm{p} C \dot{\mathrm{i}} / \mathrm{g})\end{array}$ & $\begin{array}{l}K-40 \\
\text { SDEV }^{b}\end{array}$ \\
\hline 33 & $s$ & 1.8 & 0.43 & 0.20 & 1.2 & 0.09 & 0.06 & 26 & 1 \\
\hline 34 & $s$ & 2.0 & -0.03 & 0.34 & 0.3 & 0.51 & 0.07 & 16 & 1 \\
\hline 35 & $s$ & 0.5 & 0.03 & 0.17 & 4.7 & 0.22 & 0.05 & 21 & 1 \\
\hline 41 & $s$ & 0.9 & 0.07 & 0.16 & 1.3 & 0.20 & 0.04 & 19 & 1 \\
\hline 42 & $s$ & 1.0 & -0.09 & 0.16 & 1.9 & 0.00 & 0.04 & 14 & 1 \\
\hline 43 & $s$ & 1.8 & -0.07 & 0.16 & 5.0 & 0.00 & 0.04 & 16 & 1 \\
\hline 45 & $s$ & 1.7 & 0.12 & 0.18 & 5.7 & 0.29 & 0.05 & 20 & 1 \\
\hline 46 & $s$ & 1.2 & 0.22 & 0.27 & 0.4 & 0.12 & 0.05 & 20 & 1 \\
\hline 49 & $s$ & 1.4 & -0.17 & 0.21 & 1.0 & 0.13 & 0.05 & 24 & 1 \\
\hline 51 & $s$ & 1.1 & -0.01 & 0.16 & 2.5 & 0.00 & 0.03 & 18 & 1 \\
\hline 52 & $s$ & 0.9 & 0.06 & 0.17 & 1.4 & 0.06 & 0.05 & 17 & 1 \\
\hline $53 \mathrm{~A}$ & $s$ & 0.9 & -0.03 & 0.18 & 1.6 & 0.10 & 0.06 & 16 & 1 \\
\hline 53 B & $s$ & 1.3 & -0.14 & 0.15 & 5.2 & 0.16 & 0.05 & 15 & 1 \\
\hline $53 \mathrm{C}$ & $s$ & 1.0 & 0.14 & 0.16 & 3.9 & 0.13 & 0.05 & 17 & 1 \\
\hline 54 & $s$ & 0.9 & -0.16 & 0.17 & 6.2 & 0.23 & 0.06 & 28 & 1 \\
\hline 55 & $\mathrm{~s}$ & 1.8 & -0.05 & 0.17 & 3.5 & 0.15 & 0.06 & 16 & 1 \\
\hline 56 & $s$ & 0.7 & -0.04 & 0.15 & 4.5 & 0.12 & 0.05 & 17 & 1 \\
\hline 57 & $s$ & 2.4 & -0.03 & 0.15 & 1.2 & 0.00 & 0.04 & 22 & 1 \\
\hline 58 & P & 1.4 & 0.06 & 0.17 & 2.8 & 0.38 & 0.06 & 20 & 1 \\
\hline 59 & P & 1.0 & 0.15 & 0.17 & 0.9 & 0.13 & 0.06 & 17 & 1 \\
\hline 60 & $P$ & 1.8 & -0.10 & 0.16 & 1.7 & 0.00 & 0.04 & 18 & 1 \\
\hline 61 & $P$ & 1.4 & -0.04 & 0.16 & 1.3 & 0.00 & 0.04 & 15 & 1 \\
\hline 62 & $c$ & 3.0 & 0.03 & 0.15 & 2.8 & 0.20 & 0.06 & 12 & 1 \\
\hline 63 & $\mathrm{P}$ & 1.8 & -0.01 & 0.27 & 0.9 & 0.09 & 0.04 & 17 & 1 \\
\hline 64 & $\mathrm{P}$ & 2.0 & -0.01 & 0.22 & 0.9 & 0.52 & 0.10 & 27 & 2 \\
\hline 65 & $\mathrm{P}$ & 1.5 & -0.03 & 0.34 & 0.6 & 0.77 & 0.08 & 19 & 1 \\
\hline 66 & $s$ & 1.0 & 0.09 & 0.23 & 1.1 & 0.00 & 0.04 & 17 & 1 \\
\hline \multicolumn{10}{|c|}{$\begin{array}{l}{ }^{2} \text { Location types: } S=S N L / N M, P=\text { Perimeter, } C=\text { Community } \\
\text { bvariability of the radioactive disintegration process (counting error) at the } 95 \text {-percent confidence } \\
\text { level, } 1.96 \text { sigma }\end{array}$} \\
\hline
\end{tabular}


Table F-5. Surface Water Sample Analysis, May 1993

\begin{tabular}{|c|c|c|c|c|c|c|c|c|c|}
\hline Location & $\begin{array}{c}\text { Location } \\
\text { Type }\end{array}$ & $\begin{array}{l}\text { Gross } \\
\text { Alpha } \\
\text { (pCi/L) }\end{array}$ & $\begin{array}{l}\text { Gross } \\
\text { Alpha } \\
\text { SDEv }\end{array}$ & $\begin{array}{c}\text { Gross } \\
\text { Beta } \\
\text { (pCi/L) }\end{array}$ & $\begin{array}{l}\text { Gross } \\
\text { Beta } \\
\text { SDEv }\end{array}$ & $\begin{array}{l}\text { Gross } \\
\text { Gamma } \\
\text { (pCi/L) }\end{array}$ & $\underset{(m g / L)}{U_{t o x}}$ & $\begin{array}{c}\mathrm{H}-3 \\
(\mathrm{pCi} / \mathrm{mL})\end{array}$ & $\begin{array}{c}\text { H-3 } \\
\text { SDEV }\end{array}$ \\
\hline \multicolumn{10}{|l|}{ Number 8} \\
\hline $\begin{array}{l}\text { Solution } \\
\text { Total } \\
\text { Suspended Solids }\end{array}$ & & $\begin{array}{r}2 \\
6 \\
16\end{array}$ & $\begin{array}{r}1 \\
2 \\
10\end{array}$ & $\begin{array}{r}5 \\
7 \\
21\end{array}$ & $\begin{array}{r}1 \\
2 \\
10\end{array}$ & $\begin{array}{l}\mathrm{ND}^{\mathrm{c}} \\
\mathrm{ND} \\
\mathrm{ND}\end{array}$ & $\begin{array}{l}<0.005 \\
<0.005 \\
-\end{array}$ & $\begin{array}{c}-0.15 \\
-- \\
--\end{array}$ & $\begin{array}{l}0.41 \\
-- \\
--\end{array}$ \\
\hline \multicolumn{10}{|l|}{ Number 68} \\
\hline $\begin{array}{l}\text { Solution } \\
\text { Total } \\
\text { Suspended Solids }\end{array}$ & & $\begin{array}{l}1 \\
1 \\
9\end{array}$ & $\begin{array}{l}1 \\
2 \\
7\end{array}$ & $\begin{array}{l}3 \\
2 \\
6\end{array}$ & $\begin{array}{l}1 \\
2 \\
7\end{array}$ & $\begin{array}{l}\text { ND } \\
\text { ND } \\
\text { ND }\end{array}$ & $\begin{array}{l}<0.005 \\
<0.005 \\
--\end{array}$ & $\begin{array}{l}-0.14 \\
-- \\
--\end{array}$ & $\begin{array}{l}0.17 \\
-- \\
--\end{array}$ \\
\hline \multicolumn{10}{|l|}{ Number 33} \\
\hline $\begin{array}{l}\text { Solution } \\
\text { Total } \\
\text { Suspended Solids }\end{array}$ & & $\begin{array}{r}8 \\
2 \\
-1\end{array}$ & $\begin{array}{r}7 \\
13 \\
7\end{array}$ & $\begin{array}{l}35 \\
45 \\
19\end{array}$ & $\begin{array}{r}8 \\
15 \\
10\end{array}$ & $\begin{array}{l}\text { ND } \\
\text { ND } \\
\text { ND }\end{array}$ & $\begin{array}{l}0.006 \\
<0.005 \\
--\end{array}$ & $\begin{array}{c}-0.06 \\
-- \\
--\end{array}$ & $\begin{array}{l}0.17 \\
-- \\
--\end{array}$ \\
\hline \multicolumn{10}{|l|}{ Number $11 \mathrm{~A}$} \\
\hline $\begin{array}{l}\text { Solution } \\
\text { Total } \\
\text { Suspended Solids }\end{array}$ & & $\begin{array}{r}1 \\
3 \\
15\end{array}$ & $\begin{array}{l}1 \\
2 \\
8\end{array}$ & $\begin{array}{r}4 \\
6 \\
37\end{array}$ & $\begin{array}{r}1 \\
2 \\
10\end{array}$ & $\begin{array}{l}\text { ND } \\
\text { ND } \\
\text { ND }\end{array}$ & $\begin{array}{l}<0.005 \\
<0.005 \\
--\end{array}$ & $\begin{array}{c}-0.02 \\
-- \\
--\end{array}$ & $\begin{array}{l}0.17 \\
-- \\
--\end{array}$ \\
\hline \multicolumn{10}{|l|}{ Number 11B } \\
\hline $\begin{array}{l}\text { Solution } \\
\text { Total }\end{array}$ & & $\begin{array}{l}2 \\
3\end{array}$ & $\frac{1}{2}$ & $\begin{array}{l}9 \\
7\end{array}$ & $\frac{1}{2}$ & $\begin{array}{l}\mathrm{ND} \\
\mathrm{ND}\end{array}$ & $\begin{array}{r}<0.005 \\
0.006\end{array}$ & -0.15 & $\begin{array}{l}0.17 \\
--\end{array}$ \\
\hline \multicolumn{10}{|l|}{ Number $11 \mathrm{C}$} \\
\hline $\begin{array}{l}\text { Solution } \\
\text { Total }\end{array}$ & & $\begin{array}{l}2 \\
3\end{array}$ & $\frac{1}{2}$ & $\begin{array}{l}6 \\
7\end{array}$ & $\begin{array}{l}1 \\
2\end{array}$ & $\begin{array}{l}\mathrm{ND} \\
\mathrm{ND}\end{array}$ & $\begin{array}{l}<0.005 \\
<0.005\end{array}$ & -0.12 & 0.17 \\
\hline \multicolumn{10}{|c|}{$\begin{array}{l}\text { DLocation types: } C=\text { Community, } S=S N L / N M \\
\text { bVariability of the radioactive disintegration process (counting error) at the } 95 \text {-percent confidence level, } \\
1.96 \text { sigma } \\
{ }_{\text {NDD no gamma-emitting radionuclides detected above instrument background }}\end{array}$} \\
\hline
\end{tabular}


Table F-6. Surface Water Sample Analysis, August 1993

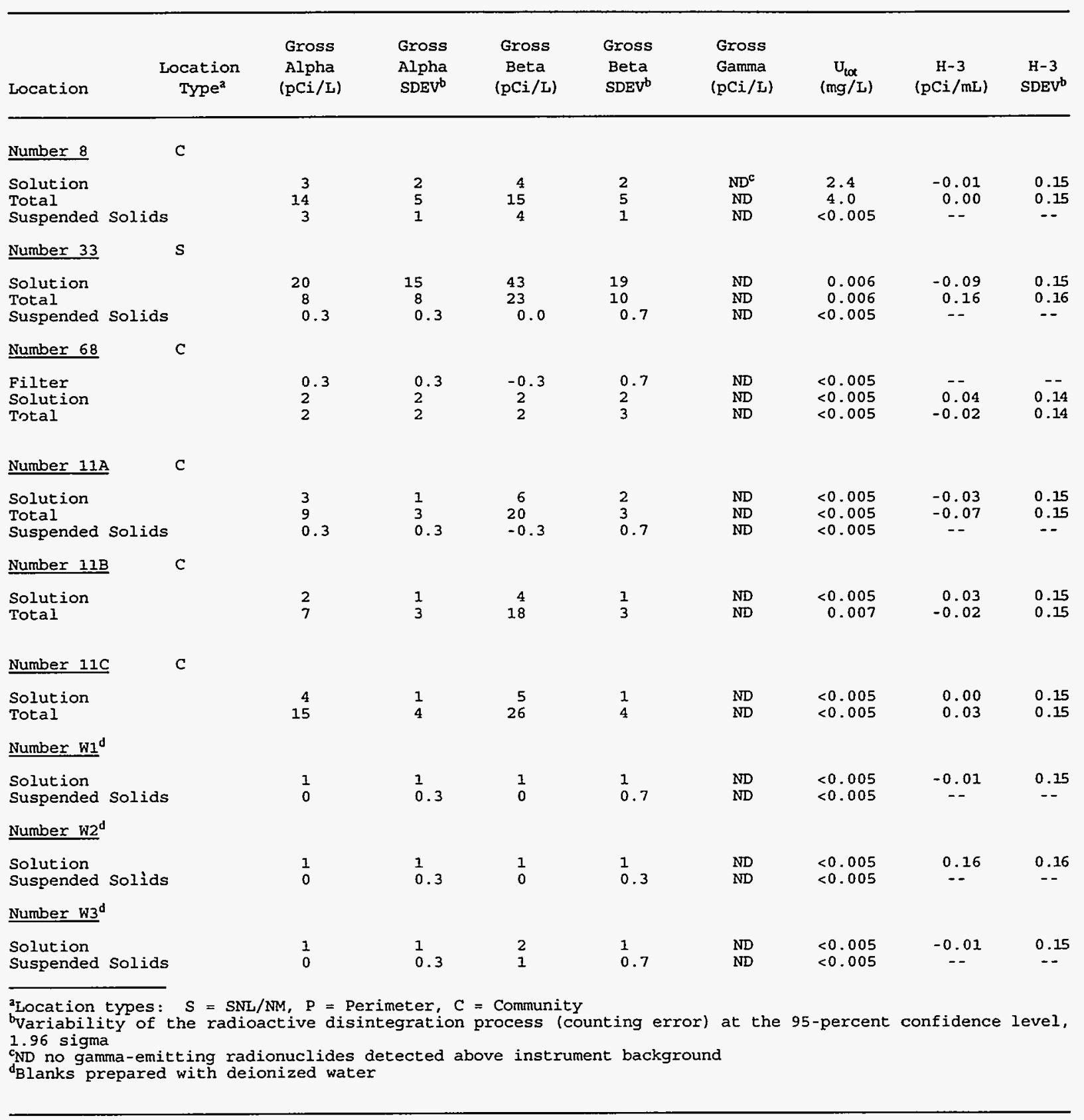


Table F-7. Arroyo Sediment Sample Analysis, May 1993

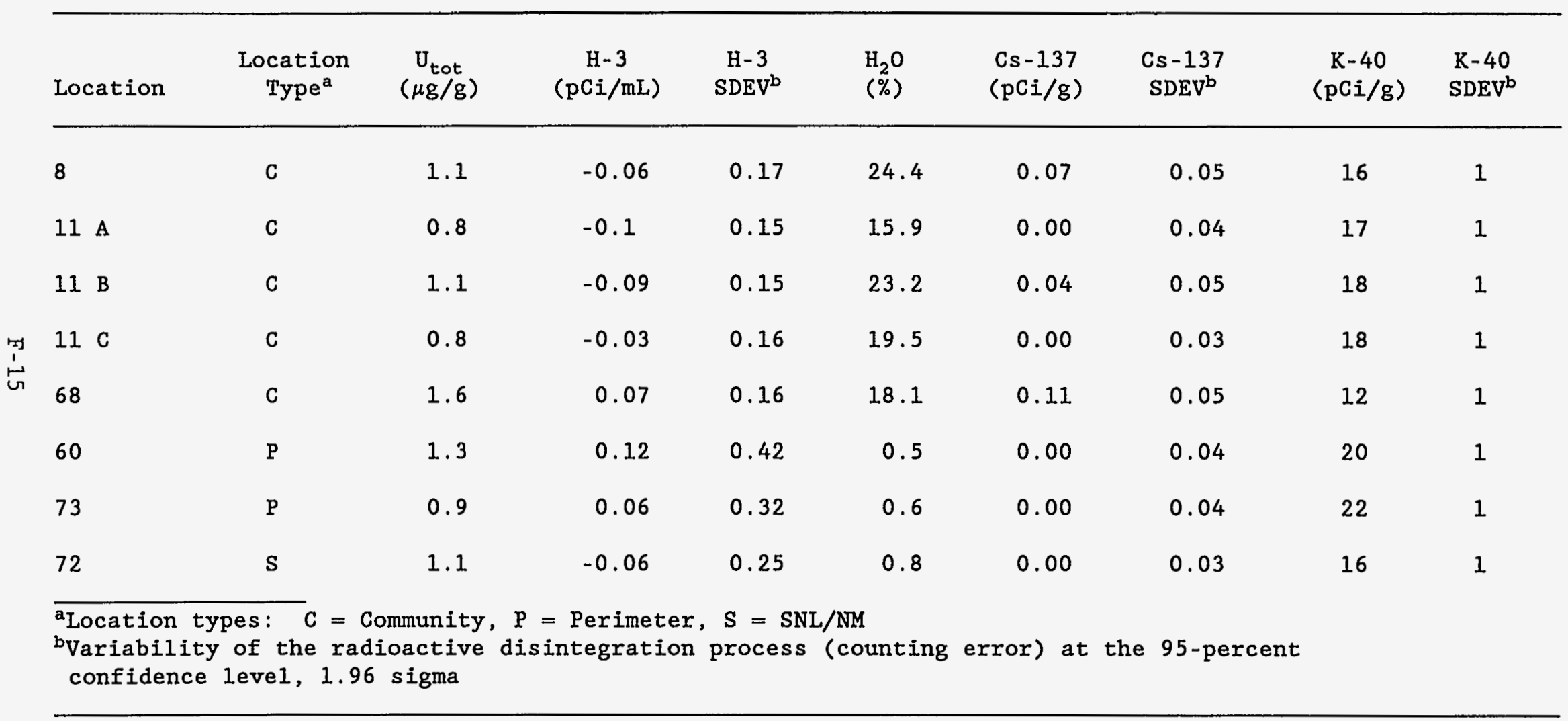


Table F-8. Arroyo Sediment Sample Analysis, August 1993

\begin{tabular}{|c|c|c|c|c|c|c|c|c|c|}
\hline Location & $\begin{array}{c}\text { Location } \\
\text { Type }^{a}\end{array}$ & $\begin{array}{c}\mathrm{U}_{\mathrm{tot}} \\
(\mu \mathrm{g} / \mathrm{g})\end{array}$ & $\begin{array}{c}\mathrm{H}-3 \\
(\mathrm{pCi} / \mathrm{mL})\end{array}$ & $\begin{array}{c}\mathrm{H}-3 \\
\text { SDEV }^{\mathrm{b}}\end{array}$ & $\begin{array}{l}\mathrm{H}_{2} \mathrm{O} \\
(\%)\end{array}$ & $\begin{array}{l}\mathrm{Cs}-137 \\
(\mathrm{pCi} / \mathrm{g})\end{array}$ & $\begin{array}{c}\text { Cs }-137 \\
\text { SDEV }^{\mathrm{b}}\end{array}$ & $\begin{array}{c}\mathrm{K}-40 \\
(\mathrm{pC} i / g)\end{array}$ & $\begin{array}{l}\mathrm{K}-40 \\
\mathrm{SDEV}\end{array}$ \\
\hline 8 & C & 1.3 & -0.03 & 0.15 & 13.4 & 0.04 & 0.05 & 17 & 1 \\
\hline $11 \mathrm{~A}$ & C & 1.0 & -0.08 & 0.14 & 11.8 & 0.00 & 0.03 & 17 & 1 \\
\hline $11 \mathrm{~B}$ & C & 1.1 & -0.10 & 0.14 & 9.5 & 0.00 & 0.04 & 19 & 1 \\
\hline $11 \mathrm{C}$ & $\mathrm{C}$ & 1.0 & 0.02 & 0.14 & 8.1 & 0.04 & 0.03 & 20 & 1 \\
\hline 68 & $\mathrm{C}$ & 2.1 & -0.01 & 0.14 & 18.1 & 0.08 & 0.03 & 12 & 1 \\
\hline 60 & $P$ & 1.7 & -0.21 & 0.41 & 0.5 & 0.00 & 0.04 & 19 & 1 \\
\hline $73 \mathrm{~A}$ & $\mathrm{P}$ & 1.3 & 0.00 & 0.25 & 0.7 & 0.00 & 0.04 & 24 & 1 \\
\hline $73 \mathrm{~B}$ & $\mathrm{P}$ & 1.4 & -0.10 & 0.14 & 2.4 & 0.00 & 0.04 & 26 & 1 \\
\hline $73 \mathrm{C}$ & $\mathrm{P}$ & 1.6 & 0.02 & 0.14 & 1.9 & 0.00 & 0.04 & 26 & 1 \\
\hline 72 & $S$ & 1.4 & -0.01 & 0.27 & 0.9 & 0.10 & 0.05 & 17 & 1 \\
\hline
\end{tabular}


Table F-9. Thermoluminiscent Dosimeter Sumary Radiation Exposure Data, 1993

\begin{tabular}{|c|c|c|c|c|c|c|c|c|c|}
\hline \multirow[b]{2}{*}{ Location } & \multicolumn{2}{|c|}{ 1st Quarter } & \multicolumn{2}{|c|}{ 2nd Quarter } & \multicolumn{2}{|c|}{ 3xd Quarter } & \multicolumn{2}{|c|}{ 4th Quarter } & \multirow[b]{2}{*}{$\begin{array}{l}\text { Annual } \\
\text { Exposure } \\
\text { (mR/yr) }\end{array}$} \\
\hline & $\begin{array}{l}\text { Field } \\
\text { Days }\end{array}$ & $\begin{array}{c}\text { Exposure } \\
\text { (mR) }\end{array}$ & $\begin{array}{l}\text { Field } \\
\text { Days }\end{array}$ & $\begin{array}{l}\text { Exposure } \\
\text { (mR) }\end{array}$ & $\begin{array}{l}\text { Field } \\
\text { Days }\end{array}$ & $\begin{array}{c}\text { Exposure } \\
(\mathrm{mR})\end{array}$ & $\begin{array}{l}\text { Field } \\
\text { Days }\end{array}$ & $\begin{array}{c}\text { Exposure } \\
\text { (mR) }\end{array}$ & \\
\hline \multicolumn{10}{|c|}{ Location Type: Community } \\
\hline 10 & 90 & $22.30 \pm 2.10$ & 91 & $24.90 \pm 2.30$ & 98 & $29.90 \pm 1.50$ & 84 & $23.20 \pm 4.6$ & $100.3 \pm 9.5$ \\
\hline 11 & 90 & $23.70 \pm 1.50$ & 91 & $20.10 \pm 3.60$ & 98 & $22.90 \pm 2.30$ & 84 & $19.80 \pm 1.9$ & $85.5 \pm 9.3$ \\
\hline 21 & 90 & $26.30 \pm 2.00$ & 91 & $23.30 \pm 2.60$ & 98 & $24.60 \pm 4.10$ & 84 & $23.40 \pm 2.5$ & $97.6 \pm 11.2$ \\
\hline 22 & 90 & $21.60 \pm 2.10$ & 91 & $20.10 \pm 2.30$ & 98 & $23.10 \pm 1.50$ & 84 & $19.60 \pm 2.1$ & $84.4 \pm 8.0$ \\
\hline 23 & 90 & $22.40 \pm 2.30$ & 91 & $23.10 \pm 2.30$ & 98 & $22.40 \pm 2.80$ & 84 & $20.40 \pm 3.0$ & $88.3 \pm 9.4$ \\
\hline 24 & 90 & $27.70 \pm 1.10$ & 91 & $23.20 \pm 3.80$ & 98 & $24.60 \pm 2.50$ & 84 & $22.40 \pm 4.3$ & $97.9 \pm 11.7$ \\
\hline 25 & 90 & $24.80 \pm 4.70$ & 91 & $21.70 \pm 2.10$ & 98 & $25.30 \pm 1.00$ & 84 & $21.10 \pm 2.1$ & $92.9 \pm 9.9$ \\
\hline 26 & 90 & $31.10 \pm 4.20$ & 91 & $25.80 \pm 2.80$ & 98 & $30.80 \pm 1.30$ & 84 & $25.80 \pm 4.0$ & $113.5 \pm 12.3$ \\
\hline 27 & 90 & $25.40 \pm 2.80$ & 91 & $22.40 \pm 2.20$ & 98 & $26.00 \pm 1.00$ & 84 & $24.10 \pm 3.5$ & $97.9 \pm 9.5$ \\
\hline 28 & 90 & $25.40 \pm 1.90$ & 91 & $24.10 \pm 3.90$ & 98 & $21.40 \pm 6.60$ & 84 & $23.30 \pm 1.1$ & $94.2 \pm 13.5$ \\
\hline 29 & 90 & $20.40 \pm 0.80$ & 91 & $22.00 \pm 4.20$ & 98 & $24.90 \pm 1.40$ & 84 & $20.00 \pm 2.9$ & $87.3 \pm 9.3$ \\
\hline 30 & 90 & $27.00 \pm 1.80$ & 91 & $26.20 \pm 2.10$ & 98 & $26.40 \pm 2.10$ & 84 & $24.80 \pm 3.6$ & $104.4 \pm 9.6$ \\
\hline \multicolumn{10}{|c|}{ Location Type: Perimeter } \\
\hline 4 & 90 & $28.20 \pm 3.20$ & 91 & $20.90 \pm 3.90$ & 98 & $25.30 \pm 2.60$ & 84 & $22.60 \pm 2.1$ & $97.0 \pm 11.8$ \\
\hline 5 & 90 & $23.7 \pm 2.60$ & 91 & $20.70 \pm 1.90$ & 98 & $22.30 \pm 1.50$ & 84 & $20.50 \pm 1.6$ & $87.2 \pm 7.6$ \\
\hline 16 & 90 & $27.10 \pm 0.90$ & 91 & $30.30 \pm 2.40$ & 98 & $31.30 \pm 2.00$ & 84 & $26.20 \pm 2.9$ & $114.9 \pm 8.2$ \\
\hline 18 & 90 & $25.00 \pm 2.50$ & 91 & $23.30 \pm 2.10$ & 98 & $23.60 \pm 2.80$ & 84 & $21.50 \pm 2.1$ & $93.4 \pm 9.5$ \\
\hline 19 & 90 & $25.20 \pm 2.40$ & 91 & $24.50 \pm 2.10$ & 98 & $27.30 \pm 2.90$ & 84 & $22.90 \pm 2.5$ & $99.9 \pm 9.9$ \\
\hline
\end{tabular}


Table F-9. Thermoluminiscent Dosimeter Summary Radiation Exposure Data, 1993 (Concluded)

\begin{tabular}{|c|c|c|c|c|c|c|c|c|c|}
\hline \multirow[b]{2}{*}{ Location } & \multicolumn{2}{|c|}{ 2st Quartex } & \multicolumn{2}{|c|}{ 2nd Quarter } & \multicolumn{2}{|c|}{3 rd Quarter } & \multicolumn{2}{|c|}{ 4th Quarter } & \multirow[b]{2}{*}{$\begin{array}{l}\text { Annual } \\
\text { Exposure } \\
\text { (mR/yr) }\end{array}$} \\
\hline & $\begin{array}{l}\text { Field } \\
\text { Days }\end{array}$ & $\begin{array}{c}\text { Exposure } \\
\text { (mR) }\end{array}$ & $\begin{array}{l}\text { Field } \\
\text { Days }\end{array}$ & $\begin{array}{l}\text { Exposure } \\
\text { (mR) }\end{array}$ & $\begin{array}{l}\text { Field } \\
\text { Days }\end{array}$ & $\begin{array}{c}\text { Exposure } \\
\text { (mR) }\end{array}$ & $\begin{array}{l}\text { Field } \\
\text { Days }\end{array}$ & $\begin{array}{c}\text { Exposure } \\
(m R)\end{array}$ & \\
\hline \multicolumn{10}{|c|}{ Location Type: Perimeter (Concluded) } \\
\hline 39 & 90 & $24.40 \pm 1.30$ & 91 & $20.90 \pm 2.80$ & 98 & $21.60 \pm 1.70$ & 84 & $21.40 \pm 3.0$ & $88.3 \pm 8.8$ \\
\hline 40 & 90 & $20.90 \pm 2.00$ & 91 & $20.20 \pm 2.00$ & 98 & $22.10 \pm 2.50$ & 84 & $19.70 \pm 3.4$ & $82.9 \pm 9.9$ \\
\hline \multicolumn{10}{|c|}{ Location Type: SNL/NM } \\
\hline 1 & 90 & $29.20 \pm 1.50$ & 91 & $25.40 \pm 3.00$ & 98 & $28.00 \pm 2.70$ & 84 & $25.00 \pm 2.6$ & $107.6 \pm 9.8$ \\
\hline 2 & 90 & $25.10 \pm 1.10$ & 91 & $22.50 \pm 2.70$ & 98 & $26.90 \pm 2.20$ & 84 & $21.70 \pm 2.4$ & $96.2 \pm 7.4$ \\
\hline 3 & 90 & $23.10 \pm 1.60$ & 91 & $24.10 \pm 2.80$ & 98 & $26.20 \pm 1.20$ & 84 & $22.30 \pm 4.9$ & $95.7 \pm 10.5$ \\
\hline 6 & 90 & $26.90 \pm 2.40$ & 91 & $22.10 \pm 2.00$ & 98 & $23.50 \pm 3.80$ & 84 & $23.40 \pm 2.1$ & $95.9 \pm 20.3$ \\
\hline 7 & 90 & $23.60 \pm 3.70$ & 91 & $23.80 \pm 2.90$ & 98 & $27.20 \pm 2.10$ & 84 & $24.20 \pm 1.1$ & $98.8 \pm 9.8$ \\
\hline 20 & 90 & $27.50 \pm 2.10$ & 91 & $23.20 \pm 2.40$ & 98 & $25.90 \pm 2.60$ & 84 & $22.50 \pm 3.8$ & $99.1 \pm 10.9$ \\
\hline 31 & 90 & $25.10 \pm 2.50$ & 91 & $23.50 \pm 3.00$ & 98 & $26.40 \pm 1.00$ & 84 & $22.40 \pm 2.4$ & $97.4 \pm 8.9$ \\
\hline 41 & 90 & $23.20 \pm 2.30$ & 91 & $23.10 \pm 3.90$ & 98 & $25.00 \pm 2.90$ & 84 & $22.20 \pm 1.8$ & $93.5 \pm 10.9$ \\
\hline 42 & 90 & $23.10 \pm 1.60$ & 91 & $22.80 \pm 2.00$ & 98 & $24.50 \pm 2.10$ & 84 & $21.10 \pm 1.8$ & $91.5 \pm 7.5$ \\
\hline 43 & 90 & $21.20 \pm 2.00$ & 91 & $23.10 \pm 2.40$ & 98 & $25.30 \pm 1.70$ & 84 & $22.70 \pm 3.1$ & $92.3 \pm 9.2$ \\
\hline $45 \mathrm{~A}$ & 90 & $23.30 \pm 5.50$ & 91 & $21.90 \pm 2.00$ & 98 & $25.50 \pm 4.40$ & 84 & $21.10 \pm 3.3$ & $91.6 \pm 15.2$ \\
\hline $45 B$ & 90 & $25.70 \pm 3.10$ & 91 & $21.30 \pm 2.10$ & 98 & $25.30 \pm 1.20$ & 84 & $21.50 \pm 2.2$ & $93.8 \pm 8.6$ \\
\hline 46 & 90 & $27.80 \pm 2.90$ & 91 & $22.90 \pm 1.90$ & 98 & $30.60 \pm 1.80$ & 84 & $24.10 \pm 2.3$ & $105.4 \pm 8.9$ \\
\hline 47 & 90 & $30.10 \pm 3.90$ & 91 & $24.80 \pm 2.90$ & 98 & $29.90 \pm 2.30$ & 84 & $23.90 \pm 3.1$ & $108.7 \pm 12.2$ \\
\hline 48 & 90 & $27.10 \pm 2.40$ & 91 & $23.60 \pm 2.20$ & 98 & $25.70 \pm 2.70$ & 84 & $24.60 \pm 1.4$ & $101.0 \pm 8.7$ \\
\hline
\end{tabular}


Table F-10. Concentrations (ppm) of Metals in Onsite Soil Samples (Group 1: Technical Areas I, II, and IV), May 1993

\begin{tabular}{|c|c|c|c|c|c|c|}
\hline & $\begin{array}{r}\text { Site: } \\
\text { Sample No.: }\end{array}$ & $\begin{array}{l}20 \\
12521\end{array}$ & $\begin{array}{c}32 \mathrm{~S} \\
9917\end{array}$ & $\begin{array}{c}32 E \\
9916\end{array}$ & $\begin{array}{l}49 \\
9915\end{array}$ & $\begin{array}{l}57 \\
9913\end{array}$ \\
\hline Aluminum & 7600 & 9100 & 7000 & 7000 & 8600 & 8000 \\
\hline Barium & 93 & 93 & 82 & 120 & 120 & 140 \\
\hline Beryllium & 0.5 & 0.5 & 0.5 & 0.5 & 0.5 & 0.5 \\
\hline Cadmium & 0.5 & 1.7 & 0.5 & 0.7 & 0.5 & 0.5 \\
\hline Calcium & 25000 & 17000 & 35000 & 32000 & 42000 & 38000 \\
\hline Chromium & 16 & 18 & 17 & 25 & 18 & 14 \\
\hline Cobalt & 4.5 & 4.5 & 4.4 & 3.9 & 4.9 & 4.2 \\
\hline Copper & 8.9 & 13 & 13 & 47 & 9.4 & 7.6 \\
\hline Iron & 11000 & 10000 & 11000 & 11000 & 12000 & 12000 \\
\hline Lead & 11 & 11000 & 19 & 560 & 8 & 7 \\
\hline Magnesium & 3700 & 3400 & 2700 & 2900 & 3800 & 3600 \\
\hline Manganese & 250 & 230 & 180 & 190 & 240 & 210 \\
\hline Nicke1 & 7 & 8 & 6 & 7 & 9 & 6 \\
\hline Potassium & 2600 & 2900 & 1600 & 1600 & 2000 & 2000 \\
\hline Silica & 400 & 890 & 85 & 120 & 200 & 240 \\
\hline Silver & 0.5 & 0.6 & 0.6 & 0.6 & 0.5 & 0.5 \\
\hline Strontium & 40 & 31 & 46 & 54 & 72 & 80 \\
\hline Titanium & 500 & 490 & 460 & 520 & 640 & 710 \\
\hline Vanadium & 19 & 21 & 23 & 22 & 28 & 28 \\
\hline Zinc & 36 & 36 & 40 & 72 & 28 & 33 \\
\hline
\end{tabular}


Table F-11. Concentrations (ppm) of Metals in Onsite Soil Samples (Group 2: Technical Areas III and V), May 1993

\begin{tabular}{|c|c|c|c|c|c|c|c|c|c|c|c|}
\hline $\begin{array}{r}\text { Site: } \\
\text { Sample No.: }\end{array}$ & $\begin{array}{c}2 N W \\
12584\end{array}$ & $\begin{array}{c}2 S W \\
12582\end{array}$ & $\begin{array}{c}2 \mathrm{SE} \\
12580\end{array}$ & $\begin{array}{c}2 \mathrm{NE} \\
12590\end{array}$ & $\begin{array}{c}2 \mathrm{NE} \\
12589\end{array}$ & $\begin{array}{c}2 \mathrm{NE} \\
12588\end{array}$ & $\begin{array}{c}6 \\
12594\end{array}$ & $\begin{array}{c}7 \mathrm{~A} \\
12562\end{array}$ & $\begin{array}{c}7 \mathrm{~B} \\
12561\end{array}$ & $\begin{array}{c}7 C \\
12560\end{array}$ & $\begin{array}{c}35 \\
12564\end{array}$ \\
\hline Aluminum & 6800 & 8500 & 7700 & 7500 & 8300 & 8000 & 9000 & 9400 & 9200 & 8700 & 8100 \\
\hline Barium & 54 & 80 & 74 & 94 & 71 & 71 & 61 & 76 & 75 & 79 & 76 \\
\hline Beryllium & 0.5 & 0.5 & 0.5 & 0.5 & 0.5 & 0.5 & 0.5 & 0.5 & 0.5 & 0.5 & 0.5 \\
\hline Cadmium & 0.5 & 0.5 & 0.5 & 0.5 & 0.5 & 4.9 & 0.5 & 0.5 & 0.5 & 0.5 & 0.5 \\
\hline Calcium & 4400 & 9600 & 10000 & 12000 & 11000 & 15000 & 4300 & 3000 & 3200 & 3200 & 7300 \\
\hline Chromium & 6.7 & 19 & 18 & 21 & 19 & 20 & 24 & 16 & 19 & 18 & 17 \\
\hline Cobalt & 2.3 & 2.8 & 2.5 & 2.7 & 3 & 2.7 & 2.8 & 3.5 & 3.5 & 3.9 & 2.5 \\
\hline Copper & 4 & 5.7 & 4.5 & 5.2 & 4.7 & 6 & 5.8 & 7.5 & 7.6 & 8.6 & 7 \\
\hline Iron & 7400 & 8600 & 7200 & 7400 & 8900 & 8500 & 8600 & 9900. & 9700 & 10000 & 7900 \\
\hline Lead & 7 & 6 & 5 & 6 & 17 & 5 & 10 & 11 & 11 & 16 & 7 \\
\hline Magnesium & 1600 & 2300 & 2200 & 2200 & 2200 & 2400 & 2000 & 2400 & 2400 & 2500 & 2200 \\
\hline Manganese & 120 & 140 & 110 & 120 & 130 & 140 & 130 & 210 & 200 & 220 & 150 \\
\hline Nickel & 4 & 6 & 6 & 5 & 6 & 13 & 6 & 10 & 7 & 8 & 5 \\
\hline Potassium & 1600 & 2000 & 1900 & 2000 & 2100 & 2000 & 2200 & 2400 & 2300 & 2200 & 2300 \\
\hline Silica & 160 & 170 & 450 & 160 & 160 & 160 & 130 & 330 & 190 & 190 & 290 \\
\hline Silver & 0.5 & 0.5 & 0.5 & 0.5 & 0.5 & 0.5 & 0.5 & 0.5 & 0.5 & 0.5 & 0.5 \\
\hline Strontium & 16 & 25 & 26 & 30 & 30 & 35 & 15 & 15 & 16 & 15 & 22 \\
\hline Titanium & 170 & 150 & 170 & 160 & 200 & 190 & 170 & 240 & 240 & 190 & 140 \\
\hline Vanadium & 13 & 15 & 13 & 14 & 16 & 15 & 15 & 16 & 17 & 16 & 14 \\
\hline Zinc & 22 & 27 & 44 & 30 & 32 & 29 & 32 & 31 & 31 & 36 & 44 \\
\hline
\end{tabular}


Table F-11. Concentrations (ppm) of Metals in Onsite Soil Samples (Group 2: Technical Areas III and V), May 1993 (Concluded)

\begin{tabular}{|c|c|c|c|c|c|c|c|c|c|}
\hline Sample & $\begin{array}{cc}\text { Site: } & 41 \\
\text { e No.: } & 12572\end{array}$ & $\begin{array}{c}42 \\
12574\end{array}$ & $\begin{array}{c}43 \\
12576\end{array}$ & $\begin{array}{c}45 \\
12592\end{array}$ & $\begin{array}{c}51 \\
12556\end{array}$ & $\begin{array}{c}52 \\
12598\end{array}$ & $\begin{array}{c}54 \\
12596\end{array}$ & $\begin{array}{c}55 \\
12604\end{array}$ & $\begin{array}{c}56 \\
9912\end{array}$ \\
\hline Aluminum & 9000 & 8800 & 9300 & 9000 & 7900 & 13000 & 10000 & 8400 & 7000 \\
\hline Barium & 70 & 73 & 67 & 76 & 94 & 100 & 100 & 91 & 70 \\
\hline Beryllium & 0.5 & 0.5 & 0.5 & 0.5 & 0.5 & 0.5 & 0.5 & 0.5 & 0.5 \\
\hline Cadmium & 0.5 & 0.5 & 0.5 & 0.5 & 0.5 & 0.5 & 0.5 & 0.5 & 0.5 \\
\hline Calcium & 14000 & 30000 & 12000 & 9600 & 30000 & 17000 & 22000 & 33000 & 21000 \\
\hline Chromium & 18 & 14 & 19 & 16 & 17 & 16 & 19 & 14 & 24 \\
\hline Cobalt & 3.2 & 3.1 & 3 & 2.6 & 2.9 & 4 & 3.4 & 2.9 & 3.6 \\
\hline Copper & 6.4 & 7.1 & 6.3 & 6.4 & 7 & 8.6 & 11 & 5.7 & 9.4 \\
\hline Iron & 8900 & 9000 & 9200 & 7700 & 8200 & 12000 & 9300 & 8100 & 9000 \\
\hline Lead & 21 & 5 & 5 & 6 & 9 & 7 & 9 & 5 & 7 \\
\hline Magnesium & 2500 & 3000 & 2500 & 2300 & 2700 & 3400 & 3000 & 3000 & 2100 \\
\hline Manganese & 150 & 150 & 140 & 140 & 130 & 180 & 140 & 150 & 160 \\
\hline Nicke1 & 6 & 8 & 6 & 7 & 6 & 8 & 10 & 6 & 8 \\
\hline Potassium & 2300 & 2400 & 2400 & 2300 & 1700 & 2600 & 2000 & 2700 & 1400 \\
\hline Silica & 140 & 130 & 160 & 210 & 180 & 170 & 160 & 170 & 200 \\
\hline Silver & 0.5 & 0.5 & 0.5 & 0.5 & 0.5 & 0.6 & 0.9 & 0.5 & 0.5 \\
\hline Strontium & 25 & 42 & 27 & 24 & 49 & 36 & 41 & 59 & 35 \\
\hline Titanium & 230 & 250 & 220 & 160 & 210 & 230 & 210 & 160 & 340 \\
\hline Vanadium & 16 & 16 & 18 & 14 & 16 & 20 & 17 & 15 & 18 \\
\hline Zinc & 30 & 28 & 26 & 30 & 30 & 33 & 69 & 26 & 75 \\
\hline
\end{tabular}


Table F-12. Concentrations (ppm) of Metals in Perimeter Soil Samples, May 1993

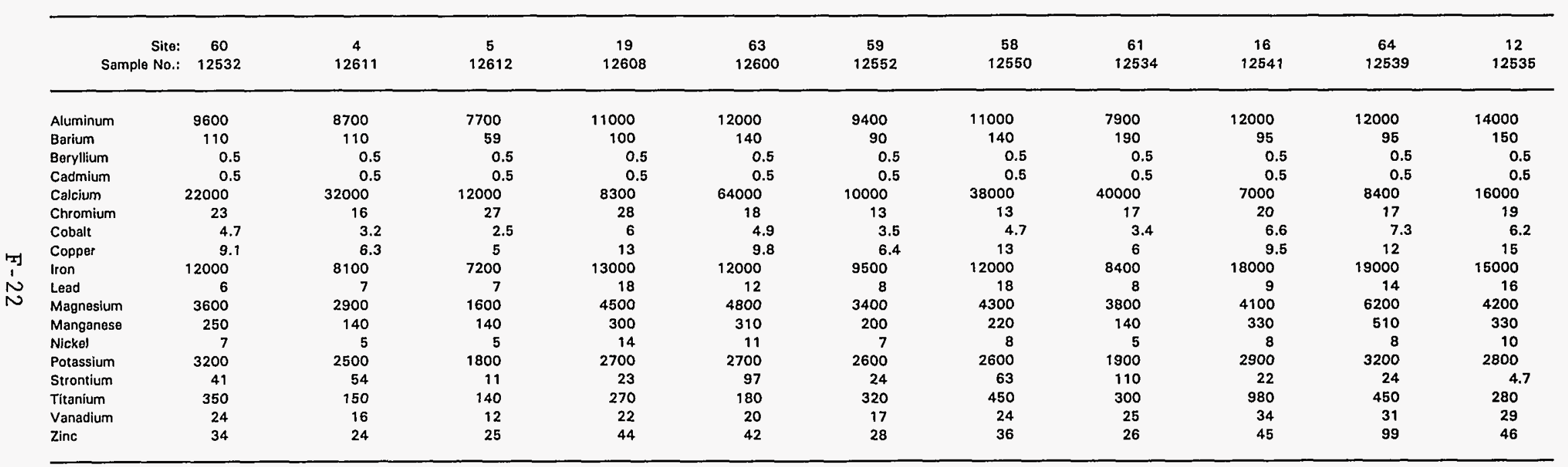


Table F-13. Concentrations (ppm) of Metals in offsite Soil Samples, May 1993

\begin{tabular}{|c|c|c|c|c|c|c|c|c|c|}
\hline $\begin{array}{r}\text { Site: } \\
\text { Sample No.: }\end{array}$ & $\begin{array}{c}8 \\
9907\end{array}$ & $\begin{array}{c}25 \\
12517 \\
\end{array}$ & $\begin{array}{c}65 \\
12548 \\
\end{array}$ & $\begin{array}{c}11 \mathrm{~A} \\
12511\end{array}$ & $\begin{array}{c}11 \mathrm{~B} \\
12510\end{array}$ & $\begin{array}{c}11 C \\
12509\end{array}$ & $\begin{array}{c}9 \\
12527 \\
\end{array}$ & $\begin{array}{c}10 \\
12525\end{array}$ & $\begin{array}{c}62 \\
12523 \\
\end{array}$ \\
\hline Aluminum & 5600 & 9600 & 9500 & 6400 & 5800 & 6300 & 23000 & 16000 & 23000 \\
\hline Barium & 180 & 140 & 87 & 180 & 180 & 180 & 240 & 100 & 200 \\
\hline Beryllium & 0.5 & 0.5 & 0.5 & 0.5 & 0.5 & 0.5 & 0.8 & 0.5 & 0.9 \\
\hline Cadmium & 0.9 & 0.5 & 0.5 & 0.5 & 0.5 & 0.5 & 0.5 & 0.5 & 0.5 \\
\hline Calcium & 16000 & 43000 & 8600 & 16000 & 16000 & 15000 & 46000 & 60000 & 48000 \\
\hline Chromium & 18 & 20 & 19 & 17 & 29 & 21 & 24 & 22 & 22 \\
\hline Cobalt & 3.6 & 4.2 & 5.2 & 3.6 & 3.6 & 3.5 & 8 & 5.9 & 8.6 \\
\hline Copper & 21 & 8.7 & 9.3 & 5.9 & 6 & 5.8 & 20 & 8.5 & 16 \\
\hline Iron & 16000 & 9900 & 12000 & 9800 & 9500 & 9400 & 20000 & 15000 & 19000 \\
\hline Lead & 100 & 30 & 15 & 7 & 7 & 8 & 45 & 10 & 10 \\
\hline Magnesium & 4100 & 3000 & 3600 & 2700 & 2600 & 2700 & 7100 & 3400 & 5200 \\
\hline Manganese & 250 & 270 & 250 & 280 & 290 & 280 & 470 & 500 & 530 \\
\hline Nickel & 8 & 8 & 7 & 6 & 7 & 6 & 16 & 11 & 21 \\
\hline Potassium & 2100 & 2400 & 2700 & 2100 & 2000 & 2000 & 3700 & 3400 & 5500 \\
\hline Silica & 130 & 320 & 160 & 190 & 140 & 160 & 250 & 220 & 380 \\
\hline Silver & 0.5 & 0.5 & 0.5 & 0.5 & 0.5 & 0.5 & 0.5 & 0.5 & 0.5 \\
\hline Strontium & 68 & 58 & 20 & 49 & 51 & 50 & 75 & 100 & 90 \\
\hline Titanium & 180 & 240 & 410 & 310 & 240 & 270 & 260 & 380 & 300 \\
\hline Vanadium & 17 & 21 & 23 & 23 & 21 & 21 & 44 & 34 & 38 \\
\hline Zine & 120 & 54 & 36 & 29 & 26 & 29 & 77 & 35 & 61 \\
\hline
\end{tabular}


Table F-14. Concentrations (ppm) of Metals in Onsite Soil Samples (Group 1: Technical Areas I, II, and IV), August 1993

\begin{tabular}{|c|c|c|c|c|c|c|c|}
\hline & $\begin{array}{r}\text { Site: } \\
\text { Sample No.: }\end{array}$ & $\begin{array}{l}20 \\
13310\end{array}$ & $\begin{array}{l}32 S \\
13284\end{array}$ & $\begin{array}{c}32 E \\
13285\end{array}$ & $\begin{array}{c}49 \\
13304\end{array}$ & $\begin{array}{c}57 \\
13283\end{array}$ & $\begin{array}{c}46 \\
13308\end{array}$ \\
\hline Aluminum & 7000 & 9300 & 6900 & 8600 & 9600 & 7800 & 10000 \\
\hline Barium & 95 & 93 & 86 & 98 & 120 & 160 & 93 \\
\hline Beryllium & 0.5 & 0.5 & 0.5 & 0.5 & 0.5 & 0.5 & 0.5 \\
\hline Cadmium & 0.5 & 1.7 & 0.6 & 0.7 & 0.5 & 0.5 & 0.5 \\
\hline Calcium & 36000 & 17000 & 36000 & 40000 & 47000 & 57000 & 18000 \\
\hline Chromium & 15 & 20 & 14 & 21 & 16 & 15 & 19 \\
\hline Cobalt & 4.1 & 5.4 & 4.4 & 4.5 & 4.6 & 3.9 & 4.8 \\
\hline Copper & 9.4 & 11 & 11 & 15 & 14 & 8.7 & 7.7 \\
\hline Iron & 11000 & 11000 & 9200 & 11000 & 11000 & 9400 & 13000 \\
\hline Lead & 9 & 260 & 12 & 400 & 7 & 11 & 9 \\
\hline Magnesium & 3200 & 3400 & 6100 & 3200 & 3600 & 3700 & 3600 \\
\hline Manganese & 210 & 230 & 230 & 220 & 200 & 200 & 250 \\
\hline Nickel & 7 & 10 & 7 & 8 & 6 & 8 & 8 \\
\hline Potassium & 1700 & 2600 & 1900 & 1900 & 2300 & 1800 & 2800 \\
\hline Silica & 0.5 & 0.5 & 290 & 240 & 120 & 210 & 0.5 \\
\hline Silver & 110 & 110 & 150 & 160 & 0.5 & 160 & 130 \\
\hline Strontium & 59 & 28 & 51 & 67 & 68 & 110 & 32 \\
\hline Titanium & 450 & 430 & 380 & 680 & 550 & 560 & 670 \\
\hline Vanadium & 22 & 22 & 18 & 23 & 25 & 23 & 26 \\
\hline Zinc & 28 & 35 & 36 & 46 & 27 & 31 & 36 \\
\hline
\end{tabular}


Table F-15. Concentrations (ppm) of Metals in Onsite Soil Samples (Group 2: Technical Areas III and V), August 1993

\begin{tabular}{|c|c|c|c|c|c|c|c|c|c|c|}
\hline $\begin{array}{l}\text { Site } \\
\text { Sample No }\end{array}$ & $\begin{array}{r}2 \mathrm{NW} \\
9889\end{array}$ & $\begin{array}{r}2 S W \\
9887\end{array}$ & $\begin{array}{r}2 S E \\
9885\end{array}$ & $\begin{array}{l}\text { 2NEA } \\
9883\end{array}$ & $\begin{array}{l}2 \mathrm{NEB} \\
9882\end{array}$ & $\begin{array}{l}\text { 2NEC } \\
9881\end{array}$ & $\begin{array}{c}6 \\
9877\end{array}$ & $\begin{array}{c}7 A \\
9853\end{array}$ & $\begin{array}{c}7 \mathrm{~B} \\
9852\end{array}$ & $\begin{array}{c}7 C \\
9851\end{array}$ \\
\hline Aluminum & 8100 & 9500 & 9300 & 8200 & 7700 & 7700 & 8700 & 10000 & 10000 & 12000 \\
\hline Barium & 67 & 81 & 72 & 68 & 61 & 61 & 68 & 67 & 67 & 69 \\
\hline Beryllium & 0.5 & 0.5 & 0.5 & 0.5 & 0.5 & 0.5 & 0.5 & 0.5 & 0.5 & 0.5 \\
\hline Cadmium & 0.5 & 0.5 & 0.5 & 0.5 & 0.5 & 0.5 & 0.5 & 0.5 & 0.5 & 0.5 \\
\hline Calcium & 4800 & 7500 & 7100 & 2800 & 2900 & 2000 & 4600 & 12000 & 2800 & 8800 \\
\hline Chromium & 20 & 20 & 22 & 26 & 21 & 20 & 18 & 22 & 21 & 17 \\
\hline Cobalt & 2.8 & 2.9 & 2.8 & 2.9 & 2.6 & 2.7 & 2.9 & 4.5 & 4.1 & 4.3 \\
\hline Copper & 5.6 & 5.6 & 5.5 & 5.3 & 5 & 4.4 & 7 & 7.7 & 7.3 & 8.6 \\
\hline Iron & 8500 & 9400 & 9000 & 9300 & 8200 & 8600 & 8600 & 11000 & 11000 & 11000 \\
\hline Lead & 8 & 6 & 6 & 5 & 7 & 10 & 11 & 12 & 10 & 10 \\
\hline Magnesium & 2000 & 2200 & 2200 & 1700 & 1600 & 1500 & 2000 & 2800 & 2600 & 3000 \\
\hline Manganese & 140 & 150 & 140 & 160 & 140 & 140 & 140 & 210 & 200 & 210 \\
\hline Nickel & 6 & 5 & 7 & 5 & 5 & 4 & 6 & 8 & 7 & 7 \\
\hline Potassium & 1900 & 2100 & 2100 & 1800 & 1800 & 1700 & 1900 & 2400 & 2400 & 2700 \\
\hline Silica & 0.5 & 0.5 & 0.5 & 0.5 & 0.5 & 0.5 & 0.5 & 0.5 & 0.5 & 0.5 \\
\hline Silver & 70 & 90 & 80 & 80 & 90 & 80 & 90 & 130 & 120 & 130 \\
\hline Strontium & 18 & 23 & 23 & 16 & 15 & 14 & 17 & 31 & 17 & 28 \\
\hline Titanium & 220 & 240 & 240 & 240 & 240 & 250 & 220 & 380 & 360 & 350 \\
\hline Vanadium & 17 & 19 & 18 & 19 & 16 & 17 & 16 & 21 & 20 & 21 \\
\hline Zinc & 24 & 26 & 23 & 24 & 21 & 21 & 31 & 32 & 32 & 33 \\
\hline
\end{tabular}


Table F-15. Concentrations (ppm) of Metals in Onsite Soil Samples (Group 2: Technical Areas III and V), August 1993 (Concluded)

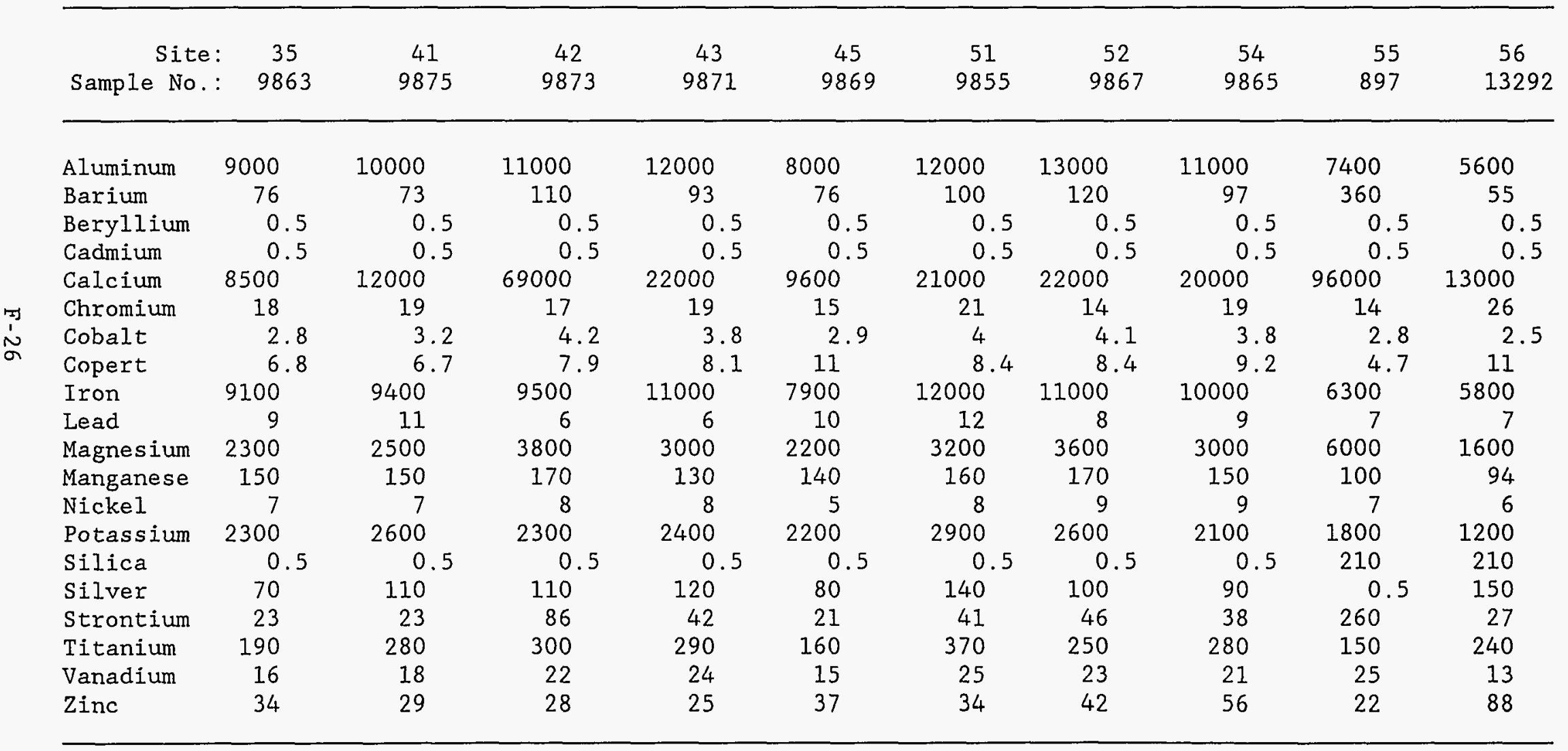


Table F-16. Concentrations (ppm) of Metals in Perimeter Soil Samples, August 1993

\begin{tabular}{|c|c|c|c|c|c|c|c|c|c|c|c|}
\hline $\begin{array}{l}\text { Site } \\
\text { Sample No. }\end{array}$ & $\begin{array}{c}4 \\
9848\end{array}$ & $\begin{array}{c}5 \\
950\end{array}$ & $\begin{array}{c}12 \\
13320\end{array}$ & $\begin{array}{c}16 \\
13324\end{array}$ & $\begin{array}{c}19 \\
901\end{array}$ & $\begin{array}{c}58 \\
13330\end{array}$ & $\begin{array}{c}59 \\
13328\end{array}$ & $\begin{array}{c}60 \\
13302\end{array}$ & $\begin{array}{c}61 \\
13299\end{array}$ & $\begin{array}{c}63 \\
893\end{array}$ & $\begin{array}{c}64 \\
13322\end{array}$ \\
\hline Aluminum & 7100 & 5000 & 11000 & 11000 & 5600 & 11000 & 9600 & 16000 & 7500 & 12000 & 14000 \\
\hline Barium & 130 & 49 & 110 & 87 & 84 & 140 & 210 & 190 & 200 & 150 & 120 \\
\hline Beryllium & 0.5 & 0.5 & 0.5 & 0.5 & 0.5 & 0.5 & 0.5 & 0.7 & 0.5 & 0.5 & 0.5 \\
\hline Cadmium & 0.5 & 0.5 & 0.5 & 0.5 & 0.5 & 0.5 & 0.5 & 0.5 & 0.5 & 0.5 & 0.5 \\
\hline Calcium & 56000 & 1500 & 8300 & 5700 & 8200 & 38000 & 63000 & 34000 & 42000 & 46000 & 31000 \\
\hline Chromium & 19 & 19 & 24 & 19 & 19 & 14 & 18 & 35 & 16 & 19 & 17 \\
\hline Cobalt & 2.7 & 2.2 & 6.4 & 6.1 & 3.6 & 4.6 & 3.8 & 6.9 & 3.2 & 5.5 & 14 \\
\hline Copper & 5.2 & 3.8 & 11 & 8.7 & 7.3 & 11 & 6.3 & 16 & 6.2 & 8.1 & 21 \\
\hline Iron & 6700 & 5900 & 12000 & 15000 & 8700 & 12000 & 9600 & 16000 & 6900 & 12000 & 29000 \\
\hline Lead & 5 & 8 & 11 & 9 & 8 & 16 & 10 & 9 & 9 & 8 & 19 \\
\hline Magnesium & 2800 & 1300 & 3900 & 3900 & 2100 & 4300 & 4100 & 5400 & 3600 & 3600 & 9400 \\
\hline Manganese & 120 & 130 & 290 & 300 & 170 & 210 & 150 & 400 & 130 & 310 & 760 \\
\hline Nickel & 6 & 6 & 10 & 7 & 8 & 7 & 6 & 12 & 5 & 11 & 9 \\
\hline Potassium & 1600 & 1600 & 2200 & 2600 & 1300 & 2600 & 2100 & 4300 & 1500 & 2800 & 3300 \\
\hline Strontium & 86 & 10 & 25 & 20 & 21 & 62 & 100 & 62 & 110 & 89 & 43 \\
\hline Titanium & 150 & 130 & 280 & 860 & 250 & 530 & 440 & 360 & 230 & 300 & 1000 \\
\hline Vanadium & 15 & 9.8 & 24 & 28 & 16 & 27 & 25 & 31 & 20 & 22 & 49 \\
\hline Zinc & 36 & 57 & 38 & 42 & 40 & 38 & 26 & 53 & 25 & 40 & 110 \\
\hline
\end{tabular}


Table F-17. Concentrations (ppm) of Metals in Offsite Soil Samples, August 1993

\begin{tabular}{|c|c|c|c|c|c|c|c|c|c|}
\hline $\begin{array}{r}\text { Site: } \\
\text { Sample No.: }\end{array}$ & $\begin{array}{c}8 \\
13291\end{array}$ & $\begin{array}{c}9 \\
13282\end{array}$ & $\begin{array}{c}10 \\
13280\end{array}$ & $\begin{array}{c}11 \mathrm{~A} \\
13705\end{array}$ & $\begin{array}{c}11 B \\
13704\end{array}$ & $\begin{array}{c}11 \mathrm{C} \\
13703\end{array}$ & $\begin{array}{c}25 \\
13276\end{array}$ & $\begin{array}{c}65 \\
13326\end{array}$ & $\begin{array}{c}62 \\
13278\end{array}$ \\
\hline Aluminum & 6000 & 28000 & 18000 & 5200 & 5000 & 4600 & 5000 & 10000 & 18000 \\
\hline Barium & 180 & 260 & 110 & 180 & 170 & 160 & 110 & 94 & 180 \\
\hline Beryllium & 0.5 & 1.1 & 0.6 & 0.5 & 0.5 & 0.5 & 0.5 & 0.5 & 0.6 \\
\hline Cadmium & 0.5 & 0.5 & 0.6 & 0.5 & 0.5 & 0.5 & 0.5 & 0.5 & 0.6 \\
\hline Calcium & 16000 & 28000 & 61000 & 12000 & 10000 & 9100 & 34000 & 13000 & 86000 \\
\hline Chromium & 27 & 34 & 25 & 24 & 31 & 32 & 32 & 16 & 24 \\
\hline Cobalt & 3.1 & 10 & 6.1 & 2.8 & 2.5 & 2.7 & 2.2 & 4.9 & 7.1 \\
\hline Copper & 23 & 18 & 8.4 & 4.3 & 4.9 & 4.3 & 4.6 & 8.8 & 11 \\
\hline Iron & 14000 & 25000 & 15000 & 7800 & 6900 & 7400 & 6300 & 12000 & 15000 \\
\hline Lead & 80 & 19 & 11 & 6 & 8 & 7 & 10 & 15 & 12 \\
\hline Magnesium & 3600 & 7800 & 4000 & 2000 & 1900 & 1700 & 1700 & 3700 & 4600 \\
\hline Manganese & 240 & 510 & 530 & 230 & 230 & 210 & 180 & 240 & 430 \\
\hline Nickel & 9 & 20 & 13 & 5 & 7 & 6 & 6 & 7 & 15 \\
\hline Potassium & 2300 & 3300 & 3300 & 1600 & 1600 & 1400 & 1400 & 2600 & 3500 \\
\hline Silica & 280 & 200 & 120 & 230 & 200 & 190 & 70 & 0.5 & 180 \\
\hline Silver & 320 & 310 & 140 & 0.5 & 0.5 & 0.5 & 0.5 & 110 & 180 \\
\hline Strontium & 62 & 61 & 120 & 40 & 34 & 32 & 49 & 28 & 160 \\
\hline Titanium & 180 & 330 & 280 & 280 & 240 & 270 & 180 & 570 & 240 \\
\hline Vanadium & 15 & 54 & 32 & 18 & 16 & 17 & 14 & 24 & 33 \\
\hline Zinc & 78 & 81 & 38 & 21 & 19 & 19 & 21 & 37 & 44 \\
\hline
\end{tabular}


Table F-18. Concentrations (ppm) of Metals in Perimeter Sediment Samples, May 1993

\begin{tabular}{|c|c|c|c|}
\hline & $\begin{array}{rc}\text { Site: } & 60 \\
\text { Sample No.: } & 12530\end{array}$ & $\begin{array}{c}72 \\
12529\end{array}$ & $\begin{array}{c}73 \\
12528\end{array}$ \\
\hline Aluminum & 5200 & 5600 & 6100 \\
\hline Barium & 79 & 52 & 72 \\
\hline Beryllium & 0.5 & 0.5 & 0.5 \\
\hline Cadmium & 0.5 & 0.5 & 0.5 \\
\hline Calcium & 28000 & 91000 & 2800 \\
\hline Chromium & 22 & 17 & 19 \\
\hline Cobalt & 4.7 & 3.1 & 3.6 \\
\hline Copper & 6.3 & 6.7 & 6.1 \\
\hline Iron & 14000 & 7400 & 8800 \\
\hline Lead & 6 & 5 & 0.5 \\
\hline Magnesium & 2400 & 3500 & 2700 \\
\hline Manganese & 200 & 190 & 210 \\
\hline Nicke1 & 7 & 7 & 6 \\
\hline Potassium & 1400 & 1100 & 1600 \\
\hline Strontium & 46 & 170 & 47 \\
\hline Titanium & 730 & 210 & 700 \\
\hline Vanadium & 30 & 15 & 18 \\
\hline Zinc & 24 & 26 & 25 \\
\hline
\end{tabular}

Table F-19. Concentrations (ppm) of Metals in Offsite Sediment Samples, May 1993

\begin{tabular}{|c|c|c|c|c|c|}
\hline Samp1 & $\begin{array}{cc}\text { Site: } & 11 \mathrm{~A} \\
\text { e No.: } & 12505\end{array}$ & $\begin{array}{c}11 B \\
12504\end{array}$ & $\begin{array}{c}11 \mathrm{C} \\
12503\end{array}$ & $\begin{array}{c}8 \\
9905\end{array}$ & $\begin{array}{c}68 \\
12512\end{array}$ \\
\hline Aluminum & 2300 & 6300 & 4500 & 8800 & 5500 \\
\hline Barium & 91 & 150 & 130 & 160 & 270 \\
\hline Beryllium & 0.5 & 0.5 & 0.5 & 0.5 & 0.5 \\
\hline Cadmium & 0.5 & 0.5 & 0.5 & 0.5 & 0.5 \\
\hline Calcium & 5800 & 17000 & 11000 & 18000 & 160000 \\
\hline Chromium & 24 & 19 & 30 & 22 & 16 \\
\hline Cobalt & 1.8 & 3 & 2.6 & 3.8 & 3.2 \\
\hline Copper & 2.8 & 5.2 & 11 & 6.9 & 5.8 \\
\hline Iron & 5000 & 8500 & 7600 & 10000 & 13000 \\
\hline Lead & 3 & 5 & 4 & 3 & 11 \\
\hline Magnesium & 960 & 2900 & 1800 & 3600 & 3000 \\
\hline Manganese & 110 & 160 & 140 & 230 & 310 \\
\hline Nickel & 3 & 5 & 6 & 6 & 7 \\
\hline Potassium & 660 & 1500 & 1100 & 1900 & 1300 \\
\hline Strontium & 18 & 55 & 33 & 72 & 190 \\
\hline Titanium & 180 & 240 & 260 & 230 & 350 \\
\hline Vanadium & 12 & 18 & 18 & 21 & 23 \\
\hline Zinc & 16 & 27 & 22 & 29 & 220 \\
\hline
\end{tabular}


Table F-20. Concentrations (ppm) of Metals in Perimeter Sediment Samples, August 1993

\begin{tabular}{lccccc}
\hline & Site: & 60 & & & \\
\multicolumn{1}{c}{ Sample No.: } & 13300 & 72 & $73 \mathrm{~A}$ & $73 \mathrm{~B}$ & $73 \mathrm{C}$ \\
& & 13313 & 13297 & 13268 & 13267 \\
\hline & & & & & \\
Aluminum & 6400 & 9100 & 5300 & 5800 & 5200 \\
Barium & 110 & 82 & 64 & 61 & 350 \\
Beryllium & 0.5 & 0.5 & 0.5 & 0.5 & 0.5 \\
Cadmium & 0.5 & 0.5 & 0.5 & 0.5 & 0.5 \\
Calcium & 38000 & 75000 & 36000 & 32000 & 29000 \\
Chromium & 24 & 21 & 31 & 34 & 30 \\
Cobalt & 5 & 4.2 & 3.8 & 4.4 & 4 \\
Copper & 8.4 & 9.7 & 7.1 & 6.2 & 6.2 \\
Iron & 13000 & 10000 & 8100 & 11000 & 9100 \\
Lead & 6 & 17 & 5 & 5 & 6 \\
Magnesium & 3100 & 4400 & 2800 & 2500 & 2200 \\
Manganese & 260 & 240 & 200 & 200 & 190 \\
Nickel & 6 & 8 & 5 & 7 & 6 \\
Potassium & 1500 & 1800 & 1100 & 1500 & 1300 \\
Strontium & 61 & 140 & 56 & 54 & 58 \\
Titanium & 840 & 260 & 620 & 950 & 910 \\
Vanadium & 26 & 22 & 17 & 22 & 19 \\
Zinc & 28 & 31 & 21 & 25 & 20 \\
\hline
\end{tabular}

Table F-21. Concentrations (ppm) of Metals in Offsite Sediment Samples, August 1993

\begin{tabular}{lccccc}
\hline & Site: & 8 & & & \\
\multicolumn{1}{c}{ Sample No.: } & 13289 & $11 \mathrm{~A}$ & $11 \mathrm{~B}$ & $11 \mathrm{C}$ & 68 \\
& & 13699 & 13698 & 13697 & 13271 \\
\hline & & & & & \\
Aluminum & 6300 & 4300 & 3600 & 3400 & 9100 \\
Barium & 140 & 140 & 120 & 110 & 140 \\
Beryllium & 0.5 & 0.5 & 0.5 & 0.5 & 0.5 \\
Cadmium & 0.5 & 0.5 & 0.5 & 0.5 & 0.5 \\
Calcium & 1300 & 7000 & 6000 & 5600 & 120000 \\
Chromium & 41 & 45 & 38 & 31 & 21 \\
Cobalt & 3 & 2.6 & 2.5 & 2.2 & 4.8 \\
Copper & 7 & 4 & 3.7 & 3.3 & 7.4 \\
Iron & 8000 & 7200 & 7100 & 6100 & 9700 \\
Lead & 7 & 6 & 0.5 & 7 & 10 \\
Magnesium & 2400 & 1400 & 1200 & 1200 & 3900 \\
Manganese & 180 & 140 & 120 & 120 & 290 \\
Nickel & 5 & 6 & 5 & 6 & 12 \\
Potassium & 1400 & 1200 & 1000 & 940 & 1700 \\
Strontium & 48 & 28 & 24 & 22 & 150 \\
Titanium & 240 & 260 & 2770 & 230 & 170 \\
Vanadium & 18 & 16 & 17 & 14 & 18 \\
Zinc & 22 & 16 & 15 & 14 & 31 \\
\hline
\end{tabular}




\section{APPENDIX G}

\section{ENVIRONMENTAL REGULATIONS AND STANDARDS}




$$
\text { G-2 }
$$




\section{CONTENTS}

Page

G. 1

INTRODUCTION

G-5

TABLES

G-1 Derived Concentration Guides (DCGs) For Selected Radionuclides G-6

G-2 Radiation Standards for Protection of the Public in the Vicinity of U.S. Department of Energy Facilities for

Calendar Year 1993

G-3 Groundwater Monitoring Parameters Required by 40 CFR 265, Subpart F. . . . . . . . . . . . . . . . . . . G-8

G-4 U.S. Environmental Protection Agency Interim Primary Drinking Water Supply Parameters . . . . . . . . . . . . . . . G-9 


$$
G-4
$$




\section{G.1 INTRODUCTION}

Radiation-protection standards for the public have been established by the U.S. Department of Energy (DOE) to protect public health. This is accomplished by limiting radiation doses (resulting from DOE operations) received by individuals residing in uncontrolled areas. These standards are based on the risk to members of the public. Environmental monitoring requirements for DOE operations are established in DOE Order 5400.1, "General Environmental Protection Program" (DOE 1988). Radiation protection standards are provided in DOE Order 5400.5, "General Radiation Protection of the Public and the Environment" (DOE 1990). DOE Order 5400.5 limits the annual effective dose equivalent to any member of the public to 100 millirems per year (mrem/yr). This limit is predicated on the dose to the maximally exposed individual in an uncontrolled area from all emission sources and all exposure pathways. DOE order 5400.5 also contains the derived concentration guide (DCG) for concentrations of radionuclides in water and air that could be continuously consumed or inhaled ( 365 days/year) and not exceed the DOE primary radiation protection standard of $100 \mathrm{mrem} / \mathrm{yr}$ effective dose equivalent (EDE). Table G-1 contains the DCGs pertinent to Sandia National Laboratories/New Mexico (SNL/NM) activities and to this report.

DOE facilities are also required to comply with U.S. Environmental Protection Agency (EPA) standards for radiation protection. On December 15, 1989, the EPA issued its final rule on National Emission Standards for Hazardous Air Pollutants (NESHAP) for radionuclides (EPA 1989). This rule mandates that air emissions from DOE facilities shall not cause any individual of the public to receive in any year an EDE of greater than $10 \mathrm{mrem} /$ year. Table G-2 summarizes the public radiation protection standards that are applicable to DOE facilities. In addition to these quantitative standards, the overriding DOE policy is that exposures to the public shall be maintained as low as reasonably achievable (ALARA).

Table G-3 lists the 40 CFR 265, Subpart F, parameters required for groundwatermonitoring analysis. Table G-4 shows the EPA interim primary drinking-water standards (40 CFR 265, Appendix III) for the groundwater-monitoring parameters. 
Table G-1. Derived Concentration Guides (DCGs) For Selected Radionuclides ${ }^{a}$

\begin{tabular}{|c|c|c|c|c|}
\hline \multirow[b]{2}{*}{ Nuclide } & \multicolumn{2}{|c|}{ Drinking Water } & \multicolumn{2}{|c|}{ Inhaled $\mathrm{Air}^{\mathrm{b}}$} \\
\hline & $\begin{array}{l}\text { DCG } \\
(\mu \mathrm{Ci} / \mathrm{L})\end{array}$ & $\begin{array}{c}f, \\
\text { Value }\end{array}$ & $\begin{array}{c}\text { DCG } \\
\left(\mu \mathrm{Ci} / \mathrm{m}^{3}\right)\end{array}$ & $\begin{array}{c}\text { Solubility } \\
\text { Class }\end{array}$ \\
\hline H-3 (Water) & $2 E+00$ & - & $1 E-01$ & -- \\
\hline Cs -137 & $3 \mathrm{E}-03$ & $1 \mathrm{E}+00$ & $4 E-04$ & $\mathrm{D}$ \\
\hline Gross Alpha ${ }^{a}$ & $15 E-06$ & -- & -- & -- \\
\hline Eross Betac & $3 E-05$ & - & -- & -- \\
\hline Total $U^{d}$ & $6 \mathrm{E}-04$ & -- & $6 \mathrm{E}-6$ & -- \\
\hline \multicolumn{5}{|c|}{ 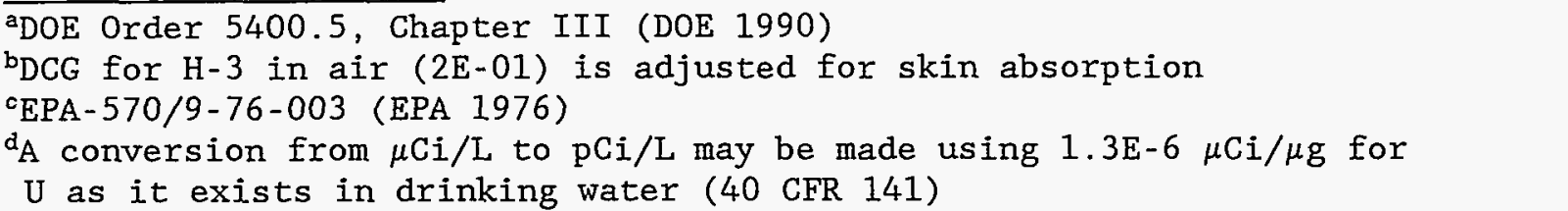 } \\
\hline
\end{tabular}


Table G-2. Radiation Standards for Protection of the Public in the Vicinity of U.S. Department of Energy Facilities for CY 1993

General Dose Limits

$\underline{\text { A11 }}^{\text {Pathways }^{a}}$

The effective dose equivalent for any member of the public from all routine DOE operations ${ }^{b}$ (natural background and medical exposures excluded) shall not exceed the values given below:

\begin{tabular}{|c|c|c|}
\hline & Effective & Equivalen \\
\hline & mrem/yr & $(\mathrm{mSv} / \mathrm{yr})$ \\
\hline Primary limit & 100 & (1) \\
\hline
\end{tabular}

Air Pathway ${ }^{d}$

Effective Dose Equivalent

$\underline{m r e m} / \mathrm{yr} \quad \underline{(\mathrm{mSv} / \mathrm{yr})}$

Maximum offsite residence

10

$(0.10)$

aDOE Order 5400.5, Chapters I and II (DOE 1990)

${ }^{b}$ Routine DOE operations means normal planned activities, including remedial actions and naturally occurring radionuclides released by DOE processes and operations.

'Effective dose equivalent (EDE) will be expressed in rem (or millirem) with the corresponding value in sievert (or millisievert) in parentheses.

d40 CFR 61, Subpart $H$ for radionuclides, National Emission Standard for Hazardous Air Pollutants (NESHAP) 
Table G-3. Groundwater Monitoring Parameters Required by 40 CFR 265, Subpart $F^{a}$

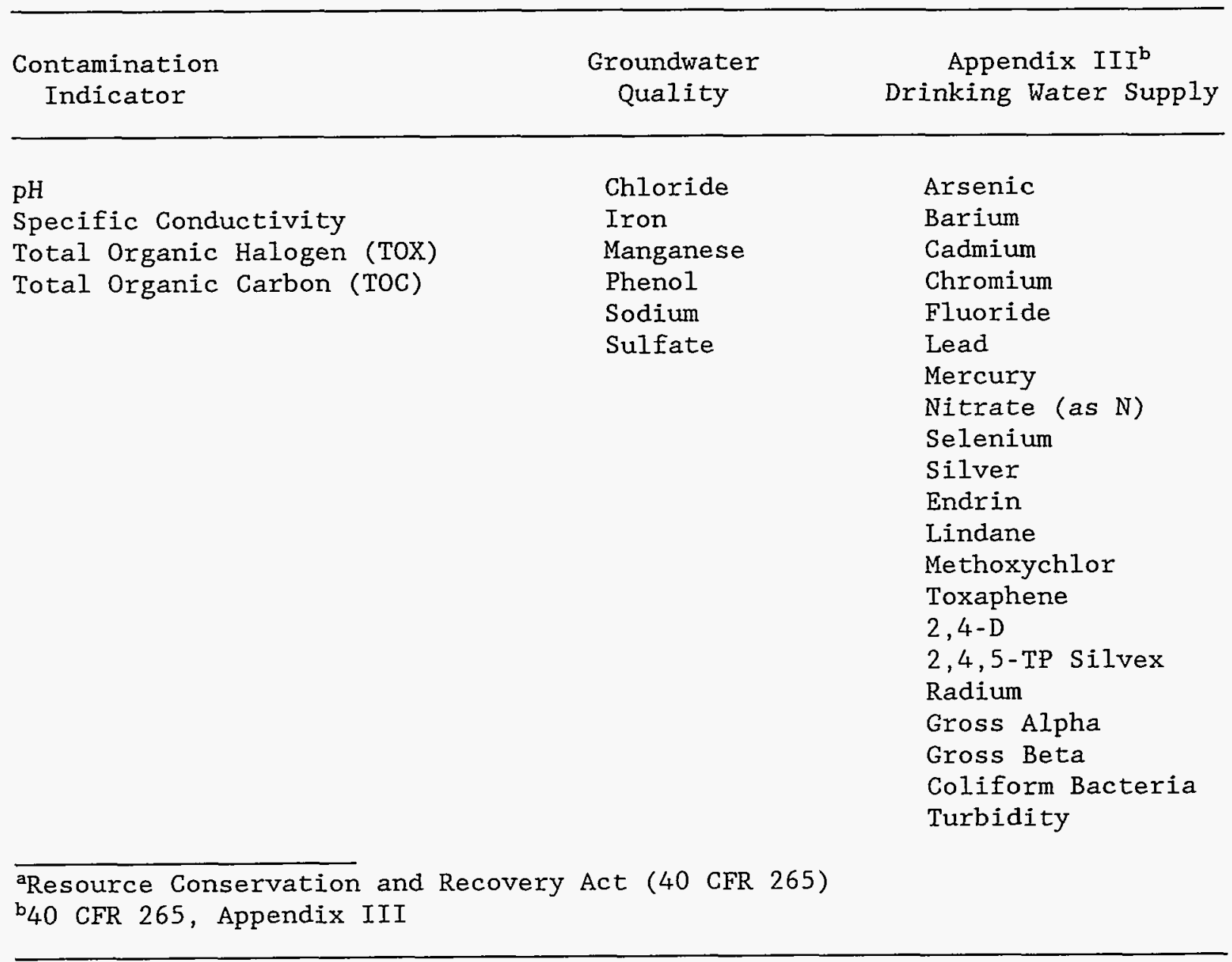


Table G-4. U.S. Environmental Protection Agency Interim Primary Drinking Water Supply Parameters

\begin{tabular}{|c|c|c|}
\hline Parameter & Standard $\mathrm{d}^{\mathrm{a}}$ & Units \\
\hline Arsenic $c^{b}$ & 0.05 & $\mathrm{mg} / \mathrm{L}$ \\
\hline Bariumb & 1.0 & $\mathrm{mg} / \mathrm{L}$ \\
\hline Cadmium $^{b}$ & 0.01 & $\mathrm{mg} / \mathrm{L}$ \\
\hline Chromium ${ }^{b}$ & 0.05 & $\mathrm{mg} / \mathrm{L}$ \\
\hline $\operatorname{Lead}^{\mathrm{b}}$ & 0.05 & $\mathrm{mg} / \mathrm{L}$ \\
\hline Mercury ${ }^{b}$ & 0.002 & $\mathrm{mg} / \mathrm{L}$ \\
\hline Selenium ${ }^{b}$ & 0.01 & $\mathrm{mg} / \mathrm{L}$ \\
\hline Silver ${ }^{b}$ & 0.05 & $\mathrm{mg} / \mathrm{L}$ \\
\hline Fluoride & $1.4-2.4$ & $\mathrm{mg} / \mathrm{L}$ \\
\hline Nitrate & 10 & $\mathrm{mg} / \mathrm{L}$ \\
\hline Total Coliform & $1 / 100 \mathrm{~mL}$ & $\mathrm{cl} / 100 \mathrm{~mL}$ \\
\hline Turbidity & $1 \mathrm{TU}$ & NTUc \\
\hline Radium-226 & $5 \mathrm{pCi} / \mathrm{L}$ & $\mathrm{pCi} / \mathrm{L}$ \\
\hline Radium-228 & $5 \mathrm{pCi} / \mathrm{L}$ & $\mathrm{pCi} / \mathrm{L}$ \\
\hline Gross Alpha & $15 \mathrm{pCi} / \mathrm{L}$ & $\mathrm{pCi} / \mathrm{L}$ \\
\hline Gross Beta & $4 \mathrm{mR} / \mathrm{yr}$ & $\mathrm{pCi} / \mathrm{L}$ \\
\hline Endrin & 0.0002 & $\mathrm{mg} / \mathrm{L}$ \\
\hline Lindane & 0.004 & $\mathrm{mg} / \mathrm{L}$ \\
\hline Methoxychlor & 0.1 & $\mathrm{mg} / \mathrm{L}$ \\
\hline Toxaphene & 0.005 & $\mathrm{mg} / \mathrm{L}$ \\
\hline $2,4-D$ & 0.1 & $\mathrm{mg} / \mathrm{L}$ \\
\hline $2,4,5-\mathrm{TP}$ Silvex & 0.01 & $\mathrm{mg} / \mathrm{L}$ \\
\hline \multicolumn{3}{|c|}{$\begin{array}{l}\text { a40 CFR 265, Appendix III } \\
\text { botal metals (unfiltered sample) } \\
\text { cNTU = nephelometric turbidity unit }\end{array}$} \\
\hline
\end{tabular}




\section{REFERENCES}

40 CFR 61, Subpart $H$ for radionuclides. National Emission Standards for Hazardous Air Pollutants (NESHAP).

40 CFR 141, 1975. "National Primary Drinking Water Regulations," as amended January 15, 1992.

40 CFR 265, 1980. "Interim Status Standards for Owners and Operators of Hazardous Waste Treatment, Storage, and Disposal Facilities," as amended December 23, 1991.

DOE 1990: U.S. Department of Energy, Chapter I, "General Radiological Protection of the Public and the Environment;" Chapter II, "Requirements for Radiation Protection of the Public and the Environment;" and Chapter III, "Derived Concentration Guides for Air and Water," DOE Order 5400.5, DOE, Washington, DC (February 1990).

DOE 1988: U.S. Department of Energy, "General Environmental Protection Program," DOE Order 5400.1, DOE, Washington, DC (1988; change 1, June $21,1990)$.

EPA 1976: U.S. Environmental Protection Agency, "USEPA National Interim Primary Drinking Water Regulations," EPA-570/9-76-003, EPA, Washington, DC (1976).

Resource Conservation and Recovery Act (RCRA) of 1976. Public Law 94-580, 1976, 90 Statute 2795. 


\section{APPENDIX H}

SEPTIC TANK REGISTRATION FOR

SANDIA NATIONAL LABORATORIES/NEW MEXICO 
H- 2 


\section{CONTENTS}

TABLE

Page

H-1 Septic Tank Registration for Sandia National

Laboratories/New Mexico . . . . . . . . . . . . . . . . H-5 
H- 4 
Table H-i. Septic Tank Registration for Sandia National Laboratories/New Mexico

\begin{tabular}{|c|c|c|}
\hline Area & Building & Location Description \\
\hline Technical Area I & 898 & Optical Maintenance Building \\
\hline Technical Area I & $8895 / \mathrm{MO100}$ & Sandia Guard House \\
\hline Technical Area I & M014/MO15 & Office/Laboratory \\
\hline $\begin{array}{l}\text { East of Technical } \\
\text { Area II }\end{array}$ & $\begin{array}{l}6969, \mathrm{MO} 118, \mathrm{MO} 251, \\
\text { and MO252 }\end{array}$ & Robotic Vehicle Range \\
\hline 6000 Igloo Area & 6020 & $\begin{array}{l}\text { Explosives Receiving and } \\
\text { Packaging }\end{array}$ \\
\hline 6000 Igloo Area & 6030 & Guard Station \\
\hline Technical Area II & $901 / 902$ & Systems Analysis Facility \\
\hline Technical Area II & 904 & $\begin{array}{l}\text { Environmental Testing } \\
\text { Laboratory }\end{array}$ \\
\hline Technical Area II & 906 & Safety Chemicals Laboratory \\
\hline Technical Area II & 907 & $\begin{array}{l}\text { Explosives Application } \\
\text { Facility }\end{array}$ \\
\hline Technical Area II & $913 / 913 \mathrm{~A}$ & $\begin{array}{l}\text { Component Assembly Building/ } \\
\text { Pressure Laboratory and } \\
\text { Training Building }\end{array}$ \\
\hline Technical Area II & $915 / 922$ & Explosive Device Laboratories \\
\hline Technical Area II & 914 & Equipment for Building 913 \\
\hline Technical Area II & 919 & Explosive Devices Building \\
\hline Technical Area II & 935 & Component Test Facility \\
\hline Technical Area II & 940 & Explosive Testing Laboratory \\
\hline Technical Area III & 6584 - East end & $\begin{array}{l}\text { Administration for Test } \\
\text { Engineering }\end{array}$ \\
\hline Technical Area III & 6584 - West end & Armory Facility \\
\hline Technical Area III & 6589 and 6600 & $\begin{array}{l}\text { Guard House and Sensor Test } \\
\text { Laboratory }\end{array}$ \\
\hline Technical Area III & 6501 & Nonhazardous Assembly Area \\
\hline Technical Area III & 6620 & Hazardous Assembly Building \\
\hline Technical Area III & 6505 & Sodium Purification Loop \\
\hline Technical Area III & $6520 / 6526$ & Hydraulic Centrifuge Facility \\
\hline Technical Area III & 6523 & Pump Building \\
\hline Technical Area III & $6530 / 6531$ & Radiant Heat Test Facility \\
\hline Technical Area III & 6536 & Thermal/Radiant Heat Testing \\
\hline Technical Area III & $6540 / 6542$ & Photometrics \\
\hline Technical Area III & $6560 / 6562 / 6563$ & Vibration Test Facility \\
\hline Technical Area III & $6570 / 6571$ & Dynamic Shock Test Facility \\
\hline Technical Area III & 6587 & Maintenance and Shop \\
\hline Technical Area III & 6610 & Complex Wave Test Facility \\
\hline Technical Area III & 6630 & Climatic Test Facility \\
\hline Technical Area III & 6631 & Remote Control Building \\
\hline Technical Area III & $6635 / 6638$ & Radiography Bunker \\
\hline Technical Area III & $6640^{\prime}$ & Acoustical Test Facility \\
\hline Technical Area III & 6643 & Establishment Type Unknown \\
\hline
\end{tabular}


Table H-1. Septic Tank Registration for Sandia National Laboratories/New Mexico (Continued)

\begin{tabular}{|c|c|c|}
\hline Area & Building & Location Description \\
\hline Technical Area III & 6650 & Vibration Data Control Center \\
\hline Technical Area III & 6710 & Air Gun Test Facility \\
\hline Technical Area III & 6715 & Explosive Test Facility \\
\hline Technical Area III & 6720 & Irradiated Sludge Facility \\
\hline Technical Area III & 6721 & $\begin{array}{l}\text { Photography/Control for } \\
\text { Building } 6720\end{array}$ \\
\hline Technical Area III & $6730-31 / 6734-35 / M 0128$ & Dynamic Shock Facility \\
\hline Technical Area III & 6741 & $\begin{array}{l}\text { Control Building for } 5000- \\
\text { Foot Sled Track }\end{array}$ \\
\hline Technical Area III & 6743 & $\begin{array}{l}\text { Rocket Motor Conditioning } \\
\text { Facility }\end{array}$ \\
\hline Technical Area III & 6750 & $\begin{array}{l}\text { Small Arms Range/Impact Test } \\
\text { Facility }\end{array}$ \\
\hline Technical Area III & 6920 & $\begin{array}{l}\text { Mixed Waste Management } \\
\text { Facility }\end{array}$ \\
\hline Technical Area III & 6922 & Explosive Test Facility \\
\hline Technical Area III & $\mathrm{T} 12 / \mathrm{T} 42 / \mathrm{T} 43$ & N/A \\
\hline Technical Area III & T52 & $\mathrm{N} / \mathrm{A}$ \\
\hline Technical Area III & MO231- 234 & Offices \\
\hline Technical Area III & MO228-230 & Offices \\
\hline Technical Area III & M0242-245 & Offices \\
\hline Technical Area V & $\begin{array}{l}6580 / 6588 / 6590-93 / \\
6596-97\end{array}$ & $\begin{array}{l}\text { Reactor Facilities and } \\
\text { Storage }\end{array}$ \\
\hline Technical Area V & 6500 & $\begin{array}{l}\text { Gate House Security } \\
\text { Operations Building }\end{array}$ \\
\hline Technical Area V & $6581-82 / M 032 / M 057-58$ & $\begin{array}{l}\text { Febetron Building/Emergency } \\
\text { Evaluation Center/Offices/ } \\
\text { Shock Test Laboratory }\end{array}$ \\
\hline Coyote Test Field & 9950 & Material Test Laboratory \\
\hline Coyote Test Field & 9956 & $\begin{array}{l}\text { Intermediate Velocity Gun } \\
\text { Facility }\end{array}$ \\
\hline Coyote Test Field & 9965 & $\begin{array}{l}\text { Remote Control Building for } \\
\text { Shock Facility }\end{array}$ \\
\hline Coyote Test Field & 9967 & HE Assembly Building \\
\hline Coyote Test Field & 9970 & Antenna Measurement Facility \\
\hline Coyote Test Field & 9972 & EMP Studies Facility A \\
\hline Coyote Test Field & 9980 & Solar Tower Facility \\
\hline Coyote Test Field & $9981 / 9982$ & $\mathrm{~N} / \mathrm{A}$ \\
\hline Coyote Test Field & Live Fire Range & Live Fire Range \\
\hline Coyote Test Field & SFER M0127-128/MO130 & Small Force Engagement Range \\
\hline Coyote Test Field & 9927 & Explosive Test Facility \\
\hline Coyote Test Field & 9930 & $\begin{array}{l}\text { Explosive Test and Laboratory } \\
\text { Building }\end{array}$ \\
\hline
\end{tabular}


Table H-1. Septic Tank Registration for Sandia National Laboratories/New Mexico (Concluded)

\begin{tabular}{lll}
\hline Area & Building & Location Description \\
\hline Coyote Test Field & $9939 / 9939 \mathrm{~A}$ & $\begin{array}{l}\text { Evaluation Explosive Facility } \\
\text { Control Building }\end{array}$ \\
Coyote Test Field & 9940 & $\begin{array}{l}\text { Explosive Test Facility } \\
\text { Coyote Test Field } \\
\text { Headquarters }\end{array}$ \\
Coyote Test Field & 9925 & $\begin{array}{l}\text { Explosive Test Facility } \\
\text { Explosives Preparation } \\
\text { Facility }\end{array}$ \\
Coyote Test Field & $9926 / 9920$ & $\begin{array}{l}\text { Earth to Orbit Launching } \\
\text { Facility }\end{array}$ \\
\hline
\end{tabular}




\section{APPENDIX I}

NATIONAL ENVIRONMENTAL POLICY ACT DOCUMENTATION 


\section{CONTENTS}

TABLES

Page

I-1 1993 Sandia Environmental Assessments Underway or Approved and Approval Status . . . . . . . . . . . . . . . . I-5

I-2 National Environmental Policy Act Documentation and Approval Status . . . . . . . . . . . . . . . . . . I-7 
I -4 
Table I-1. 1993 Sandia Environmental Assessments Underway or Approved and Approval Status

\begin{tabular}{|c|c|c|c|}
\hline Title & $\begin{array}{l}\text { DOE Request } \\
\text { for EA }\end{array}$ & $\begin{array}{l}\text { Latest } \\
\text { EA Sent } \\
\text { to DOE }\end{array}$ & FONSI ${ }^{a}$ \\
\hline $\begin{array}{l}\text { Radioactive/Mixed Waste } \\
\text { Facility }\end{array}$ & $01 / 22 / 90$ & $10 / 01 / 90$ & $04 / 23 / 93$ \\
\hline $\begin{array}{l}\text { Lurance Canyon Burn } \\
\text { Site }\end{array}$ & $08 / 11 / 89$ & & \\
\hline $\begin{array}{l}\text { Construction and Occupancy } \\
\text { of Robotic Manufacturing } \\
\text { Science Facility }\end{array}$ & $05 / 03 / 91$ & $12 / 10 / 93$ & $04 / 13 / 94$ \\
\hline $\begin{array}{l}\text { Construction and Occupancy } \\
\text { of Radioactive and Mixed } \\
\text { Waste Assay Facility }\end{array}$ & $03 / 25 / 91$ & & \\
\hline Coyote Canyon Test Complex & $11 / 10 / 92$ & & \\
\hline $\begin{array}{l}\text { Sol Se Mete Aerial Cable } \\
\text { Facility }\end{array}$ & $03 / 11 / 92$ & $10 / 18 / 93$ & \\
\hline $\begin{array}{l}\text { Site-Wide Environmental } \\
\text { Assessments for the } \\
\text { Environmental Restoration } \\
\text { Program }\end{array}$ & $12 / 03 / 93$ & & \\
\hline $\begin{array}{l}\text { Atmospheric Radiation Test } \\
\text { Program }\end{array}$ & $02 / 23 / 92$ & & \\
\hline $\begin{array}{l}\text { Construction and Occupancy } \\
\text { of Processing and } \\
\text { Environmental Technology } \\
\text { Laboratory }\end{array}$ & $03 / 25 / 91$ & $01 / 11 / 94$ & \\
\hline $\begin{array}{l}\text { Technical Support Center } \\
\text { (GIF) }\end{array}$ & $12 / 19 / 90$ & $09 / 03 / 93$ & \\
\hline $\begin{array}{l}\text { Neutron Measurement } \\
\text { Laboratory }\end{array}$ & $12 / 10 / 90$ & & \\
\hline
\end{tabular}


Table I-1. 1993 Sandia Environmental Assessments Underway or Approved and Approval Status (Concluded)

\begin{tabular}{lccc}
\hline Title & $\begin{array}{c}\text { DOE Request } \\
\text { for EA }\end{array}$ & $\begin{array}{c}\text { EA Sent } \\
\text { to DOE }\end{array}$ & FONSI a \\
\hline $\begin{array}{l}\text { Relocation of Neutron } \\
\text { Generator and Switch Tube } \\
\text { Prototyping }\end{array}$ & $11 / 10 / 92$ & $01 / 26 / 94$ & $04 / 08 / 94$ \\
$\begin{array}{l}\text { Shipment of Low-Level Waste } \\
\text { to the Nevada Test Site }\end{array}$ & $10 / 15 / 93$ & \\
\hline 'FONSI = Finding of No Significant Impact. & \\
\hline
\end{tabular}


Table I-2. National Environmental Policy Act Documentation and Approval Status

\begin{tabular}{|c|c|c|c|}
\hline Title & $\begin{array}{l}\text { Memo to } \\
\text { DOE }\end{array}$ & $\begin{array}{c}\text { DOE } \\
\text { Approval }\end{array}$ & $\begin{array}{l}\text { DOE Request } \\
\text { for } \mathrm{EA}\end{array}$ \\
\hline Sewer Modernization & $03 / 23 / 92$ & & \\
\hline $\begin{array}{l}\text { 5-kV Transmission Line for } \\
\text { Buildings } 9940,9960\end{array}$ & $01 / 16 / 92$ & & \\
\hline Payload and Satellite & $12 / 22 / 92$ & & \\
\hline $\begin{array}{l}\text { Safeguards Transporter (SGT) } \\
\text { Engulfing Fire Tests }\end{array}$ & $01 / 19 / 92$ & $01 / 29 / 93$ & \\
\hline Facilities Shop Building & $10 / 18 / 92$ & $02 / 18 / 93$ & \\
\hline $\begin{array}{l}\text { Underground Storage Tank } \\
\text { Removal at Building } 9925\end{array}$ & $12 / 03 / 92$ & $01 / 28 / 93$ & \\
\hline $\begin{array}{l}\text { Environmental Restoration } \\
\text { Program }\end{array}$ & $10 / 08 / 93$ & & $12 / 09 / 93$ \\
\hline $\begin{array}{l}\text { Shipment of Low-Level Waste } \\
\text { to the Nevada Test Site }\end{array}$ & $10 / 22 / 92$ & & $10 / 15 / 93$ \\
\hline Onsite Evaporative Processing & $11 / 06 / 92$ & & $02 / 03 / 93$ \\
\hline Motor Pool Rehabilitation & $11 / 11 / 92$ & $01 / 28 / 93$ & \\
\hline$X$-Reactor Phase II & $09 / 04 / 92$ & $01 / 12 / 94$ & \\
\hline $\begin{array}{l}\text { Continuing Operation of the } \\
\text { Existing NSTTF at SNL/NM }\end{array}$ & $09 / 15 / 92$ & $01 / 07 / 94$ & \\
\hline Building 870 Annex Remodeling & $08 / 31 / 92$ & $09 / 17 / 93$ & \\
\hline UST Removal at Building 9925 & $12 / 03 / 92$ & $01 / 28 / 93$ & \\
\hline Facilities Shop Building & $10 / 18 / 92$ & $02 / 18 / 93$ & \\
\hline Utility Backbone Project & $01 / 05 / 93$ & $03 / 31 / 93$ & \\
\hline $\begin{array}{l}\text { Code Modification, Natural } \\
\text { Gas System }\end{array}$ & $01 / 04 / 93$ & $04 / 19 / 93$ & \\
\hline PH $3 \& 5$ Electrical Metering & $01 / 25 / 93$ & & \\
\hline
\end{tabular}


Table I-2. National Environmental Policy Act Documentation and Approval Status (Continued)

\begin{tabular}{|c|c|c|c|}
\hline Title & $\begin{array}{l}\text { Memo to } \\
\text { DOE }\end{array}$ & $\begin{array}{c}\text { DOE } \\
\text { Approval }\end{array}$ & $\begin{array}{l}\text { DOE Request } \\
\text { for EA }\end{array}$ \\
\hline Decommissioning Bldg. $6650-1$ & $01 / 27 / 93$ & & \\
\hline $\begin{array}{l}\text { SAF } 1 \text { Test (Ongoing Activity } \\
\text { 03/08/93) }\end{array}$ & $01 / 27 / 93$ & $03 / 10 / 93$ & \\
\hline Bldg. 860 Shock Lab Renovation & $01 / 28 / 93$ & $02 / 18 / 93$ & \\
\hline $\begin{array}{l}\text { Environmental Sample Management } \\
\text { Office }\end{array}$ & $01 / 28 / 93$ & $03 / 31 / 93$ & \\
\hline $\begin{array}{l}\text { TA-III, Environmental } \\
\text { Restoration Landfill Capping } \\
\text { Test }\end{array}$ & $02 / 12 / 93$ & $04 / 19 / 93$ & \\
\hline Cased-Explosive Sawing Operation & $03 / 29 / 93$ & $05 / 26 / 93$ & \\
\hline $\begin{array}{l}\text { Stage Right Development and } \\
\text { Demonstration Building }\end{array}$ & $07 / 09 / 92$ & $02 / 12 / 93$ & \\
\hline $\begin{array}{l}\text { Transportation Shipping } \\
\text { Container Variant (TSCV) } \\
\text { Fire Tests }\end{array}$ & $07 / 10 / 92$ & & \\
\hline $\begin{array}{l}\text { Install/Operate Weapon } \\
\text { Component Waste Disposal } \\
\text { Integrated Demonstration } \\
\text { (WeDiD) Equipment }\end{array}$ & $02 / 22 / 93$ & $05 / 24 / 93$ & \\
\hline $\begin{array}{l}\text { Environmental Checklist for Kiva } \\
\text { Pit Modification }\end{array}$ & $03 / 05 / 93$ & $05 / 26 / 93$ & \\
\hline $\begin{array}{l}\text { Environmental Checklist } \\
\text { Submission For East Mountain } \\
\text { Study }\end{array}$ & $03 / 17 / 93$ & $04 / 02 / 93$ & \\
\hline $\begin{array}{l}\text { Perimeter Control System, } \\
\text { Bldg. } 9930\end{array}$ & $10 / 26 / 93$ & $01 / 04 / 94$ & \\
\hline $\begin{array}{l}\text { Interim Storage of Waste in } \\
\text { Bldg. } 6596\end{array}$ & $03 / 24 / 93$ & $04 / 05 / 93$ & \\
\hline Propellant Fire Tests & $03 / 17 / 93$ & $04 / 19 / 93$ & \\
\hline
\end{tabular}


Table I-2. National Environmental Policy Act Documentation and Approval Status (Continued)

\begin{tabular}{|c|c|c|c|}
\hline Title & $\begin{array}{l}\text { Memo to } \\
\text { DOE }\end{array}$ & $\begin{array}{c}\text { DOE } \\
\text { Approval }\end{array}$ & $\begin{array}{l}\text { DOE Request } \\
\text { for EA }\end{array}$ \\
\hline SGT Engulfing Fire Tests & $03 / 29 / 93$ & $05 / 24 / 93$ & \\
\hline Administrative Office Building & $03 / 30 / 93$ & $05 / 24 / 93$ & \\
\hline $\begin{array}{l}\text { WIPP-Salado Two-Phase Flow } \\
\text { Laboratory Program }\end{array}$ & $04 / 07 / 93$ & $05 / 19 / 93$ & \\
\hline Thermal Spray Laboratory & $04 / 19 / 93$ & $05 / 24 / 93$ & \\
\hline A400 Container Fire Tests & $03 / 05 / 93$ & $05 / 24 / 93$ & \\
\hline $\begin{array}{l}\text { AT400R Container Radiant Heat } \\
\text { Test }\end{array}$ & $04 / 21 / 93$ & $05 / 26 / 93$ & \\
\hline $\begin{array}{l}\text { H1224A Container Radiant Heat } \\
\text { Test }\end{array}$ & $04 / 21 / 93$ & $05 / 26 / 93$ & \\
\hline $\begin{array}{l}\text { Savannah River Container } \\
\text { Material Radiant Heat Test }\end{array}$ & $04 / 21 / 93$ & $05 / 26 / 93$ & \\
\hline Install ESM Robot & $04 / 23 / 93$ & $05 / 26 / 93$ & \\
\hline Series of Open Pool Fire Tests & $04 / 22 / 92$ & & \\
\hline $\begin{array}{l}\text { Disposition and Environmental } \\
\text { Checklist for Building } 9960 \\
\text { (Continuing Activity) }\end{array}$ & $03 / 24 / 92$ & $03 / 24 / 92$ & \\
\hline $\begin{array}{l}\text { Move } 6300 \& 6100 \text { Staff To } \\
\text { Lease Space }\end{array}$ & $04 / 30 / 93$ & $05 / 26 / 93$ & \\
\hline Remove Fume Hood System $(835 / 3)$ & $04 / 29 / 93$ & $05 / 26 / 93$ & \\
\hline $\begin{array}{l}\text { Install Fume Hood and Add Walls } \\
\text { (Bldg. 809, Room 16) }\end{array}$ & $04 / 29 / 93$ & $05 / 26 / 93$ & \\
\hline Chemical Compatibility Tests & $04 / 30 / 93$ & & \\
\hline Construct Storage Bldg. near 858 & $05 / 07 / 93$ & $05 / 28 / 93$ & \\
\hline $\begin{array}{l}\text { Environmental Checklist for } \\
\text { Electroplating Facility }\end{array}$ & $05 / 20 / 93$ & $07 / 08 / 93$ & \\
\hline
\end{tabular}


Table I-2. National Environmental Policy Act Documentation and Approval Status (Continued)

\begin{tabular}{|c|c|c|c|}
\hline Title & $\begin{array}{l}\text { Memo to } \\
\text { DOE }\end{array}$ & $\begin{array}{c}\text { DOE } \\
\text { Approval }\end{array}$ & $\begin{array}{l}\text { DOE Request } \\
\text { for EA }\end{array}$ \\
\hline Electrokinetic Clean-Field Test & $05 / 27 / 93$ & $08 / 04 / 93$ & \\
\hline Stars II Test, 06/01/93 & $05 / 20 / 93$ & $05 / 28 / 93$ & \\
\hline Storm Water Sample Stations & $05 / 25 / 93$ & $08 / 04 / 93$ & \\
\hline MAST Radiant Heat Test & $05 / 25 / 93$ & $09 / 17 / 93$ & \\
\hline Building 954 Warehouse Addition & $06 / 11 / 93$ & $09 / 17 / 93$ & \\
\hline $\begin{array}{l}\text { Direct Containment Heating } \\
\text { Tests at Containment } \\
\text { Technology Test Facility (CTTF) }\end{array}$ & $11 / 25 / 92$ & $02 / 15 / 93$ & \\
\hline $\begin{array}{l}\text { Baseline Survey for National } \\
\text { Solar Tower Test Facility }\end{array}$ & $09 / 04 / 92$ & & \\
\hline $\begin{array}{l}\text { Steam Reforming of Nitrates } \\
\text { and Ferrocyanides }\end{array}$ & $08 / 10 / 93$ & $10 / 28 / 93$ & \\
\hline $\begin{array}{l}\text { Subsurface Barrier Emplacement } \\
\text { Demonstration }\end{array}$ & $06 / 16 / 93$ & & \\
\hline Dish/Stirling Generating System & $08 / 26 / 93$ & $01 / 04 / 94$ & \\
\hline Jupiter Project & $07 / 01 / 93$ & & \\
\hline KEWD Rocket Sled Test & $07 / 14 / 93$ & & \\
\hline Oxidizer Source Term Test & $07 / 19 / 93$ & $09 / 24 / 93$ & \\
\hline $\begin{array}{l}\text { Operational Change in Lead } \\
\text { Management }\end{array}$ & $07 / 20 / 93$ & $09 / 24 / 93$ & \\
\hline $\begin{array}{l}\text { Rocket-Accelerated Trolleys } \\
\text { on Aerial Cable }\end{array}$ & $07 / 21 / 93$ & & \\
\hline Geotechnology Test Range & $12 / 21 / 93$ & $03 / 15 / 94$ & \\
\hline $\begin{array}{l}\text { Ground Source Heat Exchanger } \\
\text { Tests }\end{array}$ & $08 / 16 / 93$ & $01 / 12 / 93$ & \\
\hline
\end{tabular}


Table I-2. National Environmental Policy Act Documentation and Approval Status (Concluded)

\begin{tabular}{|c|c|c|c|}
\hline Title & $\begin{array}{l}\text { Memo to } \\
\text { DOE }\end{array}$ & $\begin{array}{c}\text { DOE } \\
\text { Approval }\end{array}$ & $\begin{array}{l}\text { DOE Request } \\
\text { for } \mathrm{EA}\end{array}$ \\
\hline $\begin{array}{l}\text { H } 1501 \text { A Container Test } \\
\text { (Continuing Action) }\end{array}$ & $08 / 09 / 93$ & $09 / 03 / 93$ & \\
\hline $\begin{array}{l}\text { Install Fence at Bldgs. } 834 \text {, } \\
844-846\end{array}$ & $09 / 09 / 93$ & & \\
\hline $\begin{array}{l}\text { Operation of Mobile } \\
\text { Environmental Monitoring } \\
\text { Systems Lab FY94 }\end{array}$ & $09 / 03 / 93$ & $01 / 12 / 94$ & \\
\hline $\begin{array}{l}\text { Soil Penetrating SAR (at } \\
\text { Sensor Test Field) }\end{array}$ & $09 / 22 / 93$ & $01 / 04 / 94$ & \\
\hline $\begin{array}{l}\text { SPARTA Rocket ATAF Missile } \\
\text { Series }\end{array}$ & $09 / 16 / 93$ & $10 / 28 / 93$ & \\
\hline \multicolumn{4}{|l|}{ Asphalt Construction Test Track } \\
\hline AT-400R Follow-on Fire Tests & $09 / 30 / 93$ & $01 / 04 / 94$ & \\
\hline AT-400A Fire Tests & $09 / 30 / 93$ & $01 / 04 / 94$ & \\
\hline $\begin{array}{l}\text { Transportation Accident- } \\
\text { Resistant Containers (TARC) } \\
\text { Lateral Impact Test at } \\
\text { 10,000 Ft. Track }\end{array}$ & $10 / 01 / 93$ & & \\
\hline Dart Test & $10 / 04 / 93$ & $01 / 04 / 94$ & \\
\hline Installation of Water Tank & $03 / 16 / 93$ & $04 / 21 / 93$ & \\
\hline Road and Instrumentation Pad & $03 / 16 / 93$ & $04 / 21 / 93$ & \\
\hline
\end{tabular}




\section{APPENDIX $J$}

1993 ENVIRONMENTAL COMPLIANCE ACTIVITIES AT THE KAUAI TEST FACILITY 


\section{CONTENTS}

Page

J.1 Introduction. . . . . . . . . . . . . . . . . . . J J-5

J.1.1 Facilities and Operations . . . . . . . . . . . . J-5

J.1.2 Geology and Hydrology . . . . . . . . . . . . . . . J J 5

J.1.3 Biology and Population . . . . . . . . . . . . . . . . J J

J.1.4 Meteorology . . . . . . . . . . . . . . . . . . J J

J.2 Significant Environmental Compliance Activities . . . . . . . . J-8

J.2.1 National Environmental Policy Act Compliance . . . . . J J-8

J.2.2 Environmental Permits . . . . . . . . . . . . . . . . . . . J J-9

J.2.3 1993 Release Reporting . . . . . . . . . . . . . J-10

J.3 Environmental Monitoring and Mitigation Action Plan . . . . . . J-10

J.4 Other Compliance Activities . . . . . . . . . . . . . . . . . . J-11

J.4.1 Spill Prevention Control and Countermeasure Plan . . . . J J-11

J.4.2 Toxic Substances Control Act . . . . . . . . . . . . . J J-11

FIGURE

J-1 Map of the Pacific Missile Range Facility (PMRF) and the Adjacent Area . . . . . . . . . . . . . . . . . . J-6

TABLE

J-1 Summary of 1993 Reportable Quantity Release Reporting . . . . J J-10

REFERENCES . . . . . . . . . . . . . . . . . . . . . . . . . . . . . J J-12 
$\mathrm{J}-4$ 


\section{J . 1 INTRODUCTION}

Sandia National Laboratories (SNL) operates a rocket preparation and launch facility called the Kauai Test Facility (KTF) at the U.S. Navy's Pacific Missile Range Facility (PMRF), Barking Sands, for the U.S. Department of Energy (DOE). PMRF is located on the west side of the island of Kauai, Hawaii (Figure $\mathrm{J}-1$ ). KTF is used to launch rockets in support of DOE missions, as well as other U.S. Government projects (DOE 1992).

\section{J.1.1 Facilities and Operations}

SNL's KTF is located on the north part of the Navy's PMRF near Nohili Point. Most facilities at KTF were constructed in the early 1960s to support the National Readiness Program. The most recent construction, completed in 1989, added five buildings and a new launch pad to support future DOE and Strategic Defense Initiative (SDI) launches.

KTF has been, and is being, used for testing rocket systems with scientific and technological payloads, advanced development of maneuvering reentry vehicles, scientific studies of atmospheric and exoatmospheric phenomena, and SDI programs. Nuclear devices have never been launched from KTF.

The KTF launcher field was originally designed to accommodate 40 launch pads, but only 15 were constructed. Of these, 12 are inactive, with the launchers removed. Beyond the implementation of portions of the original plan, two additional launch pads have been constructed, Pad 41 at Kokole Point, and Pad 42, the Strategic Targeting System (STARS) launch pad. The launcher field site has a number of permanent facilities used to support rocket operations.

The administrative area of KTF is located in a fenced compound near the North Nohili access road from PMRF. Within the fenced compound, a number of trailers and vans are interconnected with a network of concrete docks and covered walkways. The majority of these temporary facilities are used during operational periods to support field staff at KTF. In the nonoperational periods, they are in standby condition with only dehumidifiers in operation. In addition, there are a small number of permanent buildings, most of which are in use year-round to support and maintain KTF facilities (Helgesen 1990).

\section{J.1.2 Geology and Hydrology}

KTF and PMRF are located on the seaward margin of the broad Mana Coastal Plain of Kauai. This plain is composed of alluvium washed from uplands, calcareous and clayey lagoon deposits, sand dunes, and beach rock. The poorly consolidated deposits of the present plain were formed in a shallow lagoon behind an ancient beach ridge. The large wetland was largely filled in and planted with sugar cane by 1936, leaving only some small areas of wetland near Mana, about 10,000 feet (ft) (3048 meters [m]) from KTF.

KTF lies in the rain shadow of Mounts Kawaikini and Waialeale. Annual rainfall is approximately 20 inches per year (in./yr) (51 centimeters per year [cm/yr]). There is no integrated surface drainage on the site. The sand is so permeable 
Pacificocean
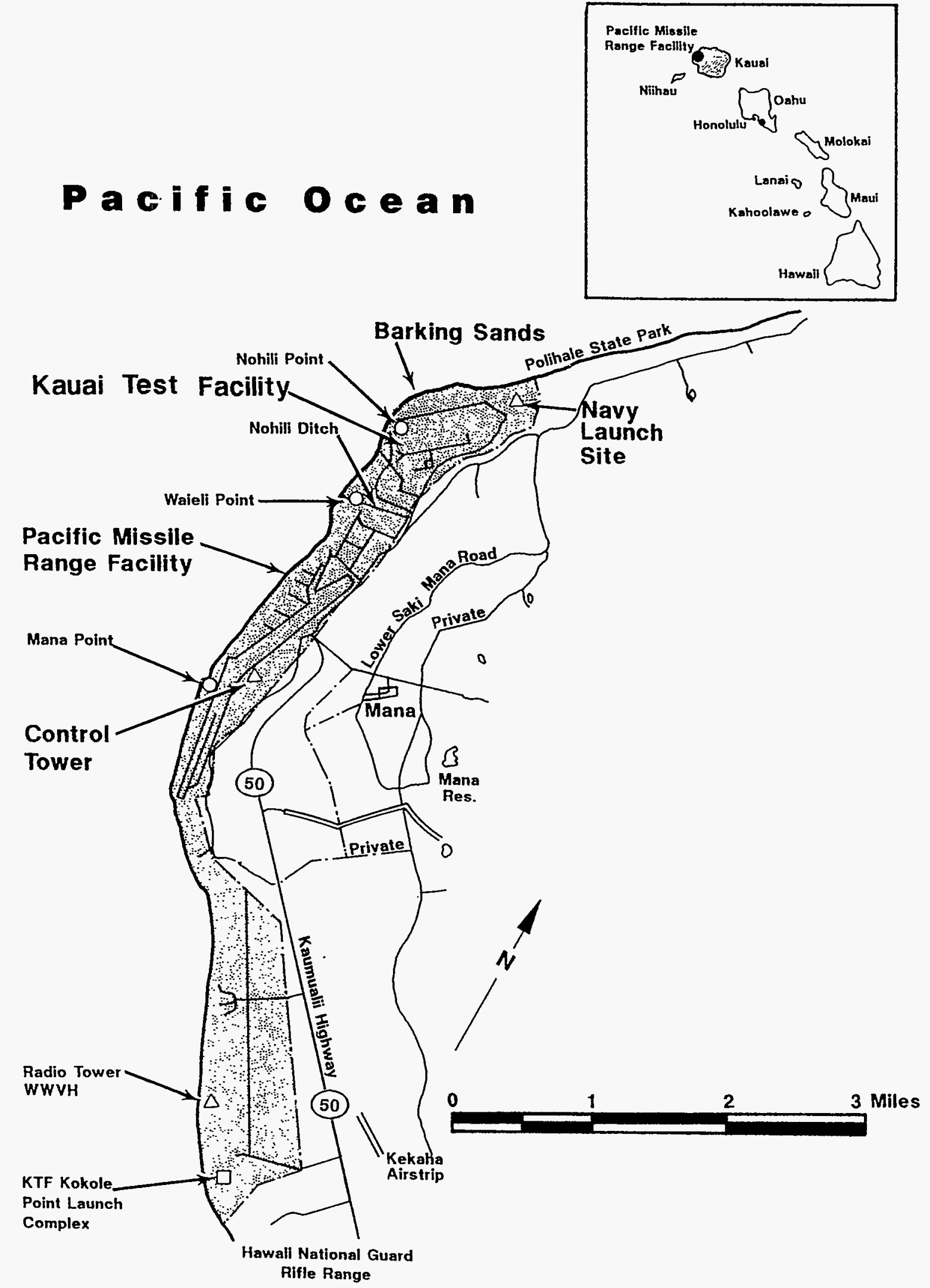

Figure J-1. Map of the Pacific Missile Range Facility (PMRF) and the Adjacent Area. The Kauai Test Facility (KTF) is to the north, near Nohili Point. 
and its moisture-holding capacity so low that no drainage pattern has become established on the surface. Rain simply sinks into the sand and disappears.

The Mana Coastal Plain is composed of a wedge of terrestrial and marine sediments overlying a volcanic basement. The basement rock forms an outcrop at the inland edge of the plain; its steep slope is a cliff formed during a former high-stand of the sea. The volcanic basement plunges below the plain at a dip of approximately 5 degrees and continues to the coast, where it is approximately $400 \mathrm{ft}(122 \mathrm{~m})$ deep.

The seaward edge of the plain is covered by fossil sand dunes formed when the sea level was lower than it is now. PMRF is located almost entirely on these dunes, which are now no higher than approximately $10 \mathrm{ft}(3 \mathrm{~m})$, except to the north of the KTF, where they are s100 ft $(30 \mathrm{~m})$ high.

The three geological formations (bedrock, alluvium, and dunes) constitute hydraulically connected aquifers. The basement volcanics are highly permeable, containing brackish water floating on seawater. The overlying sediments act as a cap rock because of their low permeability; but though they are saturated, they are not exploitable as an aquifer because of their unfavorable hydraulic characteristics.

The dune sand aquifer, on which PMRF lies, has moderate hydraulic conductivity and reasonable porosity. It consists of a lens of brackish groundwater floating on seawater and is recharged by storm rainfall and seepage from the underlying sediments. The only record of an attempt to exploit this groundwater is of a well drilled for the Navy in 1974, 4 to 5 miles (mi) (6.5 to 8 kilometers $[\mathrm{km}]$ ) south of the KTF. Drilled to a depth of $42 \mathrm{ft}(13 \mathrm{~m})$, the well encountered only fine sand and coral gravel, but when it was tested at 300 gallons per minute (gpm), it contained 2800 milligrams per liter (mg/L) chloride, which is too brackish for plants. This well is not being used (SNL 1986).

\section{J.1.3 Biology and Population}

The principal vegetation found on Kauai consists of two introduced shrub species: kiawe, a mesquite, and koahaole, a wild tamarind. Portions of the island are covered with nearly impenetrable thickets of kiawe and koahaole (DOE 1992). The land on which the present KTF facilities lie has been cleared of brush and has a thin cover of grasses and herbs. The sandy soil is barren and appears incapable of supporting agriculture unless it is improved by being mixed with organically rich soil, fertilized extensively, and irrigated.

No mammals or signs of mammals were encountered during a 1986 field survey (SNL 1986). However, it is quite likely that there may be populations of mice and rats. The endangered Hawaiian Hoary Bat (Lasiurus cinereus semotus) may also be occasionally found since there are breeding populations elsewhere on Kauai.

Twenty-two species of birds are found on the range, as well as three more just outside the range (SNL 1986). These include 5 species native to Hawaii. There 
are also several species of waterfowl present during some portion of the year, although they were not seen during the 1986 survey.

Kekah, with a 1980 population of 3300 , is the closest population center to KTF. During nonoperational periods, KTF employs 14 permanent onsite personnel. During operational periods when rocket launches are occurring, an additional 50 to 75 persons from the United States mainland are employed (DOE 1992).

\section{J.1.4 Meteorology}

Lying in the rain shadow of Mounts Kawaikini and Waialeale, KTF is sheltered from the predominant northeast tradewinds and is one of the driest sections of Kauai. Average annual rainfall at $\mathrm{KTF}$ is just over $20 \mathrm{in.}(51 \mathrm{~cm})$ and occurrs mostly between October and April. Under normal conditions, winds are generally light and variable; abnormal conditions can result in gusty winds in excess of 30 knots from the south, west, or north. The mean monthly temperature is $70^{\circ} \mathrm{F}$, with maximums in the low $90 \mathrm{~s}$ and minimums in the mid-50s.

\section{J.2 SIGNIFICANT ENVIRONMENTAL COMPLIANCE ACTIVITIES}

\section{J.2.1 National Environmental Policy Act Compliance}

For KTF, development of a comprehensive site-wide Environmental Assessment (EA), "Kauai Test Facility Environmental Assessment," was completed in 1992 (DOE 1992). A finding of no significant impact (FONSI) was issued on July 17, 1992.

In completing this EA, several environmental surveys were carried out. Reports included the following:

- A Green Sea Turtle Survey Report: This survey found at least 32 green sea turtles (Chelonia mydas agassizi) at up to five locations at KTF. The study concluded that constructing an additional launch pad and conducting further launches similar to those conducted at KTF since 1962 probably will not have any quantifiable effects on green sea turtles residing in waters near KTF (IT 1990a).

- A Botanical Survey Report: This survey identified four major vegetation types at KTF and recommended that vehicles be kept off the beach and dunes. The report recommended moving the entire Ophioglossum concinnum colony (a Category 1 proposed endangered fern) to a compatible area within PMRF because of the colony's proximity to a beach access road and its location in a frequently-mowed kiawe/koa-haole vegetation zone (IT 1990b).

- An Ornithological Survey Report: This survey determined relative densities of bird species and identified mammalian species at KTF (IT 1990c).

- A Soil Sampling Report: This sampling was undertaken to delineate the extent and concentration of lead ( $\mathrm{Pb}$ ), aluminum (Al), and beryllium (Be) in the soil at KTF and to determine whether the concentrations threaten human health or the environment. The soil sampling results 
were used to estimate the potential for future soil contamination or human exposure from use of KTF as a launch facility. Results of the data analysis are contained in an International Technology Corporation report (IT 1990d).

- Archaeological Survey and Sampling: This survey found no significant cultural resources on the surface at KTF, but subsurface testing within one area indicated a potential for subsurface cultural resource materials (Gonzalez and Berryman 1990).

Data from these letter reports were incorporated into the KTF EA.

Two rocket launches from the KTF were executed in 1993; both launches were covered by the KTF EA, published in July 1992 (DOE 1992). The STARS Flight Test Unit 1 (FTU-1) was launched on February 26, 1993. The mission successfully demonstrated the missile's flight worthiness and the capability of range equipment and personnel to safely support this type of missile system. While the primary purpose of this launch was to test the STARS missile system, the missile also deployed a mock warhead, or payload, for research purposes. The successful FTU mission demonstrated the capability of the STARS and the mission readiness of the ranges.

The STARS Mission-One (M-1) was launched on August 25, 1993. This mission was a joint venture between the United States and the United Kingdom. The purpose of the mission was to deliver two payloads at re-entry velocities into the broad ocean area near the Kwajalein Atoll. The information gathered will be applied to the development of a ballistic missile defense system. This mission was a success; all onboard systems functioned nominally and all sensors acquired valid data.

\section{J.2.2 Environmental Permits}

Air: There are no Prevention of Significant Deterioration (PSD) or National Emission Standards for Hazardous Air Pollutants (NESHAP) sources for the facility, and no air permits are held either by DOE for KTF or by the U.S. Department of Defense (DOD) for PMRF. However, the two electrical generators at KTF are permitted by the State of Hawaii.

Water: Wastewater is treated on site by a wastewater treatment system consisting of septic tanks and leach fields into brackish water. The limited quantities of sewage released from KTF do not impact any protected water. Periodic drainage of septic tanks is accomplished by State of Hawaii licensed contractors who dispose of wastes according to state regulations. The facility currently holds two permits for the two septic tanks on the site.

Solid Waste: KTF, as a tenant of PMRF, is a conditionally exempt smallquantity hazardous waste generator. Resource Conservation and Recovery Act (RCRA) permits are not required for small-quantity generators. These small quantities of hazardous chemical wastes are disposed of according to the PMRF tenant agreement. PMRF also transports nonhazardous solid waste to the county landfill. 


\section{J.2.3 1993 Release Reporting}

Reportable Quantity (RQ) information is required by the Comprehensive Environmental Response Compensation and Liability Act (CERCLA) and Superfund Amendments and Reauthorization Act (SARA), Title III. CERCLA requires that any release to the environment in any 24-hour (hr) period of any pollutant or hazardous substance in a quantity $2 R Q$ be reported immediately to the National Response Center (NRC). However, if the release is "federally permitted" under CERCLA Section $101(10)(H)$, it is exempted from CERCLA reporting. This reporting exemption also applies to any federally permitted release under SARA, Title III.

There were no RQ releases for KTF in 1993 (Table J-1).

Table J-1. Summary of 1993 Reportable Quantity Release Reporting

Date Location Material Quantity RQ $\begin{aligned} & \text { Site of } \\ & \text { Release }\end{aligned} \quad \begin{gathered}\text { NRC } \\ \text { No. }\end{gathered} \begin{gathered}\text { Report } \\ \text { Date }\end{gathered}$

No RQ releases in 1993.

\section{J.3 ENVIRONMENTAL MONITORING AND MITIGATION ACTION PLAN}

Pursuant to DOE Order 5400.1, "General Environmental Protection Program" (DOE 1988), a "Kauai Test Facility Environmental Monitoring Plan" (EMP) was drafted in September 1991 (IT 1992). This EMP will provide a comprehensive description of planned and ongoing environmental activities at KTF and demonstrate compliance with regulatory requirements imposed by applicable Federal, State, and local agencies. The EMP will also support DOE environmental management decisions for the facility.

The draft Sandia National Laboratories/Kauai Test Facility Environmental Monitoring Plan (IT 1992) addresses activities at KTF, such as rocket launches. Environmental monitoring of the 1993 launches was consistent with requirements of the KTF EA and the STARS EIS. A comprehensive monitoring program, which included air quality, noise, water, soil, vegetation, and marine resources, was conducted for the first STARS launch (FTU-I). This monitoring program was directed and coordinated by the U.S. Army Space and Strategic Defense Command (USASSDC) Environmental Office. All required State and Federal agencies were contacted and sent results. The results concluded that no adverse effects had been caused by the launch and no Federal or State standards were violated.

As described in the STARS EIS, air samples were collected during the first demonstration launch to validate the accuracy of the models and to evaluate compliance with Federal and State standards. Based on the results of the FTU mission, the monitoring program for the STARS M-1 mission was the same except that no air monitoring was performed. The results of the environmental monitoring also produced no adverse effects and no violations of Federal or 
State statues. The Kauai Test Facility Mitigation Action Plan (Appendix D of the KTF EA [DOE 1992]) contains mitigation measures that are designed to reduce potential environmental impacts to minor levels.

\section{$\mathrm{J} .4$ OTHER COMPLIANCE ACTIVITIES}

\section{J.4.1 Spill Prevention Control and Countermeasure Plan}

SNL at KTF takes part in the PMRF Spill Prevention Control and Countermeasure (SPCC) Plan which provides support in the event of a diesel fuel spill from the 10,000-gallon (gal) aboveground fuel tank just outside the compound (U.S. Navy 1991).

$\mathrm{KTF}$ has only one underground storage tank (UST) in its inventory (666C). This state-of-the-art UST system was placed in service in August 1991 and is registered with the State of Hawaii as a DOE-owned SNL UST system.

\section{J.4.2 Toxic Substances Control Act}

Under the Toxic Substances Control Act (TSCA), oil-containing electrical and mechanical equipment and hydraulic-fluid-containing systems must be assumed to be polychlorinated biphenyl (PCB) containing systems unless sampling and analysis show otherwise. The transformers on the KTF site have been tested and are free of PCBs. 


\section{REFERENCES}

Comprehensive Environmental Reponse, Compensation, and Liability Act (CERCLA) of 1980 , as amended. Title 40 U.S.C. 9601.

DOE 1988: U.S. Department of Energy, "General Environmental Protection Program," DOE Order 5400.1, DOE, Washington, DC (1988; change 1, June 21, 1990).

DOE 1992: U.S. Department of Energy Albuquerque Operations

Office (DOE/AL), "Kauai Test Facility Environmental Assessment," DOE/EA-0492, DOE/AL, Albuquerque, NM (1992).

Gonzalez and Berryman 1990: Gonzalez, T., and J. Berryman, "Archaeological Survey and Testing, Department of Energy, Kauai Test Facility," prepared for Sandia National Laboratories, Albuquerque, NM (1990).

Helgesen 1990: Helgesen, R. F., "Safety Assessment for the Kauai Test Facility at Barking Sands, Kauai," SAND89-2548, Sandia National Laboratories, NM (1990).

IT 1990a: International Technology Corporation, "A Survey of the Green Sea Turtle Population Fronting the Kauai Test Facility, Pacific Missile Range, Barking Sands, Kauai: An Analysis of Potential Impacts with Implementation of the Strategic Defense Initiative" (1990).

IT 1990b: International Technology Corporation, "Botanical

Survey of the Kauai Test Facility Site, Barking Sands, Kauai, Hawaii," prepared for Sandia National Laboratories, Albuquerque, NM (1990).

IT 1990c: International Technology Corporation, "Ornithological Survey Report of the Kauai Test Facility Site, Barking Sands, Kauai, Hawaii," prepared for Sandia National Laboratories, Albuquerque, NM (1990).

IT 1990d: International Technology Corporation, "Soil Sampling Program for Sandia National Laboratories, Kauai Test Facility, Kauai, Hawaii," prepared for Sandia National Laboratories, Albuquerque, NM (1990).

IT 1992: International Technology Corporation, "Sandia National

Laboratories Kauai Test Facility Environmental Monitoring Plan, "prepared for Sandia National Laboratories, Albuquerque, NM (1992).

SNL 1986: Sandia National Laboratories, "Environmental Report, Proposed IRBS Facilities, Kauai Test Facility," prepared by Sandia National Laboratories, Albuquerque, NM, for the DOE (1986).

Superfund Amendments and Reauthorization Act (SARA) of 1986. Title III, Section 313, "Toxic Chemical Release Reporting."

Toxic Substances Control Act (TSCA) of 1976. U.S.C. $\$ 2601$ et seq. 
U.S. Navy 1991: U.S. Navy, "Spill Prevention Control and Countermeasure Plan, Pacific Missile Range Facility," Pacific Division, Naval Facilities Engineering Command, Pearl Harbor, HI (February 1991). 


\section{APPENDIX K}

GROUNDWATER MONITORING DATA 
K-2 


\section{CONTENTS}

TABLES

Page

K-1a Summary of Volatile Organic Compound Data for Environmental

Samples Exceeding MDL, April 1993 . . . . . . . . . . . . . . . K-7

K-Ib Summary of Volatile Organic Compound Data for Environmental

Samples Exceeding MDL, July 1993 . . . . . . . . . . . . . . . . . K-8

K-1c Summary of Volatile Organic Compound Data for Environmental

Samples Exceeding MDL, September 1993 . . . . . . . . . . . . . . K-9

K-Id Summary of Volatile Organic Compound Data for Environmental

Samples Exceeding MDL, December 1993 . . . . . . . . . . . . . K-9

K-2a Summary of Environmental Samples With Data Exceeding MCL,

April 1993 . . . . . . . . . . . . . . . . . . . . . . K-10

K-2b Summary of Environmental Samples With Data Exceeding MCL, July 1993 . . . . . . . . . . . . . . . . . . . . . . . . . . . . K-10

K-2c Summary of Environmental Samples With Data Exceeding MCL, September 1993 . . . . . . . . . . . . . . . . . . . . . . . . . K-11

K-2d Summary of Environmental Samples With Data Exceeding MCL, December 1993 . . . . . . . . . . . . . . . . . . . . . . . . K-12

K-3a Summary of Field Water Quality Measurements, April 1993 . . . . . K-13

K-3b Summary of Field Water Quality Measurements, July 1993 . . . . . . K-15

K-3c Summary of Field Water Quality Measurements, September 1993 . . . K-17

K-3d Summary of Field Water Quality Measurements, December 1993 . . . . K-19

K-4a Summary of Analytical Results for Detected Organic Compounds, April 1993 . . . . . . . . . . . . . . . . . . . . . . . . K-21

K-4b Summary of Analytical Results for Detected Organic Compounds, July 1993 . . . . . . . . . . . . . . . . . . . . . . . . . . . . K-23

K-4c Summary of Analytical Results for Detected Organic Compounds, September 1993 . . . . . . . . . . . . . . . . . . . . . . . . . . K-25

K-4d Summary of Analytical Results for Detected Organic Compounds, December 1993 . . . . . . . . . . . . . . . . . . . . . K-27

K-5a Summary of Results of Library Search for Volatile Organic Compounds, April 1993 . . . . . . . . . . . . . . . . . . . . . . K-29

K-5b Summary of Results of Library Search for Volatile Organic Compounds, July 1993 ... . . . . . . . . . . . . . . . . . . . K-31

K-5c Summary of Results of Library Search for Volatile Organic Compounds, September 1993 . . . . . . . . . . . . . . . . . K-33

K-5d Summary of Results of Library Search for Volatile Organic Compounds, December 1993 . . . . . . . . . . . . . . . . K-35

K-6a Summary of Analytical Results for Inorganic Compounds and Phenolics, April 1993 . . . . . . . . . . . . . . . . . K-36

K-6b Summary of Analytical Results for Inorganic Compounds and Phenolics, July 1993 . . . . . . . . . . . . . . . . . . K-37

K-6c Summary of Analytical Results for Inorganic Compounds and Phenolics, September 1993 . . . . . . . . . . . . . . . . . K-38

K-6d Summary of Analytical Results for Inorganic Compounds and Phenolics, December 1993 . . . . . . . . . . . . . . . K-39 


\section{CONTENTS \\ (Continued)}

TABLES

Page

K-7a Summary of Analytical Results for Total Metals, April 1993 . . . . . . . . . . . . . . . . . . . . . . . . . . . . K-41

$\mathrm{K}-7 \mathrm{~b}$ Summary of Analytical Results for Total Metals, July 1993 . . . . . . . . . . . . . . . . . . . . . . . . . . . . . K-43

K-7c Summary of Analytical Results for Total Metals, September 1993 . . . . . . . . . . . . . . . . . . . . . . . . . . K-45

K-7d Summary of Analytical Results for Total Metals, December 1993 . . . . . . . . . . . . . . . . . . . . . . K-47

K-8a Summary of Analytical Results for Coliform Bacteria, April 1993 . . . . . . . . . . . . . . . . . . . . . . . . . . . . K-49

K-8b Summary of Analytical Results for Coliform Bacteria, September 1993 . . . . . . . . . . . . . . . . . . . . . . . K-50

K-9a Summary of Results of Unfiltered Radionuclide Screen, April 1993 . . . . . . . . . . . . . . . . . . . . . . . . . . . K-51

K-9b Summary of Results of Unfiltered Radionuclide Screen, July 1993 . . . . . . . . . . . . . . . . . . . . . . . . . . . . . K-52

K-9c Summary of Results of Unfiltered Radionuclide Screen, September 1993 . . . . . . . . . . . . . . . . . . . . . . K-53

K-9d Summary of Results of Unfiltered Radionuclide Screen, December 1993 . . . . . . . . . . . . . . . . . . . . K-55

K-10 Summary of Results for Radionuclide Surveillance Data, September 1993 . . . . . . . . . . . . . . . . . . K-56

K-11 Summary of Results of Tritium Analyses, December 1993 . . . . . . . K-59

K-12 Summary of Detected Compounds - Chemical Waste Landfill, February 1993 . . . . . . . . . . . . . . . . . . . . . K-61

K-13 Summary of Detected Volatile Organic Compounds - Chemical Waste Landfill, May 1993 . . . . . . . . . . . . . . . . . K-62

K-14a Summary of Detected Volatile Organic Compounds - Chemical Waste Landfill, August 1993 . . . . . . . . . . . . . . . . . . . . K-63

K-14b Summary of Detected Metals - Chemical Waste Landfill, August 1993 . . . . . . . . . . . . . . . . . . . . . . K-64

K-15 Summary of Detected Compounds - Chemical Waste Landfill, November 1993 . . . . . . . . . . . . . . . . . . . . . . . K-65

K-16a Summary of Nonradiological Analytical Results - Mixed Waste Landfill, January 1993 . . . . . . . . . . . . . . . . . . . . . K-66

K-16b Summary of Nonradiological Analytical Results - Mixed Waste Landfill, April 1993 


\section{CONTENTS \\ (Concluded)}

TABLES

Page

K-16c Summary of Nonradiological Analytical Results - Mixed Waste

Landfil1, November 1993 . . . . . . . . . . . . . . . K-74

K-17a Summary of Radiological Analytical Results - Mixed Waste

Landfill, January 1993 . . . . . . . . . . . . . . . . . . K-77

K-17b Summary of Radiological Analytical Results - Mixed Waste

Landfill, April 1993 . . . . . . . . . . . . . . . . . . . . . . . K-82

K-17c Summary of Radiological Analytical Results - Mixed Waste

Landfill, November 1993 . . . . . . . . . . . . . . . . . . . . K-88

K-18 Summary of Analytical Results for Detected Organic Compounds -

TA-II. . . . . . . . . . . . . . . . . . K-91

K-19 Summary of Analytical Results for Inorganic Compounds -

TA-II. . . . . . . . . . . . . . . . . . . . . . . . K-92

K-20 Summary of Analytical Results for Total Metals - TA-II . . . . . . K-93

K-21a Summary of Analytes Detected in Groundwater Samples - Liquid

Waste Disposal Site Monitoring Well MW-2, June 24, 1993 . . . . . . K-94

$\mathrm{K}-21 \mathrm{~b}$ Summary of Analytes Detected in Groundwater Samples -

Liquid Waste Disposal Site Monitoring Well MW-1,

November 2 and 3, 1993 . . . . . . . . . . . . . . . . . K-95

K-22 Summary of Analytical Results - South Fence Wells SFR-1D

and SFR-2S, May 6, 1993 . . . . . . . . . . . . . . K-96 


\section{Table K-la.}

Summary of Volatile Organic Compound Data for

Environmental Samples Exceeding $\mathrm{MDL}^{\mathrm{a}}$

SNL/NM Basewide Groundwater Surveillance, April 1993

\begin{tabular}{|c|c|c|c|c|c|c|}
\hline Well or Spring & $\begin{array}{c}\text { Wastewater Container } \\
\text { No. }\end{array}$ & Sample No. & Parameter & $\begin{array}{l}\text { Value } \\
\text { (mg/L) }\end{array}$ & $\begin{array}{c}\mathrm{MCL}^{\mathrm{b}} \\
(\mathrm{mg} / \mathrm{L})\end{array}$ & $\begin{array}{l}\mathrm{MDL}^{\mathrm{a}} \\
(\mathrm{mg} / \mathrm{L})\end{array}$ \\
\hline Burn Site Well & No wastewater generated & BSW0012073 & Methylene chloride & $0.006 \mathrm{~B}^{\mathrm{c}}$ & $N E^{d}$ & 0.005 \\
\hline Coyote Spring & No wastewater generated & CYSO012074 & Methylene chloride & $0.006 \mathrm{~B}$ & NE & 0.005 \\
\hline $\begin{array}{l}\text { EOD Hill Well } \\
\text { (duplicate) }\end{array}$ & No wastewater generated & HIL0012129 & Acetone & 0.046 & NE & 0.010 \\
\hline Greystone Manor Well & No wastewater generated & GSM0012078 & Methylene chloride & $0.005 \mathrm{~B}$ & NE & 0.005 \\
\hline Hubbell Spring & No wastewater generated & HBL0012079 & Methylene chloride & $0.006 \mathrm{~B}$ & NE & 0.005 \\
\hline KAFB-10 Well & No wastewater generated & K100012080 & Acetone & $0.011 \mathrm{~B}$ & NE & 0.010 \\
\hline $\begin{array}{l}\text { Sol se Mete } \\
\text { Spring }\end{array}$ & No wastewater generated & SSM0012088 & Methylene chloride & $0.005 \mathrm{~B}$ & NE & 0.005 \\
\hline SW-TA3 Well & No wastewater generated & SW30012089 & Methylene chloride & $0.006 \mathrm{~B}$ & NE & 0.005 \\
\hline \multicolumn{7}{|c|}{$\begin{array}{l}{ }^{a} \mathrm{MDL}=\text { Minimum method detection limit obtained for nondetected parameters. } \\
{ }^{\mathrm{M}} \mathrm{MCL}=\text { Maximum contaminant levels established by the U.S. Environmental Protection Agency (EPA) Primary Drinking Water } \\
\text { Regulations (PDWR) in } 40 \text { CFR } 141.11 \text { (b). } \\
{ }^{c_{B}}=\text { Compound detected in method blank. } \\
{ }^{\mathrm{N}} \mathrm{NE}=\mathrm{MCL} \text { not established for this constituent. }\end{array}$} \\
\hline
\end{tabular}


Table K-1b.

Summary of Volatile Organic Compound Data for

Environmental Samples Exceeding MDL

SNL/NM Basewide Groundwater Surveillance, July 1993

\begin{tabular}{|c|c|c|c|c|c|c|}
\hline Well or Spring & $\begin{array}{l}\text { Wastewater } \\
\text { Container No. }\end{array}$ & Sample No. & Parameter & $\begin{array}{l}\text { Value } \\
\text { (mg/L) }\end{array}$ & $\begin{array}{l}\mathrm{MCl}^{\mathrm{b}} \\
(\mathrm{mg} / \mathrm{L})\end{array}$ & $\begin{array}{l}\mathrm{MDL}^{\mathrm{a}} \\
(\mathrm{mg} / \mathrm{L})\end{array}$ \\
\hline MVMW-J Well & $\begin{array}{l}\text { No wastewater } \\
\text { generated }\end{array}$ & MVJ0012964 & $\begin{array}{l}\text { Acetone } \\
\text { Trimethyl silanol } \\
\text { Unknown } \\
\text { Unknown }\end{array}$ & $\begin{array}{l}0.012 \\
0.011 \\
0.009 \\
0.014\end{array}$ & $\begin{array}{l}N E^{c} \\
N E \\
N E \\
N E\end{array}$ & $\begin{array}{l}0.010 \\
N^{d} \\
N A \\
N A\end{array}$ \\
\hline MVMW-K Well & $\begin{array}{l}\text { No wastewater } \\
\text { generated }\end{array}$ & MVK0012965 & $\begin{array}{l}\text { Trimethyl silanol } \\
\text { Unknown alkane } \\
C_{8}-C_{12} \\
\text { Unknown alkane } \\
C_{8}-C_{12}\end{array}$ & $\begin{array}{l}0.008 \\
0.006 \\
0.016\end{array}$ & $\begin{array}{l}\text { NE } \\
\text { NE } \\
\text { NE }\end{array}$ & $\begin{array}{l}\text { NA } \\
\text { NA } \\
\text { NA }\end{array}$ \\
\hline $\begin{array}{l}\text { MVMW-K Well } \\
\text { (duplicate) }\end{array}$ & $\begin{array}{l}\text { No wastewater } \\
\text { generated }\end{array}$ & MVX0012966 & $\begin{array}{l}\text { Trimethyl silanol } \\
\text { Unknown alkane } \\
\mathrm{C}_{8}-\mathrm{C}_{12}\end{array}$ & $\begin{array}{l}0.018 \\
0.008\end{array}$ & $\begin{array}{l}\mathrm{NE} \\
\mathrm{NE}\end{array}$ & $\begin{array}{l}\text { NA } \\
\text { NA }\end{array}$ \\
\hline Burn Site Well & $\begin{array}{l}\text { No wastewater } \\
\text { generated }\end{array}$ & BSW0012953 & Trimethyl silanol & 0.010 & NE & NA \\
\hline Coyote Spring & $\begin{array}{l}\text { No wastewater } \\
\text { generated }\end{array}$ & CYS0012954 & Trimethyl silanol & 0.009 & $\mathrm{NE}$ & NA \\
\hline SW-TA3 Well & $\begin{array}{l}\text { No wastewater } \\
\text { generated }\end{array}$ & SW30012971 & Unknown & 0.006 & NE & NA \\
\hline 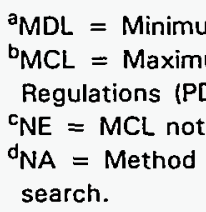 & $\begin{array}{l}\text { thod detection lim } \\
\text { ntaminant levels } \\
\text { in } 40 \text { CFR } 141.11 \\
\text { lished for this con } \\
\text { ion limit not appli }\end{array}$ & $\begin{array}{l}\text { btained for nond } \\
\text { blished by the } L \\
\text { uent. } \\
\text { le to estimated }\end{array}$ & $\begin{array}{l}\text { cted parameters. } \\
\text { Environmental Pro } \\
\text { Entrations of tent }\end{array}$ & $\begin{array}{l}\text { ency }(E \\
\text { tified } c\end{array}$ & ds fror & $\begin{array}{l}\text { Water } \\
\text { library }\end{array}$ \\
\hline
\end{tabular}


Table K-Ic.

Summary of Volatile Organic Compound Data for Environmental Samples Exceeding $\mathrm{MDL}^{\mathrm{a}}$

SNL/NM Basewide Groundwater Surveillance, September 1993

\begin{tabular}{|c|c|c|c|c|c|c|}
\hline Well or Spring & $\begin{array}{l}\text { Wastewater } \\
\text { Container No. }\end{array}$ & Sample No. & Parameter & $\begin{array}{l}\text { Value } \\
\text { (mg/L) }\end{array}$ & $\begin{array}{l}M C L^{b} \\
\text { (mg/L) }\end{array}$ & $\begin{array}{l}\mathrm{MDL}^{\mathrm{a}} \\
(\mathrm{mg} / \mathrm{L})\end{array}$ \\
\hline EOD Hill Well & $\begin{array}{l}\text { EOD092893-1 } \\
\text { EOD092893-2 } \\
\text { EOD092893-3 }\end{array}$ & EOD013478 & Acetone & 0.017 & $N E^{c}$ & 0.010 \\
\hline SW-TA3 Well & $\begin{array}{l}\text { No wastewater } \\
\text { generated }\end{array}$ & SW3013483 & $\begin{array}{l}\text { Carbon } \\
\text { tetrachloride }\end{array}$ & 0.012 & NE & 0.005 \\
\hline \multicolumn{7}{|c|}{$\begin{array}{l}{ }^{a} \mathrm{MDL}=\text { Minimum method detection limit obtained for nondetected parameters. } \\
{ }^{\mathrm{b}} \mathrm{MCL}=\text { Maximum contaminant levels established by the U.S. Environmental Protection Agency (EPA) Primary } \\
\text { Drinking Water Regulations (PDWR) in } 40 \text { CFR } 141.11 \text { (b). } \\
{ }^{\mathrm{C} N E}=\text { MCL not established for this constituent. }\end{array}$} \\
\hline
\end{tabular}

Table K-1d.

Summary of Volatile Organic Compound Data for Environmental Samples Exceeding $\mathrm{MDL}^{\mathrm{a}}$

SNL/NM Basewide Groundwater Surveillance, December 1993

\begin{tabular}{|c|c|c|c|c|c|c|}
\hline Well or Spring & $\begin{array}{l}\text { Wastewater } \\
\text { Container No. }\end{array}$ & Sample No. & Parameter & $\begin{array}{l}\text { Value } \\
(\mathrm{mg} / \mathrm{L})\end{array}$ & $\begin{array}{l}\mathrm{MCL}^{\mathrm{b}} \\
(\mathrm{mg} / \mathrm{L})\end{array}$ & $\begin{array}{l}\mathrm{MDL}^{\mathrm{a}} \\
(\mathrm{mg} / \mathrm{L})\end{array}$ \\
\hline $\begin{array}{l}\text { EOD Hill Well, } \\
\text { EOD Hill Well } \\
\text { (duplicate) }\end{array}$ & $\begin{array}{l}\text { EOD122093-1 } \\
\text { EOD122093-2 } \\
\text { EOD122993-3 }\end{array}$ & $\begin{array}{l}\text { EODO14323 } \\
\text { EOD014324 }\end{array}$ & Acetone & $\begin{array}{l}0.012 \\
0.013\end{array}$ & $\mathrm{NE}^{\mathrm{C}}$ & 0.010 \\
\hline \multicolumn{7}{|c|}{$\begin{array}{l}{ }^{a} \mathrm{MDL}=\text { Minimum method detection limit obtained for nondetected parameters. } \\
{ }^{b_{M C L}}=\text { Maximum contaminant levels established by the U.S. Environmental Protection Agency (EPA) Primary } \\
\text { Drinking Water Regulations (PDWR) in } 40 \text { CFR } 141.62(b) . \\
{ }^{c} \mathrm{NE}=\text { MCL not established for this constituent. }\end{array}$} \\
\hline
\end{tabular}


Table K-2a.

Summary of Environmental Samples With Data Exceeding MCL a

SNL/NM Basewide Groundwater Surveillance, April 1993

\begin{tabular}{|c|c|c|c|c|c|}
\hline Well or Spring & $\begin{array}{l}\text { Wastewater } \\
\text { Container No. }\end{array}$ & Sample No. & Parameter & Value & $\mathrm{MCL}^{\mathrm{a}}$ \\
\hline CWL-BW2 & EOR042693-1 & СВ20012075 & Chromium & $0.25 \mathrm{mg} / \mathrm{L}$ & $0.05 \mathrm{mg} / \mathrm{L}$ \\
\hline KAFB-10 Well & $\begin{array}{l}\text { No wastewater } \\
\text { generated }\end{array}$ & K100012080 & Cadmium & $0.017 \mathrm{mg} / \mathrm{L}$ & $0.010 \mathrm{mg} / \mathrm{L}$ \\
\hline SW-TA3 Well & $\begin{array}{l}\text { No wastewater } \\
\text { generated }\end{array}$ & SW30012089 & Chromium & $0.05 \mathrm{mg} / \mathrm{L}$ & $0.05 \mathrm{mg} / \mathrm{L}$ \\
\hline
\end{tabular}

Table K-2b.

Summary of Environmental Samples With Data Exceeding MCL ${ }^{a}$ SNL/NM Basewide Groundwater Surveillance, July 1993

\begin{tabular}{|c|c|c|c|c|c|}
\hline Well or Spring & $\begin{array}{l}\text { Wastewater } \\
\text { Container No. }\end{array}$ & Sample No. & Parameter & Value & $\mathrm{MCL}^{\mathrm{a}}$ \\
\hline Coyote Spring & $\begin{array}{l}\text { No wastewater } \\
\text { generated }\end{array}$ & CYS0012954 & Fluoride & $15.0 \mathrm{mg} / \mathrm{L}$ & $\begin{array}{l}\mathrm{MCLG}^{\mathrm{b}} \\
4 \mathrm{mg} / \mathrm{L}\end{array}$ \\
\hline Golf Course South Well & $\begin{array}{l}\text { GCSO72793-1 } \\
\text { GCSO72793-2 }\end{array}$ & GCS0012958 & Nitrate plus Nitrite & $20 \mathrm{mg} / \mathrm{L}$ & $10 \mathrm{mg} / \mathrm{L}$ \\
\hline MVMW-J Well & $\begin{array}{l}\text { No wastewater } \\
\text { generated }\end{array}$ & MVJO012964 & Nitrate plus Nitrite & $13 \mathrm{mg} / \mathrm{L}$ & $10 \mathrm{mg} / \mathrm{L}$ \\
\hline MVMW-K Well & $\begin{array}{l}\text { No wastewater } \\
\text { generated }\end{array}$ & MVK0012965 & Nitrate plus Nitrite & $20 \mathrm{mg} / \mathrm{L}$ & $10 \mathrm{mg} / \mathrm{L}$ \\
\hline MVMW-K Well (duplicate) & $\begin{array}{l}\text { No wastewater } \\
\text { generated }\end{array}$ & MVX0012966 & Nitrate plus Nitrite & $23 \mathrm{mg} / \mathrm{L}$ & $10 \mathrm{mg} / \mathrm{h}$ \\
\hline Greystone Manor Well & $\begin{array}{l}\text { No wastewater } \\
\text { generated }\end{array}$ & GSMO012959 & Barium & $1.1 \mathrm{mg} / \mathrm{L}$ & $1.0 \mathrm{mg} / \mathrm{L}$ \\
\hline CWL-BW2 & $\begin{array}{l}\text { No wastewater } \\
\text { generated }\end{array}$ & CB20012955 & Chromium & $0.39 \mathrm{mg} / \mathrm{L}$ & $0.05 \mathrm{mg} / \mathrm{L}$ \\
\hline MWL-8W1 & $\begin{array}{l}\text { No wastewater } \\
\text { generated }\end{array}$ & MB10012967 & Chromium & $0.06 \mathrm{mg} / \mathrm{L}$ & $0.05 \mathrm{mg} / \mathrm{L}$ \\
\hline South Fence Well \#2 & EQR072693-1 & SFRO 13256 & Chromium & $0.26 \mathrm{mg} / \mathrm{L}$ & $0.05 \mathrm{mg} / \mathrm{L}$ \\
\hline
\end{tabular}


Table K-2c.

Summary of Environmental Samples With Data Exceeding MCL $^{\mathrm{a}}$ SNL/NM Basewide Groundwater Surveillance, September 1993

\begin{tabular}{|c|c|c|c|c|c|}
\hline Well or Spring & $\begin{array}{l}\text { Wastewater } \\
\text { Container No. }\end{array}$ & Sample No. & Parameter & Value & $\mathrm{MCL}^{\mathrm{a}}$ \\
\hline Golf Course South Well & $\begin{array}{l}\text { GCS100693-1 } \\
\text { GCS100693-2 } \\
\text { GCS100693-3 }\end{array}$ & GCS013470 & Nitrate plus nitrite & $19 \mathrm{mg} / \mathrm{L}$ & $10 \mathrm{mg} / \mathrm{L}$ \\
\hline MVMW-J Well & MVMW-J,K091493-1 & MVJ013484 & Nitrate plus nitrite & $14 \mathrm{mg} / \mathrm{L}$ & $10 \mathrm{mg} / \mathrm{L}$ \\
\hline MVMW-K Well & MVMW-J,K091493-1 & MVK013485 & Nitrate plus nitrite & $11 \mathrm{mg} / \mathrm{L}$ & $10 \mathrm{mg} / \mathrm{L}$ \\
\hline MVMW-K Well & MVMW-J,K091493-1 & MVK013485 & Barium & $1.2 \mathrm{mg} / \mathrm{L}$ & $1.0 \mathrm{mg} / \mathrm{L}$ \\
\hline Greystone Manor Well & GSM090993-1 & GRYSO13487 & Barium & $1.3 \mathrm{mg} / \mathrm{L}$ & $1.0 \mathrm{mg} / \mathrm{L}$ \\
\hline Schoolhouse Well & SCH091393-1 & SCLH013486 & Barium & $1.1 \mathrm{mg} / \mathrm{L}$ & $1.0 \mathrm{mg} / \mathrm{L}$ \\
\hline KAFB-10 Well & $\begin{array}{l}\text { No wastewaster } \\
\text { generated }\end{array}$ & K10013480 & Cadmium & $0.87 \mathrm{mg} / \mathrm{L}$ & $0.010 \mathrm{mg} / \mathrm{L}$ \\
\hline KAFB-10 Well & $\begin{array}{l}\text { No wastewaster } \\
\text { generated }\end{array}$ & K10013480 & Lead & $0.92 \mathrm{mg} / \mathrm{L}$ & $0.05 \mathrm{mg} / \mathrm{L}$ \\
\hline South Fence Well \#2 & SF2092193-1 & SF2013482 & Chromium & $1.6 \mathrm{mg} / \mathrm{L}$ & $0.05 \mathrm{mg} / \mathrm{L}$ \\
\hline SW-TA3 Well & $\begin{array}{l}\text { No wastewaster } \\
\text { generated }\end{array}$ & SW3013483 & Chromium & $0.12 \mathrm{mg} / \mathrm{L}$ & $0.05 \mathrm{mg} / \mathrm{L}$ \\
\hline $\begin{array}{l}{ }^{\mathrm{a}} \mathrm{MCL}=\text { Maximum conta } \\
\text { Regulations (PDW) in }\end{array}$ & $\begin{array}{l}\text { Int levels established } \\
\text { FR } 141.11 \text { (b). }\end{array}$ & e U.S. Environ & ntal Protection Ag & EA) Primar & inking Water \\
\hline
\end{tabular}


Table K-2d.

Summary of Environmental Samples With Data Exceeding $\mathrm{MCL}^{\mathrm{a}}$

SNL/NM Basewide Groundwater Surveillance, December 1993

\begin{tabular}{|c|c|c|c|c|c|}
\hline Well or Spring & $\begin{array}{l}\text { Wastewater } \\
\text { Container No. }\end{array}$ & Sample No. & Parameter & Value & $\mathrm{MCL}^{\mathrm{a}}$ \\
\hline CWL-BW2 Well & $\begin{array}{c}\text { CWL-BW2112993-1 } \\
\text { CWL-BW2112993-2 } \\
\text { Decon } 112993\end{array}$ & CLB2014098 & Chromium & $0.26 \mathrm{mg} / \mathrm{L}$ & $0.1 \mathrm{mg} / \mathrm{L}$ \\
\hline $\begin{array}{l}\text { Golf Course South } \\
\text { Well }\end{array}$ & $\begin{array}{l}\text { GCSO014003-1 } \\
\text { GCSO014003-2 } \\
\text { GCS0014003-3 }\end{array}$ & GC\$0014003 & Nitrate + nitrite & $20 \mathrm{mg} / \mathrm{L}$ & $10.0 \mathrm{mg} / \mathrm{L}$ \\
\hline KAFB-10 Well & $\begin{array}{c}\text { No wastewater } \\
\text { generated }\end{array}$ & K100013940 & $\begin{array}{l}\text { Cadmium } \\
\text { Lead }\end{array}$ & $\begin{array}{c}0.029 \mathrm{mg} / \mathrm{L} \\
0.23 \mathrm{mg} / \mathrm{L}\end{array}$ & $\begin{array}{l}0.005 \mathrm{mg} / \mathrm{L} \\
0.05 \mathrm{mg} / \mathrm{L}\end{array}$ \\
\hline MVMW-J Well & $\begin{array}{c}\text { No wastewater } \\
\text { generated }\end{array}$ & MVJ0013938 & $\begin{array}{c}\text { Nitrate + nitrite } \\
\text { Barium }\end{array}$ & $\begin{array}{l}13 \mathrm{mg} / \mathrm{L} \\
2.2 \mathrm{mg} / \mathrm{L}\end{array}$ & $\begin{array}{l}10.0 \mathrm{mg} / \mathrm{L} \\
2.0 \mathrm{mg} / \mathrm{L}\end{array}$ \\
\hline MVMW-K Well & $\begin{array}{c}\text { No wastewater } \\
\text { generated }\end{array}$ & MVK0013942 & Barium & $2.1 \mathrm{mg} / \mathrm{L}$ & $2.0 \mathrm{mg} / \mathrm{L}$ \\
\hline MVMW-K Well & $\begin{array}{c}\text { No wastewater } \\
\text { generated }\end{array}$ & MVK0013942 & Nitrate + nitrite & $20 \mathrm{mg} / \mathrm{L}$ & $10.0 \mathrm{mg} / \mathrm{L}$ \\
\hline $\begin{array}{l}\text { MVMW-K Well } \\
\text { (duplicate) }\end{array}$ & $\begin{array}{c}\text { No wastewater } \\
\text { generated }\end{array}$ & MVK0013943 & Nitrate + nitrite & $17 \mathrm{mg} / \mathrm{L}$ & $10.0 \mathrm{mg} / \mathrm{L}$ \\
\hline
\end{tabular}


Table K-3a.

Summary of Field Water Quality Measurements SNL/NM Basewide Groundwater Surveillance, April 1993

\begin{tabular}{|c|c|c|c|c|c|}
\hline Site & Sampled by: & Measurements Taken: & $\mathrm{pH}^{\mathrm{a}}$ & Temp, ${ }^{\circ} \mathrm{C}$ & $s c^{b}$ \\
\hline \multirow[t]{3}{*}{ Burn Site Well } & Dedicated Pump & Before Sample & 6.57 & 17.0 & 868 \\
\hline & & & 6.77 & 16.8 & 837 \\
\hline & & After Sample & 6.89 & 16.7 & 890 \\
\hline \multirow[t]{4}{*}{ Coyote Spring } & Dipper & During Sample & 6.22 & 12.1 & 2960 \\
\hline & & & 5.91 & 12.1 & 3060 \\
\hline & & & 5.88 & 12.2 & 3020 \\
\hline & & & 5.92 & 12.1 & 3010 \\
\hline \multirow[t]{4}{*}{ CWL-BW2 } & Portable Pump & Before Sample & 7.15 & 21.6 & 1175 \\
\hline & & & 7.14 & 21.6 & 1177 \\
\hline & & & 7.13 & 21.8 & 1173 \\
\hline & & After Sample & 7.14 & 21.9 & 1172 \\
\hline \multirow[t]{4}{*}{ EOD Hill Well } & Portable Pump & Before Sample & 6.02 & 18.1 & 3700 \\
\hline & & & 6.04 & 18.1 & 3700 \\
\hline & & & 6.04 & 18.1 & 3600 \\
\hline & & After Sample & 6.05 & 18.0 & 3500 \\
\hline \multirow[t]{4}{*}{ Golf Course South Well } & Portable Pump & Before Sample & 7.55 & 20.2 & 691 \\
\hline & & & 7.57 & 20.2 & 691 \\
\hline & & & 7.58 & 20.3 & 691 \\
\hline & & After Sample & $\mathrm{NM}^{\mathrm{c}}$ & NM & NM \\
\hline \multirow[t]{4}{*}{ Greystone Manor Well } & Bailer & During Sample & 7.06 & 15.8 & 864 \\
\hline & & & 7.09 & 15.3 & 969 \\
\hline & & & 7.11 & 15.6 & 951 \\
\hline & & & 7.35 & 15.6 & 1054 \\
\hline \multirow[t]{3}{*}{ Hubbell Spring } & Dipper & During Sample & 6.70 & 12.0 & 881 \\
\hline & & & 6.48 & 12.1 & 903 \\
\hline & & & 6.69 & 12.9 & 894 \\
\hline \multirow[t]{2}{*}{ KAFB-10 Well } & Bailer & During Sample & 7.51 & 20.2 & 632 \\
\hline & & & 8.19 & 20.2 & 635 \\
\hline LF/DM-01 Well & Portable Pump & $N^{d}$ & NM & NM & NM \\
\hline \multirow[t]{4}{*}{ LF/DM-02 Well } & Portable Pump & Before Sample & 7.34 & 20.7 & 554 \\
\hline & & & 7.35 & 20.3 & 560 \\
\hline & & & 7.37 & 20.3 & 557 \\
\hline & & After Sample & 7.41 & 20.9 & 566 \\
\hline \multirow[t]{4}{*}{ MVMW-J Well } & Bailer & During Sample & 7.80 & 18.3 & 359 \\
\hline & & & 7.75 & 18.3 & 376 \\
\hline & & & 7.82 & 18.8 & 382 \\
\hline & & & $\mathrm{NM}^{\mathrm{C}}$ & NM & NM \\
\hline \multirow[t]{4}{*}{ MVMW-K Well } & Bailer & During Sample & 8.02 & 20.1 & 787 \\
\hline & & & 8.07 & 19.7 & 620 \\
\hline & & & 8.11 & 20.3 & 556 \\
\hline & & & 8.08 & 21.4 & 483 \\
\hline
\end{tabular}

Refer to footnotes at end of table. 
Table K-3a. (Concluded)

Summary of Field Water Quality Measurements SNL/NM Basewide Groundwater Surveillance, April 1993

\begin{tabular}{|c|c|c|c|c|c|}
\hline Site & Sampled by: & Measurements Taken: & $\mathrm{pH}^{\mathrm{a}}$ & Temp, ${ }^{\circ} \mathrm{C}$ & $\mathrm{Sc}^{\mathrm{b}}$ \\
\hline \multirow[t]{4}{*}{ MWL-BW1 } & Dedicated Pump & Before Sample & 7.70 & 20.7 & 670 \\
\hline & & & 7.58 & 20.8 & 672 \\
\hline & & & 7.56 & 20.7 & 672 \\
\hline & & After Sample & 7.55 & 20.5 & 675 \\
\hline \multirow[t]{4}{*}{ NW-TA3 Well } & Portable Pump & Before Sample & 7.63 & 21.0 & 548 \\
\hline & & & 7.64 & 20.9 & 547 \\
\hline & & & 7.63 & 20.9 & 547 \\
\hline & & After Sample & 7.59 & 21.1 & 547 \\
\hline \multirow[t]{4}{*}{ Schoolhouse Well } & Portable Pump & Before Sample & 6.88 & 16.8 & 1358 \\
\hline & & & 6.86 & 16.8 & 1366 \\
\hline & & & 6.87 & 16.8 & 1362 \\
\hline & & After Sample & 6.82 & 17.0 & 1366 \\
\hline \multirow[t]{2}{*}{ Sol se Mete Spring } & Dipper & During Sample & 6.18 & 8.9 & 702 \\
\hline & & & 5.48 & 9.0 & 730 \\
\hline \multirow[t]{4}{*}{ South Fence Well \#1 } & Portable Pump & Before Sample & 6.80 & 20.1 & 1347 \\
\hline & & & 6.80 & 20.2 & 1348 \\
\hline & & & 6.80 & 20.2 & 1348 \\
\hline & & After Sample & 6.81 & 20.2 & 1347 \\
\hline \multirow{4}{*}{ South Fence Well \#2 } & Portable Pump & Before Sample & 6.99 & 17.7 & 1199 \\
\hline & & & 7.00 & 17.8 & 1203 \\
\hline & & & 7.01 & 17.9 & 1207 \\
\hline & & After Sample & 7.08 & 18.2 & 1224 \\
\hline \multirow[t]{4}{*}{ SW-TA3 Well } & Bailer & During Sample $e^{e}$ & 8.01 & 20.6 & 626 \\
\hline & & & 8.61 & 19.4 & 631 \\
\hline & & & 8.76 & 21.4 & 635 \\
\hline & & & 8.82 & 20.0 & 629 \\
\hline \multirow[t]{4}{*}{ Tijeras East Well } & Portable Pump & Before Sample & 7.43 & 20.1 & 592 \\
\hline & & & 7.53 & 19.9 & 591 \\
\hline & & & 7.51 & 20.0 & 591 \\
\hline & & After Sample & 7.56 & 20.6 & 591 \\
\hline \multicolumn{6}{|c|}{ 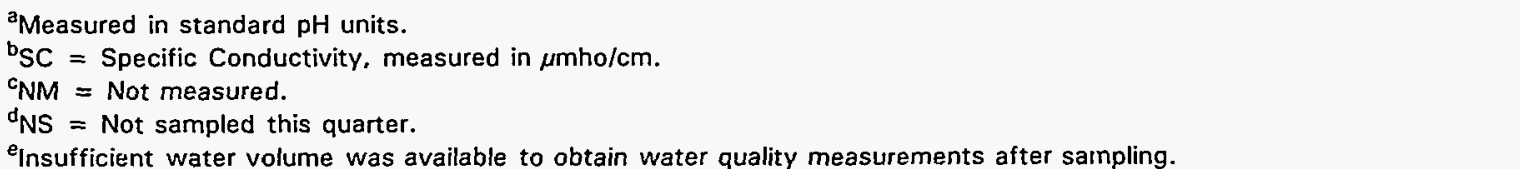 } \\
\hline
\end{tabular}


Table K-3b.

Summary of Field Water Quality Measurements SNL/NM Basewide Groundwater Surveillance, July 1993

\begin{tabular}{|c|c|c|c|c|c|}
\hline Site & Sampled by: & Measurements Taken: & $\mathrm{pH}^{\mathrm{a}}$ & Temp, ${ }^{\circ} \mathrm{C}$ & $\mathrm{SC}^{\mathrm{b}}$ \\
\hline Burn Site Well & Dedicated Pump & Before Sample & 5.84 & 18.4 & 1020 \\
\hline Coyote Spring & Dipper & During Sample & 5.72 & 17.9 & 3060 \\
\hline CWL-BW2 & Portable Pump & Before Sample & $\begin{array}{l}6.81 \\
6.76 \\
6.76 \\
6.80\end{array}$ & $\begin{array}{l}20.8 \\
20.8 \\
20.9 \\
21.3\end{array}$ & $\begin{array}{l}1025 \\
1026 \\
1026 \\
1027\end{array}$ \\
\hline EOD Hill Well & Portable Pump & $\begin{array}{l}\text { Before Sample } \\
\text { After Sample }\end{array}$ & $\begin{array}{l}6.17 \\
6.17 \\
6.17 \\
6.18\end{array}$ & $\begin{array}{l}19.6 \\
19.4 \\
19.3 \\
19.7\end{array}$ & $\begin{array}{l}4500 \\
4530 \\
4530 \\
4470\end{array}$ \\
\hline Golf Course South Well & Portable Pump & $\begin{array}{l}\text { Before Sample } \\
\text { After Sample }\end{array}$ & $\begin{array}{l}7.42 \\
7.42 \\
7.41 \\
7.43\end{array}$ & $\begin{array}{l}20.7 \\
20.7 \\
20.8 \\
21.3\end{array}$ & $\begin{array}{l}692 \\
692 \\
692 \\
691\end{array}$ \\
\hline Greystone Manor Well & Bailer & $\begin{array}{l}\text { Before Sample } \\
\text { After Sample }\end{array}$ & $\begin{array}{l}6.10 \\
6.47 \\
6.77 \\
5.97\end{array}$ & $\begin{array}{l}18.0 \\
17.3 \\
18.4 \\
17.3\end{array}$ & $\begin{array}{r}920 \\
1000 \\
990 \\
1020\end{array}$ \\
\hline Hubbell Spring & Dipper & During Sample & 6.20 & 19.8 & 940 \\
\hline KAFB-10 Well & Bailer & NS $^{c}$ & $N M^{d}$ & NM & NM \\
\hline LF/DM-01 Well & Portable Pump & $\begin{array}{l}\text { Before Sample } \\
\text { After Sample }\end{array}$ & $\begin{array}{l}7.92 \\
7.94 \\
7.94 \\
7.98\end{array}$ & $\begin{array}{l}20.2 \\
20.1 \\
20.1 \\
20.6\end{array}$ & $\begin{array}{l}286 \\
286 \\
287 \\
285\end{array}$ \\
\hline LF/DM-02 Well & Portable Pump & $\begin{array}{l}\text { Before Sample } \\
\text { After Sample }\end{array}$ & $\begin{array}{l}7.42 \\
7.46 \\
7.45 \\
7.32\end{array}$ & $\begin{array}{l}22.1 \\
22.1 \\
22.1 \\
23.7\end{array}$ & $\begin{array}{l}569 \\
570 \\
570 \\
555\end{array}$ \\
\hline MVMW-J Well & Bailer & $\begin{array}{l}\text { Before Sample } \\
\text { After Sample }\end{array}$ & $\begin{array}{l}6.67 \\
6.64 \\
6.62 \\
6.78\end{array}$ & $\begin{array}{l}22.0 \\
21.5 \\
21.6 \\
22.8\end{array}$ & $\begin{array}{l}300 \\
300 \\
300 \\
300\end{array}$ \\
\hline MVMW-K Well & Bailer & Before Sample & $\begin{array}{l}6.97 \\
7.03 \\
7.10 \\
7.03\end{array}$ & $\begin{array}{l}20.9 \\
20.8 \\
20.9 \\
21.2\end{array}$ & $\begin{array}{l}310 \\
310 \\
280 \\
300\end{array}$ \\
\hline MWL-BW1 & Dedicated Pump & $\begin{array}{l}\text { Before Sample } \\
\text { After Sample }\end{array}$ & $\begin{array}{l}7.51 \\
7.52 \\
7.51 \\
7.59\end{array}$ & $\begin{array}{l}20.2 \\
20.3 \\
20.3 \\
21.0\end{array}$ & $\begin{array}{l}670 \\
670 \\
675 \\
630\end{array}$ \\
\hline NW-TA3 Well & Portable Pump & Before Sample & $\begin{array}{l}7.31 \\
7.38 \\
7.40\end{array}$ & $\begin{array}{l}20.7 \\
20.7 \\
20.7\end{array}$ & $\begin{array}{l}545 \\
546 \\
545\end{array}$ \\
\hline Schoolhouse Well & Portable Pump & Before Sample & $\begin{array}{l}6.72 \\
6.72 \\
6.72\end{array}$ & $\begin{array}{l}19.5 \\
19.5 \\
19.6\end{array}$ & $\begin{array}{l}1347 \\
1347 \\
1347\end{array}$ \\
\hline Sol se Mete Spring & Dipper & NM & NM & NM & NM \\
\hline
\end{tabular}

Refer to footnotes at end of table. 
Table K-3b. (Concluded)

Summary of Field Water Quality Measurements SNL/NM Basewide Groundwater Surveillance, July 1993

\begin{tabular}{|c|c|c|c|c|c|}
\hline Site & Sampled by: & Measurements Taken: & $\mathrm{pH}^{\mathrm{a}}$ & Temp, ${ }^{\circ} \mathrm{C}$ & $S C^{b}$ \\
\hline \multirow[t]{4}{*}{ South Fence Well \#1 } & Portable Pump & Before Sample & 6.55 & 20.4 & 1339 \\
\hline & & & 6.54 & 20.5 & 1339 \\
\hline & & & 6.53 & 20.6 & 1340 \\
\hline & & After Sample & 6.60 & 22.2 & 1334 \\
\hline \multirow[t]{3}{*}{ South Fence Well \#2 } & Portable Pump & Before Sample & 7.49 & 19.9 & 1159 \\
\hline & & & 7.49 & 19.8 & 1160 \\
\hline & & & 7.49 & 20.0 & 1159 \\
\hline \multirow[t]{2}{*}{ SW-TA3 Well } & Bailer & During Sample ${ }^{\mathrm{e}}$ & 6.66 & 23.0 & 600 \\
\hline & & & 6.49 & 22.4 & 350 \\
\hline \multirow[t]{4}{*}{ Tijeras East Well } & Portable Pump & Before Sample & 7.25 & 21.3 & 591 \\
\hline & & & 7.25 & 21.4 & 587 \\
\hline & & & 7.26 & 21.2 & 591 \\
\hline & & After Sample & 7.26 & 23.8 & 592 \\
\hline \multicolumn{6}{|c|}{$\begin{array}{l}{ }^{a} \text { Measured in standard } \mathrm{pH} \text { units. } \\
{ }^{\mathrm{b}} \mathrm{SC}=\text { Specific conductivity, measured in } \mu \mathrm{mho} / \mathrm{cm} \text {. } \\
{ }^{\mathrm{c}} \mathrm{NS}=\text { Not sampled this quarter. } \\
{ }^{\mathrm{d}} \mathrm{NM}=\text { Not measured. } \\
{ }^{\mathrm{e}} \text { Insufficient water volume was available to obtain wa }\end{array}$} \\
\hline
\end{tabular}


Table K-3c.

Summary of Field Water Quality Measurements SNL/NM Basewide Groundwater Surveillance, September 1993

\begin{tabular}{|c|c|c|c|c|c|}
\hline Site & Sampled by: & Measurements Taken: & $\mathrm{pH}^{\mathrm{a}}$ & Temp, ${ }^{\circ} \mathrm{C}$ & $\mathrm{sc}^{\mathrm{b}}$ \\
\hline \multirow[t]{2}{*}{ Burn Site Well } & Dedicated Pump & Before Sample & 6.79 & 17.8 & 938 \\
\hline & & After Sample & 7.15 & 18.3 & 912 \\
\hline Coyote Spring & Dipper & Before Sample & 6.00 & 16.4 & 1000 \\
\hline \multirow[t]{4}{*}{ CWL-BW2 } & Portable Pump & Before Sample & 6.84 & 21.5 & 1226 \\
\hline & & & 6.83 & 21.8 & 1234 \\
\hline & & & 6.83 & 21.9 & 1238 \\
\hline & & After Sample & 6.82 & 25.3 & 1252 \\
\hline \multirow[t]{4}{*}{ EOD Hill Well } & Portable Pump & Before Sample & 6.10 & 18.9 & $N M^{c}$ \\
\hline & & & 6.05 & 18.8 & \\
\hline & & & 6.14 & 18.7 & \\
\hline & & After Sample & 6.15 & 19.0 & \\
\hline \multirow[t]{4}{*}{ Golf Course South Well } & Portable Pump & Before Sample & 7.43 & 20.1 & 694 \\
\hline & & & 7.43 & 20.4 & 695 \\
\hline & & & 7.39 & 20.4 & 693 \\
\hline & & After Sample & 7.37 & 20.9 & 693 \\
\hline \multirow[t]{4}{*}{ Greystone Manor Well } & Bailer & Before Sample & 7.28 & 17.3 & 996 \\
\hline & & & 7.04 & 17.4 & 982 \\
\hline & & & 7.09 & 17.5 & 987 \\
\hline & & After Sample & 7.22 & 17.6 & 1038 \\
\hline \multirow[t]{2}{*}{ Hubbell Spring } & Dipper & Before Sample & 7.46 & 19.4 & 882 \\
\hline & & After Sample & 7.71 & 18.2 & 887 \\
\hline \multirow[t]{2}{*}{ KAFB-10 Well } & Bailer & Before Sample & 7.65 & 21.2 & 726 \\
\hline & & After Sample & 7.90 & 21.9 & 686 \\
\hline \multirow[t]{4}{*}{ LF/DM-01 Well } & Portable Pump & Before Sample & 7.76 & 20.8 & 286 \\
\hline & & & 7.76 & 20.8 & 287 \\
\hline & & & 7.76 & 20.7 & 287 \\
\hline & & After Sample & 7.76 & 22.6 & 284 \\
\hline \multirow[t]{4}{*}{ LF/DM-02 Well } & Portable Pump & Before Sample & 7.43 & 22.0 & 565 \\
\hline & & & 7.43 & 22.2 & 564 \\
\hline & & & 7.43 & 22.2 & 564 \\
\hline & & After Sample & 7.43 & 22.2 & 560 \\
\hline \multirow[t]{4}{*}{ MVMW-J Well } & Bailer & Before Sample & 7.89 & 19.5 & 399 \\
\hline & & & 7.92 & 19.6 & 402 \\
\hline & & & 7.87 & 19.8 & 394 \\
\hline & & After Sample & 7.74 & 20.3 & 388 \\
\hline \multirow[t]{4}{*}{ MVMW-K Well } & Bailer & Before Sample & 7.80 & 18.6 & 479 \\
\hline & & & 7.79 & 18.8 & 417 \\
\hline & & & 7.79 & 19.1 & 383 \\
\hline & & After Sample & 7.88 & 19.2 & 382 \\
\hline MWL-BW1 & Dedicated Pump & $N S^{d}$ & NS & NS & NS \\
\hline
\end{tabular}

Refer to footnotes at end of table. 
Table K-3c. (Concluded)

Summary of Field Water Quality Measurements SNL/NM Basewide Groundwater Surveillance, September 1993

\begin{tabular}{|c|c|c|c|c|c|}
\hline Site & Sampled by: & Measurements Taken: & $\mathrm{pH}^{\mathrm{3}}$ & Temp, ${ }^{\circ} \mathrm{C}$ & $s c^{b}$ \\
\hline \multirow[t]{4}{*}{ NW-TA3 Well } & Portable Pump & Before Sample & 7.53 & 21.2 & 546 \\
\hline & & & 7.54 & 22.0 & 543 \\
\hline & & & 7.52 & 21.4 & 546 \\
\hline & & After Sample & 7.51 & 22.7 & 543 \\
\hline \multirow[t]{4}{*}{ Schoolhouse Well } & Bailer & Before Sample & 6.92 & 16.7 & 1247 \\
\hline & & & 6.98 & 16.8 & 1212 \\
\hline & & & 6.95 & 16.7 & 1234 \\
\hline & & After Sample & 6.94 & 17.1 & 1264 \\
\hline \multirow[t]{2}{*}{ Sol se Mete Spring } & Dipper & Before Sample & 6.93 & 13.9 & 715 \\
\hline & & After Sample & 7.34 & 13.9 & 688 \\
\hline \multirow[t]{4}{*}{ South Fence Well \#1 } & Portable Pump & Before Sample & 6.70 & 19.4 & 1328 \\
\hline & & & 6.70 & 19.5 & 1328 \\
\hline & & & 6.70 & 19.5 & 1328 \\
\hline & & After Sample & 6.68 & 20.1 & 1324 \\
\hline \multirow[t]{4}{*}{ South Fence Well \#2 } & Bailer & Before Sample & 7.15 & 18.7 & 1166 \\
\hline & & & 7.12 & 18.5 & 1183 \\
\hline & & & 7.10 & 18.8 & 1174 \\
\hline & & After Sample & 7.14 & 18.9 & 1219 \\
\hline SW-TA3 Well & Bailer & Before Sample ${ }^{e}$ & 7.73 & 21.8 & 604 \\
\hline \multirow[t]{4}{*}{ Tijeras East Well } & Portable Pump & Before Sample & 7.43 & 16.7 & 589 \\
\hline & & & 7.44 & 16.9 & 589 \\
\hline & & & 7.44 & 17.3 & 589 \\
\hline & & After Sample & 7.42 & 17.4 & 591 \\
\hline \multicolumn{6}{|c|}{ 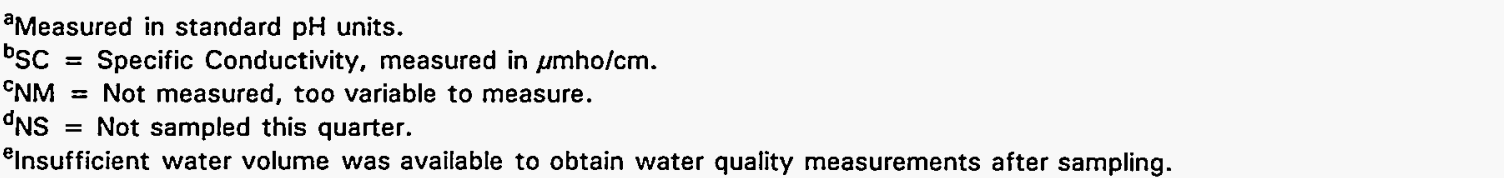 } \\
\hline
\end{tabular}


Table K-3d.

Summary of Field Water Quality Measurements SNL/NM Basewide Groundwater Surveillance, December 1993

\begin{tabular}{|c|c|c|c|c|c|c|}
\hline Site & Sampled by: & Measurements Taken: & $\mathrm{pH}^{\mathrm{a}}$ & Temp, ${ }^{\circ} \mathrm{C}$ & $s c^{b}$ & Turbidity $^{\varepsilon}$ \\
\hline \multirow[t]{3}{*}{ Burn Site Well } & Dedicated Pump & During sampling & 7.34 & 15.5 & 914 & 2.87 \\
\hline & & & 7.39 & 15.4 & 910 & 2.39 \\
\hline & & & 7.35 & 15.6 & 901 & 1.42 \\
\hline \multirow[t]{3}{*}{ Coyote Spring } & Dipper & During sampling & 6.14 & 16.5 & $3600^{d}$ & 8.13 \\
\hline & & & 6.17 & 16.4 & 3630 & 8.00 \\
\hline & & & 6.20 & 16.5 & 3560 & 9.49 \\
\hline \multirow[t]{4}{*}{ CWL-BW2 We!l } & Portable Pump & Before sampling & 6.94 & 19.9 & 1233 & 33.5 \\
\hline & & & 6.97 & 19.9 & 1236 & 29.3 \\
\hline & & & 6.89 & 19.9 & 1237 & 28.6 \\
\hline & & After sampling & 6.89 & 19.5 & 1242 & 23.0 \\
\hline \multirow[t]{4}{*}{ EOD Hill Well } & Portable Pump & Before sampling & 6.13 & 15.2 & $4590^{d}$ & 4.89 \\
\hline & & & 6.14 & 15.1 & 4590 & 4.92 \\
\hline & & & 6.14 & 15.1 & 4590 & 4.50 \\
\hline & & After sampling & 6.09 & 11.6 & 4270 & 5.57 \\
\hline Golf Course South & Portable Pump & Before sampling & 7.46 & 18.5 & 697 & 0.15 \\
\hline \multirow[t]{3}{*}{ Well } & & & 7.46 & 18.6 & 697 & 0.12 \\
\hline & & & 7.46 & 18.6 & 697 & 0.12 \\
\hline & & After sampling & 7.43 & 18.1 & 697 & 0.09 \\
\hline \multirow[t]{4}{*}{ Greystone Manor Well } & Bailer & Before sampling & 7.17 & 15.5 & 895 & 137 \\
\hline & & & 7.20 & 15.4 & 896 & 141 \\
\hline & & & 7.26 & 15.6 & 889 & 137 \\
\hline & & After sampling & 7.18 & 15.4 & 897 & 117 \\
\hline \multirow[t]{3}{*}{ Hubbell Spring } & Dipper & During sampling & 7.27 & 16.7 & 939 & 1.36 \\
\hline & & & 7.38 & 16.8 & 937 & 0.61 \\
\hline & & & 7.63 & 16.6 & 917 & 0.56 \\
\hline \multirow[t]{4}{*}{ KAFB-10 Well } & Bailer & During sampling & 7.59 & 17.0 & 697 & 25.2 \\
\hline & & & 7.66 & 17.3 & 673 & 19.8 \\
\hline & & & 7.61 & 17.4 & 663 & 30.2 \\
\hline & & & 7.58 & 17.4 & 659 & 26.4 \\
\hline \multirow[t]{4}{*}{ LF/DM-01 Well } & Portable Pump & Before sampling & 7.92 & 18.1 & 286 & 0.87 \\
\hline & & & 7.93 & 18.2 & 286 & 0.88 \\
\hline & & & 7.93 & 18.1 & 286 & 0.50 \\
\hline & & After sampling & 7.93 & 17.4 & 287 & 0.86 \\
\hline \multirow[t]{4}{*}{ LF/DM-02 Well } & Portable Pump & Before sampling & 7.31 & 18.8 & 569 & 4.30 \\
\hline & & & 7.30 & 18.9 & 572 & 4.29 \\
\hline & & & 7.31 & 18.9 & 573 & 4.30 \\
\hline & & After sampling & 7.32 & 18.1 & 571 & 4.31 \\
\hline \multirow[t]{4}{*}{ MVMW-J Well } & Bailer & Before sampling & 7.85 & $16.2^{e}$ & $429^{e}$ & 31.1 \\
\hline & & & 7.90 & 16.3 & 412 & 34.1 \\
\hline & & & 7.89 & 16.8 & 408 & 28.4 \\
\hline & & After sampling & 7.86 & 17.0 & 406 & 34.7 \\
\hline
\end{tabular}

Refer to footnotes at end of table. 
Table K-3d. (Concluded)

Summary of Field Water Quality Measurements SNL/NM Basewide Groundwater Surveillance, December 1993

\begin{tabular}{|c|c|c|c|c|c|c|}
\hline Site & Sampled by: & Measurements Taken: & $\mathrm{pH}^{\mathrm{a}}$ & Temp, ${ }^{\circ} \mathrm{C}$ & $\mathrm{sc}^{\mathrm{b}}$ & Turbidity \\
\hline MVMW-K Well & Bailer & $\begin{array}{l}\text { Before sampling } \\
\text { After sampling }\end{array}$ & $\begin{array}{l}7.76 \\
7.78 \\
7.80 \\
7.76\end{array}$ & $\begin{array}{l}17.8 \\
17.7 \\
17.8 \\
18.1\end{array}$ & $\begin{array}{l}640 \\
631 \\
642 \\
680\end{array}$ & $\begin{array}{l}49.6 \\
51.4 \\
63.2 \\
90.8\end{array}$ \\
\hline MWL-BW1 Well & Dedicated Pump & $\begin{array}{l}\text { Before sampling } \\
\text { After sampling }\end{array}$ & $\begin{array}{l}7.67 \\
7.63 \\
7.52 \\
7.46\end{array}$ & $\begin{array}{l}17.8 \\
18.8 \\
19.9 \\
19.6\end{array}$ & $\begin{array}{l}680 \\
677 \\
678 \\
678\end{array}$ & $\begin{array}{l}0.83 \\
0.57 \\
0.64 \\
0.57\end{array}$ \\
\hline NW-TA3 Well & Portable Pump & $\begin{array}{l}\text { Before sampling } \\
\text { After sampling }\end{array}$ & $\begin{array}{l}7.48 \\
7.48 \\
7.48 \\
7.46\end{array}$ & $\begin{array}{l}18.3 \\
18.1 \\
18.2 \\
19.6\end{array}$ & $\begin{array}{l}547 \\
550 \\
547 \\
546\end{array}$ & $\begin{array}{l}0.22 \\
0.28 \\
0.22 \\
0.49\end{array}$ \\
\hline Schoolhouse Well & Portable Pump & $\begin{array}{l}\text { Before sampling } \\
\text { After sampling }\end{array}$ & $\begin{array}{l}6.76 \\
6.76 \\
6.75 \\
6.76\end{array}$ & $\begin{array}{l}15.2 \\
15.1 \\
15.1 \\
12.1\end{array}$ & $\begin{array}{l}1359 \\
1360 \\
1360 \\
1372\end{array}$ & $\begin{array}{l}5.31 \\
6.62 \\
5.92 \\
6.16\end{array}$ \\
\hline Sol se Mete Spring & Dipper & $\begin{array}{l}\text { Before sampling } \\
\text { After sampling }\end{array}$ & $\begin{array}{l}7.48 \\
7.50 \\
7.50\end{array}$ & $\begin{array}{l}N M^{f} \\
N M \\
N M\end{array}$ & $\begin{array}{l}0.612 \\
0.611 \\
0.612\end{array}$ & $\begin{array}{l}3.18 \\
1.05 \\
1.17\end{array}$ \\
\hline South Fence Well \#1 & Portable Pump & $\begin{array}{l}\text { Before sampling } \\
\text { After sampling }\end{array}$ & $\begin{array}{l}6.70 \\
6.69 \\
6.70 \\
6.69\end{array}$ & $\begin{array}{l}18.1 \\
18.1 \\
18.2 \\
17.4\end{array}$ & $\begin{array}{l}1349 \\
1349 \\
1348 \\
1349\end{array}$ & $\begin{array}{l}0.24 \\
0.25 \\
0.18 \\
0.54\end{array}$ \\
\hline South Fence Well \#2 & Portable Pump & $\begin{array}{l}\text { Before sampling } \\
\text { After sampling }\end{array}$ & $\begin{array}{l}6.96 \\
6.95 \\
6.93 \\
6.91\end{array}$ & $\begin{array}{l}16.7 \\
16.8 \\
16.8 \\
15.8\end{array}$ & $\begin{array}{r}1195^{\circ} \\
1203 \\
1213 \\
1214\end{array}$ & $\begin{array}{l}2.12 \\
2.65 \\
3.58 \\
3.56\end{array}$ \\
\hline South Fence Well \#3T & Portable Pump & $\begin{array}{l}\text { Before sampling } \\
\text { After sampling }\end{array}$ & $\begin{array}{l}7.52 \\
7.53 \\
7.53 \\
7.45\end{array}$ & $\begin{array}{l}16.2^{\mathrm{e}} \\
15.1 \\
15.0 \\
13.9\end{array}$ & $\begin{array}{l}387 \\
390 \\
396 \\
396\end{array}$ & $\begin{array}{l}0.93 \\
0.43 \\
0.56 \\
0.76\end{array}$ \\
\hline South Fence Well \#3P & Portable Pump & $\begin{array}{l}\text { Before sampling } \\
\text { After sampling }\end{array}$ & $\begin{array}{l}6.94 \\
6.93 \\
6.93 \\
6.92\end{array}$ & $\begin{array}{l}16.0^{e} \\
15.9 \\
16.0 \\
11.7\end{array}$ & $\begin{array}{l}1275 \\
1272 \\
1271 \\
1281\end{array}$ & $\begin{array}{l}117 \\
71.7 \\
71.5 \\
57.1\end{array}$ \\
\hline SW-TA3 Well ${ }^{9}$ & Bailer & During sampling & $\begin{array}{l}7.84 \\
8.15\end{array}$ & $\begin{array}{l}17.8 \\
14.7\end{array}$ & $\begin{array}{l}573 \\
733\end{array}$ & $\begin{array}{l}3.53 \\
6.71\end{array}$ \\
\hline Tijeras East Well & Portable Pump & $\begin{array}{l}\text { Before sampling } \\
\text { After sampling }\end{array}$ & $\begin{array}{l}7.24 \\
7.23 \\
7.22 \\
7.24\end{array}$ & $\begin{array}{l}18.6 \\
18.5 \\
18.6 \\
18.0\end{array}$ & $\begin{array}{l}593 \\
593 \\
593 \\
584\end{array}$ & $\begin{array}{l}0.27 \\
0.48 \\
0.16 \\
0.41\end{array}$ \\
\hline \multicolumn{7}{|c|}{ 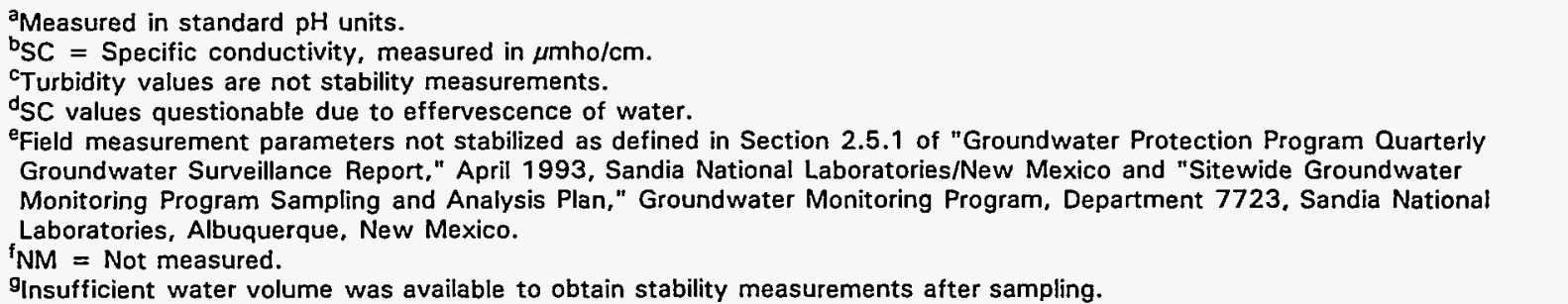 } \\
\hline
\end{tabular}


Table K-4a.

Summary of Analytical Results for Detected Organic Compounds SNL/NM Basewide Groundwater Surveillance, April 1993

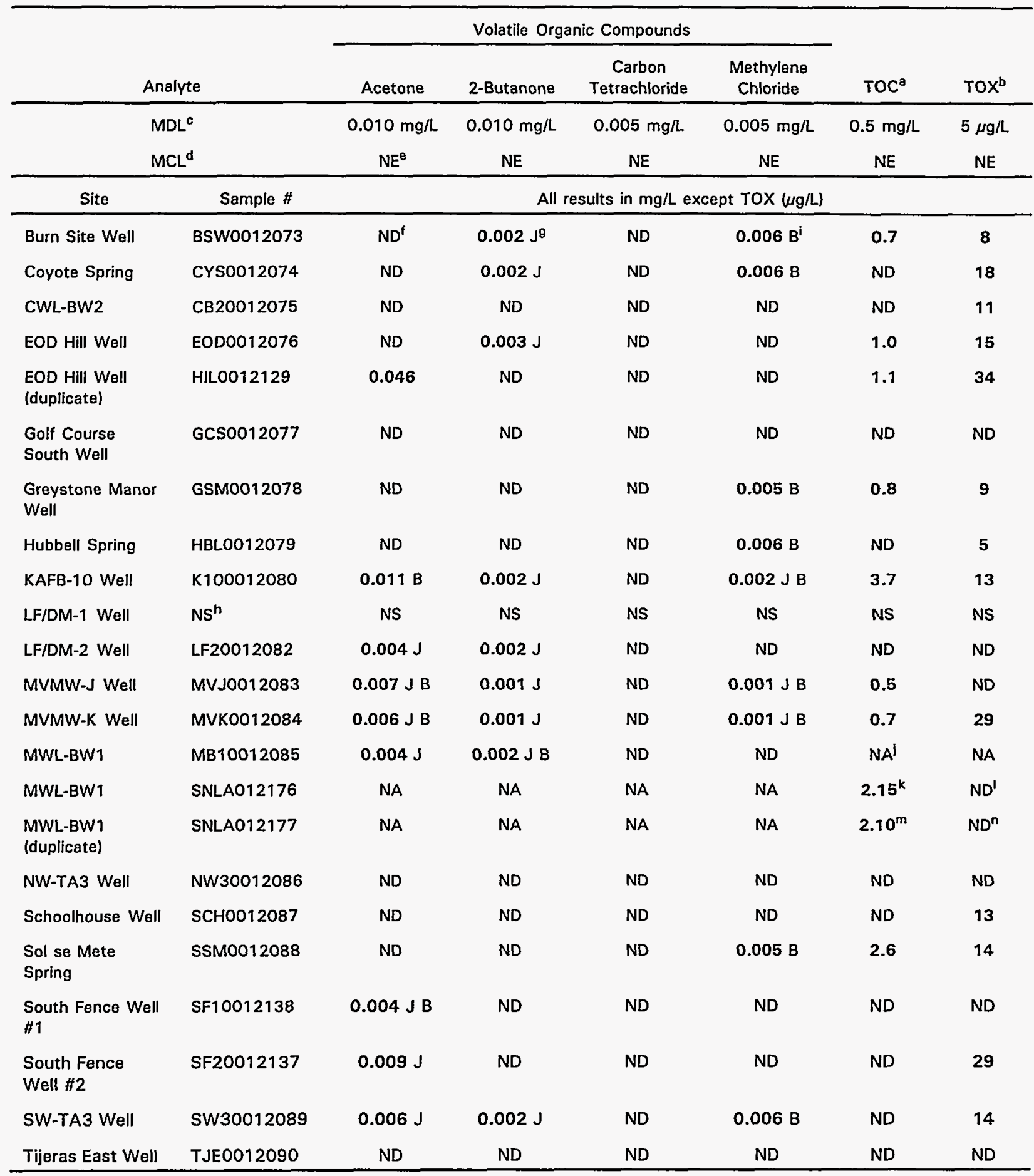

Refer to footnotes at end of table. 
Table K-4a. (Concluded)

\section{Summary of Analytical Results for Detected Organic Compounds SNL/NM Basewide Groundwater Surveillance, Apri1 1993}

\begin{tabular}{|c|c|c|c|c|c|c|c|}
\hline \multirow[b]{2}{*}{ Analyte } & & \multicolumn{4}{|c|}{ Volatile Organic Compounds } & \multirow[b]{2}{*}{ TOC $^{\mathrm{a}}$} & \multirow[b]{2}{*}{ TOX ${ }^{b}$} \\
\hline & & Acetone & 2-Butanone & $\begin{array}{c}\text { Carbon } \\
\text { Tetrachloride }\end{array}$ & $\begin{array}{l}\text { Methylene } \\
\text { Chloride }\end{array}$ & & \\
\hline \multicolumn{2}{|l|}{$\mathrm{MDL}^{c}$} & $0.010 \mathrm{mg} / \mathrm{L}$ & $0.010 \mathrm{mg} / \mathrm{L}$ & $0.005 \mathrm{mg} / \mathrm{L}$ & $0.005 \mathrm{mg} / \mathrm{L}$ & $0.5 \mathrm{mg} / \mathrm{L}$ & $5 \mu \mathrm{g} / \mathrm{L}$ \\
\hline \multicolumn{2}{|l|}{$\mathrm{MCL}^{\mathrm{d}}$} & $\mathrm{NE}^{\mathrm{e}}$ & NE & NE & NE & NE & NE \\
\hline Site & Sample \# & \multicolumn{6}{|c|}{ All results in $\mathrm{mg} / \mathrm{L}$ except TOX $(\mu \mathrm{g} / \mathrm{L})$} \\
\hline $\begin{array}{l}\text { Trip Blank - CYS, HBL, } \\
\text { SSM, BSW, GSM, SW3 }\end{array}$ & TB00012127 & ND & ND & ND & $0.006 \mathrm{~B}$ & NA & NA \\
\hline $\begin{array}{l}\text { Trip Blank - K10, MVJ, } \\
\text { MVK }\end{array}$ & TB00012128 & $0.014 \mathrm{~B}$ & ND & ND & $0.002 \mathrm{JB}$ & NA & NA \\
\hline Trip Blank - SCH, EB1 & TB00012132 & ND & ND & ND & ND & NA & NA \\
\hline Equipment Blank & EBO0012133 & ND & ND & ND & ND & ND & ND \\
\hline $\begin{array}{l}\text { Trip Blank - CB2, MB1, } \\
\text { GCS, NW3 }\end{array}$ & TB00012134 & ND & $0.002 \mathrm{JB}$ & ND & ND & NA & NA \\
\hline Trip Blank - EOD, HIL & TB00012135 & ND & ND & ND & ND & NA & NA \\
\hline \multicolumn{8}{|c|}{ 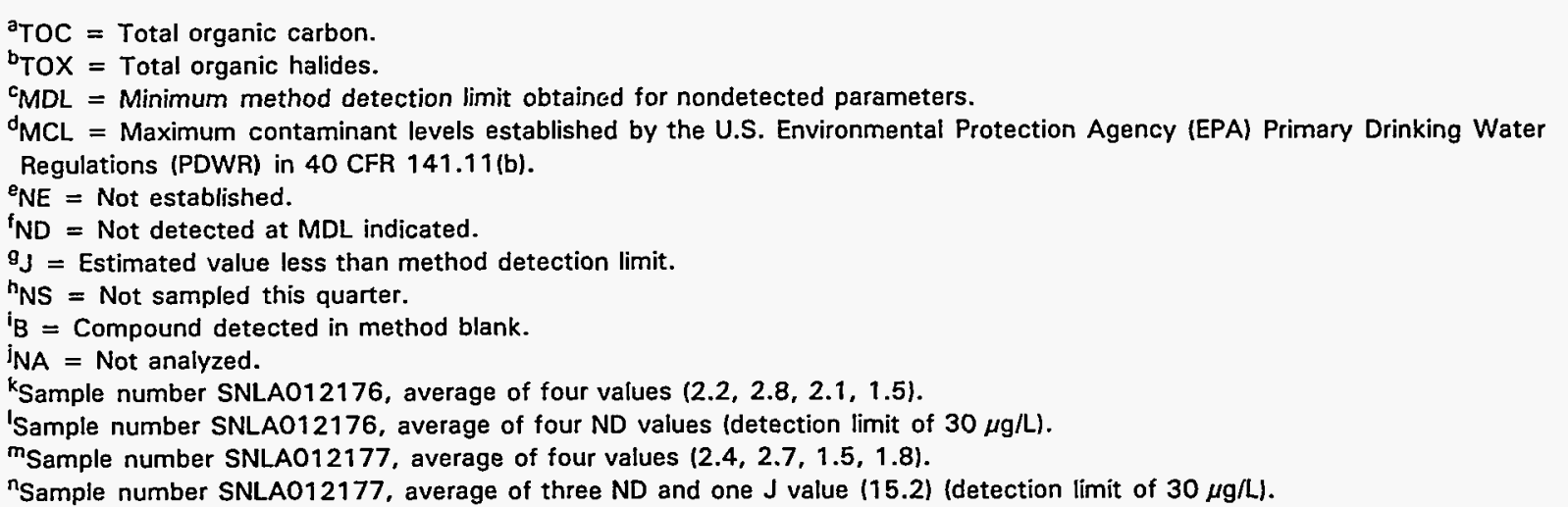 } \\
\hline
\end{tabular}


Table K-4b.

Summary of Analytical Results for Detected Organic Compounds SNL/NM Basewide Groundwater Surveillance, July 1993

\begin{tabular}{|c|c|c|c|c|c|c|c|}
\hline \multirow[b]{2}{*}{ Analyte } & & \multicolumn{4}{|c|}{ Volatile Organic Compounds } & \multirow[b]{2}{*}{ TOC $^{\mathrm{a}}$} & \multirow[b]{2}{*}{ TOX } \\
\hline & & Acetone & 2-Butanone & $\begin{array}{c}\text { Carbon } \\
\text { Tetrachloride }\end{array}$ & $\begin{array}{c}\text { Methylene } \\
\text { Chloride }\end{array}$ & & \\
\hline \multicolumn{2}{|l|}{$M^{\prime c} L^{c}$} & $0.010 \mathrm{mg} / \mathrm{L}$ & $0.010 \mathrm{mg} / \mathrm{L}$ & $0.005 \mathrm{mg} / \mathrm{L}$ & $0.005 \mathrm{mg} / \mathrm{L}$ & $0.5 \mathrm{mg} / \mathrm{L}$ & $5 \mu \mathrm{g} / \mathrm{l}$ \\
\hline \multicolumn{2}{|l|}{$M C L^{d}$} & $N E^{e}$ & NE & $\mathrm{NE}$ & $\mathrm{NE}$ & NE & $\mathrm{NE}$ \\
\hline Site & Sample \# & \multicolumn{6}{|c|}{ All results in mg/L except TOX (ug/L) } \\
\hline Burn Site Well & BSW0012953 & $N D^{f}$ & ND & ND & $0.001 J^{9} B^{h}$ & 1.0 & 14 \\
\hline Coyote Spring & CYSO012954 & ND & ND & ND & $0.001 \mathrm{~J} \mathrm{~B}$ & 1.2 & 52 \\
\hline CWL-BW2 Well & CB20012955 & ND & ND & ND & ND & ND & 21 \\
\hline EOD Hill Well & EOD0012956 & ND & ND & ND & ND & 0.6 & 32 \\
\hline EOD Hill Well (duplicate) & HIL0012957 & ND & ND & ND & ND & 2.0 & 39 \\
\hline Golf Course South Well & GCS0012958 & ND & ND & ND & ND & ND & 7 \\
\hline Greystone Manor Well & GSM0012959 & ND & ND & ND & ND & 0.8 & 28 \\
\hline Hubbell Spring & HBL0012960 & ND & ND & ND & $0.001 \mathrm{~J} \mathrm{~B}$ & ND & 6 \\
\hline KAFB-10 Well & NS $^{i}$ & NS & NS & NS & NS & NS & NS \\
\hline LF/DM-1 Well & LF10012962 & ND & ND & ND & ND & 4 & 8 \\
\hline LF/DM-2 Well & LF20012963 & ND & ND & ND & ND & ND & ND \\
\hline MVMW-J Well & MVJ0012964 & 0.012 & ND & ND & ND & 0.6 & 6 \\
\hline MVMW-K Well & MVK0012965 & $0.004 \mathrm{~J}$ & ND & ND & ND & 0.7 & 7 \\
\hline $\begin{array}{l}\text { MVMW-K Well } \\
\text { (duplicate) }\end{array}$ & MVX0012966 & ND & ND & ND & ND & ND & 23 \\
\hline MWL-BW1 & MB10012967 & ND & ND & ND & $0.004 \mathrm{~J} \mathrm{~B}$ & ND & 7 \\
\hline NW-TA3 Well & NW30012968 & ND & ND & ND & ND & 1.1 & 12 \\
\hline Schoolhouse Well & SCH0012969 & ND & ND & ND & ND & ND & 37 \\
\hline Sol se Mete Spring & SSM0012970 & ND & ND & ND & $0.002 \mathrm{~J} \mathrm{~B}$ & 2.8 & 20 \\
\hline South Fence Well \#1 & SFR10013500 & ND & ND & ND & ND & 4.4 & 61 \\
\hline South Fence Well \#2 & SFR013256 & ND & ND & ND & ND & ND & 22 \\
\hline SW-TA3 Well & SW30012971 & ND & ND & ND & ND & 0.6 & 32 \\
\hline Tijeras East Well & TJEO012972 & ND & ND & ND & ND & ND & 8 \\
\hline Equipment Blank \#1 & EB10012973 & ND & ND & ND & ND & ND & ND \\
\hline Equipment Blank \#2 & EB20012974 & ND & ND & ND & ND & ND & ND \\
\hline Trip Blank - CYS,BSW & TB10012976 & ND & ND & ND & $0.002 \mathrm{~J} \mathrm{~B}$ & $N A^{i}$ & NA \\
\hline Trip Blank - GSM,HBL & TB20012977 & ND & ND & ND & $0.002 \mathrm{JB}$ & NA & NA \\
\hline Trip Blank - MVJ,SW3 & TB30012978 & ND & ND & ND & $0.002 \mathrm{JB}$ & NA & NA \\
\hline Trip Blank - MVK,MVX & TB40012979 & ND & ND & ND & ND & NA & NA \\
\hline
\end{tabular}

Refer to footnote at end of table. 
Table K-4b. (Concluded)

Summary of Analytical Results for Detected Organic Compounds SNL/NM Basewide Groundwater Surveillance, July 1993

\begin{tabular}{|c|c|c|c|c|c|c|c|}
\hline \multirow{2}{*}{\multicolumn{2}{|c|}{ Analyte }} & \multicolumn{4}{|c|}{ Volatile Organic Compounds } & \multirow[b]{2}{*}{ TOC $^{\mathrm{a}}$} & \multirow[b]{2}{*}{$\operatorname{Tox}^{b}$} \\
\hline & & Acetone & 2-Butanone & $\begin{array}{c}\text { Carbon } \\
\text { Tetrachloride } \\
\end{array}$ & $\begin{array}{c}\text { Methylene } \\
\text { Chloride }\end{array}$ & & \\
\hline \multicolumn{2}{|c|}{$M L^{c}$} & $0.010 \mathrm{mg} / \mathrm{L}$ & $0.010 \mathrm{mg} / \mathrm{L}$ & $0.005 \mathrm{mg} / \mathrm{L}$ & $0.005 \mathrm{mg} / \mathrm{L}$ & & \\
\hline \multicolumn{2}{|c|}{$\mathrm{MCL}^{\mathbf{d}}$} & $\mathrm{NE}^{\mathrm{e}}$ & NE & NE & NE & & \\
\hline Site & Sample \# & \multicolumn{6}{|c|}{ All results in $\mathrm{mg} / \mathrm{L}$ except TOX $(\mu \mathrm{g} / \mathrm{L})$} \\
\hline Trip Blank - CB2,MB1 & TB50012980 & ND & ND & ND & $0.003 \mathrm{~J} \mathrm{~B}$ & NA & NA \\
\hline Trip Blank - SSM & TB60012981 & ND & ND & ND & $0.002 \mathrm{~J} \mathrm{~B}$ & NA & NA \\
\hline Trip Blank - EB1 & TB70012982 & ND & ND & ND & $0.002 \mathrm{~J} \mathrm{~B}$ & NA & NA \\
\hline Trip Blank - NW3 & TB80012983 & ND & ND & ND & ND & NA & NA \\
\hline Trip Blank - TJE & TB0012972 & ND & ND & ND & ND & NA & NA \\
\hline $\begin{array}{l}\text { Trip Blank - } \\
\text { SCH,SFR,EOD,HIL,EB2 }\end{array}$ & TBO00012976 & ND & ND & ND & $0.006 \mathrm{~B}$ & NA & NA \\
\hline Trip Blank - GCS,LF2 & TB0013257 & ND & ND & ND & ND & NA & NA \\
\hline Trip Blank - SFR1 & TB0013499 & ND & ND & ND & ND & NA & NA \\
\hline Trip Blank - LF1 & TB0013498 & ND & ND & ND & $0.002 \mathrm{~J}$ & NA & NA \\
\hline \multicolumn{8}{|c|}{ 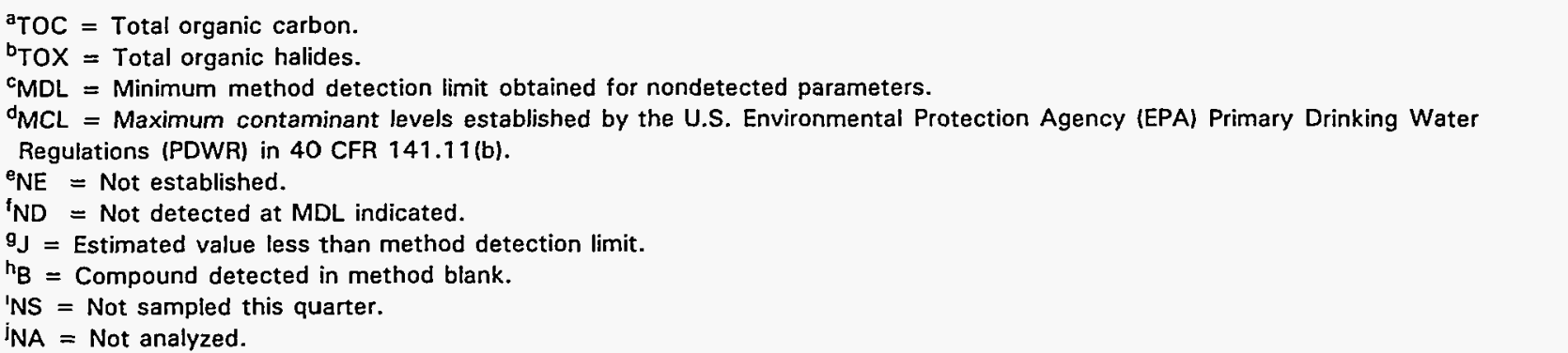 } \\
\hline
\end{tabular}


Table K-4c.

Summary of Analytical Results for Detected Organic Compounds

SNL/NM Basewide Groundwater Surveillance, September 1993

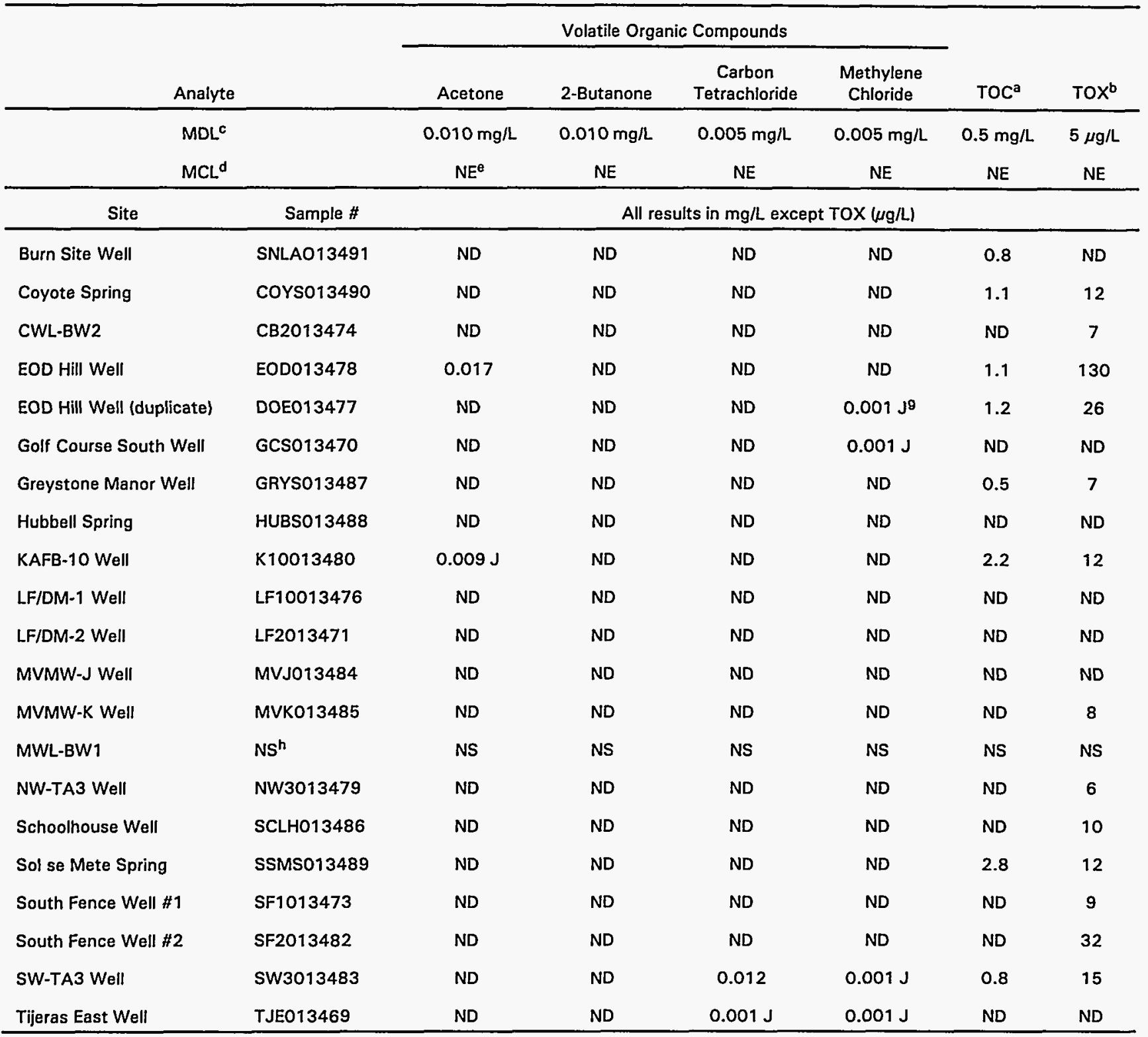

Refer to footnotes at end of table. 
Table K-4c. (Concluded)

Summary of Analytical Results for Detected Organic Compounds SNL/NM Basewide Groundwater Surveillance, September 1993

\begin{tabular}{|c|c|c|c|c|c|c|c|}
\hline & & \multicolumn{4}{|c|}{ Volatile Organic Compounds } & \multirow[b]{2}{*}{ TOC $^{\mathbf{a}}$} & \multirow[b]{2}{*}{ TOX } \\
\hline \multicolumn{2}{|l|}{ Analyte } & Acetone & 2-Butanone & $\begin{array}{c}\text { Carbon } \\
\text { Tetrachloride }\end{array}$ & $\begin{array}{l}\text { Methylene } \\
\text { Chloride }\end{array}$ & & \\
\hline \multicolumn{2}{|l|}{$\mathrm{MDL}^{\mathrm{c}}$} & $0.010 \mathrm{mg} / \mathrm{L}$ & $0.010 \mathrm{mg} / \mathrm{L}$ & $0.005 \mathrm{mg} / \mathrm{L}$ & $0.005 \mathrm{mg} / \mathrm{L}$ & $0.5 \mathrm{mg} / \mathrm{L}$ & $5 \mu \mathrm{g} / \mathrm{L}$ \\
\hline \multicolumn{2}{|l|}{$M C L^{d}$} & $N E^{e}$ & NE & NE & NE & NE & NE \\
\hline Site & Sample \# & \multicolumn{6}{|c|}{ All results in $\mathrm{mg} / \mathrm{L}$ except TOX $(\mu \mathrm{g} / \mathrm{L})$} \\
\hline Bailer Equipment Blank & EBBO13481 & ND & ND & 0.010 & $0.001 \mathrm{~J}$ & ND & ND \\
\hline Pump Equipment Blank \#1 & EBP013475 & ND & ND & ND & ND & ND & 14 \\
\hline Pump Equipment Blank \#2 & EB013472 & ND & ND & ND & ND & ND & ND \\
\hline Trip Blank - BSW & SNLA013491 & ND & ND & ND & ND & NA & NA \\
\hline Trip Blank - CB2 & CB2013474 & ND & ND & ND & $0.001 \mathrm{~J}$ & NA & NA \\
\hline Trip Blank - CYS, SSM & COYSO13490 & ND & ND & ND & ND & NA & NA \\
\hline Trip Blank - EOD \& Dup. & EOD013478 & ND & ND & ND & $0.001 \mathrm{~J}$ & NA & NA \\
\hline Trip Blank - GCS & GCS013470 & ND & ND & ND & $0.001 \mathrm{~J}$ & NA & NA \\
\hline Trip Blank - GSM & GRYS013487 & ND & ND & ND & $0.002 \mathrm{~J}$ & NA & NA \\
\hline Trip Blank - HBL & HUBSO13488 & ND & ND & ND & ND & NA & NA \\
\hline Trip Blank - K10 & K10013480 & ND & ND & ND & ND & NA & NA \\
\hline Trip Blank - LF1, EBP1 & EBP013475 & ND & ND & ND & ND & NA & NA \\
\hline Trip Blank - LF2 & LF2013471 & ND & ND & ND & ND & NA & NA \\
\hline Trip Blank - MVJ & MVJ013484 & ND & ND & ND & ND & NA & NA \\
\hline Trip Blank - MVK & MVK013485 & ND & ND & ND & ND & NA & NA \\
\hline Trip Blank - NW3 & NW3013479 & ND & ND & ND & $0.001 \mathrm{~J}$ & NA & NA \\
\hline Trip Blank - SF1 & SF1013473 & ND & ND & ND & ND & NA & NA \\
\hline Trip Blank - SF2, EBB & SF2013482 & ND & ND & 0.012 & $0.001 \mathrm{~J}$ & NA & NA \\
\hline Trip Blank - SCH & SCLHO13486 & 0.010 & ND & ND & ND & NA & NA \\
\hline Trip Blank - SW3 & SW3013483 & ND & ND & ND & $0.001 \mathrm{~J}$ & NA & NA \\
\hline Trip Blank - TJE & TJE013469 & ND & ND & ND & $0.002 \mathrm{~J}$ & NA & NA \\
\hline \multicolumn{8}{|c|}{$\begin{array}{l}{ }^{a} \mathrm{TOC}=\text { Total organic carbon. } \\
{ }^{\mathrm{O}} \mathrm{TOX}=\text { Total organic halides. } \\
{ }^{\mathrm{C}} \mathrm{MDL}=\text { Minimum method detection limit obtained for nondetected parameters. } \\
{ }^{\mathrm{d}} \mathrm{MCL}=\text { Maximum contaminant levels established by the U.S. Environmental Protection Agency (EPA) Primary Drinking Water Regulations } \\
\text { (PDWR) in } 40 \text { CFR } 141.11 \text { (b). } \\
\text { eNE = MCL not established. } \\
\mathrm{f}_{\mathrm{ND}}=\text { Not detected at MDL indicated. } \\
\mathrm{g}_{\mathrm{J}}=\text { Estimated value less than method detection limit. } \\
\mathrm{h}_{\mathrm{NS}}=\text { Not sampled this quarter. }\end{array}$} \\
\hline
\end{tabular}


Table K-4d.

Summary of Analytical Results for Detected Organic Compounds SNL/NM Basewide Groundwater Surveillance, December 1993

\begin{tabular}{|c|c|c|c|c|c|}
\hline \multirow{2}{*}{\multicolumn{2}{|c|}{ Analyte }} & \multicolumn{2}{|c|}{ Volatile Organic Compounds } & \multirow[b]{2}{*}{ TOC $^{\mathrm{a}}$} & \multirow[b]{2}{*}{$\operatorname{Tox}^{b}$} \\
\hline & & Acetone & $\begin{array}{l}\text { Methylene } \\
\text { chloride }\end{array}$ & & \\
\hline \multicolumn{2}{|c|}{$\mathrm{MDL}^{\mathrm{c}}$} & $0.010 \mathrm{mg} / \mathrm{L}$ & $0.005 \mathrm{mg} / \mathrm{L}$ & $0.5 \mathrm{mg} / \mathrm{L}$ & $5 \mu \mathrm{g} / \mathrm{L}$ \\
\hline \multicolumn{2}{|c|}{$\mathrm{MCL}^{\mathrm{d}}$} & $\mathrm{NE}^{\mathrm{e}}$ & $\mathrm{NE}$ & NE & NE \\
\hline Site & Sample \# & \multicolumn{4}{|c|}{ All results in $\mathrm{mg} / \mathrm{L}$ except TOX( $\mathrm{g} / \mathrm{L})$} \\
\hline Burn Site Well & BSW013939 & $0.005 \mathrm{Jg}^{\mathrm{g}}$ & $\mathrm{ND}^{f}$ & 0.8 & 23 \\
\hline Coyote Spring & CYS013842 & ND & ND & 1.2 & 140 \\
\hline CWL-BW2 Well & CLB2014098 & ND & ND & ND & 33 \\
\hline EOD Hill Well & EOD014323 & 0.012 & ND & 2.2 & 140 \\
\hline EOD Hill Well (duplicate) & HIL014324 & 0.013 & ND & 1.7 & 110 \\
\hline Golf Course South Well & GCS014003 & ND & $0.001 \mathrm{~J} \mathrm{~B}^{\mathrm{h}}$ & ND & 6 \\
\hline Greystone Manor Well & GSM013923 & ND & $0.001 \mathrm{~J}$ & 0.5 & 15 \\
\hline Hubbell Spring & HBL013798 & ND & ND & ND & 10 \\
\hline KAFB-10 Well & K10013940 & ND & ND & 2.4 & 42 \\
\hline LF/DM-1 Well & LF1014322 & ND & ND & ND & 7 \\
\hline MVMW-J Well & MVJ013938 & ND & ND & ND & 6 \\
\hline MVMW-K Well & MVK013942 & ND & ND & 0.6 & 38 \\
\hline MVMW-K Well (duplicate) & MVK013943 & ND & ND & 0.9 & 40 \\
\hline NW-TA3 Well & NWT3014100 & ND & ND & ND & 8 \\
\hline Schoolhouse Well & SCH014054 & ND & ND & ND & 18 \\
\hline Sol se Mete Spring & SSM013921 & $0.007 \mathrm{~J}$ & $0.001 \mathrm{~J} \mathrm{~B}$ & 3.3 & 12 \\
\hline South Fence Well \#1 & SFR1014105 & ND & ND & ND & 89 \\
\hline South Fence Well \#2 & SFR2014103 & ND & ND & ND & 14 \\
\hline South Fence Well \#3P & SFP014326 & ND & ND & ND & 16 \\
\hline South Fence Well \#3T & SFT014325 & ND & ND & ND & 12 \\
\hline SW-TA3 Well & SWT3014102 & ND & ND & 0.8 & 5 \\
\hline Tijeras East Well & TJE014106 & ND & $0.001 \mathrm{JB}$ & ND & ND \\
\hline
\end{tabular}

Refer to footnotes at end of table. 
Table K-4d. (Concluded)

Summary of Analytical Results for Detected Organic Compounds SNL/NM Basewide Groundwater Surveillance, December 1993

\begin{tabular}{|c|c|c|c|c|c|}
\hline \multirow[b]{2}{*}{ Analyte } & & \multicolumn{2}{|c|}{ Volatile Organic Compounds } & \multirow[b]{2}{*}{ TOC $^{a}$} & \multirow[b]{2}{*}{ TOX $^{b}$} \\
\hline & & Acetone & $\begin{array}{c}\text { Methylene } \\
\text { Chloride }\end{array}$ & & \\
\hline \multicolumn{2}{|l|}{$M D L^{C}$} & $0.010 \mathrm{mg} / \mathrm{L}$ & $0.005 \mathrm{mg} / \mathrm{L}$ & $0.5 \mathrm{mg} / \mathrm{L}$ & $5 \mu \mathrm{g} / \mathrm{L}$ \\
\hline \multicolumn{2}{|l|}{$M C L^{d}$} & NE & NE & NE & NE \\
\hline Site & Sample \# & \multicolumn{4}{|c|}{ All results in mg/L except TOX ( $\mu \mathrm{g} / \mathrm{L})$} \\
\hline Equipment Blank \#1 (pump) & EB1014099 & ND & ND & ND & ND \\
\hline Equipment Blank \#2 (pump) & EB2014104 & ND & ND & ND & ND \\
\hline Equipment Blank \#3 (pump) & EB3014321 & ND & $0.002 \mathrm{~J} \mathrm{~B}$ & ND & ND \\
\hline Equipment Blank \#4 (bailer) & K10013941 & ND & $0.001 \mathrm{~J}$ & ND & 44 \\
\hline Trip Blank-SSM & SSM013921 & $0.006 \mathrm{~J}$ & $0.002 \mathrm{~J}$ & ND & ND \\
\hline Trip Blank-K10 & K10013940 & $0.004 \mathrm{~J}$ & ND & ND & ND \\
\hline Trip Blank-SF1 & SFR1014105 & ND & $0.001 \mathrm{~J} \mathrm{~B}$ & ND & ND \\
\hline \multicolumn{6}{|c|}{ 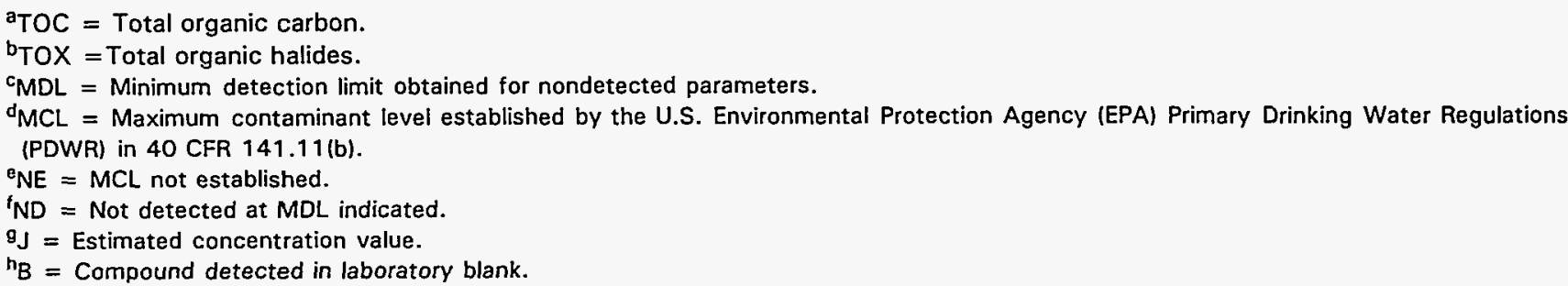 } \\
\hline
\end{tabular}


Table K-5a.

Summary of Results of Library Search for Volatile Organic Compounds SNL/NM Basewide Groundwater Surveillance, April 1993

\begin{tabular}{|c|c|c|c|}
\hline Site & Sample \# & Tentatively Identified Compound & $\begin{array}{c}\text { Estimated } \\
\text { Concentration, } \mathrm{mg} / \mathrm{L}\end{array}$ \\
\hline Burn Site Well & BSW0012073 & $\begin{array}{l}\text { Unknown alkyl benzene isomer } \\
\text { Unknown alkyl benzene isomer } \\
\text { Unknown alkyl benzene isomer }\end{array}$ & $\begin{array}{l}0.006 \\
0.012 \\
0.011\end{array}$ \\
\hline Coyote Spring & CYSO012074 & No compounds detected & $N A^{a}$ \\
\hline CWL-BW2 & CB20012075 & No compounds detected & NA \\
\hline EOD Hill Well & EOD0012076 & No compounds detected & NA \\
\hline EOD Hill Well (duplicate) & HIL.0012129 & No compounds detected & NA \\
\hline Golf Course South Well & GCS0012077 & Unknown compound detected & 0.008 \\
\hline Greystone Manor Well & GSM0012078 & Tetrahydro-Furan & 0.17 \\
\hline Hubbell Spring & HBLO0012079 & Trimethyl silanol & 0.005 \\
\hline KAFB-10 Well & K100012080 & No compounds detected & NA \\
\hline LF/DM-1 Well & $N S^{b}$ & NS & NS \\
\hline LF/DM-2 Well & LF20012082 & Library search not performed or reported & NA \\
\hline MVMW-J Well & MVJ0012083 & No compounds detected & NA \\
\hline MVMW-K Well & MVK0012084 & No compounds detected & NA \\
\hline MWL-BW1 & MB10012085 & No compounds detected & NA \\
\hline NW-TA3 Well & NW30012086 & Unknown compound detected & 0.006 \\
\hline Schoolhouse Well & SCH0012087 & Unknown compound detected & 0.032 \\
\hline Sol se Mete Spring & SSM0012088 & No compounds detected & NA \\
\hline South Fence Well \#1 & SF10012138 & Library search not performed or reported & NA \\
\hline South Fence Well \#2 & SF20012137 & Library search not performed or reported & NA \\
\hline SW-TA3 Well & SW30012089 & No compound detected & NA \\
\hline Tijeras East Well & TJE0012090 & Library search not performed or reported & NA \\
\hline $\begin{array}{l}\text { Trip Blank - CYS, HBL, SSM, } \\
\text { BSW, GSM, SW3 }\end{array}$ & TB00012127 & No compounds detected & NA \\
\hline Trip Blank - K10, MVJ, MVK & TB00012128 & No compounds detected & NA \\
\hline Trip Blank - SCH, EB1 & TB00012132 & No compounds detected & NA \\
\hline $\begin{array}{l}\text { Trip Blank - CB2, MB1, } \\
\text { GCS, NW3 }\end{array}$ & TB00012134 & No compounds detected & NA \\
\hline
\end{tabular}

Refer to footnotes at end of table. 
Table K-5a. (Concluded)

Summary of Results of Library Search for Volatile Organic Compounds SNL/NM Basewide Groundwater Surveillance, April 1993

\begin{tabular}{llll}
\hline \multicolumn{1}{c}{ Site } & Sample \# & Tentatively Identified Compound & $\begin{array}{c}\text { Estimated } \\
\text { Concentration, mg/L }\end{array}$ \\
\hline Trip Blank - EOD, HIL & TB00012135 & No compounds detected & NA \\
Trip Blank - TJE, LF2 & TB00012136 & Library search not performed or reported & NA \\
Trip Blank - EB2, SF1, SF2 & TB00012149 & Library search not performed or reported & NA \\
Equipment Blank & EB00012133 & Unknown compound detected & 0.020 \\
Equipment Blank & EB20012140 & Library search not performed or reported & NA \\
\hline $\begin{array}{l}\text { aNA }=\text { Not applicable. } \\
\text { bNS = Not sampled this quarter. }\end{array}$ & & & \\
\hline
\end{tabular}


Table K-5b.

Summary of Results of Library Search for Volatile Organic Compounds SNL/NM Basewide Groundwater Surveillance, July 1993

\begin{tabular}{|c|c|c|c|}
\hline Site & Sample \# & Tentatively Identified Compound & Estimated Concentration, $\mathrm{mg} / \mathrm{L}$ \\
\hline Burn Site Well & BSW0012953 & Trimethyl silanol & 0.010 \\
\hline Coyote Spring & CYS0012954 & Trimethyl silanol & 0.009 \\
\hline CWL-BW2 & CB20012955 & $\begin{array}{l}\text { Library search not performed or } \\
\text { reported }\end{array}$ & $N A^{a}$ \\
\hline EOD Hill Well & EOD0012956 & No compounds detected & NA \\
\hline EOD Hill Well (duplicate) & HIL0012957 & No compounds detected & NA \\
\hline Golf Course South Well & GCS0012958 & No compounds detected & NA \\
\hline Greystone Manor Well & GSM0012959 & $\begin{array}{l}\text { Library search not performed or } \\
\text { reported }\end{array}$ & NA \\
\hline Hubbell Spring & HBL0012960 & $\begin{array}{l}\text { Library search not performed or } \\
\text { reported }\end{array}$ & NA \\
\hline KAFB-10 Well & $N S^{b}$ & NA & NA \\
\hline LF/DM-1 Well & LF10012962 & No compounds detected & NA \\
\hline LF/DM-2 Well & LF20012963 & No compounds detected & NA \\
\hline MVMW-J Well & MVJ0012964 & $\begin{array}{l}\text { Trimethyl silanol } \\
\text { Unknown Compound Detected } \\
\text { Unknown Compound Detected }\end{array}$ & $\begin{array}{l}0.011 \\
0.009 \\
0.014\end{array}$ \\
\hline MVMW-K Well & MVK0012965 & $\begin{array}{l}\text { Trimethyl silanol } \\
\text { Unknown Alkane } C_{8}-C_{12} \\
\text { Unknown Alkane } C_{8}-C_{12}\end{array}$ & $\begin{array}{l}0.008 \\
0.006 \\
0.016\end{array}$ \\
\hline MVMW-K Well (duplicate) & MVX0012966 & $\begin{array}{l}\text { Trimethyl silanol } \\
\text { Unknown Alkane } C_{8}-C_{12}\end{array}$ & $\begin{array}{l}0.018 \\
0.008\end{array}$ \\
\hline MWL-BW1 & MB10012967 & $\begin{array}{l}\text { Library search not performed or } \\
\text { reported }\end{array}$ & NA \\
\hline NW-TA3 Well & NW30012968 & No compounds detected & NA \\
\hline Schoolhouse Well & SCH0012969 & No compounds detected & NA \\
\hline Sol se Mete Spring & SSM0012970 & $\begin{array}{l}\text { Library search not performed or } \\
\text { reported }\end{array}$ & NA \\
\hline South Fence Well \#1 & SFR10013500 & No compounds detected & NA \\
\hline South Fence Well \#2 & SFR013256 & No compounds detected & NA \\
\hline SW-TA3 Well & SW30012971 & Unknown Compound Detected & 0.006 \\
\hline Tijeras East Well & TJE0012972 & No compounds detected & NA \\
\hline
\end{tabular}

Refer to footnotes at end of table. 
Table K-5b. (Concluded)

Summary of Results of Library Search for Volatile Organic Compounds SNL/NM Basewide Groundwater Surveillance, July 1993

\begin{tabular}{|c|c|c|c|}
\hline Site & Sample \# & Tentatively Identified Compound & Estimated Concentration, $\mathrm{mg} / \mathrm{L}$ \\
\hline Equipment Blank \#1 & EB10012973 & No compounds detected & NA \\
\hline Equipment Blank \#2 & EB20012974 & $\begin{array}{l}\text { Library search not performed or } \\
\text { reported }\end{array}$ & NA \\
\hline Trip Blank - CYS,BSW & TB10012976 & $\begin{array}{l}\text { Unknown Compound Detected } \\
\text { Unknown Compound Detected }\end{array}$ & $\begin{array}{l}0.013 \\
0.014\end{array}$ \\
\hline Trip Blank - GSM,HBL & TB20012977 & $\begin{array}{l}\text { Library search not performed or } \\
\text { reported }\end{array}$ & NA \\
\hline Trip Blank - MVJ,SW3 & TB30012978 & No compounds detected & NA \\
\hline Trip Blank - MVK,MVX & TB40012979 & Unknown Compound Detected & 0.006 \\
\hline Trip Blank - CB2,MB1 & TB50012980 & $\begin{array}{l}\text { Library search not performed or } \\
\text { reported }\end{array}$ & NA \\
\hline Trip Blank - SSM & TB60012981 & $\begin{array}{l}\text { Library search not performed or } \\
\text { reported }\end{array}$ & NA \\
\hline Trip Blank - EB1 & TB70012982 & No compounds detected & NA \\
\hline Trip Blank - NW3 & TB80012983 & $\begin{array}{l}\text { Library search not performed or } \\
\text { reported }\end{array}$ & NA \\
\hline Trip Blank - TJE & TB0012972 & $\begin{array}{l}\text { Library search not performed or } \\
\text { reported }\end{array}$ & NA \\
\hline $\begin{array}{l}\text { Trip Blank - } \\
\text { SCH,SFR,EOD,HIL,EB2 }\end{array}$ & TB00012976 & $\begin{array}{l}\text { Library search not performed or } \\
\text { reported }\end{array}$ & NA \\
\hline Trip Blank - GCS,LF2 & TB0013257 & $\begin{array}{l}\text { Library search not performed or } \\
\text { reported }\end{array}$ & NA \\
\hline Trip Blank - SFR1 & TB0013499 & $\begin{array}{l}\text { Library search not performed or } \\
\text { reported }\end{array}$ & NA \\
\hline Trip Blank - LF1 & TB0013498 & $\begin{array}{l}\text { Library search not performed or } \\
\text { reported }\end{array}$ & NA \\
\hline
\end{tabular}


Table K-5c.

Summary of Results of Library Search for Volatile Organic Compounds SNL/NM Basewide Groundwater Surveillance, September 1993

\begin{tabular}{|c|c|c|c|}
\hline Site & Sample \# & Tentatively Identified Compound & Estimated Concentration, $\mathrm{mg} / \mathrm{L}$ \\
\hline Burn Site Well & SNLA013491 & No compounds detected & $N^{a}$ \\
\hline Coyote Spring & COYS013490 & No compounds detected & NA \\
\hline CWL-BW2 & CB2013474 & No compounds detected & NA \\
\hline EOD Hill Well & EOD013478 & No compounds detected & NA \\
\hline EOD Hill Well (duplicate) & DOE013477 & No compounds detected & NA \\
\hline Golf Course South Well & GCS013470 & No compounds detected & NA \\
\hline Greystone Manor Well & GRYSO13487 & No compounds detected & NA \\
\hline Hubbell Spring & HUBS013488 & No compounds detected & NA \\
\hline KAFB-10 Well & $K 10013480$ & No compounds detected & NA \\
\hline LF/DM-1 Well & LF10013476 & No compounds detected & NA \\
\hline LF/DM-2 Well & LF2013471 & No compounds detected & NA \\
\hline MVMW-J Well & MVJ013484 & No compounds detected & NA \\
\hline MVMW-K Well & MVK013485 & No compounds detected & NA \\
\hline MWL-BWI & $N^{b}$ & NA & NA \\
\hline NW-TA3 Well & NW3013479 & No compounds detected & NA \\
\hline Schoolhouse Well & SCLH013486 & No compounds detected & NA \\
\hline Sol se Mete Spring & SSMS013489 & Library search not performed or reported & NA \\
\hline South Fence Well \#1 & SF1013473 & No compounds detected & NA \\
\hline South Fence Well \#2 & SF2013482 & No compounds detected & NA \\
\hline SW-TA3 Well & SW3013483 & No compounds detected & NA \\
\hline Tijeras East Well & TJE013469 & No compounds detected & NA \\
\hline
\end{tabular}

Refer to footnotes at end of table. 
Table K-5c. (Concluded)

Summary of Results of Library Search for Volatile Organic Compounds SNL/NM Basewide Groundwater Surveillance, September 1993

\begin{tabular}{|c|c|c|c|}
\hline Site & Sample \# & Tentatively Identified Compound & Estimated Concentration, $\mathrm{mg} / \mathrm{L}$ \\
\hline Bailer Equipment Blank & EBB013481 & No compounds detected & NA \\
\hline Pump Equipment Blank \#1 & EBP013475 & No compounds detected & NA \\
\hline Pump Equipment Blank \#2 & EB013472 & No compounds detected & NA \\
\hline Trip Blank - BSW & SNLA013491 & Library search not performed or reported & NA \\
\hline Trip Blank - CB2 & CB2013474 & Library search not performed or reported & NA \\
\hline Trip Blank - CYS, SSM & COYS013490 & Library search not performed or reported & NA \\
\hline Trip Blank - EOD \& Dup. & EOD013478 & Library search not performed or reported & NA \\
\hline Trip Blank - GCS & GCS013470 & Library search not performed or reported & NA \\
\hline Trip Blank - GSM & GRYS013487 & Library search not performed or reported & NA \\
\hline Trip Blank - HBL & HUBS013488 & Library search not performed or reported & NA \\
\hline Trip Blank - K10 & K10013480 & Library search not performed or reported & NA \\
\hline Trip Blank - LF1, EBP1 & EBP013475 & Library search not performed or reported & NA \\
\hline Trip Blank - LF2 & LF2013471 & Library search not performed or reported & NA \\
\hline Trip Blank - MVJ & MVJ013484 & $\begin{array}{l}\text { Unknown compound detected } \\
\text { Unknown compound detected }\end{array}$ & $\begin{array}{l}0.008 \\
0.007\end{array}$ \\
\hline Trip Blank - MVK & MVK013485 & Library search not performed or reported & NA \\
\hline Trip Blank - NW3 & NW3013479 & Library search not performed or reported & NA \\
\hline Trip Blank - SCH & SCLHO13486 & Library search not performed or reported & NA \\
\hline Trip Blank - SF1 & SF1013473 & Library search not performed or reported & NA \\
\hline Trip Blank - SF2, EBB & SF2013482 & Library search not performed or reported & NA \\
\hline Trip Blank - SW3 & SW3013483 & Library search not performed or reported & NA \\
\hline Trip Blank - TJE & TJE013469 & Library search not performed or reported & NA \\
\hline $\begin{array}{l}{ }^{a} \text { NA }=\text { Not applicable. } \\
{ }^{\mathrm{b}} \mathrm{NS}=\text { Not sampled this }\end{array}$ & & & \\
\hline
\end{tabular}


Table K-5d.

Summary of Results of Library Search for Volatile Organic Compounds, SNL/NM Basewide Groundwater Surveillance, December 1993

\begin{tabular}{|c|c|c|c|}
\hline Site & Sample \# & Tentatively Identified Compound & $\begin{array}{l}\text { Estimated } \\
\text { Concentration, } \mathrm{mg} / \mathrm{L}\end{array}$ \\
\hline Burn Site Well & BSW013939 & Trimethyl Silanol & 0.006 \\
\hline Coyote Spring & CYS013842 & No compound detected & $N A^{a}$ \\
\hline CWL-BW2 Well & CLB2014098 & No compound detected & NA \\
\hline EOD Hill Well & EOD014323 & No compound detected & NA \\
\hline EOD Hill Well (duplicate) & HIL014324 & No compound detected & NA \\
\hline Golf Course South Well & GCS014003 & Chlorodifluoromethane & 0.017 \\
\hline Greystone Manor Well & GSM013923 & Tetrahydrofuran & 0.009 \\
\hline Hubbell Spring & HBL013798 & No compound detected & NA \\
\hline KAFB-10 Well & K10013940 & No compound detected & NA \\
\hline LF/DM1 Well & LF1014322 & No compound detected & NA \\
\hline LF/DM2 Well & LF2014320 & No compound detected & NA \\
\hline MVMW-J Well & MVJ013938 & No compound detected & NA \\
\hline MVMW-K Well & MVK013942 & No compound detected & NA \\
\hline MVMW-K Well (duplicate) & MVK013943 & No compound detected & NA \\
\hline MWL-BW1 Well & MWBW1014101 & No compound detected & NA \\
\hline NW-TA3 Well & NWT3014100 & No compound detected & NA \\
\hline Schoolhouse Well & $\mathrm{SCH} 014054$ & Chlorodifluoromethane & 0.016 \\
\hline Sol Se Mete Spring & SSM013921 & No compound detected & NA \\
\hline South Fence Well \#1 & SFR1014105 & Chlorodifluoromethane & 0.014 \\
\hline South Fence Well \#2 & SFR2014103 & No compound detected & NA \\
\hline South Fence Well \#3P & SFP014326 & No compound detected & NA \\
\hline South Fence Well \#3T & SFT014325 & No compound detected & NA \\
\hline SW-TA3 Well & SWT3014102 & No compound detected & NA \\
\hline Tijeras East Well & TJE014106 & Chlorodifluoromethane & 0.016 \\
\hline Equipment Blank \#1 (pump) & EB1014099 & No compound detected & NA \\
\hline Equipment Blank \#2 (pump) & EB2014104 & No compound detected & NA \\
\hline Equipment Blank \#3 (pump) & EB3014321 & Chlorodifluoromethane & 0.015 \\
\hline Equipment Blank \#4 (bailer) & K10013941 & $\begin{array}{l}\text { Chlorodifluoromethane } \\
\text { Unknown Compound }\end{array}$ & $\begin{array}{l}0.024 \\
0.012\end{array}$ \\
\hline
\end{tabular}


Table K-6a.

Summary of Analytical Results for Inorganic Compounds and Phenolics SNL/NM Basewide Groundwater Surveillance, April 1993

\begin{tabular}{|c|c|c|c|c|c|c|c|c|c|}
\hline \multicolumn{2}{|c|}{ Analyte } & Alkalinity & Bramide & Chloride & Fluoride & NPN & $\mathrm{pH}$ & Phenolics & Sulfate \\
\hline \multicolumn{2}{|c|}{$M L^{a}$, units } & $10 \mathrm{mg} / \mathrm{L}$ & $0.10 \mathrm{mg} / \mathrm{L}$ & $2.0 \mathrm{mg} / \mathrm{L}$ & $0.1 \mathrm{mg} / \mathrm{L}$ & $0.05 \mathrm{mg} / \mathrm{L}$ & S.U. & $0.05 \mathrm{mg} / \mathrm{L}$ & $50 \mathrm{mg} / \mathrm{L}$ \\
\hline \multicolumn{2}{|c|}{$\mathrm{MCL}^{\mathrm{C}}$} & $N E^{d}$ & NE & NE & $4 \mathrm{mg} / \mathrm{L}^{\mathrm{e}}$ & $10 \mathrm{mg} / \mathrm{L}$ & NE & NE & NE \\
\hline Site & Sample \# & \multicolumn{8}{|c|}{ All results in $\mathrm{mg} / \mathrm{L}$, except $\mathrm{pH}$ (standard $\mathrm{pH}$ units) } \\
\hline Burn Site Well & BSW0012073 & $230 / 256^{\wedge}$ & 0.71 & 52 & 1.0 & 1.0 & 7.2 & ND & 130 \\
\hline CWL-BW2 Well & CB20012075 & $160 / 363^{\wedge}$ & 0.20 & 17 & 0.5 & 6.4 & 7.8 & ND & 60 \\
\hline EOD Hill Well & EOD0012076 & $2000 / 1925^{\wedge}$ & 1.6 & 410 & 1.6 & ND & 6.5 & ND & 110 \\
\hline $\begin{array}{l}\text { EOD Hill Well } \\
\text { (duplicate) }\end{array}$ & HIL0012129 & $2000 / 1925^{\wedge}$ & 1.6 & 400 & 1.7 & ND & 6.5 & ND & 110 \\
\hline $\begin{array}{l}\text { Golf Course South } \\
\text { Well }\end{array}$ & GCS0012077 & $130 / 132^{n}$ & 0.61 & 44 & 0.6 & $\cdot 21$ & 7.7 & ND & 59 \\
\hline Hubbell Spring & HBL0012079 & $190 / 192^{n}$ & 0.36 & 35 & 0.9 & 0.75 & 7.8 & ND & 220 \\
\hline KAFB-10 Well & K100012080 & $120 /$ NA $^{h}$ & 0.31 & 81 & 1.2 & 0.40 & 8.1 & ND & 44 \\
\hline LF/DM-1 Well & NS ${ }^{9}$ & NS & NS & NS & NS & NS & NS & NS & NS \\
\hline LF/DM-2 Well & LF20012082 & $160 / 157^{\wedge}$ & 0.21 & 15 & 0.3 & 4.0 & 7.7 & ND & 74 \\
\hline MVMW-J Well & MVJ0012083 & $100 / 145^{\wedge}$ & 0.12 & 9.1 & 0.4 & 0.56 & 7.3 & ND & 25 \\
\hline MVMW-K Well & MVK0012084 & $110 / 169^{\wedge}$ & 0.16 & 12 & 0.4 & 1.4 & 7.4 & ND & 29 \\
\hline MWL-BW1 & MB10012085 & $230 / 256^{\wedge}$ & 0.23 & 29 & 0.9 & 5.7 & 7.6 & NA & 46 \\
\hline MWL-BW1 & SNLAO12176 & $N A^{h}$ & NA & 27.6 & NA & $5.4^{i}$ & NA & ND & 46.7 \\
\hline $\begin{array}{l}\text { MWL-BW1 } \\
\text { (duplicate) }\end{array}$ & SNLA012177 & NA & NA & 27.9 & NA & $5.5^{\prime}$ & NA & ND & 46.7 \\
\hline Sol se Mete Spring & SSM0012088 & $\begin{array}{c}240 / 256- \\
288^{\wedge}\end{array}$ & 0.40 & 25 & 0.4 & 1.2 & 7.9 & ND & 68 \\
\hline $\begin{array}{l}\text { South Fence Well } \\
\# 1\end{array}$ & SF10012138 & $420 / 407^{\wedge}$ & 0.67 & 130 & 1.7 & 0.95 & 6.9 & ND & 67 \\
\hline $\begin{array}{l}\text { South Fence Well } \\
\# 2\end{array}$ & SF20012137 & $330 / 316^{\wedge}$ & 0.68 & 130 & 1.8 & 0.96 & 7.0 & ND & 71 \\
\hline SW-TA3 Well & SW30012089 & $210 / 207^{\wedge}$ & 0.23 & 32 & 1.4 & 3.7 & 8.2 & ND & 46 \\
\hline Tijeras East Well & TJEOO12090 & $180 / 183^{\wedge}$ & 0.17 & 11 & 0.3 & 2.8 & 7.7 & ND & 76 \\
\hline \multicolumn{10}{|c|}{ 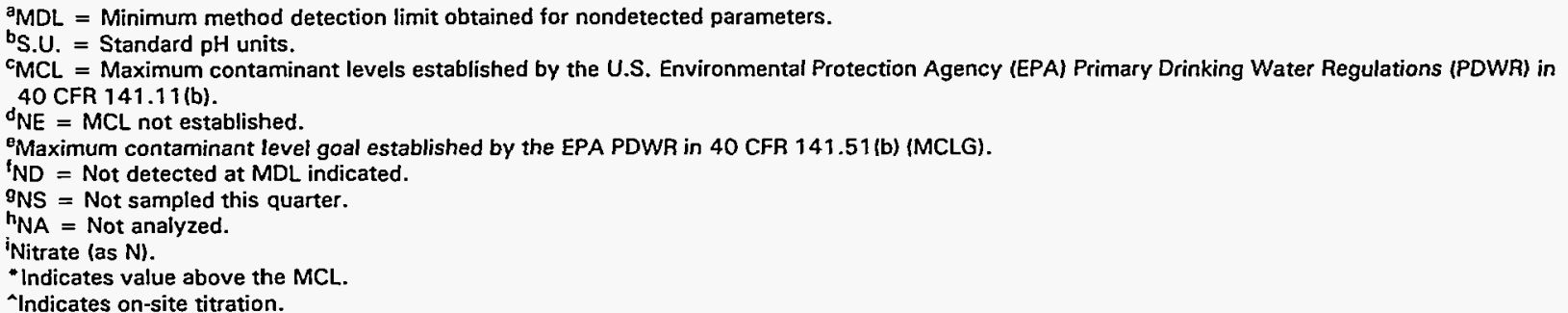 } \\
\hline
\end{tabular}


Table K-6b.

Summary of Analytical Results for Inorganic Compounds and Phenolics SNL/NM Basewide Groundwater Surveillance, July 1993

\begin{tabular}{|c|c|c|c|c|c|c|c|c|c|}
\hline \multicolumn{2}{|c|}{$\begin{array}{c}\text { Analyte } \\
\mathrm{MDL}^{\mathrm{a}} \text {, units } \\
\mathrm{MCL}^{\mathrm{C}}\end{array}$} & $\begin{array}{c}\text { Alkalinity } \\
\begin{array}{c}10 \mathrm{mg} / \mathrm{L} \\
\mathrm{NE}\end{array}\end{array}$ & $\begin{array}{c}\text { Bromide } \\
0.10 \mathrm{mg} / \mathrm{L} \\
\mathrm{NE}\end{array}$ & $\begin{array}{c}\text { Chloride } \\
2.0 \mathrm{mg} / \mathrm{L} \\
\mathrm{NE}\end{array}$ & $\begin{array}{l}\text { Fluoride } \\
0.1 \mathrm{mg} / \mathrm{L} \\
4 \mathrm{mg} / \mathrm{L}^{\mathrm{e}}\end{array}$ & $\begin{array}{c}\mathrm{NPN} \\
0.5 \mathrm{mg} / \mathrm{L} \\
10 \mathrm{mg} / \mathrm{L}\end{array}$ & $\begin{array}{c}\text { pH } \\
\text { S.U. } \\
\text { NE } \\
\end{array}$ & $\begin{array}{c}\text { Phenolics } \\
0.05 \mathrm{mg} / \mathrm{L} \\
\mathrm{NE}\end{array}$ & $\begin{array}{c}\text { Sulfate } \\
20 \mathrm{mg} / \mathrm{L} \\
\mathrm{NE}\end{array}$ \\
\hline Site & Sample \# & \multicolumn{8}{|c|}{ All results in $\mathrm{mg} / \mathrm{L}$, except $\mathrm{pH}$ (standard $\mathrm{pH}$ units) } \\
\hline Burn Site Well & BSW0012953 & $200 / 228^{\wedge}$ & 0.72 & 59 & 0.9 & 1.0 & 6.9 & $N D^{f}$ & ND \\
\hline Coyote Spring & CYSO012954 & $780 / 823^{\wedge}$ & 1.6 & 410 & $* 15.0$ & 1.2 & 6.2 & ND & 10 \\
\hline CWL-BW2 & CB20012955 & $350 / 352^{\wedge}$ & 0.67 & 130 & 1.7 & 5.4 & 7.4 & ND & 56 \\
\hline EOD Hill Well & EOD0012956 & $2000 / 1598^{\wedge}$ & 1.4 & 420 & 1.5 & ND & 6.5 & ND & 110 \\
\hline $\begin{array}{l}\text { EOD Hill Well } \\
\text { (duplicate) }\end{array}$ & HILO012957 & $2000 / 1598^{\wedge}$ & 1.6 & 410 & 1.5 & ND & 6.5 & ND & 110 \\
\hline $\begin{array}{l}\text { Golf Course South } \\
\text { Well }\end{array}$ & GCS0012958 & $130 /$ NA $^{g}$ & 0.60 & 45 & 0.4 & $\cdot 20$ & 7.7 & ND & 60 \\
\hline $\begin{array}{l}\text { Greystone Manor } \\
\text { Well }\end{array}$ & GSM0012959 & $310 / N A$ & 0.44 & 83 & 0.7 & 5.0 & 7.6 & ND & 47 \\
\hline Hubbell Spring & HBLO012960 & $180 / 238^{\wedge}$ & 0.35 & 34 & 0.9 & 0.74 & 7.8 & ND & 180 \\
\hline KAFB-10 Well & NS $^{h}$ & NS & NS & NS & NS & NS & NS & NS & NS \\
\hline LF/DM-1 Well & LF10012962 & $96 / 40^{\wedge}$ & ND & 6.3 & 0.5 & 0.45 & 8.0 & ND & 27 \\
\hline LF/DM-2 Well & LF20012963 & $160 / 782^{-}$ & 0.18 & 16 & 0.4 & 4.3 & 7.8 & ND & 79 \\
\hline MVMW-J Well & MVJ0012964 & $89 / 85^{\wedge}$ & ND & 8.3 & 0.4 & $* 13$ & 7.6 & ND & 24 \\
\hline MVMW-K Well & MVKO012965 & $93 / 93^{\wedge}$ & 0.15 & 11 & 0.5 & $\cdot 20$ & 7.3 & ND & 33 \\
\hline $\begin{array}{l}\text { MVMW-K Well } \\
\text { (duplicate) }\end{array}$ & MVX0012966 & 97/NA & 0.14 & 9.8 & 0.5 & -23 & 7.5 & ND & 30 \\
\hline MWL-BW1 & MB10012967 & $210 / 215^{\wedge}$ & 0.26 & 29 & 0.9 & 1.6 & 8.0 & ND & 47 \\
\hline NW-TA3 Well & NW30012968 & $150 / N A$ & 0.21 & 16 & 0.4 & 6.4 & 8.1 & ND & 56 \\
\hline Schoolhouse Well & SCHOO12969 & $380 / 391^{\wedge}$ & 0.68 & 150 & 1.4 & 4.6 & 7.4 & ND & 54 \\
\hline Sol se Mete Spring & SSMO012970 & $220 / 216^{\wedge}$ & 0.42 & 27 & 0.4 & 1.3 & 7.8 & ND & 60 \\
\hline $\begin{array}{l}\text { South Fence Well } \\
\# 1\end{array}$ & SFR10013500 & $410 / N A$ & 0.63 & 130 & 1.7 & 0.9 & 7.1 & ND & 70 \\
\hline $\begin{array}{l}\text { South Fence Well } \\
\sharp 2\end{array}$ & SFR013256 & $300 / N A$ & 0.67 & 130 & 2.0 & 0.9 & 7.8 & ND & 68 \\
\hline SW-TA3 Well & SW30012971 & $180 / 206^{\wedge}$ & 0.2 & 31 & 1.4 & 3.6 & 8.2 & ND & 51 \\
\hline Tijeras East Well & TJEO012972 & $170 / 230^{\wedge}$ & 0.16 & 12 & 0.3 & 2.9 & 7.7 & ND & 75 \\
\hline 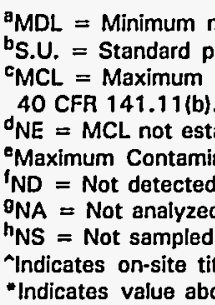 & $\begin{array}{l}\text { thod detection lin } \\
\text { units. } \\
\text { ntaminant levels } \\
\text { ished. } \\
\text { ht Level Goal est }\end{array}$ & $\begin{array}{l}\text { btained for non } \\
\text { olished by the } \\
\text { ned by the EPA }\end{array}$ & $\begin{array}{l}\text { Environmen } \\
\text { WR in } 40 \mathrm{C}\end{array}$ & $\begin{array}{l}\text { Protection } \\
141.51 \text { (b) }\end{array}$ & $\begin{array}{l}\text { Agency (EPA } \\
\text { MCLG). }\end{array}$ & Primary Drin & Water & Regulations (P & (R) in \\
\hline
\end{tabular}


Table K-6c.

Summary of Analytical Results for Inorganic Compounds and Phenolics SNL/NM Basewide Groundwater Surveillance, September 1993

\begin{tabular}{|c|c|c|c|c|c|c|c|c|c|}
\hline \multicolumn{2}{|c|}{ Analyte } & Alkalinity & Bromide & Chloride & Fluoride & NPN & $\mathrm{pH}$ & Phenolics & Sulfate \\
\hline \multicolumn{2}{|c|}{ MDL ${ }^{\mathrm{a}}$, units } & $10 \mathrm{mg} / \mathrm{L}$ & $0.10 \mathrm{mg} / \mathrm{L}$ & $2.0 \mathrm{mg} / \mathrm{L}$ & $0.1 \mathrm{mg} / \mathrm{L}$ & $0.05 \mathrm{mg} / \mathrm{L}$ & S.U.b & $0.05 \mathrm{mg} / \mathrm{L}$ & $20 \mathrm{mg} / \mathrm{L}$ \\
\hline \multicolumn{2}{|c|}{$M C L^{\mathrm{c}}$} & $N E^{d}$ & NE & NE & $4 \mathrm{mg} / \mathrm{L}^{\mathrm{e}}$ & $10 \mathrm{mg} / \mathrm{L}$ & NE & NE & $\mathrm{NE}$ \\
\hline Site & Sample \# & \multicolumn{8}{|c|}{ All results in $\mathrm{mg} / \mathrm{L}$, except $\mathrm{pH}$ (standard $\mathrm{pH}$ units) } \\
\hline Burn Site Well & SNLA013491 & $200 / 198^{\wedge}$ & 0.8 & 60 & 1.2 & 3.7 & 7.3 & ND' & 140 \\
\hline Coyote Spring & COYS013490 & 1000/911^ & 2.0 & 510 & 2.2 & 0.64 & 6.3 & ND & 100 \\
\hline CWL-BW2 & $\mathrm{CB} 2013474$ & $360 / 411^{\wedge}$ & 0.66 & 120 & 1.9 & 1.5 & 7.3 & ND & 72 \\
\hline EOD Hill Well & EOD013478 & $2000 / 1790^{\wedge}$ & 1.4 & 400 & 2.5 & ND & 6.4 & ND & 120 \\
\hline $\begin{array}{l}\text { EOD Hin Well } \\
\text { (duplicate) }\end{array}$ & DOEO13477 & $2000 / 1790^{\wedge}$ & 1.5 & 360 & 2.6 & ND & 6.5 & ND & 120 \\
\hline $\begin{array}{l}\text { Golf Course South } \\
\text { Well }\end{array}$ & GCS013470 & $140 / 117^{\wedge}$ & 0.60 & 44 & 0.4 & $* 19$ & 7.6 & ND & 55 \\
\hline $\begin{array}{l}\text { Greystone Manor } \\
\text { Well }\end{array}$ & GRYS013487 & $310 / 358^{\wedge}$ & 0.48 & 88 & 0.7 & 4.8 & 6.6 & ND & 45 \\
\hline Hubbell Spring & HUBSO13488 & $170 / 178^{\wedge}$ & 0.4 & 34 & 1.0 & 0.69 & 7.2 & ND & 190 \\
\hline KAFB-10 Well & $K 10013480$ & $70 / 217^{\wedge}$ & 0.30 & 120 & 1.3 & 2.3 & 7.6 & NS & 46 \\
\hline LF/DM-1 Well & LF10013476 & $110 / 103^{\wedge}$ & ND & 6.6 & 0.5 & ND & 7.0 & ND & 26 \\
\hline LF/DM-2 Well & LF2013471 & $170 / 138^{\wedge}$ & 0.18 & 16 & 0.4 & 4.1 & 7.8 & ND & 66 \\
\hline MVMW-J Well & MVJ013484 & $100 / 140^{n}$ & 0.1 & 7.5 & 0.3 & $* 14$ & 7.6 & ND & 30 \\
\hline MVMW-K Well & MVK013485 & $100 / 134^{\wedge}$ & ND & 9.2 & 0.4 & $* 11$ & 6.5 & ND & 31 \\
\hline MWL-BW1 & NS ${ }^{9}$ & NS & NS & NS & NS & NS & NS & NS & NS \\
\hline NW-TA3 Well & NW3013479 & $160 / 153^{\wedge}$ & 0.21 & 17 & 0.4 & 6.2 & 7.6 & ND & 75 \\
\hline Schoolhouse Well & SCLHO13486 & $360 / 268^{\wedge}$ & 0.67 & 140 & 1.4 & 3.3 & 7.0 & ND & 61 \\
\hline Sol se Mete Spring & SSMS013489 & $220 / 225^{\wedge}$ & 0.4 & 27 & 0.5 & 1.2 & 7.3 & ND & 65 \\
\hline $\begin{array}{l}\text { South Fence Well } \\
\# 1\end{array}$ & SF1013473 & $450 / 507^{\wedge}$ & 0.65 & 130 & 1.7 & 0.96 & 7.1 & ND & 71 \\
\hline $\begin{array}{l}\text { South Fence Well } \\
\# 2\end{array}$ & SF2013482 & $370 / 348^{\wedge}$ & 0.70 & 140 & 1.9 & 0.96 & 7.0 & ND & 62 \\
\hline SW-TA3 Well & SW 3013483 & $200 / 166^{\wedge}$ & 0.30 & 32 & 1.4 & 3.7 & 8.3 & ND & 50 \\
\hline Tijeras East Well & TJE013469 & $190 / 209^{\wedge}$ & 0.19 & 13 & 0.3 & 3.1 & 7.5 & ND & 85 \\
\hline 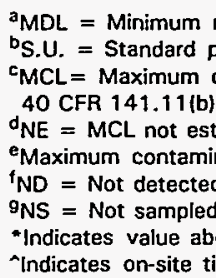 & $\begin{array}{l}\text { thod detection II } \\
\text { units. } \\
\text { itaminant levels } \\
\text { lished. } \\
\text { it level goal est } \\
t \mathrm{MDL} \text { indicated. } \\
\text { is quarter. } \\
\text { the MCL. } \\
\text { tion value. }\end{array}$ & $\begin{array}{l}\text { btained for no } \\
\text { lished by the } \\
\text { ed by the EPA }\end{array}$ & $\begin{array}{l}\text { tected param } \\
\text { Environmen } \\
\text { WR in } 40 \mathrm{CF}\end{array}$ & $\begin{array}{l}\text { Protection } \\
141.51 \text { (b) }\end{array}$ & $\begin{array}{l}\text { Agency (EPA } \\
\text { MCLG). }\end{array}$ & Primary Drink & Water & Regulations IP & R) in \\
\hline
\end{tabular}


Table K-6d.

Summary of Analytical Results for Inorganic Compounds and Phenolics SNL/NM Basewide Groundwater Surveillance, December 1993

\begin{tabular}{|c|c|c|c|c|c|c|c|c|c|}
\hline \multicolumn{2}{|c|}{ Analyte } & Alkalinity & Bromide & Chloride & Fluoride & NPN & $\mathrm{pH}$ & Phenolics & Sulfate \\
\hline \multicolumn{2}{|c|}{$M O L^{a}$, units } & $10 \mathrm{mg} / \mathrm{L}$ & $0.05 \mathrm{mg} / \mathrm{L}$ & $2.0 \mathrm{mg} / \mathrm{L}$ & $0.1 \mathrm{mg} / \mathrm{L}$ & $0.05 \mathrm{mg} / \mathrm{L}$ & S.U. ${ }^{b}$ & $0.05 \mathrm{mg} / \mathrm{L}$ & $5 \mathrm{mg} / \mathrm{L}$ \\
\hline \multicolumn{2}{|c|}{$\mathrm{MCL}^{\mathrm{c}}$} & $N E^{d}$ & NE & NE & $4 \mathrm{mg} / \mathrm{L}$ & $10 \mathrm{mg} / \mathrm{L}$ & NE & NE & NE \\
\hline Site & Sample \# & & \multicolumn{7}{|c|}{ All results in $\mathrm{mg} / \mathrm{L}$, except $\mathrm{pH}$ (standard $\mathrm{pH}$ units) } \\
\hline Burn Site Well & BSW013939 & $220 / 197^{\wedge}$ & $\begin{array}{c}0.70 \\
(0.10)\end{array}$ & 53 & 1.0 & $\begin{array}{c}2.7 \\
(0.20)\end{array}$ & 7.5 & $N D^{8}$ & $\begin{array}{l}150 \\
(10)\end{array}$ \\
\hline Coyote Spring & CYS013842 & $1000 / 956^{\wedge}$ & $\begin{array}{l}2.0 \\
(0.10)\end{array}$ & $\begin{array}{l}530 \\
(20)\end{array}$ & $\begin{array}{c}2.3 \\
(2.0)\end{array}$ & $\begin{array}{c}0.40 \\
(0.20)\end{array}$ & 6.4 & ND & $\begin{array}{c}130 \\
(100)\end{array}$ \\
\hline CWL-BW2 Well & CLB2014098 & $340 / 301^{\wedge}$ & $\begin{array}{c}0.66 \\
(0.10)\end{array}$ & $\begin{array}{r}130 \\
(4.0)\end{array}$ & 1.8 & 1.5 & 7.5 & ND & $\begin{array}{c}78 \\
(10)\end{array}$ \\
\hline EOD Hill Well & EOD014323 & $2000 / 1917^{\wedge}$ & $\begin{array}{c}1.5 \\
(1.0)\end{array}$ & $\begin{array}{l}420 \\
(40)\end{array}$ & $\begin{array}{c}1.8 \\
(1.0)\end{array}$ & ND & 6.3 & ND & $\begin{array}{c}120 \\
(100)\end{array}$ \\
\hline $\begin{array}{l}\text { EOD Hill Well } \\
\text { (duplicate) }\end{array}$ & HILO14324 & 2000 & $\begin{array}{c}1.7 \\
(1.0)\end{array}$ & $\begin{array}{l}420 \\
(40)\end{array}$ & $\begin{array}{c}2.0 \\
(1.0)\end{array}$ & ND & 6.3 & ND & $\begin{array}{l}120 \\
(100)\end{array}$ \\
\hline $\begin{array}{l}\text { Golf Course } \\
\text { South Well }\end{array}$ & GCS014003 & $130 / 96^{\wedge}$ & $\begin{array}{c}0.59 \\
(0.10)\end{array}$ & 43 & 0.4 & $\begin{array}{c}20 \\
(0.5)\end{array}$ & 7.7 & ND & $\begin{array}{c}62 \\
(50)\end{array}$ \\
\hline $\begin{array}{l}\text { Greystone Manor } \\
\text { Well }\end{array}$ & GSM013923 & $300 / 279^{\wedge}$ & $\begin{array}{c}0.50 \\
(0.10)\end{array}$ & 84 & 0.7 & $\begin{array}{c}5.0 \\
(0.20)\end{array}$ & 7.8 & ND & $\begin{array}{c}44 \\
(10)\end{array}$ \\
\hline Hubbell Spring & HBL013798 & $180 / 165^{\wedge}$ & $\begin{array}{c}0.30 \\
(0.10)\end{array}$ & 32 & 0.9 & $\begin{array}{c}0.70 \\
(0.20)\end{array}$ & 7.9 & ND & $\begin{array}{c}220 \\
(100)\end{array}$ \\
\hline KAFB-10 Well & K10013940 & $50 / 65^{\wedge}$ & $\begin{array}{c}0.30 \\
(0.10)\end{array}$ & 130 & 1.3 & $\begin{array}{c}0.80 \\
(0.20)\end{array}$ & 8.1 & ND & $\begin{array}{c}48 \\
(1.0)\end{array}$ \\
\hline LF/DM-1 Well & LF1014322 & $98 / 98^{\wedge}$ & $\begin{array}{l}\text { ND } \\
(0.10)\end{array}$ & 6.0 & 0.5 & ND & 7.9 & ND & $\begin{array}{l}27 \\
(5)\end{array}$ \\
\hline LF/DM-2 Well & LF2014320 & $160 / 146^{\wedge}$ & 0.20 & 16 & 0.32 & $\begin{array}{l}4.0 \\
(0.5)\end{array}$ & 7.5 & ND & $\begin{array}{l}78 \\
(10)\end{array}$ \\
\hline MVMW-J Well & MVJ013938 & $95 / 97^{\wedge}$ & $\begin{array}{c}0.10 \\
(0.10)\end{array}$ & 8.9 & 0.4 & $\begin{array}{c}13 \\
(2.0)\end{array}$ & 7.9 & ND & $\begin{array}{c}27 \\
(10)\end{array}$ \\
\hline MVMW-K Well & MVK013942 & $88 / 92^{\wedge}$ & $\begin{array}{c}0.10 \\
(0.10)\end{array}$ & 10 & 0.4 & $\begin{array}{l}20 \\
(2.0)\end{array}$ & 8.1 & ND & $\begin{array}{c}30 \\
(10)\end{array}$ \\
\hline $\begin{array}{l}\text { MVMW-K Well } \\
\text { (duplicate) }\end{array}$ & MVK013943 & 99 & $\begin{array}{c}0.10 \\
(0.10)\end{array}$ & 9.6 & 0.4 & $\begin{array}{c}17 \\
(2.0)\end{array}$ & 8.0 & ND & $\begin{array}{c}30 \\
(10)\end{array}$ \\
\hline MWL-BW1 Well & MWBW1014101 & $230 / 173^{\wedge}$ & $\begin{array}{c}0.23 \\
(0.10)\end{array}$ & 28 & 0.9 & $\begin{array}{l}5.6 \\
(0.2)\end{array}$ & 7.5 & ND & 45 \\
\hline NW-TA3 Well & NWT3014100 & $150 / 157^{\wedge}$ & $\begin{array}{c}0.24 \\
(0.10)\end{array}$ & 17 & $\begin{array}{l}0.4 \\
(0.10)\end{array}$ & $\begin{array}{c}6.3 \\
(0.2)\end{array}$ & $\begin{array}{l}7.6 \\
(0.2)\end{array}$ & ND & $\begin{array}{c}60 \\
(10)\end{array}$ \\
\hline $\begin{array}{l}\text { Schoolhouse } \\
\text { Well }\end{array}$ & $\mathrm{SCH} 014054$ & $390 / 330^{\wedge}$ & 0.72 & $\begin{array}{c}150 \\
(4.0)\end{array}$ & 1.4 & $\begin{array}{c}3.5 \\
(0.5)\end{array}$ & 6.9 & ND & $\begin{array}{c}62 \\
(10)\end{array}$ \\
\hline
\end{tabular}


Table K-6d. (Concluded)

Summary of Analytical Results for Inorganic Compounds and Phenolics SNL/NM Basewide Groundwater Surveillance, December 1993

\begin{tabular}{|c|c|c|c|c|c|c|c|c|c|}
\hline \multicolumn{2}{|c|}{ Analyte } & Alkalinity & Bromide & Chloride & Fluoride & NPN & $\mathrm{pH}$ & Phenolics & Sulfate \\
\hline \multicolumn{2}{|c|}{$\mathrm{MDL}^{\mathrm{a}}$, units } & $10 \mathrm{mg} / \mathrm{L}$ & $0.05 \mathrm{mg} / \mathrm{L}$ & $2.0 \mathrm{mg} / \mathrm{L}$ & $0.1 \mathrm{mg} / \mathrm{L}$ & $0.05 \mathrm{mg} / \mathrm{L}$ & s.u.b & $0.05 \mathrm{mg} / \mathrm{L}$ & $5 \mathrm{mg} / \mathrm{l}$ \\
\hline \multicolumn{2}{|c|}{$M L^{c}$} & $N E^{d}$ & $\mathrm{NE}$ & $\mathrm{NE}$ & $4 \mathrm{mg} / \mathrm{L}$. & $10 \mathrm{mg} / \mathrm{L}$ & NE & $\mathrm{NE}$ & NE \\
\hline Site & Sample \# & \multicolumn{8}{|c|}{ All results in $\mathrm{mg} / \mathrm{L}$, except $\mathrm{pH}$ (standard $\mathrm{pH}$ units) } \\
\hline $\begin{array}{l}\text { South Fence Well } \\
\# 1\end{array}$ & SFR1014105 & $430 / 325^{\wedge}$ & $\begin{array}{c}0.65 \\
(0.10)\end{array}$ & $\begin{array}{l}140 \\
(20)\end{array}$ & 1.9 & 0.87 & 6.7 & ND & $\begin{array}{c}70 \\
(50)\end{array}$ \\
\hline $\begin{array}{l}\text { South Fence Well } \\
\# 2\end{array}$ & SFR2014103 & $340 / 260^{\wedge}$ & $\begin{array}{c}0.67 \\
(0.10)\end{array}$ & $\begin{array}{l}140 \\
(20)\end{array}$ & 2.0 & 0.89 & 7.1 & ND & $\begin{array}{c}74 \\
(50)\end{array}$ \\
\hline $\begin{array}{l}\text { South Fence } \\
\text { Well \#3P }\end{array}$ & SFP014326 & $330 / 319^{\wedge}$ & $\begin{array}{c}0.70 \\
(0.10)\end{array}$ & $\begin{array}{l}130 \\
(40)\end{array}$ & 1.9 & $\begin{array}{c}0.90 \\
(0.20)\end{array}$ & 7.1 & ND & $\begin{array}{c}99 \\
(10)\end{array}$ \\
\hline $\begin{array}{l}\text { South Fence } \\
\text { Well } \# 3 T\end{array}$ & SFT014325 & $22 / 16^{\wedge}$ & $\begin{array}{c}0.55 \\
(0.10)\end{array}$ & 47 & $\begin{array}{c}1.6 \\
(0.2)\end{array}$ & ND & 7.6 & ND & $\begin{array}{l}2200 \\
(500)\end{array}$ \\
\hline $\begin{array}{l}\text { Sol se Mete } \\
\text { Spring }\end{array}$ & SSM013921 & 230 & $\begin{array}{c}0.4 \\
(0.10)\end{array}$ & 26 & 0.4 & 1.2 & 7.7 & ND & $\begin{array}{c}78 \\
(10)\end{array}$ \\
\hline SW-TA3 Well & SWT3014102 & $190 / 150^{\wedge}$ & $\begin{array}{c}0.25 \\
(0.10)\end{array}$ & 30 & 1.5 & $\begin{array}{c}3.7 \\
(0.20)\end{array}$ & 8.2 & ND & 48 \\
\hline Tijeras East Well & TJE014106 & $180 / 139^{\wedge}$ & $\begin{array}{c}0.17 \\
(0.10)\end{array}$ & 14 & 0.3 & $\begin{array}{c}2.7 \\
(0.20)\end{array}$ & 7.3 & ND & $\begin{array}{c}81 \\
(50)\end{array}$ \\
\hline $\begin{array}{l}\text { Equipment Blank } \\
\# 1 \text { (pump) }\end{array}$ & EB1014099 & $N M^{f}$ & $\begin{array}{l}\text { ND } \\
(0.10)\end{array}$ & ND & ND & ND & 7.1 & ND & ND \\
\hline $\begin{array}{l}\text { Equipment Blank } \\
\text { \#2 (pump) }\end{array}$ & EB2014104 & NM & $\begin{array}{l}\text { ND } \\
(0.10)\end{array}$ & ND & ND & ND & 7.2 & ND & ND \\
\hline $\begin{array}{l}\text { Equipment Blank } \\
\text { \#3 (pump) }\end{array}$ & EB3014321 & NM & ND & ND & ND & $\begin{array}{l}\text { ND } \\
(0.5)\end{array}$ & 6.3 & ND & ND \\
\hline $\begin{array}{l}\text { Equipment Blank } \\
\text { \#4 (bailer) }\end{array}$ & K10013941 & NM & $\begin{array}{l}\text { ND } \\
(0.10)\end{array}$ & ND & ND & $\begin{array}{c}\text { ND } \\
(0.20)\end{array}$ & 7.1 & ND & ND \\
\hline $\begin{array}{l}{ }^{\mathrm{a}} \mathrm{MDL}=\text { Minimum } \\
\text { individual analys } \\
\text { 'S.U. = Standard } \\
{ }^{\mathrm{C}} \mathrm{MCL}=\text { Maximum } \\
\text { (PDWR) in } 40 \mathrm{CF} \\
{ }^{\mathrm{d}} \mathrm{NE}=\mathrm{MCL} \text { not e } \\
{ }^{\mathrm{e}} \mathrm{ND}=\text { Not detect } \\
\text { 'NM }=\text { Not measu } \\
\text { 'Indicates on-site } \\
\text { NOTE: Values in }\end{array}$ & $\begin{array}{l}\text { method detectio } \\
\text { s. } \\
\text { pH units. } \\
\text { contaminant les } \\
\text { R } 141.11 \text { (b). } \\
\text { tablished. } \\
\text { d at } \mathrm{MDL} \text { indica } \\
\text { red. } \\
\text { titration value. } \\
\text { old exceed asso }\end{array}$ & $\begin{array}{l}\text { it obtained } \\
\text { stablished b } \\
\mathrm{MCL} \text {. }\end{array}$ & $\begin{array}{l}\text { Indetected pa } \\
\text { U.S. Environ }\end{array}$ & nemeters. & $\begin{array}{l}\text { igher actual } \\
\text { ction Ageno }\end{array}$ & $\begin{array}{l}\text { detection limi } \\
\text { (EPA) Prima }\end{array}$ & are list & $\begin{array}{l}\text { in parenthes } \\
\text { Water Regul }\end{array}$ & $\begin{array}{l}\text { s with } \\
\text { tions }\end{array}$ \\
\hline
\end{tabular}


Table K-7a.

Summary of Analytical Results for Total Metals SNL/NM Basewide Groundwater Surveillance, April 1993

\begin{tabular}{|c|c|c|c|c|c|c|c|c|c|c|c|c|c|c|}
\hline Analyte & Arsenic & Barium & Cadmium & Calcium & Chromium & Iron & Lead & Magnesium & Manganese & Mercury & Potassium & Selenium & Silver & Sodium \\
\hline$M^{2} L^{a}(m g / L)$ & 0.002 & 0.02 & 0.005 & 0.20 & 0.02 & 0.02 & 0.04 & 0.20 & 0.005 & 0.0002 & 0.20 & 0.002 & 0.01 & 0.20 \\
\hline$M C L^{b}(m g / L)$ & 0.05 & 1.0 & 0.010 & $N E^{c}$ & 0.05 & NE & 0.05 & NE & NE & 0.002 & NE & 0.01 & 0.05 & $\mathrm{NE}$ \\
\hline Site & \multicolumn{14}{|c|}{ All results in $\mathrm{mg} / \mathrm{L}$. } \\
\hline Burn Site Well & $N D^{d}$ & 0.05 & ND & 86 & ND & 0.02 & ND & 39 & ND & ND & 4.2 & 0.002 & ND & 24 \\
\hline Coyote Spring & 0.004 & 0.03 & ND & 240 & ND & 0.18 & ND & 50 & 0.97 & ND & 24 & ND & ND & 330 \\
\hline CWL-BW2 & ND & 0.06 & ND & 120 & 0.25 & 4.4 & ND & 29 & 0.037 & ND & 6.3 & ND & ND & 85 \\
\hline EOD Hill Well & 0.005 & 0.23 & ND & 550 & ND & 20 & ND & 101 & 0.76 & ND & 37 & ND & ND & 410 \\
\hline EOD Hill Well (duplicate) & 0.005 & 0.23 & ND & 530 & ND & 19 & ND & 99 & 0.74 & ND & 37 & ND & ND & 410 \\
\hline Golf Course South Well & ND & 0.17 & ND & 87 & ND & ND & ND & 15 & ND & ND & 2.2 & 0.006 & ND & 20 \\
\hline Groystone Manor Well & ND & 0.97 & ND & 99 & ND & 18 & ND & 23 & 0.16 & ND & 5.9 & 0.002 & ND & 64 \\
\hline Hubbell Spring & 0.004 & 0.03 & ND & 74 & ND & ND & ND & 32 & ND & ND & 1.4 & 0.004 & ND & 54 \\
\hline KAFB-10 Well & 0.007 & 0.14 & $\cdot 0.017$ & 29 & ND & 3.3 & 0.17 & 9.3 & 0.086 & ND & 6.0 & ND & ND & 65 \\
\hline LF/DM-1 Well & $N S^{e}$ & NS & NS & NS & NS & NS & NS & NS & NS & NS & NS & NS & NS & NS \\
\hline LF/DM-2 Well & ND & 0.05 & ND & 71 & ND & 0.03 & ND & 13 & ND & ND & 2.3 & ND & ND & 24 \\
\hline MVMW-J Well & 0.003 & 0.21 & ND & 44 & ND & 2.7 & ND & 5.9 & 0.10 & ND & 2.8 & ND & ND & 20 \\
\hline MVMW-K Well & 0.002 & 0.16 & ND & 53 & ND & 1.7 & ND & 5.9 & 0.045 & ND & 2.5 & ND & ND & 23 \\
\hline MWL-BW1 & ND & 0.073 & ND & 46.6 & ND & 0.055 & ND & 17.9 & 0.0098 & ND & 2.7 & ND & ND & 46.9 \\
\hline MWL-BW1 (duplicato) & 0.0011 & 0.075 & ND & 47.8 & ND & 0.14 & ND & 18.3 & 0.022 & ND & 2.9 & ND & ND & 47.4 \\
\hline NW-TA3 Well & ND & 0.07 & ND & 56 & ND & ND & ND & 15 & ND & ND & 43 & ND & ND & 22 \\
\hline
\end{tabular}

Refer to footnotes at end of table. 
Table K-7a. (Concluded)

Summary of Analytical Results for Total Metals SNL/NM Basewide Groundwater Surveillance, April 1993

\begin{tabular}{|c|c|c|c|c|c|c|c|c|c|c|c|c|c|c|}
\hline Analyte & Arsenic & Barium & Cadmium & Calcium & Chromium & Iron & Lead & Magnesium & Manganese & Mercury & Potassium & Selenium & Silver & Sodium \\
\hline$M D L^{2}(m g / L)$ & 0.002 & 0.02 & 0.005 & 0.20 & 0.02 & 0.02 & 0.04 & 0.20 & 0.005 & 0.0002 & 0.20 & 0.002 & 0.01 & 0.20 \\
\hline$M C L^{b}(m g / L)$ & 0.05 & 1.0 & 0.010 & NE & 0.05 & NE & 0.05 & NE & NE & 0.002 & NE & 0.01 & 0.05 & NE \\
\hline Site & \multicolumn{14}{|c|}{ All results in $\mathrm{mg} / \mathrm{L}$. } \\
\hline Schoolhouse Well & ND & 0.10 & ND & 140 & ND & 2.2 & ND & 25 & 0.057 & ND & 6.1 & ND & ND & 92 \\
\hline Sol se Mete & 0.003 & 0.07 & ND & 96 & ND & ND & ND & 17 & ND & 0.001 & 1.6 & 0.005 & ND & 11 \\
\hline South Fence Well \#1 & ND & 0.07 & ND & 148 & ND & 0.78 & ND & 35 & 0.016 & ND & 7.2 & ND & ND & 78 \\
\hline South Fence Well \#2 & ND & 0.04 & ND & 125 & ND & 0.13 & ND & 34 & 0.008 & ND & 7.3 & ND & ND & 77 \\
\hline SW-TA3 & ND & 0.07 & ND & 37 & 0.05 & 1.0 & ND & 10 & 0.020 & ND & 4.8 & ND & ND & 69 \\
\hline Tijeras East Well & ND & 0.03 & ND & 77 & ND & 0.10 & ND & 11 & ND & ND & 1.8 & ND & ND & 27 \\
\hline \multicolumn{15}{|c|}{$\begin{array}{l}{ }^{a} M D L=\text { Minimum method detection limit obtained for nondetected parameters. } \\
{ }^{\circ} \mathrm{MCL}=\text { Maximum contaminant levels established by the U.S. Environmental Protection Agency (EPA) Primary Drinking Water Regulations (PDWR) in } \\
40 \text { CFR } 141.11(b) . \\
{ }^{c} N E=\text { MCL not established. } \\
{ }^{d} N D=\text { Not detected at MDL indicated. } \\
{ }^{2} N S=\text { Not sampled this quarter. } \\
{ }^{*} \text { indicates value above the MCL. }\end{array}$} \\
\hline
\end{tabular}


Table K-7b.

Summary of Analytical Results for Total Metals SNL/NM Basewide Groundwater Surveillance, July 1993

\begin{tabular}{|c|c|c|c|c|c|c|c|c|c|c|c|c|c|c|}
\hline Analyte & Arsenic & Barium & Cadmium & Calcium & Chromium & Iron & Lead & Magnesium & Manganese & Mercury & Potassium & Selenium & Silver & Sodium \\
\hline $\mathrm{MDL}^{\mathrm{a}}(\mathrm{mg} / \mathrm{L})$ & 0.002 & 0.02 & 0.005 & 0.20 & 0.02 & 0.02 & 0.04 & 0.20 & 0.005 & 0.0002 & 0.20 & 0.002 & 0.01 & 0.20 \\
\hline $\mathrm{MCL}^{\mathrm{b}}(\mathrm{mg} / \mathrm{L})$ & 0.05 & 1.0 & 0.010 & $N E^{c}$ & 0.05 & NE & 0.05 & $\mathrm{NE}$ & NE & 0.002 & NE & 0.01 & 0.05 & NE \\
\hline Site & \multicolumn{14}{|c|}{ All results in mg/L. } \\
\hline Burn Site Well & $N D^{d}$ & 0.05 & ND & 100 & ND & ND & ND & 38 & ND & ND & 3.8 & 0.004 & ND & ND \\
\hline Coyote Spring & 0.0051 & 0.02 & ND & 250 & ND & 0.22 & ND & 52 & 0.91 & ND & 24 & ND & ND & 340 \\
\hline CWL-BW2 & ND & 0.07 & ND & 140 & *0.39 & 5.3 & ND & 32 & 0.059 & ND & 6.5 & ND & ND & 82 \\
\hline EOD Hill Well & 0.014 & 0.20 & ND & 570 & ND & 18 & ND & 110 & 0.79 & ND & 40 & ND & ND & 440 \\
\hline $\begin{array}{l}\text { EOD Hill Well } \\
\text { (duplicate) }\end{array}$ & 0.014 & 0.20 & ND & 550 & ND & 19 & ND & 110 & 0.78 & ND & 40 & ND & ND & 430 \\
\hline $\begin{array}{l}\text { Golf Course } \\
\text { South Well }\end{array}$ & ND & 0.18 & ND & 83 & ND & ND & ND & 16 & ND & ND & 2.4 & 0.005 & ND & 20 \\
\hline $\begin{array}{l}\text { Greystone } \\
\text { Manor Well }\end{array}$ & ND & $* 1.1$ & ND & 120 & ND & 41 & ND & 25 & 0.34 & ND & 6.1 & ND & ND & 65 \\
\hline Hubbell Spring & 0.004 & 0.03 & ND & 82 & ND & ND & ND & 32 & ND & ND & 1.6 & 0.003 & ND & 57 \\
\hline KAFB-10 Well & $\mathrm{NS}^{0}$ & NS & NS & NS & NS & NS & NS & NS & NS & NS & NS & NS & NS & NS \\
\hline LF/DM-1 Well & ND & 0.11 & ND & 32 & ND & 0.04 & ND & 5.1 & 0.005 & ND & 2.3 & ND & ND & 19 \\
\hline LF/DM-2 Well & ND & 0.04 & ND & 71 & ND & 0.02 & ND & 13 & ND & ND & 2.3 & ND & ND & 24 \\
\hline MVMW-J Well & 0.003 & 0.21 & ND & 52 & ND & 2.2 & ND & 6.0 & 0.10 & ND & 3.1 & ND & ND & 20 \\
\hline MVMW-K Well & ND & 0.16 & ND & 57 & ND & 1.5 & ND & 6.0 & 0.05 & ND & 2.6 & ND & ND & 23 \\
\hline $\begin{array}{l}\text { MVMW-K Well } \\
\text { (duplicate) }\end{array}$ & ND & 0.16 & ND & 58 & ND & 0.61 & ND & 5.8 & 0.040 & ND & 2.5 & ND & ND & 23 \\
\hline
\end{tabular}

Refer to footnotes at end of table. 
Table K-7b. (Concluded)

Summary of Analytical Results for Total Metals

SNL/NM Basewide Groundwater Surveillance, July 1993

\begin{tabular}{|c|c|c|c|c|c|c|c|c|c|c|c|c|c|c|}
\hline Analyte & Arsenic & Barium & $\begin{array}{c}\text { Cadmiu } \\
\mathbf{m}\end{array}$ & Calcium & Chromium & Iron & Lead & Magnesium & Manganese & Mercury & $\begin{array}{c}\text { Potassiu } \\
\text { m }\end{array}$ & Selenium & Silver & Sodium \\
\hline$M L^{a}(m g / L)$ & 0.002 & 0.02 & 0.005 & 0.20 & 0.02 & 0.02 & 0.04 & 0.20 & 0.005 & 0.0002 & 0.20 & 0.002 & 0.01 & 0.20 \\
\hline$M C L^{b}(m g / L)$ & 0.05 & 1.0 & 0.010 & $\mathrm{NE}^{\mathrm{c}}$ & 0.05 & NE & 0.05 & $\mathrm{NE}$ & NE & 0.002 & NE & 0.01 & 0.05 & $\mathrm{NE}$ \\
\hline Site & \multicolumn{14}{|c|}{ All results in mg/L. } \\
\hline MWL-BW1 & ND & 0.09 & ND & 57 & $* 0.06$ & 24 & ND & 20 & 0.008 & ND & 3.2 & 0.002 & ND & 51 \\
\hline NW-TA3 Well & ND & 0.08 & ND & 63 & ND & 0.66 & ND & 16 & 0.013 & ND & 4.7 & ND & ND & 22 \\
\hline $\begin{array}{l}\text { Schoolhouse } \\
\text { Well }\end{array}$ & ND & 0.12 & ND & 160 & ND & 0.32 & ND & 27 & 0.021 & ND & 6.7 & ND & ND & 95 \\
\hline $\begin{array}{l}\text { Sol se Mete } \\
\text { Spring }\end{array}$ & 0.003 & 0.07 & ND & 110 & ND & 0.04 & ND & 17 & ND & ND & 1.7 & 0.005 & ND & 11 \\
\hline $\begin{array}{l}\text { South Fence \#1 } \\
\text { Well }\end{array}$ & ND & 0.08 & ND & 160 & ND & ND & ND & 37 & ND & ND & 7.3 & ND & ND & 80 \\
\hline $\begin{array}{l}\text { South Fence \#2 } \\
\text { Well }\end{array}$ & ND & 0.08 & ND & 120 & $* 0.26$ & 1.5 & ND & 33 & 0.11 & ND & 6.9 & ND & ND & 78 \\
\hline SW-TA3 Well & ND & 0.08 & ND & 44 & 0.05 & 1.5 & ND & 11 & 0.028 & ND & 5.2 & ND & ND & 69 \\
\hline $\begin{array}{l}\text { Tijeras East } \\
\text { Well }\end{array}$ & ND & 0.03 & ND & 78 & ND & 0.02 & ND & 11 & ND & ND & 1.8 & ND & ND & 28 \\
\hline $\begin{array}{l}\text { Equipment } \\
\text { Blank \#1 }\end{array}$ & ND & ND & ND & ND & ND & ND & ND & ND & ND & ND & ND & ND & ND & 0.49 \\
\hline $\begin{array}{l}\text { Equipment } \\
\text { Blank \#2 }\end{array}$ & ND & ND & ND & 0.65 & 0.05 & 0.42 & ND & ND & ND & ND & ND & ND & ND & 0.35 \\
\hline $\begin{array}{l}{ }^{a} \mathrm{MDL}=\text { Minimur } \\
{ }^{{ }^{M}} \mathrm{MCL}=\text { Maximu } \\
{ }^{\mathrm{NE}}=\mathrm{MCL} \text { not } \\
{ }^{\mathrm{d} D}=\text { Not detec } \\
{ }^{\mathrm{N} S}=\text { Not samp } \\
\text { " indicates value }\end{array}$ & $\begin{array}{l}\text { method d } \\
\text { contamir } \\
\text { tablished. } \\
\text { ed at MDL } \\
\text { d this qua } \\
\text { bove the I }\end{array}$ & $\begin{array}{l}\text { tection lim } \\
\text { ant levels } \\
\text { ndicated. } \\
\text { err. } \\
\text { CL. }\end{array}$ & $\begin{array}{l}\text { obtained f } \\
\text { ablished b }\end{array}$ & $\begin{array}{l}\text { nondetect } \\
\text { he U.S. Er }\end{array}$ & $\begin{array}{l}\text { parameters } \\
\text { ronmental } P\end{array}$ & rotectior & genc & PA) Primary & nking Water & gulation & WR) in 4 & FR 141.11 & & \\
\hline
\end{tabular}


Table K-7c.

Summary of Analytical Results for Total Metals

SNL/NM Basewide Groundwater Surveillance, September 1993

\begin{tabular}{|c|c|c|c|c|c|c|c|c|c|c|c|c|c|c|}
\hline Analyte & Arsenic & Barium & Cadmium & Calcium & Chromium & Iron & Lead & Magnesium & Manganese & Mercury & Potassium & Selenium & Silver & Sodium \\
\hline $\mathrm{MDL}^{\mathrm{a}}$ (mg/L) & 0.002 & 0.02 & 0.005 & 0.20 & 0.02 & 0.02 & 0.04 & 0.20 & 0.005 & 0.0002 & 0.20 & 0.002 & 0.01 & 0.20 \\
\hline$M C L^{b}(m g / L)$ & 0.05 & 1.0 & 0.010 & $\mathrm{NE}^{\mathrm{C}}$ & 0.05 & NE & 0.05 & NE & NE & 0.002 & NE & 0.01 & 0.05 & NE \\
\hline Site & \multicolumn{14}{|c|}{ All results in mg/L. } \\
\hline Burn Site Well & $N D^{d}$ & 0.05 & ND & 96 & ND & 0.04 & ND & 38 & ND & ND & 3.7 & 0.005 & ND & 26 \\
\hline Coyote Spring & 0.005 & 0.03 & ND & 250 & ND & 0.30 & ND & 57 & 1.1 & ND & 26 & ND & ND & 370 \\
\hline CWL-BW2 & ND & 0.07 & ND & 126 & ND & 0.37 & ND & 28 & 0.007 & ND & 6.3 & ND & ND & 85 \\
\hline EOD Hill Well & 0.017 & 0.16 & ND & 530 & ND & 17 & ND & 105 & 0.76 & ND & 39 & ND & ND & 420 \\
\hline $\begin{array}{l}\text { EOD Hill Well } \\
\text { (duplicate) }\end{array}$ & 0.017 & 0.16 & ND & 520 & ND & 17 & ND & 105 & 0.76 & ND & 39 & ND & ND & 420 \\
\hline $\begin{array}{l}\text { Golf Course South } \\
\text { Well }\end{array}$ & ND & 0.18 & ND & 89 & ND & ND & ND & 16 & ND & ND & 2.6 & 0.005 & ND & 22 \\
\hline $\begin{array}{l}\text { Greystone Manor } \\
\text { Well }\end{array}$ & ND & $* 1.3$ & ND & 106 & ND & 21 & ND & 24 & 0.20 & ND & 6.5 & ND & ND & 69 \\
\hline Hubbell Spring & 0.003 & 0.03 & ND & 77 & ND & ND & ND & 32 & ND & ND & 1.4 & 0.004 & ND & 56 \\
\hline KAFB-10 Well & ND & 0.21 & $* 0.87$ & 38 & ND & 3.3 & 0.92 & 12 & 0.058 & ND & 6.8 & ND & ND & 77 \\
\hline LF/DM-1 Well & ND & 0.11 & ND & 32 & ND & ND & ND & 4.9 & ND & ND & 2.0 & ND & ND & 18 \\
\hline LF/DM-2 Well & ND & 0.05 & ND & 70 & ND & ND & ND & 13 & ND & ND & 2.5 & ND & ND & 24 \\
\hline MVMW-J Well & 0.002 & 0.23 & ND & 54 & ND & 3.5 & ND & 6.3 & 0.15 & ND & 3.0 & ND & ND & 20 \\
\hline MVMW-K Woll & 0.002 & $* 1.2$ & ND & 54 & ND & 3.5 & ND & 5.8 & 0.14 & ND & 3.9 & ND & ND & 25 \\
\hline MWL-BW1 & $N S^{\circ}$ & NS & NS & NS & NS & NS & NS & NS & NS & NS & NS & NS & NS & NS \\
\hline NW-TA3 Well & ND & 0.07 & ND & 61 & ND & 0.09 & ND & 15 & ND & ND & 4.4 & ND & ND & 22 \\
\hline Schoolhouse Well & 0.005 & $* 1.1$ & ND & 137 & ND & 23 & 0.04 & 25 & 0.15 & ND & 7.4 & ND & ND & 92 \\
\hline Sol se Mete Spring & 0.002 & 0.07 & ND & 100 & ND & ND & ND & 17 & ND & ND & 1.6 & 0.005 & ND & 11 \\
\hline South Fence Well \#1 & ND & 0.07 & ND & 150 & ND & ND & ND & 35 & ND & ND & 7.2 & ND & ND & 77 \\
\hline
\end{tabular}

Refer to footnotes at end of table. 
Table K-7c. (Concluded)

Summary of Analytical Results for Total Metals

SNL/NM Basewide Groundwater Surveillance, September 1993

\begin{tabular}{|c|c|c|c|c|c|c|c|c|c|c|c|c|c|c|}
\hline Analyte & Arsenic & Barium & Cadmium & Calcium & Chromium & Iron & Lead & Magnesium & Manganese & Mercury & Potassium & Selenium & Silver & Sodium \\
\hline$M D L^{a}(\mathrm{mg} / \mathrm{L})$ & 0.002 & 0.02 & 0.005 & 0.20 & 0.02 & 0.02 & 0.04 & 0.20 & 0.005 & 0.0002 & 0.20 & 0.002 & 0.01 & 0.20 \\
\hline$M C L^{b}(\mathrm{mg} / \mathrm{L})$ & 0.05 & 1.0 & 0.010 & $\mathrm{NE}^{\mathrm{c}}$ & 0.05 & NE & 0.05 & NE & NE & 0.002 & NE & 0.01 & 0.05 & $\mathrm{NE}$ \\
\hline Site & \multicolumn{14}{|c|}{ All results in mg/L. } \\
\hline South Fence Well \#2 & 0.006 & 0.11 & ND & 130 & $* 1.6$ & 11 & ND & 33 & 0.11 & ND & 7.0 & ND & ND & 76 \\
\hline SW-TA3 Well & 0.002 & ND & ND & 50 & $* 0.12$ & 3.4 & 0.042 & 12 & 0.076 & ND & 5.7 & 0.003 & ND & 67 \\
\hline Tijeras East Well & ND & 0.03 & ND & 77 & ND & 0.02 & ND & 10 & ND & ND & 1.6 & 0.003 & ND & 25 \\
\hline $\begin{array}{l}\text { Bailer Equipment } \\
\text { Blank }\end{array}$ & ND & ND & ND & ND & ND & 0.03 & ND & ND & ND & ND & ND & ND & ND & 0.42 \\
\hline $\begin{array}{l}\text { Pump Equipment } \\
\text { Blank \#1 }\end{array}$ & ND & ND & ND & 0.23 & ND & 0.05 & ND & ND & ND & ND & ND & ND & ND & 0.26 \\
\hline $\begin{array}{l}\text { Pump Equipment } \\
\text { Blank \#2 }\end{array}$ & ND & ND & ND & ND & ND & 0.03 & ND & ND & ND & ND & ND & ND & ND & 0.25 \\
\hline $\begin{array}{l}{ }^{a} \mathrm{MDL}=\text { Minimum me } \\
{ }^{\mathrm{M}} \mathrm{MCL}=\text { Maximum co } \\
{ }^{{ }^{\mathrm{N} E}}=\mathrm{MCL} \text { not estab } \\
{ }^{\mathrm{d}} \mathrm{ND}=\text { Not detected a } \\
{ }^{\mathrm{o} S \mathrm{~N}}=\text { Not sampled th } \\
\text { "Indicates value above }\end{array}$ & $\begin{array}{l}\text { lod detecti } \\
\text { taminant le } \\
\text { shed. } \\
\text { MDL indic } \\
\text { quarter. } \\
\text { the MCL. }\end{array}$ & $\begin{array}{l}\text { limit obt } \\
\text { els establi } \\
\text { ed. }\end{array}$ & $\begin{array}{l}\text { ed for nonc } \\
\text { edby the U }\end{array}$ & $\begin{array}{l}\text { ectedpar } \\
\text { Environ }\end{array}$ & ntal Protect & Agen & EA) $\mathrm{Pr}$ & y Drinking $\mathrm{n}$ & r Regulation & PDWR) in & CFR 141. & & & \\
\hline
\end{tabular}


Table K-7d.

Summary of Analytical Results for Total Metals

SNL/NM Basewide Groundwater Surveillance, December 1993

\begin{tabular}{|c|c|c|c|c|c|c|c|c|c|c|c|c|c|c|c|}
\hline Analyte & Arsenic & Barium & Cadmium & Calcium & Chromium & Iron & Lead & Magnesium & $\begin{array}{c}\text { Manganes } \\
e\end{array}$ & Mercury & Potassium & Selenium & Silicon & Silver & Sodium \\
\hline$M D L^{a}(\mathrm{mg} / \mathrm{L})$ & 0.002 & 0.02 & 0.005 & 0.20 & 0.02 & 0.02 & 0.04 & 0.20 & 0.005 & 0.0002 & 0.20 & 0.002 & 0.20 & 0.01 & 0.20 \\
\hline$M \mathrm{ML}^{\mathrm{b}}(\mathrm{mg} / \mathrm{L})$ & 0.05 & 2.0 & 0.005 & $\mathrm{NE}^{\mathrm{c}}$ & 0.10 & NE & 0.05 & NE & NE & 0.002 & $\mathrm{NE}$ & 0.05 & NE & NE & NE \\
\hline Site & \multicolumn{15}{|c|}{ All results in $\mathrm{mg} / \mathrm{L}$. } \\
\hline Burn Site Well & $N D^{d}$ & 0.05 & ND & 110 & ND & 0.11 & ND & 39 & ND & ND & 3.8 & ND & 4.7 & ND & 25 \\
\hline Coyote Spring & $\begin{array}{c}0.006 \\
(0.005)\end{array}$ & 0.04 & ND & 270 & ND & 0.90 & ND & 61 & 1.4 & ND & 28 & ND & 8.4 & ND & $\begin{array}{l}200 \\
2.0\end{array}$ \\
\hline CWL-BW2 Well & ND & 0.06 & ND & 120 & 0.26 & 4.6 & ND & 29 & 0.044 & ND & 6.6 & ND & $N^{e}$ & ND & 84 \\
\hline EOD Hill Well & $\begin{array}{c}0.030 \\
(0.005)\end{array}$ & 0.17 & ND & $\begin{array}{r}550 \\
(2.0)\end{array}$ & ND & 18 & ND & 110 & 0.78 & ND & 39 & ND & 23 & ND & $\begin{array}{l}420 \\
(2.0)\end{array}$ \\
\hline $\begin{array}{l}\text { EOD Hill Well } \\
\text { (duplicate) }\end{array}$ & $\begin{array}{c}0.030 \\
(0.010)\end{array}$ & 0.17 & ND & $\begin{array}{r}580 \\
(2.0)\end{array}$ & ND & 18 & ND & 110 & 0.79 & ND & 40 & ND & 24 & ND & $\begin{array}{l}440 \\
(2.0)\end{array}$ \\
\hline $\begin{array}{l}\text { Golf Course South } \\
\text { Well }\end{array}$ & ND & 0.19 & ND & 88 & ND & ND & ND & 17 & ND & ND & 2.4 & 0.005 & 13 & ND & 21 \\
\hline Greystone Manor Well & ND & 0.09 & ND & 110 & ND & 3.5 & ND & 25 & 0.13 & ND & 4.6 & ND & 13 & ND & 64 \\
\hline Hubbell Spring & 0.003 & 0.03 & ND & 85 & ND & ND & ND & 33 & ND & ND & 1.2 & 0.003 & 14 & ND & 57 \\
\hline KAFB-10 Well & ND & 0.14 & $* 0.029$ & 27 & ND & 1.6 & 0.23 & 11 & 0.033 & ND & 6.0 & ND & 1.5 & ND & 70 \\
\hline LF/DM-1 Well & ND & 0.11 & ND & 30 & ND & 0.03 & ND & 4.7 & ND & ND & 2.1 & ND & 17 & ND & 18 \\
\hline LF/DM-2 Well & ND & 0.05 & ND & 66 & ND & 0.12 & ND & 12 & ND & ND & 2.1 & ND & 14 & ND & 22 \\
\hline MVMW-J Well & ND & $\cdot 2.2$ & ND & 47 & ND & 1.3 & ND & 5.5 & 0.044 & ND & 5.8 & ND & 24 & ND & 27 \\
\hline MVMW-K Well & ND & $\cdot 2.1$ & ND & 59 & ND & 2.4 & ND & 6.5 & 0.071 & ND & 5.0 & ND & 19 & ND & 29 \\
\hline $\begin{array}{l}\text { MVMW-K Well } \\
\text { (duplicate) }\end{array}$ & ND & 1.7 & ND & 53 & ND & 1.6 & ND & 5.8 & 0.047 & ND & 4.3 & 0.003 & 18 & ND & 27 \\
\hline MWL-BW1 Well & ND & 0.08 & ND & 55 & ND & 0.03 & ND & 20 & ND & NS $^{\prime}$ & 3.3 & ND & NA & ND & 52 \\
\hline NW-TA3 Well & ND & 0.07 & ND & 60 & ND & ND & ND & 15 & ND & ND & 4.4 & ND & NA & ND & 21 \\
\hline Schoolhouse Well & ND & 0.11 & ND & 140 & ND & 1.6 & ND & 25 & 0.054 & ND & 6.0 & ND & 9.6 & ND & 90 \\
\hline
\end{tabular}

Refer to footnotes at end of table. 
Table K-7d. (Concluded)

Summary of Analytical Results for Total Metals

SNL/NM Basewide Groundwater Surveillance, December 1993

\begin{tabular}{|c|c|c|c|c|c|c|c|c|c|c|c|c|c|c|c|}
\hline Analyte & Arsenic & $\begin{array}{c}\text { Bariu } \\
\text { m }\end{array}$ & Cadmium & Calcium & Chromium & Iron & Lead & $\begin{array}{c}\text { Magnesiu } \\
\mathrm{m}\end{array}$ & Manganese & Mercury & Potassium & Selenium & Silicon & Silver & Sodium \\
\hline$M D L^{a}(m g / L)$ & 0.002 & 0.02 & 0.005 & 0.20 & 0.02 & 0.02 & 0.04 & 0.20 & 0.005 & 0.0002 & 0.20 & 0.002 & 0.20 & 0.01 & 0.20 \\
\hline$M C L^{b}(\mathrm{mg} / \mathrm{L})$ & 0.05 & 2.0 & 0.005 & $N E^{c}$ & 0.10 & $N E$ & 0.05 & $\mathrm{NE}$ & NE & 0.002 & NE & 0.05 & NE & $\mathrm{NE}$ & NE \\
\hline Site & \multicolumn{15}{|c|}{ All results in $\mathrm{mg} / \mathrm{L}$. } \\
\hline Sol se Mete Spring & ND & 0.07 & ND & 100 & ND & ND & ND & 17 & ND & ND & 1.6 & 0.004 & 8.8 & ND & 11 \\
\hline South Fence Well \#1 & ND & 0.07 & ND & 150 & ND & ND & ND & 35 & ND & ND & 7.1 & ND & 1.6 & ND & 77 \\
\hline South Fence Well \#2 & 0.006 & 0.06 & ND & 120 & 0.03 & 0.40 & ND & 33 & ND & ND & 6.7 & ND & 14 & ND & 74 \\
\hline South Fence Well $\sharp 3 P$ & 0.007 & 0.07 & ND & 120 & 0.09 & 3.6 & ND & 29 & 0.11 & ND & 5.0 & ND & 15 & ND & $\begin{array}{c}92 \\
(2.0)\end{array}$ \\
\hline South Fence Well \#3T & 0.002 & ND & ND & 450 & ND & 0.02 & ND & 41 & 0.17 & ND & 5.3 & ND & 5.3 & ND & $\begin{array}{l}500 \\
(2.0)\end{array}$ \\
\hline SW-TA3 Well & ND & 0.08 & ND & 41 & 0.07 & 1.6 & ND & 11 & 0.026 & ND & 5.3 & ND & NA & ND & 61 \\
\hline Tijeras East Well & ND & 0.04 & ND & 80 & ND & 0.02 & ND & 11 & ND & ND & 1.8 & ND & 12 & ND & 27 \\
\hline $\begin{array}{l}\text { Equipment Blank \#1 } \\
\text { (pump) }\end{array}$ & ND & NA & ND & ND & NA & ND & ND & NA & ND & ND & NA & ND & NA & ND & 0.23 \\
\hline $\begin{array}{l}\text { Equipment Blank \#2 } \\
\text { (pump) }\end{array}$ & ND & NA & NO & NO & NA & ND & ND & NA & ND & ND & NA & ND & NA & ND & 0.38 \\
\hline $\begin{array}{l}\text { Equipment Blank \#3 } \\
\text { (pump) }\end{array}$ & ND & NA & ND & ND & NA & ND & ND & NA & ND & ND & NA & ND & NA & ND & ND \\
\hline $\begin{array}{l}\text { Equipment Blank \#4 } \\
\text { (bailer) }\end{array}$ & ND & NA & ND & ND & NA & ND & ND & NA & ND & ND & NA & No & NA & ND & 0.20 \\
\hline $\begin{array}{l}{ }^{2} \mathrm{MDL}=\text { Minimum meth } \\
\mathrm{b}_{\mathrm{MCL}}=\text { Maximum cont } \\
\mathrm{c}_{\mathrm{NE}}=\mathrm{MCL} \text { not establis } \\
\mathrm{d}_{\mathrm{ND}}=\text { Not detected at } \\
{ }^{\mathrm{O}} \mathrm{NA}=\text { Not analyzed. } \\
\text { 'NS }=\text { Not sampled. } \\
\text { - Indicates value above }\end{array}$ & $\begin{array}{l}\text { detectio } \\
\text { ninant lev } \\
\text { d. } \\
\text { IDL indicat } \\
\text { MCL. }\end{array}$ & $\begin{array}{l}\text { nit obta } \\
\text { establis }\end{array}$ & $\begin{array}{l}d \text { for nond } \\
\text { by the U }\end{array}$ & $\begin{array}{l}\text { cted part } \\
\text { Environm }\end{array}$ & $\begin{array}{l}\text { ters. } \\
\text { tal Protecti }\end{array}$ & Agenc & PAI P & Drinking & ter Regula & LPOW & 10 CFR 1 & & & & \\
\hline
\end{tabular}




\section{Table K-8a.}

Summary of Analytical Results for Coliform Bacteria SNL/NM Basewide Groundwater Surveillance, April 1993

\begin{tabular}{|c|c|c|c|}
\hline Sample Site & Sample Number & Total Coliform Bacteria & Fecal Coliform Bacteria \\
\hline Burn Site Well & BSW0012073 & $A^{a}$ & $A$ \\
\hline Coyote Spring & CYS0012074 & $4 \mathrm{col} / 100 \mathrm{~mL}^{\mathrm{b}}$ & A \\
\hline CWL-BW2 & CB20012075 & A & $A$ \\
\hline EOD Hill Well & EOD0012076 & A & $A$ \\
\hline $\begin{array}{l}\text { EOD Hill Well } \\
\text { (duplicate) }\end{array}$ & HILO012179 & $7 \mathrm{col} / 100 \mathrm{~mL}^{\mathrm{b}}$ & A \\
\hline Golf Course South Well & GCS0012077 & A & $A$ \\
\hline Greystone Manor Well & GSM0012078 & $A$ & A \\
\hline Hubbell Spring & HBL0012079 & Present $^{c}$ & Present \\
\hline KAFB-10 Well & K100012080 & A & A \\
\hline LF/DM-01 Well & Not Sampled & Not Sampled & Not Sampled \\
\hline LF/DM-02 Well & LF20012082 & A & A \\
\hline MVMW-J Well & MVJ0012083 & $A$ & $A$ \\
\hline MVMW-K Well & MVK0012084 & A & $A$ \\
\hline MWL-BW1 & MB10012085 & A & A \\
\hline NW-TA3 Well & NW30012086 & A & $A$ \\
\hline Schoolhouse Well & SCHOO12O87 & A & A \\
\hline Sol se Mete Spring & SSM0012088 & $A$ & $A$ \\
\hline South Fence Well \#1 & SF10012138 & Present & A \\
\hline South Fence Well \#2 & SF20012137 & Present & A \\
\hline SW-TA3 Well & SW30012089 & A & A \\
\hline Tijeras East Well & TJE0012090 & A & $A$ \\
\hline $\begin{array}{l}{ }^{a} A-=\text { Absent. } \\
b_{4} \text { and } 7 \text { are the number } 0 \\
{ }^{c} \text { Present }=\text { Bacteria prese }\end{array}$ & $\begin{array}{r}\text { ies counted per } 1 \\
\text { no specific count }\end{array}$ & & \\
\hline
\end{tabular}


Table K-8b.

Summary of Analytical Results for Coliform Bacteria SNL/NM Basewide Groundwater Surveillance, September 1993

\begin{tabular}{|c|c|c|c|}
\hline Sample Site & Sample Number & Total Coliform Bacteria & Fecal Coliform Bacteria \\
\hline Burn Site Well & SNLA013491 & $A^{a}$ & $A$ \\
\hline Coyote Spring & COYS013490 & Present $^{b}$ & A \\
\hline CWL-BW2 & CB2013474 & $A$ & A \\
\hline EOD Hill & EOD013478 & $A$ & $A$ \\
\hline EOD Hill duplicate & DOE013477 & Present & A \\
\hline Golf Course South & GCS013470 & Present & $A$ \\
\hline Greystone Manor & GRYS013487 & Present & $A$ \\
\hline Hubbell Spring & HUBS013488 & Present & Present \\
\hline KAFB-10 & K10013480 & A & $A$ \\
\hline LF/DM-01 & LF10013476 & Present & $A$ \\
\hline LF/DM-02 & LF2013471 & Present & $A$ \\
\hline MVMW-J & MVJ013484 & Present & $A$ \\
\hline MVMW-K & MVK013485 & Present & $A$ \\
\hline MWL-BW1 & Not Sampled & Not Sampled & Not Sampled \\
\hline NW-TA3 & NW3013479 & Present & $A$ \\
\hline Schoolhouse & SCLH013486 & A & A \\
\hline Sol se Mete Spring & SSMS013489 & Present & A \\
\hline South Fence Well \#1 & SF1013473 & Present & $A$ \\
\hline South Fence Well \#2 & SF2013482 & Rejected $^{c}$ & Rejected \\
\hline SW-TA3 & SW3013483 & A & A \\
\hline Tijeras East & TJE013469 & Present & A \\
\hline Bailer Equipment Blank & EBBO 13481 & $A$ & A \\
\hline Pump Equipment Blank \#1 & EBP013475 & Present & $A$ \\
\hline Pump Equipment Blank \#2 & EB013472 & Present & A \\
\hline \multicolumn{4}{|c|}{$\begin{array}{l}\text { a } \mathrm{A}=\text { Absent. } \\
{ }^{\mathrm{b}} \text { Present }=\text { Bacteria present, but no specific count specified. } \\
\text { "Sample rejected by laboratory because of confluent bacteria growth; coliform determination could not } \\
\text { be made. }\end{array}$} \\
\hline
\end{tabular}


Table K-9a.

Summary of Results of Unfiltered Radionuclide Screen SNL/NM Basewide Groundwater Surveillance, April 1993

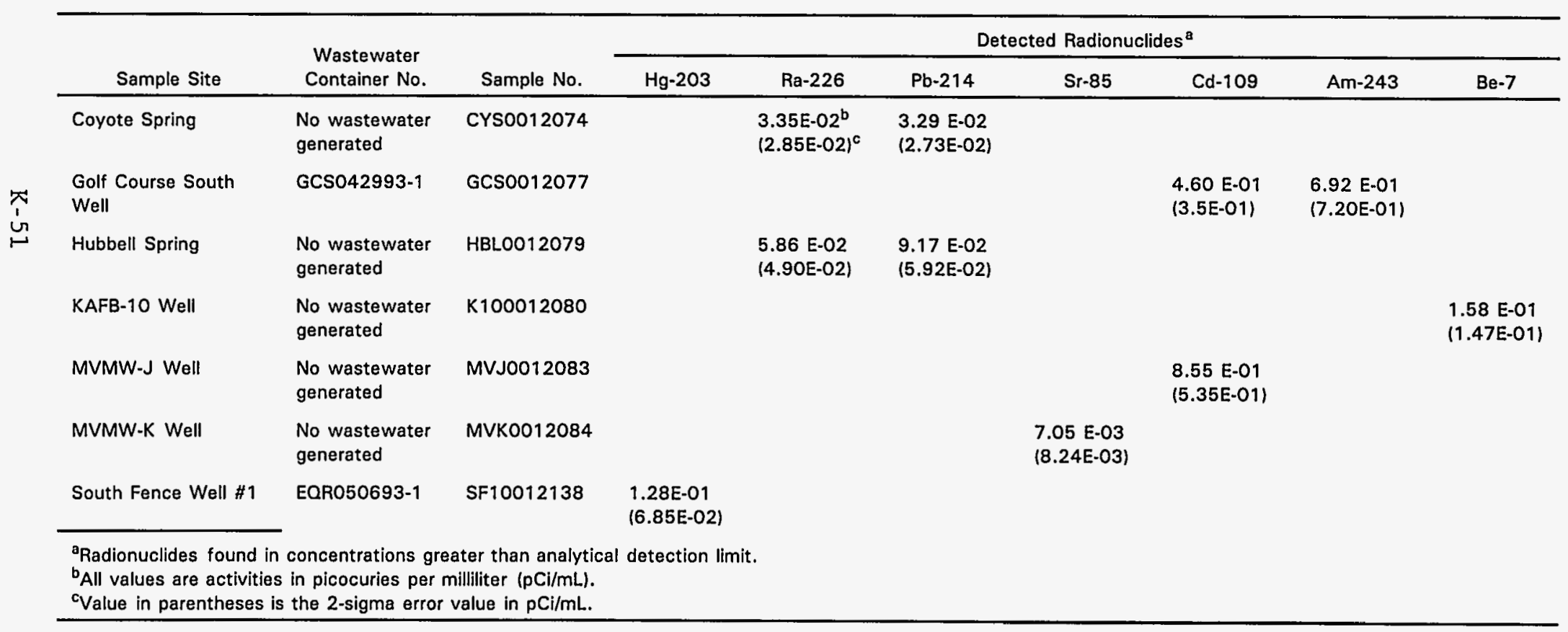


Table K-9b.

Summary of Results of Unfiltered Radionuclide Screen

SNL/NM Basewide Groundwater Surveillance, July 1993

\begin{tabular}{|c|c|c|c|c|}
\hline \multirow[b]{2}{*}{ Sample Site } & \multirow[b]{2}{*}{ Wastewater Container No. } & \multirow[b]{2}{*}{ Sample No. } & \multicolumn{2}{|c|}{ Detected Radionuclides $^{\mathrm{a}}$} \\
\hline & & & $K-40$ & Th-230 \\
\hline Coyote Spring & No wastewater generated & CYS0012954 & & $\begin{array}{l}7.74 \mathrm{E}+00^{b} \\
(7.91 \mathrm{E}+00)^{c}\end{array}$ \\
\hline Golf Course South Well & $\begin{array}{l}\text { GCS072793-1 } \\
\text { GCS072793-2 }\end{array}$ & GCS0012958 & $\begin{array}{c}2.51 \mathrm{E}-01 \\
(2.72 \mathrm{E}-01)\end{array}$ & \\
\hline Schoolhouse Well & SCH072493-1 & SCHOO12969 & $\begin{array}{c}3.64 \mathrm{E}-01 \\
(3.02 \mathrm{E}-01)\end{array}$ & \\
\hline South Fence Well \#1 & SFR1072993-1 & SFR10013500 & & $\begin{array}{c}6.82 E+00 \\
(8.04 E+00)\end{array}$ \\
\hline $\begin{array}{l}{ }^{a} \text { Radionuclides found in } \\
{ }^{b} \text { All values are activities } \\
\text { Value in parentheses is }\end{array}$ & $\begin{array}{l}\text { ations greater than the anal } \\
\text { uries per milliliter }(\mathrm{pCi} / \mathrm{mL} \text { ). } \\
\text { gma error value in } \mathrm{pCi} / \mathrm{mL} \text {. }\end{array}$ & detection limit. & & \\
\hline
\end{tabular}


Table K-9c.

Summary of Results of Unfiltered Radionuclide Screen

SNL/NM Basewide Groundwater Surveillance, September 1993

\begin{tabular}{|c|c|c|c|c|c|c|c|c|c|c|c|}
\hline \multirow[b]{2}{*}{ Sample Site } & \multirow{2}{*}{$\begin{array}{c}\text { Wastewater Container } \\
\text { No. } \\
\end{array}$} & \multirow[b]{2}{*}{ Sample No. } & \multicolumn{9}{|c|}{ Detected Radionuclides ${ }^{\mathrm{a}}$} \\
\hline & & & $\mathrm{Ba}-140$ & $\mathrm{Bi}-207$ & $B i-214$ & $k-40$ & $\mathrm{Na}-24$ & $\mathrm{~Pb}-212$ & $\mathrm{~Pb}-214$ & Ra-226 & Th-228 \\
\hline Burn Site Well & $\begin{array}{l}\text { No wastewater } \\
\text { generated }\end{array}$ & SNLA013491 & & & & $\begin{array}{l}2.40 \mathrm{E}-01^{\mathrm{b}} \\
(2.94 \mathrm{E}-01)^{\mathrm{c}}\end{array}$ & & & & & \\
\hline CWL-BW2 & $\begin{array}{l}\text { CWL-BW2093093-1 } \\
\text { CWL-BW2093093-2 }\end{array}$ & СВ2013474 & & $\begin{array}{c}3.23 E-02 \\
(2.53 E-02\rangle\end{array}$ & & $\begin{array}{c}2.61 \mathrm{E}-01 \\
(3.47 \mathrm{E}-01)\end{array}$ & & & & $\begin{array}{c}6.26 \mathrm{E}-02 \\
(4.51 \mathrm{E}-02)\end{array}$ & \\
\hline $\begin{array}{l}\text { Golf Course } \\
\text { South Well }\end{array}$ & $\begin{array}{l}\text { GCS100693-1 } \\
\text { GCS100693-2 } \\
\text { GCS100693-3 }\end{array}$ & GCS013470 & & & & $\begin{array}{c}2.34 \mathrm{E}-01 \\
(2.88 \mathrm{E}-01)\end{array}$ & & & & & \\
\hline $\begin{array}{l}\text { Greystone Manor } \\
\text { Well }\end{array}$ & GSM090993. 1 & GRYS013487 & & & $\begin{array}{c}4.98 \mathrm{E}-02 \\
(4.36 \mathrm{E}-02)\end{array}$ & & & & & $\begin{array}{c}4.76 \mathrm{E}-02 \\
(4.17 \mathrm{E}-02)\end{array}$ & \\
\hline Hubbell Spring & $\begin{array}{l}\text { No wastewater } \\
\text { generated }\end{array}$ & HUBS013488 & & & $\begin{array}{c}1.88 \mathrm{E}-01 \\
(6.04 \mathrm{E}-02)\end{array}$ & & & & $\begin{array}{c}1.65 \mathrm{E}-01 \\
(6.27 \mathrm{E}-02)\end{array}$ & $\begin{array}{c}1.80 \mathrm{E}-01 \\
(5.78 \mathrm{E}-02)\end{array}$ & \\
\hline LF/DM-02 Well & $\begin{array}{l}\text { LFDM2100593-1 } \\
\text { LFDM2100593-2 }\end{array}$ & LF2013471 & & & $\begin{array}{c}8.21 \mathrm{E}-02 \\
(5.27 \mathrm{E}-02)\end{array}$ & $\begin{array}{c}3.67 \mathrm{E}-01 \\
(2.96 \mathrm{E}-01)\end{array}$ & & & & $\begin{array}{c}7.85 \mathrm{E}-02 \\
(5.04 \mathrm{E}-02)\end{array}$ & \\
\hline MVMW-J Well & MVMW-J, K091493-1 & MVJ013484 & & & $\begin{array}{c}8.06 \mathrm{E}-02 \\
\langle 5.60 \mathrm{E}-02\rangle\end{array}$ & & & & & $\begin{array}{c}7.71 \mathrm{E}-02 \\
(5.36 \mathrm{E}-02)\end{array}$ & \\
\hline MVMW-K Well & MVMW-J,K091493-1 & MVK013485 & & & & $\begin{array}{c}2.80 \mathrm{E}-01 \\
(3.13 \mathrm{E}-01)\end{array}$ & & & & & \\
\hline NW-TA3 Well & $\begin{array}{l}\text { NWTA3092793-1 } \\
\text { NWTA3092793-2 }\end{array}$ & NW3013479 & & & $\begin{array}{c}2.06 \mathrm{E}-01 \\
(6.35 \mathrm{E}-02)\end{array}$ & & & $\begin{array}{c}5.82 E-02 \\
(4.45 E-02)\end{array}$ & $\begin{array}{c}2.19 \mathrm{E}-01 \\
(5.18 \mathrm{E}-02)\end{array}$ & $\begin{array}{c}1.97 \mathrm{E}-01 \\
(6.07 \mathrm{E}-02)\end{array}$ & $\begin{array}{r}5.79 \mathrm{E}-02 \\
(4.43 \mathrm{E}-02)\end{array}$ \\
\hline Schoolhouse Well & SCH091393-1 & SCLHO13486 & & & $\begin{array}{c}7.02 \mathrm{E}-02 \\
(4.72 \mathrm{E}-02)\end{array}$ & & & & & $\begin{array}{c}6.71 E-02 \\
(4.51 E-02)\end{array}$ & \\
\hline $\begin{array}{l}\text { Sol se Mete } \\
\text { Spring }\end{array}$ & $\begin{array}{l}\text { No wastewater } \\
\text { generated }\end{array}$ & SSMSO13489 & & & & & & & & $\begin{array}{c}1.00 \mathrm{E}-01 \\
(5.02 \mathrm{E}-02)\end{array}$ & \\
\hline $\begin{array}{l}\text { South Fence Well } \\
\# 1\end{array}$ & $\begin{array}{l}\text { SFR1 100493-1 } \\
\text { SFR1 100493-2 }\end{array}$ & SF1013473 & & & & $\begin{array}{c}2.88 \mathrm{E}-01 \\
(3.51 \mathrm{E}-01)\end{array}$ & & & & $\begin{array}{c}4.40 \mathrm{E}-02 \\
(3.79 \mathrm{E}-02)\end{array}$ & \\
\hline
\end{tabular}

Refer to footnotes at end of table. 
Table K-9c. (Concluded)

Summary of Results of Unfiltered Radionuclide Screen

SNL/NM Basewide Groundwater Surveillance, September 1993

\begin{tabular}{|c|c|c|c|c|c|c|c|c|c|c|c|}
\hline \multirow[b]{2}{*}{ Sample Site } & \multirow{2}{*}{$\begin{array}{c}\text { Wastewater Container } \\
\text { No. }\end{array}$} & \multirow[b]{2}{*}{ Sample No. } & \multicolumn{9}{|c|}{ Detected Radionuclides ${ }^{\mathrm{a}}$} \\
\hline & & & Ba-140 & $\mathrm{Bi}-207$ & $\mathrm{Bi}-214$ & $k-40$ & $\mathrm{Na}-24$ & $\mathrm{~Pb}-212$ & $\mathrm{~Pb}-214$ & Ra-226 & Th-228 \\
\hline Tijeras East Well & $\begin{array}{l}\text { TJE100793-1 } \\
\text { TJE100793-2 }\end{array}$ & TJE013469 & & & & $\begin{array}{c}5.89 \mathrm{E}-01 \\
(3.24 \mathrm{E}-01)\end{array}$ & & & & $\begin{array}{c}8.64 \mathrm{E}-02 \\
(5.50 \mathrm{E}-02)\end{array}$ & \\
\hline $\begin{array}{l}\text { Pump Equipment } \\
\text { Blank } \# 1\end{array}$ & EOD092893-3 & EBP013475 & & & & & $\begin{array}{c}3.89 E-02 \\
(3.64 E-02)\end{array}$ & & & & \\
\hline $\begin{array}{l}\text { Pump Equipment } \\
\text { Blank } \# 2\end{array}$ & SFR1100493-2 & EB013472 & $\begin{array}{c}1.11 \mathrm{E}-01 \\
(8.05 \mathrm{E}-02)\end{array}$ & & & & & & & & \\
\hline $\begin{array}{l}\text { a } \text { Radionuclides fou } \\
\text { bAll values are act } \\
\text { c Value in parenthe }\end{array}$ & $\begin{array}{l}\text { in concentrations great } \\
\text { ties in picocuries per mill } \\
\text { s is the 2-sigma error va }\end{array}$ & $\begin{array}{l}r \text { than analytic } \\
\text { liter }(\mathrm{pCi} / \mathrm{mL}) \text {. } \\
\text { ue in } \mathrm{pCi} / \mathrm{mL} \text {. }\end{array}$ & letection limi & & & & & & & & \\
\hline
\end{tabular}


Table K-9d.

Summary of Results of Unfiltered Radionuclide Screen

SNL/NM Basewide Groundwater Surveillance, December 1993

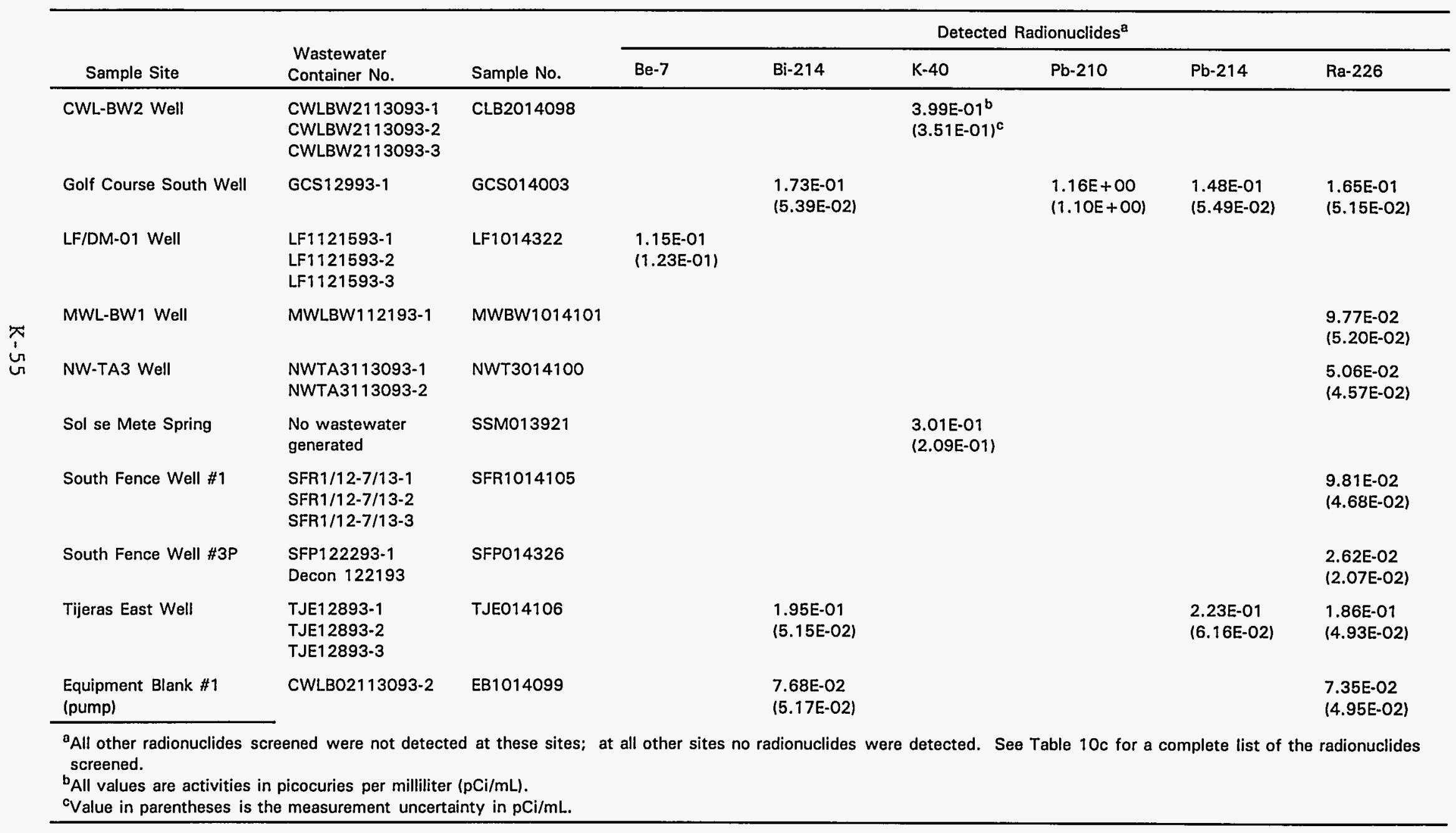


Table K-10.

Summary of Results for Radionuclide Surveillance Data, September 1993 (values in $\mathrm{pCi} / \mathrm{L}$ )

\begin{tabular}{|c|c|c|c|c|c|c|c|c|c|}
\hline & & Burn Site Well & Coyote Spring & $\begin{array}{l}\text { Sol se Mete } \\
\text { Spring }\end{array}$ & Hubbell Spring & Greystone Well & $\begin{array}{c}\text { Schoolhouse } \\
\text { Well }\end{array}$ & MVMW-K Well & MVMW-J Well \\
\hline & Sample No. & $\begin{array}{c}\text { BSW } \\
013491-11\end{array}$ & $\begin{array}{c}\text { COYS } \\
013490-11\end{array}$ & $\begin{array}{c}\text { SSMS } \\
013489-11\end{array}$ & $\begin{array}{c}\text { HUBS } \\
013488-11\end{array}$ & $\begin{array}{c}\text { GRYS } \\
013487-11\end{array}$ & $\begin{array}{c}\text { SCLH } \\
013486-11\end{array}$ & $\begin{array}{c}\text { MVK } \\
013485-11\end{array}$ & $\begin{array}{c}\text { MVJ1 } \\
03484-11\end{array}$ \\
\hline Gross Measurements & $\begin{array}{l}\text { Gross Alpha } \\
\text { Gross Beta }\end{array}$ & $\begin{array}{l}4.9 \pm 3.0^{\mathrm{a}} \\
5.3 \pm 2.7^{\mathrm{a}}\end{array}$ & $\begin{array}{l}9.8 \pm 5.2 \\
21 \pm 4.5\end{array}$ & $\begin{array}{c}5.3 \pm 2.7 \\
4.4 \pm 2.3^{\mathrm{a}}\end{array}$ & $\begin{array}{c}8.4 \pm 4.3 \\
1.6 \pm 2.3^{\mathrm{a}}\end{array}$ & $\begin{array}{l}11 \pm 4.8 \\
7.7 \pm 2.9\end{array}$ & $\begin{array}{c}42 \pm 12 \\
32 \pm 6.1\end{array}$ & $\begin{array}{l}7.1 \pm 3.2 \\
9.7 \pm 2.8\end{array}$ & $\begin{array}{l}13 \pm 4.9 \\
13 \pm 3.4\end{array}$ \\
\hline \multirow[t]{10}{*}{ Isotopic Analyses } & Pu-238 & $\mathrm{U}(0.057)$ & $U(0.020)^{a}$ & $\mathrm{U}(0.11)$ & $0.28 \pm 0.14$ & $U(0.043)$ & $0.049 \pm 0.034^{a}$ & $\mathrm{U}(0.042)^{\mathrm{a}}$ & $0.059 \pm 0.040^{a}$ \\
\hline & Pu-239/240 & $\mathrm{U}(0.049)$ & $U(0.045)$ & $U(0.12)$ & $U(0.13)^{a}$ & $U(0.037)$ & $U(0.040)$ & $0.055 \pm 0.038^{a}$ & $U(0.051)$ \\
\hline & U-233/234 & $3.9 \pm 0.45$ & $11 \pm 1.2$ & $3.6 \pm 0.43$ & $7.0 \pm 0.78$ & $4.2 \pm 0.52$ & $8.2 \pm 0.87$ & $1.2 \pm 0.22$ & $0.87 \pm 0.19$ \\
\hline & U-235 & $0.097 \pm 0.046$ & $0.089 \pm 0.046$ & $0.058 \pm 0.038$ & $0.073 \pm 0.044$ & $0.034 \pm 0.03^{a}$ & $0.14 \pm 0.06$ & $0.036 \pm 0.032^{a}$ & $0.040 \pm 0.036^{\mathrm{a}}$ \\
\hline & U-238 & $1.1 \pm 0.19$ & $2.3 \pm 0.31$ & $1.3 \pm 0.21$ & $1.8 \pm 0.27$ & $1.1 \pm 0.20$ & $2.2 \pm 0.30$ & $0.83 \pm 0.17$ & $0.63 \pm 0.16$ \\
\hline & Th-230 & $0.034 \pm 0.03$ & $U(0.032)$ & $U(0.10)$ & $U(0.14)$ & $0.11 \pm 0.052$ & $0.028 \pm 0.032^{\mathrm{a}}$ & $0.61 \pm 0.15$ & $0.43 \pm 0.13$ \\
\hline & Th-232 & $U(0.018)^{a}$ & $0.016 \pm 0.018^{a}$ & $U(0.038)$ & $U(0.16)$ & $0.079 \pm 0.048$ & $0.028 \pm 0.032^{a}$ & $0.46 \pm 0.13$ & $0.58 \pm 0.15$ \\
\hline & $\mathrm{Sr}-90$ & $U(2.2)$ & $U(1.4)$ & $U(1.7)$ & $U(3.2)$ & $U(2.1)$ & $U(6.5)$ & $U(3.1)$ & $U(3.2)$ \\
\hline & $\mathrm{Ra}-228$ & $4.3 \pm 3.6^{\mathrm{B}}$ & $U(4.5)^{\mathrm{a}}$ & $U(2.3)$ & $U(5.1)$ & $U(2.4)^{\mathrm{a}}$ & $U(2.5)$ & $U(3.0)$ & $U(3.1)$ \\
\hline & $\mathrm{Ra}-226$ & U(0.21) & $U(0.19)$ & $U(0.25)$ & $U(0.15)$ & $U(0.25)$ & $0.36 \pm 0.17$ & $0.47 \pm 0.19$ & $0.55 \pm 0.14$ \\
\hline \multirow[t]{5}{*}{ Gamma Spectrometry } & Co.60 & $U(27)$ & $U(27)$ & $U(26)$ & $U(26)$ & $U(24)$ & $U(23)$ & $U(28)$ & $U(27)$ \\
\hline & Cs-137 & $U(21)$ & $U(25)$ & $U(22)$ & $U(22)$ & $U(22)$ & $U(23)$ & $U(24)$ & $U(21)$ \\
\hline & $K-40$ & $U(470)^{a}$ & $U(720)$ & $U(690)$ & $U(690)$ & $U(680)$ & $U(710)$ & $U(750)$ & $U(760)$ \\
\hline & $\mathrm{Ra}-226$ & $U(49)$ & $U(41)$ & $U(44)$ & $U(49)$ & $U(37)$ & $U(43)$ & $\mathrm{U}(47)$ & $U(39)$ \\
\hline & $\mathrm{Ra}-228$ & $U(110)$ & U(99) & $U(110)$ & $U(100)$ & $U(85)$ & $U(100)$ & U(99) & $U(100)$ \\
\hline
\end{tabular}

Refer to footnotes at end of table. 
Table K-10. (Continued)

Summary of Results for Radionuclide Surveillance Data, September 1993 (values in $\mathrm{pCi} / \mathrm{L}$ )

\begin{tabular}{|c|c|c|c|c|c|c|c|c|c|}
\hline & & $\begin{array}{l}\text { South Fence } \\
\text { Well } \# 2\end{array}$ & $\begin{array}{l}\text { Equipment Blank } \\
\# 1\end{array}$ & KAFB-10 Well & NW-TA3 Well & EOD Hill Well & $\begin{array}{l}\text { EOD Hill Well } \\
\text { (duplicate) }\end{array}$ & $\begin{array}{l}\text { Equipment Blank } \\
\qquad \# 2\end{array}$ & LF/DM-01 Well \\
\hline & Sample No. & $\begin{array}{c}S F 2 \\
013482-11\end{array}$ & $\begin{array}{c}\text { EBBS } \\
013481-11\end{array}$ & $\begin{array}{c}K 10 \\
013480-11\end{array}$ & $\begin{array}{c}\text { NW3 } \\
013479-11\end{array}$ & $\begin{array}{c}\text { EOD } \\
013478-11\end{array}$ & $\begin{array}{c}\text { DOE } \\
013477-11\end{array}$ & $\begin{array}{c}\text { EBPO } \\
01347-11\end{array}$ & $\begin{array}{c}\text { LF10 } \\
013476-11\end{array}$ \\
\hline Gross Measurements & $\begin{array}{l}\text { Gross Alpha } \\
\text { Gross Beta }\end{array}$ & $\begin{array}{l}36 \pm 11 \\
20 \pm 4.4\end{array}$ & $\begin{array}{l}U(1.1) \\
U(3.8)\end{array}$ & $\begin{array}{c}4.2 \pm 3.1^{\mathrm{a}} \\
8.1 \pm 3.0\end{array}$ & $\begin{array}{l}3.7 \pm 2.1 \\
8.1 \pm 2.8\end{array}$ & $\begin{array}{l}38 \pm 12 \\
44 \pm 7.8\end{array}$ & $\begin{array}{l}34 \pm 12 \\
41 \pm 7.5\end{array}$ & $\begin{array}{l}U(1.5) \\
U(3.7)\end{array}$ & $\begin{array}{c}1.9 \pm 1.6 \\
U(4.0)\end{array}$ \\
\hline \multirow[t]{10}{*}{ Isotopic Analyses } & Pu-238 & $0.080 \pm 0.040$ & $U(0.021)^{\mathrm{a}}$ & $U(0.074)$ & $U(0.056)$ & $\mathrm{U}(0.058)^{\mathrm{a}}$ & $\mathrm{U}(0.060)^{\mathrm{a}}$ & $U(0.064)$ & $U(0.031)$ \\
\hline & Pu-239/240 & $U(0.044)$ & $0.012 \pm .012^{\mathrm{a}}$ & $U(0.038)$ & $U(0.047)^{a}$ & $U(0.017)$ & U(0.23) & $U(0.042)$ & U(0.068) \\
\hline & $U-233 / 234$ & $19 \pm 2.0$ & $U(0.045)$ & $0.72 \pm 0.16$ & $3.1 \pm 0.42$ & $81 \pm 7.5$ & $83 \pm 8.8$ & $U(0.054)$ & $0.68 \pm 0.14$ \\
\hline & U.235 & $0.26 \pm 0.092$ & $U(0.038)$ & $U(0.020)^{\mathrm{a}}$ & $0.035 \pm 0.032^{a}$ & $0.37 \pm 0.10$ & $0.45 \pm 0.18$ & (U0.054) & $0.017 \pm 0.020^{a}$ \\
\hline & $U-238$ & $5.0 \pm 0.62$ & $U(0.052)$ & $0.23 \pm 0.084$ & $1.2 \pm 0.22$ & $8.9 \pm 0.93$ & $8.6 \pm 1.2$ & $U(0.082)$ & $0.33 \pm 0.092$ \\
\hline & Th-230 & $0.13 \pm 0.078$ & $U(0.075)$ & $0.033 \pm 0.026^{a}$ & $0.019 \pm 0.020^{\mathrm{a}}$ & $U(0.19)^{\mathrm{a}}$ & $U(0.021)^{a}$ & U(0.038) & $U(0.031)^{a}$ \\
\hline & Th.232 & $0.17 \pm 0.088$ & $U(0.055)$ & $\mathrm{U}(0.030)^{\mathrm{a}}$ & $U(0.029)$ & $U(0.019)$ & $U(0.046)$ & $U(0.014)^{a}$ & $U(0.014)$ \\
\hline & Sr-90 & $U(2.8)$ & $U(1.6)$ & $U(1.9)$ & $U(1.9)$ & $U(1.6)^{a}$ & $U(2.1)$ & $U(1.7)$ & $U(1.8)$ \\
\hline & Ra-228 & $U(6.6)$ & $U(1.5\rangle$ & $0.91 \pm 0.57^{\mathrm{a}}$ & $1.8 \pm 0.74$ & $4.0 \pm 0.97$ & $3.3 \pm 1.0$ & $U(1.0)$ & $U(0.85)$ \\
\hline & Ra-226 & $0.20 \pm .10^{\mathrm{B}}$ & $U(0.14)$ & $0.30 \pm 0.051^{b}$ & $0.19 \pm 0.048^{b}$ & $3.7 \pm 0.54^{b}$ & $3.5 \pm 0.49^{b}$ & $0.23 \pm 0.068^{b}$ & $0.17 \pm 0.038^{b}$ \\
\hline \multirow[t]{6}{*}{ Gamma Spectrometry } & $\mathrm{Co}_{0} 60$ & $U(24)$ & $U(24)$ & $U(26)$ & $U(25)$ & $U(21)$ & $U(25)$ & $U(22)$ & $U(237)$ \\
\hline & Cs-137 & $U(23)$ & $U(24)$ & $U(26)$ & $U(23)$ & $U(21)$ & $U(23)$ & $U(24)$ & $U(251)$ \\
\hline & $K \cdot 40$ & $U(740)^{a}$ & $U(760)$ & $U(620)$ & $U(670)$ & $U(650)$ & $U(680)$ & $U(660)$ & $U(640)$ \\
\hline & $R a-226$ & $U(49)$ & $U(51)$ & $U(47)$ & $U(44)$ & $U(49)$ & $U(51)$ & U(39) & $U(5139)$ \\
\hline & $\mathrm{Ra}-228$ & $U(90)$ & $U(92)$ & $U(96)$ & $U(94)$ & $U(93)$ & $U(100)$ & $U(100)$ & $U(100)$ \\
\hline & $67 \mathrm{KeV}$ & & & & & $43 \pm 27$ & & & \\
\hline
\end{tabular}

Refer to footnotes at end of table. 
Table K-10. (Concluded)

Summary of Results for Radionuclide Surveillance Data, September 1993

(values in $\mathrm{pCi} / \mathrm{L}$ )

\begin{tabular}{|c|c|c|c|c|c|c|c|}
\hline & & $\begin{array}{l}\text { CWL-BW2 } \\
\text { Well }\end{array}$ & $\begin{array}{l}\text { South Fence } \\
\text { Well \#1 }\end{array}$ & $\begin{array}{l}\text { Equipment } \\
\text { Blank } \# 2\end{array}$ & $\begin{array}{l}\text { LF/DM-02 } \\
\text { Well }\end{array}$ & $\begin{array}{l}\text { Golf Course } \\
\text { South Well }\end{array}$ & $\begin{array}{l}\text { Tijeras East } \\
\text { Well }\end{array}$ \\
\hline & Sample No. & $\begin{array}{l}\text { CB2 } \\
013474-11\end{array}$ & $\begin{array}{c}\text { SF1 } \\
013473-11\end{array}$ & $\begin{array}{c}\text { EB2 } \\
013472-11\end{array}$ & $\begin{array}{l}\text { LF2 } \\
013471-11\end{array}$ & $\begin{array}{c}\text { GCS } \\
013470.11\end{array}$ & $\begin{array}{c}\text { TJE } \\
013469-11\end{array}$ \\
\hline Gross Measurements & $\begin{array}{l}\text { Gross Alpha } \\
\text { Gross Beta }\end{array}$ & $\begin{array}{l}17 \pm 6.1 \\
12 \pm 3.4\end{array}$ & $\begin{array}{l}20 \pm 6.8 \\
12 \pm 3.3\end{array}$ & $\begin{array}{l}U(1.5) \\
U(3.3)\end{array}$ & $\begin{array}{l}5.9 \pm 3.0 \\
6.0 \pm 2.8\end{array}$ & $\begin{array}{l}3.1 \pm 2.1^{a} \\
4.7 \pm 2.6^{a}\end{array}$ & $\begin{array}{l}4.8 \pm 2.4 \\
U(3.2)\end{array}$ \\
\hline \multirow[t]{10}{*}{ Isotopic Analyses } & Pu-238 & $U(0.32)$ & $0.38 \pm 0.12$ & $\mathrm{U}(0.020)^{\mathrm{a}}$ & $U(0.069\}$ & U0.24 $\pm 0.13^{a}$ & U(0.082) \\
\hline & Pu-239/240 & U(0.098) & $U(0.048)$ & $U(0.020)$ & $U(0.026)$ & U(0.011) & $U(0.060)$ \\
\hline & $U-233 / 234$ & $14 \pm 1.5$ & $16 \pm 1.8$ & $\mathrm{U}(0.063)^{\mathrm{a}}$ & $2.4 \pm 0.32$ & $2.1 \pm 0.35$ & $1.8 \pm 0.25$ \\
\hline & U.235 & $0.16 \pm 0.064$ & $0.098 \pm 0.058$ & $U(0.041)$ & $0.029 \pm 0.026^{\mathrm{a}}$ & $0.050 \pm 0.044^{a}$ & $0.046 \pm 0.032^{a}$ \\
\hline & $U-238$ & $3.5 \pm 0.44$ & $4.4 \pm 0.58$ & $U(0.063) 84$ & $1.2 \pm 0.20$ & $0.77 \pm 0.19$ & $0.84 \pm 0.16$ \\
\hline & Th-230 & $U(0.039)$ & $U(0.029)$ & $U(0.015)^{a}$ & $0.023 \pm 0.024^{a}$ & $U(0.060)$ & $U(0.034)$ \\
\hline & Th-232 & $U(0.013)$ & $U(0.029)$ & $U(0.034)$ & $U(0.016)^{a}$ & $U(0.027)$ & $U(0.013)^{a}$ \\
\hline & Sr-90 & $U(1.9)$ & $U(1.3)$ & $U(1.5)$ & $U(1.3)$ & $U(2.0)$ & $U(2.1)$ \\
\hline & $\mathrm{Ra}-228$ & $\mathrm{U}(0.93)^{\mathrm{a}}$ & $U(0.89)^{a}$ & $U(1.0)$ & $u(0.86)^{a}$ & $26 \pm 4.3$ & $1.0 \pm 0.64^{a}$ \\
\hline & Ra-226 & $0.26 \pm 0.054^{b}$ & $0.19 \pm 0.048^{b}$ & $0.22 \pm 0.050^{\mathrm{b}}$ & U $(0.050\}$ & $0.11 \pm 0.043^{b}$ & $0.28 \pm 0.089^{b}$ \\
\hline \multirow[t]{6}{*}{ Gamma Spectrometry } & $\mathrm{C} 0.60$ & $U(24)$ & $U(23)$ & $U(24)$ & $U(22)$ & $U(22)$ & $U(25)$ \\
\hline & Cs-137 & $U(25)$ & $\mathrm{U}(26)$ & $U(24)$ & $\mathrm{U}\{24\}$ & $U(26)$ & $\mathrm{U}(23)$ \\
\hline & $K-40$ & $U(470)$ & $U(670)$ & $U(650)$ & $U(460)$ & $U(650)$ & $U(650)$ \\
\hline & Ra-226 & $U(38)$ & $U(36)$ & $U(43)$ & $U(35)$ & $U(35)$ & $U(41)$ \\
\hline & Ra-228 & $U(100)$ & $U(98)$ & $U(100)$ & $U(97)$ & $U(100)$ & $U(100)$ \\
\hline & $67 \mathrm{KeV}$ & & & & & & \\
\hline \multicolumn{8}{|c|}{$\begin{array}{l}\text { a Measurement is within the measurement uncertainty of the minimal detectable activity (MDA). } \\
\text { bParameter detected in laboratory blank. } \\
\pm \text { indicates the measurement uncertainty of the specified measurement. } \\
U=\text { Isotope not detected; Value in parentheses is the associated MDA. }\end{array}$} \\
\hline
\end{tabular}


Table K-11.

Summary of Results of Tritium Analyses, SNL/NM Basewide Groundwater Surveillance, December 1993

\begin{tabular}{|c|c|c|c|c|}
\hline Site & Sample \# & Wastewater Container \# & $\begin{array}{c}\text { Activity (pCi/L) } \\
\pm \text { Measurement } \\
\text { Uncertainty } \\
\text { (pCi/L) }\end{array}$ & $\begin{array}{l}\mathrm{MDA}^{\mathrm{a}} \\
(\mathrm{pCi} / \mathrm{L})\end{array}$ \\
\hline Burn Site Well & BSW013939 & No wastewater generated & $26 \pm 150 U$ & 250 \\
\hline Coyote Spring & CYS013842 & No wastewater generated & $-43 \pm 150 U$ & 250 \\
\hline CWL-BW2 Well & CLB2014098 & $\begin{array}{l}\text { CWLBW2113093-3 } \\
\text { CWLBW2113093-2 } \\
\text { CWLBW2113093-1 }\end{array}$ & $370 \pm 150 \mathrm{~B}$ & 220 \\
\hline EOD Hill Well & EOD014323 & $\begin{array}{l}\text { EOD122093-1 } \\
\text { EOD122093-2 } \\
\text { LF1121593-3 }\end{array}$ & $48 \pm 160 u$ & 260 \\
\hline EOD Hill Well (duplicate) & HIL014324 & $\begin{array}{l}\text { EOD122093-1 } \\
\text { EOD122093-2 } \\
\text { LF112593-3 }\end{array}$ & $-96 \pm 150 u$ & 250 \\
\hline Golf Course South Well & GCS014003 & $\begin{array}{l}\text { GCS12993-1 } \\
\text { GCS12993-2 } \\
\text { GCS12993-3 }\end{array}$ & $230 \pm 140 \mathrm{~B}$ & 210 \\
\hline Greystone Manor Well & GSM013923 & No wastewater generated & $86 \pm 160 . U$ & 270 \\
\hline Hubbell Spring & HBL013798 & No wastewater generated & $-19 \pm 150 U$ & 250 \\
\hline KAFB-10 Well & K10013940 & No wastewater generated & $56 \pm 150 \mathrm{U}$ & 250 \\
\hline LF/DM-01 Well & LF1014322 & $\begin{array}{l}\text { LF1121593-1 } \\
\text { LF1121593-2 } \\
\text { LF1121593-3 }\end{array}$ & $82 \pm 150 \mathrm{U}$ & 250 \\
\hline LF/DM-02 Well & LF2014320 & $\begin{array}{l}\text { LF2121493-1 } \\
\text { LF2121493-2 } \\
\text { SCH121393-3 }\end{array}$ & $180 \pm 160 \mathrm{U}$ & 250 \\
\hline MVMW-J Well & MVJ013938 & No wastewater generated & $23 \pm 150 \mathrm{U}$ & 250 \\
\hline MVMW-K Well & MVK013942 & No wastewater generated & $26 \pm 150 \mathrm{U}$ & 250 \\
\hline MVMW-K Well (duplicate) & MVK013943 & No wastewater generated & $94 \pm 160 \mathrm{U}$ & 260 \\
\hline MWL-BW1 Well & MWBW104101 & MWL-BW112193-1 & $150 \pm 140 \mathrm{U}$ & 210 \\
\hline NW-TA3 Well & NWT3014100 & $\begin{array}{l}\text { NWTA3113093-1 } \\
\text { NWTA3113093-2 }\end{array}$ & $110 \pm 140 \mathrm{U}$ & 210 \\
\hline Schoolhouse Well & $\mathrm{SCH} 014054$ & $\begin{array}{l}\text { SCH121393-1 } \\
\text { SCH121393-2 }\end{array}$ & $320 \pm 170$ & 250 \\
\hline Sol se Mete Spring & SSM013921 & No wastewater generated & $87 \pm 150 \mathrm{U}$ & 250 \\
\hline
\end{tabular}

Refer to footnotes at end of table. 
Table K-11. (Concluded)

Summary of Results of Tritium Analyses, SNL/NM Basewide Groundwater Surveillance, December 1993

\begin{tabular}{|c|c|c|c|c|}
\hline Site & Sample \# & Wastewater Container \# & $\begin{array}{l}\text { Activity }(p \mathrm{Ci} / \mathrm{L}) \\
\pm \text { Measurement } \\
\text { Uncertainty } \\
(\mathrm{pCi} / \mathrm{L})\end{array}$ & $\begin{array}{l}\mathrm{MDA}^{\mathrm{a}} \\
(\mathrm{pCi} / \mathrm{L})\end{array}$ \\
\hline South Fence Well \#1 & SFR1014105 & $\begin{array}{l}\text { SFR } 1 / 12-7 / 13-1 \\
\text { SFR } 1 / 12-7 / 13-2 \\
\text { SFR } 1 / 12-7 / 13-3\end{array}$ & $230 \pm 140 B$ & 210 \\
\hline South Fence Well \#2 & SFR2014103 & $\begin{array}{l}\text { SFR212693-1 } \\
\text { SFR212693-2 }\end{array}$ & $200 \pm 140 u$ & 220 \\
\hline South Fence Well \#3P & SFP014326 & $\begin{array}{l}\text { SFP122293-1 } \\
\text { Decon } 122193\end{array}$ & $67 \pm 150 \mathrm{U}$ & 250 \\
\hline South Fence Well \#3T & SFT014325 & $\begin{array}{l}\text { SFT122193-1 } \\
\text { SFT122193-2 } \\
\text { SFT122193-3 }\end{array}$ & $-120 \pm 140 u$ & 250 \\
\hline SW-TA3 Well & SWT3014102 & No wastewater generated & $190 \pm 140 \mathrm{U}$ & 220 \\
\hline Tijeras East Well & TJE014106 & $\begin{array}{l}\text { TJE12893-1 } \\
\text { TJE12893-2 } \\
\text { TJE12893-3 }\end{array}$ & $280 \pm 140 B$ & 210 \\
\hline Equipment Blank \#1 (pump) & EB1014099 & CWLBO2113093-2 & $160 \pm 140 U$ & 210 \\
\hline Equipment Blank \#2 (pump) & EB2014104 & SFR212693-2 & $110 \pm 140 \mathrm{U}$ & 210 \\
\hline Equipment Blank \#3 (pump) & EB3014321 & $\mathrm{SCH} 121393-2$ & $-150 \pm 140 U$ & 250 \\
\hline \multicolumn{5}{|c|}{$\begin{array}{l}\text { aMDA = Minimal detectable activity. } \\
\mathrm{U}=\text { Measured value is below associated MDA. } \\
\mathrm{B}=\text { Tritium was detected in laboratory blank. } \\
\text { NOTE: Values in bold may exceed associated MDA. }\end{array}$} \\
\hline
\end{tabular}


Table K-12.

Summary of Detected Compounds

Sandia National Laboratories/New Mexico

Chemical Waste Landfill

February 1993

\begin{tabular}{|c|c|c|c|c|c|c|c|c|c|c|}
\hline \multirow[b]{3}{*}{ Parameter } & \multirow[b]{3}{*}{$\begin{array}{c}\text { EPA } \\
\text { Method }\end{array}$} & & & \multicolumn{7}{|c|}{ Environmental Groundwater Samples } \\
\hline & & \multicolumn{2}{|c|}{$\begin{array}{r}\text { Sample No.: } \\
\text { Monitor Well ID.: }\end{array}$} & $\begin{array}{c}\text { BW3011668 } \\
\text { BW-3 }\end{array}$ & $\begin{array}{c}\text { MW1A011665 } \\
\text { MW-1A }\end{array}$ & $\begin{array}{c}M W 2 A 011664 \\
M W-2 A\end{array}$ & $\begin{array}{l}\text { MW2B011667 } \\
\text { MW-2A Dup. }\end{array}$ & $\begin{array}{c}M W 3 A 011663 \\
M W-3 A\end{array}$ & $\begin{array}{c}\text { MW4011666 } \\
\text { MW-4 }\end{array}$ & $\begin{array}{c}\text { BW3011669 } \\
\text { BW3 }\end{array}$ \\
\hline & & $\begin{array}{l}\text { Detection } \\
\text { Limit mg/L }\end{array}$ & $\begin{array}{l}M A C^{a} \\
m g / L\end{array}$ & \multicolumn{7}{|c|}{ All analyses in $\mathrm{mg} / \mathrm{L}$} \\
\hline Barium & 6020 & 2.00 & 1000 & 41 & 65 & 69 & 65 & 63 & 78 & 46 \\
\hline Cadmium & 6020 & 0.20 & 10 & 0.33 & 0.29 & 0.30 & 0.21 & 0.27 & 0.44 & 0.42 \\
\hline Chromium (total) & 6020 & 0.50 & 50 & 27 & 1.2 & 22 & 21 & 2.8 & 8.9 & 53 \\
\hline Cobalt & 6020 & 0.20 & 50 & 0.48 & 0.40 & 0.73 & 0.55 & 0.75 & 1.5 & 1.3 \\
\hline Copper & 6020 & 0.20 & 1000 & 1.8 & 0.96 & 4.8 & 3.1 & 0.78 & 1.5 & 4.8 \\
\hline Lead & 6020 & 0.20 & 50 & 0.28 & NDb & 0.54 & ND & ND & 0.33 & 1.3 \\
\hline Nickel & 6020 & 0.50 & 200 & 102 & 43 & 96 & 66 & 67 & 116 & 160 \\
\hline Selenium & 7741 & 2.00 & 50 & ND & ND & 2.0 & ND & ND & ND & 2.0 \\
\hline Tin & 6020 & 1.00 & $\mathrm{NE}^{\mathrm{c}}$ & 6.7 & 5.5 & 6.2 & 6.1 & 6.4 & 6.5 & ND \\
\hline Trichloroethene (TCE) & 8260 & .001 & .010 & ND & .002 & .005 & .006 & .002 & ND & $N A^{d}$ \\
\hline Vanadium & 6020 & 0.50 & $\mathrm{NE}$ & 5.0 & 1.9 & 1.6 & 1.7 & 1.6 & 2.0 & 5.9 \\
\hline Zinc & 6020 & 4.00 & 10,000 & 10 & 24 & 62 & 47 & 7.4 & 29 & 38 \\
\hline
\end{tabular}


Table K-13.

Summary of Detected Volatile Organic Compounds

Sandia National Laboratories/New Mexico

Chemical Waste Landfill

May 1993

\begin{tabular}{|c|c|c|c|c|c|c|c|c|}
\hline & & & \multicolumn{6}{|c|}{ Environmental Groundwater Samples } \\
\hline & \multicolumn{2}{|c|}{$\begin{array}{r}\text { Sample No.: } \\
\text { Well No.: } \\
\text { Date Sampled: }\end{array}$} & $\begin{array}{c}\text { BW3013538 } \\
\text { BW3 } \\
8 / 27 / 93\end{array}$ & $\begin{array}{c}\text { MW1A013379 } \\
\text { MW1A } \\
8 / 24 / 93\end{array}$ & $\begin{array}{c}M W 2 A 013380 \\
\text { MW2A } \\
8 / 26 / 93\end{array}$ & $\begin{array}{c}\text { (Duplicate) } \\
\text { MW2A013381 } \\
\text { MW2A } \\
8 / 26 / 93\end{array}$ & $\begin{array}{c}\text { MW3A013382 } \\
\text { MW3A } \\
8 / 27 / 93\end{array}$ & $\begin{array}{c}M W 4013383 \\
\text { MW4 } \\
8 / 23 / 93\end{array}$ \\
\hline $\begin{array}{l}\text { Parameter } \\
\text { EPA Method } 8260 \\
\text { (Appendix IX List) }\end{array}$ & $\begin{array}{l}\text { Detection } \\
\text { Limit, mg/L }\end{array}$ & $\begin{array}{l}M A C^{a} \\
\mathrm{mg} / \mathrm{L}\end{array}$ & \multicolumn{6}{|c|}{ All results in $\mathrm{mg} / \mathrm{L}$} \\
\hline Acetone & .005 & $N E^{b}$ & $0.012 \mathrm{E}^{\mathrm{c}}$ & $N D^{d}$ & $0.004 \mathrm{~J}^{\mathrm{e}}$ & ND & $0.002 T^{f} J M^{9} E$ & ND \\
\hline Carbon disulfide & .001 & NE & ND & $0.002 T$ & ND & ND & ND & $0.002 \mathrm{~T}$ \\
\hline Ethylbenzene & .001 & .750 & ND & ND & ND & 0.002 & ND & ND \\
\hline Methylene chloride & .002 & .100 & $0.21 \mathrm{MT}$ & $.002 \mathrm{MT}$ & ND & ND & ND & $0.002 \mathrm{~T}$ \\
\hline Toluene & .001 & .750 & 0.001 & ND & 0.006 & ND & $0.003 \mathrm{ET}$ & ND \\
\hline Trichloroethene (TCE) & .001 & .010 & ND & ND & 0.002 & 0.002 & $0.001 \mathrm{E}$ & ND \\
\hline Trichlorofluoromethane & .001 & NE & 0.001 & ND & ND & ND & ND & ND \\
\hline
\end{tabular}


Table 14a.

Summary of Detected Volatile Organic Compounds

Sandia National Laboratories/New Mexico

Chemical Waste Landfill

August 1993

\begin{tabular}{|c|c|c|c|c|c|c|c|c|}
\hline \multirow[b]{2}{*}{ '. } & & & \multicolumn{6}{|c|}{ Environmental Groundwater Samples } \\
\hline & \multicolumn{2}{|c|}{$\begin{array}{r}\text { Sample No.: } \\
\text { Well No.: } \\
\text { Date Sampled: }\end{array}$} & $\begin{array}{c}\text { BW } 3013538 \\
\text { BW3 } \\
8 / 27 / 93\end{array}$ & $\begin{array}{c}\text { MW1A013379 } \\
\text { MW1A } \\
8 / 24 / 93\end{array}$ & $\begin{array}{c}\text { MW2A013380 } \\
\text { MW2A } \\
8 / 26 / 93\end{array}$ & $\begin{array}{c}\text { (Duplicate) } \\
\text { MW2A013381 } \\
\text { MW2A } \\
8 / 26 / 93\end{array}$ & $\begin{array}{c}\text { MW3A013382 } \\
\text { MW3A } \\
8 / 27 / 93\end{array}$ & $\begin{array}{c}\text { MW4013383 } \\
\text { MW4 } \\
8 / 23 / 93\end{array}$ \\
\hline $\begin{array}{l}\text { Parameter } \\
\text { EPA Method } 8260 \\
\text { (Appendix IX List) }\end{array}$ & $\begin{array}{l}\text { Detection } \\
\text { Limit, mg/L }\end{array}$ & $\begin{array}{l}\mathrm{MAC}^{\mathrm{a}} \\
\mathrm{mg} / \mathrm{L}\end{array}$ & \multicolumn{6}{|c|}{ All results in $\mathrm{mg} / \mathrm{L}$} \\
\hline 2-Butanone (MKE) & 0.005 & $N E^{b}$ & $N D^{c}$ & ND & $0.003 J^{d}$ & ND & ND & ND \\
\hline Methylene chloride & 0.002 & 0.100 & $0.002 E^{e} T^{f}$ & $0.008 \mathrm{ET}$ & ND & $0.001 \mathrm{ET}$ & $0.003 \mathrm{ET}$ & $0.008 \mathrm{ET}$ \\
\hline Trichloroethene (TCE) & 0.001 & 0.010 & ND & 0.007 & 0.004 & 0.005 & 0.003 & ND \\
\hline
\end{tabular}


Table K-14b.

Summary of Detected Metals

Sandia National Laboratories/New Mexico

Chemical Waste Landfill

August 1993

\begin{tabular}{|c|c|c|c|c|c|c|c|c|}
\hline & & & & \multicolumn{5}{|c|}{ Environmental Groundwater Samples } \\
\hline & & \multicolumn{2}{|c|}{$\begin{array}{r}\text { Sample No.: } \\
\text { Well No.: } \\
\text { Date Sampled: }\end{array}$} & $\begin{array}{c}\text { MW1A013379 } \\
\text { MW1A } \\
8 / 24 / 93\end{array}$ & $\begin{array}{c}M W 2 A 013380 \\
M W 2 A \\
8 / 26 / 93\end{array}$ & $\begin{array}{l}\text { (Duplicate) } \\
\text { MW2A013381 } \\
\text { MW2A } \\
8 / 26 / 93\end{array}$ & $\begin{array}{c}\text { MW3A013382 } \\
\text { MW3A } \\
8 / 27 / 93\end{array}$ & $\begin{array}{c}M W 4013383 \\
\text { MW4 } \\
8 / 23 / 93\end{array}$ \\
\hline Total Metals & $\begin{array}{l}\text { EPA } \\
\text { Method }\end{array}$ & $\begin{array}{c}\text { Detection } \\
\text { Limit, } \mu \mathrm{g} / \mathrm{L}\end{array}$ & $\begin{array}{l}\mathrm{MAC}^{\mathrm{a}} \\
\mu \mathrm{g} / \mathrm{L}\end{array}$ & \multicolumn{5}{|c|}{ All results in $\mu \mathrm{g} / \mathrm{L}$} \\
\hline Barium & 6020 & 2.00 & 1000 & 65 & 67 & 67 & 63 & 76 \\
\hline Berylium & 6020 & 0.20 & $N E^{b}$ & 0.22 & $N D^{C}$ & ND & ND & ND \\
\hline Chromium (total) & 6020 & 0.50 & 50 & $1.2 \mathrm{E}^{\mathrm{d}}$ & $9.2 \mathrm{E}$ & $8.7 \mathrm{E}$ & $1.7 \mathrm{E}$ & $1.7 \mathrm{E}$ \\
\hline Cobalt & 6020 & 0.20 & 50 & ND & 0.51 & 0.63 & 0.46 & 0.69 \\
\hline Copper & 6020 & 0.50 & 1000 & $1.8 \mathrm{EM}^{\mathrm{e}}$ & 4.4 EM & $3.8 \mathrm{EM}$ & $2.1 \mathrm{EM}$ & $2.6 \mathrm{M}$ \\
\hline Iron & 6010 & 20 & NE & 44E & 190 & 170 & ND & 73 \\
\hline Lead & 6020 & 0.20 & 50 & NDE & 0.41 & $0.51 \mathrm{E}$ & ND & 0.27 \\
\hline Nickel & 6020 & 0.50 & 200 & $49 \mathrm{E}$ & $96 \mathrm{E}$ & $100 \mathrm{E}$ & 64 & $48 \mathrm{E}$ \\
\hline Selenium & 7741 & 2.00 & 50 & 2.0 & 2.3 & 2.2 & 2.7 & ND \\
\hline Tin & 6020 & 2.00 & $\mathrm{NE}$ & $3.6 \mathrm{E}$ & $3.5 \mathrm{M}$ & 3.4 & $3.3 \mathrm{E}$ & $3.7 \mathrm{E}$ \\
\hline Vanadium & 6020 & 0.50 & $\mathrm{NE}$ & 1.7 & 1.1 & 1.1 & 1.7 & 1.8 \\
\hline Zinc & 6020 & 4.00 & 10,000 & $18 \mathrm{E}$ & 37 & 40 & 16 & 11 \\
\hline \multicolumn{9}{|c|}{ 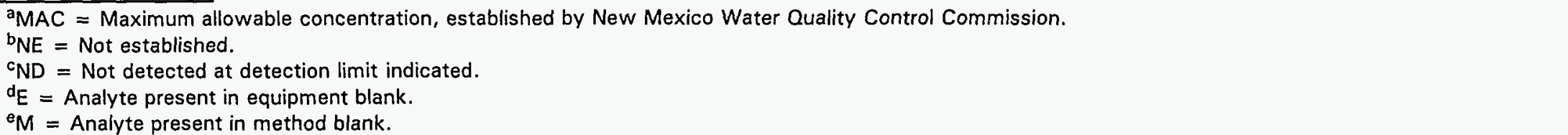 } \\
\hline
\end{tabular}


Table K-15.

Summary of Detected Compounds

Sandia National Laboratories/New Mexico

Chemical Waste Landfill

November 1993

\begin{tabular}{|c|c|c|c|c|c|c|c|c|}
\hline & & & \multicolumn{6}{|c|}{ Environmental Groundwater Samples } \\
\hline \multirow[b]{2}{*}{ Parameter } & \multicolumn{2}{|c|}{$\begin{array}{r}\text { Sample No.: } \\
\text { Well No.: } \\
\text { Date Sampled: }\end{array}$} & $\begin{array}{c}\text { BW3014031 } \\
\text { BW3 } \\
11 / 19 / 93\end{array}$ & $\begin{array}{c}\text { MW1A014032 } \\
\text { MW1A } \\
11 / 17 / 93\end{array}$ & $\begin{array}{c}\text { MW2A014033 } \\
\text { MW2A } \\
11 / 19 / 93\end{array}$ & $\begin{array}{c}\text { (Duplicate) } \\
\text { MW2A014043 } \\
\text { MW2A } \\
11 / 19 / 93\end{array}$ & $\begin{array}{c}\text { MW3A014034 } \\
\text { MW3A } \\
11 / 18 / 93\end{array}$ & $\begin{array}{c}\text { MW4014035 } \\
\text { MW4 } \\
11 / 22 / 93\end{array}$ \\
\hline & $\begin{array}{l}\text { Detection } \\
\text { Limit, mg/L }\end{array}$ & $\begin{array}{l}\mathrm{MAC}^{\mathrm{a}} \\
\mathrm{mg} / \mathrm{L}\end{array}$ & \multicolumn{6}{|c|}{ All results in $\mathrm{mg} / \mathrm{L}$} \\
\hline Barium & 2.00 & 1000 & 41 & 59 & 61 & 61 & 58 & 64 \\
\hline Cadmium & 0.20 & 10 & 0.37 & $N D^{b}$ & ND & ND & ND & ND \\
\hline Chromium (total) & 0.50 & 50 & 60 & $0.80 \mathrm{E}^{\mathrm{c}}$ & $2.2 \mathrm{E}$ & $1.7 \mathrm{E}$ & $2.5 \mathrm{E}$ & $3.8 \mathrm{E}$ \\
\hline Cobalt & 0.20 & 50 & 1.3 & 0.22 & 0.27 & 0.25 & 0.45 & 1.1 \\
\hline Copper & 0.50 & 1000 & $3.7 \mathrm{E}$ & $1.3 \mathrm{E}$ & $1.9 \mathrm{E}$ & $1.9 \mathrm{E}$ & $1.5 \mathrm{E}$ & $2.4 \mathrm{E}$ \\
\hline Iron & 20 & $N E^{d}$ & 550 & $23 E$ & 30 & 70 & $46 \mathrm{E}$ & 66 \\
\hline Nickel & 0.50 & 200 & $240 \mathrm{E}$ & $51 \mathrm{E}$ & $57 \mathrm{E}$ & $55 E$ & $57 \mathrm{E}$ & 75 \\
\hline Tin & 1.00 & NE & $5.7 \mathrm{E}$ & $5.7 \mathrm{E}$ & $5.5 \mathrm{E}$ & $5.6 \mathrm{E}$ & $5.9 \mathrm{E}$ & $5.6 \mathrm{E}$ \\
\hline Trichloroethene (TCE) & 0.001 & 0.010 & ND & ND & 0.003 & 0.004 & 0.001 & ND \\
\hline Vanadium & 0.50 & NE & 4.7 & 2.0 & 1.8 & 1.8 & 2.1 & 2.9 \\
\hline Zinc & 4.00 & 10,000 & 52 & $19 \mathrm{E}$ & $32 \mathrm{E}$ & $33 \mathrm{E}$ & 11 & $23 \mathrm{E}$ \\
\hline \multicolumn{9}{|c|}{$\begin{array}{l}\text { a MAC = Maximum allowable concentration, established by New Mexico Water Quality Control Commission. } \\
{ }^{b} \mathrm{ND}=\text { Not detected at detection limit indicated. } \\
{ }^{c_{E}}=\text { Analyte present in equipment blank } \\
{ }^{{ }^{N}} \text { A }=\text { Not established. }\end{array}$} \\
\hline
\end{tabular}


Table K-16a.

Summary of the Nonradiological Analytical Results for the Mixed Waste Landfill

Sandia National Laboratories/New Mexico

January 1993

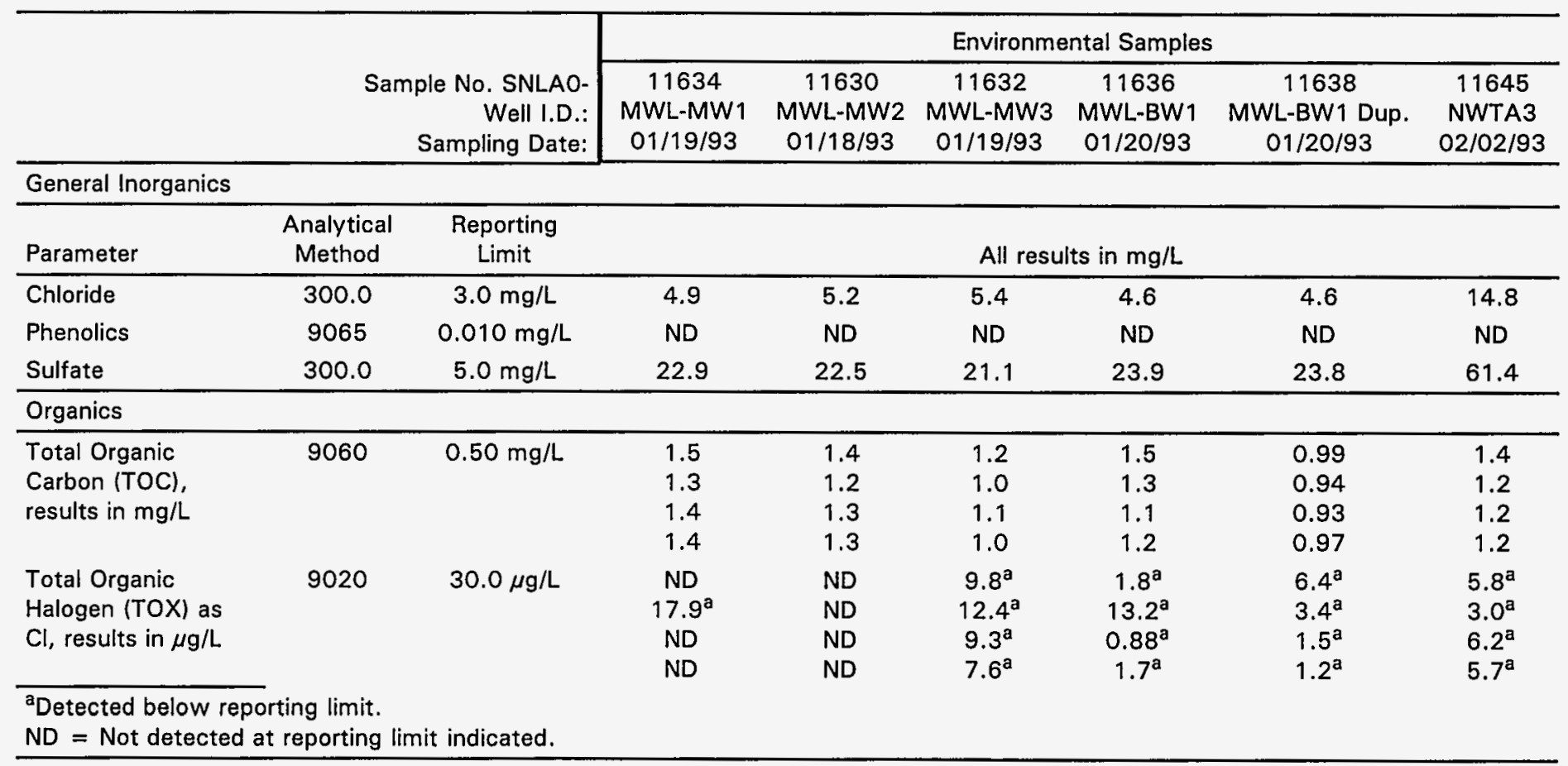


Table K-16a. (Continued)

Summary of the Nonradiological Analytical Results for the Mixed Waste Landfill

Sandia National Laboratories/New Mexico

January 1993

\begin{tabular}{|c|c|c|c|c|c|c|c|c|c|}
\hline & & \multirow{2}{*}{\multicolumn{2}{|c|}{$\begin{array}{r}\text { Sample No. SNLAO- } \\
\text { Well I.D.: } \\
\text { Sampling Date: }\end{array}$}} & \multicolumn{6}{|c|}{ Environmental Samples } \\
\hline & & & & $\begin{array}{c}11634 \\
\text { MWL-MW1 } \\
01 / 19 / 93\end{array}$ & $\begin{array}{c}11630 \\
\text { MWL-MW2 } \\
01 / 18 / 93\end{array}$ & $\begin{array}{c}11632 \\
\text { MWL-MW3 } \\
01 / 19 / 93\end{array}$ & $\begin{array}{c}11636 \\
\text { MWL-BW1 } \\
01 / 20 / 93\end{array}$ & $\begin{array}{c}11638 \\
\text { MWL-BW1 Dup. } \\
01 / 20 / 93\end{array}$ & $\begin{array}{c}11645 \\
\text { NWTA3 } \\
02 / 02 / 93\end{array}$ \\
\hline \multicolumn{10}{|c|}{ Total TAL Metals } \\
\hline Parameter & $\begin{array}{l}\text { Analytica } \\
\text { I Method }\end{array}$ & $\begin{array}{c}\text { Reporting Limit, } \\
\mathrm{mg} / \mathrm{L}\end{array}$ & $\begin{array}{c}\mathrm{MCL}^{\mathrm{a}}, \\
\mathrm{mg} / \mathrm{L}\end{array}$ & \multicolumn{6}{|c|}{ All results in $\mathrm{mg} / \mathrm{L}$} \\
\hline Aluminum & 6010 & 0.10 & NL & $0.032^{b}$ & ND & $0.034^{b}$ & $0.044^{b}$ & $0.052^{b}$ & $0.048^{b}$ \\
\hline Antimony & 6010 & 0.060 & NL & ND & ND & ND & ND & ND & ND \\
\hline Arsenic & 7060 & 0.0050 & 0.05 & ND & $0.0020^{b}$ & $0.0021^{b}$ & ND & ND & ND \\
\hline Barium & 6010 & 0.010 & 1.0 & 0.076 & 0.11 & 0.097 & 0.095 & 0.092 & 0.077 \\
\hline Beryllium & 6010 & 0.0020 & NL & ND & ND & ND & ND & ND & ND \\
\hline Cadmium & 6010 & 0.0050 & 0.01 & 0.0086 & 0.016 & 0.029 & 0.031 & 0.023 & ND \\
\hline Calcium & 6010 & 0.20 & NL & 59.1 & 50.7 & 48.6 & 53.9 & 55.1 & 62.7 \\
\hline Chromium & 6010 & 0.010 & 0.05 & 0.011 & 0.014 & 0.026 & 0.017 & 0.012 & ND \\
\hline Cobait & 6010 & 0.010 & NL & ND & ND & ND & ND & ND & ND \\
\hline Copper & 6010 & 0.020 & NL & $0.014^{\mathrm{b}}$ & $0.0053^{b}$ & $0.015^{b}$ & $0.015^{b}$ & $0.010^{b}$ & $0.011^{b}$ \\
\hline Iron & 6010 & 0.10 & NL & $0.090^{b}$ & $0.045^{b}$ & 0.37 & $0.058^{b}$ & $0.090^{b}$ & $0.052^{\mathrm{b}}$ \\
\hline Lead & 7421 & $* 0.0050-0.010$ & 0.05 & ND & ND & ND & ND & $0.0012^{b}$ & ND \\
\hline \multicolumn{10}{|c|}{$\begin{array}{l}{ }^{a} \mathrm{MCL}=\text { Maximum contaminant level, U.S. EPA Primary Drinking Water Standards. } \\
\text { betected below reporting limit. } \\
\text { ND = Not detected at reporting limit indicated. } \\
\text { NL }=\text { Not listed. }\end{array}$} \\
\hline
\end{tabular}


Table K-16a. (Concluded)

Summary of the Nonradiological Analytical Results for the Mixed Waste Landfill

Sandia National Laboratories/New Mexico

January 1993

\begin{tabular}{|c|c|c|c|c|c|c|c|c|c|}
\hline & & & & \multicolumn{6}{|c|}{ Environmental Samples } \\
\hline & & \multicolumn{2}{|c|}{$\begin{array}{r}\text { Sample No. SNLAO- } \\
\text { Well I.D.: } \\
\text { Sampling Date: }\end{array}$} & $\begin{array}{c}11634 \\
\text { MWL-MW1 } \\
01 / 19 / 93\end{array}$ & $\begin{array}{c}11630 \\
M W L-M W 2 \\
01 / 18 / 93\end{array}$ & $\begin{array}{c}01632 \\
M W L-M W 3 \\
01 / 19 / 93\end{array}$ & $\begin{array}{c}11636 \\
\text { MWL-BW1 } \\
01 / 20 / 93\end{array}$ & $\begin{array}{c}11638 \\
\text { MWL-BW1 Dup. } \\
01 / 20 / 93\end{array}$ & $\begin{array}{l}11645 \\
\text { NWTA3 } \\
02 / 02 / 93\end{array}$ \\
\hline \multicolumn{10}{|c|}{ Total TAL Metals } \\
\hline Parameter & $\begin{array}{l}\text { Analytical } \\
\text { Method }\end{array}$ & $\begin{array}{c}\text { Reporting Limit, } \\
\mathrm{mg} / \mathrm{L}\end{array}$ & $\begin{array}{c}\mathrm{MCL}^{\mathrm{a}}, \\
\mathrm{mgL}\end{array}$ & \multicolumn{6}{|c|}{ All results in $\mathrm{mg} / \mathrm{L}$} \\
\hline Magnesium & 6010 & 0.20 & NL & 18.4 & 17.6 & 15.5 & 19.3 & 19.4 & 15.3 \\
\hline Manganese & 6010 & 0.010 & $\mathrm{NL}$ & 0.011 & ND & ND & ND & ND & ND \\
\hline Mercury & 7470 & 0.00020 & 0.002 & ND & ND & ND & ND & ND & ND \\
\hline Nickel & 6010 & 0.040 & NL & 0.078 & ND & $0.026^{\mathrm{b}}$ & ND & ND & ND \\
\hline Potassium & 6010 & 5.0 & NL & $3.6^{\mathrm{b}}$ & $4.7^{b}$ & $4.2^{\mathrm{b}}$ & $3.8^{\mathrm{b}}$ & $3.7^{b}$ & $4.4^{\mathrm{b}}$ \\
\hline Selenium & 7740 & 0.0050 & 0.01 & $0.0045^{b}$ & $0.0038^{b}$ & $0.0040^{b}$ & $0.0040^{b}$ & $0.0043^{b}$ & $0.0020^{b}$ \\
\hline Silver & 6010 & 0.010 & 0.05 & ND & ND & ND & ND & ND & ND \\
\hline Sodium & 6010 & 5.0 & $\mathrm{NL}$ & 52.7 & 52.9 & 54.0 & 56.5 & 56.7 & 23.6 \\
\hline Thallium & 7841 & $0.010-0.050$ & NL & ND & ND & ND & ND & ND & ND \\
\hline Vanadium & 6010 & 0.010 & NL & $0.0076^{b}$ & $0.0076^{\mathrm{b}}$ & $0.0076^{\mathrm{b}}$ & $0.0087^{b}$ & $0.0073^{b}$ & $0.0056^{\mathrm{b}}$ \\
\hline Zinc & 6010 & 0.020 & NL & ND & 0.075 & 0.074 & 0.11 & 0.12 & 0.026 \\
\hline \multicolumn{10}{|c|}{$\begin{array}{l}{ }^{a} \mathrm{MCL}=\text { maximum contaminant level, U.S. EPA Primary Drinking Water Standards. } \\
\text { betected below reporting limit. } \\
\text { ND = Not detected at reporting limit indicated. } \\
\text { NL }=\text { Not listed. }\end{array}$} \\
\hline
\end{tabular}


Table K-16b.

Summary of the Nonradiological Analytical Results for the Mixed Waste Landfill

Sandia National Laboratories/New Mexico

April 1993

\begin{tabular}{|c|c|c|c|c|c|c|c|c|}
\hline & \multirow{2}{*}{\multicolumn{2}{|c|}{$\begin{array}{r}\text { Sample No. SNLAO- } \\
\text { Well I.D.: } \\
\text { Sampling Date: }\end{array}$}} & \multicolumn{6}{|c|}{ Environmental Samples } \\
\hline & & & $\begin{array}{c}12173 \\
\text { MWL-MW1 } \\
04 / 27 / 93\end{array}$ & $\begin{array}{c}12174 \\
\text { MWL-MW2 } \\
04 / 26 / 93\end{array}$ & $\begin{array}{c}12175 \\
\text { MWL-MW3 } \\
04 / 27 / 93\end{array}$ & $\begin{array}{c}12176 \\
\text { MWL-BW1 } \\
04 / 28 / 93 \\
\end{array}$ & $\begin{array}{c}12177 \\
\text { MWL-BW1 Dup. } \\
\text { 04/28/93 }\end{array}$ & $\begin{array}{c}12178 \\
\text { MWL-MW4 } \\
04 / 30 / 93 \\
\end{array}$ \\
\hline Parameter & $\begin{array}{l}\text { Analytical } \\
\text { Method }\end{array}$ & $\begin{array}{l}\text { Reporting } \\
\text { Limit }\end{array}$ & \multicolumn{6}{|c|}{ All results in $\mathrm{mg} / \mathrm{L}$, except TOX in $\mu \mathrm{g} / \mathrm{L}$} \\
\hline Chloride & $300.0^{a}$ & $3.0 \mathrm{mg} / \mathrm{L}$ & 29.5 & 31.9 & 33.4 & 27.6 & 27.9 & 61.2 \\
\hline Phenolics & $9065^{\mathrm{b}}$ & $0.010 \mathrm{mg} / \mathrm{L}$ & ND & ND & ND & ND & ND & ND \\
\hline Sulfate & $300.0^{\mathrm{a}}$ & $5.0 \mathrm{mg} / \mathrm{L}$ & 43.7 & 47.3 & 39.7 & 46.7 & 46.7 & 38.7 \\
\hline Nitrate (as N) & $300.0^{\mathrm{a}}$ & $0.10 \mathrm{mg} / \mathrm{L}$ & 5.0 & 4.5 & 3.7 & 5.4 & 5.5 & 1.1 \\
\hline Alkalinity $\left(\mathrm{mg} / \mathrm{L} \mathrm{CaCO}_{3}\right)$ & Field & NA & 215.7 & 207.7 & 193.4 & 257.3 & NA & 231.7 \\
\hline $\begin{array}{l}\text { Total Organic Carbon (TOC), } \\
\text { results in } \mathrm{mg} / \mathrm{L}\end{array}$ & $9060^{b}$ & $\begin{array}{l}0.50-3.0 \\
\mathrm{mg} / \mathrm{L}\end{array}$ & $\begin{array}{l}21.7 \\
21.6 \\
19.6 \\
21.5\end{array}$ & $\begin{array}{l}15.3 \\
13.8 \\
14.9 \\
14.4\end{array}$ & $\begin{array}{l}20.2 \\
22.0 \\
23.1 \\
23.2\end{array}$ & $\begin{array}{l}2.2 \\
2.8 \\
2.1 \\
1.5\end{array}$ & $\begin{array}{l}2.4 \\
2.7 \\
1.5 \\
1.8\end{array}$ & $\begin{array}{l}4.4 \\
4.4 \\
4.0 \\
4.9\end{array}$ \\
\hline $\begin{array}{l}\text { Total Organic Halogen } \\
\text { (TOX) as } \mathrm{Cl} \text {, results in } \mu \mathrm{g} / \mathrm{L}\end{array}$ & $9020^{b}$ & $30.0 \mu \mathrm{g} / \mathrm{L}$ & $\begin{array}{l}\text { ND } \\
14.2^{\mathrm{c}} \\
\text { ND } \\
12.5^{\mathrm{c}}\end{array}$ & $\begin{array}{l}\text { ND } \\
6.4^{c} \\
\text { ND } \\
\text { ND }\end{array}$ & $\begin{array}{l}\text { ND } \\
\text { ND } \\
8.7^{\mathrm{c}} \\
5.9^{\mathrm{c}}\end{array}$ & $\begin{array}{l}\text { ND } \\
\text { ND } \\
\text { ND } \\
\text { ND }\end{array}$ & $\begin{array}{l}\text { ND } \\
\text { ND } \\
\text { ND } \\
15.2^{\mathrm{C}}\end{array}$ & $\begin{array}{l}11.3^{c} \\
15.6^{c} \\
20.6^{c} \\
16.6^{c}\end{array}$ \\
\hline \multicolumn{9}{|c|}{$\begin{array}{l}\text { a"Methods for Chemical Analysis of Water and Wastes," U.S. Environmental Protection Agency, EPA-600/4-79-020, 1983. } \\
\text { b"Test Methods for Evaluating Solid Waste, Physical/Chemical Methods," U.S. Environmental Protection Agency, SW-846, 1986. } \\
\text { "Detected below reporting limit. } \\
\text { ND }=\text { Not detected at reporting limit indicated. } \\
N A=\text { Not applicable. }\end{array}$} \\
\hline
\end{tabular}


Table K-16b. (Continued)

Summary of the Nonradiological Analytical Results for the Mixed Waste Landfill

Sandia National Laboratories/New Mexico

April 1993

\begin{tabular}{|c|c|c|c|c|c|c|c|c|c|}
\hline & & \multirow{2}{*}{\multicolumn{2}{|c|}{$\begin{array}{r}\text { Sample No. SNLAO- } \\
\text { Well I.D.: } \\
\text { Sampling Date: }\end{array}$}} & \multicolumn{6}{|c|}{ Environmental Samples } \\
\hline & & & & $\begin{array}{c}12173 \\
M W L-M W 1 \\
04 / 27 / 93 \\
\end{array}$ & $\begin{array}{c}12174 \\
\text { MWL-MW2 } \\
04 / 26 / 93 \\
\end{array}$ & $\begin{array}{c}12175 \\
\text { MWL-MW3 } \\
04 / 27 / 93 \\
\end{array}$ & $\begin{array}{c}12176 \\
\text { MWL-BW1 } \\
04 / 28 / 93 \\
\end{array}$ & $\begin{array}{c}12177 \\
\text { MWL-BW1 Dup. } \\
\text { 04/28/93 }\end{array}$ & $\begin{array}{c}12178 \\
\text { MWL-MW4 } \\
04 / 30 / 93 \\
\end{array}$ \\
\hline \multicolumn{10}{|c|}{ Total TAL Metals } \\
\hline Parameter & $\begin{array}{l}\text { Analytical } \\
\text { Method }\end{array}$ & $\begin{array}{c}\text { Reporting } \\
\text { Limit, mg/L }\end{array}$ & $M C L^{\mathrm{a}}, \mathrm{mg} / \mathrm{L}$ & \multicolumn{6}{|c|}{ All results in $\mathrm{mg} / \mathrm{L}$} \\
\hline Aluminum & 6010 & 0.10 & NL & $0.063^{b}$ & $0.057^{b}$ & 0.10 & $0.068^{b}$ & 0.14 & 0.13 \\
\hline Antimony & 6010 & 0.060 & NL & ND & ND & ND & ND & ND & ND \\
\hline Arsenic & 7060 & 0.0050 & 0.05 & ND & $0.0010^{b}$ & $0.0016^{b}$ & ND & $0.0011^{b}$ & $0.0040^{b}$ \\
\hline Barium & 6010 & 0.010 & 1.0 & 0.057 & 0.074 & 0.074 & 0.073 & 0.075 & 0.082 \\
\hline Beryllium & 6010 & 0.0020 & $\mathrm{NL}$ & $0.0016^{b}$ & ND & ND & ND & ND & ND \\
\hline Cadmium & 6010 & 0.0050 & 0.01 & ND & ND & ND & ND & ND & ND \\
\hline Calcium & 6010 & 0.20 & $\mathrm{NL}$ & 51.8 & 47.1 & 42.1 & 46.6 & 47.8 & 52.1 \\
\hline Chromium & 6010 & 0.010 & 0.05 & ND & 0.016 & 0.029 & ND & ND & $N D$ \\
\hline Cobalt & 6010 & 0.010 & NL & ND & ND & ND & ND & ND & ND \\
\hline Copper & 6010 & 0.020 & NL & ND & $0.0031^{b}$ & $0.0059^{b}$ & ND & ND & ND \\
\hline Iron & 6010 & 0.10 & $N L$ & ND & ND & 0.38 & $0.055^{b}$ & 0.14 & 0.21 \\
\hline Lead & 7421 & $0.010-0.05$ & 0.05 & ND & ND & ND & ND & ND & ND \\
\hline \multicolumn{10}{|c|}{$\begin{array}{l}\text { a } M C L=\text { Maximum contaminant level, U.S. EPA Primary Drinking Water Standards. } \\
\text { bDetected below reporting limit. } \\
\text { ND = Not detected at reporting limit indicated. } \\
\mathrm{NL}=\text { Not listed. }\end{array}$} \\
\hline
\end{tabular}


Table K-16b. (Continued)

Summary of the Nonradiological Analytical Results

$$
\text { for the Mixed Waste Landfill }
$$

Sandia National Laboratories/New Mexico

April 1993

\begin{tabular}{|c|c|c|c|c|c|c|c|c|c|}
\hline & & \multirow{2}{*}{\multicolumn{2}{|c|}{$\begin{array}{r}\text { Sample No. SNLAO- } \\
\text { Well I.D.: } \\
\text { Sampling Date: }\end{array}$}} & \multicolumn{6}{|c|}{ Environmental Samples } \\
\hline & & & & $\begin{array}{l}12173 \\
\text { MWL-MW1 } \\
04 / 27 / 93\end{array}$ & $\begin{array}{l}12174 \\
\text { MWL-MW2 } \\
04 / 26 / 93\end{array}$ & $\begin{array}{l}02175 \\
\text { MWL-MW3 } \\
04 / 27 / 93\end{array}$ & $\begin{array}{l}12176 \\
M W L-B W 1 \\
04 / 28 / 93\end{array}$ & $\begin{array}{l}12177 \\
\text { MWL-BW1 Dup. } \\
\text { O4/28/93 }\end{array}$ & $\begin{array}{c}12178 \\
\text { MWL-MW4 } \\
04 / 30 / 93\end{array}$ \\
\hline \multicolumn{10}{|c|}{ Total TAL Metals } \\
\hline Parameter & $\begin{array}{c}\text { Analytical } \\
\text { Method }\end{array}$ & $\begin{array}{c}\text { Reporting } \\
\text { Limit, mg/L }\end{array}$ & $\begin{array}{c}\mathrm{MCL}^{\mathrm{a}} \text {, } \\
\mathrm{mgL}\end{array}$ & \multicolumn{6}{|c|}{ All results in $\mathrm{mg} / \mathrm{L}$} \\
\hline Magnesium & 6010 & 0.20 & $N L$ & 17.4 & 17.1 & 14.6 & 17.9 & 18.3 & 19.5 \\
\hline Manganese & 6010 & 0.010 & NL & $0.0095^{b}$ & ND & 0.056 & $0.0098^{b}$ & 0.022 & 0.16 \\
\hline Mercury & 7470 & 0.00020 & 0.002 & ND & ND & ND & ND & ND & ND \\
\hline Nickel & 6010 & 0.040 & NL & $0.097^{b}$ & $0.014^{b}$ & $0.037^{b}$ & $0.011^{b}$ & $0.016^{b}$ & ND \\
\hline Potassium & 6010 & 5.0 & NL & $2.5^{\mathrm{b}}$ & $3.6^{\mathrm{b}}$ & $3.1^{\mathrm{b}}$ & $2.7^{b}$ & $2.9^{b}$ & $4.3^{b}$ \\
\hline Selenium & 7740 & $2.5-5.0$ & 0.01 & ND & ND & ND & ND & ND & ND \\
\hline Silver & 6010 & 0.010 & 0.05 & ND & ND & ND & ND & ND & ND \\
\hline Sodium & 6010 & 5.0 & NL & 45.7 & 45.7 & 45.7 & 46.9 & 47.4 & 46.9 \\
\hline Thallium & 7841 & 0.010 & NL & ND & ND & ND & ND & ND & ND \\
\hline Vanadium & 6010 & 0.010 & NL & ND & ND & $0.0060^{b}$ & $0.0062^{b}$ & $0.0047^{b}$ & $0.0062^{b}$ \\
\hline Zinc & 6010 & 0.020 & NL & $0.011^{b}$ & 0.069 & 0.030 & 0.033 & 0.086 & $0.012^{b}$ \\
\hline \multicolumn{10}{|c|}{$\begin{array}{l}{ }^{a} \mathrm{MCL}=\text { maximum contaminant level, U.S. EPA Primary Drinking Water Standards. } \\
{ }^{b} \mathrm{Detected} \text { below reporting limit. } \\
\mathrm{ND}=\text { Not detected at reporting limit indicated. } \\
\mathrm{NL}=\text { Not listed. }\end{array}$} \\
\hline
\end{tabular}


Table K-16b. (Continued)

Summary of the Nonradiological Analytical Results

for the Mixed Waste Landfill

Sandia National Laboratories/New Mexico

April 1993

\begin{tabular}{|c|c|c|c|c|c|c|c|c|c|}
\hline & & & & \multicolumn{6}{|c|}{ Environmental Samples } \\
\hline & & \multicolumn{2}{|c|}{$\begin{array}{r}\text { Sample No. SNLAO- } \\
\text { Well I.D.: } \\
\text { Sampling Date: }\end{array}$} & $\begin{array}{c}12173 \\
\text { MWL-MW1 } \\
04 / 27 / 93 \\
\end{array}$ & $\begin{array}{c}12174 \\
M W L-M W 2 \\
04 / 26 / 93 \\
\end{array}$ & $\begin{array}{c}12175 \\
\text { MWL-MW3 } \\
04 / 27 / 93 \\
\end{array}$ & $\begin{array}{c}12176 \\
\text { MWL-BW1 } \\
04 / 28 / 93 \\
\end{array}$ & $\begin{array}{c}12177 \\
\text { MWL-BW1 Dup. } \\
04 / 28 / 93 \\
\end{array}$ & $\begin{array}{c}12178 \\
\text { MWL-MW4 } \\
04 / 30 / 93 \\
\end{array}$ \\
\hline \multicolumn{10}{|c|}{ Dissolved TAL Metals } \\
\hline Parameter & $\begin{array}{c}\text { Analytical } \\
\text { Method }\end{array}$ & $\begin{array}{c}\text { Reporting } \\
\text { Limit, mg/L }\end{array}$ & $\begin{array}{c}\mathrm{MCL}^{\mathrm{a}}, \\
\mathrm{mg} / \mathrm{L}\end{array}$ & \multicolumn{6}{|c|}{ All results in $\mathrm{mg} / \mathrm{L}$} \\
\hline Aluminum & 6010 & 0.10 & $\mathrm{NL}$ & $0.060^{b}$ & $0.032^{b}$ & $0.051^{b}$ & 0.13 & $0.087^{b}$ & $0.041^{b}$ \\
\hline Antimony & 6010 & 0.060 & NL & ND & ND & ND & ND & ND & $\therefore N D$ \\
\hline Arsenic & 7060 & 0.0050 & NL & $0.0016^{b}$ & $0.0012^{b}$ & $0.0019^{b}$ & $0.0013^{b}$ & $0.0010^{b}$ & $0.0045^{b}$ \\
\hline Barium & 6010 & 0.010 & NL & 0.056 & 0.078 & 0.070 & 0.077 & 0.075 & $\therefore 0: 081$ \\
\hline Beryllium & 6010 & 0.0020 & NL & ND & ND & 0.0024 & ND & ND & $\mathrm{ND}$ \\
\hline Cadmium & 6010 & 0.0050 & NL & ND & ND & ND & ND & ND & $N N^{N}$ \\
\hline Calcium & 6010 & 0.20 & NL & 50.7 & 47.0 & 40.5 & 48.0 & 48.5 & 1544 \\
\hline Chromium & 6010 & 0.010 & NL & ND & $0.0077^{b}$ & 0.011 & ND & ND & ND \\
\hline Cobalt & 6010 & 0.010 & NL & ND & ND & ND & ND & ND & ND \\
\hline Copper & 6010 & 0.020 & NL & $0.004^{b}$ & $0.0036^{b}$ & $0.015^{b}$ & $0.0045^{b}$ & ND & ND \\
\hline Iron & 6010 & 0.10 & NL & ND & ND & $0.033^{\mathrm{b}}$ & 0.15 & 0.12 & ND \\
\hline Lead & 7421 & $0.010-0.050$ & NL & ND & ND & ND & ND & ND & ND \\
\hline \multicolumn{10}{|c|}{$\begin{array}{l}\text { a MCL = Maximum contaminant level, U.S. EPA Primary Drinking Water Standards. } \\
\text { bDetected below reporting limit. } \\
\text { ND = Not detected at reporting limit indicated. } \\
\text { NL = Not listed. }\end{array}$} \\
\hline
\end{tabular}


Table K-16b. (Concluded)

Summary of the Nonradiological Analytical Results

for the Mixed Waste Landfill

Sandia National Laboratories/New Mexico

April 1993

\begin{tabular}{|c|c|c|c|c|c|c|c|c|c|}
\hline & & \multirow{2}{*}{\multicolumn{2}{|c|}{$\begin{array}{r}\text { Sample No. SNLAO- } \\
\text { Well I.D.: } \\
\text { Sampling Date: }\end{array}$}} & \multicolumn{6}{|c|}{ Environmental Samples } \\
\hline & & & & $\begin{array}{c}12173 \\
\text { MWL-MW1 } \\
04 / 27 / 93\end{array}$ & $\begin{array}{c}12174 \\
\text { MWL-MW2 } \\
04 / 26 / 93\end{array}$ & $\begin{array}{c}02175 \\
\text { MWL-MW3 } \\
04 / 27 / 93\end{array}$ & $\begin{array}{c}12176 \\
M W L-B W 1 \\
04 / 28 / 93\end{array}$ & $\begin{array}{c}12177 \\
\text { MWL-BW 1 Dup. } \\
04 / 28 / 93\end{array}$ & $\begin{array}{c}12178 \\
\text { MWL-MW4 } \\
04 / 30 / 93\end{array}$ \\
\hline \multicolumn{10}{|c|}{ Dissolved TAL Metals } \\
\hline Parameter & $\begin{array}{l}\text { Analytical } \\
\text { Method }\end{array}$ & $\begin{array}{l}\text { Reporting } \\
\text { Limit, mg/L }\end{array}$ & $\begin{array}{c}\mathrm{MCL}^{\mathrm{a}}, \\
\mathrm{mgL}\end{array}$ & \multicolumn{6}{|c|}{ All results in $\mathrm{mg} / \mathrm{L}$} \\
\hline Magnesium & 6010 & 0.20 & NL & 17.3 & 17.0 & 14.1 & 18.8 & 18.8 & 20.1 \\
\hline Manganese & 6010 & 0.010 & NL & 0.012 & $0.0082^{b}$ & 0.050 & 0.016 & $0.0097^{b}$ & 0.17 \\
\hline Mercury & 7470 & 0.00020 & NL & ND & ND & ND & ND & ND & ND \\
\hline Nickel & 6010 & 0.040 & NL & 0.094 & $0.013^{b}$ & $0.033^{b}$ & $0.012^{b}$ & $0.0075^{b}$ & $0.0082^{b}$ \\
\hline Potassium & 6010 & 5.0 & NL & $2.7^{b}$ & $3.6^{\mathrm{b}}$ & $3.0^{\mathrm{b}}$ & $2.9^{b}$ & $2.8^{\mathrm{b}}$ & $4.4^{b}$ \\
\hline Selenium & 7740 & 5.0 & NL & ND & ND & ND & ND & ND & ND \\
\hline Silver & 6010 & 0.010 & NL & ND & ND & ND & ND & ND & ND \\
\hline Sodium & 6010 & 5.0 & NL & 44.3 & 45.5 & 46.0 & 48.6 & 48.7 & 49.0 \\
\hline Thallium & 7841 & 0.010 & NL & ND & ND & ND & ND & ND & ND \\
\hline Vanadium & 6010 & 0.010 & $\mathrm{NL}$ & ND & $0.0059^{b}$ & 0.011 & $0.0044^{b}$ & ND & $0.0072^{b}$ \\
\hline Zinc & 6010 & 0.020 & NL & $0.0089^{b}$ & ND & 0.014 & 0.045 & 0.031 & ND \\
\hline \multicolumn{10}{|c|}{$\begin{array}{l}{ }^{a} \mathrm{MCL}=\text { maximum contaminant level, U.S. EPA Primary Drinking Water Standards. } \\
\mathrm{b}_{\mathrm{D}} \text {.tected below reporting limit. }\end{array}$} \\
\hline
\end{tabular}


Table $16 \mathrm{c}$.

Summary of the Nonradiological Analytical Results for the Mixed Waste Landfill

Sandia National Laboratories/New Mexico

November 1993

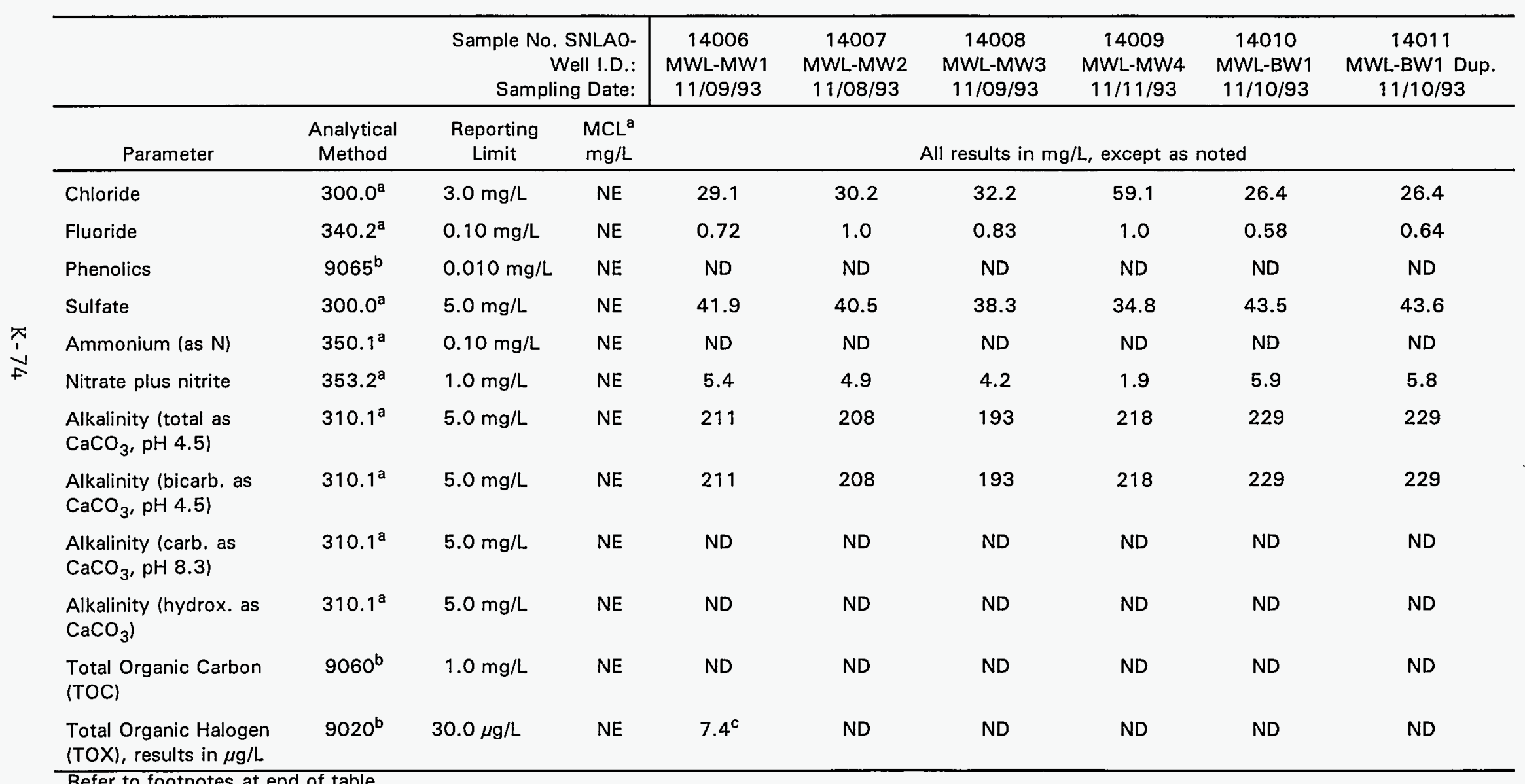

Refer to footnotes at end of table. 
Table 16c. (Continued)

Summary of the Nonradiological Analytical Results

for the Mixed Waste Landfill

Sandia National Laboratories/New Mexico

November 1993

\begin{tabular}{|c|c|c|c|c|c|c|c|c|c|}
\hline & & Sample No. & $\begin{array}{l}\text { SNLAO- } \\
\text { ell I.D.: } \\
\text { g Date: }\end{array}$ & $\begin{array}{c}14006 \\
\text { MWL-MW1 } \\
11 / 09 / 93\end{array}$ & $\begin{array}{c}14007 \\
\text { MWL-MW2 } \\
11 / 08 / 93 \\
\end{array}$ & $\begin{array}{c}14008 \\
\text { MWL-MW3 } \\
11 / 09 / 93\end{array}$ & $\begin{array}{c}14009 \\
\text { MWL-MW4 } \\
11 / 11 / 93\end{array}$ & $\begin{array}{c}14010 \\
\text { MWL-BW1 } \\
11 / 10 / 93\end{array}$ & $\begin{array}{c}14011 \\
\text { MWL-BW1 Dup. } \\
11 / 10 / 93\end{array}$ \\
\hline Parameter & $\begin{array}{l}\text { Analytical } \\
\text { Method }\end{array}$ & $\begin{array}{c}\text { Reporting } \\
\text { Limit }\end{array}$ & $\begin{array}{l}\mathrm{MCL}^{\mathrm{a}} \\
\mathrm{mg} / \mathrm{L}\end{array}$ & \multicolumn{6}{|c|}{ All results in $\mathrm{mg} / \mathrm{L}$, except as noted } \\
\hline $\begin{array}{l}\text { Ion Balance Difference } \\
\text { in \% }\end{array}$ & $104 C^{d}$ & $0.1 \%$ & NE & 2.44 & 3.20 & -0.15 & -2.74 & 1.11 & 1.55 \\
\hline $\begin{array}{l}\text { Total Anions, results in } \\
\text { milliequivalents } / L\end{array}$ & NA & $0.30 \mathrm{meq} / \mathrm{L}$ & NE & 6.3 & 6.2 & 5.9 & 6.9 & 6.6 & 6.6 \\
\hline $\begin{array}{l}\text { Total Cations, results in } \\
\text { milliequivalents } / \mathrm{L}\end{array}$ & NA & $0.10 \mathrm{meq} / \mathrm{L}$ & NE & 6.6 & 6.6 & 5.8 & 6.5 & 6.8 & 6.8 \\
\hline $\mathrm{pH}$ & $9040^{b}$ & NA & NE & 7.8 & 7.8 & 8.1 & 7.6 & 7.9 & 7.8 \\
\hline $\begin{array}{l}\text { Specific Conductance } \\
\text { at } 25^{\circ} \mathrm{C} \text {, results in } \\
\mu \mathrm{mhos} / \mathrm{cm}\end{array}$ & $120.1^{\mathrm{a}}$ & $1.0 \mu \mathrm{mhos} / \mathrm{cm}$ & NE & 628 & 575 & 573 & 688 & 639 & 636 \\
\hline Total Dissolved Solids & $160.1^{\mathrm{a}}$ & $10.0 \mathrm{mg} / \mathrm{L}$ & NE & 382 & 372 & 333 & 401 & 388 & 388 \\
\hline Aluminum & 6010 & 0.10 & NE & ND & $0.078^{b}$ & ND & ND & ND & ND \\
\hline Antimony & 6010 & 0.060 & NE & ND & ND & ND & ND & ND & ND \\
\hline Arsenic & 7060 & 0.0050 & 0.05 & ND & ND & $0.0015^{b}$ & $0.0047^{b}$ & ND & $0.0015^{b}$ \\
\hline Barium & 6010 & 0.010 & 1.0 & 0.061 & 0.11 & 0.085 & 0.085 & 0.081 & 0.078 \\
\hline Beryllium & 6010 & 0.0020 & NE & ND & ND & ND & ND & ND & ND \\
\hline Cadmium & 6010 & 0.0050 & 0.01 & ND & ND & ND & ND & ND & ND \\
\hline Calcium & 6010 & 0.20 & NE & 57.1 & 51.3 & 44.2 & 55.4 & 54.1 & 54.7 \\
\hline Chromium & 6010 & 0.010 & 0.05 & 0.010 & ND & 0.010 & $0.0030^{b}$ & 0.011 & $0.0092^{b}$ \\
\hline
\end{tabular}

Refer to footnotes at end of table. 
Table 16c. (Concluded)

Summary of the Nonradiological Analytical Results

for the Mixed Waste Landfill

Sandia National Laboratories/New Mexico

November 1993

\begin{tabular}{|c|c|c|c|c|c|c|c|c|c|}
\hline & & $\begin{array}{r}\text { Sample N } \\
\text { Sam } \\
\end{array}$ & $\begin{array}{l}\text { SNLAO- } \\
\text { /ell I.D.: } \\
\text { g Date: }\end{array}$ & $\begin{array}{c}14006 \\
\text { MWL-MW1 } \\
11 / 09 / 93 \\
\end{array}$ & $\begin{array}{c}14007 \\
\text { MWL-MW2 } \\
11 / 08 / 93 \\
\end{array}$ & $\begin{array}{c}14008 \\
\text { MWL-MW3 } \\
11 / 09 / 93 \\
\end{array}$ & $\begin{array}{c}14009 \\
M W L-M W 4 \\
11 / 11 / 93 \\
\end{array}$ & $\begin{array}{c}14010 \\
\text { MWL-BW1 } \\
11 / 10 / 93 \\
\end{array}$ & $\begin{array}{c}14011 \\
\text { MWL-BW1 Dup. } \\
11 / 10 / 93\end{array}$ \\
\hline Parameter & $\begin{array}{l}\text { Analytical } \\
\text { Method }\end{array}$ & $\begin{array}{l}\text { Reporting } \\
\text { Limit }\end{array}$ & $\begin{array}{l}\mathrm{MCL}^{\mathrm{a}} \\
\mathrm{mg} / \mathrm{L}\end{array}$ & \multicolumn{6}{|c|}{ All results in $\mathrm{mg} / \mathrm{L}$, except as noted } \\
\hline Cobalt & 6010 & 0.010 & NE & ND & ND & ND & ND & ND & ND \\
\hline Copper & 6010 & 0.020 & $\mathrm{NE}$ & $0.0053^{b}$ & ND & $0.0092^{b}$ & ND & $0.0079^{b}$ & $0.0036^{b}$ \\
\hline Iron & 6010 & 0.10 & $\mathrm{NE}$ & 0.22 & ND & 0.12 & 0.10 & $0.054^{b}$ & $0.041^{b}$ \\
\hline Lead & 7421 & $0.010-0.05$ & 0.05 & 0.018 & ND & ND & $0.0036^{b}$ & ND & ND \\
\hline Magnesium & 6010 & 0.20 & $\mathrm{NE}$ & 17.8 & 18.5 & 15.9 & 19.7 & 19.1 & 19.3 \\
\hline Manganese & 6010 & 0.010 & $\mathrm{NE}$ & ND & ND & $0.0043^{b}$ & 0.040 & ND & ND \\
\hline Mercury & 7470 & 0.00020 & 0.002 & ND & ND & ND & ND & ND & ND \\
\hline Nickel & 6010 & 0.040 & $\mathrm{NE}$ & 0.095 & ND & $0.014^{b}$ & ND & ND & ND \\
\hline Potassium & 6010 & 5.0 & $\mathrm{NE}$ & $3.3^{b}$ & $4.8^{b}$ & $3.6^{\mathrm{b}}$ & $4.8^{b}$ & $3.6^{\mathrm{b}}$ & $3.6^{\mathrm{b}}$ \\
\hline Selenium & 7740 & $2.5-5.0$ & 0.01 & $0.0023^{b}$ & $0.0040^{b}$ & $0.0023^{b}$ & $0.0020^{b}$ & $0.0017^{b}$ & $0.0017^{b}$ \\
\hline Silver & 6010 & 0.010 & 0.05 & ND & ND & ND & ND & ND & ND \\
\hline Sodium & 6010 & 5.0 & $\mathrm{NE}$ & 50.9 & 55.4 & 51.5 & 46.2 & 56.0 & 56.2 \\
\hline Thallium & 7841 & 0.010 & NE & ND & ND & ND & ND & ND & ND \\
\hline Vanadium & 6010 & 0.010 & $\mathrm{NE}$ & $0.0063^{b}$ & ND & $0.0074^{b}$ & $0.0069^{b}$ & $0.0071^{b}$ & $0.0071^{b}$ \\
\hline Zinc & 6010 & 0.020 & NE & $0.016^{b}$ & 0.054 & 0.030 & $0.0057^{b}$ & 0.048 & 0.040 \\
\hline \multicolumn{10}{|c|}{$\begin{array}{l}\text { a"Methods for Chemical Analysis of Water and Wastes," U.S. Environmental Protection Agency, EPA-600/4-79-020, 1983. } \\
\text { b"Test Methods for Evaluating Solid Waste, Physical/Chemical Methods," U.S. Environmental Protection Agency, SW-846, } 1986 . \\
\text { cDetected below reporting limit. } \\
\text { d"Standard Methods for the Examination of Water and Wastewater," 15th ed., American Public Health Association, } 1980 . \\
\text { ND = Not detected at reporting limit indicated. } \\
\text { NA }=\text { Not applicable } \\
\text { NE = Not established. }\end{array}$} \\
\hline
\end{tabular}


Table K-17a.

Summary of the Radiological Analytical Results for the Mixed Waste Landfill Sandia National Laboratories/New Mexico January 1993

\begin{tabular}{|c|c|c|c|c|c|c|}
\hline & $\begin{array}{r}\text { Sample No.: } \\
\text { Well ID: } \\
\text { Sampling Date: }\end{array}$ & \multicolumn{5}{|c|}{$\begin{array}{c}\text { SNLA011635 } \\
\text { MWL-MW1 } \\
1 / 19 / 93\end{array}$} \\
\hline \multicolumn{7}{|c|}{ All results in $\mathrm{pCi} / \mathrm{L}$} \\
\hline Parameter $^{a}$ & $\begin{array}{c}\mathrm{DCG}^{\mathrm{b}} \\
(\mathrm{pCi} / \mathrm{L})\end{array}$ & $\begin{array}{l}\text { Results } \\
(\mathrm{pCi} / \mathrm{L})^{\mathrm{c}}\end{array}$ & 2 Sigma & $\begin{array}{c}\text { Critical } \\
\text { Level, Lc }\end{array}$ & $\begin{array}{l}\text { Detection } \\
\text { Limit, Ld }\end{array}$ & $\begin{array}{c}\text { Determination } \\
\text { Limit, Lq }\end{array}$ \\
\hline Gross Alpha & 15 & 10.7 & 3.8 & 1.2 & 3.2 & 29 \\
\hline Gross Alpha & 15 & 13.9 & 4.2 & 0.7 & 2 & 26 \\
\hline Gross Alpha & 15 & 10.9 & 3.8 & 1.3 & 3.3 & 28 \\
\hline Gross Alpha & 15 & 11.7 & 4 & 1.4 & 3.5 & 30 \\
\hline Average Gross Alpha & & 11.80 & 3.95 & 1.15 & 3.00 & 28.25 \\
\hline Gross Beta & 30 & 5.53 & 2.7 & 1.9 & 4 & 16 \\
\hline Gross Beta & 30 & 6.46 & 2.98 & 2.1 & 4.4 & 17 \\
\hline Gross Beta & 30 & 5.8 & 2.63 & 1.8 & 3.9 & 15 \\
\hline Gross Beta & 30 & 4.24 & 2.67 & 2 & 4.2 & 16 \\
\hline Average Gross Beta & & 5.51 & 2.75 & 1.95 & 4.13 & 16.00 \\
\hline Tritium & 80000 & 1 & 113 & 93 & 210 & 790 \\
\hline Tritium & 80000 & -74 & 107 & 91 & 190 & 770 \\
\hline Tritium & 80000 & -45 & 109 & 91 & 190 & 780 \\
\hline Tritium & 80000 & 42 & 111 & 91 & 190 & 770 \\
\hline Average Tritium & & -19.00 & 110.00 & 91.50 & 195.00 & 777.50 \\
\hline Radium-226 & 4 & 0.113 & 0.107 & 0.046 & 0.14 & 2 \\
\hline Radium-228 & 4 & 2.13 & 1.64 & 1.3 & 2.6 & 9.7 \\
\hline Americium-241 & 1.2 & -0.0196 & 0.0393 & 0.047 & 0.15 & 2.1 \\
\hline Cesium-137 & 120 & 17.619 & NA & 7.6 & 17.619 & 107.6 \\
\hline lodine-129 & 20 & 0.33 & 3.28 & 2.7 & 5.7 & 22 \\
\hline Iron-55 & 8000 & 0.072 & 0.047 & 37 & 76 & 270 \\
\hline Polonium-210 & 3.2 & 0 & 0.557 & 0.5 & 1.3 & 15 \\
\hline Strontium-90 & 40 & -0.2 & 1 & 0.8 & 1.8 & 7.2 \\
\hline Thorium-228 d & 16 & 385 & 364 & NG & NG & NG \\
\hline
\end{tabular}

Refer to footnotes at end of table. 
Table K-17a. (Continued)

Summary of the Radiological Analytical Results

for the Mixed Waste Landfill

Sandia National Laboratories/New Mexico

January 1993

\begin{tabular}{|c|c|c|c|c|c|c|}
\hline & $\begin{array}{r}\text { Sample No.: } \\
\text { Well ID: } \\
\text { Sampling Date: }\end{array}$ & \multicolumn{5}{|c|}{$\begin{array}{c}\text { SNLA011631 } \\
\text { MWL-MW2 } \\
1 / 18 / 93 \\
\end{array}$} \\
\hline \multicolumn{7}{|c|}{ All results in $\mathrm{pCi} / \mathrm{L}$} \\
\hline Parameter ${ }^{\mathbf{a}}$ & $\begin{array}{c}\mathrm{DCG}^{\mathrm{b}} \\
(\mathrm{pCi} / \mathrm{L})\end{array}$ & $\begin{array}{l}\text { Results }^{c} \\
\text { (pCi/L) }\end{array}$ & 2 Sigma & $\begin{array}{c}\text { Critical } \\
\text { Level, Lc }\end{array}$ & $\begin{array}{l}\text { Detection } \\
\text { Limit, Ld }\end{array}$ & $\begin{array}{l}\text { Determination } \\
\text { Limit, Lq }\end{array}$ \\
\hline Gross Alpha & 15 & 11.6 & 2.5 & 0.5 & 1.2 & 10 \\
\hline Gross Alpha & 15 & 13.4 & 2.8 & 0.6 & 1.5 & 12 \\
\hline Gross Alpha & 15 & 8.34 & 2.09 & 0.6 & 1.5 & 11 \\
\hline Gross Alpha & 15 & 7.34 & 1.98 & 0.6 & 1.5 & 11 \\
\hline Average Gross Alpha & & 10.17 & 2.3425 & 0.575 & 1.425 & 11 \\
\hline Gross Beta & 30 & 4.77 & 2.53 & 1.8 & 3.8 & 15 \\
\hline Gross Beta & 30 & 6.14 & 2.71 & 1.9 & 4 & 16 \\
\hline Gross Beta & 30 & 6.46 & 2.76 & 1.9 & 4 & 16 \\
\hline Gross Beta & 30 & 6.16 & 2.63 & 1.8 & 3.8 & 15 \\
\hline Average Gross Beta & & 5.8825 & 2.6575 & 1.85 & 3.9 & 15.5 \\
\hline Tritium & 80000 & -89 & 177 & 150 & 310 & 1100 \\
\hline Tritium & 80000 & -130 & 175 & 150 & 300 & 1100 \\
\hline Tritium & 80000 & -159 & 172 & 150 & 300 & 1100 \\
\hline Tritium & 80000 & -183 & 176 & 150 & 310 & 1100 \\
\hline Average Tritium & & -140.25 & 175 & 150 & 305 & 1100 \\
\hline Radium-226 & 4 & 0.0919 & 0.0976 & 0.045 & 0.1 & 2 \\
\hline Radium-228 & 4 & 0.07 & 1.39 & 1.2 & 2.4 & 8.8 \\
\hline Americium-241 & 1.2 & 0.02 & 0.0283 & 0 & 0.03 & 1.1 \\
\hline Cesium-137 & 120 & 19.524 & NA & 8.5 & 19.5 & 117 \\
\hline lodine-129 & 20 & -0.33 & 3.26 & 2.7 & 5.7 & 22 \\
\hline Iron-55 & 8000 & 222 & 51 & 29 & 60 & 220 \\
\hline Polonium-210 & 3.2 & 0.2 & 1.03 & 0.8 & 2.2 & 21 \\
\hline Strontium-90 & 40 & 0.45 & 1.08 & 0.87 & 1.8 & 7.4 \\
\hline Lead-212 & 1.2 & 20.4 & 18.6 & NG & NG & NG \\
\hline Thorium-234 & 400 & 119 & 165 & NG & NG & NG \\
\hline Uranium-238 & 24 & 119 & 165 & NG & NG & NG \\
\hline
\end{tabular}

Refer to footnotes at end of table. 
Table K-17a. (Continued)

Summary of the Radiological Analytical Results for the Mixed Waste Landfill

Sandia National Laboratories/New Mexico

January 1993

\begin{tabular}{|c|c|c|c|c|c|c|}
\hline & $\begin{array}{r}\text { Sample No.: } \\
\text { Well ID: } \\
\text { Sampling Date: }\end{array}$ & \multicolumn{5}{|c|}{$\begin{array}{c}\text { SNLA011633 } \\
\text { MWL-MW3 } \\
1 / 19 / 93\end{array}$} \\
\hline \multicolumn{7}{|c|}{ All results in $\mathrm{pCi} / \mathrm{L}$} \\
\hline Parameter ${ }^{\mathrm{a}}$ & $\begin{array}{l}\mathrm{DCG}^{\mathrm{b}} \\
(\mathrm{pCi} / \mathrm{L})\end{array}$ & $\begin{array}{l}\text { Results }^{\mathrm{C}} \\
\text { (pCi/L) }\end{array}$ & 2 Sigma & $\begin{array}{c}\text { Critical } \\
\text { Level, Lc }\end{array}$ & $\begin{array}{l}\text { Detection } \\
\text { Limit, Ld }\end{array}$ & $\begin{array}{l}\text { Determination } \\
\text { Limit, Lq }\end{array}$ \\
\hline Gross Alpha & 15 & 9.85 & 2.24 & 0.6 & 1.4 & 11 \\
\hline Gross Alpha & 15 & 8.82 & 2.09 & 0.4 & 1.2 & 11 \\
\hline Gross Alpha & 15 & 10.3 & 2.3 & 0.5 & 1.3 & 11 \\
\hline Gross Alpha & 15 & 9.92 & 2.27 & 0.6 & 1.5 & 11 \\
\hline Average Gross Alpha & & 9.72 & 2.23 & 0.53 & 1.35 & 11.00 \\
\hline Gross Beta & 30 & 4.54 & 2.27 & 1.6 & 3.4 & 13 \\
\hline Gross Beta & 30 & 7.01 & 2.6 & 1.7 & 3.7 & 14 \\
\hline Gross Beta & 30 & 5.49 & 2.45 & 1.7 & 3.6 & 14 \\
\hline Gross Beta & 30 & 7.35 & 2.6 & 1.7 & 3.6 & 14 \\
\hline Average Gross Beta & & 6.10 & 2.48 & 1.68 & 3.58 & 13.75 \\
\hline Tritium & 80000 & -380 & 183 & 160 & 320 & 1200 \\
\hline Tritium & 80000 & -354 & 184 & 160 & 320 & 1200 \\
\hline Tritium & 80000 & -216 & 188 & 160 & 330 & 1200 \\
\hline Tritium & 80000 & -268 & 187 & 160 & 330 & 1200 \\
\hline Average Tritium & & -304.50 & 185.50 & 160.00 & 325.00 & 1200.00 \\
\hline Radium-226 & 4 & 0.178 & 0.132 & 0.048 & 0.151 & 2.1 \\
\hline Radium-228 & 4 & 1.4 & 2.32 & 1.9 & 3.9 & 14 \\
\hline Americium-241 & 1.2 & 0.0316 & 0.0634 & 0.038 & 0.121 & 1.7 \\
\hline Cesium-137 & 120 & 13.889 & NA & 5.8 & 13.889 & 99.8 \\
\hline lodine-129 & 20 & 0.38 & 3.29 & 2.7 & 5.7 & 22 \\
\hline Iron-55 & 8000 & 632 & 12 & 53 & 110 & 390 \\
\hline Polonium-210 & 3.2 & 0.000252 & $\begin{array}{c}0.00050 \\
7\end{array}$ & 0.00031 & 0.00096 & 0.013 \\
\hline Strontium-90 & 40 & 0.338 & 0.992 & 0.8 & 1.7 & 6.9 \\
\hline Thorium-234 & 400 & 38 & 166 & NG & NG & NG \\
\hline Uranium-238 & 24 & 38 & 166 & NG & NG & NG \\
\hline
\end{tabular}

Refer to footnotes at end of table. 
Table K-17a. (Continued)

Summary of the Radiological Analytical Results

for the Mixed Waste Landfill

Sandia National Laboratories/New Mexico

January 1993

\begin{tabular}{|c|c|c|c|c|c|c|}
\hline & \multirow[t]{2}{*}{$\begin{array}{r}\text { Sample No.: } \\
\text { Well ID: } \\
\text { Sampling Date: } \\
\end{array}$} & \multicolumn{5}{|c|}{$\begin{array}{c}\text { SNLA011637 } \\
\text { MWL-BW1 } \\
1 / 20 / 93 \\
\end{array}$} \\
\hline \multicolumn{6}{|c|}{ All results in $\mathrm{pCi} / \mathrm{L}$} & \\
\hline Parameter $^{a}$ & $\begin{array}{l}\mathrm{DCG}^{\mathrm{b}} \\
(\mathrm{pCi} / \mathrm{L})\end{array}$ & $\begin{array}{c}\text { Results }^{c} \\
(\mathrm{pCi} / \mathrm{L})\end{array}$ & 2 Sigma & $\begin{array}{c}\text { Critical } \\
\text { Level, Lc }\end{array}$ & $\begin{array}{l}\text { Detection } \\
\text { Limit, Ld }\end{array}$ & $\begin{array}{c}\text { Determination } \\
\text { Limit, Lq }\end{array}$ \\
\hline Gross Alpha & 15 & 13 & 4.1 & 1.3 & 3.3 & 27 \\
\hline Gross Alpha & 15 & 10.4 & 3.6 & 1 & 2.8 & 28 \\
\hline Gross Alpha & 15 & 10.6 & 3.5 & 0.6 & 1.9 & 23 \\
\hline Gross Alpha & 15 & 28.1 & 6.1 & 0.8 & 2.4 & 28 \\
\hline Average Gross Alpha & & 15.53 & 4.33 & 0.93 & 2.60 & 26.50 \\
\hline Gross Beta & 30 & 7.45 & 2.55 & 1.7 & 3.5 & 14 \\
\hline Gross Beta & 30 & 6.95 & 2.53 & 1.7 & 3.5 & 14 \\
\hline Gross Beta & 30 & 4.56 & 2.25 & 1.6 & 3.3 & 13 \\
\hline Gross Beta & 30 & 7.03 & 2.59 & 1.7 & 3.6 & 14 \\
\hline Average Gross Beta & & 6.50 & 2.48 & 1.68 & 3.48 & 13.75 \\
\hline Tritium & 80000 & -80 & 112 & 95 & 200 & 790 \\
\hline Tritium & 80000 & -126 & 111 & 96 & 200 & 810 \\
\hline Tritium & 80000 & -125 & 112 & 96 & 200 & 810 \\
\hline Tritium & 80000 & -180 & 108 & 94 & 200 & 790 \\
\hline Average Tritium & & -127.75 & 110.75 & 95.25 & 200.00 & 800.00 \\
\hline Radium-226 & 4 & 0.133 & 0.141 & 0.075 & 0.21 & 2.4 \\
\hline Radium-228 & 4 & 1.5 & 2.42 & 1.9 & 4 & 15 \\
\hline Americium-241 & 1.2 & 0.0341 & 0.0209 & 0 & 0.0093 & 0.3 \\
\hline Cesium-137 & 120 & 13.446 & NA & 5.5 & 13.446 & 100.7 \\
\hline lodine-129 & 20 & -1.5 & 3.22 & 2.7 & 5.7 & 22 \\
\hline Iron-55 & 8000 & 69 & 43 & 33 & 69 & 250 \\
\hline Polonium-210 & 3.2 & 0.29 & 1.02 & 0.7 & 2.2 & 31 \\
\hline Strontium-90 & 40 & 0.446 & 0.95 & 0.8 & 1.69 & 6.6 \\
\hline Potassium- $40^{d}$ & 280 & 80.9 & 157 & NG & NG & NG \\
\hline Thorium-234 & 400 & 120 & 208 & NG & $N G$ & NG \\
\hline Uranium-238 & 24 & 120 & 208 & NG & NG & NG \\
\hline
\end{tabular}

Refer to footnotes at end of table. 
Table K-17a. (Concluded)

\section{Summary of the Radiological Analytical Results \\ for the Mixed Waste Landfill \\ Sandia National Laboratories/New Mexico}

January 1993

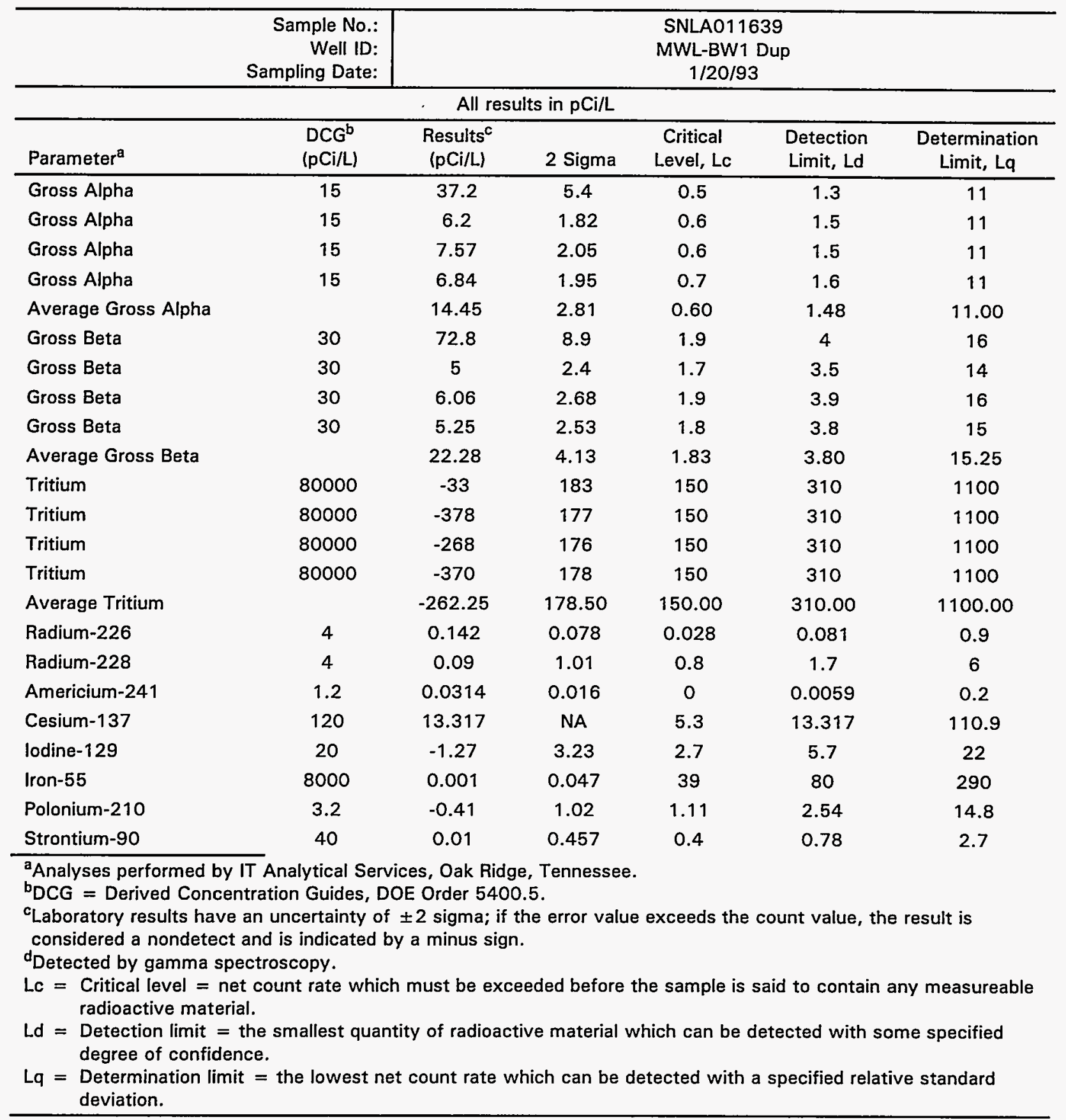


Table K-17b.

Summary of the Radiological Analytical Results for the Mixed Waste Landfill

Sandia National Laboratories/New Mexico

April 1993

\begin{tabular}{|c|c|c|c|c|c|}
\hline & $\begin{array}{r}\text { Sample No.: } \\
\text { Well ID: } \\
\text { Sampling Date: } \\
\end{array}$ & \multicolumn{4}{|c|}{$\begin{array}{c}\text { SNLA012180 } \\
\text { MWL-MW1 } \\
04 / 27 / 93 \\
\end{array}$} \\
\hline \multicolumn{6}{|c|}{ All results in $\mathrm{pCi} / \mathrm{L}$} \\
\hline Parameter $^{\mathbf{a}}$ & $\mathrm{DCG}^{\mathrm{b}}(\mathrm{pCi} / \mathrm{L})$ & $\begin{array}{l}\text { Results } \\
(\mathrm{pCi} / \mathrm{L})^{\mathrm{C}}\end{array}$ & 2 Sigma & $\mathrm{MDA}^{\mathrm{d}}$ & $\begin{array}{c}\text { Decision } \\
\text { Amount, } \mathrm{DA}^{\mathrm{e}} \\
\end{array}$ \\
\hline Gross Alpha & 15 & 11 & 4.4 & 1.9 & 1.20 \\
\hline Gross Alpha & 15 & 8.6 & 3.8 & 2.5 & 1.20 \\
\hline Gross Alpha & 15 & 7.8 & 3.5 & 2.6 & 1.05 \\
\hline Gross Alpha & 15 & 9.6 & 4.1 & 2.7 & 1.20 \\
\hline Gross Beta & 30 & 4.5 & 1.8 & 2.4 & 1.21 \\
\hline Gross Beta & 30 & 5.2 & 1.7 & 2.0 & 1.21 \\
\hline Gross Beta & 30 & 5.3 & 1.7 & 2.0 & 1.18 \\
\hline Gross Beta & 30 & 4.8 & 1.8 & 2.1 & 1.21 \\
\hline Tritium & 80000 & 160 & 230 & 370 & 191.62 \\
\hline Tritium & 80000 & 270 & 240 & 370 & 183.29 \\
\hline Tritium & 80000 & 35 & 220 & 370 & 183.29 \\
\hline Tritium & 80000 & 370 & 240 & 370 & 191.62 \\
\hline Radium-226 & 4 & 0.40 & 0.11 & 0.10 & 0.05 \\
\hline Radium-228 & 4 & 0.71 & 0.48 & 0.63 & 0.28 \\
\hline Americium-241 & 1.2 & 0.001 & 0.016 & 0.032 & 0.03 \\
\hline Cesium-137 & 120 & ND & NL & 29 & 18.52 \\
\hline lodine-129 & 20 & 6.3 & 5.2 & 8.3 & 4.80 \\
\hline Iron-55 & 8000 & -5.0 & 24 & 37 & 20.00 \\
\hline Polonium-210 & 3.2 & 0.062 & 0.070 & 0.062 & 0.03 \\
\hline Strontium-90 & 40 & 5.7 & 2.7 & 3.2 & 1.62 \\
\hline
\end{tabular}

Refer to footnotes at end of table. 
Table $\mathrm{K}-17 \mathrm{~b}$. (Continued)

Summary of the Radiological Analytical Results

for the Mixed Waste Landfill

Sandia National Laboratories/New Mexico

April 1993

\begin{tabular}{|c|c|c|c|c|c|}
\hline & $\begin{array}{r}\text { Sample No: } \\
\text { Well ID: } \\
\text { Sampling Date: }\end{array}$ & \multicolumn{4}{|c|}{$\begin{array}{c}\text { SNLA012181 } \\
\text { MWL-MW2 } \\
04 / 26 / 93\end{array}$} \\
\hline \multicolumn{6}{|c|}{ All results in $\mathrm{pCi} / \mathrm{L}$} \\
\hline & & Results ${ }^{c}$ & & & Decision \\
\hline Parameter ${ }^{\mathrm{a}}$ & $D C G^{b}(p C i / L)$ & $(\mathrm{pCi} / \mathrm{L})$ & 2 Sigma & $M^{\prime d}$ & Amount, $\mathrm{DA}^{\mathrm{e}}$ \\
\hline Gross Alpha & 15 & 12 & 4.7 & 2.5 & 1.20 \\
\hline Gross Alpha & 15 & 13 & 5.3 & 4.3 & 1.05 \\
\hline Gross Alpha & 15 & 19 & 6.8 & 3.5 & 1.40 \\
\hline Gross Alpha & 15 & 10 & 4.3 & 3.1 & 1.20 \\
\hline Gross Beta & 30 & 6.8 & 2.0 & 2.1 & 1.21 \\
\hline Gross Beta & 30 & 7.6 & 2.0 & 2.1 & 1.21 \\
\hline Gross Beta & 30 & 9.9 & 2.3 & 2.1 & 1.21 \\
\hline Gross Beta & 30 & 7.6 & 2.1 & 2.3 & 1.21 \\
\hline Tritium & 80000 & 270 & 240 & 370 & 183.29 \\
\hline Tritium & 80000 & 240 & 230 & 370 & 183.29 \\
\hline Tritium & 80000 & 98 & 220 & 370 & 183.29 \\
\hline Tritium & 80000 & 130 & 230 & 370 & 183.29 \\
\hline Radium-226 & 4 & 0.35 & 0.11 & 0.12 & 0.05 \\
\hline Radium-228 & 4 & 0.67 & 0.54 & 0.76 & 0.29 \\
\hline Americium-241 & 1.2 & -0.003 & 0.001 & 0.022 & 0.02 \\
\hline Cesium-137 & 120 & ND & NL & 27 & 18.52 \\
\hline lodine-129 & 20 & 7.9 & 5.6 & 9.2 & 5.30 \\
\hline Iron-55 & 8000 & 19 & 28 & 37 & 22.38 \\
\hline Polonium-210 & 3.2 & 0.029 & 0.054 & 0.078 & 0.02 \\
\hline Strontium-90 & 40 & 2.2 & 1.2 & 1.6 & 0.74 \\
\hline Lead-212 & 120 & 36 & 64 & 100 & 30.13 \\
\hline
\end{tabular}

Refer to footnotes at end of table. 
Table K-17b. (Continued)

Summary of the Radiological Analytical Results

for the Mixed Waste Landfill

Sandia National Laboratories/New Mexico

ApriI 1993

\begin{tabular}{|c|c|c|c|c|c|}
\hline & $\begin{array}{r}\text { Sample No.: } \\
\text { Well ID: } \\
\text { Sampling Date: }\end{array}$ & \multicolumn{4}{|c|}{$\begin{array}{c}\text { SNLA012182 } \\
\text { MWL-MW3 } \\
04 / 27 / 93\end{array}$} \\
\hline \multicolumn{6}{|c|}{ All results in $\mathrm{pCi} / \mathrm{L}$} \\
\hline & & Results $^{c}$ & & & Decision \\
\hline Parameter $^{a}$ & $\mathrm{DCG}^{\mathrm{b}}(\mathrm{pCi} / \mathrm{L})$ & (pCi/L) & 2 Sigma & $\mathrm{MDA}^{\mathrm{d}}$ & Amount, $\mathrm{DA}^{\mathrm{e}}$ \\
\hline Gross Alpha & 15 & 11 & 4.2 & 1.6 & 1.05 \\
\hline Gross Alpha & 15 & 7.1 & 3.3 & 2.3 & 1.05 \\
\hline Gross Alpha & 15 & 6.3 & 3.2 & 2.7 & 1.05 \\
\hline Gross Alpha & 15 & 8.8 & 3.7 & 2.3 & 1.05 \\
\hline Gross Beta & 30 & 4.5 & 1.8 & 2.4 & 1.18 \\
\hline Gross Beta & 30 & 7.4 & 2.0 & 2.0 & 1.18 \\
\hline Gross Beta & 30 & 7.3 & 2.0 & 2.0 & 1.18 \\
\hline Gross Beta & 30 & 7.6 & 2.0 & 2.1 & 1.18 \\
\hline Tritium & 80000 & 280 & 240 & 370 & 191.62 \\
\hline Tritium & 80000 & -14 & 220 & 370 & 183.29 \\
\hline Tritium & 80000 & 77 & 220 & 370 & 183.29 \\
\hline Tritium & 80000 & 58 & 220 & 370 & 183.29 \\
\hline Radium-226 & 4 & 0.34 & 0.093 & 0.060 & 0.04 \\
\hline Radium-228 & 4 & 0.55 & 0.52 & 0.74 & 0.28 \\
\hline Americium-241 & 1.2 & 0.008 & 0.016 & 0.010 & 0.03 \\
\hline Cesium-137 & 120 & ND & $\mathrm{NL}$ & 29 & 18.52 \\
\hline lodine-129 & 20 & 16 & 6.0 & 9.1 & 5.22 \\
\hline Iron-55 & 8000 & 5.9 & 29 & 37 & 23.79 \\
\hline Polonium-210 & 3.2 & 0.081 & 0.068 & 0.016 & 0.02 \\
\hline Strontium-90 & 40 & 2.5 & 1.2 & 1.5 & 0.72 \\
\hline Potassium-40 & 280 & 270 & 510 & 640 & 441.05 \\
\hline
\end{tabular}

Refer to footnotes at end of table. 
Table K-17b. (Continued)
Summary of the Radiological Analytical Results for the Mixed Waste Landfill
Sandia National Laboratories/New Mexico
April 1993

\begin{tabular}{|c|c|c|c|c|c|}
\hline & $\begin{array}{r}\text { Sample No.: } \\
\text { Well ID: } \\
\text { Sampling Date: }\end{array}$ & \multicolumn{4}{|c|}{$\begin{array}{c}\text { SNLA012183 } \\
\text { MWL-BW1 } \\
04 / 28 / 93\end{array}$} \\
\hline \multicolumn{6}{|c|}{ All results in $\mathrm{pCi} / \mathrm{L}$} \\
\hline Parameter $^{\mathbf{a}}$ & $\mathrm{DCG}^{\mathrm{b}}(\mathrm{pCi} / \mathrm{L})$ & Results $^{c}(\mathrm{pCi} / \mathrm{L})$ & 2 Sigma & $\mathrm{MDA}^{\mathrm{d}}$ & $\begin{array}{c}\text { Decision } \\
\text { Amount, } \mathrm{DA}^{\mathrm{e}}\end{array}$ \\
\hline Gross Alpha & 15 & 5.8 & 3.4 & 3.1 & 1.40 \\
\hline Gross Alpha & 15 & 10 & 4.5 & 2.7 & 1.40 \\
\hline Gross Alpha & 15 & 13 & 5.4 & 3.1 & 1.40 \\
\hline Gross Alpha & 15 & 13 & 6.1 & 5.7 & 1.40 \\
\hline Gross Beta & 30 & 6.3 & 1.9 & 2.3 & 1.21 \\
\hline Gross Beta & 30 & 5.3 & 1.9 & 2.3 & 1.21 \\
\hline Gross Beta & 30 & 6.5 & 2.0 & 2.1 & 1.21 \\
\hline Gross Beta & 30 & 5.9 & 1.8 & 2.1 & 1.21 \\
\hline Tritium & 80000 & 58 & 220 & 370 & 191.62 \\
\hline Tritium & 80000 & -150 & 210 & 370 & 186.53 \\
\hline Tritium & 80000 & 150 & 230 & 370 & 183.29 \\
\hline Tritium & 80000 & -20 & 220 & 370 & 191.62 \\
\hline Radium-226 & 4 & 0.41 & 0.12 & 0.10 & 0.04 \\
\hline Radium-228 & 4 & 0.76 & 0.58 & 0.81 & 0.29 \\
\hline Americium-241 & 1.2 & -0.005 & 0.001 & 0.030 & 0.01 \\
\hline Cesium-137 & 120 & ND & NL & 31 & 18.52 \\
\hline lodine-129 & 20 & 35 & 8.0 & 12 & 6.83 \\
\hline Iron-55 & 8000 & -4.0 & 38 & 37 & 31.86 \\
\hline Polonium-210 & 3.2 & 0.026 & 0.056 & 0.081 & 0.03 \\
\hline Strontium-90 & 40 & 4.0 & 1.6 & 1.8 & 0.69 \\
\hline Lead-212f & 120 & 40 & 62 & 98 & 30.13 \\
\hline
\end{tabular}

Refer to footnotes at end of table. 
Table K-17b. (Continued)

Summary of the Radiological Analytical Results for the Mixed Waste Landfill

Sandia National Laboratories/New Mexico

April 1993

\begin{tabular}{|c|c|c|c|c|c|}
\hline & $\begin{array}{r}\text { Sample No.: } \\
\text { Well ID: } \\
\text { Sampling Date: }\end{array}$ & \multicolumn{4}{|c|}{$\begin{array}{c}\text { SNLA012184 } \\
\text { MWL-BW1 Dup } \\
04 / 28 / 93\end{array}$} \\
\hline \multicolumn{6}{|c|}{ All results in $\mathrm{pCi} / \mathrm{L}$} \\
\hline & & Results $^{c}$ & & & Decision \\
\hline Parameter $^{\mathrm{a}}$ & $D C G^{b}(p C i / L)$ & $(\mathrm{pCi} / \mathrm{L})$ & 2 Sigma & $\mathrm{MDA}^{\mathrm{d}}$ & Amount, $\mathrm{DA}^{\mathrm{e}}$ \\
\hline Gross Alpha & 15 & 12 & 5.2 & 3.4 & 1.40 \\
\hline Gross Alpha & 15 & 12 & 5.3 & 4.1 & 1.40 \\
\hline Gross Alpha & 15 & 9.8 & 4.4 & 2.3 & 1.40 \\
\hline Gross Alpha & 15 & 16 & 6.1 & 3.3 & 1.40 \\
\hline Gross Beta & 30 & 7.9 & 2.1 & 2.1 & 1.21 \\
\hline Gross Beta & 30 & 6.7 & 2.1 & 2.3 & 1.21 \\
\hline Gross Beta & 30 & 6.0 & 2.0 & 2.4 & 1.21 \\
\hline Gross Beta & 30 & 6.8 & 2.0 & 2.1 & 1.21 \\
\hline Tritium & 80000 & 160 & 230 & 370 & 183.29 \\
\hline Tritium & 80000 & 300 & 240 & 370 & 183.29 \\
\hline Tritium & 80000 & 290 & 220 & 330 & 183.29 \\
\hline Tritium & 80000 & 140 & 210 & 330 & 183.29 \\
\hline Radium-226 & 4 & 0.37 & 0.11 & 0.13 & 0.04 \\
\hline Radium-228 & 4 & 1.0 & 0.58 & 0.75 & 0.29 \\
\hline Americium-241 & 1.2 & 0.006 & 0.012 & 0.008 & 0.02 \\
\hline Cesium-137 & 120 & ND & NL & 31 & 18.52 \\
\hline lodine- 129 & 20 & 29 & 7.3 & 11 & 6.34 \\
\hline Iron-55 & 8000 & 20 & 140 & 37 & 117.47 \\
\hline Polonium-210 & 3.2 & 0.073 & 0.072 & 0.058 & 0.02 \\
\hline Strontium-90 & 40 & 0.83 & 1.2 & 1.9 & 0.88 \\
\hline
\end{tabular}

Refer to footnotes at end of table. 
Table K-17b. (Concluded)

\section{Summary of the Radiological Analytical Results \\ for the Mixed Waste Landfill \\ Sandia National Laboratories/New Mexico}

April 1993

\begin{tabular}{|c|c|c|c|c|c|}
\hline & $\begin{array}{r}\text { Sample No.: } \\
\text { Well ID: } \\
\text { Sampling Date: }\end{array}$ & \multicolumn{4}{|c|}{$\begin{array}{c}\text { SNLA012185 } \\
\text { MWL-MW4 } \\
04 / 30 / 93\end{array}$} \\
\hline \multicolumn{6}{|c|}{ All results in $\mathrm{pCi} / \mathrm{L}$} \\
\hline Parameter $^{a}$ & $D_{C G}(p C i / L)$ & Results $^{c}(\mathrm{pCi} / \mathrm{L})$ & 2 Sigma & MDA $^{d}$ & $\begin{array}{c}\text { Detection } \\
\text { Amount, } \mathrm{DA}^{\mathrm{e}}\end{array}$ \\
\hline Gross Alpha & 15 & 8.5 & 4.4 & 3.7 & 1.40 \\
\hline Gross Alpha & 15 & 8.7 & 4.4 & 3.5 & 1.40 \\
\hline Gross Alpha & 15 & 12 & 5.2 & 3.5 & 1.40 \\
\hline Gross Alpha & 15 & 7.2 & 3.8 & 2.8 & 1.68 \\
\hline Gross Beta & 30 & 8.5 & 2.1 & 2.0 & 1.21 \\
\hline Gross Beta & 30 & 6.4 & 2.0 & 2.1 & 1.21 \\
\hline Gross Beta & 30 & 8.9 & 2.3 & 2.3 & 1.21 \\
\hline Gross Beta & 30 & 13 & 2.6 & 0.80 & 1.21 \\
\hline Tritium & 80000 & 280 & 220 & 330 & 191.62 \\
\hline Tritium & 80000 & 160 & 230 & 370 & 186.53 \\
\hline Tritium & 80000 & 180 & 230 & 370 & 186.53 \\
\hline Tritium & 80000 & 88 & 220 & 370 & 186.53 \\
\hline Radium-226 & 4 & 0.13 & 0.10 & 0.14 & 0.05 \\
\hline Radium-228 & 4 & 1.2 & 0.62 & 0.80 & 0.30 \\
\hline Americium-241 & 1.2 & 0.027 & 0.028 & 0.008 & 0.02 \\
\hline Cesium-137 & 120 & ND & NL & 28 & 18.52 \\
\hline lodine-129 & 20 & 12 & 5.4 & 8.1 & 4.67 \\
\hline Iron-55 & 8000 & 13 & 21 & 37 & 17.24 \\
\hline Polonium-210 & 3.2 & -0.005 & 0.042 & 0.093 & 0.02 \\
\hline Strontium-90 & 40 & 1.9 & 1.4 & 2.0 & 0.98 \\
\hline Potassium-40 & 280 & 200 & 480 & 650 & 441.05 \\
\hline Lead-212 & 120 & 58 & 80 & 130 & 30.13 \\
\hline \multicolumn{6}{|c|}{$\begin{array}{l}\text { analyses performed by TMA/Eberline, Albuquerque, New Mexico. } \\
\text { bDCG = Derived Concentration Guides, DOE Order } 5400.5 \text {. } \\
\text { cLaboratory results have an uncertainty of } \pm 2 \text { sigma; if the error value exceeds the count value, the result is considered } \\
\text { a nondetect and is indicated by a minus sign. } \\
{ }^{\mathrm{d}} \mathrm{MDA}=\text { Minimum detectable activity. } \\
\text { eDA = Decision amount = activity that must be exceeded before the sample is said to contain any measurable } \\
\text { radioactive material. } \\
\text { 'Detected by gamma spectroscopy. } \\
\text { ND = Not detected. } \\
\mathrm{NL}=\text { Not listed. }\end{array}$} \\
\hline
\end{tabular}


Table K-17c.

Summary of the Radiological Analytical Results

for the Mixed Waste Landfill

Sandia National Laboratories/New Mexico

November 1993

\begin{tabular}{|c|c|c|c|c|c|c|}
\hline & $\begin{array}{r}\text { Sample No.: } \\
\text { Well ID: } \\
\text { Sampling Date: }\end{array}$ & \multicolumn{5}{|c|}{$\begin{array}{c}\text { SNLA014013 } \\
\text { MWL-MW1 } \\
11 / 09 / 93\end{array}$} \\
\hline \multicolumn{7}{|c|}{ All results in $\mathrm{pCi} / \mathrm{L}$} \\
\hline Parameter $^{a}$ & $\mathrm{DCG}^{\mathrm{b}}(\mathrm{pCi} / \mathrm{L})$ & Results $(\mathrm{pCi} / \mathrm{L})^{\mathrm{c}}$ & 2 Sigma & $L c^{d}$ & $\mathrm{MDA}^{e}$ & $\mathrm{DA}^{f}$ \\
\hline Gross Alpha & 15 & 11 & 4.1 & 5 & 2.1 & 1 \\
\hline Gross Beta & 30 & 5.9 & 1.8 & 31 & 2.2 & 1 \\
\hline Tritium & 80000 & -9.0 & 220 & 27 & 360 & 176 \\
\hline Uranium-233/234 & 200 & 6.1 & 0.82 & 16 & 0.085 & 0.22 \\
\hline Uranium-235 & 24 & 0.064 & 0.064 & 0 & 0.085 & 0.00 \\
\hline Uranium-238 & 24 & 3.0 & 0.49 & 15 & 0.085 & 0.21 \\
\hline Thorium-230 & 12 & -0.008 & 0.016 & 0 & 0.083 & 0.00 \\
\hline Thorium-232 & 2 & 0.013 & 0.024 & 0 & 0.054 & 0.00 \\
\hline Plutonium-238 & 1.6 & 0.011 & 0.012 & 4 & 0.010 & 0.01 \\
\hline Plutonium-239/240 & 1.2 & -0.007 & 0.010 & 3 & 0.033 & 0.01 \\
\hline Strontium-90 & 40 & NA & NA & NA & NA & NA \\
\hline & $\begin{array}{r}\text { Sample No.: } \\
\text { Well ID: } \\
\text { Sampling Date: }\end{array}$ & \multicolumn{5}{|c|}{$\begin{array}{c}\text { SNLA014014 } \\
\text { MWL-MW2 } \\
11 / 08 / 93\end{array}$} \\
\hline \multicolumn{7}{|c|}{ All results in $\mathrm{pCi} / \mathrm{L}$} \\
\hline Parameter $^{a}$ & $D C G^{b}(p C i / L)$ & Results $(p C i / L)^{c}$ & 2 Sigma & $L c^{d}$ & MDA $^{e}$ & $\mathrm{DA}^{f}$ \\
\hline Gross Alpha & 15 & 9.7 & 3.8 & 5 & 2.5 & 1 \\
\hline Gross Beta & 30 & 5.5 & 1.8 & 31 & 2.1 & 1 \\
\hline Tritium & 80000 & 120 & 230 & 27 & 360 & 184 \\
\hline Uranium-233/234 & 200 & 5.5 & 0.74 & 16 & 0.080 & 0.21 \\
\hline Uranium-235 & 24 & 0.12 & 0.082 & 0 & 0.036 & 0.00 \\
\hline Uranium-238 & 24 & 2.6 & 0.44 & 15 & 0.095 & 0.20 \\
\hline Thorium-230 & 12 & 0.001 & 0.026 & 0 & 0.090 & 0.00 \\
\hline Thorium-232 & 2 & 0.001 & 0.026 & 0 & 0.090 & 0.00 \\
\hline Plutonium-238 & 1.6 & -0.004 & 0.007 & 0 & 0.026 & 0.00 \\
\hline Plutonium-239/240 & 1.2 & 0.007 & 0.018 & 0 & 0.033 & 0.00 \\
\hline Strontium-90 & 40 & NA & NA & NA & NA & NA \\
\hline
\end{tabular}

Refer to footnotes at end of table. 
Table K-17c. (Continued)

Summary of the Radiological Analytical Results

for the Mixed Waste Landfill

Sandia National Laboratories/New Mexico

November 1993

\begin{tabular}{|c|c|c|c|c|c|c|}
\hline & $\begin{array}{r}\text { Sample No.: } \\
\text { Well ID: } \\
\text { Sampling Date: }\end{array}$ & \multicolumn{5}{|c|}{$\begin{array}{c}\text { SNLA014015 } \\
\text { MWL-MW3 } \\
11 / 09 / 93\end{array}$} \\
\hline \multicolumn{7}{|c|}{ All results in $\mathrm{pCi} / \mathrm{L}$} \\
\hline Parameter $^{\mathrm{a}}$ & $\mathrm{DCG}^{\mathrm{b}}(\mathrm{pCi} / \mathrm{L})$ & Results $(\mathrm{pCi} / \mathrm{L})^{c}$ & 2 Sigma & $L c^{d}$ & $\mathrm{MDA}^{\mathrm{e}}$ & $\mathrm{DA}^{f}$ \\
\hline Gross Alpha & 15 & 12 & 4.3 & 5 & 2.4 & 1 \\
\hline Gross Beta & 30 & 4.3 & 1.7 & 31 & 2.2 & 1 \\
\hline Tritium & 80000 & 4.9 & 220 & 27 & 360 & 184 \\
\hline Uranium-233/234 & 200 & 5.2 & 0.65 & 16 & 0.079 & 0.18 \\
\hline Uranium-235 & 24 & 0.099 & 0.066 & 0 & 0.030 & 0.00 \\
\hline Uranium-238 & 24 & 2.5 & 0.39 & 15 & 0.079 & 0.17 \\
\hline Thorium-230 & 12 & 0.016 & 0.022 & 0 & 0.036 & 0.00 \\
\hline Thorium-232 & 2 & 0.013 & 0.022 & 0 & 0.043 & 0.00 \\
\hline Plutonium-238 & 1.6 & 0.003 & 0.010 & 0 & 0.022 & 0.00 \\
\hline Plutonium-239/240 & 1.2 & 0.006 & 0.012 & 0 & 0.022 & 0.00 \\
\hline Strontium-90 & 40 & NA & NA & NA & NA & NA \\
\hline & $\begin{array}{r}\text { Sample No.: } \\
\text { Well ID: } \\
\text { Sampling Date: }\end{array}$ & \multicolumn{5}{|c|}{$\begin{array}{c}\text { SNLA014016 } \\
\text { MWL-MW4 } \\
11 / 11 / 93\end{array}$} \\
\hline \multicolumn{7}{|c|}{ All results in $\mathrm{pCi} / \mathrm{L}$} \\
\hline Parameter ${ }^{\mathrm{a}}$ & $\mathrm{DCG}^{\mathrm{b}}(\mathrm{pCi} / \mathrm{L})$ & Results (pCi/L) & 2 Sigma & $L c^{d}$ & $\mathrm{MDA}^{\mathrm{e}}$ & $\mathrm{DA}^{\mathrm{f}}$ \\
\hline Gross Alpha & 15 & 9.3 & 3.9 & 6 & 2.4 & 1 \\
\hline Gross Beta & 30 & 9.7 & 2.4 & 27 & 2.2 & 1 \\
\hline Tritium & 80000 & 140 & 160 & 37 & 250 & 126 \\
\hline Uranium-233/234 & 200 & 5.4 & 0.39 & 21 & 0.021 & 0.06 \\
\hline Uranium-235 & 24 & 0.13 & 0.042 & 0 & 0.021 & 0.00 \\
\hline Uranium-238 & 24 & 2.4 & 0.21 & 20 & 0.008 & 0.06 \\
\hline Thorium-230 & 12 & -0.003 & 0 & 15 & 0.032 & 0.08 \\
\hline Thorium-232 & 2 & 0.008 & 0.016 & 0 & 0.032 & 0.00 \\
\hline Plutonium-238 & 1.6 & 0.016 & 0.022 & 4 & 0.036 & 0.02 \\
\hline Plutonium-239/240 & 1.2 & 0.016 & 0.022 & 3 & 0.036 & 0.01 \\
\hline Strontium-90 & 40 & -0.49 & 0.56 & 30 & 0.99 & 0.69 \\
\hline
\end{tabular}

Refer to footnotes at end of table. 
Table K-17c. (Concluded)

Summary of the Radiological Analytical Results
for the Mixed Waste Landfill
Sandia National Laboratories/New Mexico

November 1993

\begin{tabular}{|c|c|c|c|c|c|c|}
\hline & $\begin{array}{r}\text { Sample No.: } \\
\text { Well ID: } \\
\text { Sampling Date: }\end{array}$ & \multicolumn{5}{|c|}{$\begin{array}{c}\text { SNLA014017 } \\
\text { MWL-BW1 } \\
11 / 10 / 93\end{array}$} \\
\hline \multicolumn{7}{|c|}{ All results in $\mathrm{pCi} / \mathrm{L}$} \\
\hline Parameter $^{a}$ & $D_{C G^{b}}(p C i / L)$ & Results $(p C i / L)^{c}$ & 2 Sigma & $L c^{d}$ & $\mathrm{MDA}^{\mathrm{e}}$ & $\mathrm{DA}^{f}$ \\
\hline Gross Alpha & 15 & 9.7 & 3.8 & 5 & 2.2 & 1 \\
\hline Gross Beta & 30 & 8.0 & 2.1 & 31 & 2.0 & 1 \\
\hline Tritium & 80000 & 13 & 220 & 27 & 360 & 184 \\
\hline Uranium-233/234 & 200 & 6.8 & 0.90 & 16 & 0.10 & 0.22 \\
\hline Uranium-235 & 24 & 0.071 & 0.064 & 0 & 0.039 & 0.00 \\
\hline Uranium-238 & 24 & 3.0 & 0.50 & 15 & 0.10 & 0.21 \\
\hline Thorium-230 & 12 & 0.013 & 0.022 & 0 & 0.043 & 0.00 \\
\hline Thorium-232 & 2 & 0.006 & 0.012 & 0 & 0.016 & 0.00 \\
\hline Plutonium-238 & 1.6 & 0.012 & 0.014 & 0 & 0.011 & 0.00 \\
\hline Plutonium-239/240 & 1.2 & -0.008 & 0.011 & 0 & 0.036 & 0.00 \\
\hline Strontium-90 & 40 & NA & NA & NA & NA & NA \\
\hline & $\begin{array}{r}\text { Sample No.: } \\
\text { Well ID: } \\
\text { Sampling Date: }\end{array}$ & \multicolumn{5}{|c|}{$\begin{array}{c}\text { SNLA014018 } \\
\text { MWL-BW1 Duplicate } \\
11 / 10 / 93\end{array}$} \\
\hline \multicolumn{7}{|c|}{ All results in $\mathrm{pCi} / \mathrm{L}$} \\
\hline Parameter $^{a}$ & $\mathrm{DCG}^{\mathrm{b}}(\mathrm{pCi} / \mathrm{L})$ & Results $(p C i / L)^{c}$ & 2 Sigma & $L c^{d}$ & $\mathrm{MDA}^{\mathrm{e}}$ & $\mathrm{DA}^{f}$ \\
\hline Gross Alpha & 15 & 8.7 & 3.7 & 5 & 2.5 & 1 \\
\hline Gross Beta & 30 & 4.5 & 1.8 & 31 & 2.5 & 1 \\
\hline Tritium & 80000 & 78 & 220 & 27 & 360 & 176 \\
\hline Uranium-233/234 & 200 & 6.3 & 0.70 & 16 & 0.056 & 0.15 \\
\hline Uranium-235 & 24 & 0.11 & 0.066 & 0 & 0.025 & 0.00 \\
\hline Uranium-238 & 24 & 3.0 & 0.41 & 15 & 0.025 & 0.14 \\
\hline Thorium-230 & 12 & 0.003 & 0.012 & 0 & 0.036 & 0.00 \\
\hline Thorium-232 & 2 & 0 & 0.001 & 0 & 0.016 & 0.00 \\
\hline Plutonium-238 & 1.6 & 0 & 0.001 & 0 & 0.026 & 0.00 \\
\hline Plutonium-239/240 & 1.2 & 0 & 0.001 & 0 & 0.010 & 0.00 \\
\hline Strontium-90 & 40 & NA & NA & NA & NA & NA \\
\hline \multicolumn{7}{|c|}{$\begin{array}{l}\text { analyses performed by TMA/Eberline, Albuquerque, New Mexico. } \\
\text { bDCG = Derived Concentration Guides, DOE Order } 5400.5 \text {. } \\
\text { 'Laboratory results have an uncertainty of } \pm 2 \text { sigma; if the error value exceeds the count value, the result is } \\
\text { considered a nondetect and is indicated by a minus sign. } \\
\text { d } \mathrm{LC}=\text { Critical level = net count rate which must be exceeded before the sample is said to contain any measureable } \\
\text { radioactive material. } \\
e^{2} \mathrm{MDA}=\text { Minimum detectable activity. } \\
\text { fDA = Decision amount = activity that must be exceeded before the sample is said to contain any measureable } \\
\text { radioactive material. } \\
\mathrm{ND}=\text { Not detected. } \\
\mathrm{NA}=\text { Not analyzed. }\end{array}$} \\
\hline
\end{tabular}


Table K-18.

Summary of Analytical Results for Detected Organic Compounds Sandia National Laboratories/New Mexico

TA-2 Groundwater Monitoring, 1993

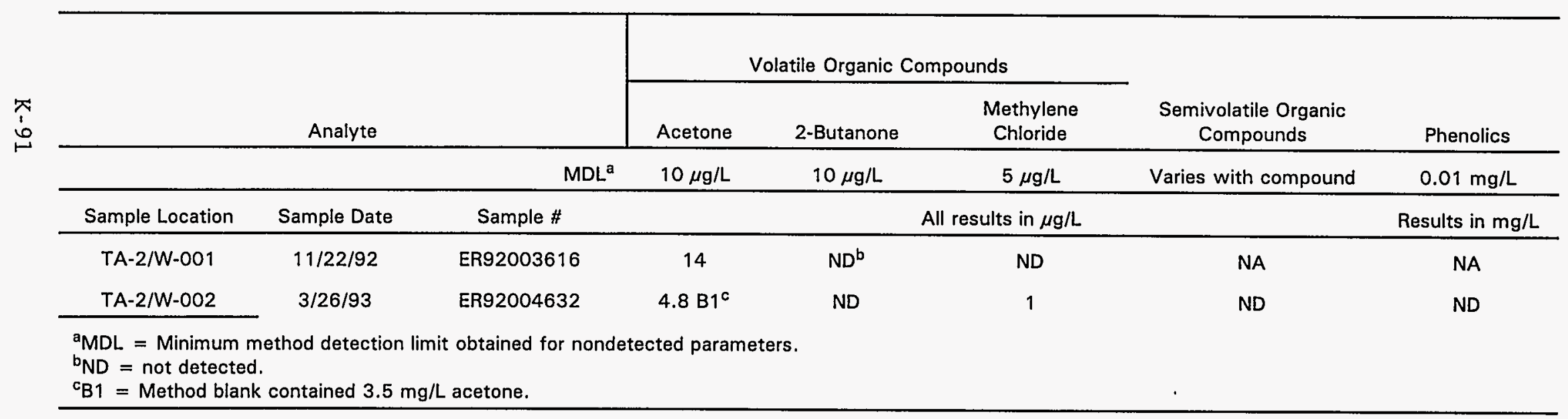


Table K-19.

Summary of Analytical Results for Inorganic Compounds

Sandia National Laboratories/New Mexico

TA-2 Groundwater Monitoring, 1993

\begin{tabular}{|c|c|c|c|c|c|c|c|c|c|c|c|}
\hline & Analyte & & Alkalinity & Chloride & Fluoride & $\begin{array}{c}\text { Nitrate } \\
\text { Plus } \\
\text { Nitrite } \\
\end{array}$ & Ammonia & Sulfate & $\begin{array}{c}\text { Total } \\
\text { Phosphorus }\end{array}$ & $\mathrm{pH}$ & $\begin{array}{c}\text { Specific } \\
\text { Conductance }\end{array}$ \\
\hline & $\mathrm{MDL}^{\mathrm{a}}$, units & & 10 & 2.0 & 0.1 & 0.05 & 0.1 & 20 & 0.05 & & 1.0 \\
\hline $\begin{array}{l}\text { Sample } \\
\text { Location }\end{array}$ & $\begin{array}{c}\text { Sample } \\
\text { Date }\end{array}$ & Sample \# & \multicolumn{7}{|c|}{ All results in $\mathrm{mg} / \mathrm{L}$} & $\begin{array}{l}\text { Standard } \\
\text { pH units, } \\
\text { no MDL }\end{array}$ & $\mu \mathrm{mhos} / \mathrm{cm}$ \\
\hline TA-2/W-001 & $11 / 22 / 92$ & ER92003616 & $N A^{b}$ & NA & NA & 9.4 & NA & NA & 0.14 & NA & NA \\
\hline TA-2/W-002 & $3 / 26 / 93$ & ER92004632 & 95.7 & 98.9 & 0.35 & 4.1 & $N D^{c}$ & 111 & NA & 7.8 & 740 \\
\hline TA-2/W-003 & $6 / 11 / 93$ & ER92004934 & 158 & 14.8 & 0.42 & $\begin{array}{c}1.3 \\
\text { (Nitrate) }\end{array}$ & ND & 77.4 & NA & 7.9 & 517 \\
\hline TA-2/W-003 & $6 / 13 / 93$ & ER92004940 & 153 & 15.1 & 0.47 & 4.6 & ND & 40.1 & NA & 7.9 & 473 \\
\hline
\end{tabular}


Table K-20.

Summary of Analytical Results for Total Metals

Sandia National Laboratories/New Mexico

TA-2 Groundwater Monitoring, 1993

\begin{tabular}{|c|c|c|c|c|c|c|c|c|c|c|}
\hline & Analyte & & Aluminum & Antimony & Arsenic & Barium & Beryllium & Cadmium & Calcium & Chromium \\
\hline & $M \mathrm{ML}^{\mathrm{a}}$ & & 0.1 & 0.06 & 0.01 & 0.01 & 0.002 & 0.01 & 0.2 & 0.01 \\
\hline $\begin{array}{l}\text { Sampling } \\
\text { Location }\end{array}$ & Sample Date & Sample \# & \multicolumn{8}{|c|}{ All results in $\mathrm{mg} / \mathrm{L}$. } \\
\hline TA-2/W-002 & $3 / 26 / 93$ & ER92004632 & 0.03 & $N D^{c}$ & ND & 0.15 & ND & ND & 94.0 & ND \\
\hline TA-2/W-003 & $6 / 11 / 93$ & ER92004934 & $N A^{b}$ & NA & NA & NA & NA & NA & 68.1 & NA \\
\hline TA-2/W-003 & $6 / 13 / 93$ & ER92004940 & NA & NA & NA & NA & NA & NA & 60.4 & NA \\
\hline \multirow[t]{3}{*}{ TA-2/W-003 } & $6 / 24 / 93$ & ER92004947 & NA & NA & NA & NA & NA & NA & 64.0 & NA \\
\hline & Analyte & & Cobalt & Copper & Iron & Lead & Mercury & Magnesium & Manganese & Nickel \\
\hline & MDL & & 0.01 & 0.02 & 0.1 & 0.01 & 0.0002 & 0.2 & 0.01 & 0.04 \\
\hline $\begin{array}{l}\text { Sampling } \\
\text { Location }\end{array}$ & Sample Date & Sample \# & \multicolumn{8}{|c|}{ All results in $\mathrm{mg} / \mathrm{L}$. } \\
\hline TA-2/W-002 & $3 / 26 / 93$ & ER92004632 & ND & 0.0033 & 0.07 & ND & ND & 13.5 & 0.17 & ND \\
\hline TA-2/W-003 & $6 / 11 / 93$ & ER92004934 & NA & NA & 0.21 & NA & NA & 11.9 & NA & NA \\
\hline TA-2/W-003 & $6 / 13 / 93$ & ER92004940 & NA & NA & 0.21 & NA & NA & 11.1 & NA & NA \\
\hline \multirow[t]{3}{*}{ TA-2/W-003 } & $6 / 24 / 93$ & ER92004947 & NA & NA & 0.47 & NA & NA & 11.8 & NA & NA \\
\hline & Analyte & & Potassium & Selenium & Silver & Sodium & Thallium & Vanadium & Zinc & \\
\hline & MDL & & 5 & 0.01 & 0.01 & 5 & 0.05 & 0.01 & 0.02 & \\
\hline $\begin{array}{l}\text { Sampling } \\
\text { Location }\end{array}$ & Sample Date & Sample \# & \multicolumn{8}{|c|}{ All results in $\mathrm{mg} / \mathrm{L}$. } \\
\hline TA-2/W-002 & $3 / 26 / 93$ & ER92004632 & 3.1 & 0.01 & ND & 22.0 & ND & ND & NA & \\
\hline TA-2/W-003 & $6 / 11 / 93$ & ER92004934 & ND & $N A$ & NA & 29.3 & NA & NA & NA & \\
\hline TA-2/W-003 & $6 / 13 / 93$ & ER92004940 & ND & NA & NA & 24.2 & NA & NA & NA & \\
\hline TA-2/W-003 & $6 / 24 / 93$ & ER92004947 & 5.5 & NA & NA & 27.6 & NA & NA & NA & \\
\hline
\end{tabular}


Table 2la.

Summary of Analytes Detected in Groundwater Samples

Liquid Waste Disposal Site Monitoring Well MW-2

Sandia National Laboratories/New Mexico

June 24, 1993

\begin{tabular}{|c|c|c|c|c|c|c|c|c|c|}
\hline \multirow[b]{3}{*}{ Metals } & \multirow[b]{2}{*}{ Analyte } & \multicolumn{3}{|c|}{ SNLA013024 } & \multicolumn{3}{|c|}{ SNLA013025 (Duplicate) } & \multirow[b]{2}{*}{ Detection } & \multirow[b]{2}{*}{ Limit } \\
\hline & & Result & Units & Flag & Result & Units & Flag & & \\
\hline & Barium & 0.07 & $\mathrm{mg} / \mathrm{L}$ & & 0.07 & $\mathrm{mg} / \mathrm{L}$ & & 0.02 & $\mathrm{mg} / \mathrm{L}$ \\
\hline & Calcium & 47 & $\mathrm{mg} / \mathrm{L}$ & & 47 & $\mathrm{mg} / \mathrm{L}$ & & 0.20 & $\mathrm{mg} / \mathrm{L}$ \\
\hline & Iron & 0.24 & $\mathrm{mg} / \mathrm{L}$ & & 0.22 & $\mathrm{mg} / \mathrm{L}$ & & 0.02 & $\mathrm{mg} / \mathrm{L}$ \\
\hline & Magnesium & 13 & $\mathrm{mg} / \mathrm{L}$ & & 13 & $\mathrm{mg} / \mathrm{L}$ & & 0.20 & $\mathrm{mg} / \mathrm{L}$ \\
\hline & Potassium & 2.6 & $\mathrm{mg} / \mathrm{L}$ & & 2.6 & $\mathrm{mg} / \mathrm{L}$ & & 0.20 & $\mathrm{mg} / \mathrm{L}$ \\
\hline & Selenium & 0.002 & $\mathrm{mg} / \mathrm{L}$ & & 0.002 & $\mathrm{mg} / \mathrm{L}$ & & 0.002 & $\mathrm{mg} / \mathrm{L}$ \\
\hline & Sodium & 40 & $\mathrm{mg} / \mathrm{L}$ & & 41 & $\mathrm{mg} / \mathrm{L}$ & & 0.20 & $\mathrm{mg} / \mathrm{L}$ \\
\hline \multirow{5}{*}{$\begin{array}{l}\text { General } \\
\text { Inorganics }\end{array}$} & Alkalinity & 170 & $\mathrm{mg} / \mathrm{L}$ & & 170 & $\mathrm{mg} / \mathrm{L}$ & & 10 & $\mathrm{mg} / \mathrm{L}$ \\
\hline & Chloride & 12 & $\mathrm{mg} / \mathrm{L}$ & & 12 & $\mathrm{mg} / \mathrm{L}$ & & 2.0 & $\mathrm{mg} / \mathrm{L}$ \\
\hline & $\begin{array}{l}\text { Nitrate plus } \\
\text { nitrite }\end{array}$ & 7.4 & $\mathrm{mg} / \mathrm{L}$ & & 7.7 & $\mathrm{mg} / \mathrm{L}$ & & 0.40 & $\mathrm{mg} / \mathrm{L}$ \\
\hline & $\begin{array}{l}\text { Total dissolved } \\
\text { solids }\end{array}$ & 160 & $\mathrm{mg} / \mathrm{L}$ & & 130 & $\mathrm{mg} / \mathrm{L}$ & & 10 & $\mathrm{mg} / \mathrm{L}$ \\
\hline & Sulfate & 38 & $\mathrm{mg} / \mathrm{L}$ & & 38 & $\mathrm{mg} / \mathrm{L}$ & & 5 & $\mathrm{mg} / \mathrm{L}$ \\
\hline \multirow{3}{*}{$\begin{array}{l}\text { Volatile } \\
\text { Organics }\end{array}$} & Acetone & 0.004 & $\mathrm{mg} / \mathrm{L}$ & $J^{a}$ & 0.003 & $\mathrm{mg} / \mathrm{L}$ & $J$ & 0.010 & $\mathrm{mg} / \mathrm{L}$ \\
\hline & 2-Butanone & 0.002 & $\mathrm{mg} / \mathrm{L}$ & $\mathrm{J}$ & $N D^{b}$ & $\mathrm{mg} / \mathrm{L}$ & & 0.010 & $\mathrm{mg} / \mathrm{L}$ \\
\hline & $\begin{array}{l}\text { Methylene } \\
\text { chloride }\end{array}$ & 0.004 & $\mathrm{mg} / \mathrm{L}$ & $\mathrm{J}, \mathrm{B}^{\mathrm{b}}$ & ND & $\mathrm{mg} / \mathrm{L}$ & & 0.005 & $\mathrm{mg} / \mathrm{L}$ \\
\hline $\begin{array}{l}\text { Semivolatile } \\
\text { Organics }\end{array}$ & $\begin{array}{l}\text { Bis(2-ethylhexyl) } \\
\text { phthalate }\end{array}$ & 0.007 & $\mathrm{mg} / \mathrm{L}$ & $J$ & 0.007 & $\mathrm{mg} / \mathrm{L}$ & $J$ & 0.010 & $\mathrm{mg} / \mathrm{L}$ \\
\hline \multirow[t]{2}{*}{ Radiologic } & Gross alpha & $3.8 \pm 2.3$ & $1.8^{d}$ & $\mathrm{pCi} / \mathrm{L}$ & $4.6 \pm 2.4$ & $1.7^{\mathrm{d}}$ & $\mathrm{pCi} / \mathrm{L}$ & & \\
\hline & Gross beta & $3.1 \pm 1.6$ & $2.1^{d}$ & $\mathrm{pCi} / \mathrm{L}$ & $2.9 \pm 1.7$ & $2.3^{d}$ & $\mathrm{pCi} / \mathrm{L}$ & & \\
\hline
\end{tabular}


Table K-21b.

Summary of Analytes Detected in Groundwater Samples

Liquid Waste Disposal Site Monitoring Well MW-1

Sandia National Laboratories/New Mexico

November 2 and 3, 1993

\begin{tabular}{|c|c|c|c|c|c|c|c|c|c|}
\hline & \multirow[b]{2}{*}{ Analyte } & \multicolumn{3}{|c|}{ ER92002113 } & \multicolumn{3}{|c|}{ ER92002114 (Duplicate) } & \multirow[b]{2}{*}{ Detection } & \multirow[b]{2}{*}{ Limit } \\
\hline & & Result & Units & Flag & Result & Units & Flag & & \\
\hline \multirow[t]{10}{*}{ Metals } & Arsenic & 0.006 & $\mathrm{mg} / \mathrm{L}$ & & 0.007 & $\mathrm{mg} / \mathrm{L}$ & & 0.002 & $\mathrm{mg} / \mathrm{L}$ \\
\hline & Barium & 0.09 & $\mathrm{mg} / \mathrm{L}$ & & 0.10 & $\mathrm{mg} / \mathrm{L}$ & & 0.02 & $\mathrm{mg} / \mathrm{L}$ \\
\hline & Calcium & 50 & $\mathrm{mg} / \mathrm{L}$ & & 51 & $\mathrm{mg} / \mathrm{L}$ & & 0.20 & $\mathrm{mg} / \mathrm{L}$ \\
\hline & Chromium & $N D^{a}$ & $\mathrm{mg} / \mathrm{L}$ & & 0.01 & $\mathrm{mg} / \mathrm{L}$ & & 0.01 & $\mathrm{mg} / \mathrm{L}$ \\
\hline & Iron & 0.14 & $\mathrm{mg} / \mathrm{L}$ & & 0.14 & $\mathrm{mg} / \mathrm{L}$ & & 0.02 & $\mathrm{mg} / \mathrm{L}$ \\
\hline & Magnesium & 15 & $\mathrm{mg} / \mathrm{L}$ & & 15 & $\mathrm{mg} / \mathrm{L}$ & & 0.20 & $\mathrm{mg} / \mathrm{L}$ \\
\hline & Manganese & 0.10 & $\mathrm{mg} / \mathrm{L}$ & & 0.098 & $\mathrm{mg} / \mathrm{h}$ & & 0.005 & $\mathrm{mg} / \mathrm{L}$ \\
\hline & Potassium & 3.9 & $\mathrm{mg} / \mathrm{L}$ & & 3.9 & $\mathrm{mg} / \mathrm{L}$ & & 0.20 & $\mathrm{mg} / \mathrm{L}$ \\
\hline & Selenium & 0.003 & $\mathrm{mg} / \mathrm{L}$ & & 0.004 & $\mathrm{mg} / \mathrm{L}$ & & 0.002 & $\mathrm{mg} / \mathrm{L}$ \\
\hline & Sodium & 120 & $\mathrm{mg} / \mathrm{L}$ & & 120 & $\mathrm{mg} / \mathrm{L}$ & & 0.20 & $\mathrm{mg} / \mathrm{L}$ \\
\hline \multirow{8}{*}{$\begin{array}{l}\text { General } \\
\text { Inorganics }\end{array}$} & Alkalinity & 260 & $\mathrm{mg} / \mathrm{L}$ & & 270 & $\mathrm{mg} / \mathrm{L}$ & & 10 & $\mathrm{mg} / \mathrm{L}$ \\
\hline & Chloride & 72 & $\mathrm{mg} / \mathrm{L}$ & & 72 & $\mathrm{mg} / \mathrm{L}$ & & 2.0 & $\mathrm{mg} / \mathrm{L}$ \\
\hline & Fluoride & 1.1 & $\mathrm{mg} / \mathrm{L}$ & & 1.1 & $\mathrm{mg} / \mathrm{L}$ & & 0.1 & $\mathrm{mg} / \mathrm{L}$ \\
\hline & $\begin{array}{l}\text { Nitrate plus } \\
\text { nitrite }\end{array}$ & 7.3 & $\mathrm{mg} / \mathrm{L}$ & & 7.2 & $\mathrm{mg} / \mathrm{L}$ & & 0.05 & $\mathrm{mg} / \mathrm{L}$ \\
\hline & $\begin{array}{l}\text { Total organic } \\
\text { carbon }\end{array}$ & 0.94 & $\mathrm{mg} / \mathrm{L}$ & & 0.93 & $\mathrm{mg} / \mathrm{L}$ & & 0.5 & $\mathrm{mg} / \mathrm{L}$ \\
\hline & Phosphorus & 2.6 & $\mathrm{mg} / \mathrm{L}$ & & 3.3 & $\mathrm{mg} / \mathrm{h}$ & & 0.05 & $\mathrm{mg} / \mathrm{L}$ \\
\hline & $\begin{array}{l}\text { Total dissolved } \\
\text { solids }\end{array}$ & 480 & $\mathrm{mg} / \mathrm{L}$ & & 520 & $\mathrm{mg} / \mathrm{L}$ & & 10 & $\mathrm{mg} / \mathrm{L}$ \\
\hline & Sulfate & 78 & $\mathrm{mg} / \mathrm{L}$ & & 77 & $\mathrm{mg} / \mathrm{L}$ & & 5 & $\mathrm{mg} / \mathrm{L}$ \\
\hline \multirow{5}{*}{$\begin{array}{l}\text { Volatile } \\
\text { Organics }\end{array}$} & Benzene & ND & $\mathrm{mg} / \mathrm{L}$ & & 0.006 & $\mathrm{mg} / \mathrm{L}$ & & 0.005 & $m g / L$ \\
\hline & $\begin{array}{l}\text { total-1,2- } \\
\text { Dichloroethene }\end{array}$ & 0.001 & $\mathrm{mg} / \mathrm{L}$ & $J^{b}$ & 0.001 & $\mathrm{mg} / \mathrm{L}$ & $J$ & 0.005 & $\mathrm{mg} / \mathrm{L}$ \\
\hline & $\begin{array}{l}\text { Methylene } \\
\text { chloride }\end{array}$ & 0.004 & $\mathrm{mg} / \mathrm{L}$ & $J, B^{C}$ & 0.004 & $\mathrm{mg} / \mathrm{L}$ & J,B & 0.005 & $\mathrm{mg} / \mathrm{L}$ \\
\hline & Toluene & 0.002 & $\mathrm{mg} / \mathrm{L}$ & $J$ & 0.002 & $\mathrm{mg} / \mathrm{L}$ & $J$ & 0.005 & $\mathrm{mg} / \mathrm{L}$ \\
\hline & Trichloroethene & 0.006 & $\mathrm{mg} / \mathrm{L}$ & & ND & $\mathrm{mg} / \mathrm{L}$ & & 0.005 & $\mathrm{mg} / \mathrm{L}$ \\
\hline \multirow[t]{3}{*}{ Radiologic } & Gross alpha & $14 \pm 6.1$ & 4.2 & $\mathrm{pCi} / \mathrm{L}$ & $-0.21 \pm 0.50$ & 0.93 & $\mathrm{pCi} / \mathrm{L}$ & & \\
\hline & Gross beta & $18 \pm 3.9$ & $3.0^{d}$ & $\mathrm{pCi} / \mathrm{L}$ & $-1.3 \pm 1.2$ & $2.1^{\mathrm{d}}$ & $\mathrm{pCi} / \mathrm{L}$ & & \\
\hline & Total uranium & $6.1 \pm 0.47$ & $0.50^{d}$ & $\mu \mathrm{g} / \mathrm{L}$ & $-0.006 \pm 0.001$ & $0.50^{d}$ & $\mu g / L$ & & \\
\hline \multicolumn{10}{|c|}{$\begin{array}{l}{ }^{a} N D=\text { Not detected } \\
b_{J}=\text { Detected below quantitation limit; reported results is an estimated value. } \\
{ }^{{ }_{B}}=\text { Analyte detected in method blank. } \\
{ }^{d} \text { MDA = Minimum detectable activity. }\end{array}$} \\
\hline
\end{tabular}


Table K-22.

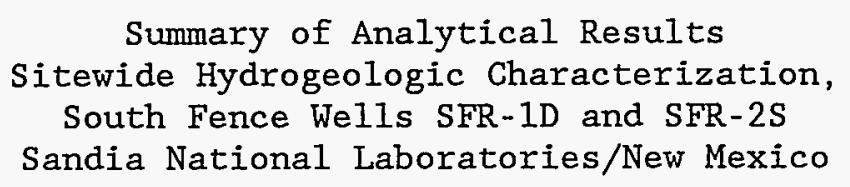

May 6, 1993

\begin{tabular}{|c|c|c|c|c|}
\hline & & Well SFR-1D & Well SFR-2S & Equipment Blank \\
\hline Parameter, Units & $M C L^{a}$ & $\begin{array}{c}\text { Sample \# } \\
\text { SF10012138 }\end{array}$ & $\begin{array}{c}\text { Sample \# } \\
\text { SF20012137 } \\
\end{array}$ & $\begin{array}{c}\text { Sample \# } \\
\text { EB20012140 }\end{array}$ \\
\hline Acetone, $\mathrm{mg} / \mathrm{L}$ & $N E^{b}$ & $0.004 \mathrm{~J}^{c} \mathrm{~B}^{\mathrm{d}}$ & $0.009 \mathrm{~J}$ & $N D^{e}$ \\
\hline Other VOC ${ }^{f}, \mathrm{mg} / \mathrm{L}$ & Varies & ND & ND & ND \\
\hline $\mathrm{TOC}^{\mathrm{g}}, \mathrm{mg} / \mathrm{L}$ & & ND & ND & ND \\
\hline $\mathrm{TOX}^{\mathrm{h}}, \mu \mathrm{g} / \mathrm{L}$ & NE & ND & 29 & 17 \\
\hline Pesticides, mg/L & & ND & ND & ND \\
\hline Herbicides, mg/L & & ND & ND & ND \\
\hline Total Phenolics, mg/L & & ND & ND & ND \\
\hline Total Coliform Bacteria & Present or absent & Present & Present & $N S^{i}$ \\
\hline Fecal Coliform Bacteria & Present or absent & Absent & Absent & NS \\
\hline Total Alkalinity, $\mathrm{mg} / \mathrm{L}$ as $\mathrm{CaCO}_{3}$ & $\mathrm{NE}$ & 420 & 330 & ND \\
\hline Chloride, $\mathrm{mg} / \mathrm{L}$ & $250 \mathrm{mg} / \mathrm{L}^{\mathrm{j}}$ & 130 & 130 & ND \\
\hline Fluoride, $\mathrm{mg} / \mathrm{L}$ & $4.0 \mathrm{mg} / \mathrm{L}$ & 1.7 & 1.8 & ND \\
\hline Nitrate + Nitrite, $\mathrm{mg} / \mathrm{L}$ & $11.0 \mathrm{mg} / \mathrm{L}$ & 0.95 & 0.96 & ND \\
\hline $\mathrm{pH}$, Standard Units & NE & 6.9 & 7.0 & 8.0 \\
\hline Sulfate, $\mathrm{mg} / \mathrm{L}$ & $250 \mathrm{mg} / \mathrm{L}^{\mathrm{j}}$ & 67 & 71 & ND \\
\hline Bromide, $\mathrm{mg} / \mathrm{L}$ & NE & 0.67 & 0.68 & ND \\
\hline \multicolumn{5}{|l|}{ Metals, mg/L: } \\
\hline Barium & 1.0 & 0.07 & 0.04 & ND \\
\hline Calcium & NE & 148 & 125 & ND \\
\hline Iron & $0.3^{\mathrm{j}}$ & 0.78 & 0.13 & ND \\
\hline Magnesium & $\mathrm{NE}$ & 35 & 34 & ND \\
\hline Manganese & $0.05^{\mathrm{i}}$ & 0.016 & 0.008 & ND \\
\hline Potassium & NE & 7.2 & 7.3 & 0.34 \\
\hline Sodium & $20^{j}$ & 78 & 77 & ND \\
\hline Other Metals & various & ND & ND & ND \\
\hline \multicolumn{5}{|c|}{ 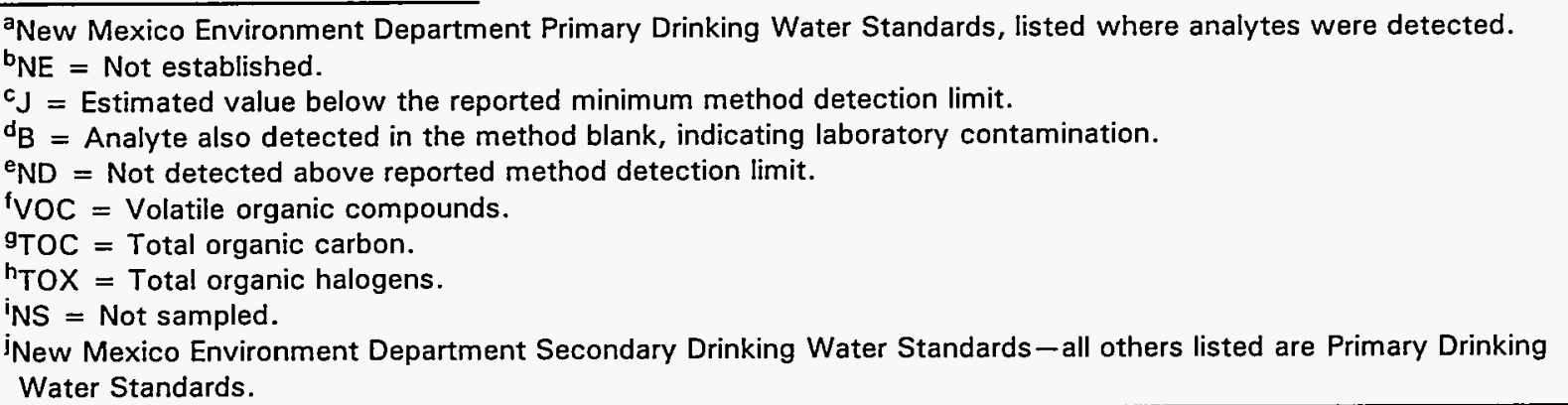 } \\
\hline
\end{tabular}




\section{UNLIMITED RELEASE DISTRIBUTION}

U.S. Department of Energy (80)

Kirtland Area Office (KAO)

Environment, Safety, Health, and

Compliance Branch

P.0. Box 5400

Albuquerque, NM 87185

New Mexico Environment Department (1)

c/O DOE-KAO-ESHCB

P.O. Box 5400

Albuquerque, NM 87185-5400

Albuquerque City Environmental Services

(1)

400 Marquette Ave. NW

Albuquerque, NM 87117

Captain Robert C. Viramontes (1)

377 ABW/EMP

KAFB, NM 87117-5606

J . J . Thompson (1)

Inhalation Toxicology Research Institute

P.0. Box 5800

Albuquerque, NM 87185

Environmental Protection Agency (EPA) (1)

Headquarters office

Washington, DC

Environmental Protection Agency (EPA) (I)

Region VI Office

1445 Ross Ave.

Dallas, TX 75202-2733 


\section{SANDIA NATIONAL LABORATORIES, INTERNAL DISTRIBUTION}

$\begin{array}{lll}10 & \text { (MS 0100) } & \text { Document Processing, 7613-2 } \\ & & \text { for DOE/OSTI } \\ 1 & \text { (MS 0141) } & \text { C. B. Hal1, 11300 } \\ 1 & \text { (MS 0141) } & \text { R. J. Park, 11300 } \\ 1 & \text { (MS 0141) } & \text { T. A. Vandenberg, 11300 } \\ 1 & \text { (MS 0167) } & \text { W. Keener, 12630 } \\ 1 & \text { (MS 0167) } & \text { A. Stotts, 12630 } \\ 1 & \text { (MS 0619) } & \text { Technical Publications, 13416 } \\ 1 & \text { (MS 0617) } & \text { G. L. West, 2701 } \\ 1 & \text { (MS 0658) } & \text { R. G. Hay, 2723 } \\ 1 & \text { (MS 0875) } & \text { A. O. Bendure, 7258 } \\ 1 & \text { (MS 0875) } & \text { T. A. Wolff, 7258 } \\ 5 & \text { (MS 0899) } & \text { Technical Library, 13414 } \\ 1 & \text { (MS 9018) } & \text { Central Technical Files, 8523-2 } \\ 1 & \text { (MS 1064) } & \text { J. Lewis, 7001 } \\ 1 & \text { (MS 1067) } & \text { A. N. Blackwel1, 7000 } \\ 1 & \text { (MS 1067) } & \text { G. E. Chavez, 7002 } \\ 1 & \text { (MS 1303) } & \text { J. R. Guth, 7573 } \\ 1 & \text { (MS 1303) } & \text { M. Lincoln, 7573 } \\ 1 & \text { (MS 1305) } & \text { E. R. Copus, 7574 } \\ 1 & \text { (MS 1305) } & \text { N. A. Durand, 7576 } \\ 1 & \text { (MS 1305) } & \text { C. H. Fink, 7574 } \\ 1 & \text { (MS 1305) } & \text { J. D. Fish, 7576 } \\ 1 & \text { (MS 1305) } & \text { M. J. Irwin, 7574 } \\ 1 & \text { (MS 1305) } & \text { A. K. Jones, 7574 } \\ 1 & \text { (MS 1305) } & \text { C. E. Robertson, 7574 } \\ 1 & \text { (MS 1307) } & \text { K. J. Mo1ley, 7572 } \\ 1 & \text { (MS 1307) } & \text { J. G. Yeager, 7572 } \\ 20 & \text { (MS 1309) } & \text { Records Center, 7512 } \\ 1 & \text { (MS 1311) } & \text { C. Cheng, 7575 } \\ 2 & \text { (MS 1311) } & \text { T. A. Culp, 7575 } \\ 1 & \text { (MS 1311) } & \text { H. A. Hwang, 7575 } \\ 4 & \text { (MS 1311) } & \text { R. Sanchez, 7575 } \\ 1 & \text { (MS 1311) } & \text { Y. McClellan, 7511 } \\ 1 & \text { (MS 1311) } & \text { S. J. Ward, 7511 } \\ 2 & \text { (MS 1315) } & \text { T. E. Blejwas, 7500 } \\ 1 & \text { (MS 1347) } & \text { W. B. Cox, 7581 } \\ 1 & \text { (MS 1347) } & \text { F. B. Nimick, 7582 } \\ 1 & \text { (MS 1348) } & \text { J. A. Fernandez, 7583 } \\ 1 & \text { (MS 1350) } & \text { F. Lauffer, 7584 } \\ 1 & \text { (MS 1350) } & \text { D. L. Stermer, 7584 } \\ 1 & \text { (MS 9017) } & \text { Central Technical Files, 8523 }\end{array}$

Dist-2

is 